\title{
Sistemática, filogenia e morfologia de Alcantarea (Bromeliaceae)
}

LEONARDO M. VERSIEUX

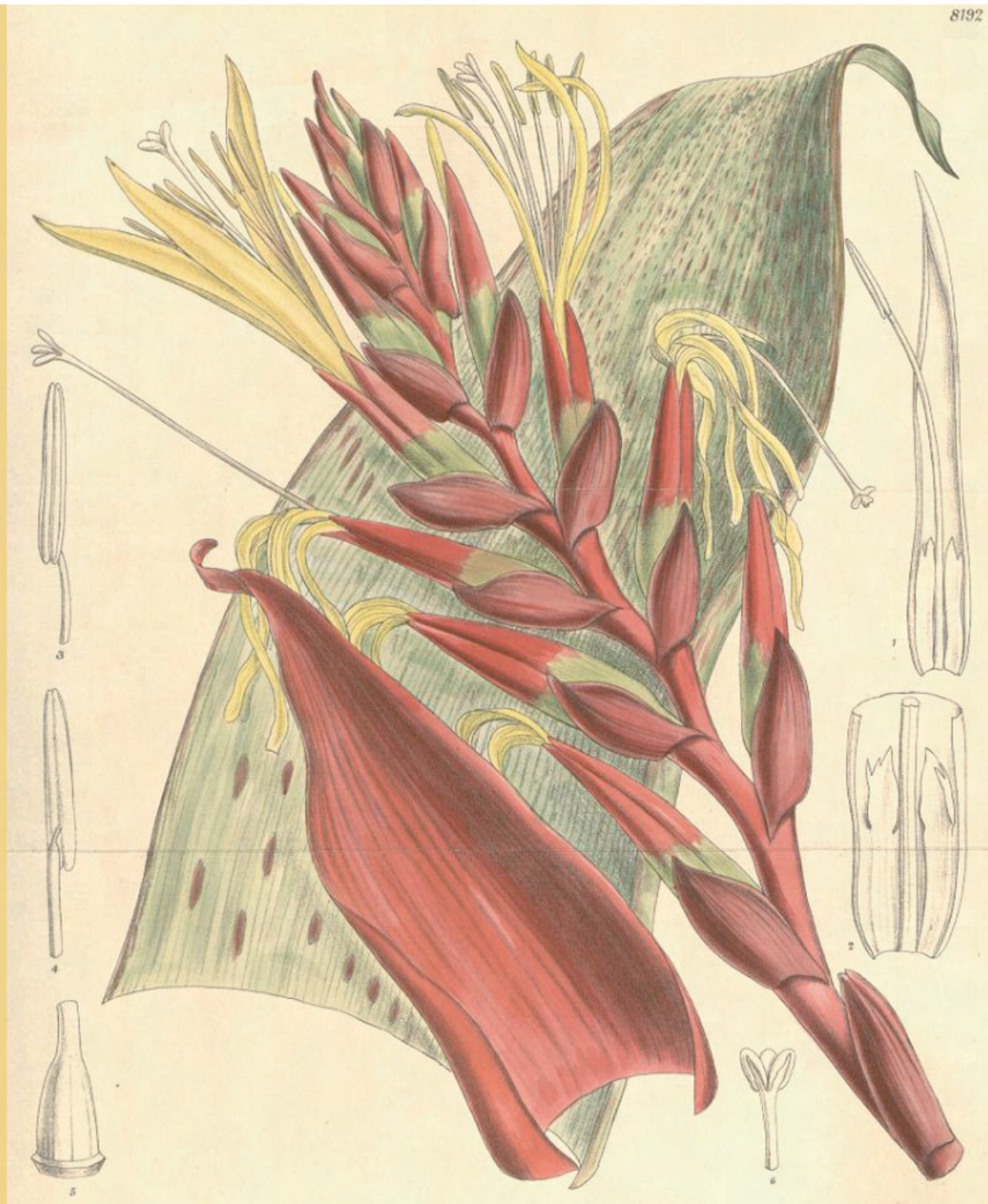


Ilustração DA CAPA: Tillandsia blokii Hemsley, Bot. Mag. 134: pl. 8192. 1908. Atualmente considerada sinônimo de Alcantarea imperialis (Carrière) Harms. 
LEONARDO DE MELO VERSIEUX

SisTEMÁTICA, FILOGENIA E MORFOLOGIA DE ALCANTAREA (BROMELIACEAE)

SÃO PAULO

2009 
LEONARDO DE MELO VERSIEUX

SistemÁtiCA, FILOGENiA E MORFOlogia de AlCANTAREA (BROMELIACEAE)

Tese apresentada aO Instituto DE BIOCIÊNCIAS DA UNIVERSIDADE DE SÃO Paulo, Para a obTenção de Título de DOUTOR EM CIÊNCIAS, NA ÁrEA DE BOTÂNICA.

Orientadora: Profar. DR ${ }^{a}$. MARIA DAS GRAÇAS LAPA WANDERLEY

SÃO PAULO 2009 


\section{FICHA CATALOGRÁFICA}

Versieux, Leonardo de Melo

Sistemática, filogenia e morfologia de Alcantarea

(Bromeliaceae)

xi, 252 f. : il. (algumas color.)

Tese (Doutorado) - Instituto de Biociências da Universidade de São Paulo. Departamento de Botânica.

1. Bromeliaceae 2. Alcantarea 3. Tillandsioideae I. Universidade de São Paulo. Instituto de Biociências. Departamento de Botânica.

Aprovado em: /2009

\section{BANCA EXAMINADORA}

$\operatorname{Prof}(a) . \operatorname{Dr}(a)$.

$\operatorname{Prof}(a) \cdot \operatorname{Dr}(a)$.

$\operatorname{Prof}(a)$. Dr(a).

$\operatorname{Prof}(a) . \operatorname{Dr}(a)$.

Profa. Dra. Maria das Graças Lapa Wanderley

Presidente 
Com amor, para Alice.

$A$ todos que me abriram portas e me mostraram veredas. 
“O TEMPO É QUE É A MATÉRIA D O EN TEN DIMEN TO." Guimarães Rosa 


\section{A. G R A E C I M E N T O S}

É com prazer que agradeço à minha orientadora e amiga, Prof ${ }^{a}$. Dra . Maria das Graças Lapa Wanderley por todo o acompanhamento e atenção, pelos inúmeros ensinamentos, pela companhia, no laboratório e no campo e, mais que tudo, pelo respeito, incentivo e pelos momentos alegres que desfrutamos neste projeto. Ao Dr. Christian Lexer, à Dra ${ }^{a}$ Thelma Barbará, e ao Dr. Mike Fay, do Royal Botanic Gardens, Kew, pela orientação e apoio à realização da filogenia molecular de Alcantarea, pela troca de inúmeras informações e ensinamentos no laboratório e pela amizade. À grande Profa ${ }^{\text {a }} \mathbf{D r}^{\mathbf{a}}$. Nanuza Menezes pelos ensinamentos, amizade e pelo "batismo" nos campos rupestres. À Alice Calvente pela parceria integral enquanto esposa e também por toda sua ajuda no campo e no laboratório, subindo inúmeras pedras, correndo de alguns nelores bravos ou coletando debaixo de muita chuva... Se Alcantarea veio cair em minhas mãos, é à ela e ao seu entusiasmo pela Mata Atlântica que devo agradecer. Sua compreensão, amor, incentivo e respeito serão sempre indispensáveis.

Agradeço ao Instituto de Botânica (IBt), casa que me recebeu de braços abertos, onde desenvolvi a maior parte desta tese e criei diversos laços de amizade que guardarei para sempre. Às curadoras, Dras. Inês Cordeiro e Maria Cândida Mamede, e à Ana Célia Calado agradeço pela disposição em ajudar, sempre. Aos demais pesquisadores e funcionários da Seção de Curadoria do Herbário, Biblioteca e de Plantas Ornamentais, especialmente aos $\mathbf{D r}^{\mathrm{s}}$. Shoey Tamashiro e Armando Tavares, que disponibilizaram uma área para cultivo das plantas vivas. Aos amigos do IBt, pela companhia e discussão de inúmeros assuntos e pela parceria no dia-a-dia da pós-graduação: Rafael Louzada, Suzana Martins, Gisele Oliveira, Luciana Fioratto, Anderson Santos, Marília Duarte, Beatriz Rossi, Maria Medeiros, Elisa Aoyama, Elisete Anunciação, Bianca Moreira, Renata Sebastiani, Fátima Souza, Cintia Vieira e vários outros estagiários que chegaram e se foram neste meio tempo. Agradeço muito ao Biólogo e Artista Klei Rodrigo Sousa, por retratar com fidelidade os táxons, resultando num trabalho bem feito, de paciência e dedicação. Ao Prof. Dr. Antonio Salatino agradeço pela orientação nos primeiros meses, assim como pela disponibilidade em ajudarme sempre que solicitado. À Profa ${ }^{a}$. Dra . Lúcia Lohmann por colocar à disposição o uso do laboratório de Sistemática Molecular, pelo apoio à expedição de coleta na América do Sul e incentivo à realização do curso de Sistemática na Costa Rica. Aos Professores: Dr ${ }^{a}$. Maria Luíza Salatino, Dr ${ }^{\text {a }}$. Rosangela Bianchini e Dr. Paulo Sano pelas importantes sugestões durante o exame de qualificação. À amiga Paula Maria Elbl pelo auxílio no laboratório de anatomia vegetal e discussão de vários temas relacionados. Ao Instituto de Biociências da Universidade de São Paulo, aos professores e funcionários do Departamento de Botânica, agradeço pela oportunidade de realização do curso de doutorado e pelas excelentes disciplinas oferecidas. Aos colegas de pós-graduação do Laboratório de Sistemática da USP (Sobre-as-Ondas) agradeço pela parceria.

Agradeço muito à Fundação de Amparo a Pesquisa do Estado de São Paulo (Fapesp) pela bolsa de doutorado concedida que viabializou a realização deste projeto À International Association of Plant 
Taxonomy por financiar parte da visita aos herbários dos EUA e à Society of Systematic Biology e à Organization for Tropical Studies pela bolsa para realizar o curso Sistemática de Plantas Tropicales, na Costa Rica. Ao Royal Botanic Gardens, Kew, pelo Prance Fellowship in Neotropical Botany Award. Ao IBAMA e ao IEF-MG pelas autorizações de coleta.

Muitas vezes foi graças à irmandade que existe entre os Biólogos que pude viajar economizando \$. Agradeço a hospedagem e os bons momentos que tive em diferentes lares, como o da minha amiga Alice Oliffson em NY, Angelo Rayol e Martha Abranches e David e Isabel Miller em Nova Friburgo, Robert e Audrey Faden em Washington DC, à família Calvente e ao meu irmão Henrique, meus QG's cariocas, além dos alojamentos do Missouri Botanical Gardens e dos Parques Nacionais da Serra do Cipó, Serra dos Órgãos e do Caparaó (Sr. Estevão Fonseca), e da Reserva Biológica Córrego do Veado (Sr. José Maria Assis Poubel). Agradeço aos herbários citados no texto, especialmente aqueles que enviaram várias duplicatas como doação permitindo o estudo detalhados dos espécimes ou onde sequei amostras (HUEFS e LOJA). Às pessoas que contribuíram com informações, às que me enviaram fotos de espécimes ou ainda aos que me acompanharam no campo, especialmente: Dr. Alexandre Salino, Dr. Robbin Moran, Dr. Gustavo Martinelli, Dr. Jefferson Prado, Dra ${ }^{a}$ Rafaela Forzza, Dra ${ }^{a}$ Andrea Costa, Miguel d'Ávila de Moraes, Pedro Viana, Nara Mota, Flávio França, Flávio Fonseca, Fábio Pinheiro, Rafael Louzada, Roberto Kautsky, Cláudio Nicoletti, Reinaldo Vasconcelos, J. Francisco Morales, Michael Barfuss, Derek Butcher, Mark Paul, Robert Smythe, Celso Paiva, Ludovic Kollmann e Ricardo de Moura. Às pessoas que me auxiliaram na importante tarefa de traduzir do Latim ou do Alemão textos históricos, agradeço pela paciência: Prof. Dr. Tarciso Filgueiras, Dra ${ }^{\mathbf{a}}$ Katharina Schulte e Natascha Wagner. Ao Prof. Tarciso, minha especial estima pelas correções de várias diagnoses latinas e ensinamentos ao longo deste projeto.

A todos os amigos e amigas, antigos e aos novos, pelo apoio em diferentes momentos, tornando este período mais enriquecedor. Em Kew: Prof. Dra . Dulcinéia de Carvalho, Amélia Baracat, Marcelo Sellaro, Itayguara Costa, Leónie Sutter, Inélia Escobar, Cláudia Leme, Cynthia Sothers e Mary Henderson. Agradeço pelo treinamento técnico em sistemática molecular e genética de populações recebido do staff do Jodrell Laboratory, em especial à Dra. Thelma Bárbara, Dr. Jeffrey Joseph, Dr. Dion Devey e Dr ${ }^{a}$. Laura Kelly. À Lynn Parker, por todo auxílio na obtenção de bibliografia. No período que antecedeu a tese, agradeço à $\mathbf{D r}^{\mathbf{a}}$. Andrea Costa, Dr ${ }^{\mathbf{a}}$. Tatiana Konno, Dr ${ }^{\mathbf{a}}$. Lívia Temponi por diferentes sugestões ao meu projeto. Durante a tese, amigos que estiveram presentes em diferentes momentos, com sugestões, conselhos, cartas de recomendação e etc: Dr ${ }^{a}$. Tânia Wendt, Dr. W. John Kress, Dr. Robert Faden, Dr. Julio Lombardi, Dr. Leonardo Lopes, Dra . Clarisse Palma-Silva, Dr. João Renato Stehmann, Pedro Viana, Nara Mota, Ricardo Boaventura, Dra. Sônia Baumgratz e outros companheiros que apesar do tempo e distância mantêm viva a amizade... Agradeço à toda minha família pelo constante apoio e compreensão, em especial meus pais Carlos Alberto Versieux (in memoriam) e Maria Elizabeth Versieux, que me ensinaram a enxergar além das montanhas... à minha irmã Juliana e à sua família (Leo, Ana, Tonico), à Raquel e Henrique Versieux, por estarem dispostos a colaborar, sempre. 


\section{ÍNDICE}

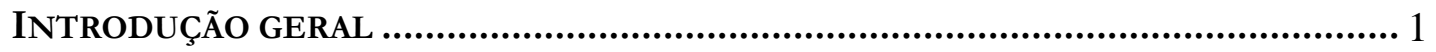

A família Bromeliaceae ………………………...........................................................

Caracterização morfológica ........................................................................................ 5

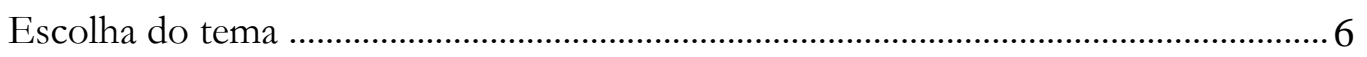

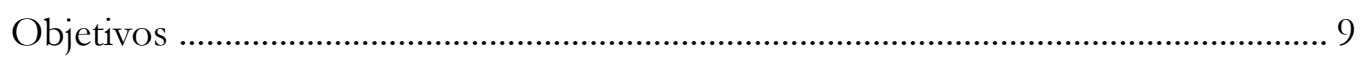

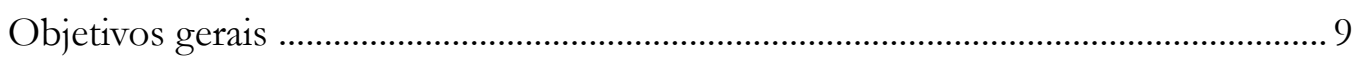

Objetivos específicos ................................................................................................. 9

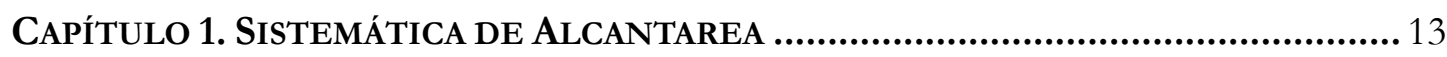

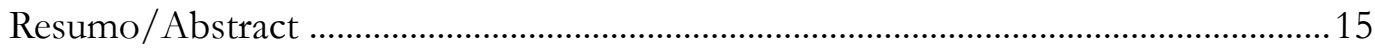

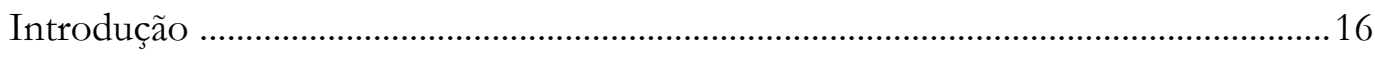

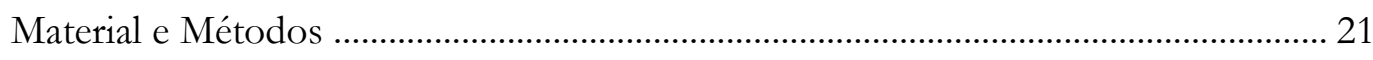

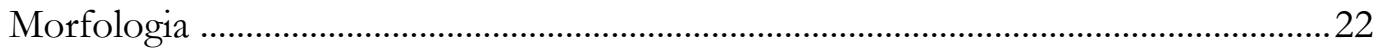

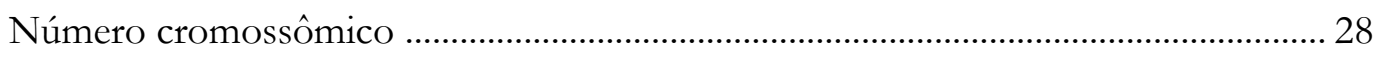

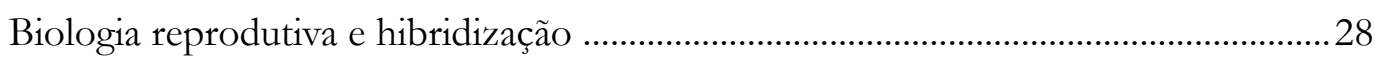

Distribuição e habitat .................................................................................................... 29

Posicionamento e delimitação de Alcantarea ................................................................. 29

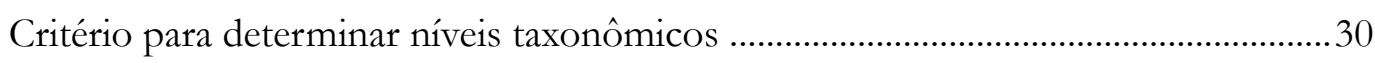

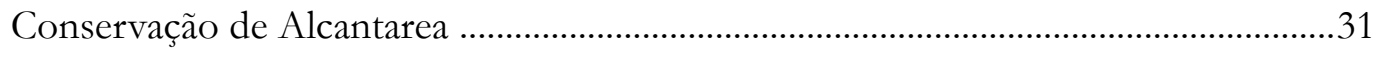

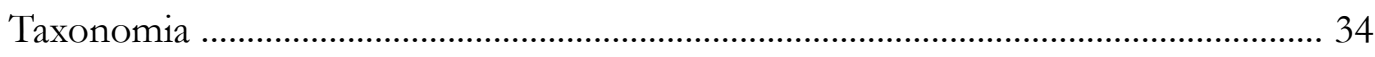

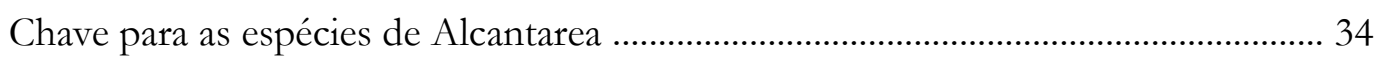

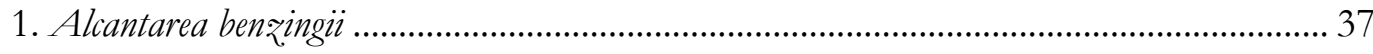

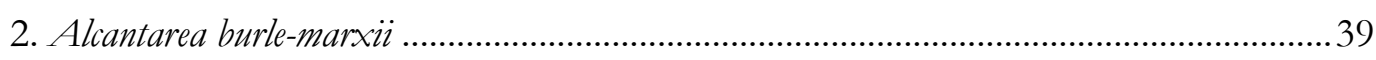

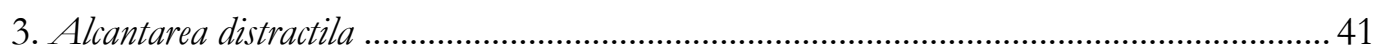

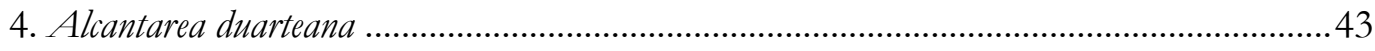

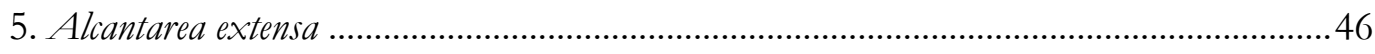

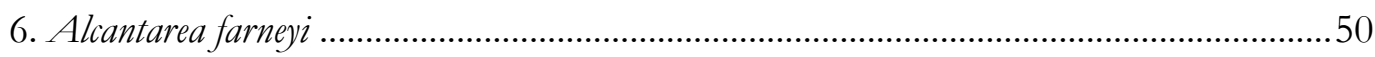

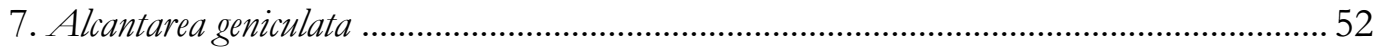

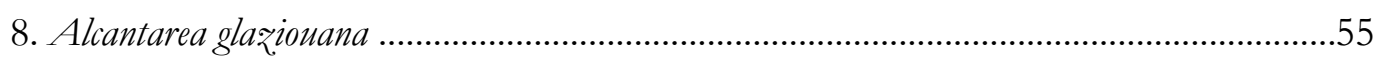

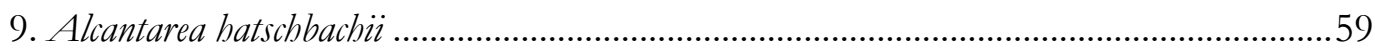

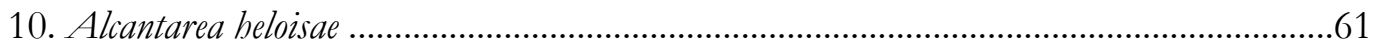

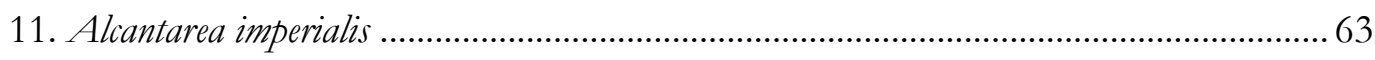

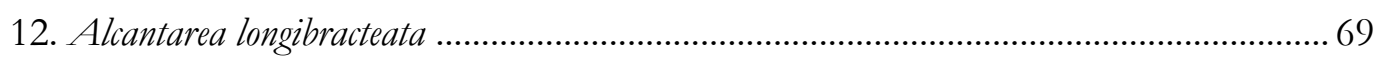

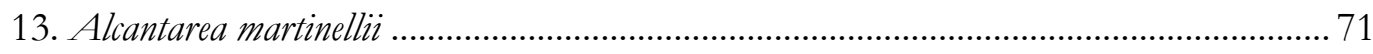

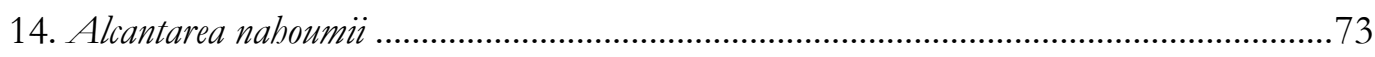

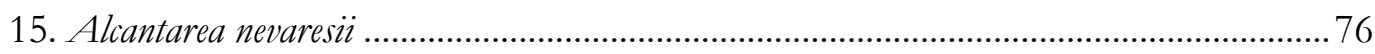

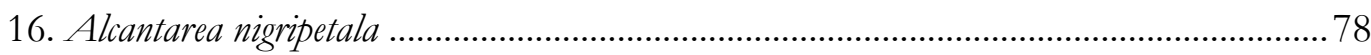




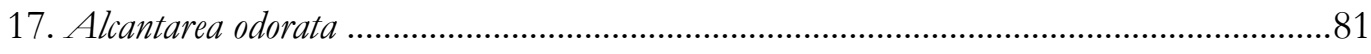

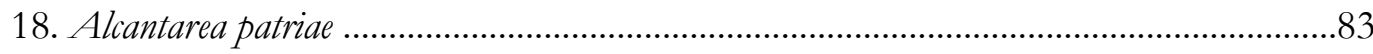

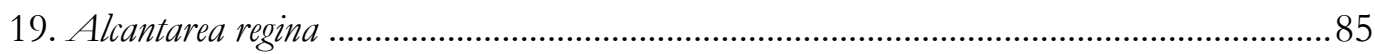

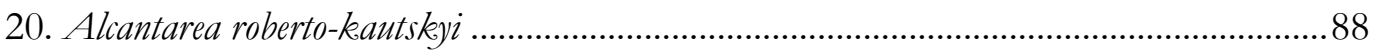

21. Alcantarea simplicisticha ......................................................................................... 90

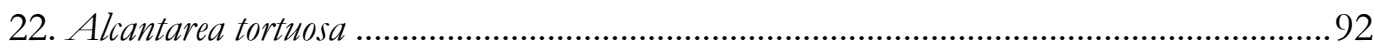

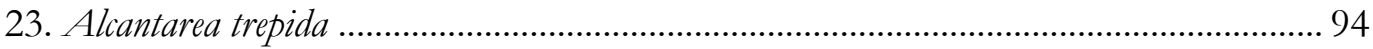

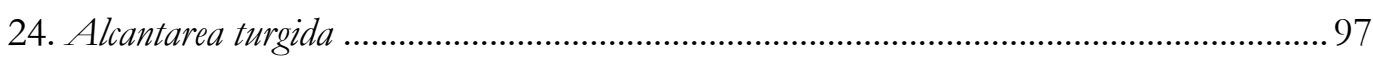

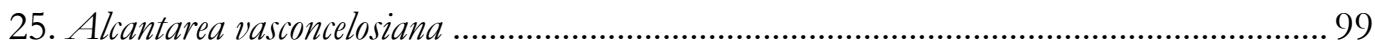

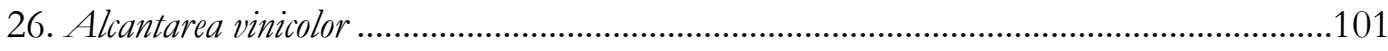

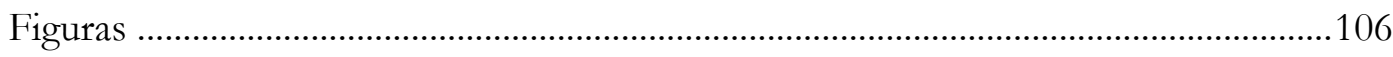

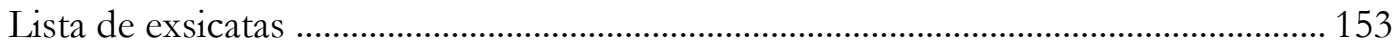

Capítulo 2. Molecular phylogeny of AlCantarea (Bromeliaceae)

BASED ON DNA SEQUENCES AND MICROSSATELITE LOCI INDICATES THE MONOPHYLY OF THE GENUS AND SUGGESTS INTERSPECIFIC

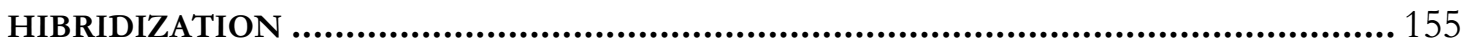

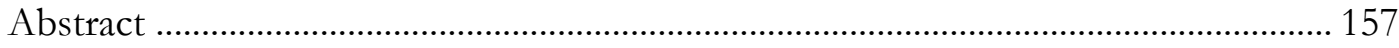

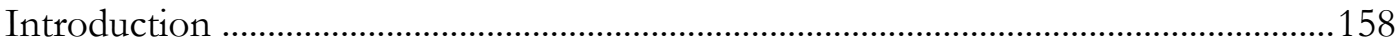

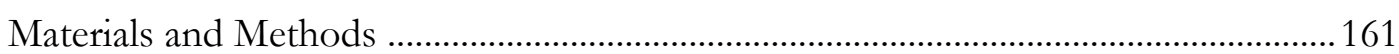

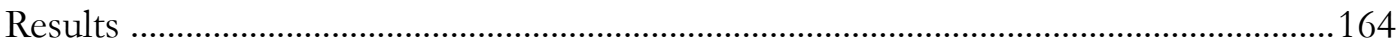

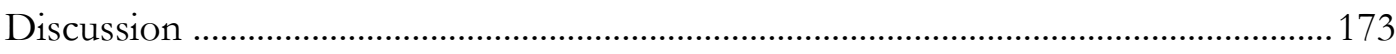

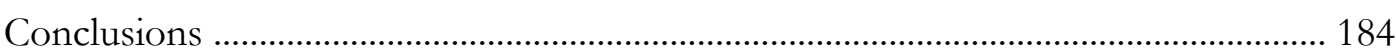

Capítulo 3. Delimitation of THE AlCANTAREA EXTENSA COMPLEX

(BROMELIACEAE) AND ONE NEW SPECIES FROM ESPÍRITO SANTO, BRAZIL ........... 193

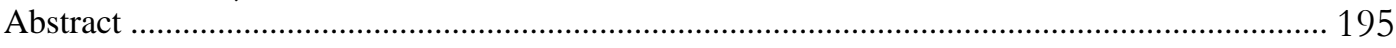

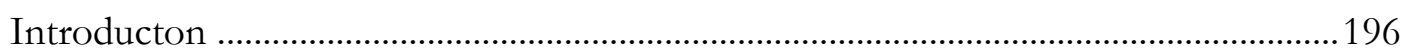

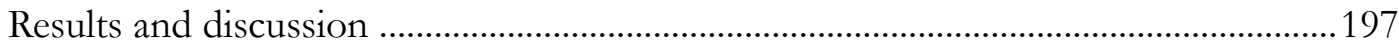

\section{Capítulo 4. AlcaNtarea (Bromeliaceae) LEAF ANATOMical \\ CHARACTERIZATION AND ITS SYSTEMATICS}

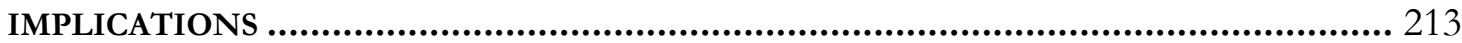

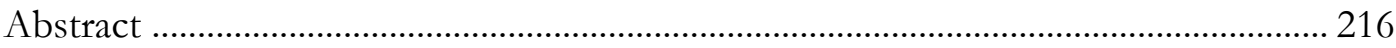

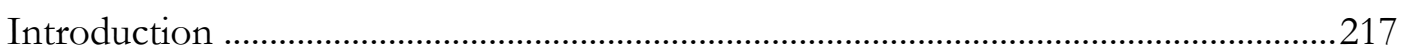

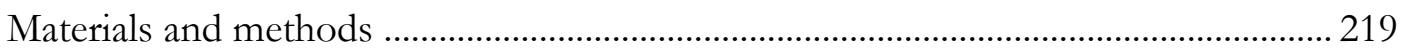

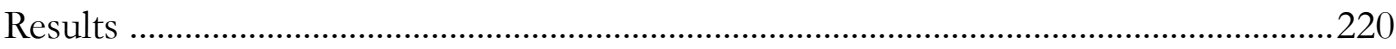

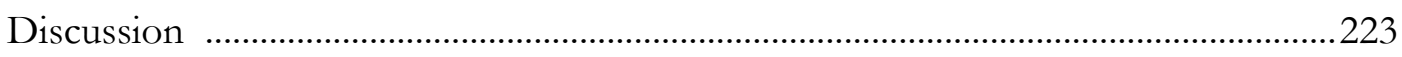

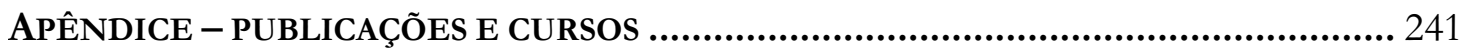




\section{RESUMO}

VERSIEUX, L.M. Sistemática, filogenia e morfologia de Alcantarea (Bromeliaceae). 2009. Tese (Doutorado) Instituto de Biociências, Universidade de São Paulo, São Paulo, 2009.

Esta tese compreende a revisão taxonômica, filogenia e morfologia do gênero Alcantarea (E. Morren ex Mez) Harms, bromeliáceas rupícolas endêmicas dos afloramentos rochosos do leste do Brasil. Apresenta-se inicialmente uma caracterização geral de Bromeliaceae, os objetivos e justificativas da tese, que segue estruturada em capítulos. O capítulo 1 apresenta a caracterização morfológica e a revisão do gênero baseada nos trabalhos de campo, de herbários e bibliografia. São apresentadas as descrições para as espécies, chave para identificação, ilustrações, mapa de distribuição e estado de conservação dos táxons. Entre os resultados desse capítulo destaca-se que são reconhecidas 26 espécies, sendo cinco novas e descritas pelo autor no decorrer do projeto (A. martinellii Versieux \& Wand., A. patriae Versieux \& Wand., A. tortuosa Versieux \& Wand., A. trepida Versieux \& Wand., $A$. turgida Versieux \& Wand.), quatro novos sinônimos são apresentados (A. brasiliana (L.B. Sm.) J.R. Grant, A. edmundoi (Leme) J.R. Grant, A. lurida Leme, A. mucilaginosa Leme) e um neótipo é designado. Em quase sua totalidade os táxons estão individualmente ilustrados em detalhe e são também apresentadas pranchas fotográficas. Amplo material foi coletado e incorporado aos herbários e uma coleção-viva foi montada no Instituto de Botânica. Apesar de geralmente formarem grandes populações em locais de difícil acesso, seis táxons são considerados ameaçados de extinção em razão de áreas de ocorrência restritas e por perda do habitat e para seis espécies não foi possível determinar o estado de conservação em razão de insuficiência de dados. No capítulo 2 é apresentada a filogenia de Alcantarea baseada em caracteres

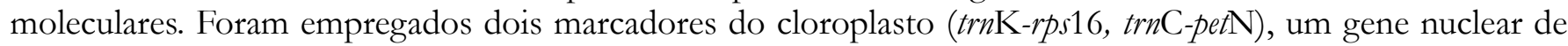
baixa cópia (Floricaula/Leafy) e também 20 loci de microssatélites nucleares. Os resultados obtidos nas análises Bayesianas e de Parcimônia apontam para o bem suportado monofiletismo de Alcantarea. Nesta análise Alcantarea surge como grupo-irmão das espécies de Vriesea do leste do Brasil. Entre os marcadores, o Floricaula/Leafy apresenta os melhores resultados e se mostra com uma região potencial para outros estudos com Bromeliaceae. Os microssatélites delimitam grupos de espécies, com forte correspondência biogeográfica e também sugerem que a hibridização interespecífica seja um fenômeno freqüente em Alcantarea, sendo observados indivíduos de uma mesma espécie aparecendo proximamente relacionados a grupos díspares. No capítulo 3 é delimitado o complexo "Alcantarea extensa" com ocorrência predominante no Espírito Santo e ao leste de Minas Gerais, sendo esse complexo corroborado pelos dados dos microssatélites (cap. 2). São pelo menos 10 táxons que apresentam pouca variação na morfologia floral, vegetativa e proximidade geográfica entre as populações. Ainda neste capítulo é apresentada a ocorrência de viviparidade nos frutos de Alcantarea e uma nova espécie é descrita. No capítulo 4 é apresentada a caracterização morfo-anatômica foliar. Várias das características anatômicas observadas contribuem para a sobrevivência em ambientes xéricos (campo rupestre/inselbergs). Entre elas destacam-se a epiderme com paredes espessadas, abundante cobertura de ceras epicuticulares, hipoderme mecânica, parênquima aqüífero, parênquima esponjoso preenchendo canais de ar estreitos e estômatos restritos à face abaxial. Os dados obtidos nos capítulos 1, 2 e 4 serviram de base para decisão de manter Alcantarea como gênero distinto, independente de Vriesea. Os caracteres moleculares indicam que se trata de um grupo monofilético bem suportado e irmão de Vriesea s.s. O histórico taxonômico; a morfologia das pétalas longas, liguladas, espiraladas e efêmeras; as sementes bicomosas; a posição do ovário semi-ínfero também sustentam tal segregação. Em adição, os caracteres diagnósticos disponíveis para o caso da união de Alcantarea e V risea são inconsistente e baseados exclusivamente em simplesiomorfias. Sugere-se o potencial dos caracteres anatômicos tais como a extensão do parênquima aqǘf́ero, o formato dos canais de ar, a extensão das projeções das fibras do feixe vascular, que conferem nervuras mais salientes, e a presença de nectários septais mais desenvolvidos como características adicionais,facilmente observáveis e que separam tais gêneros.

Palavras-chave: anatomia foliar, campo rupestre, conservação, inselberg, mata atlântica, revisão taxonômica. 


\begin{abstract}
Versieux, L.M. Systematics, phylogeny, and morphology of Alcantarea (Bromeliaceae). 2009. Tese (Doutorado) - Instituto de Biociências, Universidade de São Paulo, São Paulo, 2009.

This thesis comprises the taxonomic revision, phylogeny, and morphology of the genus Alcantarea (E. Morren ex Mez) Harms, composed of rupiculous bromeliads endemic to eastern Brazil rock outcrops. An overall characterization of Bromeliaceae is presented initially then followed by the objectives and justification of the thesis, which is structured in chapters. Chapter 1 presents the morphological characterization and revision of the genus based in field, herbaria and bibliography. Species descriptions, identification key, map and taxa conservation statuses are presented. The highlight results of this chapter are that 26 species are recognized, five of them being new and described by the author during the project $(A$. martinellii Versieux \& Wand., A. patriae Versieux \& Wand., A. tortuosa Versieux \& Wand., A. trepida Versieux \& Wand., A. turgida Versieux \& Wand.), four new synonyms are presented (A. brasiliana (L.B. Sm.) J.R. Grant, A. edmundoi (Leme) J.R. Grant, A. lurida Leme, A. mucilaginosa Leme), and one neotype is designated. Almost all taxa are illustrated in detail, and photographic plates are also presented. A large number of specimens were collected and incorporated in herbaria and a living-collection was built at the Instituto de Botânica. In spite of usually forming large populations in difficult to access places six taxa are threatened of extinction due to restricted occurrence areas and habitat loss. In addition, it was not possible to determine conservation statuses for six species due to data deficiency. In Chapter 2 the molecular phylogeny of Alcantarea is presented. Two chloroplast markers $(\operatorname{trnK}-r p s 16, \operatorname{trn} \mathrm{C}-p e t \mathrm{~N})$, one low copy nuclear gene (Floricaula/Leafy), and also 20 nuclear microsatellites loci were employed. Results point to a well supported monophyly of Alcantarea, in both bayesian and parsimony analyses. In these analyses Alcantarea emerges as the sister genus of eastern Brazilian Vriesea. Floricaula/Leafy provides better resolution and is recommended for future studies within Bromeliaceae. Microsatellites delimit species groups with strong biogeographic correspondence and also suggest that hybridization is frequent, once individuals of the same species appear closely related to different species groups. In chapter 3, a species complex predominantly from Espírito Santo and eastern Minas Gerais States is delimited and named "Alcantarea extensa complex" and its status as a complex is supported by microsatellite analysis (Ch. 2). At least 10 taxa that show low floral and vegetative morphological variation and posses geographic proximity among populations are included in this complex. A new species and viviparous seeds in Alcantarea fruit are also described in this chapter. Leaf anatomical characterization for nine species of Alcantarea is presented in chapter 4. Several of the observed features contribute to the survival of Alcantarea in xeric environments (campo rupestre/inselbergs) as the thick-walled epidermis, abundant covering of epicuticular waxes, mechanic hypodermis, aquiferous parenchyma, narrow air-lacunae filled up with the spongy parenchyma, and stomata restricted to the abaxial surface. Data obtained in chapters 1, 2, and 4 provided evidence to keep Alcantarea as a distinct genus, independent from Vriesea. Molecular data indicate that it is a monophyletic and well supported group sister of Vriesea s.s. The taxonomic history; the morphological distinctiveness of the long, ligulate, spiraled and ephemeron petals; seeds with basal and apical appendages and semi-inferior ovary also support this segregation. In addition, diagnostic characters available for the recognition of Alcantarea and Vrisea united are inconsistent and based on sympleisiomorphies exclusively. It is also suggested that the anatomical features such as the extension of the aquiferous parenchyma, the shape of the air channels and the extensions of the fibers bundles that forms more salient nerves and the presence of more developed septal nectaries are additional useful features to separate both taxa.
\end{abstract}

Key words: Atlantic forest, campo rupestre, conservation, inselberg, leaf anatomy, taxonomic revision. 


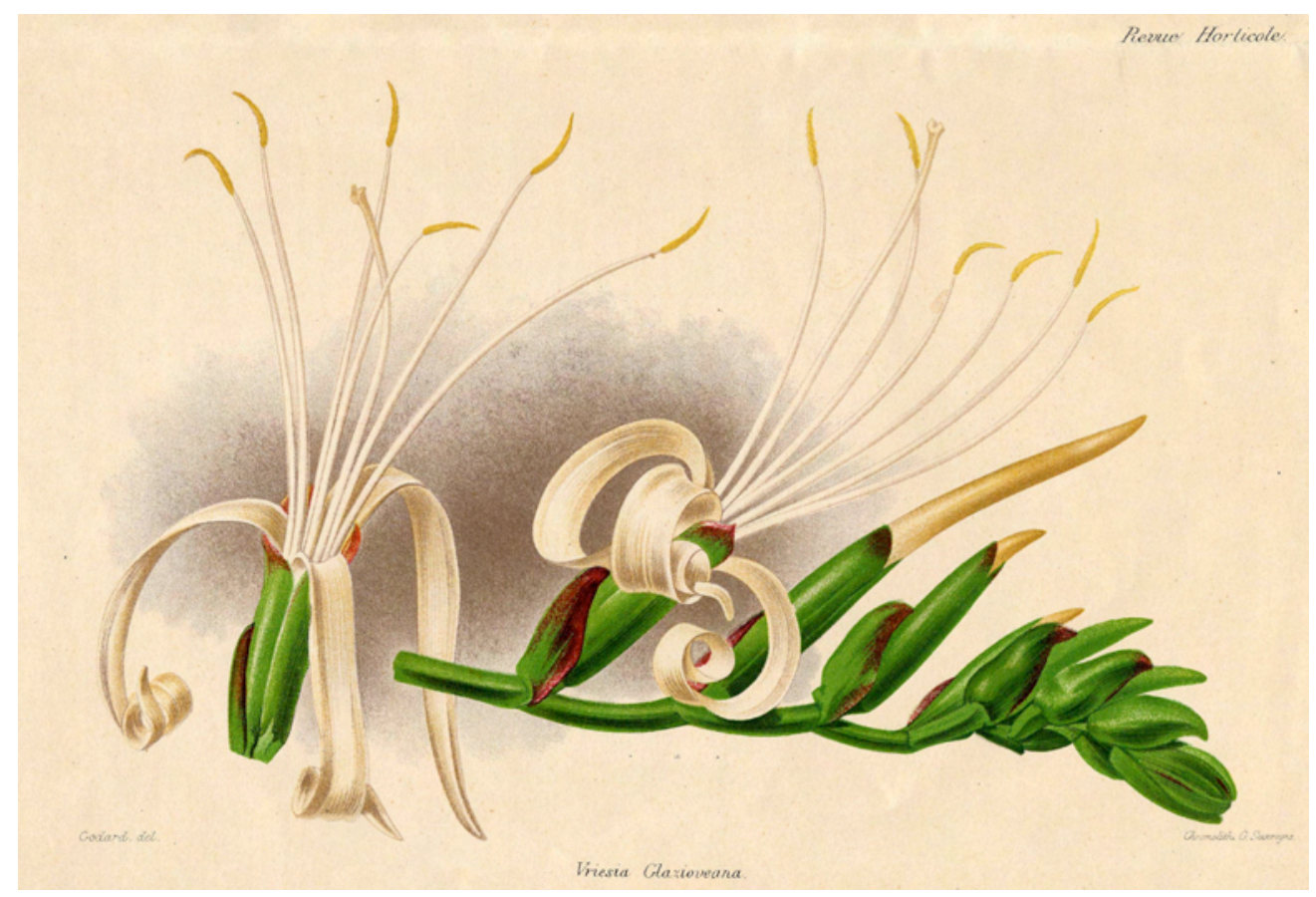

INTRODUÇÃO GERAL

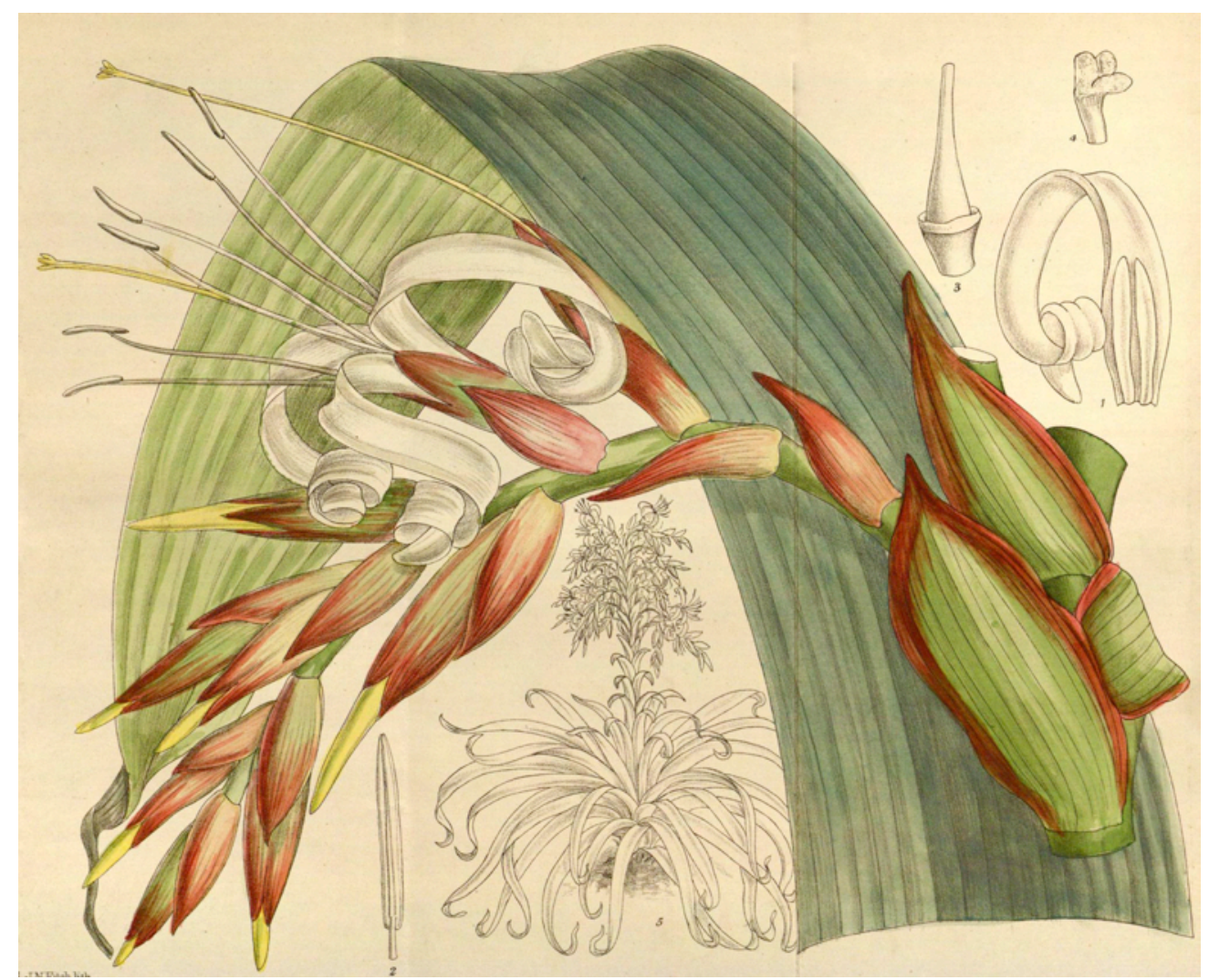


ILUSTRAÇÕES DA PÁGINA ANTERIOR: Ao alto, Alcantarea imperialis, identificada como Vriesea glazioveana (Carrière, 1881). Em baixo, Alcantarea aff. imperialis, identificada como Tillandsia regina (Wright, 1915). Nos séc. XIX e XX, Alcantarea já era amplamente cultivada nos grandes jardins botânicos europeus. 


\title{
INTRODUÇÃO GERAL
}

\author{
A FAMÍLIA BROMELIACEAE
}

Bromeliaceae Juss. inclui cerca de 58 gêneros e 3200 espécies, que se distribuem do leste do estado da Virginia ao Texas, nos EUA, por toda a América Central, Índias Ocidentais e América do Sul até à Patagônia e entre a costa do Brasil e as ilhas de Juan Fernández, a cerca de $500 \mathrm{~km}$ a oeste da costa do Chile. A única exceção a essa distribuição estritamente americana é registrada pela espécie Pitcairnia feliciana (A. Chevalier) Harms \& Mildbraed na costa oeste do continente africano, na Guiné, disjunção atribuída a uma dispersão a longa distância recente (Smith 1934; Smith \& Downs 1974; Jacques-Felix 2000; Luther 2008; Givnish et al. 2007).

Em virtude de ser facilmente reconhecida e bastante distinta das demais monocotiledôneas, Bromeliaceae já foi considerada uma família isolada e de relacionamentos incertos, classificada por alguns autores na ordem Bromeliales (Cronquist 1981; Dahlgren et al. 1985; Judd et al. 1999). No que se refere aos seus parentes mais próximos, com base morfológica, essa família já foi relacionada a grupos díspares, tais como Agavaceae, Velloziaceae, Zingiberales, sem se chegar a um consenso (Clark et al. 1993).

Entre as características que fazem Bromeliaceae ser tão singular, incluem-se a formação de roseta, a predominância da forma de vida epífita, a presença de escamas foliares especializadas à absorção de umidade e nutrientes, os estigmas espiral-conduplicados e o número básico de cromossomos $(x)$ igual a 25 , podendo as duas últimas características variar entre os diferentes gêneros (Marchant 1967; Cronquist 1981; Dahlgren et al. 1985; Gilmartin \& Brown 1987). Algumas dessas características, com forte valor adaptativo, como a roseta e as escamas absortivas, associadas à fotossíntese do tipo CAM, são consideradas inovações-chave para o processo de diversificação ou radiação adaptativa e colonização de ampla gama de ambientes (Benzing 2000; Crayn 2004).

Nos trabalhos de filogenia mais recentes, que utilizam dados moleculares, Bromeliaceae é sempre considerada monofilética (Ranker et al. 1990; Terry et al. 1997; Barfuss et al. 2005; Givnish et al. 2007) e integra a ordem Poales (APG II 2003). Os parentescos de Bromeliaceae com os demais membros das Poales ainda são motivos de controvérsia, porém a presença de nectários septais e de flores epíginas a difere das demais famílias dessa ordem (Sajo et al. 2004). Para Bremer (2000), o grupo-irmão das bromélias seria Rapateaceae, relacionamento já proposto por autores do início do séc. XX (cf. Smith 1934 e referências lá citadas). Outros trabalhos (Bremer 2002; Givnish et al. 2004; 2007) apontam para Typhaceae. Entretanto, hipóteses diferentes vem surgindo (e.g. Chase et al. 2006), nas quais Bromeliaceae seria a primeira família a emergir isoladamente no clado Poales, seguida por Typhaceae e Rapateaceae. Apesar desta questão permanecer em aberto, todas as evidências indicam para um posicionamento pleisiomórfico para Bromeliaceae, que juntamente com Typhaceae e 
Rapateaceae constituem um grado denominado Poales basais (Linder \& Rudall 2005; Soltis et al. 2005) com idades estimadas entre 110 a 80 milhões de anos (Bremer 2000; Givnish 2004).

O histórico de classificação infrafamiliar apresenta mudanças graduais. Beer (1857) ao monografar a família a subdivide em três grupos ("Hauptabtheilung”: Bromelieae, Ananassaeae e Diaphoranthemeae) com base na morfologia das inflorescências. Em 1888, Wittmack reconheceu quatro tribos: I. Bromelieae, II. Pitcairnieae, III. Puyae e IV. Tillandsieae. Os autores subseqüentes sinonimizaram Puyae em Pitcairnieae até que em 1930, Hermann Harms elevou as três tribos remanescentes ao status de subfamília. Essa última classificação em três subfamílias foi tradicionalmente empregada ao longo do séc. XX, sendo aceita, até então, uma polaridade na evolução desses taxa, partindo de Pitcairnioideae, passando por Tillandsioideae e chegando-se à especializada Bromelioideae, em virtude de diferenças na posição do ovário, tipo de fruto, de semente, de indumento, de margem foliar além da forma de vida (Smith \& Downs 1974, 1977, 1979; Smith \& Till 1998).

Todavia, ao se analisar as três subfamílias com métodos cladísticos, nenhuma hipótese evolutiva robusta e unânime foi gerada para elucidar o parentesco entre tais grupos (Brown 2000), o que talvez seja explicado pelas diferentes amostragens empregadas e pelo fato da subfamília Pitcairnioideae s.l. ser considerada polifilética. Atualmente, ao invés de três, são admitidas oito subfamílias, sendo que Bromelioideae e Tillandsioideae se mantêm como grupos monofiléticos (Terry et al. 1997; Crayn 2004; Givnish 2007) e Pitcainioideae é segregada em seis subfamílias, sendo uma Pitcairnioideae s.s., quatro novas e Navioideae Harms é re-estabelecida (Givnish et al. 2007).

O grande desafio da sistemática da família trata-se agora da investigação da circunscrição e da compreensão do parentesco dos gêneros, especialmente em Bromelioideae e Tillandsioideae, bem como dos relacionamentos infragenéricos (Terry et al. 1997; Smith \& Till 1998; Brown 2000; Costa 2002; Faria et al. 2004).

Quanto a importância econômica e usos, algumas espécies são citadas, como o Ananas comosus (L.) Merrill, o popular abacaxi, fonte de frutos e também de uma enzima proteolítica, a bromelina, que é extraída do pedúnculo e utilizada na indústria farmacêutica e de alimentos. Também são reportadas para o abacaxi propriedades medicinais, como anti-helmíntico e estomático, sendo preparados sucos ou vinhos a partir dos frutos (Mez 1894). Neoglaziovia variegata (Arruda) Câmara, conhecido como caroá, assim como Ananas spp. e Tillandsia usneoides L. (crina vegetal) são empregadas como fontes de fibras naturais (Mez 1894). O interesse pela horticultura das Bromeliaceae é secular (Smith 1955). Atualmente, em todo o mundo várias espécies de bromélias são colecionadas como plantas ornamentais, existindo numerosas associações que congregam aficionados. São empregadas como plantas de vaso, jardins e, em pequena escala, são cultivadas como flores de corte (Rauh 1990).

Uma das maiores importâncias da família está relacionada com as amplas interações ecológicas, nas quais muitas bromélias participam como espécies-chave, nos ambientes onde vivem. 
Bromeliaceae é indicada como a família mais importante no fornecimento de néctar volumoso e concentrado para mais de 35\% das espécies de beija-flores da mata atlântica brasileira (Buzato et al. 2000) e em ambientes extremos e periféricos à mata atlântica (e.g. mangues, campos de altitude, restingas) as Bromeliaceae criam micro-ambientes mais propícios ao estabelicimento e crescimento de outras espécies vegetais, sendo então chamadas de "nurse-plants" (Scarano 2002). Além disso, grande parte das espécies apresentam fitotelma (tanque), uma cavidade formada em virtude da sobreposição das bainhas foliares imbricadas que, quando preenchido pela água das chuvas e colonizado por organismos aquáticos, recebe o nome de fitotelmata (Benzing 2000). Tais fitotelmatas disponibilizam água e nutrientes para outros organismos, muitas vezes vertebrados, nos dosséis das florestas tropicais, assim como em ambientes xéricos, como campos rupestres, inselbergs e restingas. Deste modo, muitas vezes as bromélias são consideradas amplificadoras da biodiversidade, não sendo raro encontrar publicações recentes (e.g. Foissner et al. 2003) onde dezenas de novas espécies de organismos são descritas a partir de um inventário mais detalhado dos fitotelmatas.

\section{CARACTERIZAÇÃO MORFOLÓGICA}

Bromeliaceae caracteriza-se por reunir plantas herbáceas, raras vezes com portes arborescentes ou arbustivos (Puya spp., Deuterocohnia spp.), epífitas, rupícolas ou terrícolas, com caules geralmente pouco desenvolvidos, folhas alternas, espiraladas, recobertas por tricomas especializados (escamas foliares, escamas peltadas, tricomas peltados), em geral formando uma roseta (Cronquist 1981; Dahlgren et al. 1985; Smith \& Till 1998).

A margem foliar é inteira ou espinescente e as bainhas foliares são geralmente alargadas. As inflorescências são racemosas, dispostas em espigas, panículas ou as flores são solitárias, em geral, terminais, partindo do interior da roseta e sustentadas por um pedúnculo (ou escapo), que freqüentemente apresenta brácteas vistosas. O pedúnculo pode ser curto, quase ausente, caracterizando as inflorescências capituliformes. As flores são bissexuais, raramente funcionalmente unissexuais, actinomorfas ou levemente zigomorfas, trímeras, variando de hipóginas a epíginas, subtendidas por uma bráctea floral, em geral, vistosa (Cronquist 1981; Dahlgren et al. 1985).

As sépalas são livres ou conatas, em geral, verdes, algumas vezes com textura petalóide. As pétalas são livres ou conatas, alvacenta ou de cores diversas, como amarelada, azulada, avermelhada, alaranjada, esverdeada, rosada ou vinosa. Alguns táxons apresentam um par de apêndices basais na face interna das pétalas, que pode apresentar a função de proteção do néctar. Os estames estão distribuídos em dois verticilos quase que indistintos $(3+3)$, geralmente livres, raramente adnatos à corola ou conatos, formando um tubo. As anteras são tetrasporângiadas, bitecas com deiscência rimosa (Cronquist 1981; Dahlgren et al. 1985).

Os grãos de pólen podem ser monocolpados, porados e inaperturados (Wanderley \& Melhem 
1991; Halbritter 1992).

O gineceu é composto por três carpelos unidos, ovário trilocular, súpero, ínfero ou semiínfero, com nectários septais sempre presentes. O estilete é terminal com estigma, em geral, trífido, sendo que os ramos ou lobos estigmáticos apresentam, comumente, um arranjo contorcido (espiralconduplicados), com bordas papilares e superfície estigmática úmida, ou mais raramente seca (Smith \& Till 1998).

Os óvulos são escassos ou numerosos com placentação axilar, anátropos ou raramente campilótropos, crassinucelados, bitegumentados com endosperma helobial. O tipo de fruto varia de cápsula septicida, loculicida, baga, ou fruto composto (Ananas). As sementes são, em geral, pequenas sendo aladas ou plumosas nas de frutos capsulares. O tamanho do embrião varia, em geral é pequeno cilíndrico e de posicionamento basal, periférico ou axilar em relação ao endosperma, que é rico em grãos de amido e apresenta lipídios e aleurona na periferia (Cronquist 1981; Dahlgren et al. 1985).

O número básico de cromossomos $(x=25)$ é relativamente constante nas três subfamílias (Marchant 1967; Ceita 2008) constituindo uma sinapomorfia de Bromeliaceae (Brown \& Gilmartin 1989a), porém também há registros de poliplóides e aneupoliplóides.

São citadas como potenciais sinapomorfias morfológicas da família a presença de escamas foliares e de estigmas do tipo conduplical-espiralados (Smith \& Till, 1998).

Os membros da família são adaptados à polinização por aves (predominantemente Trochilidae), morcegos, insetos (Hymenoptera ou Lepidoptera) ou pelo vento (Smith \& Till, 1998).

\section{ESCOLHA DO TEMA}

A escolha de Alcantarea como objeto de estudo desta tese levou em consideração, primordialmente, tratar-se de um gênero brasileiro praticamente endêmico da mata atlântica, bioma considerado um hotspot e com mais de $90 \%$ de área original já devastados, apesar da flora ainda ser pouco conhecida (Fonseca et al. 2004). Outros aspectos discutidos abaixo também nos guiaram nesta seleção:

Falta de conbecimento taxonômico do gênero. O trabalho de Smith \& Donws (1977) é a referência mais recente para identificação das espécies de Alcantarea. Após a publicação desta obra, espécies novas vem sendo periodicamente descritas, mostrando o desconhecimento deste gênero. Além disso, uma chave atualizada, bem como uma publicação mais aprofundada sobre a morfologia do grupo são necessárias, uma vez que já foi dado ênfase a existência de complexos de espécies no gênero (Versieux $\&$ Wendt 2006).

Sistemática. A delimitação de gêneros dentro da subfamília Tillandsioideae ainda é insuficientemente compreendida e considerada pouco consistente (Smith \& Downs 1979; Barfuss et al. 2005). São diversos os trabalhos que propõem novas combinações ao nível genérico, porém 
poucas dessas alterações são baseadas em metodologia filogenética ou apresentam dados morfológicos novos que realmente corroborem as hipóteses e acrescentem, de fato, informações relevantes ao progresso do entendimento da evolução da família. Novas abordagens para as delimitações genéricas em Bromeliaceae tem sido feitas recentemente, lançando mão de filogenias moleculares (Terry et al. 1997; Horres et al. 2000; Barfuss et al. 2005; Schulte et al. 2009) e do emprego de caracteres morfológicos florais e vegetativos pouco explorados em análises prévias, observáveis apenas em materiais frescos ou conservados em líquido (e.g. Faria et al. 2004; Sousa 2004). Em uma análise com caracteres moleculares de diferentes representantes da subfamília Tillandsioideae apresentada por Barfuss et al. (2005), o gênero Alcantarea se mostrou monofilético, embora esteja representado por apenas duas espécies. Nessa análise, Alcantarea emergiu como um clado dentro de Vriesea, que se mostrou um gênero parafilético. Visto haver uma longa controvérsia quanto à aceitação ou não do status de gênero para Alcantarea, é fundamental uma análise filogenética conjunta com Vriesea, com uma amostragem o mais completa possível.

Conservação. Apesar dos representantes de Alcantarea freqüentemente formarem extensas populações, medidas de conservação para alguns táxons são necessárias. Muitas espécies desse gênero apresentam área de distribuição restrita, sem ocorrência em unidades de conservação (Versieux \& Wendt 2007). Alcantarea duarteana (L.B. Sm.) J.R. Grant é conhecida, apenas, no planalto de Diamantina, na serra do Espinhaço, em Minas Gerais (Versieux \& Wendt 2007), enquanto outros exemplos de distribuição restrita e pontual são $A$. farneyi dos campos de altitude do município de Santa Maria Madalena e $A$. martinellii, exclusiva de Petrópolis. Por ser um gênero de grande potencial ornamental, algumas espécies sofrem freqüentemente com o extrativismo para fins comerciais, não sendo raras as apreensões de indivíduos adultos ilegalmente arrancados do seu habitat, inclusive de dentro de Parques Nacionais (Parque Nacional Serra dos Órgãos, com. pes.). Essa remoção de indivíduos adultos compromete a dinâmica das populações, tendo em vista o longo tempo que levam para atingir a maturidade nos ambientes oligotróficos em que vivem.

Carência de coleções. Como já bem relatado na literatura científica de Bromeliaceae, em geral espécies de grande porte são pouco amostradas nas coleções de herbário. O mesmo parece ocorrer em outras famílias de monocotiledôneas com representante de grande porte e de difícil herborização. Em Alcantarea, além das grandes dimensões da inflorescência e folhas, o acesso ao habitat, frequentemente paredões rochosos, associado às florações concentradas nos meses mais chuvosos, são agravantes adicionais para a coleta. Em uma análise inicial constatamos que os poucos materiais disponíveis nos herbários representavam, em geral, um pequeno número de espécies. Soma-se a isso o fato da maioria dos espécimes apresentar poucos detalhes (cores, dimensões, etc.) nas etiquetas, além das dificuldades no entendimento e análise dos caracteres florais após a herborização. $\mathrm{O}$ aumento do esforço amostral, a obtenção de dados completos durante a coleta (medidas, fotografias, anotações), assim como a preservação de flores em meio líquido e o cultivo ex situ são cuidados 
necessários à um trabalho que permita a maior compreensão da morfologia e caracterização dos táxons deste grupo.

Importância econômica e ecológica. Muitas espécies de Alcantarea vem sendo frequentemente empregadas por paisagistas como plantas ornamentais em jardins, com destaque para a Alcantarea imperialis (bromélia-imperial). Nota-se um grande interesse, também, de colecionadores de diferentes partes do mundo em cultivar essas plantas. Mas talvez a maior importância apresentada pelo gênero refira-se ao seu papel ecológico dentro das comunidades onde ocorre, visto que a água que fica disponibilizada nos fitotelmas, constitui uma reserva segura para invertebrados e vertebrados que habitam os inselbergs. A temperatura na superfície rochosa no inselbergs pode atingir os $61.5{ }^{\circ} \mathrm{C}$ (Carauta and Oliveira 1984). Constata-se, então, a importância que tem as grandes populações de Alcantarea, comuns em tais ambientes, algumas vezes com milhares de indivíduos que podem armazenar até 40 litros d'água por roseta (Martinelli 1997).

Bromélias versus dengue. Nas últimas décadas, um grande debate se instalou na comunidade científica em torno da importância das bromélias acumuladoras de água como locais de procriação de mosquitos (e.g. Aragão 1968; Reitz 1983; Lounibos et al. 2003), principalmente do transmissor da dengue (Aedes aegypti). Alcantarea inclui as bromélias brasileiras que mais acumulam água nos tanques. Coincidentemente, também são as mais empregadas em paisagismo e formam extensas populações em afloramentos rochosos dentro das áreas urbanas (e.g. Rio de Janeiro, Nova Friburgo). A literatura científica aponta para a ocorrência de larvas dos mosquitos da dengue em tanques de Alcantarea (Gonçalves \& Messias 2008), entretanto a importância das bromélias como local de procriação de tais vetores parece ser pequena em porcentagem, correspondendo à $1.5 \%$ das capturas, quando comparada a criadouros artificiais, como ralos, garrafas e pratos de vasos de planta, que concentram quase $70 \%$ das ocorrências (Silva et al. 2006). Assim, Alcantarea pode representar um veículo epidemiológico, caso seja comprovada sua ligação com a ocorrência do mosquito transmissor da dengue. O conhecimento da sistemática e da distribuição geográfica do grupo pode contribuir com novos dados para a discussão relativa à essa epidemia. 


\section{OBJETIVOS GERAIS}

Aprofundar o conhecimento sistemático da subfamília Tillandsioideae buscando novas evidências para uma classificação mais estável para Bromeliaceae como um todo. Ampliar as coleções científicas dos herbários nacionais, de forma que dados novos estejam disponíveis, não só para o presente trabalho, como também para investigações futuras. Formar recurso humano capacitado a desenvolver pesquisa e docência através do uso das novas técnicas aplicadas à botânica contemporânea.

\section{OBJETIVOS ESPECÍFICOS}

Realizar a revisão do gênero Alcantarea sob o aspecto morfológico, visando estabelecer a circunscrição mais precisa para as espécies, assim como elucidar problemas taxonômicos evidenciados no gênero.

Analisar o estado de conservação dos táxons a partir do estudo das populações, dos padrões de distribuição geográfica e do diagnóstico da pressão antrópica existente.

Reavaliar os caracteres diagnósticos do gênero com base no estudo morfológico detalhado.

Reconstruir a filogenia de Alcantarea através caracteres moleculares do núcleo e cloroplasto. 


\section{LITERATURA CITADA}

APG II. 2003. An update of the angiosperm phylogeny group classification for the orders and families of flowering plants: APG II. Botanical Journal of the Linnean Society 141: 399-436.

Aragão, M. B. 1968. Sobre a distribuição vertical dos criadouros de Anopheles do subgênero Kertesžia, no sul do Brasil. Memórias do Instituto Oswaldo Cruz 66: 131-144.

Barfuss, M. H. J., R. Samuel, W. Till, and T. F. Stuessy. 2005. Phylogenetic relationships in subfamily Tillandsioideae (Bromeliaceae) based on DNA sequence data from seven plastid regions. American Journal of Botany 92: 337-351.

Beer, J. G. 1857. Die Familie der Bromeliaceen nach ibrem babituellen charakter bearbeitet mit bersonderer berücksichtigung der Ananassa. Wien: Tendler \& Comp. 271p.

Benzing, D. H. 2000. Bromeliaceae: profile of an adaptive radiation. Cambridge, United Kingdom: Cambridge University Press.

Bremer, K. 2000. Early Cretaceous lineages of monocot flowering plants. Proceedings of the National Academy of Sciences 97: 4707-4711.

- 2002. Gondwanan evolution of the grass alliance of families (Poales). Evolution 56: 1374-1387.

Brown, G. K. 2000. Dados moleculares em Bromeliaceae. Pp. 198-201 in Nidularium: Bromélias da Mata Atlântica, ed. E. M. C. Leme. Rio de Janeiro: GMT Editores Ltda.

—. and A. J. Gilmartin. 1989. Chromosome numbers in Bromeliaceae. American Journal of Botany 76: 657-665.

Buzato, S., M. Sazima, and I. Sazima. 2000. Hummingbird-pollinated floras at three atlantic forest sites. Biotropica 32: 824-841.

Carauta J. P. P. and Oliveira R. R. 1984. Plantas vasculares dos morros da Urca, Pão de Açúcar e Cara de Cão. Rodriguésia 36: 13-24.

Ceita, G. O., J. G. A. Assis, M. L. S. Guedes, and A. L. P. C. Oliveira. 2008. Cytogenetics of Brazilian species of Bromeliaceae. Botanical Journal of the Linnean Society 158: 189-193.

Chase, M. W., Fay, M. F., Devey, D. S., Maurin, O., Ronsted, N., Davies, T. J., Pillon, Y., Petersen, G., Seberg, O., Tamura, M. N., Asmussen, C. B., Hilu, K., Borsch, T., Davis, J. I., Stevenson, D. W., Pires, J. C., Givnish, T. J., Sytsma, K. J., McPherson, M. A., Graham, S. W., and Rai, H. S. 2006. Multigene analyses of monocot relationships: a summary. Aliso 22: 63-75.

Clark, W. D., B. S. Gaut, M. R. Duvall, and M. T. Clegg. 1993. Phylogenetic relationships of the Bromeliiflorae - Commeliniflorae - Zingiberiflorae complex of monocots based on $r b c \mathrm{~L}$ sequence comparisons. Annals of the Missouri Botanic Garden 80: 987-998.

Costa, A. F. 2002. Revisão taxonômica do complexo Vriesea paraibica Wawra (Bromeliaceae). Ph.D. thesis. São Paulo: Universidade de São Paulo.

Crayn, D. M., K. Winter, and A. C. Smith. 2004. Multiple origins of crassulacean acid metabolism and the epiphytic habit in the Neotropical family Bromeliaceae. Proceeding of the National Academy of Science 101: 3703-3708.

Cronquist, A. 1981. An Integrated System of Classification of Flowering Plants. New York: Columbia University Press.

Dahlgren, R. M. T., H. T. Clifford, and P. F. Yeo. 1985. The families of the monocotiledons: structure, evolution and taxonomy. Berlin: Springer-Verlag.

Faria, A. P. G., T. Wendt, and G. K. Brown. 2004. Cladistics Relationship of Aechmea (Bromeliaceae, Bromelioideae) and allied genera. Annals of the Missouri Botanic Garden 91: 303-319.

Foissner, W., M. S. Struder-Kypke, G. W. M. van der Staay, S. Y. Moon-van der Staay, and H. P. Hackstein, 2003. Endemic ciliates (Protozoa, Ciliophora) from tank bromeliads (Bromeliaceae): a combined morphological, molecular, and ecological study. European Journal of Protistology 39: 365-372.

Fonseca, G. A. B., A. Rylands, A. Paglia and R. A. Mittermeier. 2004. Atlantic Forest. Pp. 84-90 in Hotspots Revisited: Earth's Biologically Richest and Most Endangered Ecoregions. 2 ed. Eds. R. A. Mittermeier, P. R. Gil, M. Hoffmann, J. D. Pilgrim, T. Brooks, C. G. Mittermeier, J. Lamoreux and G. A. B. Fonseca. Cidade do México: CEMEX. 
Gilmartin, A. J. and G. K. Brown. 1987. Bromeliales, related monocots, and resolution of relationships among Bromeliaceae subfamilies. Systematic Botany 12: 493-500.

Givnish, T. J., K. C. Millam, T. M. Evans, J. C. Hall, J. C. Pires, P. E. Berrie, and K. J. Sytsma. 2004. Ancient vicariance or recent long-distance dispersal? Inferences about phylogeny and South American-African disjunctions in Rapateaceae and Bromeliaceae based on $n d h \mathrm{~F}$ sequence data. International Journal of Plant Sciences 165: S35-S54.

—., —., P. E. Berry, and K. J. Sytsma, 2007. Phylogeny, adaptive radiation, and historical biogeography of Bromeliaceae inferred from $n d h F$ sequence data. Aliso 23: 3-26.

Gonçalves, K. S. and Messias, M. T. 2008. Ocorrência de Aedes (Stegomyia) aegypti (Linnaeus, 1762) (Insecta, Diptera, Culicidae) em bromélias, no município do Rio de Janeiro (Rio de Janeiro, Brasil). Biota Neotropica 8: 235-237.

Halbritter, H. 1992. Morphologie und sistematische bedeutung des pollens der Bromeliaceae. Grana 31: 197-212.

Harms, H. 1930. Bromeliaceae. Pp. 65-159 in Die natürlichen Pflanzenfamilien nebst ibren Gattungen und wichtigsten Arten, insbesondere den Nutzpflanzen. Ed. 2, 15a, eds. A. Engler \& K. Prantl. Leipzig: Wilhelm Engelmann.

Horres, R., G. Zizka, G. Kahl, and K. Weising. 2000. Molecular phylogenetics of Bromeliaceae: evidence from trnL (UAA) intron sequences of the chloroplast genome. Plant Biology 2: 306-315.

Jacques-Félix, H. 2000. The discovery of a bromeliad in Africa: Pitcairnia feliciana. Selbyana 21: 118-124.

Judd, W. S., Campbell, C. S., Kellogg, E. A., and Stevens, P. F. 1999. Plant Systematics: a phylogenetic approach. Sunderland: Sinauer Associates, Inc.

Linder, H. P., P. J. Rudall. 2005. Evolutionary history of Poales. Annual Review of Ecology, Evolution, and Systematics 36: 107-24.

Lounibos, L. P., G. F. O’Meara, N. Nishimura, and R. L. Escher. 2003. Interactions with native mosquito larvae regulate the production of Aedes albopictus from bromeliads in Florida. Ecological Entomology 28: 551-558.

Luther, H. E. 2008. An Alphabetical List of Bromeliad Binomials, 11 th ed. The Bromeliad Society International, Inc., Orlando, Florida, USA.

Marchant, C. J. 1967. Chromosome evolution in the Bromeliaceae. Kew Bulletin 21: 161-168.

Martinelli, G. 1997. Biologia reprodutiva de Bromeliaceae na Reserva Ecológica de Macaé de Cima. Pp. 213-250 in Serra de Macaé de Cima: Diversidade Florística e Conservação em Mata Atlântica. eds. H. C. Lima, and R. R. Guedes-Bruni. Rio de Janeiro: Instituto de Pesquisa Jardim Botânico do Rio de Janeiro.

Mez, C. 1894. Bromeliaceae. Pp. 173-643 in Flora Brasiliensis vol. 3, pars 3, eds. C. F. P. Von Martius, A. G. Eichler, and I. Urban. Leipzig: F. Fleischer.

Ranker, T. A., D. E. Soltis, P. S. Soltis, and A. J. Gilmartin. 1990. Subfamilial phylogenetic relationships of the Bromeliaceae: evidence from chloroplast DNA restriction site variation. Systematic Botany 15: 425-434.

Rauh, W. 1979. Bromeliads for Home, Garden and Greenhouse. (Translated by P. Temple and H. L. Harvey) Poole, Great Britain: Blandford Press.

Reitz, R. 1983. Bromeliáceas e a malária - bromélia endêmica. Pp.1-559 in Flora Ilustrada Catarinense. Parte 1, fasc. Brom., ed. R. Reitz. Itajaí: Herbário Barbosa Rodrigues.

Sajo, M. G, Rudall, P. J., and Prychid, C. J. 2004. Floral anatomy of Bromeliaceae, with particular reference to the evolution of epigyny and septal nectaries in commelinid monocots. Plant Systematics and Evolution 247: 215-231.

Scarano, F. R. 2002. Structure, function and floristic relationships of plant communities in stressful habitats marginal to the Brazilian Atlantic rainforest. Annals of Botany 90: 517-524.

Schulte, K., Barfuss, M. H. J, and Zizka, G. 2009. Phylogeny of Bromelioideae (Bromeliaceae) inferred from nuclear and plastid DNA loci reveals the evolution of the tank habit within the subfamily. Molecular Phylogenetics and Evolution 51: 327-339. 
Silva, V. C., Scherer, P. O., Falcão, S. S., Alencar, J., Cunha, S. P., Rodrigues, I. M., Pinheiro, N. L. Diversidade de criadouros e tipos de imóveis freqüentados por Aedes albopictus e Aedes aegypti. Revista de Saúde Pública 40: 1106-1111.

Smith, L. B. 1934. Geographical evidence on the lines of evolution in the Bromeliaceae. Botanische Jahrbücher für Systematik, Pflanzengeschichte und Pflanzengeographie 66: 446-468. 1955. The Bromeliaceae of Brazil. Smithsonian Miscellaneous Collections 126: 1-290.

.and R. J. Downs. 1974. Pitcairnioideae (Bromeliaceae). Flora Neotropica Monograph 14:1-658. and _ 1977. Tillandsioideae (Bromeliaceae). Flora Neotropica Monograph 14: 663-1492.

and — 1979. Bromelioideae (Bromeliaceae). Flora Neotropica Monograph 14: 1493-2142.

—., and Till, W. 1998. Bromeliaceae. Pp. 74-99 in The families and genera of vascular plants, vol. 4, ed. K. Kubitzki. Berlin: Springer Verlag.

Soltis, D. E., P. S. Soltis, P. K. Endress, and M. W. Chase. 2005. Phylogeny and evolution of angiosperms. Sunderland, Massachusetts: Sinauer Associates.

Sousa, G. M. 2004. Revisão taxonômica de Aechmea Ruiz \& Pavon subg. Chevaliera (Gaudich. ex Beer) Baker Bromelioideae-Bromeliaceae. Ph.D. thesis, São Paulo: Universidade de São Paulo.

Terry, R. G., G. K. Brown, and R. G. Olmstead. 1997. Examination of subfamilial phylogeny in Bromeliaceae using comparative sequencing of the plastid locus ndbF. American Journal of Botany 84: 664-670.

Versieux, L. M. and T. Wendt. 2006. Checklist of Bromeliaceae of Minas Gerais, Brazil, with notes on taxonomy and endemism. Selbyana 27: 107-146. . and 2007. Bromeliaceae diversity and conservation in Minas Gerais, Brazil. Biodiversity and Conservation 16: 2989-3009.

Wanderley, M. G. L. and T. S. Melhem. 1991. Flora Polínica da Reserva do Parque Estadual das Fontes do Ipiranga - Família 178 Bromeliaceae. Hoebnea 18: 5-42.

Wittmack, L. 1888. Bromeliaceae. Pp. 32-48. In Die Naturlichen Pflanzenfamilie nebst ibren Gattungen und wichtigeren Arten insbesondere den Nutapflanzen, bearbeitet unter Mitwirkung zablreicher hervorragender Fachgelehrten, ed. 4, bei 2, eds. A. Engler, and K. Prantl. Leipzig: Wilhelm Engelmann. 
"Taxonomy is the most important of the biological sciences. Without the predictive framework of classification developed over the past 2,000 years, human culture as we know it would have been very different and perhaps even still grossly underdeveloped. The need to understand the objects in our environment, both animate and inanimate, and to arrange these into a logical and predictive framework is essential to buman condition and doubtless fundamental to the development of language and of patterns of thinking in general."

TOD STUESSY, 1990.

PLANT TAXONOMY. P. 405

\section{CAPÍTULO 1: SISTEMÁTICA DE ALCANTAREA (BROMELIACEAE)*}

"Any attempt to stultify the buman imagination is bad by definition. We all know perfectly well that we occupy a universe most of which we can never hope fully to understand. But I do not think that we wish to live like ants on the bottom of a bowl, without ever looking up from our daily tasks to see what lies around us. Speculation, imagination, intuition are all precious attributes of the buman mind, and must not be proscribed. Without them even the most severely quantitative sciences would never have gotten off the ground. Since, in my view, systematics is an art as well as a science, these phases of the process of understanding should be welcomed into the general synthesis."

LINCOLN CONSTANCE, 1964. SYSTEMATIC BOTANY. AN UNENDING SYNTHESIS. TAXON 13 (8): 257-273

\footnotetext{
* Manuscrito a ser submetido à revista Systematic Botany Monographs.
} 


\section{SISTEMÁTICA DE ALCANTAREA (BROMELIACEAE)}

AbSTRACT. A monograph of Alcantarea (E. Morren ex Mez) Harms, based on field, herbarium, and library studies is provided. Alcantarea is a genus segregated from Vriesea Lindl. by the presence of linear, long, spiralescent and ephemeral petals, by the seed with both basal and apical appendages, and by the semi-inferior ovary. Three new synonyms are proposed: A. brasiliana (L.B. Sm. \& Read) J.R. Grant, Alcantarea lurida Leme, A. mucilaginosa Leme respectively under A. imperialis (Carrière) Harms, A. turgida Versieux \& Wand., and A. extensa (L.B. Sm) J.R. Grant. One neotype is designated. The genus is endemic to eastern Brazil, occuring on gneiss-granitic inselbergs from Atlantic Forest domain or, more rarely, on quarzite outcrops in the campo rupestre vegetation at the Serra do Espinhaço. All the taxa are obligatory rupicolous and many species stand out by their great dimensions and high capacity to hold a large amount of water in their phytotelma. Several are cultivated in gardens and collected world wide, and in Brazil some taxa are threatened of extinction by the destruction of habitat by fires and mining, and also due to overcollection. Maps, morphological characterization, an identification key and IUCN conservation status for each taxon are presented.

Resumo. A monografia de Alcantarea (E. Morren ex Mez) Harms, baseada em estudos de campo, herbário e biblioteca é apresentada. Alcantarea é um gênero segregado de Vriesea Lindl. com base na presença de pétalas longas, lineares e efêmeras, de sementes comosas na base e no ápice e ovário semi-ínfero. Três espécies são colocadas em sinonímia: A. brasiliana (L.B. Sm. \& Read) J.R. Grant, Alcantarea lurida Leme, A. mucilaginosa Leme sob, respectivamente, $A$. imperialis (Carrière) Harms, $A$. turgida Versieux \& Wand. e A. extensa (L.B. Sm) J.R. Grant. Um neótipo é designado. O gênero é endêmico do leste do Brasil, ocorrendo em inselbergs gneiss-graníticos no domínio da floresta atlântica ou, mais raramente, em afloramentos de quartzito em áreas de campo rupestre na serra do Espinhaço. De forma de vida obrigatoriamente rupícola, as espécies são marcantes pelo grande porte e também pelo elevado volume d'água armazenado nos fitotelmas. Várias espécies possuem grande potencial ornamental e são cultivadas em jardins e colecionadas mundo afora e encontram-se ameaçadas de extinção em razão da destruição do habitat por queimadas, mineração e extrativismo. Mapas, caracterização morfológica, chave de identificação e o estado de conservação (IUCN) para os taxa são apresentados. 


\section{INTRODUÇÃO}

"Cette plante, très majestueuse par son port, d'un aspect grandiose dans son ensemble à l'époque de sa floraison..." E. A. Carrière, 1881. Revue Horticole.

\section{HISTÓRICO TAXONÔMICO}

O nome Alcantarea aparece pela primeira vez em um manuscrito do botânico belga Charles Jacques Édouard Morren (1833-1886). Morren era especialista em Bromeliaceae, com grande experiência no cultivo e introdução de espécies para a horticultura e estabeleceu uma grande coleção de bromélias no Jardim Botânico de Liège. Em suas anotações, atualmente guardadas no herbário de Kew, está registrado seu anseio de criar um gênero que homenageasse o segundo imperador do Brasil, D. Pedro II ou D. Pedro de Alcântara. Tal gênero seria caracterizado por incluir espécies de inflorescência de até 5 metros, do tipo "panicula ramosa", pétalas "ligulatas, elongatas, belicoides, tortas" e "seminis bicomosas" e chamar-se-ia Dalcantarea ou Alcantarea, sem o "D", como lhe sugeriu em correspondência o botânico suiço, Alphonse de Candolle (Fig. 1).

Mas foi a outro botânico, posterior a Morren, que coube a tarefa de efetivar a publicação do nome Alcantarea (Tab. 1). O alemão Carl Christian Mez (1866-1944), em sua monografia de Bromeliaceae para a Flora Brasiliensis (1894) descreve Alcantarea como um subgênero, na copla B da chave de identificação das espécies de Vriesea, como segue:

"Seminis appendicula apicalis (e cauda ovulis prodiens) in pilorum fassem dissoluta. Petala perlonge exserta fasciata, flaccida, saepius spiraliter torta. Flores distiche ordinati...........

Subgenus Alcantarea E. Morr.” (Mez, 1894: 516).

É possível que Mez tenha consultado o manuscrito e as correspondências de Morren e quis publicar Alcantarea apenas com Morren como autor, numa forma respeitosa aos nomina inedita do seu antecessor. Entretanto Mez (loc. cit.) não faz refência ao status hierárquico apresentado no manuscrito original - no qual o nome Alcantarea é tratado como gênero - e também não fornece sua etimologia. Resume-se a dizer que no subgênero estão as espécies de maior tamanho para a família no Brasil ("genus familiae formas fere maxima in Alcantareae subgenere") e apresenta quatro espécies (Vriesea imperialis E. Morr., Vriesea regina Ant., Vriesea geniculata Wawra e descreve V riesea vasta Mez). 
Dois anos após a efetivação do nome Alcantarea, Mez (1896) publica o tratamento para a obra Monographiae Phanerogamarum onde inclui dentro do subgênero Alcantarea outras 2 espécies: Vriesea panniculata e $V$. alta, do Caribe e da América Central, respectivamente.

Apesar do nome Alcantarea ter sido oficialmente publicado por um botânico alemão, muitos anos antes já havia sido descrita por um brasileiro, mineiro, uma espécie de Bromeliaceae rupícola de grande porte, com pétalas longas e flácidas, chamada Tillandsia regina Vellozo. O frei José Mariano da Conceição Vellozo (1742-1811) descreveu na obra Florae Fluminensis de 1825 (data de publicação efetiva 1829, cf. Carauta 1973) uma Bromeliaceae rupícola, de grande dimensões da região de Parati (RJ), conhecida em Latim como Pharmacopolis (Stearn 2004). Nesta época eram comuns as descrições sumárias, o que associado à tábula pouco detalhada apresentada por Vellozo [(1827), data efetiva 1831: Táb. 142)], dificultou o reconhecimento e a correta identificação de Alcantarea regina (=Tillandsia regina). Com base no conhecimento atual é possível ligar a descrição de Vellozo às plantas que ocorrem no costões rochosos na região sul fluminense, cuja ocorrência estende-se pelo litoral norte de São Paulo e Serra da Mantiqueira em Minas Gerais. Entretanto, ao longo do tempo, nota-se que tal espécie foi fonte de muitas controvérsias e dúvidas, tendo sua circunscrição revista e re-estabelecida apenas recentemente (Versieux \& Wanderley 2007).

Beer (1857) pronuncia-se sobre a espécie de Vellozo, da seguinte forma: "Diese pflanze ist nur ihrem Blüthenstande nach bier anzuführen. Da aber die Zeichnung vollständig unverständlich, auch keine Beschreibung vorhanden ist, begnüge ich mich damit, selbe nur namentlich an₹uführen". "Esta planta foi posicionada aqui em razão de sua inflorescência. A ilustração é completamente incompreensível e também falta uma descrição. Esta aí o por quê de deixá-la aqui, apenas listando o seu nome.” (tradução nossa)

Wawra (1883), cria três seções dentro de Vriesea, reunindo dentro da seção Reginae a Tillandsia regina de Vellozo, assim como as outras três espécies de inflorescência paniculada, pétalas estreitoespatuladas com apêndices obovais, estigma globoso levemente trissulcado e estames exsertos, na qual incluiu a: Vriesea regina Beer, V. regina var. glazionana Wawra, V. gracilis Gaud. V. philippo-coburgi Wawra, V. morreni Wawra, V. morreni var. disticha Wawra.

Baker (1889), que também teve acesso ao manuscrito e ilustrações de Morren, que foram comprados por Kew, publicou a etimologia do nome Alcantarea, porém tratou as espécies dentro do gênero Tillandsia, amplamente circunscrito. $\mathrm{Na}$ mesma obra Baker afirma que o tipo do subgênero Alcantarea E. Morren seria Tillandsia regina Vellozo.

Mez (1896) monografa Bromeliaceae para a série Monographie Phanerogamarum, e trata Alcantarea como subgênero de Vriesea. São apresentadas seis espécies.

Já no século XX, outro botânico alemão, Hermann August Theodore Harms (1870-1942) apresenta a primeira combinação nova, tratando Alcantarea como um gênero independente (Harms, 1929) e em 1930, o mesmo autor monografa Bromeliaceae para a segunda edição da obra Die Natürlichen Pflanżenfamilien (Harms, 1930), onde apresenta em detalhe a descrição do gênero e também 
as demais combinações. Harms (1930) divide o gênero em dois grupos informais: um com plantas de brácteas florais e flores secundas e outro com brácteas florais e flores dísiticas.

Mez (1934) sinonimiza Alcantarea sob Vriesea, e o retorna para a posição de subgênero.

Lyman Smith (1934) deixa claro por que não aceita o gênero Alcantarea: "Harms has made a separate genus of Alcantarea, but in view of the fact that his distinction of apical coma does not hold for all the species, it seems better to follow Mez and retain the group under Vriesia. The other distinction, the form of the petals, is not considered to be of generic value anywhere else in the family, even by Harms".

Smith (1955) e Smith \& Downs (1977), mantém o pensamento de Mez (1934), e tratam Alcantarea como subgênero. Alcantarea paniculata (L.) Harms, primeira espécie a ser transferida ao status de gênero em Alcantarea por Harms (1929) é transferida por Smith \& Downs (1977) para Tillandsia subgênero Pseudalcantarea Harms. De fato, a morfologia da semente dessa espécie é totalmente distinta daquela das espécies brasileiras, não apresentando o coma apical desenvolvido, o que talvez explique a afirmação de Smith (1934), reproduzida acima.

Jason R. Grant (1995a), exclui uma espécie das Antilhas (Vriesea gibba L.B. Sm.) e uma outra da América Central (Vriesea alta E. Morren ex Mez) e re-estabelece Alcantarea como gênero, apoiandose no padrão de distribuição geográfica restrito ao Brasil e nos caracteres florais de comprimento das pétalas e nas sementes que apresentam coma apical e basal desenvolvidos. Segundo Grant (1995a), Alcantarea representaria um grupo-relito, com espécies que deveriam estar entre as mais primitivas da subfamília Tillandsioideae e que teria dado origem ao gênero Vriesea. Esse autor afirma que a presença de inflorescência composta de grande porte em nove de um total de dez espécies conhecidas até então, seria um forte indicativo da primitividade do grupo. Todavia, hoje se sabe que tais hipóteses estão em desacordo com o pensamento cladístico.

Em uma análise com caracteres morfológicos de 66 espécies de Vriesea, Costa (2002) inclui dois taxa de Alcantarea, A. farneyi e a A. glazionana. Alcantarea forma um clado dentro de Vriesea, sustentado pela presença de pétalas fortemente recurvadas e pelo coma apical da semente reto e longo. Este clado, apesar de ser irmão de V. neoglutinosa (V riesea seção Vriesea), encontra-se dentro de um clado maior, que reúne, em sua maioria, táxons da seção Xiphion do gênero Vriesea. Por esta análise entende-se que tanto V riesea, quanto suas seções formam grupos parafiléticos.

A tipificação do gênero Alcantarea é um pouco complexa, porém foi abordada por Grant \& Zijlstra (1998), que designaram um novo lectótipo para gênero, após constatarem vários problemas na escolha de $A$. imperialis, até então tida como lectotypus. O problema começa com a publicação do nome Alcantarea em si, dentro da chave de identificação de espécies de Vriesea, na obra de Mez (1894), que não estabeleu qual seria a espécie tipo do novo subgênero. Segundo Grant \& Zijlstra (1998), considerar A. imperialis como lectótipo de Alcantarea, conforme feito por Smith (1955 apud Grant \& Zijlstra 1998) e Smith \& Downs (1977) implica em dois problemas distintos. O primeiro envolve a citação da autoria do binômio, visto que Smith (1955 apud Grant \& Zijlstra 1998) cita que o tipo seria 
"Vriesia imperialis E. Morr.", sendo que Morren não publicou tal binômio. O segundo e maior problema envolve a citação e a legitimidade dos nomes Vriesea imperialis E. Morren e Vriesea imperialis E. Morren ex Mez. Smith \& Downs (1977: 1071) citam como lectótipo do subgênero Alcantarea, Vriesea imperialis E. Morren ex Mez in Martius, Fl. Bras. 3(3): 516. 1894, o que gera, de acordo com Grant \& Zijlstra (1998) três problemas menores: $\left(1^{\circ}\right)$ a refêrencia à página da chave, e não à página onde a Vriesea imperialis aparece descrita (i.e., Fl. Bras 3(3): 568); $\left(2^{\circ}\right)$ o fato deste nome ser um homônimo posterior à Vriesea imperialis Carrière, Rev. Hort. 60: 58. 1888, o qual Mez aparentemente desconhecia, $\left(3^{\circ}\right)$ por ser um nome ilegítimo, visto que Mez coloca um nome válido ( $V$. gigantea Lem., Ill. Hort. 14: pl. 516. 1867) e anterior como sinônimo, no ato da descrição de Vriesea imperialis E. Morren ex Mez. Tendo em vista tais problemas, Grant (1995a) e Grant e Zijlstra (1998) adotam novamente o lectótipo já sugerido por Baker (1889), que seria Tillandsia regina Vellozo (Fl. Flum. Iconografia 3, táb. 142. (1827) 1831). Essa escolha parece ser a mais acertada, não só por que Vellozo foi o primeiro autor a apresentar uma ilustração que permite de pronto reconhecer o gênero Alcantarea através das flores e do hábito, como também por Alcantarea regina sensu Vellozo (1827) e sensu Versieux e Wanderley (2007) ser uma espécie bem delimitada, que não apresenta os problemas de legitimidade encontrados em $A$. imperialis.

Entretanto, chamamos atenção aqui para a necessidade de esclarecer que o autor da seleção de Tillandsia regina Vell. como lectótipo do gênero Alcantarea não é Baker (1889), ao contrário do que é afirmado por Grant (1995a). A razão pela qual isso ocorre é cronológica, pois Baker em 1889, não poderia ter lectotipificado um nome que só viria a ser validamente publicado em 1894. A referência que Baker faz (1889: 227) ao afirmar que o tipo do subgênero Alcantarea E. Morren seria a Tillandsia regina Vell refere-se ao manuscrito não publicado de Morren (Fig. 1).

Neste mesmo manuscrito é possível ver que Morren considerou como alternativa ao nome Dalcantarea o nome Glaz̧iova (Fig. 1). Apesar de não ter sido efetivamente publicado por Morren, constatamos no presente trabalho que tal nome foi publicado por Carrière (1881). Entretanto, tal nome é ilegítimo por ser um homônimo posterior à Glaz̧iova Bur. (Bignoniaceae) e também por ser um nome nú.

O nome Alcantara Glaziou ex G.M. Barroso (Asteraceae) foi considerado um homônimo, sendo descrito, então, o novo nome Xerxes J.R. Grant, para acomodar a espécie Xerxes ekmanianum (Philipson) J.R.Grant (Grant 1994). 


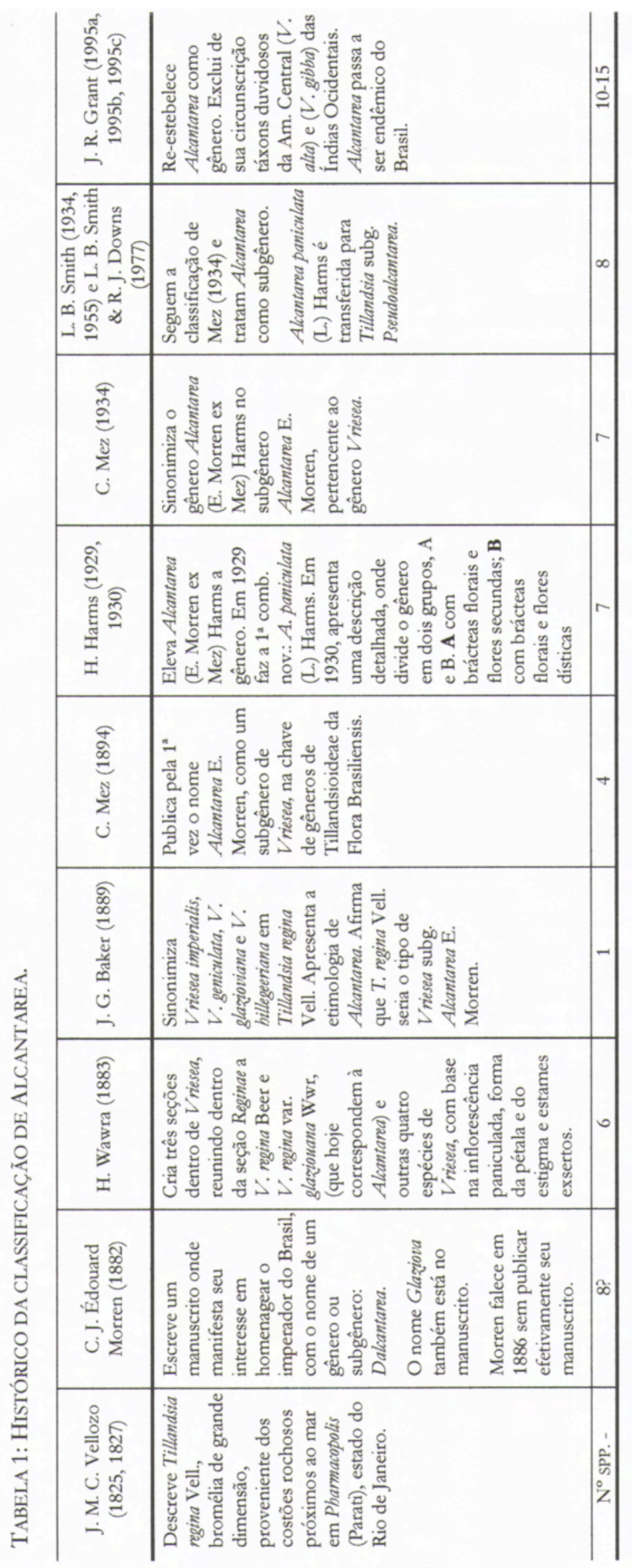




\section{MATERIAL E MÉTODOS}

Inventário de coleções científicas e expedições de coleta. Foi feito o levantamento dos acervos dos herbários BHCB, C, CESJ*, GUA*, HB, HBR, HRB*, HRCB, HUEFS, K, LOJA, LPB, MBM, MBML*, MO, NY, P, R, RB, RFA, SEL*, SP, SPF, UB, UEC, US, USM, QCA, QCNE, VIC*, aqueles indicados por asterisco enviaram empréstimos. Foram percorridas áreas de afloramentos rochosos nos estados da Bahia, Minas Gerais, Espírito Santo, Rio de Janeiro e São Paulo. Buscou-se expandir o esforço amostral, além das localidades típicas e também, sempre que possível, realizar coletas fora de unidades de conservação. O material coletado está depositado no herbário SP e duplicatas no BHCB, RB, SEL, SPF.

Medidas. As medidas aqui apresentadas foram obtidas no campo, nas diferentes populações amostradas durante as expedições de coleta e a partir das flores frescas fixadas e complementadas com os espécimes depositados nas coleções científicas. Observações de características das margens, nervação e indumento e formatos dos ápices e apículos foram feitas no estéreo-microscópio. As medidas foram obtidas empregando-se paquímetro e trena conforme indicado na Figura 2. A terminologia adotada para órgãos e estruturas também está indicada na Figura 2 e segue os conceitos de Stearn (2004) ou aquele convecionais para as angiospermas, evitando-se, sempre que possível, o emprego desnecessário de termos exclusivos para Bromeliaceae.

Microscopia Eletrônica de Varredura - MEV. O microscópio eletrônico de varredura foi utilizado para se observar detalhadamente estruturas reprodutivas e vegetativas. Foram feitas fotomicrografias utilizando-se o aparelho Digital Scanning Microscope DSM940 (Zeiss) do Laboratório de Microscopia Eletrônica do IB-USP para: grãos de pólen não-acetolisados, epiderme mediana da bainha e lâmina foliares, partes florais (apêndices das pétalas, antera, estigma) e sementes, sendo o material preparado de acordo com os procedimentos tradicionais, que envolvem desidratação por série alcóolica, secagem até o ponto-crítico, montagem das amostras em stubs e a metalização. Para o pólen, botões florais de plantas vivas foram desidratados em sílica, posteriormente as anteras foram removidas, o pólen foi depositado sobre o stub e metalizado com platina.

Mapas. O mapa de distribuição dos taxa foi elaborado através do software Google Earth, empregando-se as coordenadas obtidas no trabalho de campo ou das exsicatas analisadas, quando disponível ou a sede do município.

Estado de conservação. O estado de conservação dos táxons é proposto conforme os critérios da IUCN (2001), tomando por base observações feitas nas populações no campo. 


\section{MORFOLOGIA}

Hábito. Plantas herbáceas, arrosetadas, de 0.2 a $5 \mathrm{~m}$ altura quando floridas. Todas as Alcantarea são rupícolas e nenhum indivíduo epífito foi observado durante o trabalho de campo. Existe uma grande variação intraespecífica no que se refere ao porte das espécies. Em $A$. regina podem ser vistos, dentro de uma mesma população, adultos floridos variando entre 0.9 a $2.4 \mathrm{~m}$ de altura. A forma e dimensões das rosetas são bem variáveis, predominando a infundibuliforme, de mais estreita (A. odorata) a mais larga (A. regina), porém outros formatos como sub-bulbosa (A. farneyi) e tubular (A. benzingii) também são observáveis. O número de folhas também é variável. O volume de água armazenado no fitotelma nas espécies de maior porte pode chegar a 40 litros (Martinelli 1997) enquanto que em outras praticamente não se acumula água (e.g. A. duarteana, $A$. farneyı).

Raí. As raízes são adventícias e desenvolvidas e se originam a partir do caule (intracaulinares). Nos indivíduos adultos e com caules mais robustos observa-se a formação de um anel de raízes adventícias envolvendo o caule, essas raízes podem estar esclerificadas, auxiliando na sustenção da planta. Como em outras espécies de Bromeliaceae rupícolas, observa-se em Alcantarea uma forte adesão das raízes ao substrato. Reitz (1983) atribui essa aderência à secreção de um mastique (resina) pardacento pelas raízes, que endureceria ao entrar em contato com o ar, permitindo a fixação da planta em substratos verticais.

Caule. Em Alcantarea o caule pode ser desde muito curto e totalmente ocultado pelas folhas (e.g. $A$. farneyi, A. hatschbachic) até muito desenvolvido e robusto (e.g. A. imperialis, A. roberto-kautskyi). Do caule surgem brotações laterais que podem formar pequenas touceiras de indivíduos jovens em torno da planta-mãe (e.g. A. geniculata, A. turgida), brotações isoladas, separadas da mãe por um estolho curto (e.g. A. benzingii ) ou as brotações podem sair da axila das folhas periféricas da roseta (e.g. A. extensa, A. burle-marxii) (Fig. 3).

Bainha foliar. Em todas as espécies nota-se a presença de uma bainha foliar dilatada e desenvolvida que pode ser oval a largo-oval, oblonga ou trapeziforme. É nessa região que se concentra a maior densidade de escamas, sendo densamente lepidota em ambas as superfícies e de coloração bege a castanho-escura ou enegrescida, com ou sem matizes vinosos.

Lâmina foliar. A lâmina foliar apresenta geralmente formato ligulado, mas também pode ser triangular. O ápice mostra-se agudo ou obtuso, freqüentemente acuminado e pode assumir diferentes posições, como voltado para baixo, dobrado e voltado para a base da folhas, torcido ou se manter reto seguindo a orientação da lâmina. Uma grande variação na coloração das lâminas pode ser observada e, também, 
entre a face abaxial e adaxial. Geralmente a lâmina apresenta tons vermelho-vinosos, sendo que podem ser vistas desde pequenas máculas isoladas até manchas. Também é comum observar listras oblíquas e paralelas, vinosas, na base abaxial. Nas margens, frequentemente se observa uma fina linha vinosa, com menos de $1 \mathrm{~mm}$ de largura que acompanha toda a lâmina até o ápice, sendo que em poucas espécies esta linha não está presente. Notam-se projeções ou saliências ao longo da folha junto das nervuras, tais projeções são geradas por um acúmulo de fibras acima dos feixes vasculares. Em A. imperialis tais projeções ou vincos longitudinais estão presentes a ponto de conferirem à lâmina um aspecto levemente plicado próximo ao ápice. É freqüente haver heterofilia, sendo que as brotações jovens apresentam, frequentemente, folhas estreitas, fortemente canalicudadas, carnosas, densamente lepidotas, que contrastam bastante com a folha adulta expandida, relativamente fina e glabrescente (e.g $A$. geniculata, $A$. heloisae, $A$. nahoumii). Outras espécies emitem brotações axilares, com folhas já semelhantes às do indivíduo adulto (e.g. A. extensa).

Indumento das folhas. As folhas geralmente são glabrescentes na face adaxial e de esparsamente a densamente lepidotas na face abaxial. Em $A$. duarteana e $A$. farneyi as lâminas são densamente revestidas por escamas em ambas as superfícies. Mesmo nas folhas que se mostram verdes e lustrosas é possível observar escamas, ou pelo menos vestígios, na altura média do comprimento das lâminas. $\mathrm{Na}$ face abaxial podem ser vistas escamas associadas aos estômatos, que podem ser observados na lupa como pequenas pontuações amarronzadas. As escamas seguem o padrão de simetria radial, típica das Tillandsioideae, porém podem ser levemente assimétricas (A. duarteana). A presença de cera epicuticular é freqüente (A. extensa, A. glazionana, A patriae), sendo que em $A$. roberto-kantskyi chegam a se formar grandes depósitos em placas pulverulentas.

Brácteas. O pedúnculo, os pedúnculos laterais e as flores são bracteados. A brácteas do pedúnculo são geralmente polísticas e vistosas, geralmente com a base dilatada ou inflada, mas também podem ser eretas e justapostas aos entrenós, imbricadas ou, mais raramente, remotas, acumulando ou não pequena quantidade de água na base. As brácteas dos pedúnculos laterais são geralmente denominadas brácteas estéreis, pois não protegem nenhuma flor, entretanto são muito similares em tamanho e morfologia às brácteas florais, apesar de frequentemente se observar a formação de uma pequena carena, em virtude do dobramento da bráctea sobre o pedúnculo. Tal característica não necessariamente é observada nas brácteas florais. A coloração pode variar do verde ao vinoso, passando pelo rosado e amarelado. $\mathrm{O}$ indumento das brácteas proximais do pedúnculo geralmente é semelhante ao das folhas, por outro lado, as brácteas primárias, as estéreis dos pedúnculos laterais e as florais geralmente apresentam a face adaxial lepidota enquanto que a abaxial é glabra. 
Estrutura da inflorescência. As inflorescências em Alcantarea eram conhecidas tradicionalmente como panículas ou racemos, entretanto após análise da anatomia floral, especialmente da região tradicionalmente denominada pedicelo, notou-se que as flores são sésseis. A mesma conclusão foi obtida por Beaman \& Judd (1996) ao se estudar Tillandsia subg. Psendoalcantarea. Sendo assim, adotouse aqui o termo espiga para as inflorescências simples e panícula de espigas para as compostas. Foi observado em alguns casos que apesar de mostrar-se sem ramificações, algumas inflorescências simples podem conter pequeninos ramos atrofiados e ocultados pelas brácteas distais do pedúnculo (e.g. A. extensa, A. trepida). Quanto ao formato, observa-se que varia de piramidal, ovoidal, elipsoidal, obovoidal ou pode ser semelhante a um candelabro, com ramos fastigiados (A. roberto-kautskyz). Em A. extensa e espécie afins, a inflorescência geralmente apresenta um contorno irregular, assimétrico, com ramos muitas vezes de tamanhos distintos entre si.

Flores. As flores em Alcantarea são marcantes pelo seu grande tamanho, especialmente quando comparadas às de Vriesea. Uma das principais características utilizadas na separação desses dois gêneros encontra-se nas pétalas longas, lineares, efêmeras e em espiral das Alcantarea. As flores são semi-epígenas, i.e., o ovário é semi-ínfero com hipanto. Grant (1995a) e Smith \& Till (1998) já mencionam a presença do ovário cripticamente semi-ínfero para o gênero. Nota-se que os óvulos estão distibuídos com placentação axial, do ápice dos lóculos até alguns milímetros abaixo da linha de inserção das sépalas, pétalas e estames. Entretanto, a observação dessa característica está condicionada à forma como o corte longitudinal é feito. Abaixo do ovário ou entre os seus lóculos há a o tecido secretor que forma os nectários septais, que apresentam posicionamento infra e interlocular. Este tecido é abundante e desenvolvido e prolonga-se quase até próximo ao ponto de inserção da flor com a ráquila. Após a antese, esse tecido regride e murcha e a base da flor perde diâmetro, dando origem à estrutura que vem sendo erroneamente referida como pedicelo, por alguns autores. No presente trabalho conclui-se que as flores são sésseis e tratamos aqui como hipanto toda a região entre o ponto de fixação da flor à raque ou ráquila até o ponto de onde emerge o perianto (Fig. 24 C). Beaman \& Judd (1996) apresentam interpretação semelhante para a morfologia floral de Tillandsia subg. Pseudoalcantarea, sendo que para Alcantarea um abordagem detalhada da anatomia floral encontra-se em fase de preparação (Versieux, dados não publicados).

Poucos dados estão disponíveis sobre o horário exato de abertura das flores, parte das espécies possuem antese noturna, enquanto as que apresentam pétalas amarelas abrem-se durante o dia ou no crepúsculo e recebem a visita de diferentes insetos. As flores podem se abrir da base para o ápice ou o vice-versa (Figs. $14 \mathrm{I}, 41 \mathrm{H}$ ). Algumas espécies apresentam odor levemente adocicado (A. glaziouana, $A$. odorata), enquanto outras cheiram a alho (A. imperialis, $A$. regina), indicativo de quiropterofilia. A pré-floraçao é imbricada, sendo que em alguns indivíduos do complexo $A$. extensa observa-se uma torção na corola ainda em botão (Fig. 14 I). De acordo com Martinelli (1994), as 
flores de Alcantarea produzem néctar muito volumoso, se comparada às de outros gêneros de Bromeliaceae, entretanto menos concentrado em açúcares. Quando em botão, é frequente o acúmulo de mucilagem entre as brácteas. Essa substância gelatinosa está amplamente presente nos táxons do complexo Alcantarea extensa. Em alguns casos foram observadas vespas coletanto a mucilagem, quando seca.

Cálice. Em todas as espécies o cálice é trímero, as sépalas são livres logo acima do curto hipanto formado, de formato variando do oblongo (e.g. A. roberto-kautskyi, $A$. imperialis e $A$. regina) até obovado (e.g. Alcantarea extensa). Na maioria das espécies as sépalas são verdes, algumas vezes totalmente vinosas, coloração essa que varia conforme a exposição ao sol. O cálice na antese forma uma pequena abertura, ficando as pétalas constritas, enquanto que em $A$. imperialis e em alguns indivíduos de $A$. regina as sépalas podem apresentar uma maior abertura. A textura das sépalas nas plantas vivas é, geralmente, carnosa e quebradiça ao longo da linha de sutura com hipanto e assumem textura coriácea quando secas. Em $A$. imperialis essa textura é mais fina.

Corola. A corola é trímera, as pétalas são livres logo acima do curto hipanto formado, relativamente longas $(>7 \mathrm{~cm})$ na maioria das espécies, de formato ligulado, com ápice variando de agudo a obtuso. Os apêndices petalíneos estão presentes em todas as espécies, exceto $A$. hatschbachii, que apresenta pétalas nuas. Os apêndices são ligulados, adnatos às pétalas ao longo de uma sutura central e apresentam ápice (ou lobo) livre, agudo a obtuso e com margens inteiras ou inconspicuamente irregulares. Logo acima dos apêndices pode haver uma calosidade discreta, visível em poucas espécies (A. geniculata, A. nahoumii e $A$. roberto-kautskyi). As pétalas são predominantemente amarelas, com gradação de tons entre o amarelo-claro passando a alvacento (A. imperialis, A. regina, A. roberto-kaustyz) e o amarelo-ouro (e.g. $A$. duarteana, $A$. nahoumii). No complexo $A$. extensa são comuns as pétalas vinoso-alaranjadas na face abaxial e amareladas na adaxial ou, como observado por Wittmack (1891), cor de carne ou amarelo-ocre. Leme et al. (2008) descrevem $A$. nigripetala, com pétalas negras, porém não mostram flores completamente abertas, mas sim o botão floral que foi dissecado para elaboração da descrição. Neste ponto ressalva-se que em $A$. burle-marxii as pétalas no botão são de coloração vinho-escuro e no decorrer da antese as pétalas tornam-se desde cor de bronze até rosadas (Fig. 12 E, $\mathrm{G}, \mathrm{H})$. Flores maduras e com pétalas totalmente desenvolvidas mostrarão se esse também é o caso de A. nigripetala. Em $A$. imperialis e $A$. regina o botão é amarelo e, em poucas horas do decorrer da antese, as pétalas passam a alvacentas (Martinelli 1994). Pétalas albas estão presentes em A. glaz̧ionana e em cor-de-creme a alvacentas em $A$. roberto-kaustskyi. O comprimento e duração das pétalas são caracteres reforçados por Harms (1930) como importantes na delimitação de Alcantarea. Em geral as flores não duram mais de 12 h. Após a antese, as pétalas tornam-se flácidas, involutas e enrrugadas e logo estão completamente murchas e escurecidas. A orientação longitudinal das pétalas é muito variável, 
podendo-se, aí, distinguir alguns grupos informais de espécies: em um primeiro grupo as pétalas são fortemente recurvadas para trás e se enrolam sobre si mesmas (semelhante a uma mola de relógio), e sofrem torções. Aí se encontra a maior parte das espécies de pétalas amarelas (e.g. A. duarteana, $A$. farneyi, A. tortuosa, A geniculata) (Figs. $12 \mathrm{~K}, 17$ D, H, 41 I, J, M). Num segundo grupo, as pétalas são fortemente recurvadas para trás e espiraladas do ápice para a base, como se sofressem uma torção mais leve do que a do primeiro grupo, e as pétalas se mostram flácidas já na antese (e.g. complexo da A. extensa, A. turgida, Figs. $12 \mathrm{C}, \mathrm{E})$. O terceiro grupo é uma combinação dos dois grupos anteriores sendo que logo apos estar enrolada sobre si mesma a pétala começa a murchar e se torna levemente espiralada (e.g. A. imperialis, A. regina, Figs. 23 C, 25 B). Há ainda o formato de "âncora" descrito por Grant (2003) para $A$. heloisae, no qual a pétala se mostra fortemente voltada para trás, não se enrola e murcha-se das bordas para o centro (Fig. 21 B).

Androceu. $\mathrm{O}$ androceu é composto por 6 estames livres, em dois verticilos pouco distintos entre si: no mais externo os estames estão entre as pétalas e no mais interno, epipétalos. O filete é alvo, cilíndrico, algumas vezes levemente aplanado na base passando a cilíndrico, essa alteração na morfologia se deve a pressão exercida pelos apêndices petalíneos, cujas laterais podem se sobrepor e levemente comprimir os filetes. Eventualmente, no pós-antese a porção distal do filete pode assumir um formato levemente plicado. O comprimento dos filetes pode variar em uma mesma espécie e em uma mesma flor, além de estar sujeito ao estágio de desenvolvimento floral. Os estames podem ser apresentados em feixe, isto é próximos entre si e circundando o estilete, semelhantes a um tubo ou ainda podem ser polísticos, isto é radialmente dispostos e afastados do gineceu. As anteras na maior parte das espécies são dorsifixas próximo à base que é ultrapassada apenas pela pequena projeção sagitada dos sacos polínicos que antecedem o conetivo. Em A. roberto-kantskyi a inserção do filete pode ocorrer próximo ao $1 / 3$ basal dorsal da antera, que assume um posicionamento versátil.

Pólen. O emprego da morfologia polínica na elucidação das relações de parentesco entre os taxa de Bromeliaceae já vem desde o trabalho de Carl Mez (1894), onde apresentam-se as subfamílias Pitcairnioideae e Tillandsioideae como estenopolínicas e Bromelioideae, euripolínica, encontra-se dividida nas tribos Integrae - com grãos inaperturados, Poratae - com grãos porados e Sulcatae - com grãos sulcados. O padrão de abertura é um caráter importante na palinotaxonomia da família e essa divisão em três grupos (sulcado, porado e inaperturado) prevalece até os dias atuais. Todavia os grãos de pólen das Bromeliaceae ainda são pouco conhecidos quando comparados ao de outras famílias de monocotiledôneas, apesar de seu potencial na distinção de gêneros e espécies (Wanderley \& Melhem 1991; Halbritter 1992). O grão de pólen das Bromeliaceae é esférico em estado turgescente ou quando distendido atinge ao máximo a proporção de $2.5: 1$ e o tamanho dos grãos é variável e depende do estado de turgor (Halbritter 1992). 
Em Alcantarea os grão de pólen apresentam tamanho grande, simetria bilateral, são heteropolares, de âmbito elíptico, equatorialmente apresentam contorno plano de um lado e convexo do outro, exina reticulada, heterobrocada, com malhas menores junto às extremidades do diâmetro equatorial e próximo à região do colpo, lumens variando de arredondados a poligonais, lisos ou com granulação (A. burle-marxii, A. duarteana, A. patriae, A. roberto-kautskyi), em alguns casos os lumens grandes podem encontrar-se circundados por microrretículos (A. heloisae), os muros são lisos, largos (A. burle-marxii, A. geniculata, A. patriae) a estreitos, retos a curvos, com ou sem apêndices, esparsamente perfurados ou sem perfurações (Fig. 4).

Entre as diferentes espécies analisadas o tamanho dos lumens nas extremidades dos grãos é um caráter variável (Fig. 4 C, F, I), assim como a espessura do muro (Fig. 4 G, K, N). Frequentemente são observadas inclusões, também conhecidas como pilos, no interior dos lumens (Fig. 4, B, E, K), sendo que em $A$. roberto-kautskyi estas inclusões são maiores e diferentes de todas as demais espécies. A morfologia do sulco é bastante peculiar e rara, sendo denominada "tipo Vriesea imperialis" presente apenas em Alcantarea, Tillandsia subg. Anoplophytum e em Billbergia (Halbritter 1992). Tal tipo caracteriza-se por apresentar campo de germinação distal composto por elementos coerentes de exina que se rompem no decorrer da dilatação, de forma mais ou menos lisa. Entretanto tal característica de ornamentação da abertura não pôde ser observada com as imagens de MEV devido a invaginação sofrida na região da abertura, quando da metalização. Conclui-se que a morfologia polínica apresenta caracteres variáveis e seu uso tem potencial na elucidação de questões taxonômicas, quiçá filogenéticas no gênero.

Estigma. A morfologia do estigma em Tillandsioideae apresenta informações úteis para a sistemática (Brown \& Gilmartin 1984). As espécies de Alcantarea apresentam estigmas conduplicados-espiralados, conforme foi observado por Leme (2007) (Fig. $5 \mathrm{~K}$ ) ou simples eretos, como em A. imperialis (Fig. 5 C, I), sendo que os lobos passam de eretos a suberetos ou patentes na antese. A superfície estigmática é papilosa e pode estar espiraladamente disposta ao longo do lobo ou concentrada em uma das faces (Fig. 5). Anteriormente, o estigma era referido como sendo do tipo lâmina convoluta (Grant 1995a; Smith \& Till 1998), entretanto tal observação não é corroborada pelos resultados aqui obtidos.

Frutos e sementes. O fruto é uma cápsula septicida, pesa entre 0.9-1,3 g e possui sementes numerosas (士300). As sementes são anemófilas, possuem apêndices apicais e basais, pesam em torno de $2 \mathrm{mg}$. As sementes em Alcantarea são relativamente pesadas, ca. de 4 vezes mais, se comparadas às de Vriesea. A morfologia dos apêndices apicais e basais é diferente. Enquanto os apêndices apicais se mostram mais rígidos e levemente unidos, os basais são, geralmente, mais curtos e aparentemente mais finos. $\mathrm{Na}$ dispersão das sementes, os apêndices apicais e basais atuam de forma distinta. Enquanto cada um dos três carpídios se abre, as semente são levantadas pelo feixe de apêndices apicais, que são mais rígidos 
e mais unidos, e o coma basal fica exposto. À medida que as fímbrias basais secam, elas se afastam da semente, num movimento semelhante a abertura de um guarda-chuva, auxiliando na dispersão. Eventualmente as sementes germinam dentro dos carpídios semi-abertos (Fig. 41 Q) ou, mais raramente, germinam na base das folhas, próximo à bainha (Fig. $3 \mathrm{O}$ ), sendo que tais observações merecem ser aprofundadas em outros estudos. A interpretação de Leme (2007), quanto à posição e tamanho dos apêndices da semente está equivocada, pois os apêndices basais são aqueles voltados para a placenta, enquanto que os apêndices apicais são geralmente maiores e voltadados para a parede externa do ovário/fruto e se originam da cauda do óvulo, conforme já explicado por Mez (1894) (Fig. 3).

NÚMERO CROMOSSÔMICO. O número cromossômico básico para Bromeliaceae é $x=25$, e tal característica vem sendo tratada como uma sinapomorfia para a família, porém com variação entre os diferentes gêneros (Marchant 1967; Brown \& Gilmartin, 1989). Ceita et al. (2008) apresentam a primeira contagem de cromossômos para espécies de Alcantarea: A. imperialis e A. nahoumii, ambas $\operatorname{com} 2 n=50$. Os cromossomos apresentam tamanhos uniformes o que é ressaltado por Ceita et al. (loc. cit.) como uma diferença marcante entre os gêneros Alcantarea e Vriesea, cujos cromossomos seriam bimodais, i.e., apresentando duas classes de tamanhos diferentes.

BIOLOGIA REPRODUTIVA E HIBRIDIZAÇÃO. Existem dados de biologia reprodutiva para poucas espécies de Alcantarea. Martinelli (1994) investigou Alcantarea imperialis e A. regina e constatou que diferentes visitantes florais são observados, tais como abelhas, beija-flores, mariposas e morcegos. Esse autor notou que as flores dessas espécies são autocompatíveis, porém com mecanismos de dicogamia, como a protândria. Para A. geniculata são indicados como polinizadores putativos as abelhas e as Sphingidae (Ule 1898; Knuth 1904; Porsch 1924; todas ref. apud Martinelli 1994). A quiropterofilia foi apresentada por Vogel (1969) para A. regina e é confirmada por Martinelli (1994) tanto para $A$. regina quanto $A$. imperialis. Barbará et al. (2007) observaram que as populações de $A$. imperialis são tão distintas geneticamente que é possível que o polinizador (morcego) não seja capaz de percorrer distâncias grandes, entre diferentes inselbergs. Sugere-se aqui que a polinização por mariposas (Sphingidae) pode ser ainda mais frequente, visto que várias espécies de flores amarelas apresentam odor adocicado, antese no crepúsculo e estames em feixe, formando um tubo. Entretanto, tal observação necessita ser corroborada por estudos detalhados para o maior número de espécies possível. A floração de Alcantarea é concentrada durante o verão e frequentemente observase uma grande sincronia de florada entre todos os indivíduos adultos em uma dada população. $\mathrm{O}$ pedúnculo começa a se formar no mês de setembro e outubro e a inflorescência inicia o período de antese no final do mês de novembro ou início de dezembro, podendo se estender além dos meados do ano seguinte. Os frutos estarão maduros e dispersando sementes no verão seguinte ao da floração. 
Quanto a hibridização, há registros de hibridização artificial, intergenérica, entre Alcantarea e Vriesea, com o notogênero $\times$ Vriecantarea Grant (Grant \& Zijlstra 1998). Entre as Alcantarea, Barbará et al. (2007) observaram a existência de fluxo gênico entre populações de $A$. imperialis e $A$. geniculata em simpatria. Incongruências observadas aqui (Cap. 2) entre as topologias obtidas com marcadores do cloroplasto e nucleares são indícios de que a hibridização é mais freqüente do que previamente se conhecia para o gênero.

DISTRIBUIÇÃO E HABITAT. Alcantarea é endêmico do Brasil com ocorrência registrada para os estados da Bahia (1 sp.), Minas Gerais (12 spp.), Espírito Santo (9 spp.), Rio de Janeiro (12 spp.) e São Paulo (1 sp.), desde poucos metros acima do nível do mar, onde chegam a tolerar respingos d'água salgada (A. glazionana, A. regina) até cerca de 2000 m.s.m. nos campos de altitude (A. benzingii, $A$. farney, A. tortuosa). A afirmação de Leme (2007), de que teria sido ele quem estendeu a ocorrência do gênero ao Estado de São Paulo, é inconsistente, uma vez que Baker (1889: 227) já indicava que Tillandsia regina $(=$ A regina $)$ ocorria nas florestas do Rio de Janeiro e São Paulo.

Ocorrem principalmente em afloramentos gneiss-graníticos (inselbergs, do alemão, insel = ilha, berg = montanha) do leste do Brasil, popularmente conhecidos como "Pães de Açúcar" e que podem estar inseridos nos domínios da floresta ombrófila densa e campos de altitude associados, da floresta estacional semidecidual ou da caatinga. Na serra do Espinhaço, quatro espécies ocorrem sobre afloramentos quartzíticos em vegetação de campo rupestre. Os inselbergs do leste do Brasil, habitat da maioria das Alcantarea, são caracterizados por possuírem uma geologia muito antiga, précambriana, do proterozóico posterior, sendo formados pela intrusão de granitos e migmatitos nos cratóns do Brasil e do Congo, região localizada na porção sul do continente Gondwanico. A forma dos inselbergs foi moldada por diferentes processos erosivos desencadeados por alterações cíclicas da temperatura e chuvas entre períodos mais secos do Quaternário (Cenozóico) e também por tectonismos neogênicos mais recentes (Safford \& Martinelli 2000). Do ponto de vista da fisiologia vegetal, inselbergs são considerados ambientes extremamente estressantes para as plantas, em razão da escassez de água, elevadas incidências luminosas e altas temperaturas sendo chamados de "ilhas xéricas" e requerendo a presença de diferentes adaptações (Porembski et al. 1998; Szarzynski 2000). A diversidade florística dos inselbergs é fortemente influenciada pela diversidade e estrutura da vegetação do entorno do mesmo (Porembski et al. 1998) e, como sugerido por Bárbara et al. (2007), a própria ocorrência das espécies de Alcantarea em determinadas regiões pode estar relacionada à disponibilidade de polinizadores (e.g. morcegos) que dependam das áreas florestadas periféricas.

\section{POSICIONAMENTO E DELIMITAÇÃO DE ALCANTAREA}

Circunscrição e posicionamento do gênero. Alcantarea (sensu Harms 1930) é um gênero que apresenta o 
arranjo das flores semelhantes às de Vriesea, porém com pétalas efêmeras, em forma de fita (em alemão, bandförmig) que tornam-se flácidas ou curvado-espiraladas, e com sementes que são comosas no ápice e na base. Outros caracteres ressaltados por Harms (loc. cit), envolvem o porte elevado, "o maior para a família", e a forma de vida rupícola. As circunscrições de Grant (1995a, c) e Till (2000) seguem, basicamente, a delimitação de Harms (1930). Considerando-se as duas características macroscópicas mais marcantes (i.e. formato das pétalas e o tipo de semente), pode-se considerar que seja um gênero bem caracterizado e facilmente reconhecível. Desde o primeiro manuscrito de Morren, Alcantarea já foi concebido como um grupo proximamente relacionado à Vriesea. Gilmartin (1983) em análises cladísticas morfológicas demonstra o relacionamento de Vriesea subg. Vriesea com Vriesea subg. Alcantarea como grupos-irmãos e aponta como diferenças entre eles a presença de pétalas eretas no subg. Vriesea vs. não-eretas no subg. Alcantarea, filetes não-plicados vs. plicados, lâmina foliar triangular-filiforme presente vs. ausente e apêndice apical da semente ausente ou minuto e não dividido vs. dividido em um coma curto. Outros autores, como Beaman \& Judd (1996) tratam Tillandsia subg. Pseudalcantarea como um grupo feneticamente próximo à Alcantarea, entretanto facilmente diferenciado por apresentar pétalas sem apêndices petalíneos, sementes sem coma apical e anteras versáteis. Barfuss et al. (2005) demonstram o relacionamento próximo entre Alcantarea e Vriesea, como grupos-irmãos, na análise com o gene matK, entretanto na análise combinada com outros marcadores, Vriesea surge como parafilética. Esses mesmos autores posicionam Alcantarea na tribo Vrieseae Till \& Barfuss, juntamente com os gêneros Vriesea e Weraubia.

\section{CRITÉRIO PARA DETERMINAR NÍVEIS TAXONÔMICOS}

Atualmente, é sabido que um grande número de novas espécies brasileiras de Bromeliaceae é apresentado à comunidade científica, o que em parte se justifica pela aumento de esforço amostral em áreas subcoletadas e também pelo leste do Brasil ser um centro de diversidade para a família. Entretanto, é necessário rever se as caracterísiticas que vem sendo empregadas comumente nessas descrições são as mais adequadas e incluir, cada vez mais, uma abordagem populacional, quando da circunscrição do que se considera novo. Tamanho ou altura da planta, presença e número de brácteas estéreis nos pedúnculos laterais, quantidade de tricomas, variação no comprimento dos apêndices petalíneos, presença ou não de cera, variação entre a coloração verde e vinosa (fruto de produção de antocianinas) são caracteres fenotípicos frequentemente empregados nas descrições de novas espécies de Alcantarea e que devem ser reconsiderados quanto à sua utilidade, especialmente àqueles que variam conforme as condições ambientais ou de cultivo. Pode-se argumentar que conceitos e delimitações de espécies são amplos e variáveis, entretanto o que parece ser feito por alguns estudiosos do grupo, sequer incluiria-se dentro das discussões mais aprofundadas de conceitos de espécies, mas sim refere-se a uma prática metodológica de se ignorar a série de indivíuos coletados 
numa região, excluindo as graduais alterações observadas dentro da variação intraespecífica e basear julgamentos em apenas um único exemplar com características extremas, sobre-estimando as diferenças para o suposto táxon vizinho. No caso de Alcantarea, adotou-se aqui o conceito morfológico de espécies (Judd et al. 1999), sendo consideradas espécies novas apenas aquelas para as quais há nítida interrupção morfológica, para um conjunto de caracteres em diferentes indivíduos observados através do material acumulado nas coleções científicas e / ou na observação das populações no campo. Não foram aqui adotadas categorias infraespecíficas.

\section{CONSERVAÇÃO DE ALCANTAREA}

O extrativismo de muitas espécies de Bromeliaceae de interesse ornamental, aliado à perda de habitat, vem levando populações ou mesmos espécies ao risco de extinção. Cerca de 40\% das Bromeliaceae registradas na mata atlântica brasileira encontram-se listadas sob alguma categoria de ameaça (Martinelli et al. 2008). A recém publicada lista das espécies da flora brasileira ameaçadas de extinção, inclui sete espécies de Alcantarea (27\% do gênero) dentro do apêndice II, com deficiência de dados (Ministério do Meio Ambiente, 2008). Tal fato revela a falta de conhecimento das populações no campo e carência de registros que comprovem a extensão de ocorrência das espécies.

A proteção efetiva das espécies de Alcantarea, está relacionada à conservação do seu habitat, isto é, dos afloramentos rochosos. De acordo com Meirelles et al. (1999), tais ambientes são caracterizados naturalmente por altas taxas de raridade, endemismo e fragilidade que, sozinhos, já justificariam a sua conservação. Em áreas de inselbergs, a pressão de ameaça dá-se pela ocorrência de queimadas, pela invasão por espécies exóticas de gramíneas, além da remoção dos substratos rochosos, especialmente granito (Porembski et al. 1998; Forzza et al. 2003). Foi constatado no presente trabalho que estes mesmos fatores são ameaças às populações de Alcantarea, além do extrativismo e a abertura de trilhas ou vias de escaladas (Fig. 7).

Plantas rupícolas de inselbergs estariam menos susceptíveis à ação antrópica, uma vez que o inselberg em si representa uma barreira à ocupação humana ou agrícola, servindo de refúgios (Porembski et al. 1998). Várias espécies de Alcantarea crescem paredões verticais, só acessíveis através de técnicas de escalada, o que assegura sua sobrevivência. Entretanto, ainda assim as populações podem estar ameaçadas, pois a destruição das florestas periféricas agrava o risco de queimadas e aumenta as possibilidade de invasão por espécies exóticas, como gramíneas africanas, e.g. Panicum maximum Jacq (Guedes-Bruni \& Lima 1997). Tal processo de empobrecimento do entorno parece ser análogo ao efeito de borda que ocorre com fragmentos florestais. Barbará et al. (2007) ressaltam a importância que a matriz de floresta pode apresentar para a sobrevivência de polinizadores de espécies rupícolas, estabelencendo-se aí uma estreita dependência entre as Alcantarea dos afloramentos rochosos com polinizadores e florestas do entorno. 
O fogo destrói populações inteiras, se alastrando pelas folhas secas mais externas das rosetas. Durante o trabalho de campo, foram observadas queimadas (Fig. 7) ou seus vestígios. Após sucessivos incêndios, fica evidente o empobrecimento ao qual a vegetação está submetida. Em Minas Gerais, próximo a Almenara, um morador local, apontando para uma grande população de Alcantarea afirmou "durante a seca, o fogo queima tudo e a pedra chega a ficar iluminada". Quando perguntado sobre as razões para tal prática, respondeu alegando a diminuição dos mosquitos e cobras na vizinhança. Foram observadas extensas queimadas, também, dentro de unidades de conservação, como no Parque Natural Municipal da Prainha, no Rio de Janeiro, ou no Parque Nacional da Serra dos Órgãos.

Em alguns lugares o extrativismo é praticado indiscriminadamente, amparado pela crença de que as populações jamais serão afetadas. Na Bahia, na Serra da Jibóia, uma moradora nos relatou sobre a Alcantarea nahoumii, espécie é localmente comercializada ao longo das rodovias: "Eu já arranquei muito. Tem para encher caminhão”. Apreensões de indivíduos vivos coletados ilegalmente dentro de parques também foram constatadas, mas atualmente já há produção em larga escala de várias espécies para suprir a demanda do mercado de plantas ornamentais, especialmente de $A$. imperialis. No Espírito Santo, assim como em outros estados, a exploração de granito leva à destruição do substrato rochoso o que pode afetar as espécies de distribuição restrita. A abertura de trilhas ou de vias de escalada, apesar de ser um problema localizado, pode ter impacto negativo sobre populações. No Parque Estadual do Desengano (RJ), A. farneyi cresce ao longo da trilha que dá acesso ao pico principal, estando exposta ao pisoteio. O início dessa mesma trilha é feito utilizando-se grandes indivíduos de $A$. imperialis como 'escada'. No Pão de Açúcar, as vias de escaladas mais empregadas deixam veios abertos no meios das ilhas de $A$. glazionana (Fig. 7).

Em muitos casos, a área de ocupação das espécies de Alcantarea é bem pequena, uma vez que ocorrem apenas nas porções nuas das rochas do inselbergs, que são formação naturalmente fragmentadas. Tal fato, pode facilmente levar a espécie a se enquadrar como Vulnerável, usando os critérios de área de ocupação inferior a $2000 \mathrm{~km}^{2}$ (Vulnerable B2, cf. IUCN 2001). Entretanto, se tais áreas, ainda que pequenas, encontram-se protegidas dentro de unidades de conservação, a probabilidade de que haja queda contínua na qualidade/extensão do habitat ou no número de populações fica mais limitada. Parece ser este o caso, por exemplo, da $A$. duarteana, que apesar da área de ocupação pequena, tem ocorrências dentro de parques, onde espera-se que o habitat esteja protegido. Em um futuro próximo muitas das espécies aqui tratadas como Near Threatened, poderão ser incluídas em uma categoria de ameaça mais severa, caso haja redução do número de populações, ou queda acentuada na área de ocupação.

O quadro a seguir apresenta os estados de conservação adotados no presente trabalho, de acordo com as categorias da IUCN (2001). Táxons recém descritos, cujas populações não foram examinadas pelo autor, encontram-se classificados como Data Deficient. 
Quadro 1. Estado de conservação das espécies de Alcantarea de acordo com IUCN (2001). Os critérios empregados são apresentados individualmente, dentro dos comentários da espécie na secção seguinte.

\begin{tabular}{|l|l|l|l|l|l|}
\hline 1. Alcantarea benqingii & DD & & & & \\
\hline 2. Alcantarea burle-marxii & & & NT & & \\
\hline 3. Alcantarea distractila & DD & & & & \\
\hline 4. Alcantarea duarteana & & & NT & & \\
\hline 5. Alcantarea extensa & & LC & & & \\
\hline 6. Alcantarea farneyi & & & & VU & \\
\hline 7. Alcantarea geniculata & & LC & & & \\
\hline 8. Alcantarea glaziouana & & & & VU & \\
\hline 9. Alcantarea hatschbachii & DD & & & & \\
\hline 10. Alcantarea heloisae & & & NT & & \\
\hline 11. Alcantarea imperialis & & LC & & & \\
\hline 12. Alcantarea longibracteata & DD & & & & \\
\hline 13. Alcantarea martinellii & & & & & EN \\
\hline 14. Alcantarea nahoumii & & & & VU & \\
\hline 15. Alcantarea nevaresii & & LC & & & \\
\hline 16. Alcantarea nigripetala & DD & & & & \\
\hline 17. Alcantarea odorata & & LC & & & \\
\hline 18. Alcantarea patriae & & LC & & & \\
\hline 19. Alcantarea regina & & LC & & & \\
\hline 20. Alcantarea roberto-kautskyi & & LC & & & \\
\hline 21. Alcantarea simplicisticha & & & & & \\
\hline 22. Alcantarea tortuosa & & LC & & & \\
\hline 23. Alcantarea trepida & & LC & & & \\
\hline 24. Alcantarea turgida & & & & VU & \\
\hline 25. Alcantarea vasconcelosiana & & & 5 & \\
\hline 26. Alcantarea vinicolor & & & & \\
\hline Totais & & & & \\
\hline
\end{tabular}

Para seis das sete espécies listadas pelo Ministério do Meio Ambiente (2008) como Data Deficient, foi possível estabelecer uma categoria mais precisa. Apenas para $A$. benżingii não foi possível incrementar o conhecimento de suas populações e assim estabelecer um estado de conservação confiável. Entretanto, outras espécies descritas recentemente e com a área de ocupação ainda pouco conhecida estão incluídas, agora, na categoria DD. Onze espécies apresentam populações grandes, ocorrência em parques e em locais de difícil acesso, o lhes garante a sobrevivência. Três espécies estão próximas a serem enquadradas como ameaçadas (NT). Espécie de distribuição muito restrita, ou que estão expostas a perda de habitat ou diminuição do tamanho de 
suas populações estão listadas como vulneráveis. Alcantarea martinellii, apresenta poucos registros de herbário, ocorre em uma unica área em Petrópolis, RJ, formando uma população pequena, exposta ao pastoreio/pisoteio de caprinos e à espécies de gramíneas invasoras, sendo aqui considerada como Em Perigo (Endangered).

\section{TAXONOMIA}

Alcantarea (E. Morren ex Mez) Harms, Notizbl. Bot. Gart. Berlin-Dahlem 10: 802. 1929.LECTÓTIPO: designado por Grant \& Zijlstra (1998): Alcantarea regina (Vell.) Harms [=Tillandsia regina Vellozo, Fl. flum. Icones 3, t. 142. (1827) 1831].

HERBÁCEAS rupícolas, propagando-se vegetativamente por brotações basais ou axilares, vistosas, perenes, 0.4-5 m; caule curto, inconspícuo, ou robusto e coberto por restos de bainhas foliares. ROSETA em geral infundibuliforme, raramente tubular ou graminiforme. FOLHAS em geral liguladas, distintamente divididas entre lâmina e bainha. PEDÚNCULO ereto, robusto, raramente subereto e delgado, coberto por brácteas vistosas, polísticas ou imbricadas. INFLORESCÊNCIA simples ou composta, espiga ou panícula de espigas; pedúnculos laterais bracteados, raramente nús. FLORES vistosas, dísticas ou secundas; pétalas freqüentemente amarelas, comumente esmaecendo-se entre a pré-floração e a antese, amarelo-vinosas, raramente albas ou vinosas, efêmeras, longas, liguladas, ápice agudo a obtuso, tornando-se espiraladas, fortemente recurvadas ou flácidas, pétalas com 2 apêndices petalíneos basais ou nuas (A. hatschbachii); estames e estilete inclusos ou exsertos, filetes apresentados em feixe ou polísticos; ovário cripticamente semiínfero; nectários septais inter e infraloculares desenvolvidos. FRUTO cápsula septicida, ovóide, acuminada; sementes numerosas, comosas no ápice e na base.

\section{CHAVE PARA AS EsPÉCIES DE AlCANTAREA}

1. Inflorescência simples (2)

2. Roseta infundibuliforme; fitotelma desenvolvido (3)

3. Lâmina foliar estreito-triangular; bráctea floral orbicular, ca. $25 \mathrm{~mm}$ compr. (A. martinellii)

3. Lâmina foliar ligulada ou subligulada; bráctea floral elíptica a largo-oval, maior que $36 \mathrm{~mm}$ compr. (4)

4. Bráctea distal do pedúnculo ereta, justaposta ao entrenó, sem acumular água; pedúnculo 1-1.3 cm de diâm.; folha cartácea (A. simplicisticha)

4. Bráctea distal do pedúnculo subereta a arqueada, infladada na base, acumulando água; pedúnculo 1.8-3 cm de diâm.; folha coriácea (5) 
5. Ráquila reta, com entrenós1-1.6 cm diâm.; espiga geralmente reta e ereta (A. trepida)

5. Ráquila geniculada, raramente quase reta, com entrenós de 0.6-0.7 cm diâm.; espiga encurvado-patente (A. extensa)

2. Roseta graminiforme, sublageniforme ou tubular; fitotelma pouco desenvolvido (6)

6. Planta florida acima de $1.2 \mathrm{~m}$ alt.; pedúnculo ereto; pétalas nuas (A. hatschbachii)

6. Planta florida até $0.7 \mathrm{~m}$ alt.; pedúnculo encurvado a subereto; pétalas com apêndices (7)

7. Brácteas do pedúnculo amarelo-avermelhadas; lâminas foliares ca. $3 \mathrm{~cm}$ larg. (A. benzingii)

7. Brácteas escapais vermelho-vinho, raramente verde-avermelhadas; lâminas foliares $0.4-1.5 \mathrm{~cm}$ larg. (A. farneyi)

1. Inflorescência composta (8)

8. Brácteas florais e flores secundas para cima na antese (9)

9. Pétalas cor de vinho escuras a negras no botão floral; bráctea floral orbicular, ecarinada; pedúnculo com até $2 \mathrm{~cm}$ de diâm. (A. nigripetala)

9. Pétalas amarelas no botão floral; bráctea floral oval a largo-oval, carenada ao menos próximo ao ápice; pedúnculo com mais de $3 \mathrm{~cm}$ de diâm. (10)

10. Lâmina foliar verde lustrosa, ápice longo-atenuado; filetes mais longos que as pétalas ( $A$. regina)

10. Lâmina foliar glauca, verde-avermelhada ou vermelho-vinosa, ápice acuminhado; filetes mais curtos que as pétalas (A. imperialis)

8. Brácteas florais e flores dísticas na antese (11)

11. Brácteas primárias maiores ou iguais ao compr. dos pedúnculos laterais da inflorescência (12)

12. Pétalas albas na antese; lâminas foliares e brácteas do pedúnculo com faixas transversais albo-cerosas, frequentemente encontrada em costões rochosos próximo ao mar no municípios de Niterói e do Rio de Janeiro (A. glaz̧ionana)

12. Pétalas amarelas na antese; lâminas foliares e brácteas do pedúnculo verde-lustrosas ou totalmente cerosas; frequentemente encontradas em regiões montanhosas do interior (13)

13. Ramos da inflorescência suberetos na antese; lâmina foliar densamente lepidota adaxialmente; plantas de campo rupestre $(A$. duarteana)

13. Ramos da inflorescência patentes ou encurvados para baixo na antese; lâmina foliar glabrescente a esparsamente lepidota adaxialmente; plantas da mata atlântica (14)

14. Planta florida com $0.6-0.9 \mathrm{~m}$ alt.; ráquilas $3-4.5 \mathrm{~cm}$ compr. (A. vasconcelosiana)

14. Planta florida com 1.1-3 m alt.; ráquilas 5-32 cm compr. (16)

15. Brácteas florais e pétalas totalmente amarelas na antese (16)

16. Lâmina verde-lustrosa, glabrescente, maior que 1.2 m compr.; inflorescência com 13 $16 \operatorname{ramos}$ (A. longibracteata) 
16. Lâmina glauca, coberta por cera epicuticular, menor que $1 \mathrm{~m}$ compr.; inflorescência com 20-41 ramos (A. odorata)

15. Brácteas florais verdes a verde-amareladas e pétalas amarelas na antese (17)

17. Ápice da lâmina acuminado, geralmente verde-arroxeado ou vinoso; lâmina com faixas transversais cerosas; pétalas fortemente voltadas para trás e murchando sem espiralar (A. beloisae)

17. Ápice da lâmina atenuado, verde concolor; lâmina verde lustrosa; pétalas fortemente voltadas para trás e espiralando-se (18)

18. Filetes maiores que $6.5 \mathrm{~cm}$ compr.; pétala com protuberância carnosa logo acima dos apêndices (A. geniculata)

18. Filetes ca. $5 \mathrm{~cm}$ compr.; pétalas sem protuberância carnosa logo acima dos apêndices $(A$. nevaresii)

11. Brácteas primárias sempre menores que os pedúnculos laterais da inflorescência (19)

19. Inflorescência jovem fastigiada (i.e. em formato de candelabro) com ramos fortemente encurvados (ráquila formando ângulo de ca. $90^{\circ}$ com o pedúnculo lateral); anteras dorsifixas na altura de $1 / 3$ do seu compr. (A. roberto-kautskyl)

19. Inflorescência com ramos polísticos, ou todos voltados para cima, retos, levemente encurvados ou sigmóides; anteras dorsifixas próximo à base (20)

20. Pedúnculo subereto, curvo ou, se ereto, tortuoso; brácteas do pedúnculo densamente imbricadas, sem acumular água na base; plantas da Serra do Desengano (Santa Maria Madalena, RJ) (A. tortuosa)

20. Pedúnculo ereto, reto; brácteas do pedúnculo polísticas, inflada pelo menos um pouco na base e podendo aí acumular água; plantas predominantemente dos estados do ES, MG, BA, raramente $\mathrm{RJ}(21)$

21. Brácteas florais e pétalas totalmente amarelas, sem quaisquer máculas ou pontuações vinosas; estames apresentados em feixe(22)

22. Ramos da inflorescência suberetos ou eretos na antese; folhas com faixas transversais de cera (A. patriae)

22. Ramos da inflorescência patentes a pêndulos; folhas lustrosas, sem vestígios de cera (A. nahoumii)

21. Brácteas florais verdes, acastanhadas, verde-vinosas ou vinosas; pétalas amarelo-vinosas ou vinoso-alaranjadas passando a rosado-alvacentas; estames polísticos (23)

23. Ramos da inflorescência suberetos a eretos na antese; ráquila reta ou quase (A. trepida)

23. Ramos da inflorescência patentes a pêndulos (exceto o terminal); ráquila geniculada 
24. Pétalas amarelo-claras no botão e na antese, sem quaisquer máculas ou pontuações vinosas; plantas da região central de Minas Gerais (A. turgida)

24. Pétalas amarelo-vinosas, amarelo-ocre ou rosadas; plantas do leste e nordeste de Minas Gerais, Espírito Santo e norte do RJ (25)

25. Bainha foliar 8-11 cm larg.; pedúnculos laterais $20-25 \mathrm{~cm}$ (A. distractila)

25. Bainha foliar 13-23 cm larg.; pedúnculos laterais 6-18 cm (26)

26. Ápice da lamina foliar agudo, atenuado; brácteas distais do pedúnculo triangulares; folhas predominantemente verdes sem cera; brácteas verdes, raramente vinosas, pétalas alvacento-rosadas ou cor de bronze na antese (A. burle-marxii)

26. Ápice da lâmina acuminado; brácteas distais do pedúnculo ovais, largo-ovais ou elípticas; folhas glaucas ou vinosas; pétalas amarelo-vinosas na antese (27)

27. Brácteas florais $3.6-4.2 \mathrm{~cm}$ compr, $3.8-4.6 \mathrm{~cm}$ larg.; sépalas 4-3 cm compr., ramos suberetos ou patentes; folhas geralmente glaucas (A. extensa)

27. Brácteas florais 2-3.2 cm compr., 2.2-3.5 cm larg.; sépalas 2.9-3.3 cm compr., ramos arqueados; folhas geralmente vinosas (A. vinicolor)

1. Alcantarea benzingit Leme, Bromélia 2(3): 19. 1995.-Tipo: Brasil. Espírito Santo: Castelo, Forno Grande, R. Kautsky s.n., florida em cultivo, Jan - Fev 1995, E. M. C. Leme 850 (holótipo: $\mathrm{HB} !)$.

RUPÍCOLA, ca. $0.7 \mathrm{~m}$ alt., propagando-se por brotações basais, curto-caulescente. ROSETA tubular, fitotelma pouco desenvolvido. FOLHAS ca. 6, eretas a suberetas; BAINHA 16-18 x 3-4.5 cm, oblongo-elíptica, verde in vivo, bege in sicco, esparsamente marrom-lepidota em ambas as faces, coriácea, margens membranáceas; LÂMINA 26 × 2.5-4 cm, linear, verde, concolor, glauca, esparsamente passando a densamente lepidota no ápice abaxialmente, esparsamente lepidota em direção ao ápice adaxialmente, ereta, coriácea, distintamente nervada, margens revolutas in sicco; ÁPICE DA LÂMINA agudo, verde. PEDÚNCULO ca. 41 x $0.3 \mathrm{~cm}$, subereto, encurvado, esguio, quase circular em secção transversal, verde, glabro, distintamente nervado, sulcado, entrenós 3-4.5 cm; BRÁCTEAS 5-9 x 1.2-2.4 cm, as proximais: oblongo-lanceoladas, eretas; as medianas e distais: ovais, ápice acuminado, amarelo-avermelhadas in vivo, bege in sicco, esparsamente lepidotas, eretas, imbricadas, finamente nervadas, cartáceas; margens hialinas, membranáceas in sicco. INFLORESCÊNCIA ca. 15 × $8 \mathrm{~cm}$ (excluindo as pétalas), espiga, de contorno elíptico, 7-florida, subereta a patente com ápice ligeiramente ascendente; RÁQUILA flexuosa, quase quadrangular em secção transversal, entrenós de 1.4(distal)-3(proximal) x ca. $0.2 \mathrm{~cm}$, verde, inconspicuamente hialinolepidota; BRÁCTEA FLORAL ca. 4.2 x $2.5 \mathrm{~cm}$, oval, ápice obtuso, amarelo-avermelhada, glabra abaxialmente, subdensamente marrom-lepidota adaxialmente, envolvendo completamente o cálice, 
finamente nervada, coriácea, ecarinada; margens hialino-amareladas, membranáceas in sicco. FLORES dísticas, suberetas na antese; SÉPALAS ca. 3.7 x $1.4 \mathrm{~cm}$, elípticas, ápice subagudo, simétricas ou com pequena assimetria entre os lados da base, igualando-se às brácteas florais, verdes a amareloesverdeadas em direção ao ápice, glabras abaxialmente, esparsamente lepidota adaxialmente, coriácea, ecarinadas; margens hialinas, mebranáceas in sicco; PÉTALAS $6.5-7.5$ x $0.7 \mathrm{~cm}$, liguladas, ápice obtuso, amarelas, fortemente recurvada para trás e enroladas; APÊNDICES PETALÍNEOS 20-25 x ca. $2 \mathrm{~mm}$, lineares, adnatos à pétala longitudinalmente por ca. $17 \mathrm{~mm}$, ápices obtusos; ESTAMES apresentados em feixe e passando a polísticos; FILETE cilíndrico, branco; ANTERA ca. 8 mm, linear, dorsifixa próximo à base; ESTILETE ca. 5,5 cm, cilíndrico, branco; LOBOS DO ESTIGMA ca. 4 × $1 \mathrm{~mm}$, polísticos, brancos; OVÁRIO ca. 10 × $4 \mathrm{~mm}$, estreitamente ovado. CÁPSULA E SEMENTES desconhecidas. Fig. 8.

DISTRIBUIÇÃO, ECOLOGIA E CONSERVAÇÃO. Alcantarea benzingii só é conhecida do Parque Estadual do Forno Grande, em Castelo, região serrana do Espírito Santo. A espécie está incluída na lista das espécies da flora brasileira ameaçadas de extinção, dentro do apêndice II, com deficiência de dados (Ministério do Meio Ambiente, 2008). No presente estudo não foi possível esclarecer seu estado de conservação por falta de dados de abundância e distribuição, uma vez que não foram amostradas populações. Entretanto, sua área de ocorrência corresponde ao Parque Estadual do Forno Grande, o que provavelmente assegura sua proteção. IUCN Red List Category: Data Deficient, DD.

FENOLOGIA. Floresceu em cultivo entre janeiro e fevereiro.

ETIMOLOGIA. O epíteto-específico homenageia o Dr. David Benzing especialista em fisiologia de epífitas, com ênfase em Bromeliaceae.

DISCUSSÃO. Espécie pouco conhecida e de distribuição muito restrita. Apesar dos nossos esforços em se obter licença de coleta para o Parque Estadual do Forno Grande, e ainda durante a visita que fizemos ao mesmo, não nos foi permitido subir em direção ao pico do Forninho e Forno Grande onde as populações ocorrem (R. Kautsky com. pes.). A descrição aqui feita baseia-se no material tipo, que é depauperado e contém poucas flores passadas, sendo que os dados de medidas para peças florais e coloração foram obtidos na obra original (Leme 1995), onde é possível observar fotos do exemplar tipo florido em cultivo. Alcantarea benzingii foi descrita como sendo muito próxima à $A$. farneyi (Leme 1995). Ambas as espécies apresentam fitotelmas pouco desenvolvidos, inflorescência simples, estames apresentados em feixe e pétalas amarelas, fortemente recurvadas e enroladas na antese. Além disso, apresentam semelhança quanto ao habitat, ambas ocorrendo nas maiores altitudes registradas para o gênero, em torno dos 2000 m.s.m. Entretanto, A. benzingii apresenta rosetas 
tubulares (vs. sub-bulbosa em $A$. farneyz), lâminas foliares mais largas, flores mais espaçadas e brácteas florais e sépalas mais longas. As brácteas em $A$. benz̧ingii assumem um coloração esmaecida, levemente avermelhadas passando a paleáceas. Em A. farneyi as brácteas são vermelho-vinho intenso, entretanto tais colorações variam em resposta ao ambiente/cultivo. Apesar de só haver a coleção tipo, a espécie não apresenta problemas de delimitação, entretanto novos registros permitirão que outras características morfológicas, dados fenológicos e o real estado de conservação das populações sejam melhor compreendidos.

MATERIAL EXAMINADO: Brazil. EsPíRITO SANTO: Castelo, Forno Grande, R. Kautsky s.n., florida em cultivo, E.M.C. Leme 850, Jan.-Fev. 1995 (HB).

2. Alcantarea burle-marxiI (Leme) J. R. Grant, Bromélia 2(3): 26. 1996. Vriesea burle-marxii Leme, Pabstia 4(3): 4, fig. 3. 1993.-TiPO: BRASIL. Minas Gerais, Pedra Azul, florida em cultivo no sítio do coletor em Fevereiro de 1992, R. Burle Marx s.n. (Holotypus: HB 77777!).

RUPÍCOLA, 1.7-2.1 m alt., propagando-se por brotações axilares, curto caulescente. ROSETA ca. 70 x $110 \mathrm{~cm}$, infundibuliforme, fitotelma desenvolvido. FOLHAS 16-22, suberetas; BAINHA 18-23 x 10-12 cm, elíptica a oblonga, verde-clara a bege in vivo, densamente marrom-lepidota em ambas as faces, coríacea; margens membranáceas, verde-claras hialinas; LÂMINA 55-62 x 4.5-6.5 cm, lineartriangular, verde, concolor, densamente lepidota abaxialmente, esparsamente lepidota a glabra adaxialmente, levemente canaliculada, coriácea, subereta, distintamente nervada; margens com 2-3 nervuras proeminentes, com fina linha lateral e máculas vinosas; ÁPICE DA LÂMINA agudo, atenuado, verde, reto ou quase, apiculado por ca. $10 \mathrm{~mm}$. PEDÚNCULO 80-100 x 1.1(distal) a 1.5 (proximal) $\mathrm{cm}$, ereto, reto, cilíndrico, verde, raramente vinoso, glabro, distintamente nervado, entrenós 7.5-9 cm; BRÁCTEAS proximais: 12-20 x 2-2.6 cm, subfoliáceas, suberetas; medianas e distais: (2-)5-11 x 1-2 cm, triangulares, ápice agudo, verdes em ambas as faces, raramente vinosas, de esparsamente a densamente lepidotas em direção ao ápice abaxialmente, esparsamente lepidotas adaxialmente, encurvado-patentes, levemente infladas na base, finamente nervadas, cartácea, margens vinosas. INFLORESCÊNCIA ca. 95 x $60 \mathrm{~cm}$ (excluindo as pétalas), composta, panícula de espigas, elipsoidal a ovoidal, ereta, entrenós da raque de 8-9 cm, retos a levemente flexuosos; BRÁCTEA PRIMÁRIA $2-4$ x $1.8-2.4 \mathrm{~cm}$, oval a oblonga, ápice obtuso-acuminado, verde, raramente vinosa, densamente marrom-lepidota em direção ao ápice abaxialmente, glabra adaxialmente, involuta, muito mais curta que o pedúnculo lateral, finamente nervada, cartácea, com as margens basais membranáceas; RAMOS DA INFLORESCÊNCIA 4-12, (3-)9-15-floridos, botão terminal frequentemente pouco desenvolvido ou abortado; PEDÚNCULOS LATERAIS 9-10 x 0.4-0.6 cm, subcilíndricos, distintamente nervados, verdes, glabros; BRÁCTEAS ESTÉREIS 0-2; RÁQUILA 15- 
$32 \mathrm{~cm}$, reta a geniculada (i.e. divergindo até $30^{\circ}$ para cada lado), verde, glabra a esparsamente lepidota; entrenós (0.9)1.6-4 x 0.2-0.5 cm; BRÁCTEA FLORAL 2-2.4 x 1.8-2.8 cm, suborbicular, ápice obtuso, verde, esparsamente lepidota abaxialmente, subdensamente marrom-lepidota adaxialmente, envolvendo parcialmente o cálice, frequentemente com o 1/3 basal dos bordos se tocando, levemente rugosa nos bordos, porção central mais lisa, coriácea, ecarinada, margens membranáceas, hialinoamareladas in sicco. FLORES inodoras, dísticas, em geral suberetas; SÉPALAS ca. 3.4 x $1.8 \mathrm{~cm}$, elípiticas a oblongo-elípiticas, ápice obtuso, simétricas, excedendo as brácteas florais em ca. de $1.8 \mathrm{~cm}$, geralmente verdes a verde-amareladas, raramente verde-vinosas, eventualmente manchadas de verde ao longo dos bordos, glabras abaxialmente, subdensamente marrom-lepidotas adaxialmente, levemente carnosas, ecarinadas, margens membranáceas, hialino-amareladas in sicco; PÉTALAS ca. 10.5 x $1 \mathrm{~cm}$, liguladas, ápice agudo, constritas ao redor do ápice das sépalas, vinoso-alaranjadas no botão passando a vinosas abaxialmente, cor de creme a alvacento-rosadas adaxialmente na antese, recurvadas e levemente espiraladas antese; APÊNDICES PETALÍNEOS 29-32 x 2-3 mm, ligulados, longitudinalmente adnatos à pétala por $25 \mathrm{~mm}$, ápice agudo, assimétrico; ESTAMES polísticos na antese; FILETE $10 \mathrm{~cm}$ x 0.4-1 mm, complanado a cilíndrico próximo ao ápice, branco; ANTERA ca. 13 x $1 \mathrm{~mm}$, linear, amarela, dorsifixa próximo à base; ESTILETE 11 x ca. $2 \mathrm{~mm}$, cilíndrico a levemente anguloso, branco; LOBOS DO ESTIGMA ca. 4 x $1 \mathrm{~mm}$, patentes, brancos, densamente papilosos; OVÁRIO ca. 8 x $5 \mathrm{~mm}$ (porção supera), levemente anguloso, verde-alvacento, hipanto ca. $6 \mathrm{~mm}$; ÓVULOS ca. $1.6 \mathrm{~mm}$, numerosos. CÁPSULA $4.2 \times 1.2 \mathrm{~cm}$, fusiforme, marrom; SEMENTE ca. 7 x $1 \mathrm{~mm}$, ca. 260, elipsoidal, marrom; COMA BASAL ca. $6 \mathrm{~mm}$, fimbriado, alvacento; COMA APICAL ca. 8 mm, fimbriado, ferrugíneo. Figs. 9, 12 A-H.

DISTRIBUIÇÃO, ECOLOGIA E CONSERVAÇÃO. Alcantarea burle-marxii só é conhecida dos municípios de Pedra Azul e Santa Maria do Salto, região nordeste de Minas Gerais. Em virtude de sua distribuição geográfica restrita e por ter sido constatado que a espécie é rara, com populações pequenas e esparsas, propõe-se aqui que seja monitorada no futuro próximo, visto que foi observada uma grande degradação dos entornos dos inselbergs em que ocorre, pelo estabelecimento de pastagens, que poderá levá-la a alguma categoria de ameaça. Não há registros de $A$. burle-marxii em unidades de conservação, entretanto a espécie é cultivada em jardins botânicos no Brasil e no exterior. IUCN Red List Category: Near Threatened, NT.

FENOLOGIA. Floresce entre dezembro e fevereiro.

ETIMOLOGIA. O epíteto-específico homenageia o artista e paisagista brasileiro Roberto Burle Marx, coletor do typus. 
DISCUSSÃO. Espécie bem caracterizada pela inflorescência laxa com poucos ramos paucifloros e suberetos. A coloração das pétalas nos botões florais varia com o desenvolvimento da flor. No botão a coloração é alanjado-vinosa e, na antese, as pétalas se mostram alvacentas com um leve tom rosado na face adaxial ou ainda pode assumir uma coloração semelhante ao bronze, levemente acastanhada (Fig. 12). Leme (1993) ao descrever A. burle-marxii a compara com A. vinicolor, da qual difere por apresentar folhas com ápice acuminado-caudado, inflorescência mais longa, com maior número de ramos suberetos. Leme \& Kollmann (in Leme et al. 2008) descreveram $A$. nigripelata, com a qual $A$. burle-marxii partilha várias similaridades, entre elas o porte, a forma da roseta, das folhas e das brácteas do pedúnculo, entretanto A. burle-marxii não possui flores secundas. A coleta de Versieux 421, de Pedra Grande, MG, apresenta afinidades com A. burle-marxii, principalmente pela morfologia da inflorescência, porém com folhas diferentes, mais largas e ápice obtuso, mais similares às folhas de A. nahoumii. Os dados de microssatélites (Cap. 2) também indicam a proximidade desse indivíduo $\operatorname{com} A$. burle-marxii e $A$. naboumii e sua identidade será melhor averiguada no futuro, com a análise de um maior número de coleções. Em $A$. burle-marxii também é possível observar indivíduos que ao florescerem assumem uma coloração totalmente vinosa ou verde na inflorescência (Fig. 12).

MATERIAL EXAMINADO: Brazil. Minas Gerais. Pedra Azul, 16 Jan 1965, Pabst \& Pereira 8314 (HB, K); Ibidem, Dec 1994, Nahoum s.n. (HB73900). Pedra Grande, 9 Feb 2007, Versieux 421 (SP) “affinis". Santa Maria do Salto, afloramento de granito, 11 Oct 2003, Salino et al. 9305 (BHCB). Without exact locality, cultivada no sítio do coletor, Jan 1992, Burle Marx s.n. (HB77777).

3. Alcantarea Distractila Leme \& Paula, J. Bromeliad Soc. 58(1): 5. 2008.-TipO: Brasil. Minas Gerais: Ouro Verde de Minas, along the road to Itambacuri, ca. 300 m, 29 Set 2002, E. M. C. Leme 5601, C. C. Paula \& M. Grossi (holótipo: RB!).

RUPÍCOLA, ca. $2 \mathrm{~m}$ alt., curto-caulescente. ROSETA estreito infundibuliforme, fitotelma desenvolvido. FOLHAS ca. 20, suberetas a eretas; BAINHA 11-15 x 8-11 cm, oblonga a estreito oval, bege e densamente marrom-lepidota em ambas as faces, coriácea, margens membranáceas, hialino-amareladas; LÂMINA 34-40 x 5.5-6.5 cm, ligulada, verde em ambas as superfícies, esparsamente lepidota sobre as nervuras abaxialmente, de glabra a esparsamente lepidota em direção ao ápice adaxialmente, reta a levemente arqueada, coriácea, distintamente nervada, com nervuras proeminentes, margens verdes; ÁPICE DA LÂMINA obtuso-acuminado, verde, em geral voltado para a base da folha. PEDÚNCULO ca. $100 \times 1.2-1.5 \mathrm{~cm}$, ereto, reto, cilíndrico, verde, vinoso nas áreas expostas, glabro, distintamente nervado; entrenós $5(-8)$ cm; BRÁCTEAS proximais: ca. 15 x 4.5 $\mathrm{cm}$, subfoliáceas e eretas; as medianas e distais: 5-8 x 3-4 cm, ovais, ápice acuminado, verdes, verdevinosas a totalmente vinosas, geralmente subdensamente marrom-lepidotas em ambas as faces ou 
glabra apenas abaxialmente, suberetas, involutas, acumulando água na base, distintamente nervadas, coriáceas, margens membranáceas, hialino-amareladas. INFLORESCÊNCIA ca. 1.1 x 0.9 m, composta, panícula de espigas, contorno irregular, ereta; entrenós da raque ca. $9 \mathrm{~cm}$; BRÁCTEA PRIMÁRIA ca. $4.5 \times 3.2 \mathrm{~cm}$, oval, ápice obtuso-acuminado ou apiculado, verde ou vinosa, lustrosa ou com pouca cera, glabra abaxialmente, densamente lepidota adaxialmente, involuta, patente a subereta, muito mais curta que a base estéril do pedúnculo lateral, distintamente nervado-rugosa, coriácea, margens hialino-amareladas a marrons, membranáceas in sicco; RAMOS DA INFLORESCÊNCIA ca. 3, porém alguns ramos atrofiados podem ser observados sob as brácteas distais do pedúnculo, 20-26floridos ou com todas as flores abortadas, subereto-encurvados passando a pêndulos; PEDÚNCULOS LATERAIS 20-25 x $0.7 \mathrm{~cm}$, geralmente levemente complanados, a cilíndricos, vinosos, glabros; BRÁCTEAS ESTÉREIS 3.6-5 x 2-3 cm, 3-4, oval a elíptica, ápice obtuso apiculado, marrom-escuras no centro e amareladas nos bordos in sicco, opacas, cerosas, glabras abaxialmente, densamente marrom lepidotas adaxialmente, remotas, distintamente nervadas, ecarinadas a carenadas, coriácea, margens hialino-amareladas, membranáceas in sicco; RÁQUILA 55$80 \mathrm{~cm}$, quase reta, verde a vinosa, glabra ou quase; entrenós (1.8-)2.8-4.6 x 0.4-0.8 cm; BRÁCTEA FLORAL 4.1-4.6 × 3-3.3 cm, largo oval, ápice obtuso, marrom-escura concolor no centro com bordos vinoso-amarelados in sicco, amarelada na base passando a vinosa ao longo dos bordos in vivo, esparsamente lepidota ao longo dos bordos abaxialmente, densamente marrom-lepidota adaxialmente, envolvendo parcialmente o cálice, subereta, distintamente rugosa no centro, finamente nervada nos bordos in sicco, coriácea, inconspicuamente carinada 1/4 distal, margens membranáceas, vinosas. FLORES dísticas, antese noturna; SÉPALAS 4-4.5 x 1.8-2 cm, elípticas a oboelípticas, ápice obtuso, simétricas, excedendo em ca. $0.7 \mathrm{~cm}$ as brácteas florais, verdes com ápice verde-vinoso, esparsamente lepidotas abaxialmente, subdensamente lepidotas adaxialmente, coriáceas, ecarinadas, margens membranáceas, hialino-amareladas in sicco; PÉTALAS 9-11 x $1 \mathrm{~cm}$, liguladas, ápice obtuso, constritas ao redor do ápice das sépalas, com máculas e pequenos traços vinosos na face abaxial, amarelas adaxialmente, recurvadas e pouco espiraladas; APÊNDICES PETALÍNEOS 33-35 x 2 $\mathrm{mm}$, ligulados, longitudinalmente adnatos à pétala, $7 \mathrm{~mm}$ distais livres, ápice agudo a obtuso; ESTAMES polísticos; FILETE cilíndrico, branco; ANTERA ca. 16 × $2 \mathrm{~mm}$, linear, amarela, dorsifixa próximo à base; ESTILETE ca. 95 x $2 \mathrm{~mm}$, cilíndrico a levemente anguloso, branco; LOBOS DO ESTIGMA, OVÁRIO e ÓVULOS não vistos. CÁPSULA 4.5-5 x 1-1.3cm, ovóide, marrom-escura; SEMENTE $6 \times 1 \mathrm{~mm}$, fusiforme, marrom-escura quase negra; COMA BASAL ca. $7 \mathrm{~mm}$, bege; COMA APICAL ca. 15 mm, ferrugíneo. Fig. 10.

DISTRIBUIÇÃO, ECOLOGIA E CONSERVAÇÃO. Espécie conhecida apenas pela coleção tipo, da região de Itambacuri, nordeste de Minas Gerais, onde foi coletada em afloramentos rochosos, a cerca de 300 m.s.m. Não há registros de sua ocorrência em unidades de conservação e é pouco 
cultivada. De acordo com Leme \& Paula (2008) na localidade típica a espécie forma grandes populações em paredões rochosos verticais. Levando-se em conta que o nordeste de Minas Gerais é uma área subamostrada para Bromeliaceae (Versieux \& Wendt, 2007) e em razão do táxon ter sido descrito recentemente, ainda faltam dados sobre sua possível área de distribuição. IUCN Red List Category: Data Deficient, DD.

FENOLOGIA. Coletada com frutos imaturos em setembro.

ETIMOLOGIA. O epíteto distractila faz alusão aos ramos bem separados da inflorescência (Leme \& Paula 2008)

DISCUSSÃO. Espécie muito semelhante a Alcantarea extensa da qual difere, basicamente, pelo hábito, com roseta menor e inflorescência mais ampla e laxa. Além disso, apresenta brácteas florais maiores e flores proximais mais espaçadas. A disposição laxa dos ramos é a característica mais marcante neste táxon, os entrenós da raque apresentam ca. 9 cm de compr., sendo essa a característica chave em sua distinção de $A$. extensa. O material tipo apresenta um ramo da inflorescência abortado, sem nenhuma flor desenvolvida, que não ultrapassa $28 \mathrm{~cm}$. Como observado para outras espécies do complexo $A$. extensa, pode-se observar no exemplar tipo a presença de ramos atrofiados sob as brácteas distais do pedúnculo. Entretanto é importante mencionar que o formato da inflorescência, com poucos ramos polísticos e subereto-encurvados, não é exclusivo desse táxon. Também pode ser observado tanto em A. extensa como em $A$. turgida, existindo espécimes em cultivo que apresentam tais caracterísiticas (Fig. 14 P).

MATERIAL EXAMINADO: Brazil. MinAS GERAIS: Ouro Verde de Minas, along the road to Itambacuri, 29 Set 2002, Leme et al. 5601 (HB).

4. Alcantarea duarteana (L. B. Sm.) J. R. Grant, Trop. Subtrop. Pflanzenwelt 91: 13. 1995. Vriesea duarteana L. B. Sm., Phytologia 16(2): 80, figs. 3-5. 1968.-TIPO: BRASIL. Minas Gerais: Diamantina, 2 Fev 1965, A. P. Duarte 9017 (holótipo: HB!; isótipos: RB!, US!).

RUPÍCOLA, (0.6-)0.7-1.1 m alt., propagando-se por brotações basais, curto caulescente. ROSETA 40-50 x 12-25 cm, estreito-infundibuliforme, fitotelma pouco desenvolvido. FOLHAS 9-15, suberetas; BAINHA 9-17 x 4-6.5 cm, estreito-oval, castanho-escura passando ao bege abaxialmente, castanho-clara ou cor de creme adaxialmente in sicco, verde-cinérea a levemente vinosa em ambas as faces in vivo, densamente marrom-lepidota em ambas as faces, coríacea; margens membranáceas, verde-claro hialinas; LÂMINA 40-60(-68) x (0.6-)2.4-3(-4) cm, estreito-triangular, verde-cinérea 
concolor, paleácea in sicco, densamente lepidota abaxialmente, de esparsamente a densamente lepidota em direção ao ápice adaxialmente, canaliculada e levemente carnosa in vivo, involuta, coriácea e quebradiça in sicco, suberetas, finamente nervada, com ca. 10 nervuras proeminentes e de coloração um pouco mais clara que o resto do limbo; margens planas, verdes, in vivo; ÁPICE DA LÂMINA agudo, em geral levemente complanado, verde, reto, apiculado por ca. $5 \mathrm{~mm}$. PEDÚNCULO 45-70(85) x 0.5-0.8(distal) a $0.8-1.4$ (proximal) $\mathrm{cm}$, ereto, reto, delgado, cilíndrico, verde, glabro, distintamente nervado, entrenós $5-7 \mathrm{~cm}$ (proximal) a 3.2-6 cm (distal); BRÁCTEAS proximais: 20$30(-43)$ x 3.5-5 cm, subfoliáceas, polísticas; medianas e distais: (5.5-)10-20(-30) x (1.2-)1.6-2.4(-3.5) $\mathrm{cm}$, ovais, ápice longo-caudado, verdes em ambas as faces, de esparsamente a densamente lepidotas em direção ao ápice abaxialmente, glabras ou esparsamente lepidotas adaxialmente, eretas a suberetas com ápices recurvados, levemente infladas na base, finamente nervadas, cartáceas, margens verdes, revolutas in sicco. INFLORESCÊNCIA 22-54 x 9-13 cm (excluindo as pétalas), composta, em panícula de espigas, estreito-elipsoidal, ereta; entrenós da raque 1.6-3.6 cm; BRÁCTEA PRIMÁRIA 3.5-8 x 1.5-2 cm, oval, longo-caudada, verde, glabra a esparsamente marrom-lepidota em direção ao ápice abaxialmente, esparsamente a densamente marrom-lepidota adaxialmente, involuta, envolvendo e excedendo o pedúnculo lateral, finamente nervada, cartácea, com as margens basais membranáceas; RAMOS DA INFLORESCÊNCIA 6-16, 5-8-floridos, botão terminal em geral pouco desenvolvido ou abortado; PEDÚNCULOS LATERAIS (0.6-)1.5-3.1 x 0.4-0.6 cm, achatados, sulcados, verdes, glabros; BRÁCTEAS ESTÉREIS geralmente ausentes, raramente 1 ou 2; RÁQUILA 3.5-6 cm, levemente geniculada (i.e. divergindo ca. $5^{\circ}$ para cada lado), verde, glabra; entrenós (0.4-)1-1.5 x 0.2$0.3 \mathrm{~cm}$; BRÁCTEA FLORAL (1.4-)2-2.5 x 1.4-2 cm, largo-oval, ápice arredondado, verde, glabra abaxialmente, esparsamente lepidota adaxialmente, envolvendo parcialmente o cálice, frequentemente com o $1 / 3$ basal dos bordos se tocando, finamente rugosa, cartácea, ecarinada, mas com leve linha mais espessada abaixo do ápice, levemente inflada, margens membranáceas, castanho-amareladas in sicco. FLORES inodoras, levemente secundas, em geral patentes; SÉPALAS (2.2-)2.8-3.4 x (0.7-)1$1.3 \mathrm{~cm}$, levemente obovais, ápice obtuso, simétricas, excedendo as brácteas florais em ca. de $1.5 \mathrm{~cm}$, amarelas, glabras abaxialmente, esparsamente marrom-lepidotas adaxialmente, cartáceas, ecarinadas, margens membranáceas, hialino-amareladas in sicco; PÉTALAS 5.5-6.7 x ca. $0.6 \mathrm{~cm}$, liguladas, ápice obtuso, constritas ao redor do ápice das sépalas, amarelas, fortemente recurvadas para trás e enroladas antese; APÊNDICES PETALÍNEOS ca. 14 × $2 \mathrm{~mm}$, ligulados, longitudinalmente adnatos à pétala por ca. $10 \mathrm{~mm}$, ápice obtuso a irregular; ESTAMES em feixe na antese; FILETE 45-52 x $1 \mathrm{~mm}$, complanado, branco; ANTERA ca. 11 x $1 \mathrm{~mm}$, linear, amarela, dorsifixa próximo à base; ESTILETE 60-76 x ca. 2 mm, cilíndrico, branco; LOBOS DO ESTIGMA ca. 1-3 x $1 \mathrm{~mm}$, patentes, brancos; OVÁRIO ca. 6 × 3 mm, estreitamente ovado, verde-alvacento, hipanto ca. $5 \mathrm{~mm}$; ÓVULOS ca. 1 mm, numerosos. CÁPSULA (2.1-)2.5-3.4 x 0.8-1 cm, estreito-elipsoidal com ápice agudo, marrom; 
SEMENTE ca. 6 × $1 \mathrm{~mm}$, elíptica, marrom; COMA BASAL ca. $6 \mathrm{~mm}$, fimbriado, alvacento; COMA APICAL ca. 8 mm, fimbriado, bege. Figs. 11, 12 I-L.

DISTRIBUIÇÃO, ECOLOGIA E CONSERVAÇÃO. Alcantarea duarteana é heliófila em campo rupestre, crescendo entre 1000-1250 m.s.m., em Diamantina, Datas e São Gonçalo do Rio Preto, Minas Gerais. Baseado em critérios da IUCN (IUCN, 2001), foi considerada Vulnerável por Mendonça \& Lins (2000) e Em Perigo por Versieux \& Wendt (2007), mas em razão das recentes coleções obtidas dentro de Unidades de Conservação (Parques Estaduais de Biri-Biri e do Rio Preto) o táxon pode ser rebaixado agora ao status de Near Threatened (NT). Além de só haver registros para esses municípios do planalto de Diamantina, as populações são pequenas, isoladas e sofrem com queimadas e extrativismo. Existem plantas vivas em cultivo em diferentes coleções científicas. Os frutos são eventualmente empregados na confecção de artesanato. IUCN Red List Category: Near Threatened, NT.

FENOLOGIA. Floresce de novembro a março, com pico em dezembro. Frutos coletados em dezembro.

ETIMOLOGIA. Alcantarea duarteana homenageia o coletor do typus, Apparicio Pereira Duarte, do Jardim Botânico do Rio de Janeiro (RB).

DISCUSSÃO: Espécie bem caracterizada pelas folhas longo-atenuadas, densamente cinéreolepidotas, por apresentar roseta com fitotelma pouco desenvolvido e pela inflorescência com ramos laterais curtos e frequentemente sem brácteas estéreis nos pedúnculos laterais. Smith (1968) descreveu Vriesea duarteana comparando-a com $V$. geniculata, da qual diferiria por apresentar lâminas longoatenuadas e flores secundas para baixo. O mesmo autor refere-se na obra original ao material HB 35657 apenas como "type" e escreve "isotype" na etiqueta do mesmo, porém deve-se considerar o referido material como holótipo, conforme citado na obra princeps e a duplicata do US (fragmentos), assim como a duplicata do $\mathrm{RB}$, que até recentemente era desconhecida, como isótipos. A análise molecular baseada em dados do cpDNA (trnK-rps16), indica relacionamento da espécie com $A$. turgida, também de ambiente de campo rupestre em MG. Os dados de microssatélites indicam proximidade da espécie com $A$. odorata, espécie do extremo leste de MG e porção centro-norte do RJ que também apresenta roseta com poucas folhas, que são geralmente longo atenuadas e cretáceas. É interessante observar que já na década de 70 do séc. XX, Lyman Smith identificava materiais que hoje correspondem a $A$. odorata, como $A$. aff. duarteana o que corrobora o relacionamento morfológico entre esses dois taxa. Outro grupo que se mostra próximo a essa espécie inclui a $A$. tortuosa e $A$. 
farneyi, ambas de Santa Maria Madalena (RJ), também com fitotelmas pouco desenvolvidos, pétalas amarelas antes e durante a antese, fortemente enroladas e retorcidas e estames apresentados em feixe.

MATERIAL EXAMINADO: Brazil. MiNAS GERAIs: Datas, 5 Feb 1972, Anderson et al. 35521 (NY); Ibidem, $15 \mathrm{~km} \mathrm{~S}$ of Diamantina, 5 Feb 1972, Anderson et al. 35541 (UB). Diamantina, 2 Feb 1965, Duarte 9017 (HB, RB, US); Ibidem, Guinda, 19 Jan 1972, Hatschbach et al. 28977 (C, HB, K, MBM, NY, US); Ibidem, estrada para Conselheiro Mata, 25 Feb 1987, Zappi et al. CFCR10398 (K, SPF); Ibidem, rodovia Guinda - Conselheiro Mata, 16 Mar 1988, Hatschbach et al. 50973 (MBM); Ibidem, estrada para Biribiri, 21 Nov 1991, Leme et al. 1813 (HB); Diamantina, Mar 1992, Nahoum s.n. (HB74126); Ibidem, estrada Guinda - São João da Chapada, 10 Dec 1997, Forzza et al. 546 (SPF); Ibidem, estrada Conselheiro Mata - Diamantina, 12 Jan 1998, Forzza et al. 612 (SPF); Ibidem, rodovia Guinda Conselheiro Mata, 15 Dec 2005, Versieux et al. 254, 255 (SP). São Gonçalo do Rio Preto, Parque Estadual do Rio Preto, 15 Sep 2006, Mota et al. 3137 (BHCB, RB), Ibidem, 24 May 2007, Wanderley et al. 2621 (BHCB, SP). Without exact locality, s.d., Sellfeld 13 (MBM).

5. Alcantarea extensa (L. B. Sm.) J. R. Grant, Trop. Subtrop. Pflanzenwelt 91: 13. 1995. Vriesea extensa L. B. Sm., Arq. Bot. Estado São Paulo 1: 116. t. 120. 1943.-TipO: BrasiL. Espírito Santo: Cachoeiro do Itapemirim, Pico de Itabira, 900 m.s.m., 7 Jul 1939, M. B. Foster \& R. Foster 163 (holótipo: GH!).

Alcantarea mucilaginosa Leme, J. Bromeliad Soc. 59(1): 12. 2009.-TIPO: BRASIL. Espírito Santo: Conceição do Castelo, near Venda Nova dos Imigrantes, rupiculous along BR 262, ca. $700 \mathrm{~m}$ elev., 29 Apr. 1995, E. Leme \& R. Kautsky 3086, fl. cult. Dec. 2007 (holótipo: RB!; isótipo: RB!). syn. nov.

RUPÍCOLA, 0.9-3 m alt., propagando-se por brotações axilares, curto-caulescente. ROSETA 0.5-0.7 x $0.5-1.1 \mathrm{~m}$, infundibuliforme, fitotelma desenvolvido. FOLHAS numerosas, suberetas; BAINHA 18-25 x 13-17 cm, elíptica a largo-oval, castanho-escura a bege abaxialmente, bege a alvacenta adaxialmente, densamente marrom-lepidota em ambas as faces, coriácea, margens membranáceas, hialino-amareladas; LÂMINA 32-75 x 5-12 cm, ligulada, geralmente glauca, eventualmente verdevinosa a verde-arroxeada adaxialmente, verde com ou sem máculas vinosas adaxialmente, subdensamente lepidota entre as nervuras abaxialmente, de glabra a esparsamente lepidota em direção ao ápice adaxialmente, reta a levemente arqueada, coriácea, distintamente nervada, com nervuras proeminentes, margens com fina linha vinosa (< $1 \mathrm{~mm}$ larg.); ÁPICE DA LÂMINA obtusoacuminado a agudo, vinoso ou verde, em geral reto, raramente torcido. PEDÚNCULO (65-)80-110 x (1.8-) $2.5-3 \mathrm{~cm}$, ereto, reto, cilíndrico a levemente sulcado, verde escuro a vinoso nas áreas expostas, 
glabro, distintamente nervado; entrenós 4-5 cm; BRÁCTEAS proximais: 10-16(-28) x 3-6 cm, subfoliáceas e suberetas; as medianas e distais: 3,5-5 × 3-4 cm, ovais a elípticas, ápice acuminado, verdes, verde-vinosas a totalmente vinosas, geralmente cerosas na face abaxial, geralmente subdensamente marrom-lepidotas em ambas as faces ou glabra apenas abaxialmente, suberetas, involutas, acumulando água na base, distintamente nervadas, coriáceas, margens membranáceas, hialino-amareladas. INFLORESCÊNCIA $0.6-0.9(-1.3)$ x $0.3-0.5 \mathrm{~m}$, composta, em panícula de espigas, raramente simples, contorno em geral irregular, algumas vezes elipsoidal ou piramidal, ereta; entrenós da raque 3-4.5(-7) cm; BRÁCTEA PRIMÁRIA 4-10 x 4-7 cm, largo-oval a orbicular, ápice obtuso-acuminado ou apiculado, verde, glauca ou vinosa, cobertas por cera ou lustrosa, glabra a esparsamente lepidota abaxialmente, densamente lepidota na base adaxialmente, involuta, patente a subereta, muito mais curta que a base estéril do pedúnculo lateral, distintamente nervado-rugosa, coriácea, margens hialino-amareladas a marrons, membranáceas in sicco; RAMOS DA INFLORESCÊNCIA (1-)3-7(-9), 12-26-floridos, suberetos a patentes; PEDÚNCULOS LATERAIS (6-)8-18 x 0.6-1 cm, geralmente levemente complanados, a cilíndricos, verdes a cor-devinho, glabros a inconspicuamente lepidotos; BRÁCTEAS ESTÉREIS 3-4.2 x 2.5-3.5 cm, 2 ou 3 variando no mesmo indivíduo, oval a elíptica, ápice obtuso, marrom-escuras no centro e amareladas nos bordos in sicco, opacas, cerosas, glabras abaxialmente, densamente marrom lepidotas adaxialmente, distintamente nervadas, ecarinadas mas com a porção central mais espessa e carnosa, remotas a parcialmente imbricadas, coriácea, margens hialino-amareladas, membranáceas in sicco; RÁQUILA 17$30(-60) \mathrm{cm}$, quase reta a geniculada em até $30^{\circ}$, verde a vinosa, glabra ou quase; entrenós $0.8-3.2 \mathrm{x}$ 0.6-0.7 cm; BRÁCTEA FLORAL 3.6-4.2 x 3.8-4.6 cm, largo oval, ápice obtuso, marrom-escura concolor no centro com bordos amarelados in sicco, verde a vinosa in vivo, glabra abaxialmente, glabra a esparsamente marrom-lepidota em direção ao ápice adaxialmente, envolvendo parcialmente o cálice, subereta, distintamente nervado-rugosa principalmente nos bordos in sicco, coriácea, ecarinada, margens membranáceas, hialino amareladas. FLORES dísticas, antese noturna; SÉPALAS 4-4.3 x 2$2.3 \mathrm{~cm}$, elípticas a oboelípticas, ápice obtuso, simétricas, excedendo em ca. $1.5 \mathrm{~cm}$ as brácteas florais, verdes com ápice verde-vinoso, esparsamente lepidotas abaxialmente, subdensamente lepidotas adaxialmente, coriáceas, ecarinadas, margens membranáceas, hialino-amareladas in sicco; PÉTALAS 8$9 \times 1 \mathrm{~cm}$, liguladas, ápice obtuso, constritas ao redor do ápice das sépalas, com máculas e pequenos traços vinosos na face abaxial, amarelas adaxialmente, recurvadas e pouco espiraladas; APÊNDICES PETALÍNEOS 30-35 x $4 \mathrm{~mm}$, ligulados, longitudinalmente adnatos à pétala, $5 \mathrm{~mm}$ distais livres, ápice agudo a obtuso com margens incospicuamente denteadas; ESTAMES polísticos; FILETE 7-9 cm x $2 \mathrm{~mm}$, achatado na base passando a cilíndrico, branco; ANTERA ca. 15 × 2 mm, linear, amarela, dorsifixa próximo à base; ESTILETE 82-100 x $2 \mathrm{~mm}$, cilíndrico a levemente anguloso, branco; LOBOS DO ESTIGMA ca. 4 x 1 mm, suberetos passando a patentes, brancos; OVÁRIO 10-15 mm 
(porção supera) x $5 \mathrm{~mm}$, estreitamente ovóide, verde-alvacento na base a alvacento, hipanto ca. 10 mm; ÓVULOS ca. 3 mm, numerosos. CÁPSULA (3.5-)4.5-5.8 x 1-1.3 cm, ovóide, marrom-escura; SEMENTE 8-11 × $1 \mathrm{~mm}$, fusiforme, marrom-escura quase negra; COMA BASAL ca. $8 \mathrm{~mm}$, ferrugíneo; COMA APICAL ca. 15 mm, ferrugíneo. Figs. 13, 14.

DISTRIBUIÇÃO, ECOLOGIA E CONSERVAÇÃO. Espécie amplamente distribuída pelos setores leste e oeste da porção norte da serra da Mantiqueira, nos estados do ES e MG e por toda a porção leste do ES. Forma populações muito grandes e está protegida em diferentes unidades de conservação, justificando seu estado de conservação como não ameaçada. IUCN Red List Category: Least Concern, LC.

FENOLOGIA. Coletada em flores entre junho e fevereiro com pico em janeiro. Frutos maduros coletados abril, junho, setembro e janeiro.

ETIMOLOGIA. O epíteto faz alusão aos ramos extensos da inflorescência que, na época da descrição da espécie, eram os maiores registrados para o gênero.

DISCUSSÃO. Alcantarea extensa é, sem dúvida, o táxon mais difícil de ser circunscrito, em virtude das variações observadas entre as populações dentro de sua ampla área de ocorrência. Versieux \& Wendt (2006) apontam para a existência de um complexo de espécies envolvendo $A$. extensa, no qual haveria grande variação na forma da inflorescência, comprimento dos ramos e padrão de coloração das brácteas do pedúnculo e florais. Dessa forma, é difícil delimitar este táxon em virtude do grande polimorfismo apresentado entre as populações associado a acentuada uniformidade nos caracteres florais. A espécie foi descrita por Smith (1943) a partir de um exemplar coletado com frutos, em Cachoeiro do Itampemirim, no pico de Itabira. Esse autor comparou a espécie com Vriesea geniculata, da qual diferiria por apresentar ramos da panícula mais longos e brácteas gibosas e indica como sinônimo Vriesea regina sensu Wittmack. Ao traduzir a descrição feita por Wittmack (1891), Smith (loc. cit.) teria entendido que a planta ali descrita seria originária da Serra do Picú (i.e. serra de Itatiaia, RJ/ MG), daí atribuiu a ocorrência da $V$. extensa também ao estado do RJ. Porém, analisando atentamente a descrição de Wittmack (1891) nota-se que a planta por ele retratada provém da região do rio Doce (MG ou ES) e estava sendo cultivada a partir de sementes no Jardim Botânico de Lüttich, na Bélgica. A planta retratada por Wittmack como Vriesea regina, muito se parece com indivíduos que podem ser vistos atualmente em jardins ou livros de plantas ornamentais (Lorenzi \& Souza 2001: 316), mas que apresentam ramos suberetos e mais curtos que aqueles observados na população típica de $A$. extensa, e possivelmente corresponda a uma nova variedade. 
Alcantarea extensa apresenta grande variação intraespecífica, não é relacionada a $A$. geniculata, sendo morfologicamente mais próxima à $A$. simplicisticha, $A$. turgida, $A$. trepida e a $A$. vinicolor. $\mathrm{De} A$. vinicolor, espécie simpátrica, difere pelas brácteas estéreis do pedúnculo lateral ecarinadas, pela ráquila geralmente mais longa com entrenós mais grossos, pelas brácteas florais maiores e que envolvem completamente o cálice (vs. parcialmente, em A. vinicolor) e pelos apêndices petalíneos mais curtos. De A. trepida difere por possuir ramos da inflorescência mais curtos, patentes ou suberetos (vs. ramos longos, eretos). Alcantarea turgida é diferente por apresentar distribuição geográfica mais interiorana e inflorescência com maior número de ramos, em geral patentes, pétalas amarelo-claras em ambas as faces.

As folhas dos indivíduos na localidade típica apresentam depósitos transversais de cera, já as populações do leste de MG (Araponga, Carangola, Padre Paraíso) em geral apresentam folhas lustrosas, frequentemente vinosas e hábito menor, aproximando-se do conceito de A. vinicolor. Em outras populações nota-se que as folhas são lustrosas mas que a face abaxial das brácteas proximais são totalmente cobertas por cera. Uma análise molecular no nível populacional deverá ser feita para que se compreendam melhor os limites entre os táxons envolvidos, pois parece que há hibridização e retrocruzamentos que geram um contínuo de variação, sendo que algumas das novas espécies recém descritas poderão ser rebaixadas a níveis de variedades ou subespécies. Alcantarea mucilaginosa Leme é aqui incluída na sinonímia, pois suas características em grande parte se sobrepõe àquelas observadas na população típica de $A$. extensa em Cachoeiro do Itapemerim. Além disso, os dados de microssatélite (Cap. 2) indicam a proximidade entre os indivíduos da população típica (Versieux 380 ) com o indivíduo coletado em Castelo, do Parque Estadual do Forno Grande (Versieux 372), vizinho da localidade típica de $A$. mucilaginosa. No Parque Estadual do Forno Grande observa-se um contínuo na variação do formato da inflorescência dos indivíduos de $A$. extensa, havendo aqueles com maior número de ramos e inflorescência mais densa, iguais a $A$. mucilaginosa, lado a lado de indivíduos com inflorescências menos densas, ramos polísticos e com flores mais espaçadas. Nessas populações do Forno Grande também se observa grande variação na altura dos indivíduos floridos e tamanho das rosetas formadas. As características enfatizadas por Leme (2009) para diferenciar A. mucilaginosa de $A$. extensa, como a quantidade de cera nas brácteas e a produção de mucilagem nos botões florais são condicionadas pelo ambiente ou condições de cultivo. Ao contrário do que é afirmado por Leme (2009) a produção copiosa de mucilagem não é exclusiva de $A$. mucilaginosa sendo que $A$. turgida a produz também em grande quantidade, a tal ponto de pingar dos botões florais (Versieux \& Wanderley 2007), especialmente durante períodos chuvosos (obs. pes.). A maior quantidade de cera observada nas brácteas pode ser fruto do clima, uma vez que o frio é um promotor para uma maior deposição de ceras epicuticulares em uma mesma espécie (Barber 1955).

O exemplar Forzza 5044 (RB) apresenta características comuns tanto a Alcantarea extensa quanto à $A$. turgida, possui pétalas albo-rosados e é aqui provisoriamente posicionado como affinis. 
MATERIAL EXAMINADO: Brazil. EsPíRITO SANTO: Alfredo Chaves, 7 Jul 1996, Hatschbach \& Barbosa 65296 (C, MO). Cachoeiro do Itapemirim, pico de Itabira, 21 Jan 2007, Versieux et al. 379, 380 (SP). Cariacica, Reserva Biológica Duas Bocas, 16 Feb 2008, Forzza et al. 5044 (RB). Castelo, sítio ao lado do Parque do Forno Grande, 18 Jan 2007, Versienx et al. 368, 369, 372, 373 (SP). Domingos Martins, Pedra Azul, rota do Lagarto, 20 Jan 2007, Versieux et al. 378 (SP). Santa Teresa, 19 Apr 1975, Reitz 7845 (HBR); Ibidem, Estação Biológica de Santa Lúcia, 17 Oct 1995, Costa et al. 524 (MBML, R). Ibidem, Nova Lombárdia, 18 Jun 2002, Vervloet et al. 372 (MBML). Without exact locality, de Vitória para Timbuí, 13 Aug 1965, Duarte 8893 (HB, HBR, RB). Without exact locality, cultivated, 30 Jun 1974, Reitz 7709 (HBR). Minas GERAIS: Alto Caparaó, cultivated at Parque Nacional do Caparaó, 16 Jan 2007, Versieux et al. 357, 359, 360, 361, 362 (SP). Araponga, pedra do Pato, 20 Jan 1990, Leoni 1051 (RB); Ibidem, Parque Estadual da serra do Brigadeiro, 2 Feb 1995, Paula 1008 (VIC). Ibidem, Parque Estadual da serra do Brigadeiro, 22 Sep 1999, Goldschmidt 19 (VIC). Carangola, pedra do Pato, Dec 1999, Pinheiro \& Rivadavia 27 (SP). Fervedouro, Parque Estadual da Serra do Brigadeiro, 21 Jun 1996, Paula 1133 (SP, VIC). Manhuaçu, rodovia BR-262, 4 Dec 1984, Hatschbach \& Silva 48595 (C, MBM, MO). Sericita, Parque Estadual da serra do Brigadeiro, 12 Jan 1996, Paula 1092 (VIC). Serra dos Aimorés, 10 Apr 1996, Martinelli et al. 14857 (RB). SÃo PAUlO: São Paulo, cultivated at IBt, 11 Jan 2007, Versieux 344 (SP).

6. Alcantarea farneyi (Martinelli \& A. F. Costa) J. R. Grant, Trop. Subtrop. Pflanzenwelt 91: 13. 1995. Vriesea farneyi Martinelli \& A. F. Costa, J. Bromeliad Soc. 40(4): 151, figs. 3-4. 1990.TIPO: BRASIL. Rio de Janeiro: Santa Maria Madalena, Parque Estadual do Desengano, pedra do Desengano, Campos de Altitude, entre 1500 e 1650 m.s.m., 17 Set 1986, C. Farney \& J. Caruqo 1217 (holótipo RB!, foto: K!; isótipo: NY não encontrado).

RUPÍCOLA, (0.2-)0.4-0.5 m alt., cespitosa, propagando-se por brotações axilares e basais, curtocaulescente. ROSETA 10-20 × 3-5 cm, sub-bulbosa, fitotelma pouco desenvolvido. FOLHAS 9-15, suberetas; BAINHA $4.2-8.5 \times 3-4.5 \mathrm{~cm}$, largo-oval a trapeziforme, a base branca, tornando-se marrom-clara amarelada, com um arco distal de pontos vermelho-vinho e com células do disco das escamas cor-de-vinho em ambas as faces in vivo, densamente marrom-lepidota e rugosa em ambas as faces in sicco, margens membranáceas, bege-hialinas in sicco; LÂMINA 14-30(-60) x (0.4-)0.7-1.5 cm, estreito-linear, subulada quando jovem, verde em ambas as faces, com uma fina linha (i.e., ca. $0.8 \mathrm{~mm}$ larg.) vermelho-vinho ao longo das margens, densamente marrom-lepidota abaxialmente, cinéreolepidota a glabra adaxialmente, canaliculada, eretas a suberetas, carnosa in vivo a coriácea in sicco, finamente nervada, margens involutas; ÁPICE DA LÂMINA agudo, verde concolor, reto quando jovem, amarelado a castanho-paleáceo, torcido e involuto quando senescente. PEDÚNCULO 21- 
47(-62) x 0.4-0.7 cm, subereto recurvado, delgado, cilíndrico a quase quadrangular em secção transversal, verde, glabro, distintamente nervado a sulcado, entrenós $2.5-4.4 \mathrm{~cm}$; BRÁCTEAS proximais: subfoliáceas e polísticas; medianas e distais: $4.2-8.5 \times 1.6-3.2 \mathrm{~cm}$, estreito-ovais a elípticas, ápice longo-caudado a acuminado, discretamente apiculado, vermelho-vinho, verde-avermelhadas quando em cultivo, densamente marrom-lepidotas, eretas, densamente imbricadas, o terço basal envolvendo firmemente o pedúnculo e com as margens se sobrepondo, lisas, cartáceas, margens membranáceas. INFLORESCÊNCIA 9-15 x 3-5.5 cm (excluindo as pétalas), espiga, de contorno elíptico a oval, 7-13-florida, subereta ou pêndula; RÁQUILA flexuosa, quase quadrangular em secção transversal, verde, glabra; entrenós 1.1-1.5 (proximal) a (0.4-) 0.7-1 (distal) x 0.2-0.4 cm; BRÁCTEA FLORAL 3.2-4.5 x 2.2-3 cm, oval a largamente oval, ápice obtuso, vermelho-vinho, raramente verde-avermelhada quando em cultivo, esparsamente lepidota abaxialmente, marrom-lepidota adaxialmente, envolvendo completamente o cálice, distintamente nervada, cartácea, ecarinada, margens hialinas e lisas. FLORES inodoras, dísticas, suberetas; SÉPALAS ca. 3 x $1.1 \mathrm{~cm}$, elípticas, ápice agudo, simétricas a levemente assimétricas, igualando-se ou ultrapassando as brácteas florais em 3-7 mm, verdes a verde-amareladas em direção ao ápice, glabras, levemente carnosas, ecarinadas; PÉTALAS $7.2-7.8 \times 0.6-0.8 \mathrm{~cm}$, liguladas, constritas ao redor dos ápices das sépalas, levemente onduladas ao longo da margem na metade superior, amarelas, inconspicuamente maculada de branco, voltadas para trás e fortemente retorcidas; APÊNDICES PETALÍNEOS 22-26 x ca. 1 mm, ligulados, adnatos à pétala longitudinalmente por 18-20 $\mathrm{mm}$, ápice agudo ou arredondado, assimétricos; ESTAMES apresentados em feixe na antese; FILETE 60-65 x 1.5-1.8 mm, complanado, branco; ANTERA ca. $10 \times 1 \mathrm{~mm}$, levemente sagitada, amarela, dorsifixa próximo à base; ESTILETE 63-67 x ca. 1.6 mm, cilíndrico, branco; LOBOS DO ESTIGMA ca. 3 x 1 mm, polísticos, brancos; OVÁRIO ca. 11 x 3-4 mm, estreitamente ovóide, verde-alvacento, hipanto 4-6 mm; ÓVULOS 1.5-2 mm, numerosos. CÁPSULA ca. $2.5 \mathrm{~cm}$, elipsóide-acuminada, marrom-escura. SEMENTE desconhecida. Figs. 15, 17 G-H.

DISTRIBUIÇÃO, ECOLOGIA E CONSERVAÇÃO. Alcantarea farneyi é heliófila e ocorre acima de 1200 m.s.m. juntamente com Alcantarea tortuosa Versieux \& Wand. e Vellozia variegata Goeth. \& Henrard, próximo ao pico do inselberg principal do Parque Estadual do Desengano, e também na pedra DuBois, Santa Maria Madalena, Rio de Janeiro. Até o momento, a espécie é endêmica desse município. A espécie está incluída na lista das espécies da flora brasileira ameaçadas de extinção, dentro do apêndice II, com deficiência de dados (Ministério do Meio Ambiente, 2008). Foi verificado aqui que tal táxon apresenta restrita área de ocorrência, pequeno tamanho da população e sofrerá com provável declínio na qualidade de seu habitat, uma vez que cresce ao longo da trilha que leva ao pico do Desengano, sendo que a população típica está exposta ao pisoteio. IUCN Red List Category: Vulnerable, VU B1a, b(iii), D2. 
FENOLOGIA. Floresce do fim de novembro a fevereiro, com pico em dezembro.

ETIMOLOGIA. Alcantarea farneyi homenageia o botânico Cyl Catharino Farney, do Jardim Botânico do Rio de Janeiro (RB), coletor do typus.

DISCUSSÃO. Espécie bem caracterizada pelas inflorescências simples, arqueadas com pétalas fortemente enroladas e pela roseta pequena e estreita, com folhas finas, formando pequenas touceiras semelhante ao hábito de algumas gramíneas. Apresenta morfologia floral muito semelhante à de $A$. tortuosa com a qual está geneticamente relacionada. A espécies apresenta as menores dimensões para o hábito do gênero e coloração variável para as brácteas do pedúnculo e florais, que podem ser verdes quando em cultivo. Descrita sob V riesea por Martinelli \& Costa (1990), foi comparada à V . barclayana, espécie do Equador que apresenta hábito semelhante, porém morfologia floral e sementes distintas.

MATERIAL EXAMINADO: Brazil. Rio De JANEIRO: Santa Maria Madalena, Parque Estadual do Desengano, 17 Sep 1986, Farney \& Caruso 1217 (RB, K Foto). Ibidem, Parque Estadual do Desengano, 5 Oct 1988, Martinelli et al. 13143 (RB). Ibidem, Parque Estadual do Desengano, 21 Dec 1988, Costa et al. 258 (RB). Ibidem, Parque Estadual do Desengano, 25 Nov 2005, Versieux \& Calvente 245, 246, 247 (SP); Ibidem, Parque Estadual do Desengano, 12 Nov 2008, Fraga 2382 (RB).

7. Alcantarea geniculata (Wawra) J. R. Grant, Trop. Subtrop. Pflanzenwelt 91: 13. 1995. Platystachys geniculata Wawra, Oesterr. Bot. Z. 11: 345. 1862. Vriesea geniculata (Wawra) Wawra, Bot. Ergebn. 156, t. 25. 1866.-TIPO: BRASIL. Rio de Janeiro: Petropolis in praecipitii saxosis nudis superpendentibus, Wawra \& Maly 419 (holótipo: W, destruído), (lectótipo designado por Smith \& Downs, 1977. Bot. Ergebn. 156, t. 25. 1866, exceto as folhas serreadas).

RUPÍCOLA, 1.1-2.3 m alt., propagando-se por brotações basais, curto caulescente. ROSETA infundibuliforme, fitotelma desenvolvido, geralmente com mais de $1 \mathrm{~m}$ de diâm. FOLHAS numerosas, suberetas; BAINHA 13-24 x 8-16 cm, elíptica, bege a marrom-escura e densamente marrom-lepidota em ambas as faces, coríacea, margens membranáceas, bege in sicco; LÂMINA 6080(-110) x 6-9 cm, linear triangular, verde concolor, densamente marrom-lepidota em direção ao ápice abaxialmente, esparsamente lepidota em direção ao ápice adaxialmente, levemente canaliculada na base passando a plana, coriácea, distintamente nervada, margens verdes, sem fina linha vermelhovinosa; ÁPICE DA LÂMINA agudo-atenuado, verde, reto. PEDÚNCULO 40-70 x 0.7-1(distal)3 (proximal) cm, ereto, reto, robusto, cilíndrico, verde, glabro, distintamente nervado, entrenós de 4-5 cm (proximal) a 1.5-3 cm (distal); BRÁCTEAS as proximais: subfoliáceas, polísticas; as distais: 15-34 
x $2.5-4.7 \mathrm{~cm}$, ovais a largo-ovais, ápice caudado voltado para baixo, base rosado-vinosa passando a verde-claro seguida por verde-escuro abaxialmente, alvacenta com máculas vinosas na base passando a verde-concolor adaxialmente, lustrosa, densamente lepidotas abaxialmente, esparsamente lepidota adaxialmente, suberetas com ápices encurvados, distintamente nervadas, coriáceas, margens coriáceas, verdes a rosadas. INFLORESCÊNCIA $60-120$ x 35-50 cm (excluindo as pétalas), composta, em panícula de espigas, de contorno elipsoidal, entrenós da raque $1.5-4.5 \mathrm{~cm}$; BRÁCTEA PRIMÁRIA (6-)15-25 x (1.5-)3.5-6 cm, oval a largo-oval, ápice caudado a acuminado, verde, esparsamente lepidota abaxialmente, densamente lepidota em direção ao ápice adaxialmente, involuta, geralmente excedendo os pedúnculos laterais, distintamente nervada, coriácea, com as margens coriáceas, rosadas; RAMOS DA INFLORESCÊNCIA 20-30, (6-)12-31-floridos, geralmente patentes com a porção distal ascendente a levemente sigmóides; PEDÚNCULOS LATERAIS 3-9.5 x 0.4-0.6 cm, achatados, sulcados, verdes a verde-rosados, glabros a inconspicuamente lepidotos; BRÁCTEAS ESTÉREIS 2.3-3 x 1.2-1.6 cm, geralmete 1, raramente 2, elípticas, ápice obtuso, verde, bege adaxialmente in sicco, glabra abaxialmente, subdensamente marrom-lepidota adaxialmente, coriácea, carenadas; margens membranáceas, finamente nervadas; RÁQUILA (5-)13-32 cm, levemente geniculada, divergindo $10-20^{\circ}$, verde, geralmente marrom-escura ou quase negra in sicco, esparsamente lepidota; entrenós 1-2 x 0.3 cm; BRÁCTEA FLORAL 2.8-3.2 x $3.3 \mathrm{~cm}$, suborbicular, ápice obtuso, incospicuamente emarginado, verde-alvacenta, glabra a esparsamente lepidota abaxialmente, subdensamente marrom-lepidota adaxialmente, envolvendo parcialmente o cálice, com a 1/2-basal dos bordos se tocando, lisas in vivo, finamente nervadas in sicco, coriácea, geralmente carenada próximo ao ápice; margens membranáceas, hialino-amareladas in sicco. FLORES com odor levemente adocicado, dísticas, suberetas a patentes; SÉPALAS 3.4-4 x 1.4-1.9 cm, obovais, ápice arredondado, simétricas, excedendo as brácteas florais em ca. $1 \mathrm{~cm}$, verdes, minutamente lepidotas abaxialmente, subdensamente lepidota adaxialmente, levemente carnosas, ecarinadas, margens membranáceas hialino-amareladas in sicco; PÉTALAS ca. 76-80 × 8-10 mm, liguladas, ápice obtuso, constritas ao redor do ápice das sépalas, amarelas no botão e na antese, fortemente voltadas e para trás espiraladas na antese; APÊNDICES PETALÍNEOS ca. 27 × 2 mm, ligulados, longitudinalmente adnatos à pétala por ca. $20 \mathrm{~mm}$, ápices agudos e assimétricos; ESTAMES apresentados em feixe na antese, passando a ligeiramente polísticos; FILETE 65-70 × $2 \mathrm{~mm}$, complanado, branco; ANTERA linear, ca. 12 × $1 \mathrm{~mm}$, amarela, dorsifixa próximo à base; ESTILETE ca. 80 × $2 \mathrm{~mm}$, cilíndrico, branco; LOBOS DO ESTIGMA ca. 4 × $0.7 \mathrm{~mm}$, patentes a levemente encurvados e torcidos, brancos; OVÁRIO ca. 11 x $6 \mathrm{~mm}$ (porção súpera), estreito-ovoidal, verde, hipanto ca. $7 \mathrm{~mm}$; ÓVULOS ca. 4 mm, numerosos. CÁPSULA 2.5-4 x 0.9-1.4 cm, ovóide, com ápice agudo, marromescura quase negra; SEMENTE ca. 7 × $1 \mathrm{~mm}$, estreito-elípsoidal, marrom-escura; COMA BASAL 7 mm, bege; COMA APICAL ca. 11 mm, marrom. Figs. 16, 17 A-F. 
DISTRIBUIÇÃO, ECOLOGIA E CONSERVAÇÃO. Espécie exclusiva dos municípios do Rio de Janeiro, Petrópolis, Teresópolis e Magé, entre 700-1700 (Leme, 1997a), onde ocorre como heliófila ou semi-ciófila em afloramenos rochosos em meio a floresta. Para a cidade do Rio de Janeiro há registros para o Pico da Tijuca, porém nenhuma coleta foi obtida nesta localidade nos últimos 50 anos e há indícios de que exista uma pequena população na vertente leste do Pão de Açúcar. As maiores populações estão dentro do Parque Nacional da Serra dos Órgãos, onde frequentemente occorem em rochas isoladas no meio da floresta, em áreas de difícil acesso. Outras populações fora desse parque também existem na Serra dos Órgãos, como na RPPN Pedra do Amarylis, exibindo diversidade genética suficiente para garantir a sobrevivência da espécie (Barbará et al. 2007). Espécie amplamente cultivada por colecionadores. IUCN Red List Category: Least Concern, LC.

FENOLOGIA. Floresce de novembro a abril, com pico em dezembro. Frutos coletados em abril, junho e julho.

ETIMOLOGIA. O epíteto faz alusão às ráquilas geniculadas, que assim podem ser observadas mesmo antes da antese.

DISCUSSÃO. Espécie de delimitação bem caracterizada e facilmente reconhecida pelas flores com pétalas amarelo-ouro, que não perdem a cor durante a antese e pelas folhas verde-escuras concolores, linear-triangulares e brácteas primárias longas e encurvadas. Pode ser confundida com $A$. nevaresii que, entretanto, geralmente apresenta porte menor e inflorescência com menor número de ramos, que também são mais curtos. Pode ser confundida, in sicco, com A. glazionana, entretanto a última apresenta pétalas brancas e folhas cerosas (vs. pétalas amarelas e folhas lustrosas). A coloração quase negra da ráquila pode auxiliar na identificação de exsicatas de $A$. geniculata, diferenciando-a de $A$. glaz̧iouana. Leme (1997a) revisou a sinonímia e apresenta uma delimitação mais precisa para $A$. geniculata e $A$. glaziouana, visto que Smith \& Downs (1977) não fazem a separação entre essas duas espécies, havendo aí uma miscelânia de diferentes taxa e materiais examinados. Entre os materiais citados por Smith \& Downs (1977), a coleção de Itabira do Campo (MG) é aqui tratada como $A$. turgida, os exemplares obtidos em Grumari, Pão de Açúcar e na Pedra de Itaúna, na cidade do Rio de Janeiro são tratados com A. glaz̧iouana, e as coleções de Santa Maria Madalena, (Santos-Lima \& Brade 14178, Emygdio 1147) correspondem à A. heloisae. É importante mencionar que Smith (1943), ao descrever $A$. brasiliana, inclui na sinonímia $A$. regina sensu Mez, baseada na coleção Glazion 11685. O exame desse exemplar não deixa dúvidas de que se trata de $A$. geniculata. Sendo assim, $A$. brasiliana foi descrita baseando se em uma mistura de materiais que podem corresponder tanto a $A$. geniculata quanta à $A$. imperialis (veja comentário detalhado em $A$. imperialis). 
MATERIAL EXAMINADO: Brazil. Rio De JANEIRO: Petrópolis, Parque da Serra dos Órgãos, 25 Dec 1961, Reitz 6831 (HBR); Ibidem, serra das Estrelas, 18 Feb 1967, Pereira 10546 (HB, K); Ibidem, serra de Petrópolis, 20 Feb 1974, Reitz 7578 (HBR); Ibidem, estrada Petrópolis-Teresópolis, 28 Apr 1977, Martinelli 1781 (RB); Ibidem, estrada Itaipava-Teresópolis, 1 Jun 1978, Pereira 10795 (HB); Ibidem, Araras, 28 Jun 1999, Martinelli et al. 15517 (RB); Ibidem, BR-040, próximo ao viaduto do Ouriço, 29 Dec 2007, Versieux \& Calvente 456 (SP). Rio de Janeiro, pico de la Tijuca, 3 Apr 1878, Glaziou 8016 (C, K, P); Ibidem, 5 Mar 1884, Glaziou 15470 (C, K, P); Ibidem, pico da Tijuca, 27 Nov 1962, Castellanos 23497 (GUA, HB, K, RB). Theresopolis, Nacimento, 8 Jan 1879, Glaziou 11685 (C, K, P). Teresópolis, Parque Nacional da Serra dos Órgãos, 4 Dec 1966, Strang \& Castellanos 721 (HB); Ibidem, Parque Nacional da Serra dos Órgãos, 20 Jul 2006, Versieux \& Calvente 285 (SP). Without exact locality, serra dos Órgãos, Aug 1952, Vidal s.n. (R173703).

8. Alcantarea glaziouana (Lem.) Leme, Bromélia 4(2): 35. 1997. Vriesea glazionana Lemaire, Ill. Hort. 14(Misc.): 43, t. 2. 1867.-Tipo: BRASIL. Rio de Janeiro. Glaziou s.n. (lectótipo designado por Leme, 1997. Ill. Hort. 14(Misc.): 43, t. 2. 1867).

Vriesea vasta Mez in Mart., Fl. bras. 3(3): 572. 1894.-TIPO: BRASIL. Rio de Janeiro: Copacabana, Glazion 15468 (lectótipo designado por Leme, 1997: B, foto do lectótipo SP!; isolectótipos: C!, $\mathrm{K}$ !, P!).

RUPÍCOLA, 1.5-2 m alt., propagando-se por brotações axilares, caulescente. ROSETA 85-110 x 60$120 \mathrm{~cm}$, infundibuliforme, fitotelma desenvolvido. FOLHAS numerosas, suberetas; BAINHA 15-26 x 10-19 cm, elíptica a oval, castanho-escura passando a castanho-clara e verde-claro, com máculas vinosas abaxialmente, castanho-clara concolor adaxialmente, densamente marrom-lepidota em ambas as faces, coríacea, margens membranáceas, hialino-alvacentas com máculas vinosas in vivo; LÂMINA 30-80(-100) × 6-9 cm, estreito-triangular, verde concolor com algumas faixas transversais albocerosas em ambas as faces, densamente marrom-lepidota abaxialmente, glabra em direção ao ápice adaxialmente, levemente canaliculada, coriácea, distintamente nervada com algumas nervuras proeminentes; margens com fina linha vermelho-vinosa; ÁPICE DA LÂMINA agudo, verde, torcido, frequentemente encurvado, discretamente apiculado. PEDÚNCULO 55-120 x (1-)2.6(distal)4.2 (proximal) cm, ereto, reto, robusto, cilíndrico, verde, rosa escuro nas partes expostas, densamente alvo-lepidoto, distintamente nervado, entrenós de 5-6 cm (proximal) a 2-4.5 cm (distal); BRÁCTEAS as proximais: subfoliáceas, polísticas; as distais: 7-17(-32) x 2-4.5 cm, ovais a largo-ovais, ápice caudado, apículo ca. $2 \mathrm{~mm}$, vermelho-rosadas abaxialmente, verde adaxialmente, cerosa, subdensamente a esparsamente lepidotas abaxialmente, glabras adaxialmente, suberetas com ápices encurvados, distintamente nervadas, coriáceas; margens membranáceas, vermelho-vinosas a rosadas, 
bege in sicco. INFLORESCÊNCIA ca. 50 x $40 \mathrm{~cm}$ (excluindo as pétalas), composta, em panícula de espigas, de contorno elipsoidal a ovoidal, entrenós da raque 1.5-2.2 cm; BRÁCTEA PRIMÁRIA 4$9(-18) \times 2.5-4 \mathrm{~cm}$, oval a largo-oval, ápice cuspidado a curtamente caudado, encurvado, vermelhorosadas a verdes, subdensamente marrom-lepidota abaxialmente, densamente marrom-lepidota adaxialmente, involuta, excedendo até mais curtas que os pedúnculos laterais, distintamente nervada, cartácea, margens basais membranáceas, hialino-alvacentas; RAMOS DA INFLORESCÊNCIA 1115, 11-17(-26)-floridos; PEDÚNCULOS LATERAIS 3-12 x 0.4-0.6 cm, achatados, sulcados, inconspicuamente alados, verdes, inconspicuamente alvo-lepidotos; BRÁCTEAS ESTÉREIS 2.4-3 x 1.4-2 cm, 1-2, elípticas, ápice obtuso, verde-oliva, esparsamente marrom-lepidota abaxialmente, subdensamente marrom-lepidota adaxialmente, cartácea, distintamente nervadas, carenada; margens membranáceas; RÁQUILA 13-25 cm, quase reta até levemente geniculada, divergindo ca. $30^{\circ}$, verde, esparsamente marrom-lepidota; entrenós 1-1.8 x ca. 0.4 cm; BRÁCTEA FLORAL 2.8-3.1(-3.5) x 2.2-2.8(-3) cm, largo-elíptica, ápice obtuso, incospicuamente emarginado, verde-alvacenta, com pequenas placas de cera e desde glabra a esparsamente lepidota abaxialmente, esparsamente marromlepidota adaxialmente, envolvendo parcialmente o cálice, com a 1/2-basal dos bordos se tocando, lisas in vivo, nervado-rugosa in sicco, decurrente com a ráquila, levemente carnosa in vivo, ecarinada, margens membranáceas, amareladas in sicco. FLORES com odor levemente adocicado, dísticas, suberetas; SÉPALAS 3-3.7 x 1.4-1.7 cm, elípticas a subobovais, ápice arredondado, simétricas, excedendo as brácteas florais em $0.8-1.5 \mathrm{~cm}$, base verde, verde-alvacentas em direção ao ápice, esparsamente marrom-lepidotas em ambas as faces, carnosas, ecarinadas, margens membranáceas e bege in sicco; PÉTALAS ca. 72-95 x $10 \mathrm{~mm}$, liguladas, ápice obtuso, inconspicuamente cuculado, constritas ao redor do ápice das sépalas, levemente onduladas ao longo das margens na metade distal, levemente amareladas nos botões passando a totalmente albas na antese, fortemente voltadas para trás e pouco enroladas na antese; APÊNDICES PETALÍNEOS 17-25 x 2-5 mm, ligulados, longitudinalmente adnatos à pétala por ca. $15 \mathrm{~mm}$, ápices obtusos ou irregularmente bidentados e assimétricos; ESTAMES apresentados em feixe na antese, passando a ligeiramente polísticos; FILETE ca. 70 × 2 mm, complanado, branco; ANTERA linear, ca. 15 x $1 \mathrm{~mm}$, amarela, dorsifixa próximo à base; ESTILETE ca. 70 x 2 mm, cilíndrico, branco; LOBOS DO ESTIGMA ca. 3 x 1 $\mathrm{mm}$, patentes a levemente encurvados e torcidos, dispostos como "pás de ventilador", brancos; OVÁRIO ca. 9 x $4 \mathrm{~mm}$ (porção súpera), estreito-ovóide, verde, hipanto ca. $8 \mathrm{~mm}$; ÓVULOS ca. 1 mm, numerosos. CÁPSULA 4.5-6 x $1 \mathrm{~cm}$, estreito-elipsoidal com ápice agudo, marrom-clara; SEMENTE ca. 6 × $1 \mathrm{~mm}$, fusiforme, marrom-escura; COMA BASAL 5-7 mm, fimbriado, bege; COMA APICAL 7-9 mm, fimbriado, bege. Figs. 18, 19A.

DISTRIBUIÇÃO, ECOLOGIA E CONSERVAÇÃO. Espécie exclusiva dos municípios de Niterói e Rio de Janeiro, onde ocorre, geralmente, em costões rochosos próximos ao mar. Na cidade do Rio de 
Janeiro pode ser observada em diferentes locais, onde forma populações muito densas: Pão de Açúcar, praia da Macumba, Parques Naturais Municipais da Catacumba, da Chacrinha, da Prainha, entre outras áreas, especialmente da zona Oeste. Em Niterói ocorre em grande população no Alto Mourão e no costão de Itacoatiara. A distribuição geográfica restrita, a ocorrência de queimadas, a abertura de diversas vias de escalada nas áreas onde ocorre (Fig. 7 C) e a degradação gerada pela ocupação irregular de encostas nessas cidades são riscos aos quais está exposta. A espécie é amplamente cultivada desde o século XVIII. Dados de genética apontam para uma elevada endogamia nas populações desta espécie, o que em parte se explicaria pela autofecundação e limitada capacidade de dispersão das sementes (Barbará et al. 2008). Assim, apesar de protegida em parques, as autoridades devem evitar a extinção de populações localizadas, uma vez que isso aumentaria os efeitos deletérios decorrentes das populações pequenas, isoladas e com acentuadas taxas de endocruzamento. Sugere-se que seja feito um mapeamento atualizado de suas populações, uma vez que muitas das localidades citadas no material de herbário, já foram descaracterizadas por estarem dentro de áreas urbanas em expansão. IUCN Red List Category: Vulnerable, VU B1a, b(iii, iv).

FENOLOGIA. Floresce do fim de novembro a fevereiro, com pico em dezembro. Frutos coletados entre janeiro e fevereiro.

ETIMOLOGIA. Alcantarea glazionana homenageia o paisagista francês Auguste François Marie Glaziou que viveu no Rio de Janeiro e introduziu em cultivo várias espécies de Alcantarea.

DISCUSSÃO. Espécie bem caracterizada pela presença de depósitos transversais de cera na epiderme das folhas e brácteas, pela coloração verde com base vermelho-rosada das brácteas do pedúnculo e flores albas (Fig 18) com odor adocicado. Por ser comum em locais de fácil acesso na cidade do Rio de Janeiro há material abundante nas coleções e a espécie foi frequentemente enviada aos herbários europeus já no séc. XIX, onde a retrataram em diferentes publicações de horticultura (Figs. $18 \mathrm{~J}-\mathrm{L}$ ). Neste período foi sempre identificada como $A$. regina, tomando por base a estampa publicada por Vellozo $(1827,1831)$ e o comentário de A. F. Glaziou, que ao enviar uma duplicata à Europa, afirmou se tratar, com toda a certeza, da planta de Vellozo. Começou-se aí o equívoco de identificação que pode ser visto nas publicações de horticultura do século XIX (e.g. Vriesea regina sensu auct. non. Gard. Chron. n. ser. 3: 234, t. 41. 1875) e que perdura até os dias atuais nas coleções dos herbários. É comum ser confundida, também, com A. geniculata, especialmente in sicco. Smith \& Downs (1977) consideravam A. glaz̨iouana sinônimo de A. geniculata, posicionamento não seguido por Leme (1997a), que separou novamente os dois táxons. Entre as diferenças que podem ser facilmente observadas entre Alcantarea glazionana e $A$. geniculata, nota-se que a primeira apresenta folhas mais coriáceas, maiores dimensões para as peças florais e pétalas brancas na antese (vs. amarelas), além disso, o 
habitat das espécies é distinto, A. glaz̧ionana ocorre preferencialmente em afloramentos graníticos próximo ao mar (costões) enquanto $A$. geniculata é mais comum na serra dos Órgão, em áreas mais elevadas, acima de 800 m.s.m. No entanto, no Pão de Açúcar é possível encontrar as duas espécies, mas ainda assim, com a aparente separação na preferência altitudinal.

$\mathrm{Na}$ análise com microssatélites (Cáp. 2) A. glazionana aparece próxima de A. nahoumii, espécie que ocorre na Bahia. Em comum essas espécies apresentam um crescimento clonal muito desenvolvido, formando densas touceiras em torno de uma planta-mãe, há certa semelhança, também, na posição e formato dos ramos da inflorescência e, algumas vezes, em pequenas deformações que podem ser observadas no pistilo e estames.

MATERIAL EXAMINADO: Brazil. RIO DE JANEIRO: Itaipuaçú, pico Alto Moirão, 17 Apr 1985, Andreata et al. 671 (RB, RUSU). Niterói, Itacoatiara, 22 Jan 1980, Moltinho 51 (HB). Rio de Janeiro, São Christovão, 17 Nov 1883, Glaẓiou 15468 (C, K, P); Ibidem, Horto Botânico do Museu Nacional, Oct 1897, Ule s.n. (R46307); Ibidem, Jardim Botânico do Rio de Janeiro, 1918, Dionyżio s.n. (RB11527); Ibidem, Jardim Botânico do Rio de Janeiro, 8 Jan 1935, Occhioni s.n. (RB78006); Ibidem, Restinga de Sernambetiba, 6 Dec 1938, Markgraf \& Brade 37645 (RB); Ibidem, cultivated at JBRJ, 21 Dec 1941, Kulmann 6179 (RB); Ibidem, praia de Sernambetiba, 4 Apr 1952, Smith et al. 6829 (K, NY, R); Ibidem, restinga de Jacarepaguá, 16 Feb 1960, Angeli 15 (GUA, HRB, K, NY); Ibidem, Pão de Açúcar, 30 Jan 1960, Carauta 132 (R); Ibidem, Recreio dos Bandeirantes, morro do Rangel, Dec 1961, Santos s.n. (R173702); Ibidem, Campo Grande, praia de Grumari, Nov 1962, Mee s.n. (SP69016); Ibidem, pedra de Itaúna, 25 Nov 1965, Moreira 107 (GUA, HRB, NY); Ibidem, Barra da Tijuca, 7 Dec 1966, Pereira 10501 (HB); Ibidem, em frente a lagoa de Jacarepaguá, 1 Dec 1966, Sucre \& Pereira 1307 (RB); Ibidem, morro do Rangel, 21 Jan 1968, MacWilliams s.n. (HB48522, R); Ibidem, morro da Urca, 30 Nov 1969, Occhioni 3822 (RFA); Ibidem, Alto da Tijuca, 21 May 1974, Reitz, 7604 (HBR); Ibidem, pedra de Itaúna, 8 Jan 1978, Carauta \& Martinelli 2810 (GUA, RB); Ibidem, Pão de Açúcar, 10 Dec 1979, Carauta 3345 (GUA, HB, HRB, RB); Ibidem, Pão de Açúcar, 7 Dec 1980, Ribeiro 102 (GUA); Ibidem, Pão de Açúcar, 26 Oct 1980, Carauta 3550 (RB); Ibidem, Pão de Açúcar, 26 Oct 1980, Carauta et al. 3558 (GUA, RB); Ibidem, picada em direção à pedra da Gávea, 11 Jan 1984, Farney \& Dalcin 391 (RB); Ibidem, Recreio dos Bandeirantes, 13 Jan 1985, Gentry \& Zardini 49496 (MO); Ibidem, pedra da Urca, 5 Dec 1989, Reinert s.n. (RB283950); Ibidem, cultivated, Nov 1995, Leme s.n. (HB84605); Ibidem, Barra da Tijuca, Jan 1995, Oliveira s.n. (HB84646); Ibidem, Parque Natural Municipal da Prainha, 29 Jan 2004, Calvente \& Versieux 82 (RFA); Ibidem, Urca, pista Cláudio Coutinho, 29 Dec 2006, Versieux \& Peixoto 342, 343 (SP); Ibidem, pedra do Pontal, s.d., Pereira s.n. (HB74679). Without EXACT LOCALiTY: Mar 1872, Glaziou s.n. (K); Mar 1990, Reinert s.n. (RB285577); São Paulo, cultivated at IBt, Jan 1993, Wanderley 2066 (SP). 
9. Alcantarea hatschbachit (L. B. Sm. \& Read) Leme, Bromélia 2(3): 22. 1995. Vriesea batschbachii L. B. Sm. \& Read, Phytologia 30: 292. 1975.-TIPO: BRASIL. Minas Gerais: Gouveia, rodovia BR 259, encosta rochosa de morro, 21 Jan 1972, G. G. Hatschbach, L. B. Smith \& E. Ayensu 29085 (holótipo: US!; isótipos: MBM!, SPF!, Z!).

RUPÍCOLA, 1.2-1.4 m alt., forma de propagação desconhecida; CAULE ca. 4 x 1,5 cm. ROSETA estreito-infundibuliforme, fitotelma pouco desenvolvido. FOLHAS ca. 10, suberetas. BAINHA 9-11 x 2-3 cm, estreito-elíptica, bege in sicco, densamente lepidota em ambas as faces, subcoriáceas; margens membranáceas, glabras, amarelado-alvacentas e onduladas in sicco. LÂMINA 50-60 x 1-1.6 $\mathrm{cm}$, linear, ápice agudo, de densamente a esparsamente lepidota abaxialmente, densamente hialinolepidota adaxialmente, margens involutas in sicco. PEDÚNCULO ca. $1 \mathrm{~m}$ x $0.5-1 \mathrm{~cm}$, ereto, reto a levemente flexuoso, cilíndrico, glabro a esparsamente lepidoto, distintamente nervado, entrenós proximais: 5-6.5 cm; medianos e distais: 3-7.5 cm; BRÁCTEAS proximais: subfoliáceas, eretas a suberetas; medianas e distais: $3.4-25$ x 1-2.3 cm, base estreito-oval, lâmina linear-triangular, ápice longo-caudado a acuminado, densamente lepidota passando a glabra abaxialmente, adaxialmente marrom-lepidotas, eretas, excedendo os entre-nós, o 1/4 basal envolvendo o pedúnculo, lisas, coriáceas, finamente nervadas; margens membranáceas, amareladas in sicco. INFLORESCÊNCIA 1530 x 3-4 (excluindo as pétalas), espiga, de contorno elíptico a oval, 10-22-florida, ereta; RÁQUILA reta a levemente encurvada, circular em secção transversal, entrenós 2-2.3 (proximal) a 0.9-1.5(distal) x 0.5-0.7 cm, glabra; BRÁCTEA FLORAL 2.9-4 x 1.6-2.3 cm, oval a largo oval, ápice obtuso, apiculada, esparsamente marrom-lepidota abaxialmente, glabra adaxialmente, finamente nervada, cartácea, ecarinada ou com espessamento próximo ao ápice, margens hialino-amareladas. FLORES dísticas, suberetas, ca. $6 \mathrm{~cm}$ compr.; SÉPALAS 3-3.2 x $1.1 \mathrm{~cm}$, elípticas, ápice obtuso, simétricas, ultrapassando as brácteas florais em 7-10 mm, glabras abaxialmente, esparsamente marrom-lepidota adaxialmente, membranáceas, ecarinadas a carinadas; PÉTALAS ca. 6.5 x $0.7 \mathrm{~cm}$, liguladas, constritas ao redor dos ápices das sépalas, inconspicuamente maculadas de branco; APÊNDICES PETALÍNEOS ausentes; FILETE ca. 55 x $1 \mathrm{~mm}$, complanado; ESTILETE ca. 50 x $1 \mathrm{~mm}$, cilíndrico; OVÁRIO ca. 7 × 3-4 mm, estreitamente ovado, hipanto ca. $4 \mathrm{~mm}$. CÁPSULAS E SEMENTES desconhecidos. Figs. 19 E-K.

DISTRIBUIÇÃO, ECOLOGIA E CONSERVAÇÃO. Alcantarea hatschbachii é conhecida de duas coleções apenas, ambas do município de Gouveia, Minas Gerais. Apesar dos nossos esforços para reencontrá-la no campo durante três expedições focadas na área da localidade típica, não houve êxito. A espécie é considerada extinta na lista da flora ameaçada de extinção de MG (Mendonça \& Lins 2000). Segundo o Dr. Hatschbach (com. pess.), a localidade típica foi descaracterizada pelo extrativismo de diversas espécies vegetais, além das queimadas constantes. Entretanto, novas buscas 
não devem ser descartadas e o táxon não foi aqui considerado como extinto, uma vez que o habitat da espécie ainda não foi exaustivamente explorado, conforme requisitado pela IUCN (2001) para que qualquer espécie seja enquadrada na categoria de Extinct (EX). A suposta localidade típica é indicada por kilometragem ao longo de uma rodovia que teve seu trajeto alterado nas últimas décadas, o que amplia substancialmente as possibilidades a serem investigadas. IUCN Red List Category: Data Deficient, DD.

FENOLOGIA. Foi coletada com flores e frutos passados em fevereiro.

ETIMOLOGIA. Homenageia o Dr. Gert Gunther Hatschbach do Museu Botânico Municipal de Curitiba (MBM), coletor do typus.

DISCUSSÃO. Em virtude do holótipo não conter flores ou sementes, na descrição original Smith \& Read (1975) relacionaram este táxon à Vriesea goniorachis e não ao subgênero Alcantarea. A mesma posição foi seguida por Smith \& Downs (1977). Como a espécie foi descrita a partir de materiais que continham apenas pedúnculos e inflorescências passadas, as folhas também não são mencionadas na obra original. Os caracteres da roseta, das folhas e flores só puderam ser analisados a partir da segunda coleção (Hatschbach 40820), da mesma localidade. A partir dessa segunda coleção, Leme (1995) notou que as pétalas longas apresentadas por $V$. hatschbachii, a incluiriam em Alcantarea e propôs a nova combinação e uma emenda à descrição, na qual ressalta as pétalas nuas, característica presente apenas nesta espécie de Alcantarea. Essa espécie é muito singular, não apenas por carecer de apêndices petalíneos, mas também por ser a única do gênero a possuir pétalas com coloração cremeesverdeada (fide Hatschbach). O aspecto vegetativo também é interessante pelo pequeno número de folhas longas, fortemente involutas in sicco e que compõem uma roseta estreita pouco desenvolvida. No isótipo do SPF assim como a coleção Hatschbach 40820, as flores são aparentemente secundas, entretanto na obra original menciona-se que a inflorescência é dística. A espécie apresenta algumas similaridades $\operatorname{com} A$. duarteana, tais como a roseta pouco desenvolvida e as brácteas do pedúnculo longo-caudadas, além disso ambas apresentam a mesma distribuição, sendo restritas ao planalto de Diamantina, MG. No presente trabalho tentou-se proceder uma extração de DNA com base nos materiais existentes, porém sem êxito, mesmo aplicando diferentes protocolos indicados para casos de materiais de exsicatas antigas. Uma especulação que poderia explicar a raridade e extinção da espécie, bem como a presença de pétalas nuas, seria atribuir sua existência a um evento fortuito de hibridização, envolvendo como possíveis parentais a $A$. duarteana, relativamente comum na região, com alguma das muitas espécies do gênero Tillandsia que ocorrem na região, que apresenta pétalas nuas. A obtenção de novos materiais seria extremamente útil na melhor compreensão do táxon e consideramos prematura a decisão de classíficá-la como uma espécie extinta. 
MATERIAL EXAMINADO. Brazil. MINAS GERAIS: Gouveia, rodovia BR-259, encosta rochosa de morro, 21 Jan 1972, Hatschbach et al. 29085 (MBM, SPF, US, Z); Ibidem, rodovia BR-259, 10 km S de Gouveia, 22 Jan 1978, Hatschbach 40820 (MBM).

10. Alcantarea heloisae J. R. Grant, Vidalia 1(1): 31. 2003.-Tipo: Brasil. Rio de Janeiro: “Retiro de Triunfo", Triunfo, near Santa Maria Madalena, 2203’350” S, 4156’980” W, 26 Mar 1999, J. R. Grant 99-03470 \& E. Dias, collected sterile, bloomed in cultivation at the Université de Neuchâtel, Switzerland (May-August 2002). (holótipo HB n.v.; isótipo US!).

RUPÍCOLA, 1.6-3 m alt., propagando-se por brotações axilares ou basais, caulescente. ROSETA 6090 x 60-80 cm, infundibuliforme, fitotelma desenvolvido. FOLHAS numerosas, suberetas; BAINHA 12-20 x 8-15 cm, ovais, castanho-escura passando ao púrpura abaxialmente, castanho-clara com pontos vermelho-vinho adaxialmente in vivo, marrom em ambas as faces quando seca, densamente marrom-lepidota em ambas as faces, coríacea, margens membranáceas, hialinas; LÂMINA 35-84 x 6-7(-10) cm, linear a linear-lanceolada, verde-vinosa abaxialmente, verde com algumas faixas transversais alvacento-cerosas adaxialmente, subdensamente lepidota abaxialmente, glabra em direção ao ápice adaxialmente, plana a levemente canaliculada, coriácea, distintamente nervada com algumas nervuras proeminentes, margens coriáceas, com fina linha púrpura ou vinosa; ÁPICE DA LÂMINA agudo a acuminado, verde, verde-arroxeado ou vinoso, torcido, recurvado para a base da folha, discretamente apiculado. PEDÚNCULO 55-120 x (1-)2.6(distal)-4.2(proximal) cm, ereto, reto a levemente encurvado, robusto, cilíndrico, verde, vermelho nas partes expostas, glabro, distintamente nervado, sulcado, entrenós 4-4.5 cm (proximal) a $3 \mathrm{~cm}$ (distal); BRÁCTEAS as proximais: 20-43 x 5$7 \mathrm{~cm}$, subfoliáceas, polísticas; as distais: $2.2-5.5(-22) \times 3.5-5.5 \mathrm{~cm}$, largo-ovais, ápice longo-caudado, apículo torcido, vermelhas abaxialmente, verdes adaxialmente, frequentemente ceroso-pulverulentas, esparsamente lepidotas abaxialmente, glabras adaxialmente, eretas com ápices polísticos, distintamente nervadas, cartáceas, margens com linha vermelho-vinosa de $1 \mathrm{~mm}$ larg. INFLORESCÊNCIA 40-50 x 25-40 cm (excluindo as pétalas), composta, em panícula de espigas, elipsoidal, esférica a ovoidal, entrenós da raque 2.8-3.2 (proximal) a 1.6-2.4 (distal) cm; BRÁCTEA PRIMÁRIA (2.9-)3.3-4(-10.5) x 2.7-3.2(-4.5) (excluindo o apículo de $3 \mathrm{~mm}$ ), largamente oval, ápice agudo, apiculado, verde com ápice vinoso, glabra abaxialmente, densamente marrom-lepidota adaxialmente, involuta, envolvendo e geralmente excedendo a base estéril do pedúnculo, distintamente nervada, coriácea, com as margens basais aladas e membranáceas; RAMOS DA INFLORESCÊNCIA 7-27, 4-11(-26)-floridos, sendo a terminal em geral pouco desenvolvida ou abortada, PEDÚNCULOS LATERAIS 2-3(-12) x 0.4-0.5 cm, achatados, sulcados, verde, glabros; BRÁCTEAS ESTÉREIS 2.4 x $1.4 \mathrm{~cm}, 1-2$, elípticas, ápice agudo, verde-oliva, glabra abaxialmente, 
densamente marrom-lepidota adaxialmente, cartácea, margens membranáceas, distintamente nervada, carenada; RÁQUILA 6-10 cm, de levemente geniculada a quase reta, verde, glabra; entrenós 1-1.5(2) x $0.3 \mathrm{~cm}$; BRÁCTEA FLORAL 3-3.2(-3.6) x 2.4-3 cm, largamente elíptica, ápice obtuso, verdeoliva a verde-amareladas, glabra abaxialmente, densamente marrom-lepidota adaxialmente, envolvendo completamente o cálice, com o 1/3 basal dos bordos se tocando, nervado-rugosa, decurrente com a ráquila, rígida, ecarinada mas com leve linha negra espessada abaixo do ápice, margens membranáceas, castanho-amareladas in sicco. FLORES inodoras, dísticas, patentes ou suberetas; SÉPALAS 3-3.7 x (1.4-1.6-1.9 cm, elípticas a levemente obovadas, ápice arredondado, simétricas, excedendo as brácteas florais em 1.1-1.4 cm, base verde, verde-amareladas em direção ao ápice, glabras, carnosas, ecarinadas, margens membranáceas e amareladas in sicco; PÉTALAS 82-88 x 9-10 mm, liguladas, constritas ao redor do ápice das sépalas, levemente onduladas ao longo das margens na metade distal, amarelas, fortemente recurvadas para trás e eventualmente enroladas; APÊNDICES PETALÍNEOS 27-30 x ca. 2 mm, 2, ligulados, longitudinalmente adnatos à pétala por ca. $23 \mathrm{~mm}$, ápices agudos, assimétricos; ESTAMES apresentados em feixe na antese; FILETE 62-66 x ca. $1 \mathrm{~mm}$, complanado, branco; ANTERA ca. 16 × $2 \mathrm{~mm}$, linear-atenuada, amarela, dorsifixa próximo à base; ESTILETE 77-82 x ca. $2 \mathrm{~mm}$, cilíndrico a levemente trígono, branco; LOBOS DO ESTIGMA ca. 3 × $1 \mathrm{~mm}$, convoluto-patentes, falciformes, brancos; OVÁRIO ca. 15 × 3-4 mm, estreitamente ovóide, verde, hipanto ca. $6 \mathrm{~mm}$; ÓVULOS ca. $1 \mathrm{~mm}$, numerosos, CÁPSULA 4.5-5.5 x $1 \mathrm{~cm}$, estreito-elíptica com ápice agudo e torcido, marrom; SEMENTE ca. 6 × $1 \mathrm{~mm}$, elíptica, marrom; COMA BASAL ca. $7 \mathrm{~mm}$, fimbriado, bege; COMA APICAL ca. $10 \mathrm{~mm}$, fimbriado, ferrugíneo. Figs. 20, 21 A-D.

DISTRIBUIÇÃO, ECOLOGIA E CONSERVAÇÃO. Alcantarea heloisae cresce como heliófila sobre rochas, entre 300-900 m.s.m., em Santa Maria Madalena, estado do Rio de Janeiro, Brasil. Alcantarea heloisae apresenta restrita área de ocorrência e registros de queimadas em suas populações (Fig. 7 B). Localmente, é explorada para cultivo em praças e jardins. Só há ocorrências para o município de Santa Maria Madalena. Porém, suas populações são, em geral, muito grandes, com centenas de indivíduos e encontra-se protegida dentro do Parque Estadual do Desengano. IUCN Red List Category: Near Threatened, NT.

FENOLOGIA. Floresce do fim de novembro a fevereiro, com pico em dezembro. Frutos coletados entre março e abril.

ETIMOLOGIA. Alcantarea heloisae é uma homenagem à Profa. Heloísa Burrowes Raposo Dias, de Campos dos Goytacazes, RJ. 
DISCUSSÃO. Grant (2003) ao descrever $A$. heloisae indicou como táxons afins $A$. naboumii, A. nevaresii e $A$. odorata usando a forma e coloração das brácteas do pedúnculo e o formato da inflorescência para discutir tais afinidades. Para o autor o novo táxon diferiria de $A$. nevaresii por apresentar folhas com faixas transversais cerosas (vs. verdes e brilhantes) e brácteas florais amarelo brilhantes (vs. amarelo esverdeadas). Seria semelhante a $A$. nahoumii por apresentar brácteas florais amarelas e flores laxamente dispostas nos ramos, porém seria diferente dessa espécie por possuir brácteas do pedúnculo menores, longo-lineares (vs. maiores e infladas). Nas populações analisadas no presente trabalho, entretanto, as brácteas florais não se mostravam amarelas, mas verdes, ou verde-amareladas e observou-se que o tamanho da inflorescência é muito variável. Comparando a folhagem de $A$. heloisae com a de $A$. odorata (que possui folhas densamente cerosas), Grant (loc. cit) concluiu que esse seria o táxon mais próximo, visto que $A$. heloisae também apresenta folhas e brácteas com depósitos de cera bem marcados. Os resultados aqui obtidos apóiam tal hipótese, sendo a proximidade entre $A$. heloisae e $A$. odorata dada não só pelas características vegetativas, mas também pela morfologia floral e distribuição geográfica. As flores são semelhantes às de duas espécies da região de Santa Maria Madalena, $A$. farneyi e $A$. tortuosa que também apresentam os estames em feixe na antese. Chama a atenção o formato do conetivo, levemente saliente e as cápsulas que se mantêm sempre dísticas. Apesar de enfatizado por Grant (2003), o formato em "âncora" das pétalas, assim como o forma de "J invertido" dos lobos do estigma (i.e. patentes e recurvados sobre si mesmos) são características que estão presentes nas outras espécies da região, inclusive em $A$. odorata.

MATERIAL EXAMINADO: Brazil. RIO DE JANEIRO: Santa Maria Madalena, pedra Dubois, 27 Feb 1935, Santos Lima \& Brade 1417 (RB); Ibidem, morro atrás do horto Santos Lima, 19 Jan 1957, Mello Filho 1147 (R); Ibidem, Apr 1974, Burle Marx s.n. (RB202513); Ibidem, subida para a pedra do Desengano, 2 Mar 2004, Forzza et al. 2843 (K, MBM, SP); Ibidem, barragem da Tudelândia, 24 Nov 2005, Versieux \& Calvente 238, 239 (SP); Ibidem, morro da torre, 10 Feb 2006, Forzza et al. 4159 (MBM, RB).

11. Alcantarea imperialis (Carrière) Harms, in H.G.A. Engler, Nat. Pflanzenfam. ed. 2, 15a: 126. 1930. Vriesea imperialis Carrière, Rev. Hort. 60: 58. 1888.-TIPO: Material cultivado no Museu de Paris, nenhum espécime preservado. Neótipo, ic designatus: Mez (1894): Fl. bras. vol. iii. pars 3, t. 105.

Vriesea blokii (Hemsley) Mez, in H.G.A. Engler Pflanzenr. IV. 32: 405. 1935. Tillandsia blokii Hemsley, Bot. Mag. 134: pl. 8192. 1908.-Tipo: Cultivated at the Royal Botanic Gardens, Glasnevin, 3 Jul 1907, W. Moore s.n. (K382037!). 
? Alcantarea brasiliana (L.B. Sm.) J.R. Grant, Trop. Subtrop. Pflanzenwelt 91: 12. 1995. Vriesea brasiliana L.B. Sm. Arq. Bot. Estado São Paulo 1: 115. 1943.-Tipo: Brasil. Rio de Janeiro. Petrópolis, sobre rochas expostas perto de Meio da Serra, a cerca de 500 m.s.m., 7 Abr 1929, L. B. Smith \& A. C. Brade 2295 (holótipo: GH n.v.; isótipos: B não encontrado, S!). syn. nov.

RUPÍCOLA, (1.5-)3-5 m alt., caulescente, monocárpica ou raramente propagando-se por brotações basais. ROSETA 0.7-1.7 x 1-1.6 m, infundibuliforme, fitotelma muito desenvolvido. FOLHAS ca. de 160, suberetas a eretas; BAINHA 21-30(-42) x (14-)20-30(-36) cm, largo-oval, oblongo-elíptica a quase trapeziforme, castanho-escura passando ao castanho-claro em ambas as faces in sicco, verdeclaro a castanho-claro e densamente maculada de vermelho-vinoso em ambas as faces, com linhas oblíquas vinosas próximas da base da lâmina in vivo, densamente marrom-lepidota em ambas as faces, coriácea; margens membranáceas, vinosas a hialino-vinosas; LÂMINA 52-80(-150) x 13-16(-22.5) $\mathrm{cm}$, ligulada longo-atenuada, verde a vinosa, lustrosa, com ou sem máculas vinosas abaxialmente, glauca, frequentemente com faixas transversais cerosas (de 2-12 cm larg.), com ou sem máculas vinosas de áte $1 \mathrm{~cm}$ diâm. que se aglutinam em direção ao ápice, ou totalmente vinosa adaxialmente, densamente lepidota abaxialmente, de esparsamente lepidota a glabra em direção ao ápice adaxialmente, levemente canaliculada, reta a levemente arqueada em direção ao ápice, coriácea, distintamente nervada, com nervuras proeminentes bem marcadas principalmente próximo ao ápice; margens com fina linha $(<1 \mathrm{~mm})$ vinosa, raramente verdes; ÁPICE DA LÂMINA agudo, acuminado, verde ou vinoso, em geral torcido ou voltado para trás. PEDÚNCULO (50-)70-100 x 56 (distal) a 9-10 (proximal) cm, ereto, reto, robusto, cilíndrico a levemente sulcado, verde-claro concolor, raramente com máculas vinosas, glabro, distintamente nervado; entrenós 2-6 cm; BRÁCTEAS as proximais: subfoliáceas densamente imbricadas e eretas; as medianas e distais, 26-38 x 6-11 cm, ovais a triangulares, ápice agudo, acuminado, totalmente vermelho-vinosas em ambas as faces ou a base vinosa passando ao verde concolor, com ou sem máculas, bordos e ápice vinosos, raramente verdes concolores em ambas as faces, densamente lepidotas em ambas as faces, suberetopatentes, infladas na base, acumulando água, distintamente nervadas, coriáceas; margens vermelhovinosas a verdes. INFLORESCÊNCIA $1-2$ × 0.5-0.8 m, composta, em panícula de espigas, estreito piramidal a elipsoidal, ereta, entrenós da raque (1.5-)3-4(-6) cm; BRÁCTEAS PRIMÁRIAS as proximais: ca. $25 \times 12 \mathrm{~cm}$; as distais: 8-22 x 5-11 cm, gradualmente menores, largo-oval, ápice agudo, inconspicuamente apiculado por ca. $5 \mathrm{~mm}$, voltado para baixo, de coloração igual à das brácteas do pedúnculo, densamente lepidotas em ambas as faces, involutas, acumulando água, excedendo a base estéril do pedúnculo lateral, distintamente nervadas, coriáceas; margens basais vinosas e membranáceas; RAMOS DA INFLORESCÊNCIA (36-)40-60, (8-)14-18-floridos, suberetopatentes na antese, passando arqueados, até sigmóides no pós-antese e frutificação; PEDÚNCULOS LATERAIS (12-)15-18(-31) x (0.6-)1-1.2 cm, levemente achatados, verdes a verde-vinosos nas 
porções expostas, glabros; BRÁCTEAS ESTÉREIS (3-)3.5-4.5(-5.5) x (1.2-)1.8-2.7 cm, 2, raramente 3, ovais, ápice agudo e uncinado, verdes no centro e vermelho-vinosas na base, nos bordos e no ápice ou totalmente vinosas e lustrosas, esparsamente lepidotas abaxialmente, subdensamente lepidotas adaxialmente, eretas, adpressas ao pedúnculo, remotas ou imbricadas, distintamente nervadas, carenadas, cartáceas; margens hialino-vinosas, membranáceas; RÁQUILA 13-32 cm, de levemente a medianamente geniculada (i.e. divergindo até ca. $10^{\circ}$ para cada lado), verde, vinosa no lado adaxial, glabra; entrenós 5-40 x 2-6 mm; BRÁCTEA FLORAL (2.2-)3-3.5(-4.5) x (1.3-)2$2.8(-3.2) \mathrm{cm}$, gradualmente diminuindo de tamanho em direção aos botões distais, largo-oval, ápice agudo e uncinado, verde no centro e vermelho-vinosa na base, nos bordos e no ápice ou totalmente vinosa, esparsamente lepidota abaxialmente, subdensamente lepidota adaxialmente, envolvendo o cálice, mas sem os bordos se tocarem, finamente nervada, cartácea, carenada em quase toda a extensão ou apenas nos $2 / 3$ distais; margens membranáceas, hialino-amareladas in sicco. FLORES com um leve cheiro de alho, passando a inodoras, secundas; SÉPALAS 3.5-4.6 x 1.2-2.2 cm, elípticas, ápice obtuso, simétricas ou quase, excedendo as brácteas florais em ca. de $1.6 \mathrm{~cm}$, verdes sob as brácteas, verde-vinosas a vinho-escuro nas áreas expostas, esparsamente lepidotas em ambas as faces, cartáceas, levemente carenadas em direção ao ápice; margens membranáceas, hialino-amareladas in sicco; PÉTALAS 10-12.2 × 1.1-1.4 cm, liguladas, ápice agudo a obtuso, inconstritas ou pouco constritas ao redor do ápice das sépalas, base alvacenta e porção distal amarela no botão, passando do amarelo-pálido ao alvacento no pós-antese, fortemente recurvadas para trás e enrolando-se do ápice para a base na antese, margens levemente onduladas no 1/3 proximal; APÊNDICES PETALÍNEOS 24-28 x 3-5 mm, 2, ligulados, longitudinalmente adnatos à pétala por 14-19 mm, ápices obtusos a inconspicuamente trucado-denteados; ESTAMES polísticos, em um raio de ca. $6 \mathrm{~cm}$; FILETE 98103 x 1-2 mm, mais curto que as pétalas, levemente aplanado na base passando a quase cilíndrico, gradualmente diminuindo de diâmetro em direção ao ápice, branco; ANTERA 13-14 x $1 \mathrm{~mm}$, linear, amarela, dorsifixa próximo à base; ESTILETE 98-110 x 1.5-2.6 mm, cilíndrico, branco; LOBOS DO ESTIGMA ca. 6 × $1 \mathrm{~mm}$, com porção papilosa de ca. $3 \mathrm{~mm}$, eretos passando a patentes, brancos; OVÁRIO ca. 12 (porção suúpera) x $5 \mathrm{~mm}$, estreitamente ovóide, verde-alvacento na base a alvacento, hipanto ca. $5 \mathrm{~mm}$; ÓVULOS ca. $1 \mathrm{~mm}$, numerosos. CÁPSULA $4.2-6.3$ x 0.9-1.4 cm, estreitoelipsoidal com ápice agudo, marrom; SEMENTE 6-8 x ca. $1 \mathrm{~mm}$, fusiforme, marrom; COMA BASAL 4-7 mm, fimbriado, alvacento; COMA APICAL ca. 16 mm, fimbriado, bege. Figs. 21 E-J, 22, 23, 24, 25.

DISTRIBUIÇÃO, ECOLOGIA E CONSERVAÇÃO. Alcantarea imperialis é heliófila, ocorre entre 800-1800 m.s.m. em afloramentos rochosos de grande inclinação e em platôs nos campos de altitude da serra dos Órgãos, RJ (Martinelli 1997) e também na serra da Mantiqueira, em MG, nos municípios de Juiz de Fora e Lima Duarte, limite norte da distribuição. A espécie foi estudada quanto à biologia 
reprodutiva por Martinelli (1997), que demonstrou tratar-se de uma espécie de antese noturna, polinizada por morcegos, auto-compatível, protândrica com acentuada dicogamia. Esse autor sugeriu um interessante papel aos apêndices das pétalas, que auxiliariam na movimentação dos estames, facilitando a liberação de pólen sobre os polinizadores. As populações geralmente são grandes, muitas em locais inacessíveis como as que podem ser vistas nos municípios de Pedro do Rio e Petrópolis e há ocorrência em unidades de conservação (Parque Nacional da Serra dos Órgãos, Parque Estadual dos Três Picos, Parque Estadual do Desengano, Reserva Ecológica de Macaé de Cima, no RJ e no Parque Estadual do Ibitipoca em MG). Todavia, há registros de extrativismo e apreensões de grandes carregamentos, mesmo dentro de unidades de conservação (Parque Nacional Serra dos Órgãos, com. pes.), perda de populações por queimadas, agravadas pela invasão de gramíneas exóticas e, visto serem plantas que levam até 40 anos para atingir a fase reprodutiva (Graeff \& Pagani 1996), suas diferentes populações merecem um acompanhamento mais detalhado. De acordo com Barbará et al. (2007), os altos níveis de diferenciação genética observados entre as distintas populações dessa espécie apontam para a necessidade de se preservar o maior número possível de áreas. Apresentam alto valor no mercado paisagístico, entretanto já existem produtores cultivando a espécie em larga escala. IUCN Red List Category: Least Concern, LC.

FENOLOGIA. Floresce de novembro a março, com pico entre dezembro e janeiro. Frutos tornamse maduros no início de junho (Martinelli 1997).

ETIMOLOGIA. Segundo Carrière (1888), o epíteto imperialis foi dedicado ao Imperador do Brasil, Dom Pedro II, que enviou plantas vivas dessa espécie ao Museu História Natural de Paris, no ano de 1887.

DISCUSSÃO. A mais popular das espécies de Alcantarea é bem caracterizada pelo porte elevado e grandes dimensões das bainhas, lâminas foliares e flores, pelas brácteas florais carenadas, sendo que no pré-antese mostram-se uncinado-complanadas, flores secundas para cima e botões florais encurvados. Geralmente comporta-se como monocárpica, morrendo logo a após a produção de abundantes sementes. Raramente emite brotações basais no caule, antes ou durante a floração. O cálice possui a maior abertura observada para o gênero, visto que as sépalas são mais flexíveis e finas. No que se refere à cor das pétalas, é importante ressaltar que variam entre as populações e no próprio desenvolvimento floral. No botão maduro, logo antes da antese, são amarelas e essa cor vai se esmaecendo com o passar das horas, chegando ao alvacento.

A espécie é irmã de $A$. regina, da qual difere pelas folhas glaucas (vs. lustrosas), fortemente marcadas com vincos longitudinais próximos ao ápice (vs. lisas), com bainhas e lâminas mais largas e mais coriáceas, com ápice geralmente acuminado (vs. longo-atenuado), pela coloração geralmente 
vinosa das brácteas florais (vs. verdes), estames mais curtos que as pétalas (vs. mais longos). Além disso, as pétalas em $A$. imperialis são ligeiramente mais largas, o cálice apresenta maior abertura e o pedúnculo e a ráquila apresentam diâmetros, frequentemente, maiores.

Apresenta considerável variação morfológica intraspecífica nas diferentes populações estudadas, principalmente no que se refere à coloração das folhas centrais da roseta e brácteas do pedúnculo (Fig. 23 E), sendo que nas populações de Macaé de Cima, em Nova Friburgo, RJ, é possível observar indivíduos totalmente verdes crescendo ao lado daqueles totalmente vinosos (Bárbara et al. 2007). Para os horticultores, tais variações vêm constituindo importantes fontes de seleção de cultivares, que podem ser plantas totalmente verdes, totalmente vermelho-vinosas com variações entre os tons mais claros ou escuros, ainda, plantas com folhas quase totalmente verdes, apenas com ápice vinoso e brácteas do pedúnculo vinosas na base passando ao verde concolor. Observa-se, além da variação entre vermelho-vinoso e verde, a possibilidade das folhas serem variegadas. Para Luttge (1997) na região tropical é marcante além da variação fenotípica observada dentro de uma mesma espécie, a variação na pigmentação em resposta a diferentes luminosidades e nutrição. No caso das populações de Macaé de Cima (Nova Friburgo, RJ), essa variação é mais intrigante, pois observam-se os dois fenótipos crescendo lado a lado. Essa variação de cores, associada à beleza da espécie e sua ampla divulgação entre diferentes cultivadores na Europa no final do séc. XIX acabou gerando certa confusão taxonômica, que está registrada em diferentes publicações de horticultura européias, onde a aparece identificada sob distintos nomes (senso auctore non), como: Vriesea gigantea auc. non. Lem. (Ill. Hort. 14: t. 516. 1867) e Vriesea glazioveana auc. non. Carrière (Rev. Hort. 53: 50, fig. 15). O material ilustrado por Wright (1915) em muito se assemelha à A. imperialis, exceto pelo hábito e pela indicação de flores não secundas.

As coleções de Juiz de Fora e Lima Duarte (MG) são notáveis, quando comparadas às da serra dos Órgãos (RJ), por representarem plantas de menores dimensões, especialmente no que se refere às brácteas primárias e, também, por possuírem espigas com menor número de flores (9-12), frutos menores e ráquila geniculada em maior grau. Algumas coleções dessa região também apresentam o botão floral terminal abortado e o ápice foliar mais atenuado do que acuminado, características comuns em $A$. regina, espécie que também ocorre nessa região (Versieux \& Wanderley 2007b). É possível que um processo de hibridização /introgressão esteja ocorrendo entre essas espécies, hipótese que deverá ser testada em pesquisas futuras de genética de populações. Bárbara et al. (2007) indicam que a população de A. imperialis de Juiz de Fora é a que apresenta os maiores déficits de heterozigosidade quando comparada às populações da serra dos Órgãos, o que demonstra uma posição mais isolada geneticamente.

No material seco, algumas características são auxiliares na identificação, como os entre-nós obcônicos da ráquila, que ao sofrerem o levantamento, característico das flores secundas, dão à 
ráquila um formato crenado, a forma largo-oval das brácteas primárias e, principalmente, a bainha foliar extremamente larga.

Smith (1943) descreve Vriesea brasiliana baseando-se em um espécime Smith \& Brade 2295 coletado na localidade de Meio da Serra, distrito de Petrópolis, RJ. Tal espécime encontra-se em avançado estágio de frutificação e as poucas flores remanescentes foram usadas na descrição, onde nota-se através do curto comprimento das pétalas $(\sim 5 \mathrm{~cm})$, que as flores encontravam-se imaturas ou subdesenvolvidas. Smith (loc. cit) inclui como sinônimo Vriesea regina sensu Mez (Mez 1894; 1896; 1934), que havia sido descrita com base no espécime Glaziou 11685. Durante o nosso trabalho de campo, essa mesma localidade (Meio da Serra) foi visitada e os exemplares de Alcantarea, observados e coletados. Notou-se que nas partes mais elevadas dessa serra ocorre a $A$. geniculata, nas partes mais baixas, em torno de 500 m.s.m. ocorre um táxon muito semelhante a $A$. imperialis e que apresenta inflorescência verde e flores amarelas (Fig. 25 A-C). Posteriormente foi feita a análise dos espécime Glaziou $11685(\mathrm{~K})$ e foi constatado que o mesmo trata-se de A. geniculata. Após o estudo do material examinado e citado por Smith \& Downs (1977) para A. brasiliana, concluímos que parte dos espécimes se enquadra perfeitamente dentro da circunscrição aqui apresentada para $A$. imperialis, enquanto que os demais, se aproximam de $A$. geniculata. A dimensão e o formato da pétala e dos seus apêndices e a morfologia dos estigmas se sobrepõe muito bem à $A$. imperialis, não havendo caracteres florais que sustentem $A$. brasiliana como uma espécie distinta, justificando a proposta da nova sinonímia. Entretanto, as folhas de A. brasiliana se mostram um pouco mais curtas e, como será discutido adiante, os indivíduos amostrados em Meio da Serra aparecem isolados nas análises de microssatélites (Cap. 2), mais próximos à $A$. geniculata e $A$. nevaresii do que às outras populações de $A$. imperialis da serra dos Órgãos. É possível que $A$. brasiliana seja um híbrido entre $A$. imperialis e $A$. geniculata, com sucessivos retrocruzamentos (introgressão), dificulando a separação dessas espécies simpátricas, mas tal hipótese deverá ser testada no futuro com uma amostragem maior para todos esses taxa. $\mathrm{O}$ fluxo gênico em pequenas taxas entre $A$. geniculata e $A$. imperialis foi observada por Barbará et al. (2007) através de taxas de migração para uma outra população simpátrica dessas espécies em Petrópolis. Smith (1955: 103) utiliza como critério a forma da ráquila, fortemente geniculada e a presença de poucas flores secundas para separar $A$. brasiliana de $A$. imperialis, que apresentaria ráquila meramente flexuosa e todas as flores secundas. Mas quando se analisam os materiais examinados por esse autor, nota-se que há uma miscelânia taxonômica, na qual $A$. brasiliana está mascarada pelas características de A. geniculata. As incertezas sobre o status de Alcantarea brasiliana como espécie distinta de $A$. imperialis aumentaram após a análise do ícone de Edouard Morren arquivado em Kew (Fig. 25 D), onde se nota a clara semelhança entre as planta ilustrada na aquarela com a fotografia dos indivíduos floridos coletados no Meio da Serra (Versieux 451, 452, 453), subsidiando a manutenção daquele nome nesta sinonímia até que resultados de estudos em andamento (C. Lexer com. pes.) comprovem se A. brasiliana é, de fato, um híbrido natural. O neótipo 
designado é a ilustração detalhada da Flora Brasiliensis e foi escolhido em razão da obra original (Carrière 1888) não indicar nenhum espécime tipo ou fornecer ilustração.

MATERIAL EXAMINADO: Brazil. MINAS GERAIS: Dona Euzébia, serra da Boa Vista, 5 Feb 1996, Paula 1281 (VIC). Juiz de Fora, 27 Oct 1946, Krieger 15531 (CESJ, RB); Ibidem, pedreira Santo Cristo, 14 Nov 1999, Caiafa \& Ribeiro s.n. (CESJ30424). Lima Duarte, Parque Estadual da Serra do Ibitipoca, 11 Mar 2004, Forzza et al. 3202 (RB, SP); Ibidem Parque Estadual do Ibitipoca, 8 Mar 2006, Ferreira et al. 996 (CESJ, SP). Manhuaçu, 28 Oct 1969, Heringer 11910 (RB). Rio Novo, serra do Henrique, 27 Sep 1895, Schwacke 11911 (RB). Viçosa, cultivated at UFV, 27 Feb 2002, Paula \& Silva s.n. (VIC26367). Paraná. Curitiba, cultivated at Jardim Botânico Municipal, 1 Dec 2005, Silva \& Ribas 4531 (MBM). Rio de Janeiro: Nova Friburgo, Macaé de Cima, 22 Dec 1992, Martinelli \& Miller 14799 (RB, SP); Ibidem, Macaé de Cima, 20 Nov 2005, Versieux et al. 221, 222 (SP). Ibidem, Lumiar, Toca da Onça, 16 Nov 2005, Versieux \& Calvente 215 (SP). Petrópolis, serra da Estrela, 5 Mar 1967, Pereira \& Braga 10560 (HB); Ibidem, Feb 1882, Glaziou 13262 (C, K, P); Ibidem, serra da Estrela, 7 Nov 1967, Pereira 10644 (K); Ibidem, serra da Estrela, 12 Mar 1967, Pereira 10565 (K, NY); Ibidem, Fagundes - Pedro do Rio, 9 Nov 1967, Braga 18 (RB); Ibidem, serra das Araras, 1974, Reitz. 7725 (HBR); Ibidem, entre Araras e Vale das Videiras, 2 Jun 1984, Martinelli et al. 9853 (RB); Ibidem, Araras, Pedra do João Grande, 26 Oct 2002, Martinelli 16213 (RB); Ibidem, serra da Estrela, 29 Dec 2007, Versieux \& Calvente 451, 452, 453 (SP); Without exact locality, serra da Estrela, 5 Mar 1967, Pereira 10560 (HB). Without exact locality, Mar 1872, Glaziou s.n. (K). Without exact locality, chaîne des Orgnes, 22 Nov 1883, Glaz̧ion 15469 (C, K, NY, P). Teresópolis, estrada Teresópolis-Friburgo, 1999, Costa et al. 748 (R). São Paulo: São Paulo, cultivated at IBt, 31 Oct 2005, Versieux 214 (SP); Cultivated at IBt, 10 Jan 2006, Versieux 266 (SP); Cultivated at IBt, 27 Nov 2007, Versieux 450 (SP). France. Cultivated at the Ecole Nationale d'Horticulture de Versailles, Apr 1909, Gerôme s.n. (P). Ireland. Glasnevin, cultivated at Royal Botanic Gardens, 3 Jul 1907, Moore s.n. (K382037); Ibidem, cultivated at Royal Botanic Gardens, 17 Feb 1908, Moore s.n. (K382039).

12. Alcantarea longibracteata Leme \& Fraga, J. Bromeliad Soc. 58(5): 206. 2008.-Tipo: Brasil. Espírito Santo: Águia Branca, Santa Luzia, propriedade de Ciro Ferreira, Pedra da Bandeira, 1858'77’'S, 40³9'84’'W, 297 m, 26 Abr 2008, E. M. C. Leme 7346, L. Kollmann, A. P. Fontana, O. Ribeiro \& M. Zanoni (holótipo: RB!; isótipo MBML!).

RUPÍCOLA, ca. $2 \mathrm{~m}$ alt., curto caulescente. ROSETA estreito infundibuliforme, fitotelma desenvolvido. FOLHAS pouco numerosas (ca. 18), eretas a suberetas; BAINHA 16-20 x 8-11 cm, elíptica a oval, marrom com máculas vinho-arroxeada em direção ao ápice abaxialmente, bege adaxialmente, densamente a subdensamente marrom-lepidota em ambas as faces, coriácea; margens 
membranáceas, paleáceas in sicco; LÂMINA 110-160 x 4.5-6.7 cm, ligulada-atenuada, verde, glabrescente em ambas as faces, com estômatos acastanhados e densamente arranjados nas nervuras abaxiais, reta, coriácea, distintamente nervada, com nervuras proeminentes, margens verdes; ÁPICE DA LÂMINA agudo, caudado, verde, encurvado. PEDÚNCULO 160 x 1.5-2 cm, ereto, reto a insconspicuamente curvo, robusto, cilíndrico, vermelho, glabro, distintamente nervado, entrenós 6.5$13 \mathrm{~cm}$; BRÁCTEAS proximais: subfoliáceas e suberetas, remotas, com a base vermelha e ápice verde; as medianas e distais: $16-28 \times 4-5.5 \mathrm{~cm}$, oval-lanceoladas, ápice caudado, verdes, base vermelha, glabrescentes em ambas as superfícies, com estômatos acastanhados in sicco e densamente arranjados nas nervuras, suberetas a patente-encurvadas, canaliculadas, distintamente nervadas, coriáceas; margens verdes. INFLORESCÊNCIA 75 x 30-40 cm, composta, em panícula de espigas, elipsoidal a obovoidal, entrenós da raque 1.5-6 cm, ereta; BRÁCTEA PRIMÁRIA 2.5-13 x 2.6-5 cm, largo-oval a suborbicular, ápice caudado a acuminado, verde avermelhada a vermelha, glabrescente em ambas as superfícies ou glabra e espasamente lepidota em direção ao ápice adaxialmente, involuta, mais longa que a base estéril do pedúnculo lateral, distintamente nervada, coriácea, margens membranáceas; RAMOS DA INFLORESCÊNCIA 13-16, 9-17-floridos, patentes a patente-ascendentes; PEDÚNCULOS LATERAIS 1-7 x $0.5 \mathrm{~cm}$, elípticos em secção transversal, verdes a avermelhados, glabros; BRÁCTEAS ESTÉREIS ca. 2.5 x $1.5 \mathrm{~cm},(0) 1-2(-4)$, elípticas, ápice obtuso, castanhas in sicco, glabras abaxialmente, subdensamente lepidotas adaxialmente, suberetas, imbricadas, distintamente nervadas, carenadas, coriácea, margens bege, membranáceas in sicco; RÁQUILA 10-20 cm, levemente geniculada, verde, entrenós $0.7-2$ x 0.2-0.4 cm cm, glabra; BRÁCTEA FLORAL 2.93.4 x 2.8-3.2 cm, suborbicular, ápice obtuso e enegrescido com o passar do tempo, amarela, glabra abaxialmente, lepidota adaxialmente, envolvendo quase que completamente o cálice, subereta, lisa a rugosa, coriácea, ecarinada ou com pequena carena apenas no ápice, margens membranáceas, hialinoamareladas in sicco. FLORES dísticas; SÉPALAS ca. 3.2 × $1.6 \mathrm{~cm}$, oboelípticas, ápice obtuso, simétricas, excedendo as brácteas florais em ca. $1 \mathrm{~cm}$, amarelas, glabras abaxialmente, subdensamente marrom lepidotas adaxialmente, coriáceas, ecarinadas, margens membranáceas, hialino-amareladas in sicco; PÉTALAS 7.5-8.5 x $0.8 \mathrm{~cm}$ (fide Leme et al. 2008), liguladas, ápice obtuso, constritas ao redor do ápice das sépalas, amarelas; APÊNDICES PETALÍNEOS 34 x 2.5 mm (fide Leme et al. 2008) 2, ligulados, ápice livre, obtuso com bordo inconspicuamente irregular, adnatos à pétala por 2-2.7 mm, ápices agudos; ESTAMES polísticos; FILETE levemente aplanados, branco; ANTERA. 10-14 x 1 mm, linear, amarela, dorsifixa próximo à base; ESTILETE cilíndrico, branco; LOBOS DO ESTIGMA ca. 4 × $1 \mathrm{~mm}$, eretos, brancos; OVÁRIO 11 (porção súpera) x $5 \mathrm{~mm}$, estreitamente ovóide, hipanto ca. $7 \mathrm{~mm}$; ÓVULOS ca. $1 \mathrm{~mm}$, numerosos. CÁPSULA 3.5-4.2 x $0.9 \mathrm{~cm}$, estreitofusiforme, marrom; SEMENTE 5 × $1 \mathrm{~mm}$, elipsoidal, marrom; COMA BASAL ca. $6 \mathrm{~mm}$, alvacento; COMA APICAL ca. 14 mm, fimbriado, alvacento. Fig. 26 A-G. 
DISTRIBUIÇÃO, ECOLOGIA E CONSERVAÇÃO. Alcantarea longibracteata é conhecida apenas de duas coleções, ambas da localidade típica, no município de Águia Branca, porção noroeste do Espírito Santo. Ocorre em locais abertos e também entre ilhas de vegetação arbustiva, entre 170-600 m.s.m. (Leme et al.2008). Não há registros da espécie em unidades de conservação. Tendo em vista a pequena área de ocorrência, a espécie pode estar ameaçada. No presente trabalho o táxon não foi coletado e considera-se que mais dados sobre a sua distribuição são necessários para se estabelecer seu estado de conservação. IUCN Red List Category: Data Deficient, DD.

FENOLOGIA. Coletada ao final da floração e com frutos maduros em abril.

ETIMOLOGIA. O epíteto-específico faz referência às longas e estreitas brácteas do pedúnculo.

DISCUSSÃO. Espécie bem caracterizada, sem problemas de delimitação, muito distinta das demais pelas longas brácteas do pedúnculo, que bem justificam a escolha do nome. Também se destaca pelo hábito pouco denso da roseta e da inflorescência. A espécie foi descrita como sendo próxima à $A$. odorata, da qual difere por apresentar menor número de folhas, verdes lustrosas (vs. albo-cerosas), brácteas do pedúnculo muito mais longas que os entrenós e também lustrosas (vs. albo-cerosas), ramos da inflorescência em menor número e brácteas florais maiores (Leme et al. 2008). Outras caracterísitcas que chamam atenção neste táxon é a ocorrência de uma ramificação de segunda ordem na inflorescência (Demuner 2267), caracterísitca rara, observada apenas para $A$. odorata e $A$. naboumii.

MATERIAL EXAMINADO: Brazil. EsPíRITO SANTO: Águia Branca, Santa Luzia, propriedade de Ciro Ferreira, 27 Mar 2006, Demuner et al. 2267 (MBML). Ibidem, 26 Abr 2008, Leme et al. 7346 (MBML, RB).

13. Alcantarea martinelli Versieux \& Wand., Brittonia, No prelo.-Tipo: Brasil. Rio de Janerio: Petrópolis, Malta, posto de fruticultura do governo, 15 Nov 1968, P. I. S. Braga 1558 \& R. Braga 47 (holótipo RB!; isótipo SP!).

RUPÍCOLA, ca. $1 \mathrm{~m}$ alt., curto-caulescente. ROSETA infundibuliforme, fitotelma desenvolvido. FOLHAS ca. 40, polísticas; BAINHA 13-17 x 6.5-11 cm, elíptica a oblonga, marrom-escura passando ao castanho-claro, densamente marrom-lepidota em ambas as faces in sicco, coriácea, margens membranáceas e involutas; LÂMINA 30-40 x 2.5-4 cm, estreito-triangular, glauca com manchas vermelho-vinho em ambas as faces, densamente marrom-lepidota abaxialmente, glabra a esparsamente lepidota em direção ao ápice adaxialmente, subereta, coriácea, com algumas nervuras proeminentes, margens revolutas in sicco; ÁPICE DA LÂMINA agudo, verde passando ao verde- 
arroxeado, com mucro levemente torcido, rígido, ca. $1 \mathrm{~cm}$. PEDÚNCULO ereto, reto, esguio, ca. $75 \mathrm{x}$ $0.5 \mathrm{~cm}$, quase circular em secção transversal, verde, glabro, distintamente nervado, sulcado; entrenós ca. $3 \mathrm{~cm}$; BRÁCTEAS as proximais: subfoliáceas, polísticas; as medianas e distais: ovais, ápice caudado a acuminado, 2.2-5.2 x 1.6-2.1 cm, verdes, glabras a esparsamente lepidotas em direção ao ápice abaxialmente, densamente marrom-lepidotas adaxialmente, eretas, imbricadas, o terço basal envolvendo firmemente o pedúnculo e com as margens sobrepondo-se, distintamente nervadas, cartáceas; margens hialino-amareladas, membranáceas in sicco. INFLORESCÊNCIA ca. 19 × $8 \mathrm{~cm}$ (excluindo as pétalas), espiga, de contorno elíptico a estreito-triangular, 18-20(-31)-florida, ereta; RÁQUILA ca. 20 × 0.4 cm, flexuosa a quase reta, quase quadrangular em secção transversal, glabra; entrenós 0.8(distal)-2.5(proximal) x ca. $0.4 \mathrm{~cm}$, verdes; BRÁCTEA FLORAL ca. 2.5 x $2.5 \mathrm{~cm}$, orbicular, ápice obtuso, mucronulado, verde na porção central e vermelho-vinho em direção ao ápice, glabra abaxialmente, marrom-lepidota adaxialmente, envolvendo parcialmente e mais curta que o cálice, finamente nervada, coriácea, ecarinada; margens hialino-amareladas, membranáceas. FLORES dísticas, patentes a suberetas na antese; SÉPALAS ca. 2.5 x $1.4 \mathrm{~cm}$, elípticas a levemente obovais, ápice obtuso e inconspicuamente emarginado, simétricas ou quase, ultrapassando as brácteas florais em 5-7 mm, verdes a verde-arroxeadas em direção ao ápice, glabras abaxialmente, densamente marrom-lepidotas adaxialmente, coriáceas, ecarinadas; margens hialino-amareladas, mebranáceas in sicco; PÉTALAS 5.8-6.3 x 0.8-1 cm, liguladas, ápice obtuso, amarelas, inconspicuamente maculada de branco, fortemente recurvada para trás até a metade do compr. e se espiralando em direção ao ápice; APÊNDICES PETALÍNEOS ca. 21 x 2 mm, 2, lineares, adnatos à pétala longitudinalmente por ca. $15 \mathrm{~mm}$, ápices triangulares, assimétricos, sobrepondo-se e escondendo a base do filete antepétalo; ESTAMES polísticos; FILETE 57 × $1.4 \mathrm{~mm}$, complanado, branco; ANTERA ca. 10 x $1 \mathrm{~mm}$, linear, amarela, dorsifixa próximo à base; ESTILETE ca. 62 x $1 \mathrm{~mm}$, cilíndrico, branco; LOBOS DO ESTIGMA ca. 3 × $1 \mathrm{~mm}$, polísticos, brancos; OVÁRIO ca. 7 × $3 \mathrm{~mm}$, estreitamente ovóide, verdealvacento, hipanto ca. $7 \mathrm{~mm}$; ÓVULOS ca. $1.6 \mathrm{~mm}$, numerosos. CÁPSULA ca. 3.5 x $1 \mathrm{~cm}$, elipsóideacuminada, marrom-escura; SEMENTE ca. 6 × $1 \mathrm{~mm}$, estreito-elíptica, marrom-escura; COMA BASAL ca. $7 \mathrm{~mm}$, fimbriado, bege; COMA APICAL ca. $11 \mathrm{~mm}$, fimbriado, marrom-claro. Figs. 27, $28 \mathrm{~A}$.

DISTRIBUIÇÃO, ECOLOGIA E CONSERVAÇÃO. Alcantarea martinellii só é conhecida de dois inselbergs, entre 1000-1300 m.s.m., em Petrópolis, serra dos Órgãos. É relatado o crescimento de Utricularia nelumbifolia Gardn. (Lentibulariaceae) associada às rosetas. A distribuição geográfica do táxon é bastante restrita e documentada por coleções antigas. Foi re-encontrada na pedra do Oratório recentemente (Fig. 28 A). Apesar do local onde ocorre ser acessível somente através de escalada, a população da pedra do Oratório sofre com pastoreio de caprinos que chegam a se alimentar das rosetas jovens (Miguel D’Ávila de Moraes, com. pes.). Além deste problema, nota-se que o entorno 
da localidade típica está totalmente urbanizado e desmatado. Em razão de sua restrita área de ocorrência, estimada em menos de $100 \mathrm{~km}^{2}$, pequeno tamanho da população e provável declínio na qualidade de seu habitat, A. martinellii pode ser considerada ameaçada de extinção, entretanto caso novas populações sejam encontradas dentro de áreas protegidas tal categoria deverá ser revista. Ocorre dentro da APA Petrópolis e há um material em cultivo no Jardim Botânico do Rio de Janeiro. IUCN Red List Category: Endangered, EN B2 a, b(iii).

FENOLOGIA. Floresce em novembro. Frutifica em setembro.

ETIMOLOGIA. O epíteto-específico homenageia o Botânico Dr. Gustavo Martinelli (RB) especialista em Bromeliaceae e pioneiro na pesquisa dos inselbergs brasileiros.

DISCUSSÃO. Alcantarea martinellii apresenta uma combinação de características pouco usual para o gênero, que inclui a inflorescência simples associada à roseta desenvolvida e que acumula uma quantidade considerável de água, e presença de pétalas relativamente curtas (ca. 6 vezes mais longas do que largas). A espécie apresenta parentescos incertos, mas pode ser diferenciada de outros dois táxons que também apresentam inflorescências simples: de $A$. benzingii separa-se por suas folhas estreito-triangulares, geralmente mais largas que $3 \mathrm{~cm}$ (vs. laminas sublineares, ca. $2.5 \mathrm{~cm}$ larg.) e por suas brácteas florais menores (ca. $2.5 \mathrm{~cm}$ vs. $5 \mathrm{~cm}$ ). De $A$. hatschbachii, táxon considerado presumivelmente extinto e sem registros recentes, a $A$. martinelli diferencia-se pelas folhas mais largas e forma da roseta, menor porte quando florida (até $1 \mathrm{~m}$ de alt. vs. acima de $1.4 \mathrm{~m}$ ) e inflorescências mais curtas (até $20 \mathrm{~cm}$ vs. mais de $30 \mathrm{~cm}$ ) e por apresentar pétalas com apêndices. O exemplar Reitz 7462 (HBR) também de Petrópolis, apresenta similaridades $\operatorname{com}$ A. martinellii, entretanto possui porte maior e inflorescência composta, sendo assim, sua identificação só poderá ser confirmada quando da coleta de novos exemplares com flores completas. A análise molecular (Cap. 2) indicou parentesco próximo à espécies da serra dos Órgãos, porém há pouco suporte estatístico. Entretanto, as brácteas do pedúnculo longas e caudadas demonstram certa semelhança com $A$. geniculata.

MATERIAL EXAMINADO: Brazil. Rio De JANEIRO: Petrópolis, Malta, posto de fruticultura do governo, 15 Nov 1968, Braga 1558 \& Braga 47 (RB, SP); Ibidem, II distrito, Araras, morro da Pedra do Oratório, 25 Set 1982, Martinelli 8753 (RB, SP); Ibidem, APA Petrópolis, Pedra do Oratório, Serra da Maria Comprida, 28 Jul 2008, Moraes \& Fernandez 164 (K, RB).

14. Alcantarea nahoumit (Leme) J.R. Grant, Trop. Subtrop. Pflanzenwelt 91: 13. 1995. Vriesea nahoumii Leme, J. Bromeliad Soc. 43(6): 244. 1993.-Tipo: BrasiL, Bahia, Milagres, Jan 1993, P. I. Nahoum \& L. C. Marigo s.n. (Holótipo: HB 73936!). 
RUPÍCOLA, 1.1-3.5 m alt., propagando-se por brotações axilares ou na base da roseta, Caule em geral desenvolvido, 40-60 × 4-8 cm, reptante. ROSETA 0.5-0.9 × 1.2-1.7 m, infundibuliforme, fitotelma desenvolvido. FOLHAS numerosas, sub-eretas; BAINHA 20-25 x 15-22 cm, largamente oval, alvacenta em ambas as faces, com mancha castanho-escura no centro abaxialmente in vivo, bege com a base marrom em ambas as faces in sicco, densamente marrom-lepidota abaxialmente, coríacea; margens membranáceas com máculas vermelho-vinosas; LÂMINA 50-60 x 8-9.5 cm, liguladaatenuada, verde-amarelada, concolor, densamente lepidota abaxialmente, de esparsamente lepidota a glabra adaxialmente, quase plana, coriácea, distintamente nervada com algumas nervuras proeminentes bem marcadas; ÁPICE DA LÂMINA agudo, verde, torcido, discretamente apiculado. PEDÚNCULO 70-130 x (0.8-)1.3-3.5 cm, ereto, reto, robusto, cilíndrico ou quase, vermelhorosado, glabro, distintamente nervado, sulcado; entrenós 4-6 cm (proximal) a 2.5-4 cm (distal); BRÁCTEAS as proximais: ca. 26 x $8 \mathrm{~cm}$, subfoliáceas, polísticas; distais: (5-)8-17(-23) x 4-6.5 cm, largo-ovais, ápice acuminado a longo-acuminado, apículo torcido, vermelho-rosadas passando a verdes com máculas vinosas ou totalmente vinosas abaxialmente, vermelhas adaxialmente, esparsamente lepidotas abaxialmente, glabras adaxialmente, polísticas, distintamente nervadas, coriáceas, margens com linha vermelho-vinosa de ca. 1 mm larg. INFLORESCÊNCIA (20-)60-90 x 60-80 cm (excluindo as pétalas), composta, em panícula de espigas com ramificações de até segunda ordem, elipsoidal a esferoidal; entrenós da raque 3-4 (proximal) a 2 (distal) cm; BRÁCTEA PRIMÁRIA (3.5-)5-8 x 2.8-4.5 (excluindo o apículo de ca. $3 \mathrm{~mm}$ ), largo-oval, apiculada, vermelhorosada, esparsamente lepidota abaxialmente, densamente marrom-lepidota adaxialmente, involuta, não excedendo a base estéril do pedúnculo lateral, distintamente nervada, coriácea; margens basais aladas e membranáceas; RAMOS DA INFLORESCÊNCIA (7-)14-20(-30), 10-17(-36)-floridos; PEDÚNCULOS LATERAIS 4.5-9(-11) cm compr., 4-8 $\mathrm{mm}$ diâm., cilíndricos a levemente achatados, sulcados, amarelos, avermelhados nas porções expostas ao sol, glabros; BRÁCTEAS ESTÉREIS ca. $3 \times 2 \mathrm{~cm}, 2$, raramente 1, elípticas, ápice agudo, verde-amareladas, glabras abaxialmente, densamente marrom-lepidotas adaxialmente, cartáceas, margens membranáceas, distintamente nervadas, carenadas; RÁQUILA $6-10(-45) \mathrm{cm}$, geniculada, divergindo até $20^{\circ}$, verdeamarelada, glabra; entrenós 1-2.1 x 0.4-0.7 cm; BRÁCTEA FLORAL 3.9-4.5 x (3.4-)4-4.3 cm, suborbicular a largo-oval, ápice arredondado, amarela, glabra abaxialmente, marrom-lepidota adaxialmente, envolvendo o cálice quase que em toda a sua extensão, nervado-rugosa in sicco, levemente carnosa, carenada próximo ao ápice; margens membranáceas, lisas, castanho-amareladas in sicco. FLORES inodoras, dísticas, patentes ou sub-eretas; SÉPALAS (3-)3.5-3.7 x (1.7-)2-2.2 cm, obovais, ápice obtuso, simétricas a levemente assimétricas, se igualando ou excedendo as brácteas florais em ca. $1 \mathrm{~cm}$, verde-amareladas, glabras abaxialmente, esparsamente lepidotas adaxialmente, carnosas, ecarinadas, margens membranáceas, lisas; PÉTALAS 6-7 x 0.8-1 cm, liguladas, ápice agudo 
a subobtuso, constritas ao redor do ápice das sépalas, levemente onduladas ao longo das margens na metade distal, amarelas com pontos brancos inconspícuos, eretas a levemente recurvadas na antese, com pequena calosidade longitudinal de ca. $9 \mathrm{~mm}$ acima dos apêndices; APÊNDICES PETALÍNEOS 12-18 x ca. $3 \mathrm{~mm}, 2$, ligulados, longitudinalmente adnatos à pétala por ca. $10 \mathrm{~mm}$, ápices obtuso, com a margem inconspicuamente denteada a apiculada, assimétricos; ESTAMES apresentados em feixe na antese; FILETE 48-62 x ca. 1 mm, complanado, branco; ANTERA 13-20 x ca. $2 \mathrm{~mm}$, linear-atenuada, amarela, dorsifixa próximo à base; ESTILETE 55-72 x ca. $2 \mathrm{~mm}$, sulcado, branco; LOBOS DO ESTIGMA ca. 3 × 1 mm, polísticos, brancos; OVÁRIO ca. 11 x 4 mm, estreito-ovoidal, branco, hipanto ca. $7 \mathrm{~mm}$; ÓVULOS ca. $2 \mathrm{~mm}$ compr., numerosos. CÁPSULA 3.55 x 0.8-1.2 cm, estreito-elíptica com ápice agudo e torcido, marrom; SEMENTE ca. 5 × $0.5 \mathrm{~mm}$, linear, marrom; COMA BASAL ca. 5 mm compr., fimbriado, alvacento; COMA APICAL ca. $11 \mathrm{~mm}$ compr., fimbriado, castanho-claro. Figs. 29, 30.

DISTRIBUIÇÃO, ECOLOGIA E CONSERVAÇÃO. O limite norte da área de ocorrência do gênero Alcantarea é estabelecido por A. nahoumii, única espécie registrada, até o momento, para a Região Nordeste, no estado da Bahia. Cresce como rupícola, heliófila, formando touceiras circulares em torno de uma planta-mãe, podendo atingir grandes dimensões (Fig. 30 B, D). Foi descrita de um material coletado em Milagres, mas também ocorre em grandes populações no município de Santa Terezinha (Serra da Jibóia, Fig. 30 A) e em Feira de Santana (Serra de São José) em inselbergs que são encraves de mata atlântica em área de caatinga. Ocorre, também, em áreas de campo rupestre no município de Caetité, na serra do Espinhaço. Há registro visual de indivíduos estéreis no Parque Nacional do Descobrimento que possivelmente correspondam à essa espécie. Apesar das populações serem grandes, sofrem com queimadas e com o extrativismo, sendo localmente comercializadas como ornamentais (Fig. 30 E). IUCN Red List Category: Vulnerable, VU B2 a, b (iii).

FENOLOGIA. Floresce entre novembro e março.

ETIMOLOGIA. O epíteto-específico faz referência ao coletor do typus, o Biólogo e cultivador de bromélias Pedro Nahoum.

DISCUSSÃO. Espécie extremamente variável quanto ao tamanho dos indivíduos dentro de uma mesma população. Os indivíduos maiores frequentemente apresentam uma ramificação de segunda ordem em alguns ramos basais (Fig. 30 F), característica até então desconhecida para o gênero que também é registrada pela primeira vez para $A$. longibracteata e $A$. odorata no presente trabalho. Além disso, outro caráter que chama a atenção na espécie é a calosidade presente nas pétalas, logo acima dos apêndices petalíneos. A coloração verde-amarelada, lustrosa, bastante homogênea das folhas (Fig. 
30 A, D) contrasta com o vermelho das brácteas do pedúnculo e com o amarelo intenso das brácteas florais e das pétalas, que são relativamente curtas para o gênero. As brácteas dos botões florais distais são densamente imbricadas (Fig. 30 C) e assim se mantêm mesmo após a herborização. Em análise com microssatélites (Cap. 2), A. nanboumii surge próxima a $A$. glazionana (veja comentário da última). Também apresenta afinidades $\operatorname{com} A$. aff. burle-marxii (Versieux 421), especialmente no que se refere a forma e dimensão da roseta e das folhas. A espécie também parece ser muito próxima da recém descrita A. vasconcelosiana, entretanto difere pelo maior porte e inflorescência menos congesta e tamanho das brácteas primárias.

MATERIAL EXAMINADO: Brazil. BAHIA: Caetité, morro com antenas de Microondas de TV, 25 May 1985, Noblick 3752 (HUEFS, RB). Castro Alves, serra da Jibóia = serra da Pioneira, 8 Dec 1992, Queiroz et al. 2933 (HUEFS, K). Feira de Santana, Maria Quitéria, 8 Mar 2003, van den Berg et al. 895 (HUEFS, SP). Itatim, Morro do Leão, 26 Oct 1996, França et al. 1994 (HUEFS, SP). Santa Teresinha, serra de São José, 1 Mar 1985, Noblick \& Lemos 3547 (HUEFS). Ibidem, serra da Pioneira, 14 Nov 1986, Queiroz et al. 1096 (HUEFS); Ibidem, pedra Branca, 7 Jun 1998, Faria \& Holenwerger 56 (HRB); Ibidem, serra da Jibóia, 24 Feb 2000, Jardim et al. 2817 (HRB, HUEFS, NY, SPF); Ibidem, serra da Jibóia, 6 Feb 2007, Versieux \& Calvente 415, 416, 417, 418 (SP).

15. Alcantarea nevaresit Leme, Bromélia 2(3): 15. 1995.-Tipo: Brasil. Rio de Janeiro: Teresópolis, próximo à Nova Friburgo, Três Picos, Set 1994, E. M. C. Leme 2227, P. Nahoum \& H. Cintra, florida em cultivo em Dez 1994 (holótipo: HB!).

RUPÍCOLA, 1.3-2.2 m alt., cespitosa, propagando-se por brotações basais, curto-caulescente. ROSETA ca. 1.6 × 1.2 m, infundibuliforme, fitotelma desenvolvido; FOLHAS numerosas, suberetas a eretas; BAINHA 12-15 x 8-9.5 cm, largamente oval a elíptica, enegrescida passando a marromescuro abaxialmente, castanho-clara passando a verde-alvacenta adaxialmente, densamente marromlepidota em ambas as faces, coriácea, margens membranáceas; LÂMINA (40-)45-60(-90) x (5.5-)6$6.5 \mathrm{~cm}$, sublinear a triangular, verde concolor, densamente marrom-lepidota abaxialmente, glabra em direção ao ápice adaxialmente, plana, coriácea, com várias nervuras proeminentes; margens coriáceas, involutas in sicco; ÁPICE DA LÂMINA agudo, longo atenuado, verde, reto. PEDÚNCULO (50-)100-120 x 1-1.5 cm, ereto, reto ou levemente tortuoso, robusto, cilíndrico, verde sob as brácteas, verde-vinoso ou vinoso nas porções expostas, glabro ou com poucas escamas brancas esparsas, distintamente nervado, sulcado; entrenós (5-)6.5-7.5(-8) cm; BRÁCTEAS as proximais: subfoliáceas; as distais: (8-)12-27(-41) x (2.5-)3-3.5 cm, estreito-triangulares, ápice agudo, longoatenuado, base elíptica ou oval, vermelhas a verdes em direção ao ápice, densamente marromlepidotas abaxialmente, glabras a esparsamente lepidotas adaxialmente, polísticas, involutas, 
acumulando água na base, distintamente nervadas, cartáceas; margens vermelho-vinosas, coriáceas. INFLORESCÊNCIA 0.5-1 x 0.15-0.2 m (excluindo as pétalas), composta, em panícula de espigas, de contorno estreito-elíptico a oval, entrenós da raque 1.5-3.5(-5) x 2-3 cm; BRÁCTEA PRIMÁRIA 5.5-12(-32) x 2-2.7 cm, elíptica a largamente oval, ápice agudo, caudado, base vermelho-escura passando a verde-clara abaxialmente, verde-escura adaxialmente, densamente marrom lepidota abaxialmente, glabra a esparsamente lepidota adaxialmente, incurvada, canaliculada, envolvendo e excedendo o pedúnculo lateral sem os bordos se tocarem, distintamente nervada, cartácea, com as margens membranáceas; RAMOS DA INFLORESCÊNCIA 10-20(-30), com (7-)9-13-floridos, separadas por 1.5-2.5 (proximais) a 0.6-1 cm (distais); PEDÚNCULOS LATERAIS 7-11 x $0.5 \mathrm{~cm}$, elípticos em seção transversal, complanados, encurvados, verde-avermelhados, marrom in sicco, glabros, sulcados; BRÁCTEAS ESTÉREIS 3-3.5 x $1.5 \mathrm{~cm}, 0-2$, elípticas, ápice agudo, mucronado, torcido, verdes a verde-vinosas, densamente marrom-lepidotas em ambas as faces, adpressas ao pedúnculo e imbricadas, carenadas, cartáceas com o centro coriáceo; margens hialino-amareladas ou translúcidas, membranáceas in sicco; RÁQUILA 5-7(-10) cm, levemente geniculada a quase reta, quase quadrangular em seção transversal, sulcada e nervada, verde ou verde-vinosa, glabra; entrenós 0.61(distal)-1.5-2.5(proximal) x 0.4 cm; BRÁCTEA FLORAL (3-)3.5-3.8 x 1.8-2.2 cm, oval a lanceolada, ápice agudo, as distais com ápice levemente curvo e inflado, glabra abaxialmente, densamente marrom-lepidota adaxialmente, envolvendo completamente o cálice, com o 1/3 basal das margens se tocando, verde com máculas vinosas passando a amareladas, simétrica, carnosa no centro, carenada; margens finas e flexíveis. FLORES inodoras, dísticas; SÉPALAS 2.5-3.5 x 1-1.5 cm, elípticas a obovada, ápice agudo, excedendo as brácteas florais por $6 \mathrm{~mm}$, livres, simétricas ou quase, esparsamente lepidotas abaxialmente, distintamente marrom-lepidotas adaxialmente, verdes, concolores, inconspicuamente carenadas no 1/3 distal; margens membranáceas e hialino-amareladas in sicco; PÉTALAS liguladas com ápice arredondado, amarelas, 6-7 x $0.8 \mathrm{~cm}$, livres, simétricas, fortemente recurvadas para trás e espiraladas na antese; APÊNDICES PETALÍNEOS 1-1.8 cm x ca. $3 \mathrm{~mm}, 2$, elípticos, longitudinalmente adnatos às pétalas por ca. $10 \mathrm{~mm}$, ápice assimétrico, arredondado; ESTAMES livres, apresentados em feixe; FILETE ca. $5 \mathrm{~cm} \times 1 \mathrm{~mm}$, complanado, ondulado na 1/2 distal, branco; ANTERA ca. 10 × $1.3 \mathrm{~mm}$, sagitada, dorsifixas próximo da base; ESTILETE ca. $5 \mathrm{~cm}$ × $1 \mathrm{~mm}$, cilíndrico, branco; LOBOS DO ESTIGMA ca. 2 x $1 \mathrm{~mm}$, brancos, espiralados; OVÁRIO ca. 5 × $1.6 \mathrm{~mm}$, estreitamente ovóide; ÓVULOS ca. $1 \mathrm{~mm}$, numerosos. CÁPSULA 2.8-3.4 × 0.8-1 cm, ovóide, com ápice agudo, castanho-clara a marrom, dísticas; SEMENTE ca. 7 × $1 \mathrm{~mm}$, elípsoidal, marrom; COMA BASAL ca. $6 \mathrm{~mm}$, bege; COMA APICAL ca. $8 \mathrm{~mm}$, bege. Figs. 28 B, C, 31.

DISTRIBUIÇÃO, ECOLOGIA E CONSERVAÇÃO. Alcantarea nevaresii cresce como heliófila, formando touceiras nas fendas das rochas, 900-1200 m.s.m., em Nova Friburgo e Teresópolis (RJ). As 
populações podem ser simpátricas com $A$. imperialis e ocorrem em afloramentos próximos às áreas de florestas e também áreas de campos de altitude. A espécie está protegida no Parque Estadual dos Três Picos e na Reserva Ecológica de Macaé de Cima. IUCN Red List Category: Least Concern, LC.

FENOLOGIA. Floresce de Outubro à Janeiro, com pico em Dezembro. Frutos coletados em Abril.

ETIMOLOGIA. Alcantarea nevaresii homenageia o coletor do typus, o colecionador de bromélias e um dos fundadores da Sociedade Brasileira de Bromélias, Luiz Felipe Nevares de Carvalho, do Rio de Janeiro.

DISCUSSÃO. De acordo com Leme (1995) Alcantarea nevaresii é uma espécie muito próxima de $A$. geniculata, da qual difere pela roseta mais estreita, folhas menores, ramos da inflorescência mais curtos, pedúnculos laterais sem brácteas estéreis e pelas brácteas florais ovais mais estreitas. Porém, todos os exemplares aqui analisados, com exceção do tipo, apresentavam brácteas estéreis nos pedúnculos laterais, ou apenas nos ramos proximais da inflorescência (Costa 377), sendo essa característica inconsistente na diferenciação dessas duas espécies. Alcantarea nevaresii necessita ser melhor caracterizada, conforme foi evidenciado na elaboração da chave para o gênero, visto que a maior parte dos caracteres se sobrepõe aos de $A$. geniculata. É possível que estudos futuros indiquem a necessidade de se reposicionar $A$. nevaresii em uma subespécie de $A$. geniculata. O hábito cespitoso e as rosetas menores são, entretanto, características marcantes que induzem a manutenção das duas espécies. No campo, é comum observar folhas com áreas necrosadas, paleáceas e elípticas. No material seco, a textura áspera das folhas e das brácteas, com nervuras salientes bem justapostas, é uma característica auxiliar na identificação da espécie. $\mathrm{Na}$ análise de microssatélites $A$. nevaresii surge próxima de $A$. brasiliana (aqui tratada como um novo sinônimo de $A$. imperialis) e também de $A$. geniculata. Da primeira difere por apresentar flores dísticas (vs. secundas).

MATERIAL EXAMINADO: Brazil. RIO DE JANEIRO: Nova Friburgo, Reserva Ecológica de Macaé de Cima, 16 Apr 1991, Costa et al. 372 (RB); Ibidem, Reserva Ecológica de Macaé de Cima, 15 Apr 1991, Costa et al. 377 (RB); Ibidem, Reserva Ecológica de Macaé de Cima, 16 Dec 1992, Costa \& Pugialli 437 (RB, SP); Ibidem, Macaé de Cima, 20 Nov 2005, Versieux et al. 223 (SP). Teresópolis, próximo a Nova Friburgo, Três Picos, Oct 1993, Leme et al. 2227 (HB).

16. Alcantarea Nigripetala Leme \& L. Kollmann, J. Bromeliad Soc. 58(5): 211. 2008.-Tipo: Brasil. Minas Gerais: Nova Belém, road Santa Luzia do Córrego Azul to Nova Belém, 18²9'86’S, 4107'43'W, 613 m, 28 Apr 2008, E. M. C. Leme 7381, L. Kollmann, A. P. Fontana, O. Ribeiro \& M. Zanoni (holótipo: RB!; isótipo MBML!). 
RUPÍCOLA, 1.6-2.5 m alt., curto caulescente. ROSETA ca. 90 x $110 \mathrm{~cm}$, infundibuliforme, fitotelma desenvolvido. FOLHAS ca. 20, suberetas; BAINHA 12-22(-25) x 8-11(-16) cm, oval, verde-clara a bege in vivo, cor de palha a castanho escura abaxialmente, cor de palha alvacenta in sicco, densamente marrom-lepidota em ambas as faces, cartácea a coriácea; margens membranáceas, hialino-alvacentas in sicco; LÂMINA 46-65(-75) x 4.5-6.5 cm, ligulada, verde, concolor, glabrescente em ambas as faces, levemente canaliculada, coriácea, suberetas, distintamente nervada; margens verdes; ÁPICE DA LÂMINA agudo, verde, reto, encurvado ou torcido, apiculado por ca. $10 \mathrm{~mm}$. PEDÚNCULO ca. $130 \times 1$ (distal) a 1.7 (proximal) $\mathrm{cm}$, ereto, reto, cilíndrico, verde, glabro, distintamente nervado, entrenós 5-7.5 cm; BRÁCTEAS proximais: 20-40 x $4.5 \mathrm{~cm}$, subfoliáceas, suberetas; medianas e distais: $5.5-8 \times 1-2 \mathrm{~cm}$, ovais ápice acuminado, verdes em ambas as faces, passando a paleáceas, esparsamente lepidotas em ambas as faces, encurvado-patentes em direção ao ápice, justapostas ao pedúnculo, sem acumular água na base, finamente nervadas, cartácea, margens verdes. INFLORESCÊNCIA ca. 64-105 x 30-60 cm, composta, em panícula de espigas, elipsoidal a ovoidal, ereta, entrenós da raque de 5-9 cm, levemente flexuosos; BRÁCTEA PRIMÁRIA 2.7-5 x 2-3.5 cm, oval a largo-oval, ápice obtuso-acuminado, verde passando a paleácea, densamente marrom-lepidota em direção ao ápice abaxialmente, glabra adaxialmente, involuta, muito mais curta que o pedúnculo lateral, finamente nervada, coriácea com as margens basais membranáceas; RAMOS DA INFLORESCÊNCIA 9-13, 5-13-floridos, botão terminal frequentemente pouco desenvolvido ou abortado; PEDÚNCULOS LATERAIS 3.5-11 x 0.4-0.6 cm, subcilíndricos, distintamente nervados, verdes, glabros; BRÁCTEAS ESTÉREIS 2.5-3 x 1.2-1.5 cm,0-2, elípticas, ápice agudo, verdes a paleáceas, densamente marrom-lepidotas em ambas as faces, remotas a pouco imbricadas, carenadas, cartáceas com o centro coriáceo; margens hialino-amareladas ou translúcidas, membranáceas in sicco; RÁQUILA 7-30 cm, geniculada (i.e. divergindo até $30^{\circ}$ para cada lado), verde, glabra; entrenós (0.9)1.8-3.5 x 0.2-0.4 cm; BRÁCTEA FLORAL (2-)2.5-3 x 1.8-2.7 cm, largo-oval a suborbicular, ápice obtuso, verde a vinosa passando a acastanhada, glabra abaxialmente, subdensamente marromlepidota adaxialmente, envolvendo parcialmente o cálice, finamente nervada nos bordos, porção central rugosa, coriácea, ecarinada ou pequena projeção distal inconspícua, margens membranáceas, hialino-amareladas in sicco. FLORES dísticas passando a secundas no pós antese, suberetas; SÉPALAS 2.6-3.5 x 1.2-1.6 cm, elípiticas a oboelípiticas, ápice obtuso, simétricas, excedendo as brácteas florais em ca. de $1.8 \mathrm{~cm}$, verdes a verde-amareladas ou verde-vinosas, glabras abaxialmente, subdensamente marrom-lepidotas adaxialmente, levemente carnosas, ecarinadas, margens membranáceas, hialinoamareladas in sicco; PÉTALAS ca. 10 x $0.8 \mathrm{~cm}$, liguladas, ápice obtuso, constritas ao redor do ápice das sépalas, vinoso-escuras a enegrescidas no botão; APÊNDICES PETALÍNEOS 27-30 x 2-3 mm, ligulados, longitudinalmente adnatos à pétala por ca. $23 \mathrm{~mm}$, ápice obtuso, assimétrico; FILETE 10 cm, cilíndrico, branco; ANTERA ca. 14 x 1 mm, linear com base sagitada, amarela, dorsifixa próximo 
à base; ESTILETE ca. $10 \mathrm{~cm}$, cilíndrico a levemente anguloso, branco; LOBOS DO ESTIGMA ca. 35 × $1 \mathrm{~mm}$, eretos, brancos, densamente papilosos; OVÁRIO ca. 10 × $5 \mathrm{~mm}$ (porção supera), levemente anguloso, verde-alvacento, hipanto ca. $6 \mathrm{~mm}$; ÓVULOS ca. $1.6 \mathrm{~mm}$, numerosos. CÁPSULA ca. 4 × $1.2 \mathrm{~cm}$, fusiforme, marrom; SEMENTE ca. 6 × $1 \mathrm{~mm}$, elipsoidal, marrom; COMA BASAL ca. $6 \mathrm{~mm}$, fimbriado, alvacento; COMA APICAL ca. $8 \mathrm{~mm}$, fimbriado, ferrugíneo. Figs. 26 H-Q, 28 D-E.

DISTRIBUIÇÃO, ECOLOGIA E CONSERVAÇÃO. Alcantarea nigripetala é conhecida para a região noroeste do ES divisa com MG. O tipo é originário do município de Nova Belém, porém a espécie já havia sido coletada nos arredores do município de Pancas, mais ao sul. Ocorre como heliófila em afloramentos rochosos próximos a áreas agrícolas, em torno de 600 m.s.m. Entre os materiais analisados, nenhum provém de unidade de conservação, porém por ser recém descrita e com área de distribuição não muito restrita, ainda é prematuro inclúi-la em qualquer categoria de ameaça. IUCN Red List Category: Data Deficient, DD.

FENOLOGIA. Coletada em final de floração em abril. Frutos coletados em agosto.

ETIMOLOGIA. Nigripetala faz referência às pétalas negras.

DISCUSSÃO. Alcantarea nigripetala foi descrita a partir de espécimes que se encontravam no final da floração. Sendo assim, não foi possível examinar flores completas aqui, apenas botões, os dados relativos às pétalas, androceu e gineceu foram obtidos da obra original (Leme et al. 2009). Como os autores não mostram na obra original flores completamente desenvolvidas, ainda há dúvidas se as pétalas maduras apresentam, de fato, a coloração negra ou se tornar-se-iam vinosas. Foi descrita como muito próxima à $A$. extensa. Entretanto, aparentemente parece ter grande afinidade, também, com $A$. burle-marxii e a $A$. vinicolor, em razão da forma, coloração e dimensões das brácteas do pedúnculo, dos ramos arqueados, da raque levemente flexuosa. É possível que os estames sejam polísticos, e que a pétala esmaeça com passar do tempo. Na população de Pancas, as folhas, brácteas e sépalas também assumem a coloração verde-vinosa. Apresenta no pós-antese flores e frutos secundos, o que facilita sua distinção de $A$. burle-marxii. Em geral, também apresenta o botão floral terminal abortado, como na última espécie.

MATERIAL EXAMINADO: Brazil. EsPírito SANTO: Pancas, distrito de Laginha de Pancas, 5 Aug 2006, Louzada et al. 22 (SP). MiNAS GERAIS: Nova Belém, road Santa Luzia do Córrego Azul to Nova Belém, 28 Apr 2008, Leme et al. 7381 (MBML, RB). Nova Belém, 28 Apr 2008, Fontana et al. 5117 (MBML). 
17. Alcantarea odorata (Leme) J. R. Grant, Trop. Subtrop. Pflanzenwelt 91: 13. 1995. Vriesea odorata Leme, Bradea 5: 175, t. 9. 1989.-TIPO: BRASIL. Rio de Janeiro: próximo a Raposo. E. M. C. Leme 262. Floresceu em cultivo em dezembro de 1989. (holótipo: HB!).

RUPÍCOLA, 2-2.5 m alt., propagando-se por brotações basais, curto caulescente. ROSETA 0.7-1 x 0.8-1.2 m, estreito infundibuliforme, fitotelma desenvolvido. FOLHAS numerosas, eretas a suberetas, marcescentes; BAINHA 14-21 x 9-12 cm, elíptica a estreito trapezoidal, bege em ambas as faces, densamente marrom-lepidota em ambas as faces, coriácea, margens membranáceas, paleáceas; LÂMINA 70-100 x (4.5-)5-7 cm, estreito triangular, glauca, com ou sem máculas vinosas abaxialmente, densamente lepidota abaxialmente, glabra adaxialmente, alvacento-cerosa em ambas as faces, reta a arqueada, coriácea, distintamente nervada, com nervuras proeminentes, margens com fina linha vinosa (< $1 \mathrm{~mm}$ larg.); ÁPICE DA LÂMINA agudo, atenuado a acuminado, verde, em geral reto, raramente encurvado ou torcido. PEDÚNCULO 90-110 x 1.6-2.2 cm, ereto, reto, robusto, cilíndrico a levemente sulcado, verde, glabro, distintamente nervado, entrenós 4-5.5 cm; BRÁCTEAS as proximais: subfoliáceas e suberetas; as medianas e distais: $20-30$ x ca. $2 \mathrm{~cm}$, estreito triangulares, ápice longo-atenuado, verdes a glaucas, com máculas vinosas na base, densamente marrom-lepidotas abaxialmente, glabras adaxialmente, suberetas a patente-encurvadas, levemente canaliculadas, distintamente nervadas, coriáceas, margens vinosas. INFLORESCÊNCIA 40-140 x 26-70 cm, composta, em panícula de espigas, raramente com ramificações de segunda ordem, elipsoidal, ereta; entrenós da raque 3-6 cm; BRÁCTEA PRIMÁRIA (2.4-)9-32 x 1.5-2.5 cm, oval a largo-oval, ápice agudo, longo atenuado, de coloração igual à das brácteas do pedúnculo, densamente marrom-lepidota abaxialmente, cerosa e esparsamente lepidota adaxialmente, involuta, mais longa que a base estéril do pedúnculo lateral, distintamente nervada, coriácea; margens membranáceas; RAMOS DA INFLORESCÊNCIA 20-41, (4-)10-22-floridos, patentes a pêndulos; PEDÚNCULOS LATERAIS (2-)7-11 x 0.5-0.7 cm, elípticos em secção transversal, verdes, glabros; BRÁCTEAS ESTÉREIS (1-)2.2-3 x (0.6-)1.5-2.5 cm, 0-2, elípticas a largamente ovais, ápice agudo apiculado, verdeamareladas a amarelas, glabras abaxialmente, subdensamente lepidotas adaxialmente, suberetas, remotas a imbricadas, distintamente nervadas, carenadas, coriácea; margens hialino-amareladas, membranáceas in sicco; RÁQUILA (6-)20-30 cm, levemente geniculada, verde, glabra; entrenós 0.6-3 x 0.2-0.4 cm cm; BRÁCTEA FLORAL 2-3 x 1-2.8 cm, largo-oval a orbicular, ápice obtuso inconspicuamente inflado e mucronado, castanha com ápice e bordos amarelados in sicco, amareloesverdeadas in vivo, glabra abaxialmente, lepidota adaxialmente, envolvendo quase que completamente o cálice, subereta a patente, distintamente nervado-rugosa, coriácea, ecarinada ou com pequena carena apenas no ápice; margens membranáceas, hialino-amareladas in sicco. FLORES com odor adocicado, dísticas; SÉPALAS 2.8-3.5 x 1.8-2 cm, elípticas a obovais, ápice arredondado, simétricas 
ou quase, excedendo as brácteas florais em 1.2-2 cm, amarelas, glabras abaxialmente, subdensamente hialino-lepidotas adaxialmente, coriáceas, ecarinadas; margens membranáceas, hialino-amareladas in sicco; PÉTALAS 7.5-8.1 x 0.5-0.8 cm, liguladas, ápice agudo a subobtuso, constritas ao redor do ápice das sépalas, amarelas, fortemente recurvadas e murchando sem espiralar; APÊNDICES PETALÍNEOS 18-23 x ca. $3 \mathrm{~mm}, 2$, ligulados, porção distal mais dilatada, adnatos pela mediana à pétala por 15-20 mm; ápice agudo a arredondado; ESTAMES polísticos; FILETE 60-67 x 2 mm, levemente aplanado, branco; ANTERA 10-17 x $1 \mathrm{~mm}$, linear, amarela, dorsifixa próximo à base; ESTILETE 75-85 x 2-3 mm, cilíndrico, branco; LOBOS DO ESTIGMA ca. 3 x 1 mm, suberetos passando a patentes, brancos; OVÁRIO ca. $5 \mathrm{~mm}$ (porção ínfera), $7 \mathrm{~mm}$ (porção súpera) x $5 \mathrm{~mm}$, estreitamente ovóide, verde-alvacento na base a alvacento, hipanto ca. $7 \mathrm{~mm}$; ÓVULOS ca. $2.2 \mathrm{~mm}$, numerosos. CÁPSULA 3.5-4.2 × $1 \mathrm{~cm}$, estreito-fusiforme, castanho-clara; SEMENTE 5 x $1 \mathrm{~mm}$, elipsoidal, marrom; COMA BASAL ca. 4 mm, densamente piloso, alvacento; COMA APICAL ca. 12 mm, fimbriado, castanho-claro. Figs. 32, 33 A-C.

DISTRIBUIÇÃO, ECOLOGIA E CONSERVAÇÃO. Alcantarea odorata é conhecida para a região norte do RJ, onde fica o município de Raposo, localidade típica e leste de MG, dos municípios de Muriaé e Além Paraíba. Ocorre como heliófila em afloramentos rochosos em pastagens ou nas margens das estradas. Entre os materiais analisados, nenhum provém de unidade de conservação e as populações observadas não são muito grandes, entretanto apresenta grande área de ocorrência e é cultivada. IUCN Red List Category: Least Concern, LC.

FENOLOGIA. Floresce de dezembro a fevereiro. Frutos coletados em fevereiro.

ETIMOLOGIA. Odorata faz referência às flores de odor adocicado.

DISCUSSÃO. Leme (1989) ao descrever $A$. odorata, a considerou intimamente relacionada à $A$. geniculata e $A$. regina, das quais diferiria por apresentar menor tamanho da inflorescência, folhas e brácteas densamente cretáceas, entre outras características. A espécie apresenta lâminas e brácteas do pedúnculo longas e ápice agudo, densamente cerosas. Nas análises aqui apresentadas a espécie surge próxima de $A$. duarteana e também de $A$. heloisae. Observa-se entre os espécimes analisados uma grande variação nas dimensões das brácteas florais e demais peças do perianto. As coleções do município de Leopoldina (MG), próximo à divisa com Além Paraíba, apresentam maiores dimensões para os ramos da inflorescência e brácteas florais, quando comparadas ao typus.

MATERIAL EXAMINADO: Brazil. MINAS GERAIs: Além Paraíba, às margens da BR-116, 20 Feb 2002, Paula 2530 (VIC); Ibidem, afloramento rochoso às margens da BR-116, 12 Feb 2007, Versieux 
\& Calvente 433 (SP). Leopoldina, serra de Leopoldina, 6 Dec 1972, Duarte 14058 (HBR, RB, SP); Ibidem, BR-116, 18 Jan 1995, Hatschbach \& Silva 61610 (BHCB, C, MBM). Rio DE JANEIRO: Conceição de Macabú, estrada Conceição - Triunfo, 3 Feb 1996, Paula 1094 (VIC); Ibidem, estrada Conceição - Triunfo, 4 Feb 2002, Paula s.n. (VIC26351). Raposo, Jun 1982, Leme 262 (HB). Without exact locality, descida da serra de Muriaé, 26 Jan 1968, Duarte s.n. (HB48160, K, NY).

18. Alcantarea patriae Versieux \& Wand., Hoehnea 34(3): 409. t. 1-2, 2007.-Tipo: Brasil. Espírito Santo: Jerônimo Monteiro, Vila Cruzeiro, inselberg, 2047’46.6”S, 41²1’55.1”W, 136 m.s.m., 18 Jan 2007, L. M. Versieux 365, A. M. Calvente \& T. Trindade (holótipo: SP!; isótipos: BHCB!, HUEFS, MBML, R, SPF!).

RUPÍCOLA, 2-3.5 m alt., propagando-se por brotações basais, caulescente. ROSETA 1.5-1.7 x 1.6$2 \mathrm{~m}$, infundibuliforme, fitotelma muito desenvolvido. FOLHAS numerosas, suberetas, quase retas; BAINHA 30-43 x 15-21 cm, elíptica a largamente oval, pardacenta e com manchas, máculas e linhas oblíquas marrons abaxialmente, alvacenta ao longo da linha de inserção, passando ao castanho-claro adaxialmente in vivo, marrom-escuro passando ao castanho-claro abaxialmente, marrom-claro, concolor, adaxialmente in sicco, densamente marrom-lepidota em ambas as faces, coríacea; margens membranáceas, indistintamente maculadas de vinoso in vivo, fortemente involutas in sicco; LÂMINA (0.9-)1-1.2 m x 9-10 cm, linear a linear-lanceolada, verde concolor, com faixas transversais de cera esbranquiçada em ambas as faces, densamente marrom-lepidota abaxialmente, glabra adaxialmente, plana a levemente canaliculada, subereta, coriácea, distintamente nervada com algumas nervuras proeminentes; margens verdes, levemente revolutas in sicco; ÁPICE DA LÂMINA agudo, verde, torcido, rígido, discretamente apiculado por ca. $5 \mathrm{~mm}$. PEDÚNCULO 80-130 x 2.6-5 cm, ereto, reto, robusto, cilíndrico, verde-escuro amarronzado a verde-vinoso, glabro, distintamente nervado, entrenós 3.5-6.5 cm; BRÁCTEAS as proximais: subfoliáceas, verdes; as medianas e distais: ca. 35 x 6 $\mathrm{cm}$, ovais, ápice triangular-lanceolado, apículo torcido, vermelhas na base passando ao verde-claro, com placas de cera e densamente castanho-lepidotas abaxialmente, com máculas vinosas e esparsamente lepidota adaxialmente, imbricadas até $1 / 3$ do comprimento, encurvadas direção ao ápice, distintamente nervadas, coriáceas; margens revolutas in sicco. INFLORESCÊNCIA 45-100 x 25-50 cm, composta, em panícula de espigas, obovoidal a elipsoidal, entrenós da raque 2-5 x 1-3 cm; BRÁCTEA PRIMÁRIA 4-13.5 x 2.8-5.5, oval, ápice agudo, minutamente apiculado, torcido, verdeamarelada a amarela na base passando a alvacento-cerosa abaxialmente, vinosa adaxialmente, densamente marrom-lepidota em ambas as faces, involuta, encurvada, muito mais curtas que o pedúnculo lateral, distintamente nervada, coriácea; RAMOS DA INFLORESCÊNCIA 20-27, com 11-26(-32)-floridos, suberetos a eretos na antese; PEDÚNCULOS LATERAIS (4-)12-22 x 0.7-0.9 cm, cilíndricos, verdes, glabros, finamente nervados; BRÁCTEAS ESTÉREIS 3-3.8 x 1.5-2 cm, 2- 
4(-6), elípticas a oblongas, ápice acuminado, minutamente apiculadas, amarelas, com apículo vinoso, glabras abaxialmente, densamente marrom-lepidotas adaxialmente, adpressas ao pedúnculo, remotas, finamente nervadas, carenadas próximo ao ápice, coriáceas; margens membranáceas; RÁQUILA 25$50 \mathrm{~cm}$, de levemente geniculada a quase reta, quase quadrangular em seção transversal, glabra; entrenós (20-)30 x 7-8 mm, verde; BRÁCTEA FLORAL 3.5-4 x 4.5-5.3 cm, suborbicular, ápice obtuso minutamente apiculado, amarela, glabra abaxialmente, marrom-lepidota adaxialmente, envolvendo completamente o cálice, lisa e carnosa na porção central, nervada nas laterais e margens, ecarinada, mas com leve espessamento de $5 \mathrm{~mm}$ abaixo do apículo, margens membranáceas, hialinoamareladas in vivo. FLORES levemente odoríferas, dísticas, patentes a suberetas na antese; SÉPALAS 3.2-3.7 x 2.3-2.7 cm, obovais, ápice obtuso, simétricas ou quase, excedendo as brácteas florais em 10-15 mm, base verde-amarelada, amarelas em direção ao ápice, glabras abaxialmente, marromlepidotas, adaxialmente, carnosas, ecarinadas; margens membranáceas e amareladas in sicco; PÉTALAS 85-90 x 9-10 mm, lineares, constritas ao redor do ápice das sépalas, ápice arredondado, amarelas, com pequenos pontos alvos, voltadas para trás e pouco enroladas na antese; APÊNDICES PETALÍNEOS ca. 34 x 2 mm, 2, lineares, longitudinalmente adnatos à pétala por uma sutura carnosa de ca. 29 mm, ápices agudos, assimétricos; ESTAMES apresentados em feixe na antese; FILETE 7075 x 1.7 mm, cilíndrico, levemente complanado na 1/2 inferior, branco; ANTERA 16-18 x 1.4 mm, linear, amarela, dorsifixa próximo à base; ESTILETE ca. 85 × $2 \mathrm{~mm}$, arredondado levemente anguloso, branco; LOBOS DO ESTIGMA ca. 2.5 mm, convoluto-patentes, brancos; OVÁRIO ca. 15 x 3-4 mm, levemente hexagonal em seção transversal, com costelas inconspícuas nos vértices da porção súpera, verde, hipanto ca. $6 \mathrm{~mm}$; ÓVULOS ca. $3 \mathrm{~mm}$, numerosos. CÁPSULA e sementes desconhecidas. Figs. 33, 34.

DISTRIBUIÇÃO, ECOLOGIA E CONSERVAÇÃO. Alcantarea patriae cresce como heliófila, entre 120-400 m.s.m., em Jerônimo Monteiro, Espírito Santo, Brasil. Também ocorre em outros municípios do sul do ES, como Mimoso do Sul e Muqui (L. Kollmann, com. pes.). As características vegetativas dos exemplares Reitz 7751 (HBR) e Forzza 5219 (RB) indicam tratar-se também de $A$. patriae, o que estenderia a área de ocorrência ao norte fluminense, na ausência de flores, entretanto, essas identificações se mantêm duvidosas. Os indivíduos crescem, frequentemente, junto de Coleocephalocereus pluricostatus Buining \& Brederoo (Cactaceae). Suas populações são, em geral, muito grandes, com centenas de indivíduos e estão em paredões rochosos inacessíveis. Porém é importante considerar que vários afloramentos de granito da região vêm sendo destruídos para fins de mineração e que além disso, a espécie é explorada localmente para o cultivo em praças e jardins. IUCN Red List Category: Least Concern, LC.

FENOLOGIA. Coletada com flores em janeiro. 
ETIMOLOGIA. Alcantarea patriae (i.e., da pátria) recebeu este nome em razão das cores fortes e contrastantes observadas nos ramos da inflorescência. $O$ verde dos pedúnculos laterais e das ráquilas e o amarelo das brácteas, sépalas e pétalas, lembram as cores da bandeira do Brasil.

DISCUSSÃO. Alcantarea patriae chama a atenção pelo grande porte, bainha foliar, lâmina e roseta notoriamente maiores para o gênero, além da ampla inflorescência. $O$ táxon apresenta afinidade morfológica com $A$. odorata, da qual pode ser separado por apresentar brácteas primárias muito menores do que os pedúnculos laterais, pelo maior número de flores e também maior espaçamento entre essas. Além disso, a posição subereta ou ereta dos ramos da inflorescência na antese é um caráter muito marcante. A ráquila quase reta ou divergindo no máximo $5^{\circ}$ para um lado ou para o outro (Fig. 34 C, E) e a presença de faixas transversais de cera branca nas lâminas foliares e/ou na face abaxial das brácteas do pedúnculo proximais são características que auxiliam na distinção do táxon. $\mathrm{Na}$ análise com microssatélites (Cap. 2) a espécie aparece próxima a outros táxons do complexo A. extensa, entretanto a coloração amarela das brácteas florais é conspicuamente distinta. Em virtude de ocorrer entre as áreas que concentram $A$. extensa (sul do ES, leste de MG) e $A$. odorata (leste de MG, norte do RJ), uma hipótese de origem híbrida para essa espécie seria plausível.

MATERIAL EXAMINADO: Brazil. ESPÍRITO SANTO: Jerônimo Monteiro, Vila Cruzeiro, cultivada às margens da rodovia BR-482, 18 Jan 2007, Versieux et al. 364 (SP); Ibidem, Vila Cruzeiro, 18 Jan 2007, Versieux et al. 365 (BHCB, HUEFS, MBML, R, SP, SPF).

19. AlCantarea Regina (Vell.) Harms, in Engler \& Prantl. Nat. Pflanzenfam. ed. 2, 15a: 126. 1930. Tillandsia regina Vell., Fl. flum. 136. (1825)1829, Iconografia 3, t. 142. (1827)1831. Vriesea regina (Vell.) Beer, Bromel. 97. 1857.-TIPO: BRASIL. Rio de Janeiro: Pharmacopolis, nenhum espécime preservado. (lectótipo designado por Smith \& Downs, 1977: Fl. flum., Iconografia 3, t. 142. (1827)1831).

Alcantarea edmundoi (Leme) J.R. Grant, Bromélia 2(3): 26. 1996. Vriesea edmundoi Leme, Pabstia 4(3): 5, t. 4. 1993.-TIPO: BRASIL. Rio de Janeiro: proximidades de Angra dos Reis, afloramentos graníticos limítrofes ao mar, Feb 1982, I. A. Penna 21 (HB!).

RUPÍCOLA, 1.7-2.8 m. alt., propagando-se por brotações basais. ROSETA infundibuliforme. FOLHAS numerosas, suberetas; BAINHA 16-23 x 10-13 cm, alvacenta, tornando-se vermelhovinosa na face abaxial, oval, densamente lepidota; LÂMINA $67-135$ x 7-9(-10) cm, verde, concolor, coriácea, distintamente nervada com algumas nervuras proeminentes, lanceolada, ápice agudo longo- 
atenuado e geralmente voltado para baixo ou ligeiramente torcido, densamente lepidota abaxialmente, glabra adaxialmente. PEDÚNCULO $0.5-1 \mathrm{~m}, 4-5 \mathrm{~cm}$ diâm. na base, 3-4 cm diâm. no ápice, verde, ereto, ligeiramente sulcado, glabro; BRÁCTEAS 26-36 x 4-6 cm, triangulares, verdes, coriáceas, polísticas. INFLORESCÊNCIA (0.4)1.3-1.7 x (0.3)0.8-1.1 m, composta, em panícula de espigas, laxa, em geral coberta por fina camada de substância gordurosa e enegrecida, elipsóide a piramidal; entrenós da raque 2-7 cm, verdes; RAMOS (-)32-53, com (5-)10-15 flores espaçadas por 0.7-3(-5) $\mathrm{cm}$, arqueados, com botão floral terminal em geral abortado; PEDÚNCULO LATERAL (10-)18-30 x 0.4-0.9 cm, elíptico em seção transversal, verde, glabro, com 2-3(6) brácteas estéreis; RÁQUILA $18-35 \times 0.2-0.5 \mathrm{~cm}$, levemente geniculada, podendo se mostrar crenada no material herborizado, verde, glabra; BRÁCTEAS PRIMÁRIAS (3.5-)18-32(-37) x 2.5-4 cm, verdes, com escamas marrons na face abaxial, as proximais excedendo o pedúnculo e as distais menores, base oval, ápice caudado. BRÁCTEAS FLORAIS (1.9-)2.7-3.5 x (1.4-)2-3 cm, verdes, frequentemente secundas com as flores, raramente maculadas de vermelho-vinoso em direção ao ápice, cartáceas, igualando ou ligeiramente excedendo a metade do comprimento das sépalas, involutas mas não envolvendo completamente a flor, oval, ápice agudo e em geral levemente fendido, carenadas na porção distal. FLORES secundas; SÉPALAS (2.7-)3.5-4.2(-4.7) x (0.8-)1-1.6 cm, verdes, esparsamente lepidotas com escamas marrons em ambas as faces, cartáceas, simétricas ou quase, livres, elípticas a lanceoladas; PÉTALAS (8.5-)9.2-11 x (0.7-)0.9-1 cm, polísticas, amarelo-claro passando à alvacenta, reflexas, liguladas; APÊNDICES PETALÍNEOS $2.3-2.7$ x $0.3-0.4 \mathrm{~cm}, 2$, ligulados, levemente assimétricos, livres nos 7-9 mm distais; ESTAMES livres, polísticos; FILETES ca. $1 \mathrm{~mm}$ de diâm., levemente achatados na porção proximal e cilíndricos na distal, alvos; ANTERAS 12 x $1 \mathrm{~mm}$, sagitadas, dorsifixas próximo à base; OVÁRIO ca. 1 x $0.4 \mathrm{~cm}$, alvo, trígono-arredondado em seção transversal; ESTILETE ca. 9-10 × $0.2 \mathrm{~cm}$, cilíndrico, alvo; LOBOS DO ESTIGMA ca. de $3 \mathrm{~mm}$, alvos. CÁPSULA 3.5-5 x 0.8-1.2 cm, marrom, ovóide, acuminada, nervada, levemente torcida em direção ao ápice. SEMENTES ca. 6 × 1 mm, marroms, levemente onduladas e sulcadas; COMA BASAL ca. 7 mm, bege-hialino; COMA APICAL 1.6-1.9 cm, ferrugíneo. Figs. 35, 36 D-I.

DISTRIBUIÇÃO, ECOLOGIA E CONSERVAÇÃO. Espécie encontrada ao sul do Rio de Janeiro, litoral norte e baixada Santista em São Paulo e sudeste de Minas Gerais (Versieux \& Wanderley 2007). Ocorre restrita aos afloramentos rochosos desde o nível do mar até 1000 m.s.m. da Serra do Mar, podendo ser observada entre nos municípios de Itaguaí (RJ), limite oriental da distribuição, até São Vicente, na baixada Santista (limite meridional) e na serra da Mantiqueira em Minas Gerais (limite setentrional e ocidental). É importante ressaltar que durante este trabalho a espécie foi reencontrada em São Paulo, para onde sua ocorrência já era mencionada por Baker (1889), apesar de ser ignorada por autores subseqüentes. As flores apresentam antese noturna e são polinizadas por morcegos 
(Martinelli 1994). A distribuição ampla e a ocorrência em unidades de conservação conferem à espécie a categoria de baixo risco de extinção. IUCN Red List Category: Least Concern, LC.

FENOLOGIA. Coletada com flores entre novembro e fevereiro e com frutos entre fevereiro e abril.

ETIMOLOGIA. De acordo com Grant (1995c), regina é o termo latino referente à rainha e o epíteto homenageia D. Maria I de Portugal, que governou o império português de 1786 a 1816.

MATERIAL EXAMINADO: Brazil. MINAS GERAIS: Descoberto, Reserva Biológica da Represa do Grama, 3 Mar 2001, Forzza et al. 2080 (CESJ, MBM, SP). Lima Duarte, fazenda do rio do Salto, 22 Sep 2006, Forzza et al. 4305 (RB, SP); Ibidem, estrada para Parque Estadual do Ibitipoca, 14 Jan 2007, Versieux et al. 352 (SP). RiO DE JANEIRO: Angra dos Reis, próximo ao mar, Jan 1982, Penna 21 (HB). Mangaratiba, Reserva Ecológica Rio das Pedras, 20 Dec 1994, Vidal 13 (RB); Ibidem, rodovia RioSantos, 2 Jan 2006, Versieux \& Calvente 265 (SP); Ibidem, RPPN Rio das Pedras, 14 Apr 2006, Versieux $\&$ Calvente 270, 271 (SP); Ibidem, afloramento rochoso em frente ao Club Med, 6 Feb 2006, Versieux \& Calvente 267 (SP). U.S.A.: New Jersey, cultivated in the W.A. Manda Nursery, s.d., Merrill s.n. (NY). Parati, Paratimirim, 14 Jul 1987, Costa et al. 88 (RB). SÃo PAULO: Bertioga, Indaia, Apr 2001, Campacci s.n. (SP396342). Biritiba-Mirim, alto da serra do Mar, Jan 2003, Pinheiro \& Peixoto 189 (SP).

DISCUSSÃO. Alcantarea regina foi tratada por muito tempo como uma espécie duvidosa ou de circunscrição variável, visto não existir nenhum espécime tipo preservado ou coletas adicionais na área da localidade típica, e em razão da obra e ilustração originais (Vellozo 1929, 1931) serem pouco precisas. Na literatura, circunscrições amplas que incluem espécimes de diferentes regiões do estado do Rio de Janeiro foram adotadas por diversos autores (e.g., Mez 1894; Smith \& Downs 1977), o que por muito tempo impediu a correta identificação da espécie. Beer (1857) pronuncia-se sobre a espécie de Vellozo, da seguinte forma: "Diese pflanze ist nur ibrem Blüthenstande nach hier anzuführen. Da aber die Zeichnung vollständig unverständlich, auch keine Beschreibung vorhanden ist, begnüge ich mich damit, selbe nur namentlich anzuführen," "Esta planta foi posicionada aqui em razão de sua inflorescência. A ilustração é completamente incompreensível e também falta uma descrição. Esta aí o por quê de deixá-la aqui, apenas listando o seu nome." (tradução nossa). Morren \& Fonsny (1881), assim como Antoine (1884), tratam $V$. regina em uma ampla circunscrição, incluindo como sinônimos $V$. glaz̧ionana Lem. e $V$. geniculata Wawra. Nas coleções de herbários, permanece o uso incorreto desse nome para $A$. glaziouana (Lem.) Leme, que ocorre em ambientes semelhantes, mas com distribuição mais setentrional, restrita aos municípios do Rio de Janeiro e Niterói.

Apesar de simplificada, a ilustração de Vellozo (1831), que de acordo com Grant \& Zijlstra (1998) lectotipifica o gênero Alcantarea, retrata o ápice foliar ensiforme-acuminado voltado para baixo, 
a coloração diferenciada da bainha foliar e o tamanho das brácteas florais em relação ao das sépalas, características essas muito marcantes na espécie. Além disso, a dimensão indicada na obra original (culmus supra orgyalis i.e., colmo maior do que uma braça), a localidade típica (Pharmacopolis i.e., Parati, RJ) o habitat (cautibus maritimus i.e., penhascos marinhos), o formato dos apêndices e das anteras, o período de floração e a análise de materiais recém-coletados no mesmo habitat na região da localidade típica, justificam a proposta de sinonímia de Versieux \& Wanderley (2007b), que inclui A. edmundoi em A. regina.

Alcantarea regina apresenta afinidades morfológicas claras $\operatorname{com} A$. imperialis, como as brácteas florais carenadas e as flores secundas. Tal parentesco é sustentado pelas análises moleculares (Cap. 2). Uma característica marcante de $A$. regina é a coloração homogênea das lâminas, brácteas, pedúnculo e sépalas, que são predominantemente verdes. No entanto, podem ser observadas listras oblíquas e máculas vermelho-vinosas logo acima da bainha, na face abaxial da folha, ou pequenas manchas avermelhadas em direção ao ápice das brácteas florais e sépalas.

20. Alcantarea roberto-Kautskyi Leme, Harvard Pap. Bot. 4: 148. 1999.-Tipo: Brasil: Espírito Santo: Baixo Guandú, ca. 500 m altitude, W. Zoolawski \& E. Colnago floresceu em cultivo Mar 1997, Roberto Kautsky 1053 (holótipo HB!).

RUPÍCOLA, 1.6-3 m alt., monocárpica, caulescente. ROSETA ca. 1.6 x 1.2 m, infundibuliforme, muito densa, asumindo contorno arredondado. FOLHAS muito numerosas, polísticas; BAINHA 2532 x 16-21 cm, oval, marrom-escura e densamente marrom-lepidota em ambas as faces in vivo, lustrosa abaxialmente; margens castanho-claras amareladas e quebradiças em ambas as faces in sicco; LÂMINA (30-)35-50(-80) x (7-)9-10 cm, triangular, ápice agudo a acuminado, flexível, verde com máculas roxas em direção ao ápice a glauca, com faixas transversais albo-cerosas de 4-7 cm larg. em ambas as faces, densamente lepidota em toda a face abaxial, esparsamente lepitoda na base e subdensamente lepidota em direção ao ápice adaxialmente, plana, coriácea, com algumas nervuras proeminentes; margens com fina linha roxa. PEDÚNCULO (0.6)1-1.2 m x 4-5 cm diâm. na base, 3 cm diâm. no ápice, verde sob as brácteas, verde-vinoso ou vinho-escuro com espessa camada de cera branca nas porções expostas, glabro, distintamente nervado, sulcado, reto; entrenós 3-5 cm compr.; BRÁCTEAS as proximais: subfoliáceas; as distais: $2.2-5.5(-22) \times 3.5-5.5 \mathrm{~cm}$, triangulares, ápice agudo, esparsamente lepidotas abaxialmente, glabras adaxialmente, verdes, cerosas, polísticas, cartáceas, distintamente nervadas; margens com linha vinosa de $1 \mathrm{~mm}$ larg.; INFLORESCÊNCIA 1.1-1.6 x 0.7-1 m (excluindo as pétalas), composta, em panícula de espigas, elipsoidal a ovoidal; entrenós da raque 2-4 x 2-3 cm; RAMOS DA INFLORESCÊNCIA ca. 30, fastigiados, 10-22(-31)floridos; BRÁCTEA PRIMÁRIA 5-5.5 x 2.4-2.7, largamente oval a elíptica, ápice acuminado, marrom-lepidota abaxialmente, densamente marrom-lepidota adaxialmente, com as margens 
membranáceas, involuta, envolvendo o pedúnculo mas sem os bordos se tocarem, distintamente menores que o pedúnculo, simétrica, coriácea, levemente rugosa; PEDÚNCULOS LATERAIS (11-)16-30 x (0.5-)0.8-1.5(-2) cm, elípticos em seção transversal, achatados, sulcados, suberetopatentes, verde-oliva sob as brácteas, vinho-escuro nas porções expostas, glabros; RÁQUILA 14-30 x 0.3-0.6 cm, reta a levemente geniculada, sulcada e nervada, verde ou verde-vinosa; entrenós 1.5-2.5 (proximais) a 0.6-1 cm (distais); BRÁCTEAS ESTÉREIS 4.2-4.6 x 2-2.2 cm, (2)3-4(-6), lanceoladas, ápice agudo, mucronado, verde-claras quando jovens, passando ao verde-vinosas ou a cor de vinho-escuro, cobertas por cera branca e glabras abaxialmente, densamente marrom-lepidotas adaxialmente, involutas, adpressas ao pedúnculo, simétricas ou levemente assimétricas, coriáceas, finamente rugosas, carenadas; margens membranáceas; BRÁCTEA FLORAL 3-3.6(4.8) x 2.4-3(3.3) cm, oval, ápice obtuso, glabra abaxialmente, densamente marrom-lepidota adaxialmente, envolvendo o cálice, com o $1 / 3$ basal dos bordos se tocando, verde-oliva, marrom-clara com bordos amarelos in sicco, simétrica, rígida, rugosa, decurrente com a ráquila, ecarinada mas com leve linha negra espessada abaixo do ápice. FLORES inodoras, dísticas; SÉPALAS 3.4-3.7 x 1.6-2(2.5) cm, elípticas, ápice arredondado, excedendo as brácteas florais em 1.1-1.5 cm, livres, simétricas, glabras, base verde, verde-amareladas em direção ao ápice, ecarinadas, carnosas; margens membranáceas e amareladas in sicco; PÉTALAS 8.2-9 × 0.9-1 cm, liguladas, constritas ao redor do ápice das sépalas, levemente onduladas ao longo das margens na metade distal, amarelo-alvacentas, livres, simétricas, voltadas para trás na antese; APÊNDICES PETALÍNEOS $2.7-3 \mathrm{~cm}$ x ca. $2 \mathrm{~mm}$, ligulados, longitudinalmente adnatos às pétalas por ca. $2.3 \mathrm{~cm}$, ápice assimétrico ou agudo; ESTAMES livres, polísticos; FILETE ca. $7 \mathrm{~cm}$ x $1 \mathrm{~mm}$, complanado, branco; ANTERA ca. 16 × $2 \mathrm{~mm}$, linear-atenuada, dorsifixa na altura de 1/3 do compr.; ESTILETE 7.7-8.2 cm x ca. $2 \mathrm{~mm}$, cilíndrico-triangular, branco; LOBOS DO ESTIGMA 2-4 × $1 \mathrm{~mm}$, brancos, eretos, espiralados; OVÁRIO ca. 15 × 3-4 mm, estreitamente ovóide; ÓVULOS ca. $1 \mathrm{~mm}$, numerosos, com um apêndice elíptico no ápice, retritos à metade superior do ovário. CÁPSULA 4.5-5.5 x $1 \mathrm{~cm}$, estreito-elíptica com ápice agudo e torcido, marrom, dística; SEMENTE ca. 6 × $1 \mathrm{~mm}$, elípsoidal, marrom; COMA BASAL ca. $7 \mathrm{~mm}$, bege; COMA APICAL ca. $1 \mathrm{~cm}$, ferrugíneo. Figs. 37, 41 A-F.

DISTRIBUIÇÃO, ECOLOGIA E CONSERVAÇÃO. Apesar de acreditar-se inicialmente que $A$. roberto-kautskyi possuía distribuição restrita, constatou-se neste trabalho que a espécie é bem distribuída em toda a porção noroeste do ES e também no nordeste de Minas Gerais. Cresce como heliófila sobre paredões verticais, 300-900 ms.m., em Baixo Guandú, Pancas, Santa Teresa (ES) e em Almenara, Pedra Azul, Pedra Grande, Santa Maria do Salto (MG). Alcantarea roberto-kautskyi pode ser incluída no status de baixo risco em razão de sua ampla distribuição e ocorrência em áreas de difícil acesso, com populações muito grandes, com milhares de indivíduos. IUCN Red List Category: Least Concern, LC. 
FENOLOGIA. Floresce de Novembro à Fevereiro, com pico em Dezembro.

ETIMOLOGIA. Alcantarea roberto-kautskyi homenageia o coletor do typus, o colecionador de orquídeas e naturalista capixaba Roberto Anselmo Kautsky, de Domingos Martins.

DISCUSSÃO. Antes mesmo de ser descrita, A. roberto-kautskyi já podia ser observada com grande exuberância nos jardins do paisagista Roberto Burle Marx, que a introduziu em cultivo (Fleming 1996). A espécie não apresenta problemas de delimitação e é facilmente reconhecida, mesmo quando estéril, em razão da densa roseta de contorno quase arredondado, com folhas numerosas e polísticas (Fig. 41 A, B). O caule mostra-se bem desenvolvido e, em geral, fica coberto por bainhas velhas marcescentes. A inflorescência em formato de candelabro, com ramos fastigiados, as brácteas distais adpressas ao pedúnculo e menores do que os entrenós, a presença abundante de cera que pode revestir até as brácteas florais e as anteras versáteis são características também evidentes na espécie e que facilitam sua identificação. Ao descrever a espécie Leme (1999) destaca que o táxon não apresenta uma afinidade aparente com as espécies até então conhecidas no gênero e chama a atenção para as folhas numerosas densamente rosuladas, as flores densamente dispostas nos ramos e para os apêndices petalíneos com ápice truncado-crenulado. Observam-se pequenas variações no formato do ápice foliar, ora mais agudo, ora mais obtuso, e também nas dimensões de partes florais, no número de brácteas estéreis, e na quantidade e local de deposição da cera entre as diferentes populações. A inserção do filete na antera também parece variar um pouco, sendo que no exemplar aqui analisado com flores completas (Versieux 430), a antera é dorsifixa próximo ao $1 / 3$ basal, assumindo um aspecto versátil, enquanto nas demais espécies do gênero a inserção do filete é mais próxima da base. Uma pequena calosidade percebida logo acima dos apêndices petalíneos está presente nas pétalas da espécie e o grão de pólen também apresenta morfologia bastante característica. $\mathrm{Na}$ análise molecular (Cap. 2) a espécie é a primeira linhagem a se divergir dentro do gênero.

MATERIAL EXAMINADO: Brazil. ESPÍRITO SANTO: Baixo Guandú, Mar 1997, Kautsky et al. 1053 (HB). Santa Teresa, distrito de 25 de Julho, 29 Apr 2005, Fontana et al. 1405 (MBML). MiNAS GERAIS: Pedra Azul, pedra da Conceição, 7 Feb 2007, Versieux \& Calvente 419 (SP). Santa Maria do Salto, estrada para Talismã, 10 Feb 2007, Versieux \& Calvente 430 (SP). RiO DE JANEIRO: Rio de Janeiro, cultivated, 26 Nov 1978, Burle Marx 9 (HB).

21. Alcantarea Simplicisticha Leme \& A. P. Fontana, J. Bromeliad Soc. 58(5): 209. 2008.-TipO: BRASIL. Espírito Santo: Águia Branca, Santa Luzia, propriedade de Ciro Ferreira, Pedra da 
Bandeira, 1858'76”S, 40³9’93’W, 362 m, 26 Apr 2008, E. M. C. Leme 7355, L. Kollmann, A. P. Fontana, O. Ribeiro \& M. Zanoni (holótipo: RB!; isótipo MBML!).

RUPÍCOLA, ca. $2 \mathrm{~m}$ alt., curto-caulescente. ROSETA estreito infundibuliforme, fitotelma desenvolvido. FOLHAS ca. 10, suberetas; BAINHA 14-20 x (8.5-)11-13 cm, oval, castanho-escura a quase negra abaxialmente, castanho-clara adaxialmente, densamente marrom-lepidota em ambas as faces, coriácea, margens membranáceas, hialino-amareladas; LÂMINA 44 x 4.5-7 cm, ligulada, verde em ambas as faces, glabra, reta, coriácea, distintamente nervada, com nervuras proeminentes, margens verdes; ÁPICE DA LÂMINA obtuso-acuminado a agudo, verde com pequenas máculas vinosas, em geral encurvado para baixo. PEDÚNCULO 170 x (0.8-)1.5-2 cm, ereto, reto, cilíndrico a levemente sulcado, verde a vinoso nas áreas expostas, glabro, distintamente nervado; entrenós 5-9 cm; BRÁCTEAS proximais: 14-22 x 5-6 cm, subfoliáceas e suberetas; as medianas e distais: ca. 5 x 3 $\mathrm{cm}$, semelhantes às brácteas florais, ovais a elípticas, ápice acuminado, verdes, verde-vinosas a totalmente vinosas, levemente cerosas na face abaxial, glabras abaxialmente, subdensamente marromlepidotas adaxialmente, suberetas, involutas, as basais acumulando água na base, imbricadas passando a remotas, distintamente nervadas, coriáceas, margens membranáceas, hialino-amareladas. INFLORESCÊNCIA 0.7 x ca. 0.1 (excluindo as pétalas), espiga, de contorno elíptico, 30-47-florida, subereto-encurvada; RÁQUILA reta a pouco flexuosa, quase quadrangular em secção transversal, verde, glabra; entrenós 6-7 (proximal) a 2-3.5 (distal) x 0.4-0.6 cm; BRÁCTEA FLORAL ca. 4.6 x 4 $\mathrm{cm}$, largo oval, ápice obtuso, marrom-escura concolor no centro com bordos amarelados in sicco, glabra abaxialmente, marrom-lepidota adaxialmente, envolvendo parcialmente o cálice, subereta, rugosa no centro, nervada nos bordos in sicco, coriácea, ecarinada, margens membranáceas, hialino amareladas. FLORES dísticas; SÉPALAS 4-4.3 x 2-2.3 cm, oboelípticas, ápice obtuso, simétricas, excedendo em ca. $1.7 \mathrm{~cm}$ as brácteas florais, verdes com ápice verde-vinoso, glabras abaxialmente, subdensamente lepidotas adaxialmente, coriáceas, ecarinadas, margens membranáceas, hialinoamareladas in sicco; PÉTALAS 10-11 x $0.8 \mathrm{~cm}$, liguladas, ápice obtuso, constritas ao redor do ápice das sépalas, com máculas e pequenos traços vinosos na face abaxial, amarelas adaxialmente; APÊNDICES PETALÍNEOS ca. 35 x $2 \mathrm{~mm}$, ligulados, longitudinalmente adnatos à pétala, ca. $5 \mathrm{~mm}$ distais livres, ápice agudo; ESTAMES polísticos; FILETE ca. $11 \mathrm{~cm}$ x $2 \mathrm{~mm}$, cilíndrico, branco; ANTERA ca. 15 × $2 \mathrm{~mm}$, linear, amarela, dorsifixa próximo à base; ESTILETE 115 x $2 \mathrm{~mm}$, cilíndrico a levemente anguloso, branco; LOBOS DO ESTIGMA ca. 4 x $1 \mathrm{~mm}$, eretos passando a patentes, brancos; OVÁRIO 8-10 mm (porção supera) x 4 mm, estreitamente ovóide, hipanto ca. 10 mm; ÓVULOS ca. $2 \mathrm{~mm}$, numerosos. CÁPSULA 5-5.5 x 1-1.3 cm, ovóide, marrom-escura; SEMENTE ca. 6 × $1 \mathrm{~mm}$, fusiforme, marrom-escura quase negra; COMA BASAL ca. $7 \mathrm{~mm}$, alvacento; COMA APICAL ca. 13 mm, ferrugíneo. Fig. 26 R-Y. 
DISTRIBUIÇÃO, ECOLOGIA E CONSERVAÇÃO. Espécie conhecida apenas da localidade típica, no município de Águia Branca, porção noroeste do Espírito Santo. Ocorre em locais abertos e também entre ilhas de vegetação arbustiva, entre 180-360 m.s.m. (Leme et al. 2008). Não há registros da espécie em unidades de conservação. No presente trabalho o táxon não foi coletado e considera-se que mais dados sobre a sua distribuição são necessários para se estabelecer seu estado de conservação. IUCN Red List Category: Data Deficient, DD.

FENOLOGIA. Coletada em final de floração e com frutos em abril.

ETIMOLOGIA. O epíteto faz alusão à inflorescência simples.

DISCUSSÃO. A espécie foi descrita com sendo muito próxima à $A$. distractila, da qual diferiria por apresentar inflorescência simples (Leme et al. 2008). Entre outras características apontadas no protólogo da espécie que a diferenciam de $A$. distractila, encontra-se o maior número de flores. A espécie também aparenta ser muito próxima de $A$. extensa, mas com flores mais espaçadas e brácteas florais relativamente maiores. Também aparenta ter afinidades com $A$. trepida, entretanto pode ser diferenciada pela brácteas distais do pedúnculo justapostas ao entrenós (vs. brácteas suberetas e infladas na base), pelo pedúnculo com menor diâmetro (1--1.3 vs. $2.5--3 \mathrm{~cm})$, ráquila flexuosa a geniculada (vs. quase reta).

MATERIAL EXAMINADO: Brazil. EsPíRITO SANTO: Águia Branca, Santa Luzia, propr. Ciro Ferreira, 4 Apr 2007, Demuner et al. 3551 (MBML); Ibidem, Pedra da Bandeira, 26 Apr 2008, Kollmann et al. 10940 (MBML); Ibidem, 26 Apr 2008, Leme et al. 7355 (MBML).

22. Alcantarea tortuosa Versieux \& Wand., Brittonia 59(1): 61, t. 2, 2007.-Tipo: Brasil. Rio de Janeiro: Santa Maria Madalena, afloramento rochoso próximo ao pico da pedra do Desengano, 2153’59” S, 4154'40.2” W, 1.900 m.s.m., 25 Nov 2005, L. M. Versieux \& A. M. Calvente 240. (holótipo SP!).

RUPÍCOLA, 0.8-1.4 m alt., propagando-se por brotações axilares, curto caulescente. ROSETA ca. 40 x $22 \mathrm{~cm}$, funilforme, fitotelma medianamente desenvolvido; FOLHAS ca. 15, suberetas; BAINHA 12-17 x 9-11 cm, largamente oval, castanho-claro passando a verde-clara abaxialmente, alvacenta passando a verde-alvacenta adaxialmente, densamente marrom-lepidota em ambas as faces, coríacea; margens membranáceas, bege in sicco; LÂMINA 24-42 x 4.5-6 cm, linear-atenuada, verde concolor, lustrosa, densamente marrom-lepidota abaxialmente, glabra a esparsamente lepidota adaxialmente, levemente canaliculada, coriácea, distintamente nervada com algumas nervuras proeminentes; 
margens com fina linha (i.e., ca. $0.8 \mathrm{~mm}$ larg.) vinosa-escura; ÁPICE DA LÂMINA agudo a cuspidado, verde a verde-vinoso, recurvado. PEDÚNCULO 60-75 x 1.3-1.7 cm, ereto a subereto, reto a encurvado, flexível, cilíndrico, verde-claro sob as brácteas, vermelho-vinho escuro nas partes expostas, glabro, distintamente nervado, entrenós $4.5-7 \mathrm{~cm}$; BRÁCTEAS as proximais: subfoliáceas e eretas; as distais: 6-14 x 3-3.6 cm, ovais, ápice longo-atenuado e levemente recurvado, verdes maculadas de vermelho-vinoso ou totalmente vermelho-vinosas na base passando a verde maculado de vermelho em direção ao ápice, alvo-lepidotas em ambas as faces, polísticas, distintamente nervadas, cartáceas; margens com linha vermelho-vinosa de menos de $1 \mathrm{~mm}$ larg. INFLORESCÊNCIA 46-54 x 23-26 m, composta, em panícula de espigas, elipsoidal, entrenós da raque 3-4 cm; BRÁCTEA PRIMÁRIA 8-15 x 6-7 cm (excluindo o apículo de $3 \mathrm{~mm}$ ), largamente oval, apiculada, verde na porção central e vinosa no ápice ou totalmente vinosa, marrom-lepidota, involuta, mais curta que base estéril do pedúnculo lateral, distintamente nervada, coriácea; margens vinosas, membranáceas; RAMOS DA INFLORESCÊNCIA 4-12, 6-14-floridos, pêndulos a arqueados, retorcidos; PEDÚNCULOS LATERAIS $4-9$ x ca. $0.7 \mathrm{~cm}$, levemente achatados, sulcados, verdes, glabros; BRÁCTEAS ESTÉREIS 3-4.2 x 2.5-3.5 cm, 1-2, largo-ovais, ápice curtamente atenuado, verde-vinoso escuro, glabras abaxialmente, densamente marrom-lepidotas adaxialmente, coriáceas, distintamente nervadas, carenadas; margens membranáceas; RÁQUILA $18-27 \mathrm{~cm}$, geniculada, quase quadrangular em secção transversal, verde-oliva em direção ao ápice, glabra; entrenós 1-3.5 x $0.3 \mathrm{~cm}$; BRÁCTEA FLORAL 2.8-3.6 x 2.5-2.8 cm, largo-oval, ápice obtuso, verde na porção central, vinosa nos bordos, glabra e lustrosa abaxialmente, marrom-lepidota adaxialmente, envolvendo completamente o cálice, com os bordos se sobrepondo na porção mediana, finamente nervada, cartácea, ecarinada; margens membranáceas, hialino-amareladas. FLORES inodoras, dísticas, suberetas; SÉPALAS 3.5-3.8 x 1.2-1.8 cm, elípticas, ápice agudo, simétricas, igualando-se ou excedendo as brácteas florais em até $2 \mathrm{~mm}$, verdes, ecarinadas; margens membranáceas, hialinas; PÉTALAS 5.7-6 x 0.6-0.7 cm, liguladas, ápice agudo, amarelas, constritas ao redor do ápice das sépalas, fortemente recurvadas para trás e espiraladas na antese; APÊNDICES PETALÍNEOS 14-20 x 1-2 mm, ligulados, longitudinalmente adnatos à pétala por 11-16 mm, ápices obtusos; ESTAMES livres, em feixe passando a quase polísticos; FILETE 5.0-5.5 cm x ca. $1 \mathrm{~mm}$, levemente achatados na base a cilíndricos, branco; ANTERA 1.2-1.5 x ca. $1 \mathrm{~mm}$, sagitada, amarela, dorsifixa próximo à base; ESTILETE 75-77 x ca. $1 \mathrm{~mm}$, cilíndrico, branco; LOBOS DO ESTIGMA ca. 3 x $1 \mathrm{~mm}$, eretos a involuto-patentes, brancos; OVÁRIO ca. 11 x 4 mm, estreitamente ovóide, verde, hipanto ca. $5 \mathrm{~mm}$; ÓVULOS ca. 1.4 mm, numerosos. CÁPSULA e SEMENTE desconhecidos. Figs. 38, 41 G-M.

DISTRIBUIÇÃO, ECOLOGIA E CONSERVAÇÃO. Alcantarea tortuosa é heliófila e ocorre acima de 1200 m.s.m. juntamente com Alcantarea farneyi e Vellozia variegata Goeth. \& Henrard, próximo ao pico do inselberg principal do Parque Estadual do Desengano Santa Maria Madalena, Rio de Janeiro. Até o 
momento a espécie é endêmica desse município. Baseado em critérios da IUCN (IUCN 2001), $A$. tortuosa pode ser incluída no status de Vulnerável, em razão de sua restrita área de ocorrência e pelo provável declínio na qualidade de seu habitat, uma vez que cresce ao longo da trilha que leva ao pico do Desengano. IUCN Red List Category: Vulnerable, VU B1a, b(iii).

FENOLOGIA. Floresce entre novembro e janeiro.

ETIMOLOGIA. Alcantarea tortuosa recebeu este epíteto em razão do pedúnculo e ramos da inflorescência tortuosos.

DISCUSSÃO. Alcantarea tortuosa é muito próxima de A. farney, entretanto apresenta rosetas com fitotelma desenvolvido e inflorescência maior, sempre ramificada. Foram observados indivíduos com pedúnculo reto e ereto, enquanto que em outros o pedúnculo se mostra encurvado ou mesmo tortuoso. A espécie é diretamente relacionada à $A$. farneyi, sendo que no habitat adquirem a mesma coloração nas brácteas e apresentam uma morfologia floral muito semelhante. Uma possível origem híbrida para esse táxon não deve ser descartada sendo possíveis parentais $A$. farneyi, com a qual é simpátrica e $A$. heloisae, com ocorrência para a região, mas em menores altitudes. Tal hipótese merece ser melhor investigada com ferramentas moleculares no futuro. Entretanto, na localidade típica se observa uma população bem estabelecida do táxon em questão.

MATERIAL EXAMINADO: Brazil. Rio DE JANEIRO: Santa Maria Madalena, pico do Desengano, 25 Nov 2005, Versieux \& Calvente 240, 241 (SP).

23. Alcantarea trepida Versieux \& Wand., Rodriguésia, No prelo.-Tipo: Brasil. Espírito Santo: Baixo Guandú, inselberg em pastagem, 27 Jan 2007, 19²9'26.8'S 4050’37.4’W, 592 m.s.m., L. M. Versieux \& A. M. Calvente 396 (holótipo: SP; isótipo: RB).

RUPÍCOLA, (1.5-)2-4 m alt., propagando-se por brotações basais, caulescente. ROSETA 0.7-0.9 x 1-1.4 m, infundibuliforme, fitotelma desenvolvido. FOLHAS numerosas, suberetas, marcescentes; BAINHA 18-30 x 12-20 cm, oval a oblongo-elíptica, castanho-clara passando a castanho-escura abaxialmente, pardacenta adaxialmente in sicco, alvacenta a esverdeada in vivo, densamente lepidota em ambas as faces, coriácea; margens membranáceas, vinosas a hialino-vinosas; LÂMINA 40-68 x 7.5$11 \mathrm{~cm}$, ligulada, verde concolor, lustrosa, com ou sem máculas vinosas abaxialmente, subdensamente lepidota abaxialmente, de glabra a esparsamente lepidota em direção ao ápice adaxialmente, reta a levemente arqueada, coriácea, distintamente nervada, com nervuras proeminentes; margens com fina linha vinosa (< $1 \mathrm{~mm}$ larg.); ÁPICE DA LÂMINA agudo a subobtuso, acuminado, vinoso ou verde, 
em geral reto, algumas vezes torcido, raramente encurvado ou voltado para baixo. PEDÚNCULO 90-110 × 2-3 cm, ereto, reto, robusto, cilíndrico a levemente sulcado, verde sob as brácteas, vinoso nas áreas expostas, glabro, distintamente nervado; entrenós $3.5-7 \mathrm{~cm}$; BRÁCTEAS as proximais: subfoliáceas e suberetas; as medianas e distais: 4.5-10 x 3-6 cm, triangulares passando a ovais, ápice agudo, atenuado (nas proximais) ou acuminado (nas distais), verdes com máculas vinosas a totalmente vermelho-vinosas e cobertas por cera alvacenta em ambas as faces, esparsamente lepidotas na base passando a densamente lepidotas abaxialmente, densamente passando a esparsamente lepidotas em direção ao ápice adaxialmente, suberetas a patente-encurvadas, infladas na base, acumulando água, distintamente nervadas, coriáceas; margens vinosas. INFLORESCÊNCIA ca. 0.7 x $0.3 \mathrm{~m}$ mas aumentando conforme o desenvolvimento das ráquilas, composta, em panícula de espigas, raramente espiga simples de até $1,1 \mathrm{~m}$ compr, ca. $11 \mathrm{~cm}$ de larg. (excl. pétalas), elipsoidal, entrenós da raque 2-5 cm, ereta; BRÁCTEA PRIMÁRIA 2-5 x 4-6 cm, oval a largamente oval, ápice acuminado, de coloração igual às das brácteas do pedúnculo, esparsamente lepidota em ambas as faces, involuta, mais curta que a base estéril do pedúnculo lateral, distintamente nervada, coriácea, margens membranáceas; RAMOS DA INFLORESCÊNCIA 1-9, 8-56-floridos, suberetos a eretos; PEDÚNCULOS LATERAIS (8.5-)13-16 x (0.8-)1-1.2 cm, cilíndricos ou quase, verdes a verdevinosos nas porções expostas, glabros; BRÁCTEAS ESTÉREIS 3.8-4.4(5) x 3.2-4.1 cm, 3-4, orbiculares a largamente elíptica, ápice obtuso levemente uncinado, castanho-vinosas, opacas, cerosas, glabras abaxialmente, subdensamente lepidotas adaxialmente, suberetas, imbricadas ao menos próximo ao ápice, distintamente nervadas, sendo a porção central mais espessa e rugosa, ecarinadas, mas podendo apresentar uma protuberância próximo ao ápice, coriácea, margens hialino-amareladas in sicco, membranáceas; RÁQUILA (13-)40-70(-110) cm, reta, raramente levemente geniculada na porção distal, verde, glabra; entrenós (1.3-)2.5-5(-6) x (0.5-)1-1.3(-1.6) cm; BRÁCTEA FLORAL $3.8-4.8$ x 3.8-5.5 cm, orbicular a largo oval, ápice obtuso, levemente uncinado, castanho-clara concolor ou com uma faixa de ca. $7 \mathrm{~mm}$ de larg. amarelada ao longo do ápice e bordos in sicco, castanho-arroxeada no centro com bordos verdes ou totalmente verde vinosa in vivo, glabra a esparsamente lepidota em direção ao ápice abaxialmente, subdensamente a densamente marrom lepidota adaxialmente, envolvendo completamente o cálice, subereta a patente, distintamente nervado-rugosa no centro e finamente nervada nos bordos, coriácea, ecarinada; margens membranáceas, com fina linha $(<1 \mathrm{~mm})$ vinosa, hialino-amareladas in sicco. FLORES inodoras no pós-antese, dísticas, ca. $11 \mathrm{~cm}$ compr. (com pétalas esticadas); SÉPALAS ca. 4 x $2.3 \mathrm{~cm}$, largo-elípticas a levemente oboelípticas, ápice obtuso, simétricas ou quase, igualando-se ou pouco excedendo (ca. 5 $\mathrm{mm}$ ) as brácteas florais, verdes com ápice verde-vinoso, glabras a esparsamente lepidota em direção ao ápice abaxialmente, densamente marrom-lepidotas adaxialmente, cartáceas, ecarinadas; margens membranáceas, hialino-amareladas in sicco; PÉTALAS 8.7-9.7 x $1 \mathrm{~cm}$, liguladas, ápice obtuso, constritas ao redor do ápice das sépalas, amarelas com pequenas máculas e traços vinosos na face 
abaxial, passando ao amarelo-pálido no pós-antese, fortemente recurvadas e murchando sem espiralar; APÊNDICES PETALÍNEOS ca. 32 × $2 \mathrm{~mm}, 2$, ligulados, porção distal mais dilatada, longitudinalmente adnatos à pétala por ca. $25 \mathrm{~mm}$, ápices obtusos; ESTAMES polísticos; FILETE ca. $95 \times 1.5 \mathrm{~mm}$, levemente aplanado na base passando a quase cilíndrico, branco; ANTERA ca. 15 x 1 $\mathrm{mm}$, linear, amarela, dorsifixa próximo à base; ESTILETE ca. 90 × $2 \mathrm{~mm}$, cilíndrico a levemente anguloso, branco; LOBOS DO ESTIGMA ca. 3 × $1 \mathrm{~mm}$, suberetos passando a patentes, brancos; OVÁRIO ca. $9 \mathrm{~mm}$ (porção súpera) x $4 \mathrm{~mm}$, estreitamente ovóide, verde-alvacento na base a alvacento, hipanto ca. $9 \mathrm{~mm}$; ÓVULOS ca. $0.6 \mathrm{~mm}$, numerosos. CÁPSULA 4-5 x $1 \mathrm{~cm}$, estreitoelipsoidal com ápice agudo, marrom; SEMENTE 5 x $1 \mathrm{~mm}$, fusiforme, marrom; COMA BASAL ca. $6 \mathrm{~mm}$, densamente piloso, ferrugíneo; COMA APICAL ca. $14 \mathrm{~mm}$, fimbriado, ferrugíneo. Figs. 39, 41 N-Q.

DISTRIBUIÇÃO, ECOLOGIA E CONSERVAÇÃO. Alcantarea trepida é heliófila e ocorre entre 300-900 m.s.m. em afloramentos rochosos de grande inclinação e pequenos platôs nos municípios de Baixo Guandú, Itaguaçu e Nova Venécia, região centro-oeste do Espírito Santo, crescendo associada à A. roberto-kautskyi, Encholirium luxor e Orthophytum gurkenii. Observou-se a germinação das sementes ainda dentro das cápsulas (viviparidade). Observou-se a presença de ninhos de Hemípteros entres as brácteas da inflorescência. Esses insetos causam lesões de formato irregular (galhas) nos tecidos do pedúnculo lateral e ráquila. A espécie ocorre em unidades de conservação e forma extensas populações em locais de difícil acesso, logo não se encontra ameaçada de extinção. IUCN Red List Category: Least Concern, LC.

FENOLOGIA. Floresce de dezembro a maio. Frutos imaturos coletados em maio e cápsulas com sementes passadas e germinando coletadas em janeiro.

ETIMOLOGIA. Trepidus a, um, em latim significa assustado, assombrado, e aqui faz alusão metafórica aos ramos voltados para cima da inflorescência, que dão um aspecto "assustado" à inflorescência, que se mantem ereta até a frutificação.

DISCUSSÃO. Alcantarea trepida é uma espécie bem caracterizada pelos ramos muito longos e eretos da inflorescência, que assim se mantêm mesmo após a antese, e pelas ráquilas geralmente retas e relativamente grossas. Vegetativamente é muito similar à Alcantarea extensa e táxons relacionados, dentro do que foi definido por Versieux \& Wendt (2006) como "complexo Alcantarea extensa". A espécie é muito relacionada a $A$. extensa, entretanto parece ter havido pequenas taxas de fluxo gênico $\operatorname{com} A$. roberto-kaustyi ao longo de sua evolução, pois ocorrem em simpatria na localidade típica e observa-se, especialmente no formato dos ramos jovens túrgidos, com brácteas florais densamente 
imbricadas, pequena semelhança morfológica. Os ramos da inflorescência se mantêm eretos e voltados para cima, enquanto em $A$. extensa e $A$. vinicolor, os ramos são polísticos, patentes ou recurvados para baixo. Alcantarea trepida também difere de A. simplicisticha por apresentar inflorescência ereta, geralmente composta, brácteas distais do pedúnculo dilatadas na base, brácteas florais maiores e ráquila reta.

MATERIAL EXAMINADO: Brazil. EsPíRITO SANTO: Baixo Guandú, inselberg em pastagem, 27 Jan 2007, Versieux 394, 395, 396 (SP). Itaguaçu, Jatiboca, 28 May 1946, Brade et al. 18489 (RB); Ibidem, serra do Sobreiro, 23 Apr 2005, Fontana et al. 1389 (MBML). Nova Venécia, APA Pedra do Elefante, 18 Feb 2008, Forzza et al. 5072 (RB); Ibidem, Reserva Biológica Duas Bocas, Serra de Baixo, Pedra do Elefante, 19 Feb 2008, Fraga 1920 (RB), Ibidem, beira da rodovia Nova Venécia - São Gabriel da Palha, prop. do Sr. Valdemar, 09 May 2008, Fontana et al. 5241 (RB).

24. Alcantarea turgida Versieux \& Wand., Brittonia 59(1): 58. 2007.-Tipo: Brasil. Minas Gerais: Conceição do Mato Dentro, alto da cachoeira do Tabuleiro, 1908'58.7” S, 43³3’05.3” W, 22 Dez 2005, L. M. Versieux 260, P. L. Viana, N. Mota \& J. C. Almeida. (holótipo: SP!; isótipos: BHCB!, MBM, RB, SEL, SPF!, VIC).

Alcantarea lurida Leme, J. Bromeliad Soc. 58(1): 8, t. 5-6. 2008.-TIPO: BRASIL. Minas Gerais: Coronel Fabriciano em direção à Braúnas, ca. 400 m, 25 May 2000, E. M C. Leme \& B. R. Silva 4898, floresceu em cultivo em maio de 2007 (holótipo: RB!; isótipo: RB!). syn. nov.

RUPÍCOLA, 1,1-2.5 m alt., propagando-se por brotações basais, curto caulescente. ROSETA 0.6-1.5 x (0.7-)1.3-1.7 m, infundibuliforme, fitotelma desenvolvido. FOLHAS numerosas, arqueadas a suberetas; BAINHA 19-27 x 8-19 cm, largamente oval, castanho-escura passando a castanho-clara com linhas inclinadas vinoso-escuras em direção ao ápice abaxialmente, castanho-clara adaxialmente, densamente marrom-lepidota em ambas as faces, coríacea; margens coríacea, bege in sicco; LÂMINA 61-75 x 7.5-11 cm, linear longo-atenuada, verde a verde-vinosa, com fina linha de pontos vermelhovinosos ao longo das margens, maculada de vinoso em ambas as faces ou apenas abaxialmente, lepidota em ambas as faces, mas glabra em direção ao ápice adaxialmente, levemente canaliculada, coriácea, distintamente nervada com algumas nervuras proeminentes; margens coriáceas, castanhas; ÁPICE DA LÂMINA agudo a cuspidado, verde a verde-vinoso, recurvado, apículo torcido. PEDÚNCULO 80-120 x 2(distal)-4(proximal) cm, ereto, reto, robusto, cilíndrico, verde sob as brácteas, maculado de vermelho-vinoso nas partes expostas, glabra, distintamente nervado, sulcado; entrenós 3.5-6.5 cm; BRÁCTEAS as proximais: subfoliáceas, suberetas; as distais: 2.2-5.5(-22) x 3.5$5.5 \mathrm{~cm}$, largamente ovais, ápice longo-caudado, mucronado, verdes maculadas de vermelho-vinoso ou 
totalmente vermelho-vinosas na base passando a verde maculado de vermelho em direção ao ápice, lepidotas em ambas as faces, polísticas, distintamente nervadas, cartáceas; margens com linha vermelho-vinosa de menos de $1 \mathrm{~mm}$ larg. INFLORESCÊNCIA 0.6-1.3 x 0.7-1 m, composta, em panícula de espigas, ovoidal a piramidal, entrenós da raque 4-9 cm; BRÁCTEA PRIMÁRIA 8-15 x 6-7 cm (excluindo o apículo de $3 \mathrm{~mm}$ ), largamente oval, apiculada, verde na porção central e vinosa ao longo das margens e do ápice ou totalmente vinosa, marrom-lepidota, involuta, mais curta que base estéril do pedúnculo lateral, distintamente nervada, coriácea; margens vinosas, membranáceas; RAMOS DA INFLORESCÊNCIA 8-32, (3-)10-18-floridos, arqueados ou com a porção mediana patente e a terminal patente ou levemente ascendente; PEDÚNCULOS LATERAIS 9-22 x 0.6-0.7 cm, cilíndricos a levemente achatados, sulcados, verdes, glabros; BRÁCTEAS ESTÉREIS 3-3.7 x 3$3.2 \mathrm{~cm}, 1-3$, suborbiculares, ápice obtuso discretamente mucronado, verde-oliva, glabras abaxialmente, densamente marrom-lepidotas adaxialmente, coriáceas, distintamente nervadas, carenadas; margens membranáceas; RÁQUILA 18-27 cm, geniculada, quase quadrangular em seção transversal, verde-oliva em direção ao ápice, glabra; entrenós de 1-3.5 x $0.3 \mathrm{~cm}$; BRÁCTEA FLORAL 3.4-3.7 x 3.6-4(-4.4) cm, suborbicular, ápice obtuso discretamente mucronado, verde na porção central, vinosa nos bordos, glabra e lustrosa abaxialmente, marrom-lepidota adaxialmente, envolvendo completamente o cálice, com os bordos se tocando na porção mediana, nervado-rugosa, coriácea, carenada, margens membranáceas, hialino-amareladas. FLORES inodoras, dísticas, patentes ou suberetas; SÉPALAS 3.6-4(-4.4) x 1.4-1.8 cm, obovais, ápice agudo e minutamente apiculado, simétricas, excedendo as brácteas florais em ca. de $1 \mathrm{~cm}$, verdes a verde-amareladas, ápice geralmente vinoso, ecarinadas; margens membranáceas, hialinas; PÉTALAS 9-11 x 1-1.3 cm, liguladas, ápice agudo, levemente onduladas ao longo das margens na metade distal, amarelas passando à alvacentas, constritas ao redor do ápice das sépalas, polísiticas na antese; APÊNDICES PETALÍNEOS 34-37 x ca. $3 \mathrm{~mm}, 2$, ligulados, longitudinalmente adnatos à pétala por 29-31 mm, ápices agudos, assimétricos, se sobrepondo e ocultando o ovário quando visto de cima; ESTAMES polísticos na antese; FILETE 90-100 x ca. $2 \mathrm{~mm}$, cilíndricos, branco; ANTERA 12-16 x ca. $1 \mathrm{~mm}$, sagitada, amarela, dorsifixa próximo à base; ESTILETE 93-100 x ca. 2 mm, cilíndrico, branco; LOBOS DO ESTIGMA ca. 4 x 1 mm, patentes, brancos; OVÁRIO ca. 22 × 6 mm, estreitamente ovóide, verde, hipanto ca. $8 \mathrm{~mm}$; ÓVULOS ca. 1.6 mm, numerosos. CÁPSULA 5.3-6.2 x 1 cm, elipsóide, marrom; SEMENTE ca. 6 x $1 \mathrm{~mm}$, elipsoidal, marrom; COMA BASAL $7 \mathrm{~mm}$, alvacento; COMA APICAL $15 \mathrm{~mm}$, castanhoclaro. Figs. 40, 41 R-U.

DISTRIBUIÇÃO, ECOLOGIA E CONSERVAÇÃO. Alcantarea turgida cresce como heliófila ou semi-ciófila sobre rochas, entre 800-1200 m.s.m., em Minas Gerais, na bacia do rio Doce. Apresenta ocorrência em três diferentes unidades de conservação, com populações grandes em locais de difícil 
acesso, como os paredões verticais da cachoeira do Tabuleiro, na localidade típica. IUCN Red List Category: Least Concern, LC.

FENOLOGIA. Floresce de dezembro a fevereiro. Frutos coletados em abril.

ETIMOLOGIA. Alcantarea turgida recebeu este epíteto em razão das brácteas e botões florais do ápice dos ramos, que são túrgidos de mucilagem transparente e viscosa.

DISCUSSÃO. Alcantarea turgida foi descrita no decorrer desta revisão, sendo muito semelhante à Alcantarea extensa, da qual pode ser diferenciada pelas folhas verdes ou vinosas lustrosas, sem cera, além de apresentar pétalas amarelo-claras (vs. amarelo-vinosa) e infloresência geralmente piramidal e bilateralmente simétrica, apresentando habitat e distribuição geográfica mais interioranos. Alcantarea lurida Leme é incluída na sinonímia pois difere de $A$. turgida apenas pelas pétalas e apêndices petalíneos um pouco mais longos e por variações nas colorações de folhas e brácteas. Tais características são polimórficas mesmo na população típica de $A$. turgida, onde se observam indivíduos de folhagem e pedúnculo vermelho-vinoso ao lado de indivíduos totalmente verdes. Além disso, a proximidade geográfica entre as localidades típicas e e sobreposição, quase que total, das medidas apresentadas nos protólogos, justificam a proposta de sinonimização. Material recém obtido na localidade típica (Versieux 474) apresenta oito ramos na inflorescência, número menor do que aquele indicado na obra original.

MATERIAL EXAMINADO: Brazil. MINAS GERAIS: Conceição do Mato Dentro, alto da cachoeira do Tabuleiro, 22 Dec 2005, Versieux et al. 260 (SP). Itabira do Campo, Jun 1902, Matos s.n. (R46318). Santana do Riacho, Parque Nacional da Serra do Cipó, 6 Jan 2004, Versieux 157 (SP); Ibidem, Parque Nacional da Serra do Cipó, 11 Dec 2005, Wanderley et al. 2488 (SP); Ibidem, Parque Nacional da Serra do Cipó, 8 Oct 2006, Versieux et al. 300 (SP); Ibidem, 26 Apr 2009, Versieux et al. 474 (SP). São Gonçalo do Rio Abaixo, Estação Ambiental de Peti CEMIG, 23 Apr 2002, Lombardi et al. 4748 (BHCB, SP).

25. Alcantarea vasconcelosiana Leme, J. Bromeliad Soc. 59(1): 20. 2009.-TiPO: Brasil. Minas Gerais, Itabirinha de Mantena, Serra do Pitengo, Pedra da Baleia, ca. 1,000 m.s.m. 20 Nov 2008, R. Vasconcelos Leitão s. n., cult. E. Leme 7650 (holótipo e isótipo: RB!).

RUPÍCOLA, 0.6-0.9 m alt. ROSETA ca. 0.4 x $0.8 \mathrm{~m}$, estreito-infundibuliforme, fitotelma desenvolvido. FOLHAS ca. 25, suberetas; BAINHA $12 \times 14 \mathrm{~cm}$, subcircular, castanho escura a quase negra abaxialmente, castanho adaxialmente, densamente marrom-lepidota em ambas as superfícies, 
coríacea; margens membranáceas, bege; LÂMINA ca. 24 × $8.5 \mathrm{~cm}$, triangular, verde, concolor, densamente marrom lepidota abaxialmente, de esparsamente lepidota a glabra adaxialmente, quase plana, coriácea, distintamente nervada com poucas nervuras proeminentes bem marcadas; ÁPICE DA LÂMINA agudo, verde ou paleáceo nas folhas mais velhas, torcido, discretamente apiculado. PEDÚNCULO $40 \times$ (0.8-)1.3-3.5 cm, ereto, reto, delicado, cilíndrico ou quase, vermelho-rosado, glabro, distintamente nervado, liso; entrenós $3-3.5 \mathrm{~cm}$; BRÁCTEAS as proximais: ca. $10 \mathrm{x} 4 \mathrm{~cm}$, ovais com ápice acuminado, eretas; distais: ca. $5.5-\mathrm{x} 3.5 \mathrm{~cm}$, ovais, ápice acuminado, curtamente apículado torcido, vermelhas abaxialmente e adaxialmente, esparsamente marrom-lepidotas em ambas as superfícies, suberetas, finamente nervadas, cartáceas, margens hialino-amareladas. INFLORESCÊNCIA ca. 20 × $13 \mathrm{~cm}$ (excluindo as pétalas), composta, panícula de espigas, elipsoidal a obovoidal; entrenós da raque 2-3.5 cm; BRÁCTEA PRIMÁRIA 4.2-5.4 x 3-3.5 cm, oval, apiculada, vermelho-rosada, esparsamente marrom-lepidotas em ambas as superfícies, involuta, excedendo a base estéril do pedúnculo lateral, finamente nervada, cartácea; margens cartáceas; RAMOS DA INFLORESCÊNCIA 7, 7-8-floridos; PEDÚNCULOS LATERAIS 3-3.5 cm compr., ca. $4 \mathrm{~mm}$ diâm., cilíndricos a levemente achatados, sulcados, amarelo-avermelhados, glabros; BRÁCTEAS ESTÉREIS 2.5-3 x $1.5 \mathrm{~cm}, 1$, elíptica, ápice agudo, verde-amareladas, glabras abaxialmente, esparsamente marrom-lepidotas adaxialmente, cartáceas, margens membranáceas, finamente nervadas, ecarinadas ou com carena fina e assimétrica; RÁQUILA 3-4.5 cm, geniculada, divergindo até $20^{\circ}$, verde-amarelada a vermelho-vinosa, glabra; entrenós $0.5-1$ x $0.4 \mathrm{~cm}$; BRÁCTEA FLORAL 2.5-3.2 x $2.8 \mathrm{~cm}$, oval, navicular em vista frontal, ápice agudo, frequentemente se rompendo (emarginado), verde-amarelada a amarela, glabra abaxialmente, esparsamente marromlepidota adaxialmente, envolvendo parcialmente o cálice sem os seus bordos se tocarem, finamente nervada in sicco, membranácea, carenada nos $2 / 3$ distais; margens membranáceas, lisas frequentemente vinosas in vivo. FLORES inodoras, dísticas, sub-eretas; SÉPALAS 3.5-3.7 x $1.1 \mathrm{~cm}$, obolongas a oboelípticas, ápice obtuso, simétricas a levemente assimétricas, se igualando ou excedendo as brácteas florais em ca. $1 \mathrm{~cm}$, verde-amareladas, glabras abaxialmente, esparsamente lepidotas adaxialmente, membranáceas, ecarinadas, margens membranáceas, lisas; PÉTALAS 5-7(-8) x $0.8 \mathrm{~cm}$, ligulada a levemente oboelípticas, ápice arredondado, inconspicuamente cuculado, constritas ao redor do ápice das sépalas, amarelas, fortemente recurvadas na antese e pouco espiraladas; APENNDICES PETALÍNEOS ca. 22 x ca. $3 \mathrm{~mm}, 2$, ligulados, longitudinalmente adnatos à pétala por ca. $19 \mathrm{~mm}$, ápices agudo a obtuso, com a margem inconspicuamente denteada a apiculada, assimétricos; ESTAMES apresentados em feixe na antese e muito mais curtos que o gineceu; FILETE ca. 30 x 1 mm, complanado, branco; ANTERA 9 x ca. $1 \mathrm{~mm}$, linear, amarela, dorsifixa próximo à base; ESTILETE 65 x ca. $2 \mathrm{~mm}$, sulcado, branco; LOBOS DO ESTIGMA ca. 1 x $1 \mathrm{~mm}$, suberetoencurvados, brancos; OVÁRIO ca. 8 x 4 mm, estreito-ovoidal, branco, hipanto ca. $5 \mathrm{~mm}$; ÓVULOS não vistos. CÁPSULA ca. 4.2 x $1.2 \mathrm{~cm}$, marrom, ovóide, acuminada, nervada. SEMENTES ca. 6 × 1 
$\mathrm{mm}$, marroms, levemente onduladas e sulcadas; COMA BASAL ca. $6 \mathrm{~mm}$, bege-hialino; COMA APICAL ca. $0.8 \mathrm{~cm}$, bege. Figs. 19 B-C, 42, 43.

DISTRIBUIÇÃO, ECOLOGIA E CONSERVAÇÃO. Alcantarea vasconcelosiana é heliófila, endêmica de Minas Gerais, e ocorre entre 1000-1800 m.s.m. em afloramentos rochosos de campos de altitudes na área entre a localidade típica, no município de Itabirinha de Mantena ao norte, até o município de Araponga, ca. de $270 \mathrm{~km}$ a sudoeste. A espécie forma touceiras densas e vinha sendo identificada como A. nahoumii. Está protegida no Parque Estadual da Serra do Brigadeiro. IUCN Red List Category: Least Concern, LC.

FENOLOGIA. Floresce em novembro. Frutifica em janeiro.

ETIMOLOGIA. Homenageia o coletor do typus, o orquidólogo e conservacionista Reginaldo Vasconcelos Leitão, de Minas Gerais.

DISCUSSÃO. Espécie de médio porte, não ultrapassando $1 \mathrm{~m}$ de altura quando florida. É bem caracterizada pela porção vegetativa, especialmente pelas folhas de bainha larga contrastando o com o comprimento relativamente curto da lâmina foliar. A inflorescência chama atenção pelos ramos pequenos e adensados, com brácteas florais praticamente ocultando os entrenós da ráquila (Fig. 43 A). No habitat, geralmente o ápice das folhas seca. A espécie foi descrita como sendo relacionada à A. nevaresii (Leme 2009). Entretanto, também parece ser próxima de Alcantarea naboumii, da qual pode ser diferenciada pela bráctea do pedúnculo distintamente apiculada, bráctea primária que excede a base estéril do pedúnculo lateral e pelo o ápice das pétalas que são arredondados. Leme (2009) menciona medidas para as pétalas acima de $8 \mathrm{~cm}$, entretanto, no holótipo, as medidas com material re-hidratado não ultrapassaram $6.8 \mathrm{~cm}$ e todas as pétalas observadas eram menores que os gineceu.

MATERIAL EXAMINADO. Brazil. MinAs GERAIS: Alto Caparaó, cultivated at the Parque Nacional do Caparaó, 16 Jan 2007, Versieux et al. 363 (SP). Araponga, Parque Estadual da Serra do Brigadeiro, região do Pico do Soares, Lage do Ouro, Dec 1999, Paula s.n. (VIC 25415). Carangola, APA da Torre, 8 Dec 2001, L.S. Leoni 4808 (GFJP). Itabirinha de Mantena, Serra do Pitengo, Pedra da Baleia, 20 Nov 2008, R. Vasconcelos Leitão s. n., cult. E. Leme 7650 (RB).

26. Alcantarea vinicolor (E. Pereira \& Reitz) J.R. Grant, Trop. Subtrop. Pflanzenwelt 91: 14 (1995). Vriesea vinicolor E. Pereira \& R. Reitz, Bradea 1(39): 387. 1974.-TIPO: BRASIL. Espírito Santo: Vargem Alta, cult. J. Botânico do Rio de Janeiro, 23 Ago 1973, A. P. Duarte \& R. Reitž 7535 (holótipo: HB!, foto do holótipo US!) 
RUPÍCOLA, 1.6-2.1 m alt., propagando-se por brotações axilares, curto-caulescente. ROSETA 0.40.7 x 0.6-1.5 m, infundibuliforme, fitotelma desenvolvido. FOLHAS numerosas, suberetas; BAINHA 12-21 x 14-17 cm, largo-oval, marrom escura, quase negra abaxialmente, castanha adaxialmente, densamente marrom-lepidota em ambas as faces, coriácea, margens membranáceas, hialinoamareladas; LÂMINA 30-60 × 6-10 cm, ligulada, verde a vinosa, com ou sem máculas e linhas obliquas vinosas abaxialmente, verde concolor, verde-vinosa a cor-de-vinho concolor adaxialmente, lustrosa, subdensamente lepidota entre as nervuras abaxialmente, de glabra a esparsamente lepidota em direção ao ápice adaxialmente, reta a levemente arqueada, coriácea, distintamente nervada, com nervuras proeminentes, margens com fina linha vinosa ( $<1 \mathrm{~mm}$ larg.); ÁPICE DA LÂMINA acuminado, vinoso ou verde, em geral reto, raramente torcido. PEDÚNCULO (54-)80-115 x (1.5-)2-2.5 cm, ereto, reto, cilíndrico a levemente sulcado, verde-oliva escuro a vinoso, com pequenas pontuações albas, distintamente nervado; entrenós 2.5-4 cm (proximais) 5-6 cm (distais); BRÁCTEAS proximais: 8-12 x 3-6 cm, subfoliáceas e suberetas; as medianas e distais: $5-7$ × 2.5-4 cm, largo-ovais, ápice caudado a acuminado, totalmente vermelho-vinosas a castanho-escuras com bordos castanho-alaranjados, esparsamente lepidotas em ambas as faces, suberetas a eretas com ápice patente, distintamente nervadas, coriáceas; margens membranáceas, hialino-amareladas. INFLORESCÊNCIA 0.6-0.9(-1.3) x 0.3-0.5 m, composta, em panícula de espigas, elipsoidal a obovoidal, ereta; entrenós da raque ca. 7 cm; BRÁCTEA PRIMÁRIA 2.2-5 x 2.5-3.4(-4.5) cm, largo-oval, ápice obtuso a acuminado, inconspicuamente mucronado por ca. $2 \mathrm{~mm}$, de coloração igual à das brácteas do pedúnculo, castanho-escura no centro e castanho-clara amarelada nas bordas in sicco, glabra abaxialmente, densamente lepidota na base adaxialmente, involuta, patente a subereta, muito mais curta que a base estéril do pedúnculo lateral, distintamente nervada, coriácea, margens hialinoamareladas, membranáceas in sicco; RAMOS DA INFLORESCÊNCIA (4-)6-17, 8-16-floridos, suberetos, arqueados na frutificação; PEDÚNCULOS LATERAIS 8-12 x 0.6-0.9 cm, levemente complanados, verde-oliva escuro a verde-vinoso, glabros a inconspicuamente lepidotos; BRÁCTEAS ESTÉREIS $2.2-3 \times 2.2-2.5 \mathrm{~cm}, 2$ raramente 1, largo-oval, ápice obtuso, castanho-vinosas bordos amarelados, cerosas, glabras abaxialmente, subdensamente lepidotas adaxialmente, remotas, distintamente nervadas, sendo a porção central mais espessa e rugosa, carenadas em quase toda a extensão, coriácea; margens hialino-amareladas, membranáceas in sicco; RÁQUILA $10-25 \mathrm{~cm}$, geniculada em até $30^{\circ}$, verde-oliva escuro a vinosa, glabra ou com pequenas pontuações alvacentas; entrenós 0.8-3.2 x 0.4-0.6 cm; BRÁCTEA FLORAL 2-3.2 x 2.2-3.5 cm, largo oval a suborbicular, ápice obtuso, castanho-lustrosa concolor no centro com ápice e bordos bege in sicco, vinosa in vivo, glabra abaxialmente, subdensamente marrom-lepidota adaxialmente, envolvendo parcialmente o cálice, subereta, distintamente nervado-rugosa principalmente nos bordos, coriácea, ecarinada; 
margens membranáceas, hialino amareladas ou paleáceas. FLORES dísticas, antese noturna; SÉPALAS 2.9-3.3 x 1.4-2 cm, elíptica a oboelíptica, ápice obtuso, simétricas, excedendo em 1-2.5 cm as brácteas florais, verdes com ápice verde-vinoso, glabras abaxialmente, subdensamente marromlepidotas adaxialmente, coriáceas, ecarinadas; margens membranáceas, hialino-amareladas in sicco; PÉTALAS 8-9.2 x $1 \mathrm{~cm}$, liguladas, ápice obtuso, constritas ao redor do ápice das sépalas, com máculas e pequenos traços vinosos na face abaxial, amarelas adaxialmente, fortemente recurvadas e murchando sem espiralar; APÊNDICES PETALÍNEOS 24-35 x 4 mm, 2, ligulados, longitudinalmente adnatos à pétala por ca. $25 \mathrm{~mm}$, ápice elíptico com margens incospicuamente denteadas, excedendo o cálice e visíveis na antese; ESTAMES polísticos; FILETE ca. 85 x 2 mm, cilíndrico, branco; ANTERA ca. 18 x $1 \mathrm{~mm}$, linear, amarela, dorsifixa próximo à base; ESTILETE ca. 93 × $2 \mathrm{~mm}$, cilíndrico a levemente anguloso, branco; LOBOS DO ESTIGMA ca. 3 x $1 \mathrm{~mm}$, suberetos passando a patentes, brancos; OVÁRIO ca. $9 \mathrm{~mm}$ (porção supera) x $5 \mathrm{~mm}$, estreitamente ovóide, verde-alvacento na base a alvacento, hipanto ca. $6 \mathrm{~mm}$; ÓVULOS ca. $7 \mathrm{~mm}$, numerosos. CÁPSULA 4-5 x 1-1.4 cm, ovoide, marrom-escura; SEMENTE ca. 5 x $1 \mathrm{~mm}$, fusiforme, marrom; COMA BASAL ca. 6 mm, bege; COMA APICAL ca. 9 mm, ferrugíneo. Fig. 28 F-H.

DISTRIBUIÇÃO, ECOLOGIA E CONSERVAÇÃO. Alcantarea vinicolor é heliófila e ocorre em afloramentos rochosos da região de Vargem Alta e no distrito de Pedra Azul, município de Domingos Martins. Encontra-se protegida no Parque Estadual da Pedra Azul. Localmente, é retirada do habitat para ser empregada em jardins residenciais. IUCN Red List Category: Vulnerable, VU B2a, b(ii, iii).

FENOLOGIA. Coletada em flores em cultivo em junho e agosto. Frutos maduros coletados em dezembro.

ETIMOLOGIA. vinicolor, i.e. cor de vinho, faz alusão à coloração das folhas.

DISCUSSÃO. Espécie pouco conhecida e com distribuição que se sobrepõe à de $A$. extensa. Foi descrita por Pereira \& Reitz (in Pereira 1974), como sendo relacionada à $A$. extensa, da qual diferiria por apresentar brácteas florais não gibosas e mais curtas que as sépalas. Os autores também afirmam que a espécie poderia ser confundida $\operatorname{com} A$. imperialis, especialmente quando estéril, mas seria muito diferente pela inflorescência. De fato, a espécie é muito semelhante à $A$. extensa, sendo que uma das características mais marcantes para diferenciá-las é o menor comprimento das brácteas florais e as lâminas foliares, que em $A$. vinicolor são geralmente mais estreitas, lustrosas em ambas as faces (vs. folhas geralmente mais largas e com depósitos de cera epicuticular) e assumem geralmente a cor-devinho muito intensa, em toda sua extensão ou em direção ao ápice. Todavia, folhas vinosas também são observadas em $A$. extensa, sugerindo a necessidade de estudos adicionais para a melhor 
delimitação dos táxons. Aparentemente, o período de floração é distinto, tendo sido coletada com flores durante o inverno (junho-agosto) e com frutos em dezembro. Alcantarea extensa concentra a florada em dezembro. Os apêndices petalíneos, aparentemente variam muito em comprimento, visto que na ilustração original medem ca. de $2.4 \mathrm{~cm}$, enquanto nos demais espécimes, ca. $3.5 \mathrm{~cm}$. No holótipo o eixo principal da inflorescência é geniculado, com entrenós divergindo até $30^{\circ}$, entretanto tal característica varia entre indivíduos diferentes, havendo aquelas com eixo quase reto. Uma característica que deve ser melhor observada nos indivíduos floridos é a coloração das flores, indicada pelos coletores do holótipo como vinulosas, com pétalas roxo escuro abaxialmente e amarelas adaxialmente. Tal caracterísitcia a aproxima de $A$. nigripetala. $\mathrm{O}$ estudo anatômico (Cap. 3 ) indicou que a espécie pode ser diferenciada de $A$. extensa por apresentar hipoderme mecânica espessada com maior número de camadas. O exemplar tipo não fornece a localidade exata, que é mencionada apenas no protólogo.

MATERIAL EXAMINADO. Brazil. Espírito SANTO: Domingos Martins, Pedra Azul, Parque Estadual da Pedra Azul, caminho para a Pedra das Flores, 14 Aug 1999, Martinelli 15727 (RB); Ibidem, Pedra Azul, rota do Lagarto, 20 Jan 2007, Versieux et al. 375, 376, 377 (SP); Ibidem, Chapéu, 23 Jan 2007, Versieux et al. 384 (SP); Santa Teresa, cultivated, 28 Jun 2001, Kollmann 4099b (MBML). Vargem Alta, 23 Aug 1973, Duarte \& Reits 7535 (HB). 


\section{TÁXON DUVIDOSO:}

Vriesea Alta (Baker) E. Morren ex Mez Monogr. Phan. 9: 617. 1896. Tillandsia alta Baker, Handb. Bromel. 226. 1889.-TIPO: PANAMÁ: Chiriquí. (lectótipo selecionado por Smith \& Downs, 1977: Iconografia de Edouard Morren, Kew).

Vriesea alta foi considerada por Smith \& Downs (1977) integrante do subgênero Alcantarea. Grant (1995a) ao re-estabelecer o gênero, excluiu essa espécie e afirma que ela seria um possível sinônimo de algum táxon mais antigo, descrito em Tillandsia, Weraubia ou Vriesea. A espécie já foi tratada como sinônimo de Vriesea panniculata (L.) Mez (=Tillandsia paniculata (L.) L.) por Mez (1934), entretanto tal sinonímia não é seguida por Beaman \& Judd (1996). Smith (1944) incluiu a espécie na monografia de Bromeliaceae do Panamá e indica que há material cultivado no Jardim Botânico de Liège. Smith \& Downs (1977) indicam que a aquarela usada como lectótipo, que encontra-se entre os ícones de Edouard Morren, em Kew (Fig. 3 do Capítulo 3) baseia-se em um espécime do herbário de Liège. No presente trabalho não foi possível consultar tal herbário e não obtivemos resposta do curador da referida instituição. Trata-se de uma espécie pouquíssimo conhecida, atribuída a uma coleção proveniente de Chiriquí, no Panamá que teria florescido em cultivo. O lectótipo em muito se assemelha às espécies brasileiras do grupo da Alcantarea extensa, com ápice do cálice vinoso, bráctea floral distalmente gibosa e pétalas amarelado-vinulosas. Não foram encontrados espécimes com esta identificação nos acervos aqui examinados. $\mathrm{Na}$ ausência de novas coleções ou caso não sejam encontrados espécimes tipo em outros herbários, não se poderá chegar a conclusão de sua real identidade. 
106

Therea : $\beta$. Macmegation

Daciuma

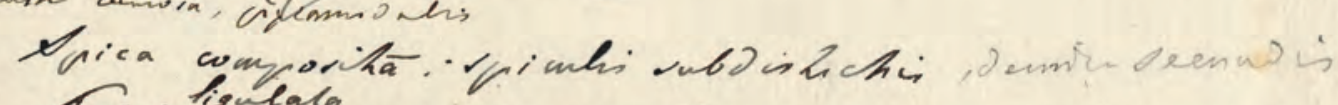

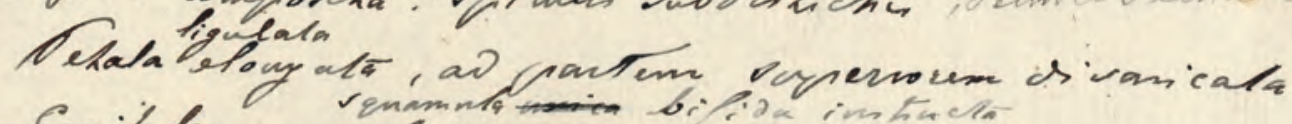

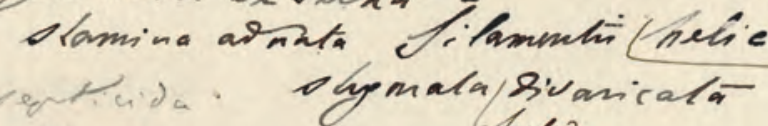
Orula vousucta hyos.

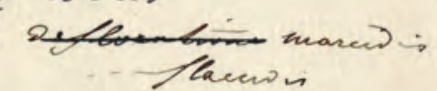

Cavinle

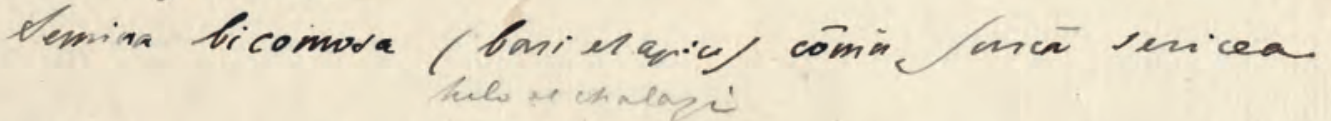

N2. Reyina ( ville.

Un glogiviana Cim.

antoine Reyina tha

Na.jorymbea Sand

Rel excecha sis.

2ee. proura thast.

N1. Heegerian. (Vom thowatis)

11. umparia hi

A

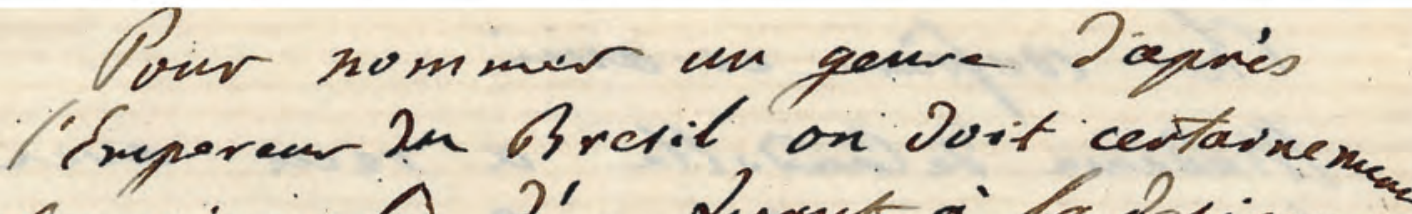

cepprimer te $\partial^{\prime}$. duant o' lo derineme

B

FIG. 1. Documentos históricos arquivados no herbário de Kew. A. Manuscrito onde J. C. E. Morren registrou o seu anseio de descrever o gênero Dalcantarea, incluindo espécies atualmente posicionadas em Vriesea ( $V$. gigantea, $V$. itatiaiae) e outas em Alcantarea ( $V$. glaz̧ionana, $V$. regina). Notar a menção da panícula ramosa, spiculis (espiguetas) e de pétalas "ligulatas, elongatas, belicoides, tortis" e sementes bicomosas. B. Trecho da carta de Alphonse de Candolle endereçada à J. C. E. Morren, datada de 23 de dezembro de 1882, onde se lê: "Para nomear um gênero para o Imperador do Brasil, certamente deverá se suprimir o d." tradução nossa. (Fotos: L.M. Versieux). 

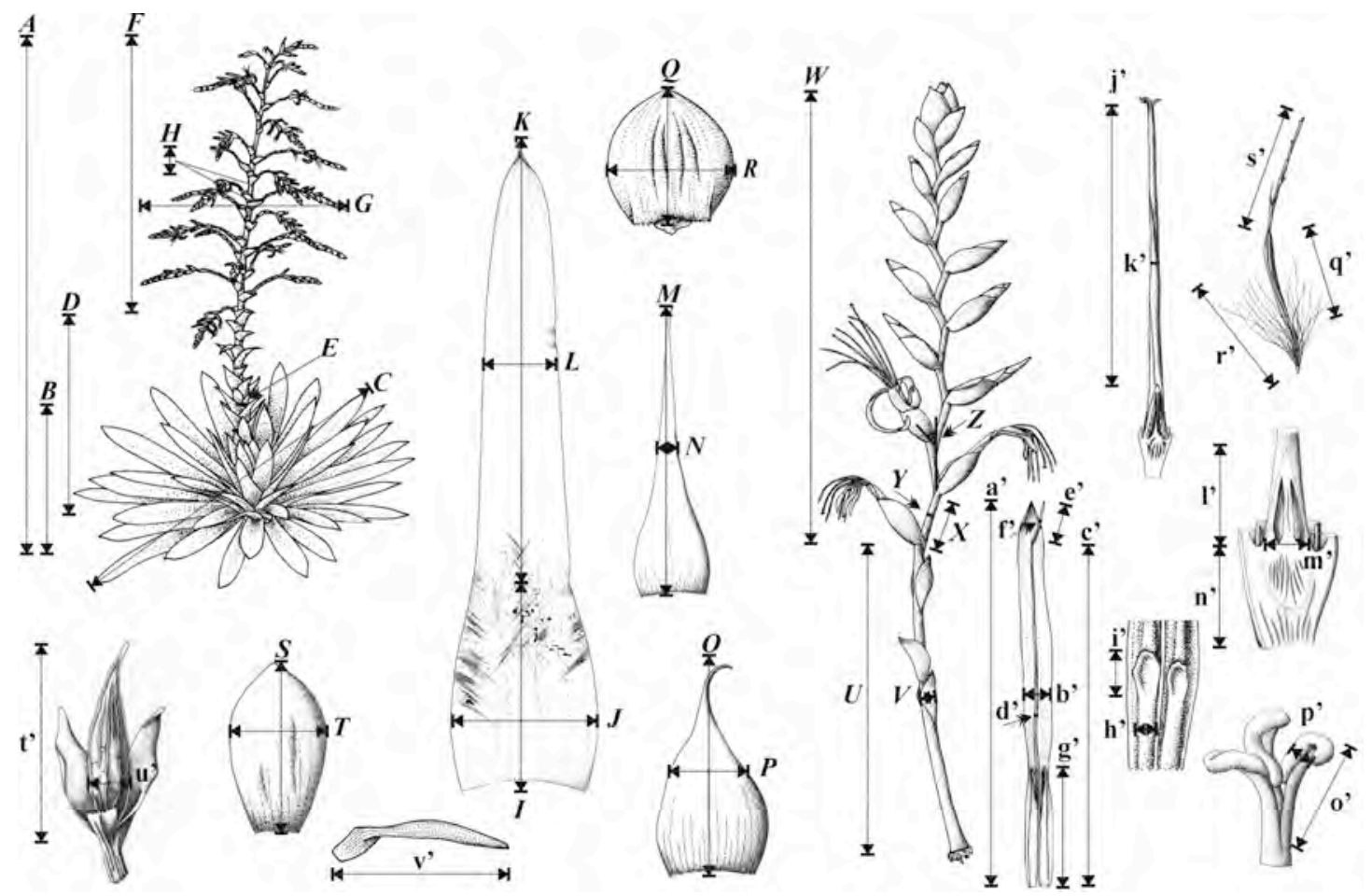

FIG. 2. Ilustrações indicando a terminologia descritiva adotada, assim como as posições onde foram medidos os espécimes de Alcantarea. A. Alt. da planta. B. Alt. da roseta. C. Diâm. da roseta. D. Compr. do pedúnculo. E. Diâm. do pedúnculo. F. Compr. da inflorescência. G. Diâm. da inflorescência. H. Compr. do entrenó da raque. I. Compr. da bainha. J. Larg. da bainha. K. Compr. da lâmina foliar. L. Larg. da lâmina. M. Compr. da bráctea do pedúnculo. N. Larg. da bráctea do pedúnculo. O. Compr. da bráctea primária. P. Larg. da bráctea primária. Q. Compr. da bráctea floral. R. Larg. da bráctea floral. S. Compr. sépala. T. Larg. da sépala. U. Compr. do pedúnculo lateral. V. Diâm. do pedúnculo lateral. W. Compr. da ráquila. X. Compr. do entrenó da ráquila. Y. Diâm. do entrenó da ráquila. Z. Ângulo de divergência entre a flor e uma reta imaginaria que passa por todos os entrenós da ráquila. a'. Compr. da pétala. b'. Larg. da pétala. c'. Compr. do filete. d'. Diâm. do filete. e'. Compr. da antera. f'. Diâm. da antera. g'. Compr. do apêndice petalino. h' larg. do apêndice petalíneo. i'. Compr. da porção livre do ápice do apêndice petalíneo. j’. Compr. do estilete. k'. Diâm. do estilete. l'. Compr. do ovário. m’. Diâm. do ovário. n’. Compr. do hipanto. o'. Compr. do lobo do estigma. p'. Diâm. do lobo. q'. Compr. da semente. r'. Compr. dos apêndices basais. s'. Compr. dos apêndices apicais. t’. Compr. da cápsula. u’. Diâm. da cápsula. v’. Compr. do óvulo. 

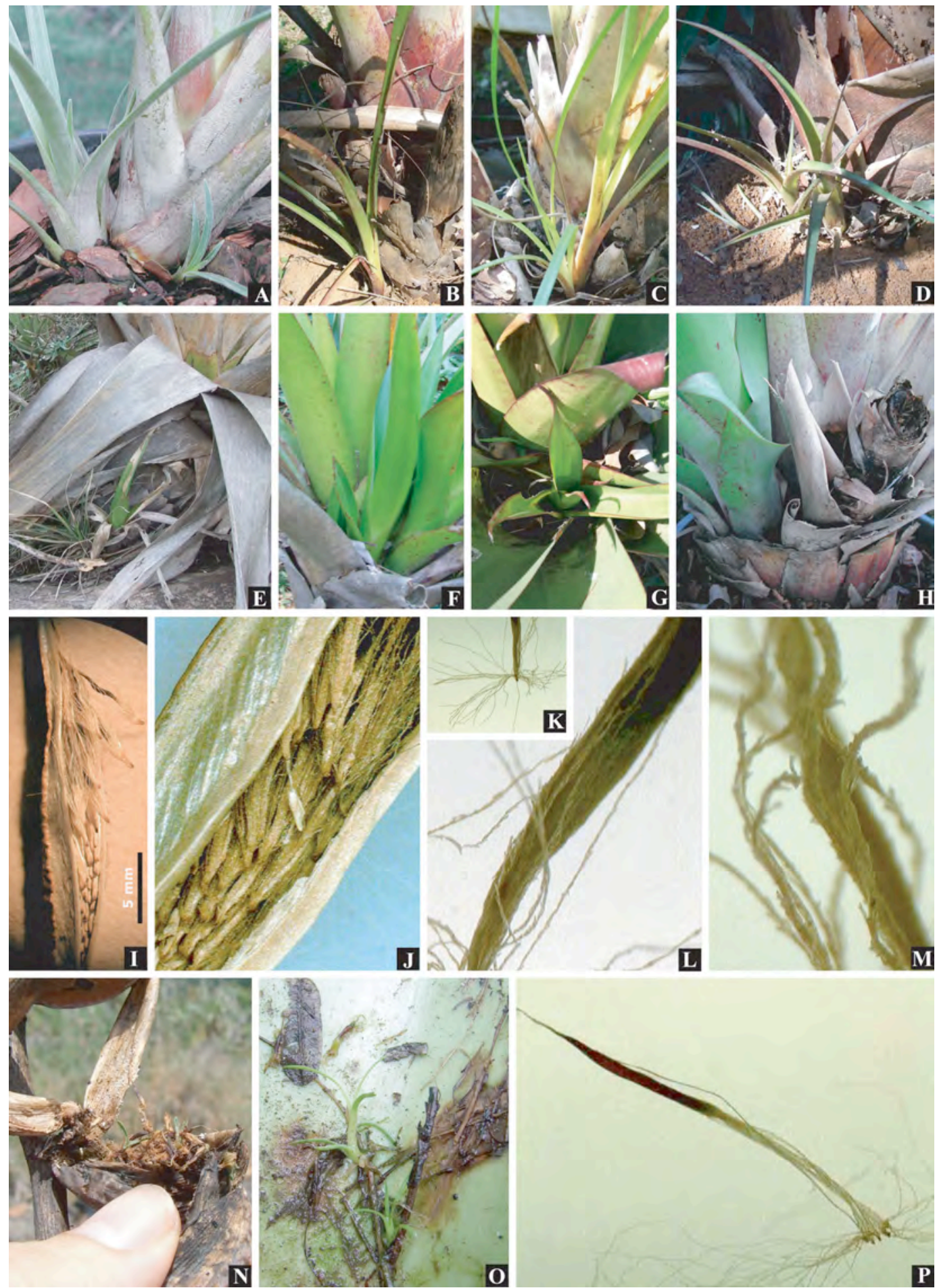

FIG. 3. Variação na forma de propagação vegetativa e morfologia da semente. A.-E. Brotações basais externas à roseta. A. Alcantarea duarteana. B. A. heloisae. C. A. geniculata. D. A. imperialis. E. A. turgida. F.H. Brotações axilares. F. A. burle-marxii. G. A. extensa. H. A. beloisae. I. Carpídeo de A. duarteana mostrando o levantamento centrípeto progressivo para dispersão. J. Detalhe da deiscência septicida de um carpídeo de A. heloisae. K.-M. Semente de A. glazionana. K. Apêndices basais se afastando da semente. L. Região de transição entre a semente e os apêndices basais. M. Detalhe da superfície irregular dos apêndices, com protuberâncias retrorsas semelhantes a pequenos anzóis. N. Germinação de sementes de $A$. trepida dentro de frutos passados (viviparidade). O. Germinação de sementes de $A$. regina dentro do tanque da planta-mãe. P. Vriesea minarum L.B. Sm., morfologia distinta de semente, sem apêndice apical desenvolvido e apêndices basais mais longos e finos se comparados aos de Alcantarea. (Fotos: L.M. Versieux, exceto N.: A.M. Calvente). 

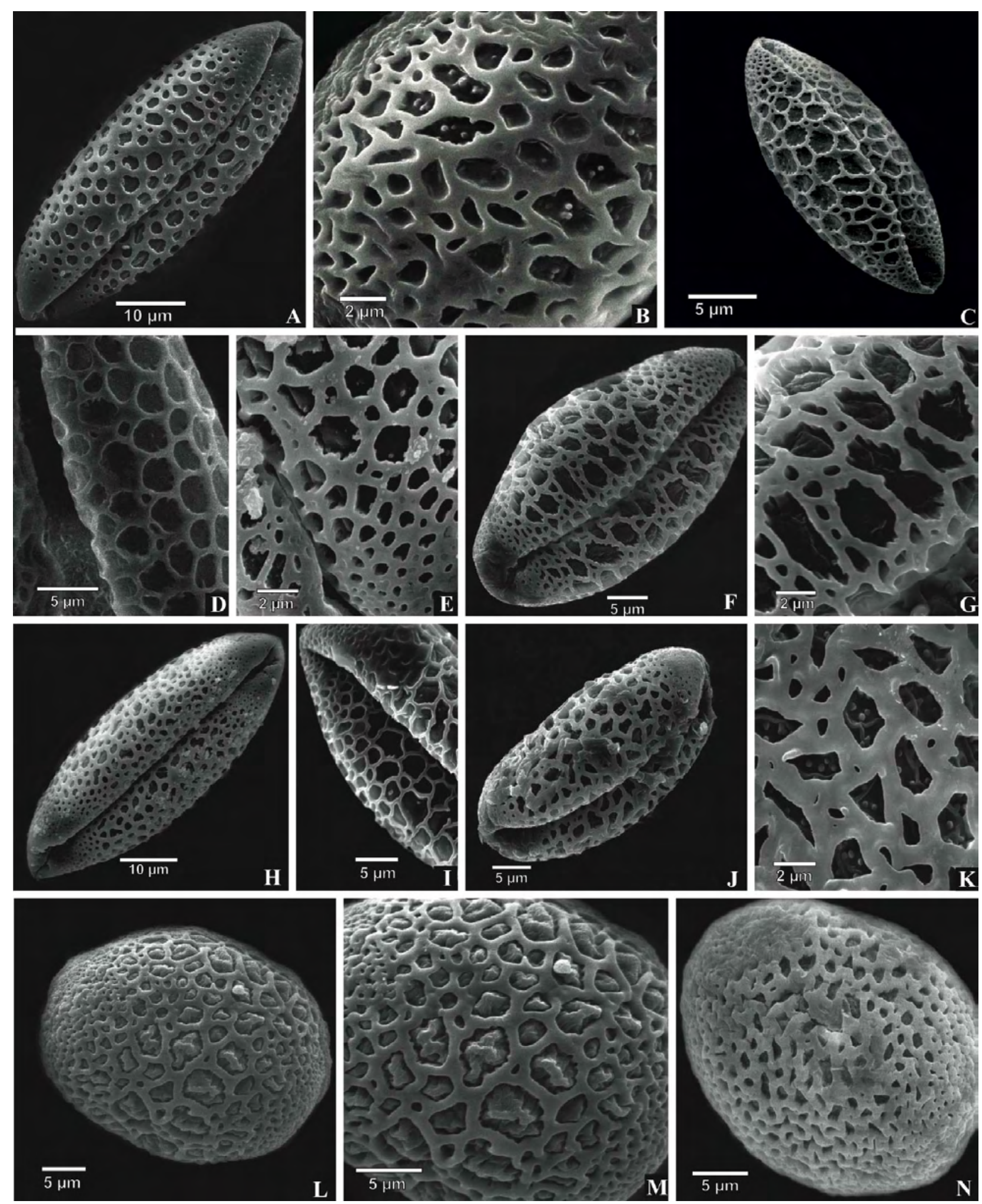

FIG. 4. Morfologia polínica de Alcantarea sob microscopia eletrônica de varredura. A.-B. Alcantarea burle-marxii. C. Alcantarea duarteana. D. Alcantarea extensa. E. Alcantarea geniculata. F-G. Alcantarea beloisae. H. Alcantarea imperialis. I. Alcantarea nahoumii. J.-K. Alcantarea patriae. L.-M. Alcantarea robertokautskyi. N. Alcantarea turgida. (Vouchers: A-B. Versieux 420, C. Versieux 255, D. Versieux 469, E. Versieux 456, F-G. Versieux 238, H. Versieux 222, I. van den Berg 895, J.-K. Versieux 365. L.-M. Versieux 430. N. Versieux 260). 

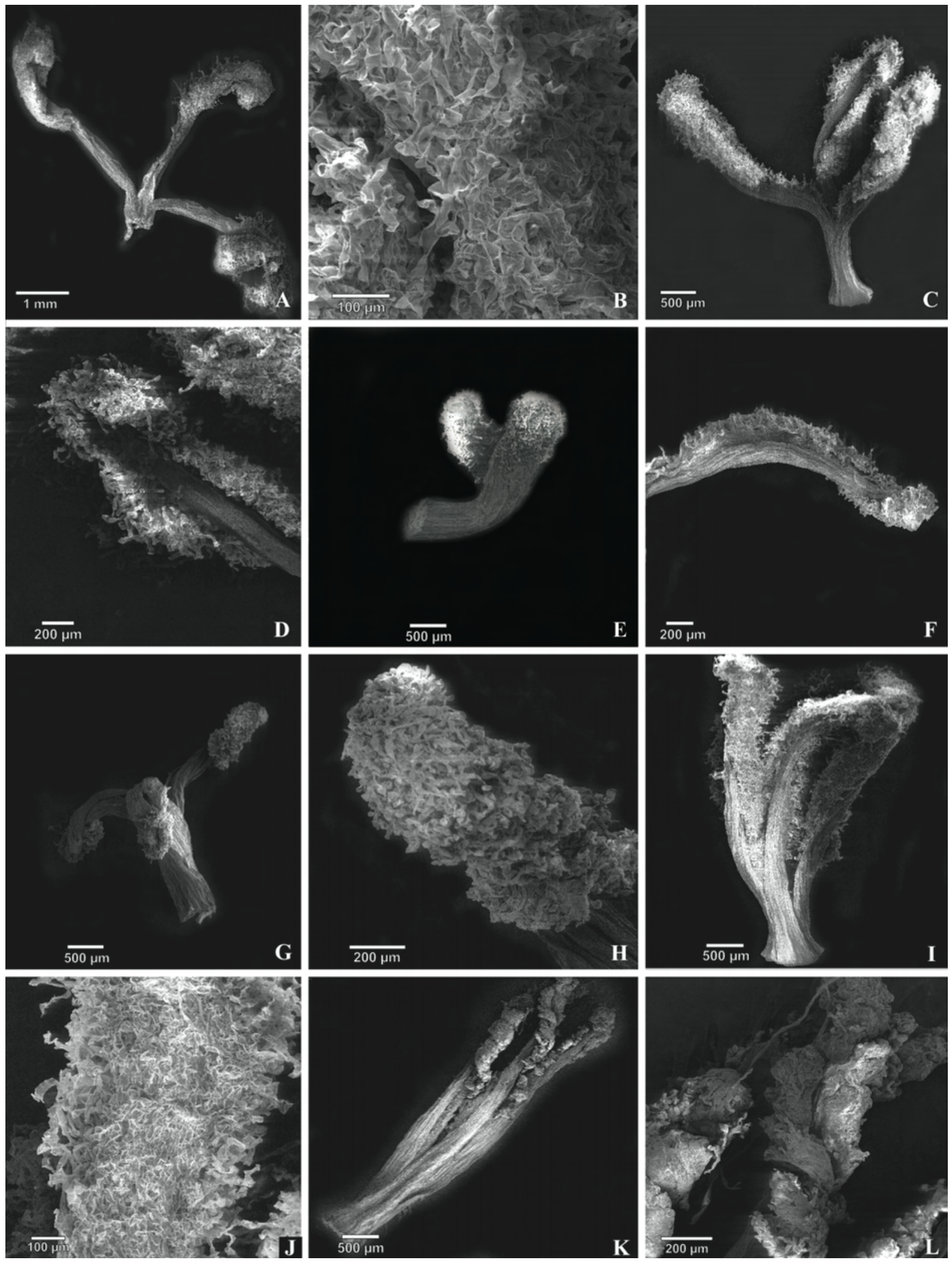

FIG. 5. Microscopia eletrônica de varredura dos estigmas de Alcantarea. A.-B. Alcantarea burle-marxii (Versieux 420). A. visão geral do estigma. B. Detalhe das papilas. C.-D. A. imperialis (Versieux 451), simples ereto. E. A. extensa (Versieux 380). F. Detalhe de um lobo de A. farneyi (Versieux 247). G.-H. A. heloisae (Versieux 238). G. Visão geral do estigma. H. Detalhe do lobo. I.-J. A. imperialis (Versieux 260), simples ereto. I. Visão geral do estigma. J. Detalhe do lobo. K.-L. A. roberto-kautskyi (Versieux 430). K. Visão geral dos lobos conduplicado-espiralados. L. Detalhe das papilas. 


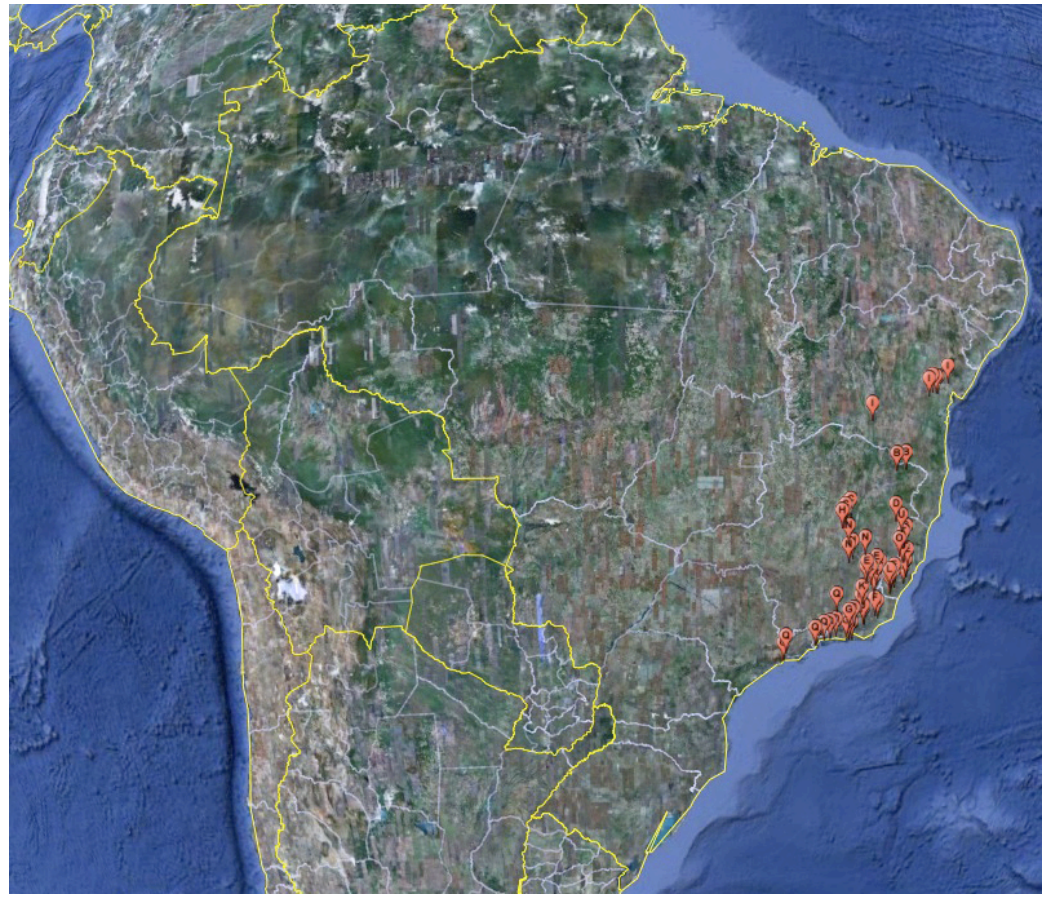

FIG. 6. Mapa do Brasil mostrando os pontos de ocorrência (em vermelho) de espécies de Alcantarea.
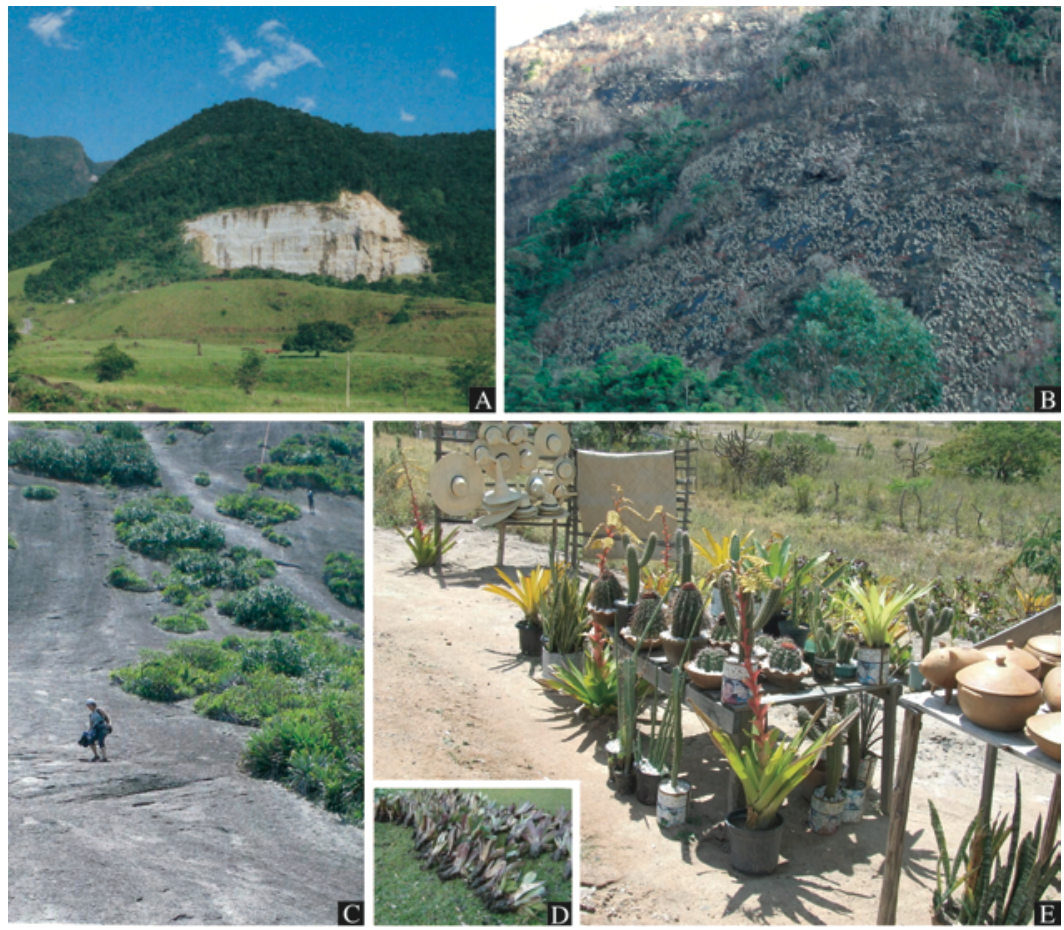

FIG. 7. Fatores de ameaça à conservacão de Alcantarea. A. Exploração de substrato rochoso, em Angra dos Reis, RJ. B. Queimada de uma populacão inteira de A. heloisae em Santa Maria Madalena, RJ. C. Abertura de vias de escalada com a eliminacão da vegetação nativa, incluindo $A$. glazionana, no Pão de Açúcar, RJ. D. Apreensão de indivíduos jovens de $A$. imperialis extraídos ilegalmente dentro do Parque Nacional da Serra dos Órgãos. E. Comércio de A. nahoumii às margens das rodovias na Bahia. (Fotos: L.M. Versieux, exceto D.: PARNA Serra dos Órgãos). 


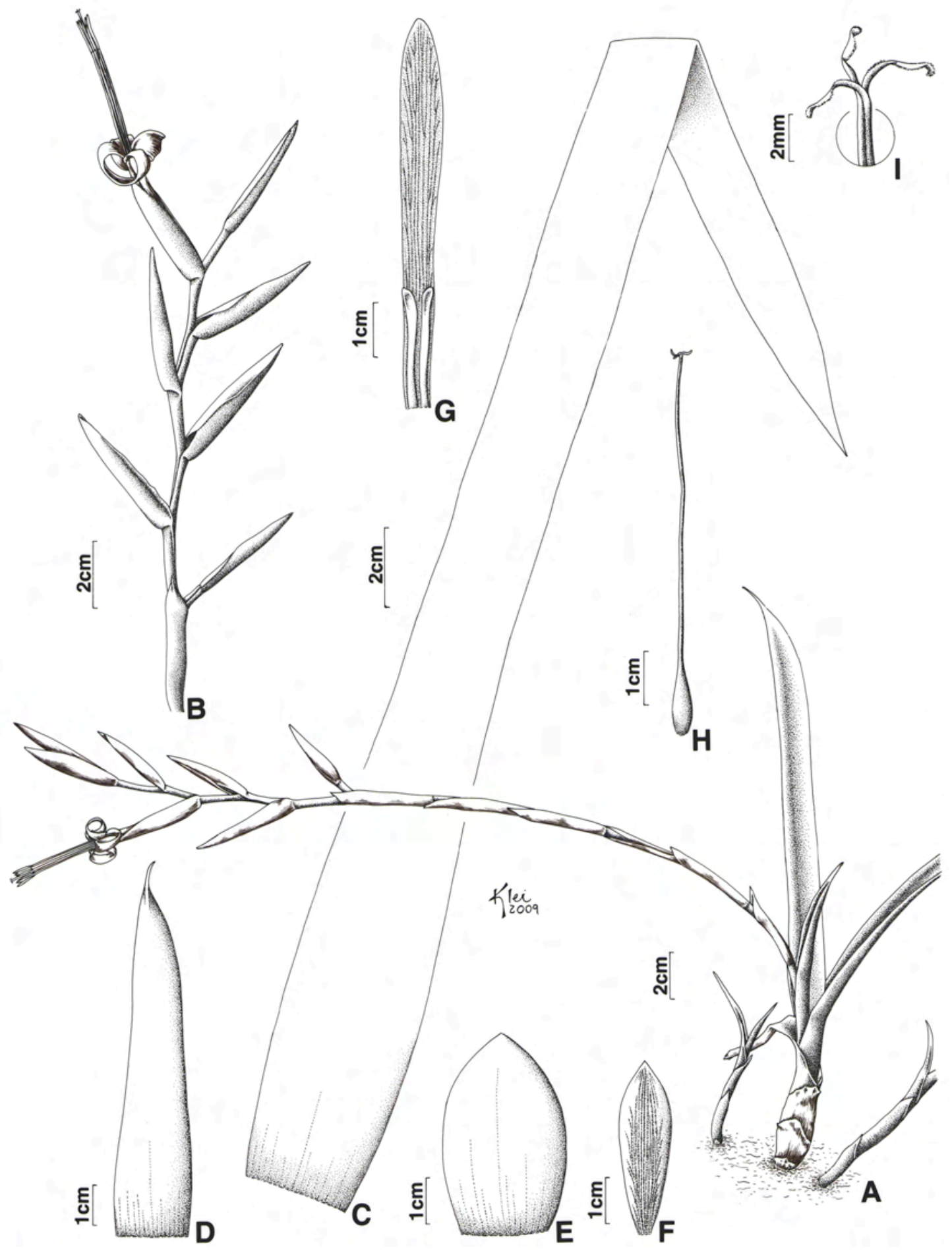

FIG. 8. Alcantarea benzingii. A. Hábito. B. Inflorescência. C. Folha. D. Bráctea do pedúnculo. E. Bráctea floral. F. Sépala. G. Pétala mostrando os dois apêndices petalíneos. H. Pistilo. I. Estigma trífido. (Baseado em: Leme 850). 


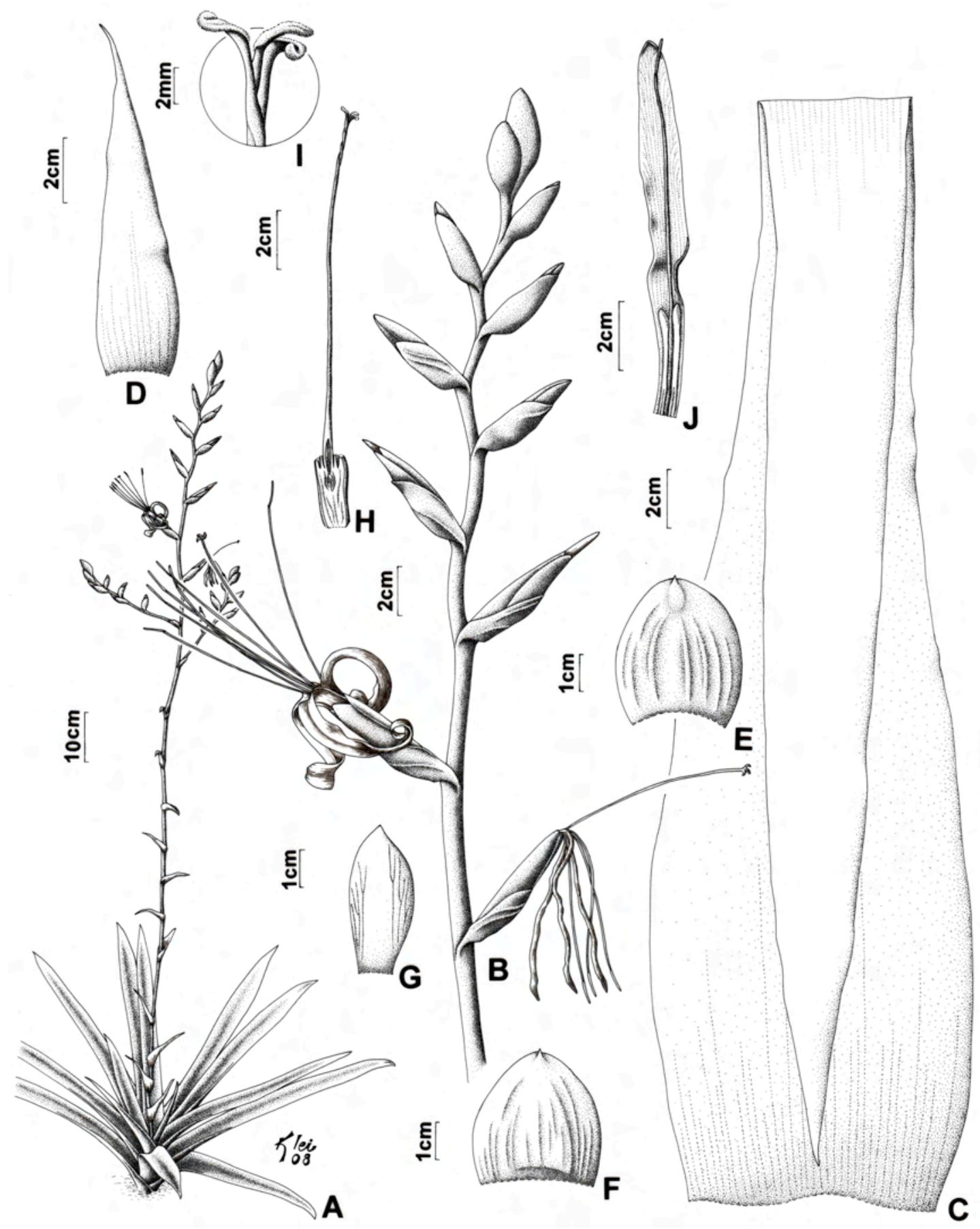

FIG. 9. Alcantarea burle-marxii. A. Hábito. B. Espiga terminal da inflorescência. C. Folha. D. Bráctea do pedúnculo. E. Bráctea primária. F. Bráctea floral. G. Sépala. H. Pistilo. I. Estigma trífido. J. Pétala, estame e apêndices. (Baseado em: Versieux 420). 


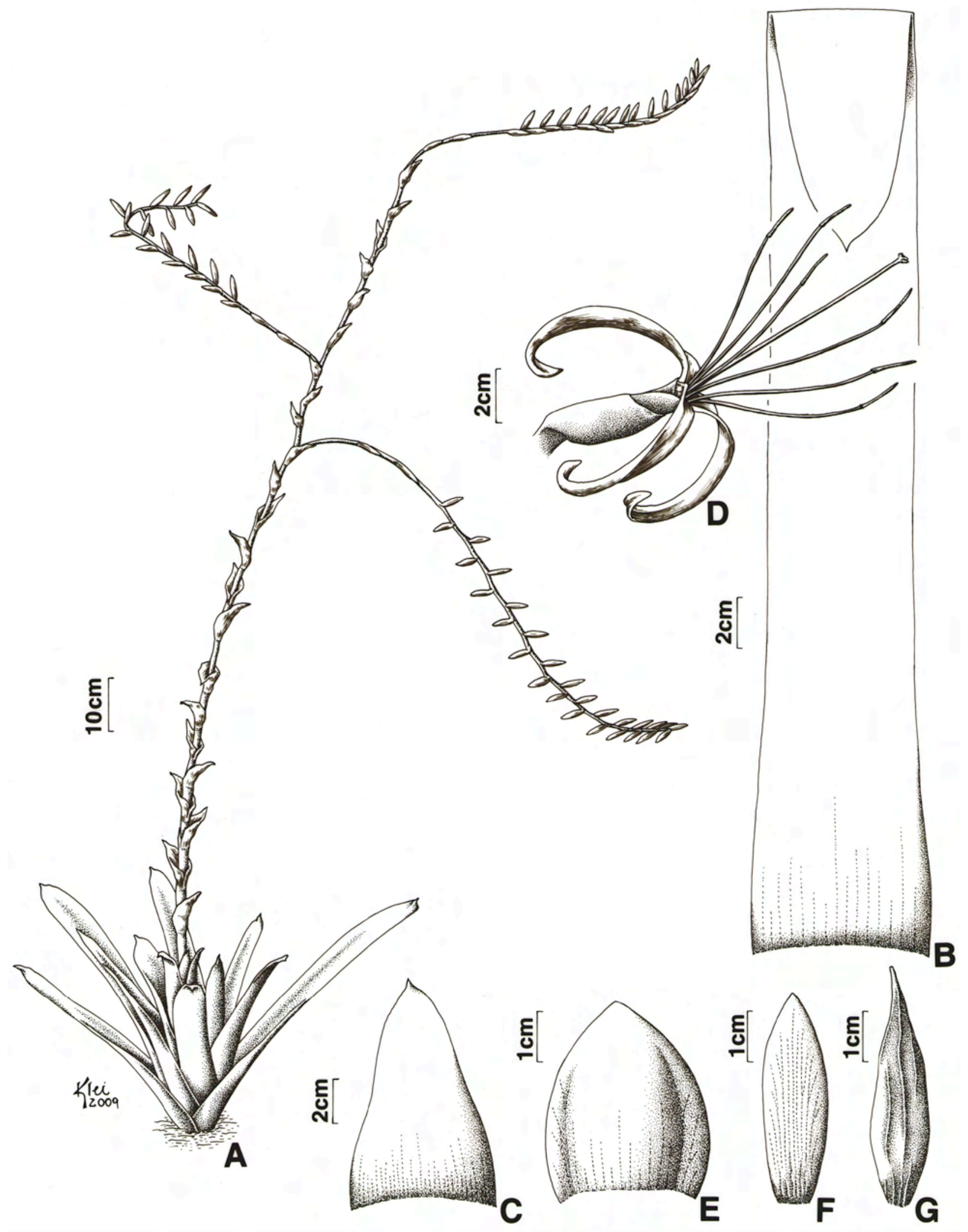

FIG. 10. Alcantarea distractila. A. Hábito. B. Folha. C. Bráctea do pedúnculo. D. Flor. E. Bráctea floral. F. Sépala. G. Cápsula. (Baseado em: Leme 5601). 


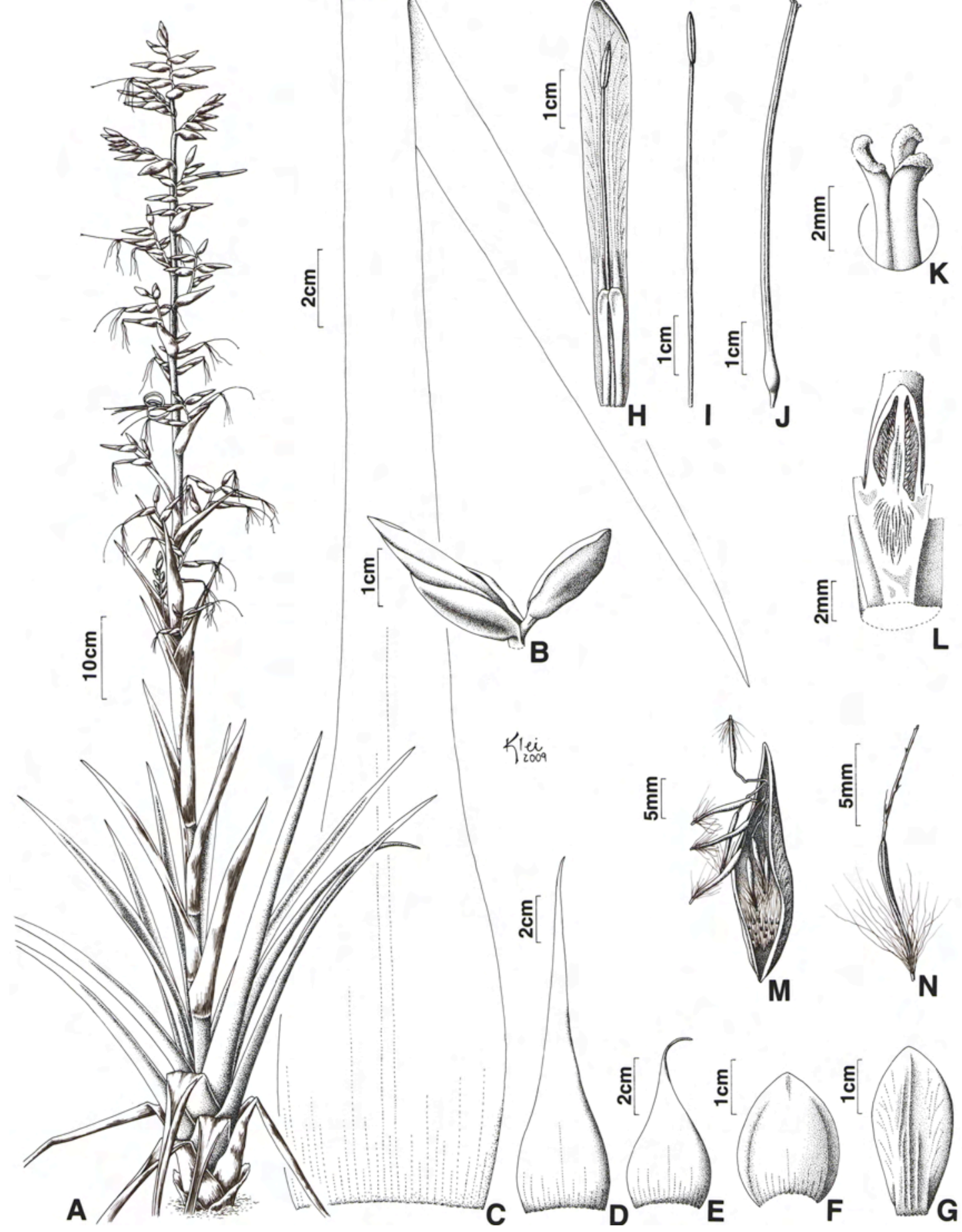

FIG. 11. Alcantarea duarteana. A. Hábito. B. Porção terminal de uma espiga. C. Folha. D. Bráctea do pedúnculo. E. Bráctea primária. F. Bráctea floral. G. Sépala. H. Pétala com calosidade acima dos apêndices e estame. I. Estame. J. Pistilo. K. Estigma trífido. L. Ovário em corte longitudinal mostrando o nectário septal infralocular. M. Cápsula aberta dispersando sementes. N. Semente. (Baseado em: A-L Versieux 468; M-N Wanderley 2621). 

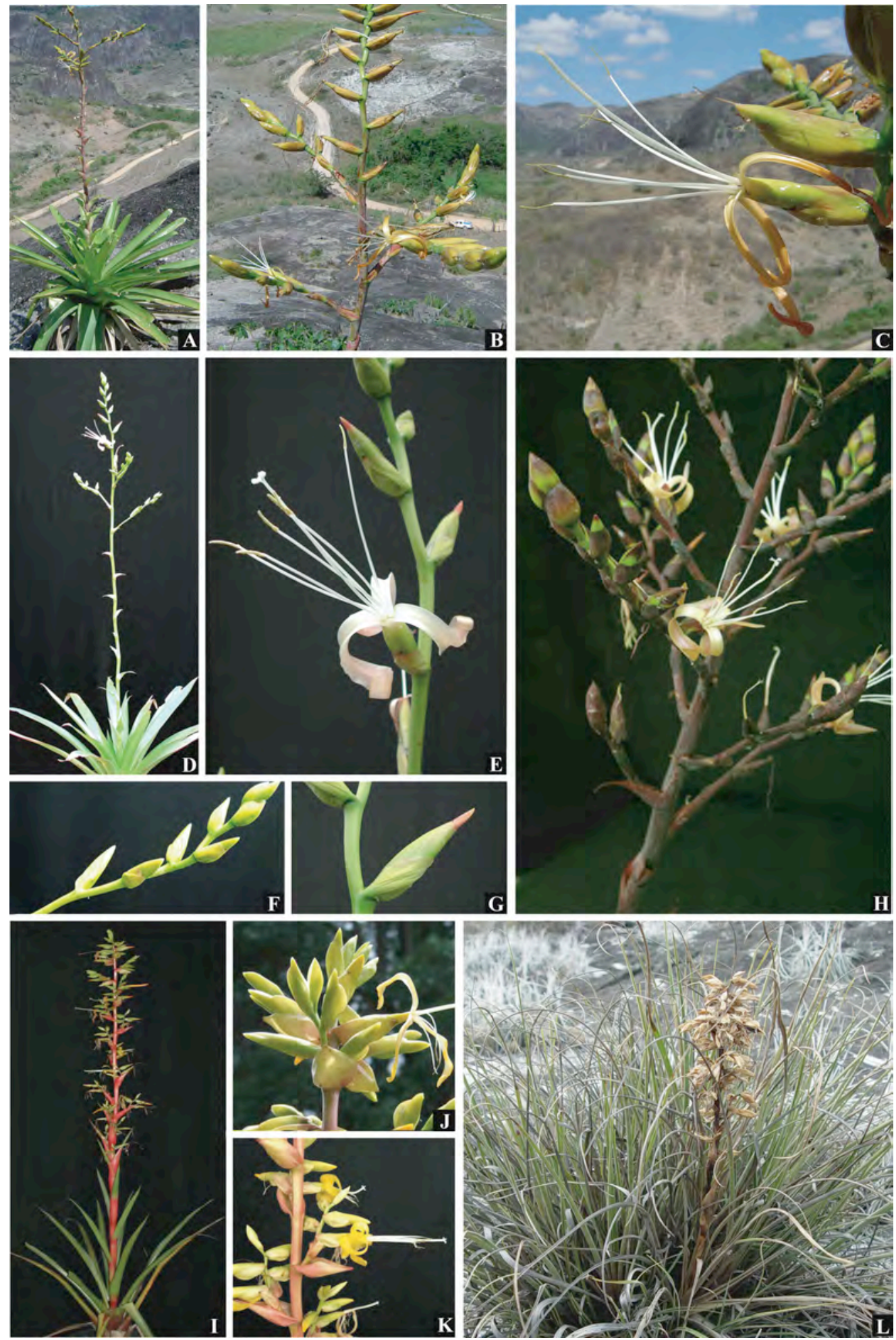

FIG. 12. Alcantarea burle-marxii e A. duarteana. A-H. A. burle-marxii. A. Hábito de indivíduo coletado em inselberg no Nordeste de MG. B. Detalhe da inflorescência. C. Flor passada. D-H. Indivíduos cultivados exibindo diferentes colorações. D. Hábito. E. Flor. F. Espiga. G. Botão (repare a coloração mais escura das pétalas no pré-antese). H. Inflorescência vinosa de indivíduo cultivado no Marie Selby Botanical Gardens. I-L. A. duarteana. I. Hábito em cultivo. J. Porção terminal da inflorescência. K. Detalhe de uma flor com estames em feixe. L. Indivíduos em fase de frutificação no Parque Estadual do Rio Preto, note a diferença na largura das lâminas foliares. (Vouchers: A-C Salino; D-G Versieux 420; I-K Versieux 470; L Mota 3137. Fotos: A-C. A. Salino, D-G. L.M. Versieux, H. Marie Selby Botanical Gardens, L.: R.C. Mota). 


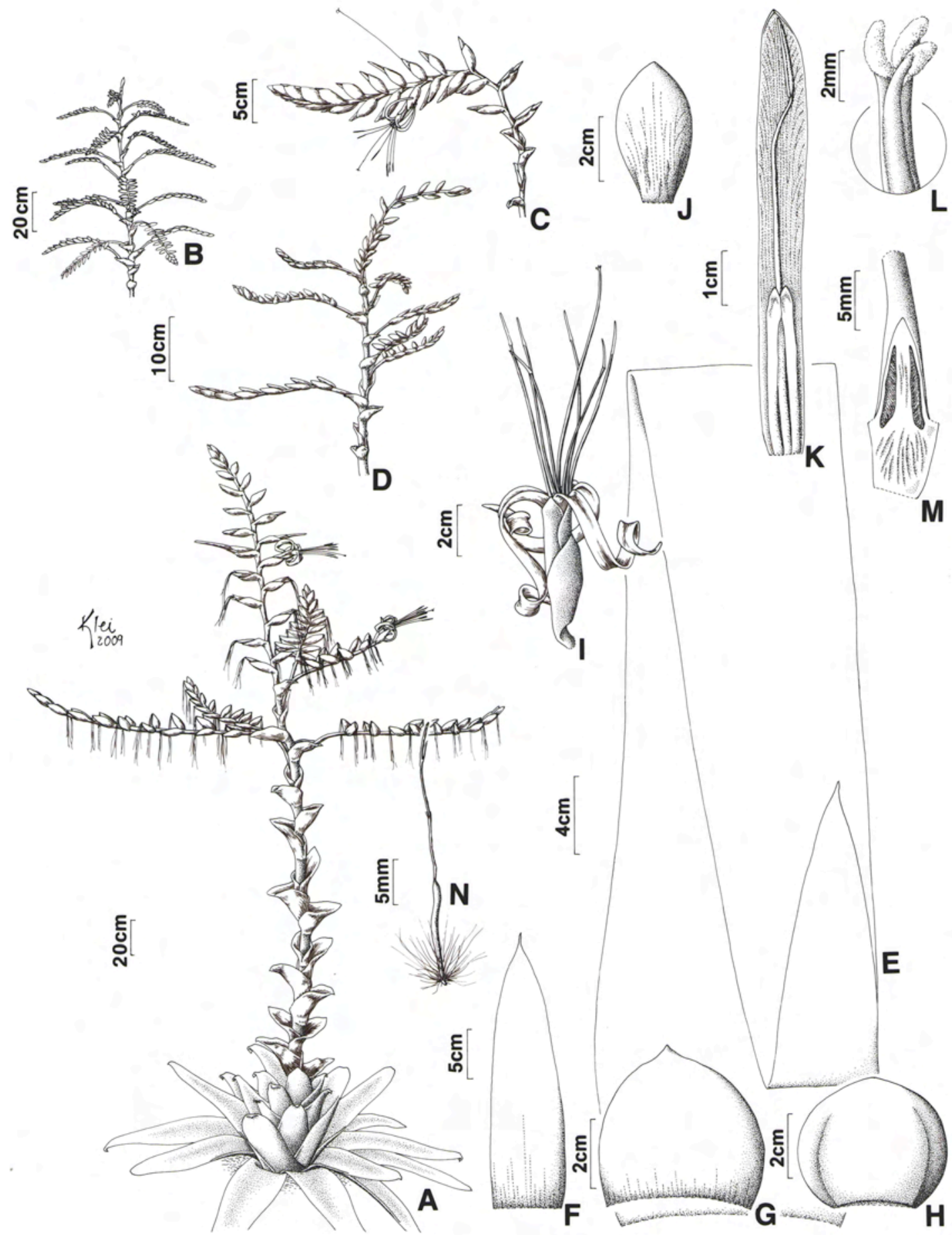

FIG. 13. Alcantarea extensa. A. Hábito. B. Inflorescência de contorno ovolado. C. Inflorescência simples. D. Inflorescência piramidal assimétrica. E. Folha. F. Bráctea do pedúnculo. G. Bráctea primária. H. Bráctea floral. I. Flor. J. Sépala. K. Pétala com apêndices petalíneos e estame. L. Estigma trífido. M. Ovário, corte longitudinal. N. Semente. (Baseado em: A, Versieux 357; B. Versieux 378; C. Versieux 344; D-H, J-M Versieux 380; I Versieux 469; N Versieux 369). 

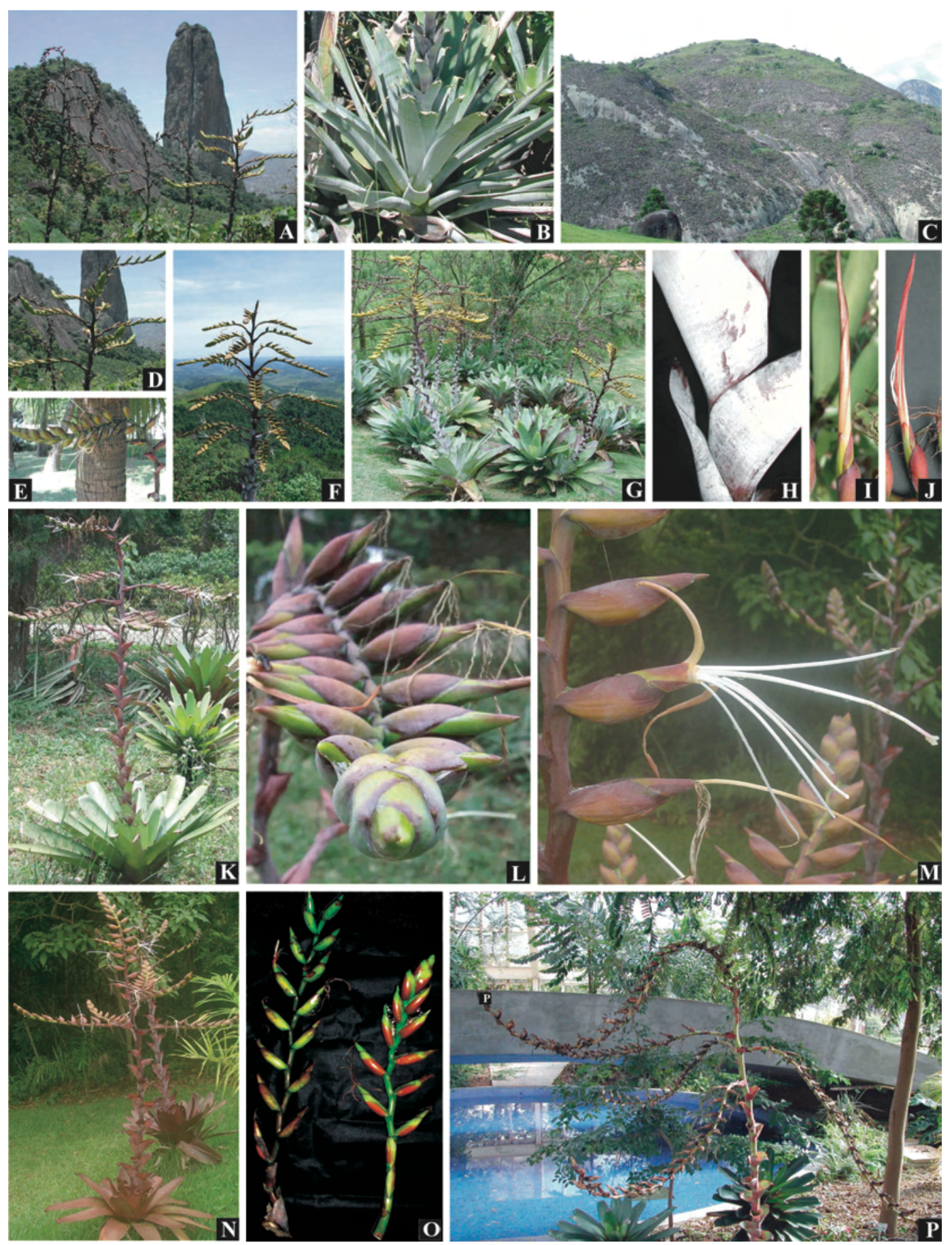

FIG. 14. Alcantarea extensa. A.-B, D. Indivíduos na localidade-típica, Cachoeiro do Itapemirim, Pico de Itabira, ES (Versieux 380). A., D. Detalhe da inflorescência. B. Detalhe da roseta. C. População com milhares de indivíduos cobrindo as rochas em Castelo, ES. E. Indivíduo cultivado no IBt com inflorescência simples (Versieux 344). F.-H (Versieux 372, 378). Variação do formato da inflorescência e da quantidade de cera produzida nos indivíduos do Parque Estadual do Forno Grande, ES. I.-L. População de Carangola, MG (Versieux 469). I. Flor com pré-floração espiralada. J. Início da antese com saída lateral dos filetes. K. Hábito do indivíduo florido, com folhas sem cera. L. Detalhe das brácteas florais distais da espiga densamente imbricadas e túrgidas. M.-N. Indivíduos cultivados no Parque Nacional do Caparaó. M. Flor no pós-antese. N. Hábito de indivíduo com roseta vinosa (Versieux 357). O. Espigas de A. vinicolor (Versieux 384, à esquerda) e A. extensa (Versieux 378, à direita). P. Indivíduo com inflorescência passada, apreendido pelo IBAMA, cultivado no Jardim Botânico de Belo Horizonte, com ramos longos e características intermediárias entre $A$. extensa, $A$. distractila e A. turgida. 


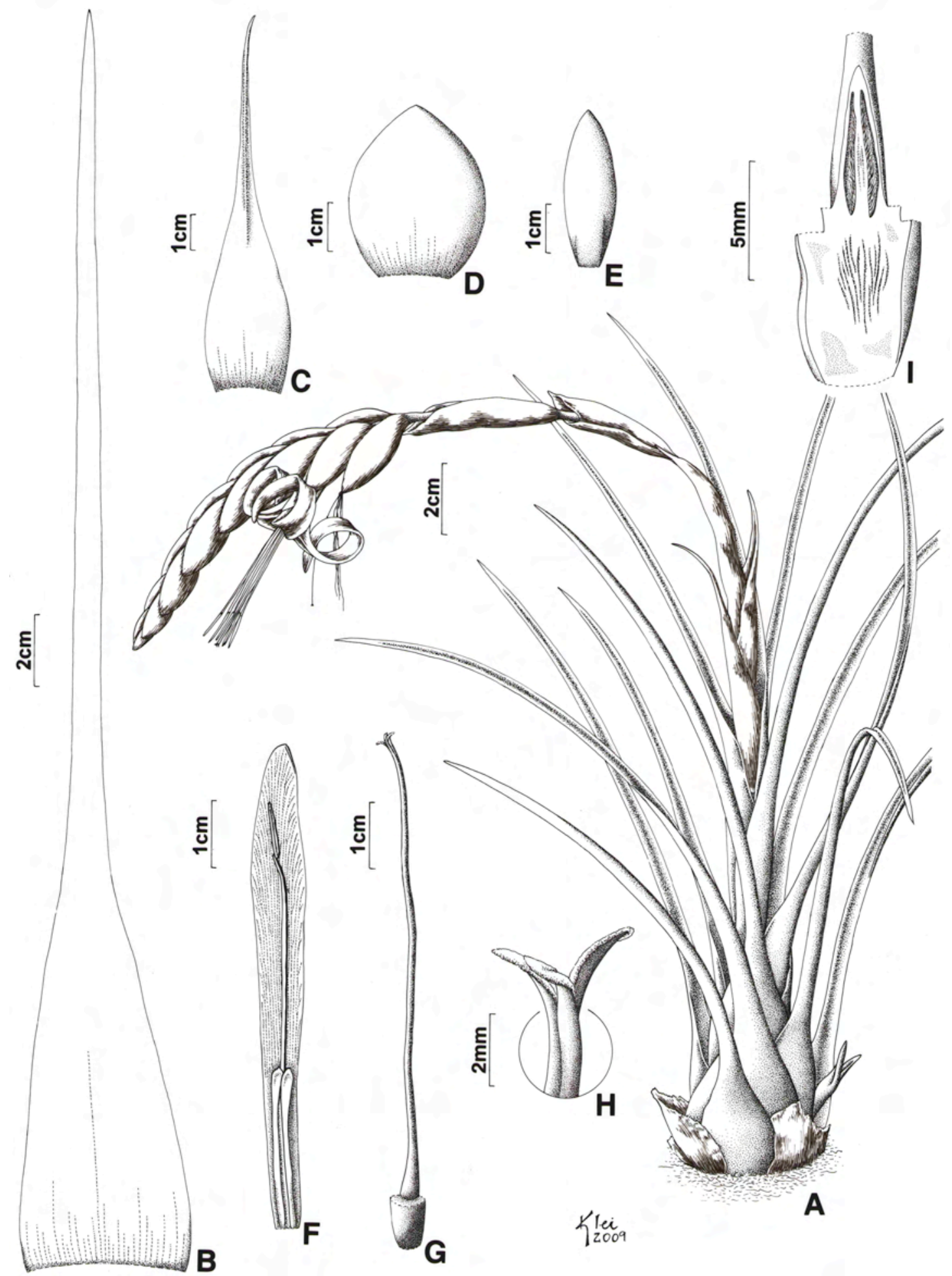

FIG. 15. Alcantarea farneyi. A. Hábito. B. Folha. C. Bráctea do pedúnculo. D. Bráctea floral. E. Sépala. F. Pétala com estame e apêndices petalíneos. G. Pistilo. H. Estigma trífido. I. Ovário, corte longitudinal. (Baseado em: Versieux 245). 


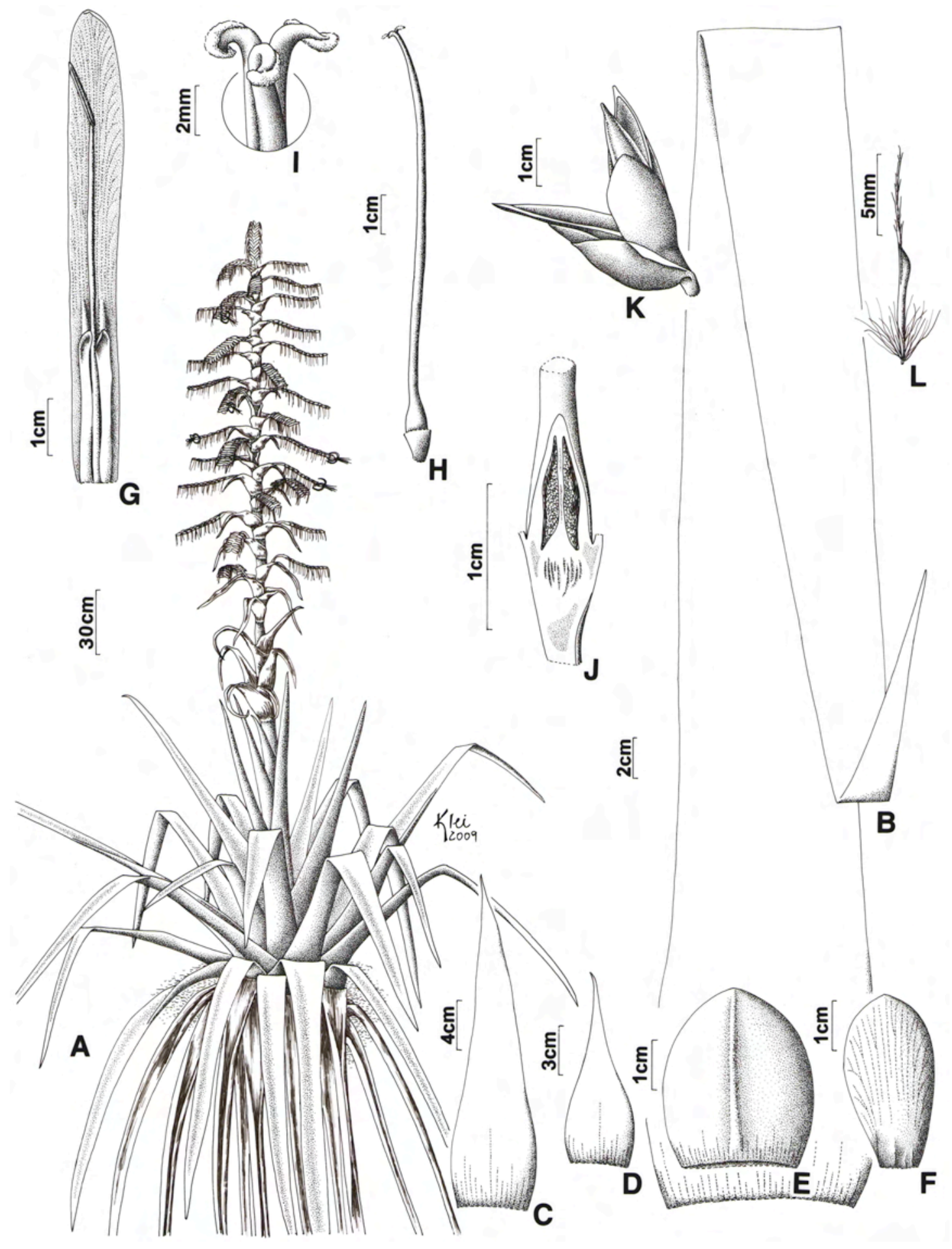

FIG. 16. Alcantarea geniculata. A. Hábito. B. Folha. C. Bráctea do pedúnculo. D. Bráctea primária. E. Bráctea floral. F. Sépala. G. Pétala com apêndices petalíneos e estame. H. Pistilo. I. Estigma trífido. J. Ovário, corte longitudinal. K. Cápsula madura. L. Semente. (Baseado em: Versieux 456, K-L Versieux 285) 

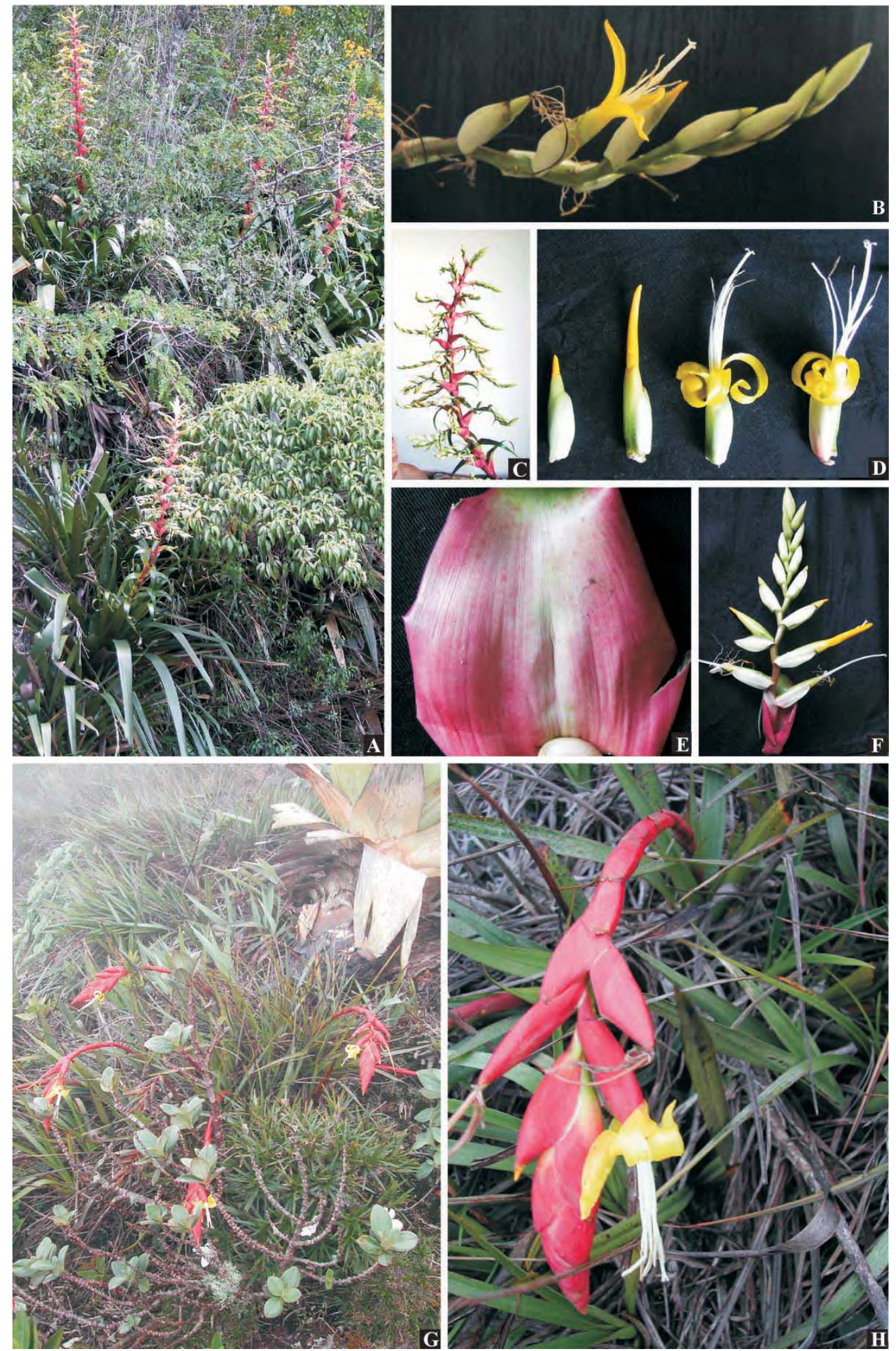

FIG. 17. Alcantarea geniculata e A. farneyi. A-F. A. geniculata. A. População com indivíduos floridos em afloramento em borda de mata. B. Ramo da inflorescência. C. Inflorescência. D. Diferentes estágios de desenvolvimento da flor, do botão à antese completa. E. Base da bráctea primária. F. Ramo da inflorescência, visto de cima, mostrando a raque geniculada. G-H. A. farneyi. G. Indivíduos floridos formando touceira no habitat. H. Detalhe da inflorescência. (Vouchers: A-F Versieux 456; G-H Versieux 245. Fotos: L.M. Versieux). 

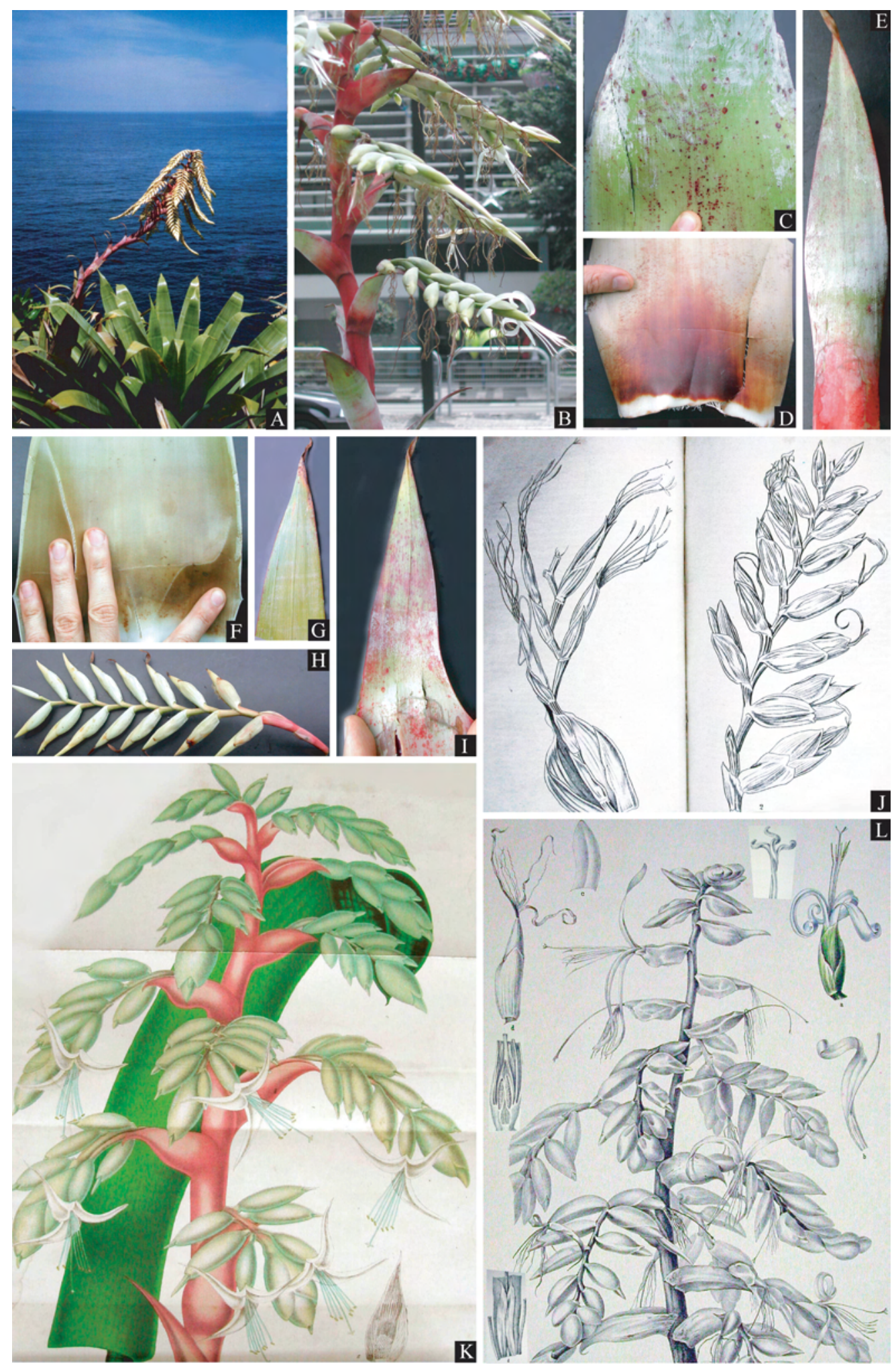

FIG. 18. Alcantarea glazionana. A-B. População com indivíduo em floração na Urca, Rio de Janeiro. B. Indivíduo florido em cultivo na Av. Paulista, São Paulo. C. Bainha foliar com máculas púrpuras e estrias cerosas, porção distal abaxial. D. Bainha foliar, porção proximal abaxial. E. Bráctea do pedúnculo. F. Bainha foliar, adaxial. G. Ápice da lâmina foliar. H. Ramo da inflorescência. I. Bráctea primária. J. Ramos com flores passadas e cápsulas, ilustração da obra princeps. K. Inflorescência e folha, ilustração da obra princeps. L. Alcantarea glaziouna ilustrada como Vriesea regina em F. Antoine, PhytoIconographie der Bromeliaceen, táb. IX, X, 1894. (Vouchers: C-I Versieux 342. Fotos: L.M. Versieux). 


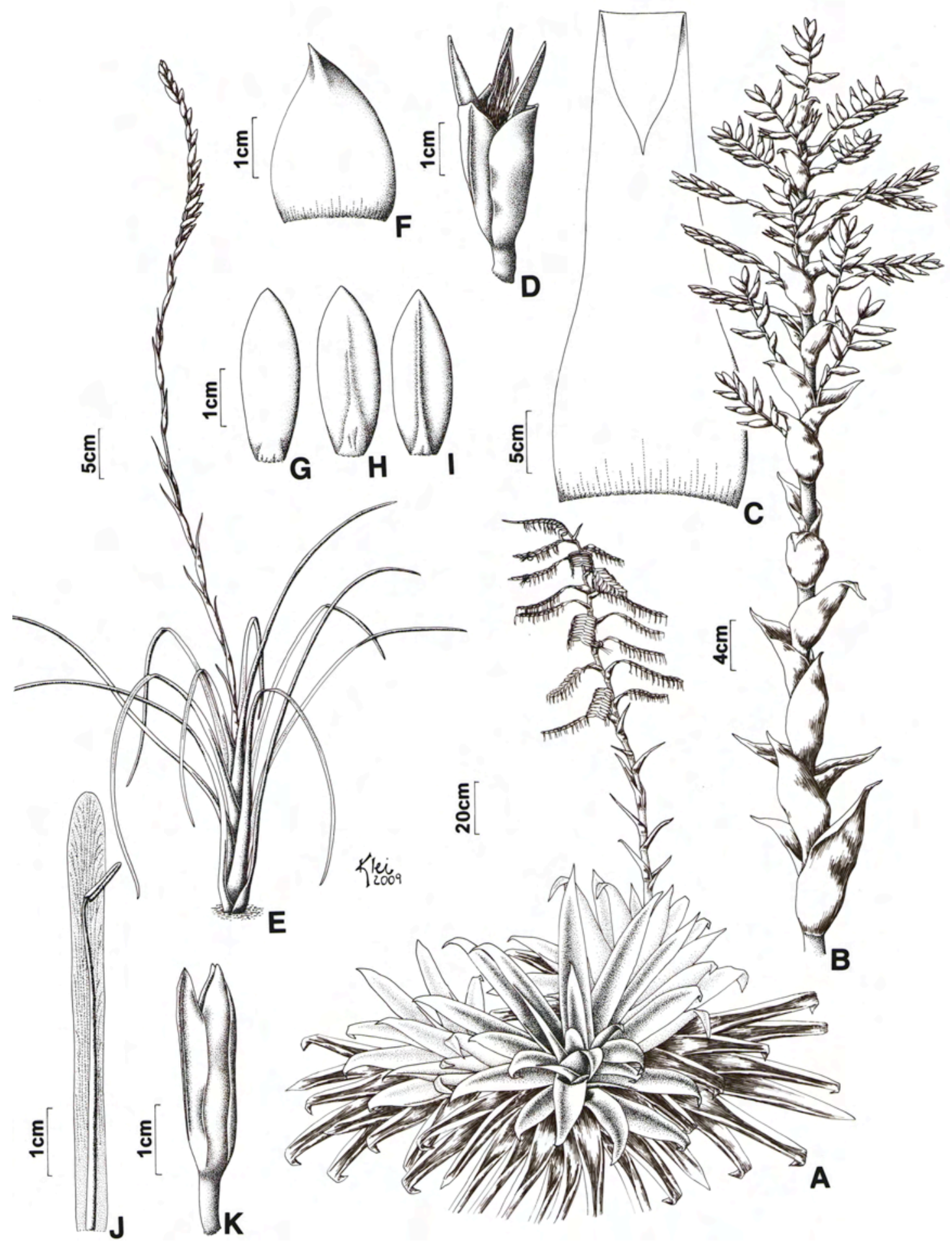

FIG. 19. Alcantarea glazionana, A. hatschbachii e A. vasconcelosiana. A. A. glazionana. Touceira com um indivíduo florido. B-D. A. vasconcelosiana. B. Inflorescência em frutificação. C. Folha. D. Cápsula. EK. A. hatschbachii. E. Hábito. F. Bráctea floral. G-I. Sépalas. J. Pétala e estame. K. Cápsula imatura. (Baseado em: A Versieux 342; B-D Versieux 363; E-I Hatschbach 40820; K Hatschbach 29085). 


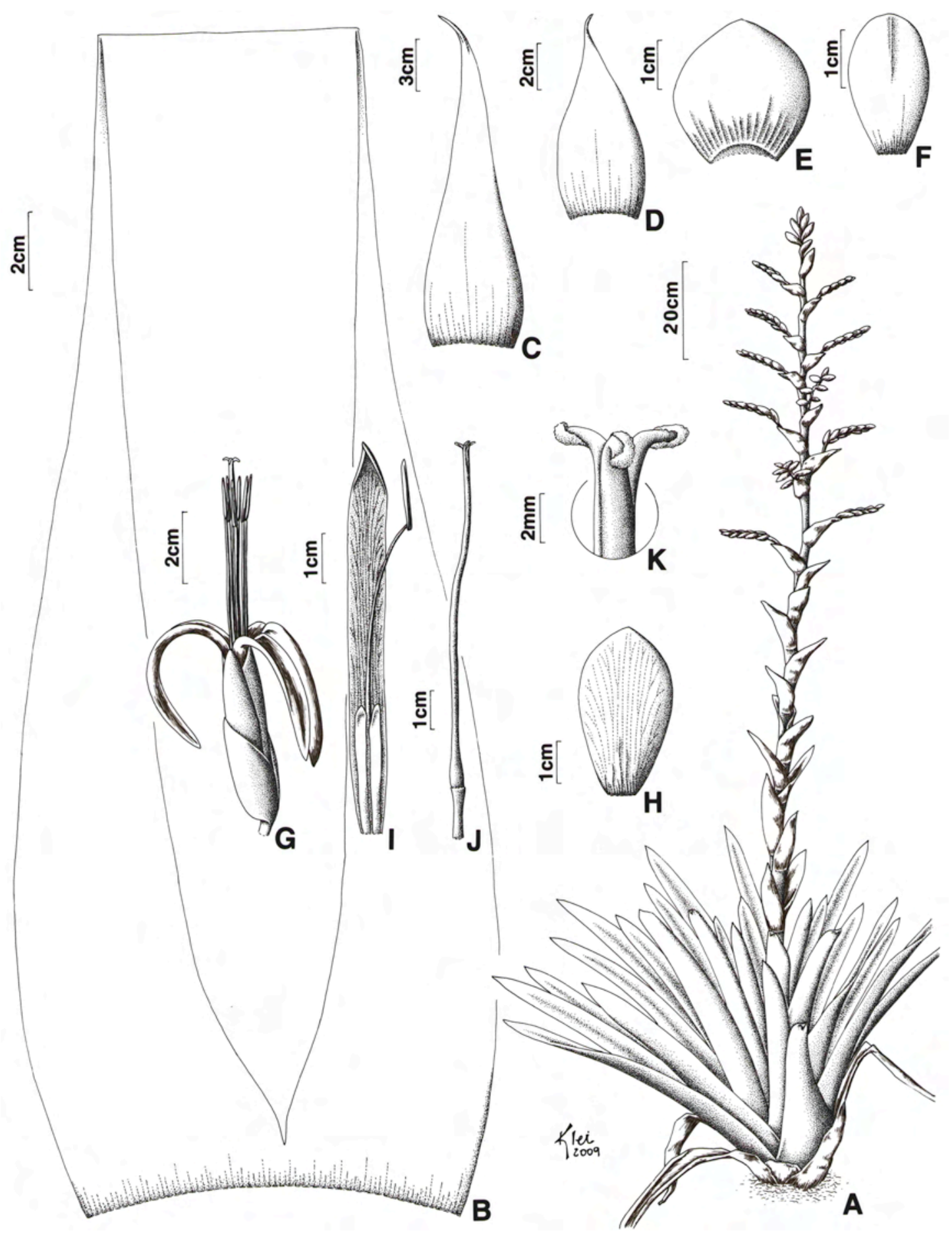

FIG. 20. Alcantarea heloisae. A. Hábito com inflorescência jovem. B. Folha. C. Bráctea do pedúnculo. D. Bráctea primária. E. Bráctea floral. F. Bráctea estéril. G. Flor. H. Sépala. I. Pétala, estame e apêndices petalíneos. J. Pistilo. K. Estigma trífido. (Baseado em: Versieux 238). 

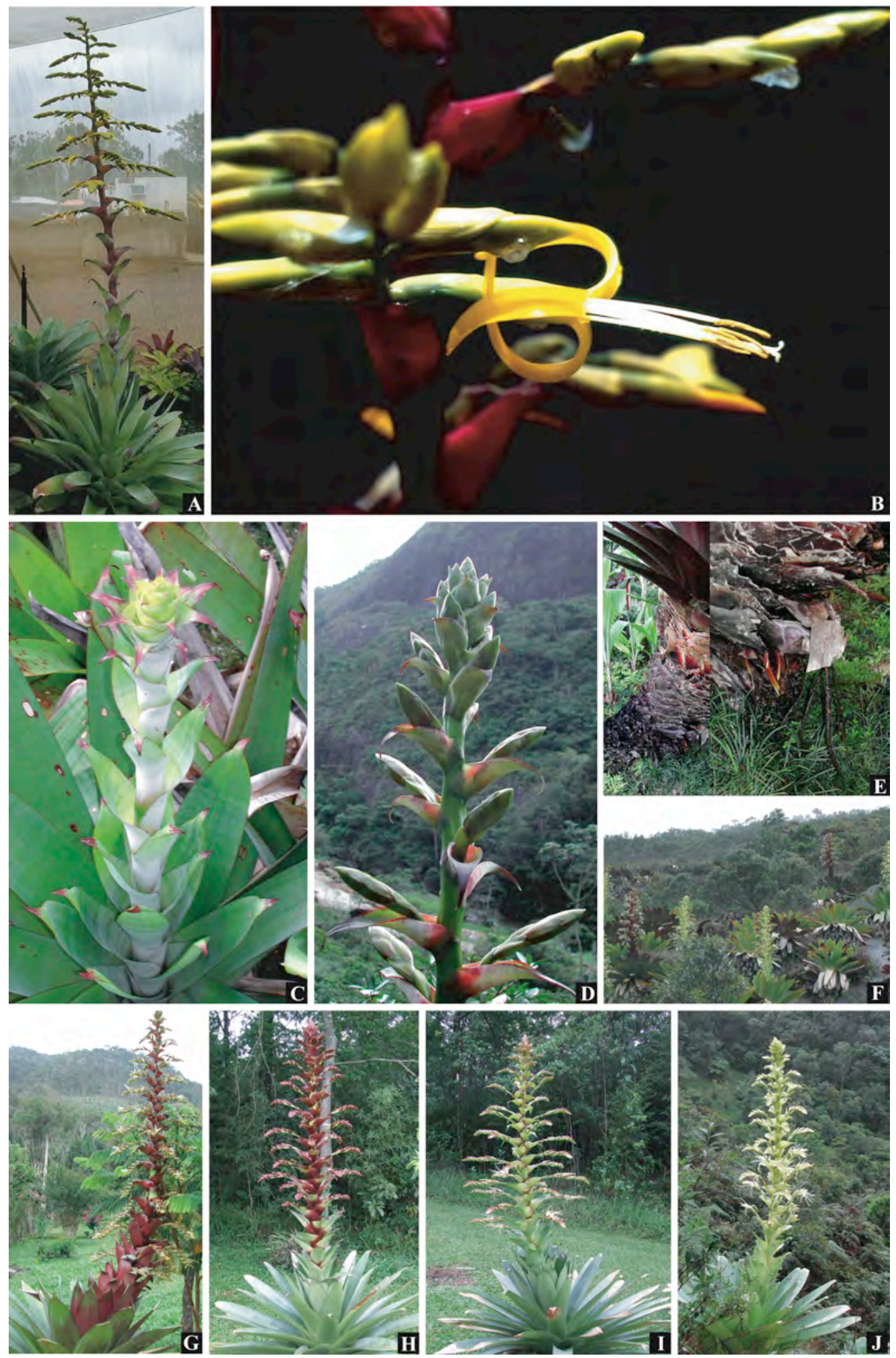

FIG. 21. Alcantarea heloisae e A. imperialis. A.-D. A. heloisae. A. Indivíduo florido em cultivo na Austrália. B. Detalhe da inflorescência. C. Indivíduo em início de emissão do pedúnculo. D. Indivíduo com inflorescência imatura. E.-J. A. imperialis. E. Caule coberto por restos de bainhas e detalhe das raízes adventícias. F. População em Macaé de Cima, Nova Friburgo, RJ com as duas morfo-cores. G. Indivíduo com folhas internas e brácteas vinosas. H. Indivíduo com folhas verdes e brácteas transitando do verde ao vinoso. I. Indivíduo com folhas e brácteas predominantemente verdes mas com leve matizes vinosos. J. Indivíduo com folhas e brácteas totalmente verdes. (Vouchers: B-E Versieux 238, 239; H Versieux 215; I Versieux 221. Fotos: L.M. Versieux exceto A. Mark Paul). 


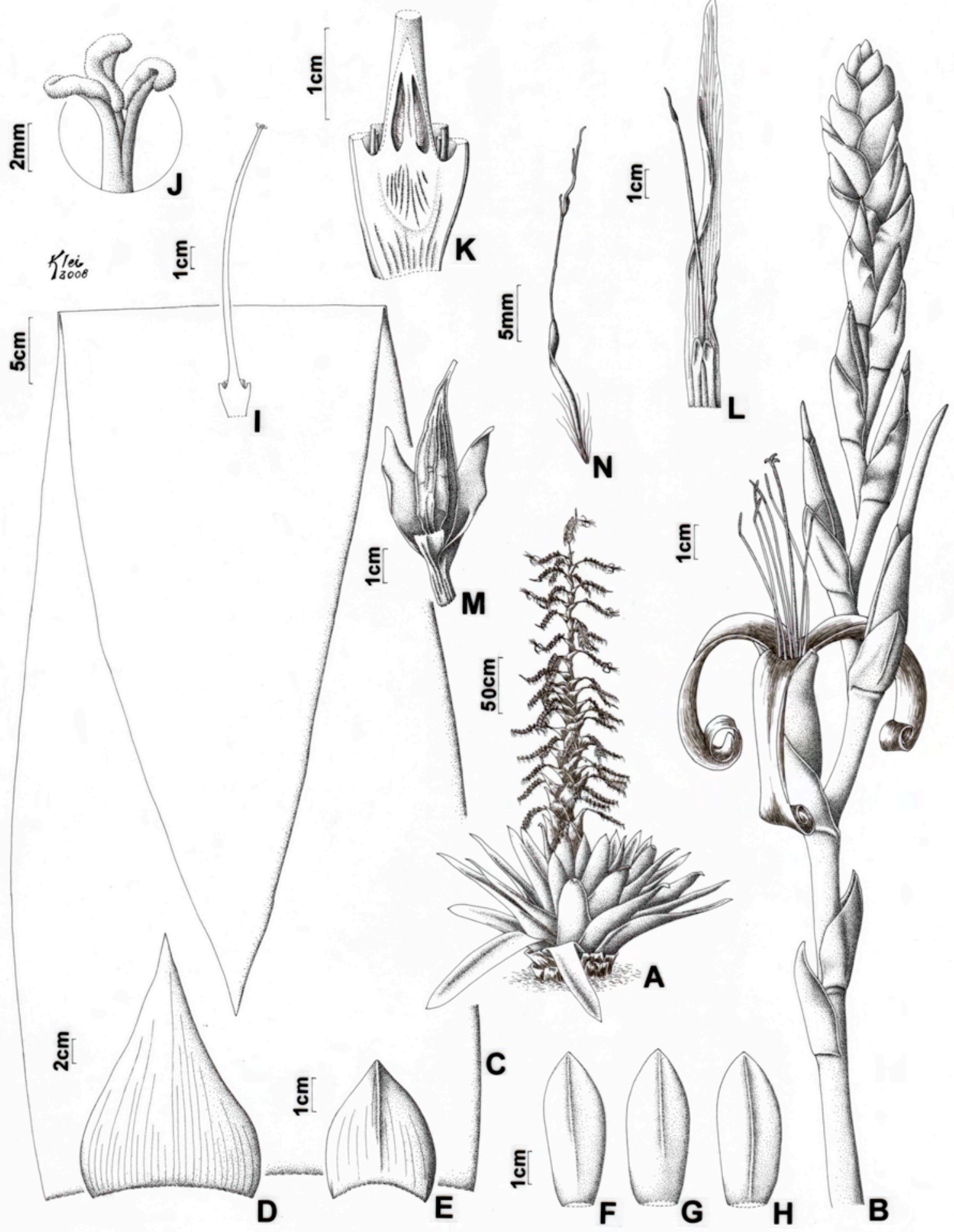

FIG. 22. Alcantarea imperialis. A. Hábito. B. Ramo da inflorescência. C. Folha. D. Bráctea primária. E. Bráctea floral. F., H. Sépalas dorsais. G. Sépala ventral. I. Pistilo. J. Estigma trífido. K. Ovário em corte longitudinal. L. Pétala e estame imaturo. M. Cápsula. N. Semente. (Baseado em: A-L Versieux 215; M-N Versieux 260). 

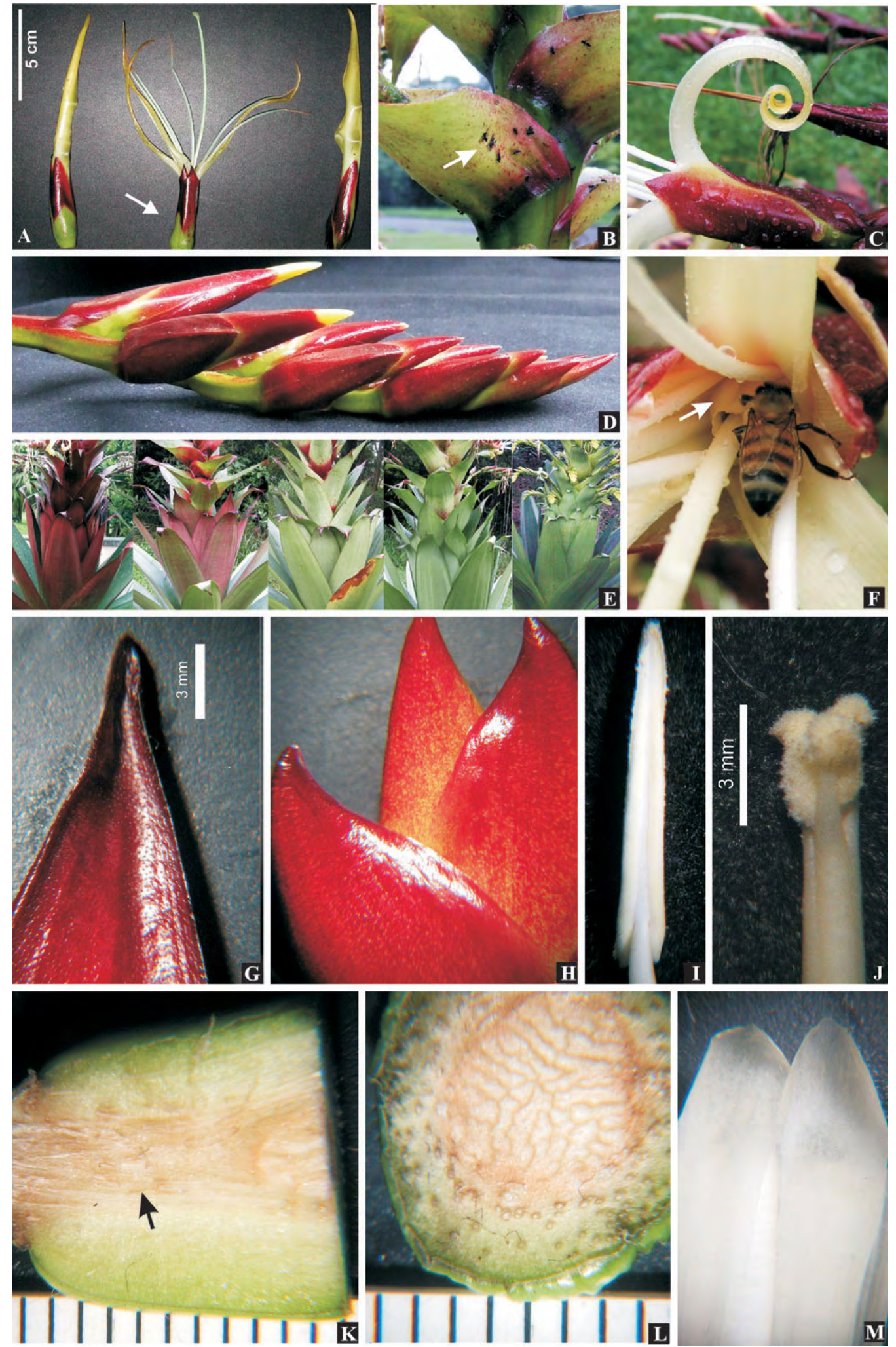

FIG. 23. Alcantarea imperialis. A. Botões florais e flores com cálice verde sob as brácteas e vinoso nas porções expostas ao sol. B. Insetos presos no exsudato viscoso que cobre a inflorescência. C. Pétala se enrolando no início da antese, no formato "mola de relógio". D. Ramo da inflorescência com botões florais tornando-se secundos. E. Rosetas mostrando variações de cor, do vinoso ao verde. F. Apêndice petalíneo (seta) bloqueando o acesso da abelha à base do ovário. G. Ápice apiculado da folha. H. Brácteas florais uncinadas. I. Antera (vista dorsal). J. Estigma com lobos eretos no préantese. K. Corte longitudinal da região do receptáculo. L. Corte transversal mostrando os nectários septais. M. Apêndices petalíneos. (Voucher: A-M, exceto E, Versieux 450. Fotos: L.M. Versieux). 

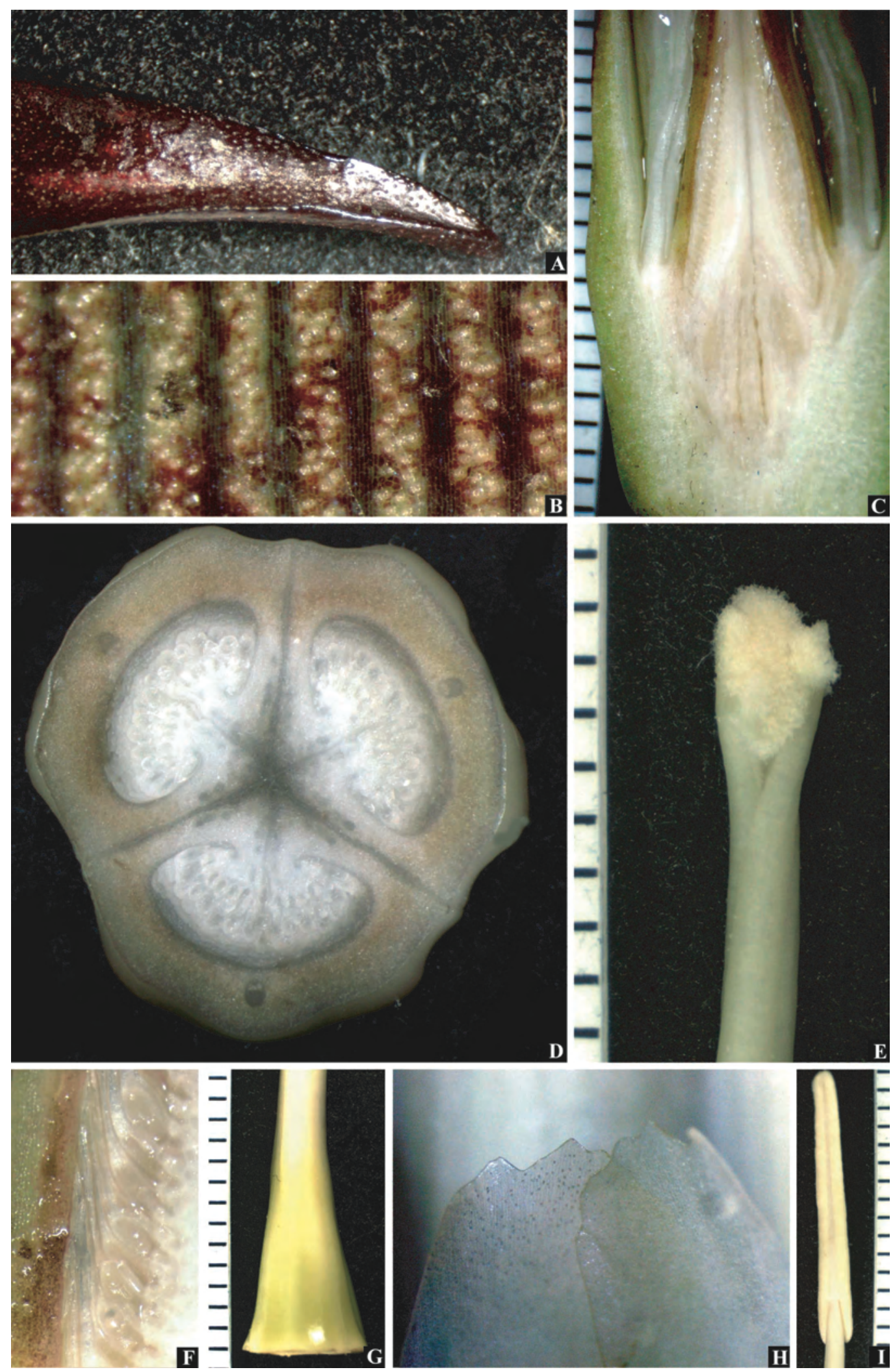

FIG. 24. Alcantarea imperialis. A. Detalhe do apículo da folha. B. Face abaxial da folha com estômatos organizados em fileiras. C. Corte longitudinal da flor, mostrando o hipanto e nectário septal. D. Corte transversal do ovário. E. Estigma com lobos eretos no pré-antese. F. Detalhe dos óvulos caudados. G. Ovário (porção súpera). H. Detalhe dos ápices dos apêndices petalíneos, denticulados. I. Antera mostrando a região do conetivo. (Escalas em mm). (Baseado em: Versieux 450, Fotos: L.M. Versieux). 

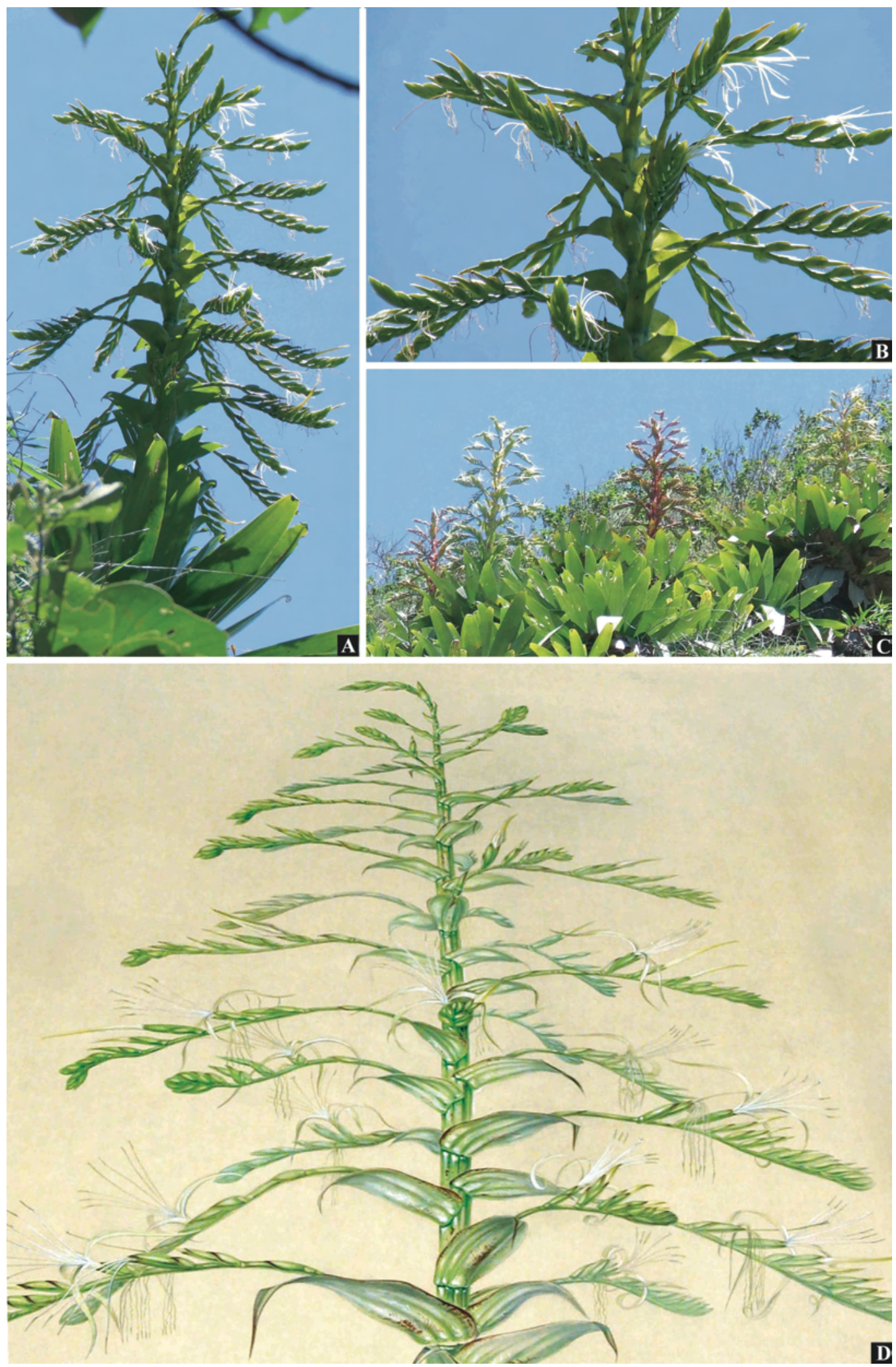

FIG. 25. Alcantarea imperialis. A.-B. Indivíduo florido na localidade-típica de $A$. brasiliana (=A. imperialis), em Meio da Serra, Petrópolis, RJ. C. População com indivíduos com brácteas verdes ou vinosas. D. Aquarela de E. Morren ilustrando A. imperialis feita em tamanho real e com grande semelhança aos indivíduos das populações de Meio da Serra, Petrópolis. Baseado em: A.-C. Versieux 451, 452, 453. (Fotos: A.-C. L.M. Versieux, D. Lynn Parker). 


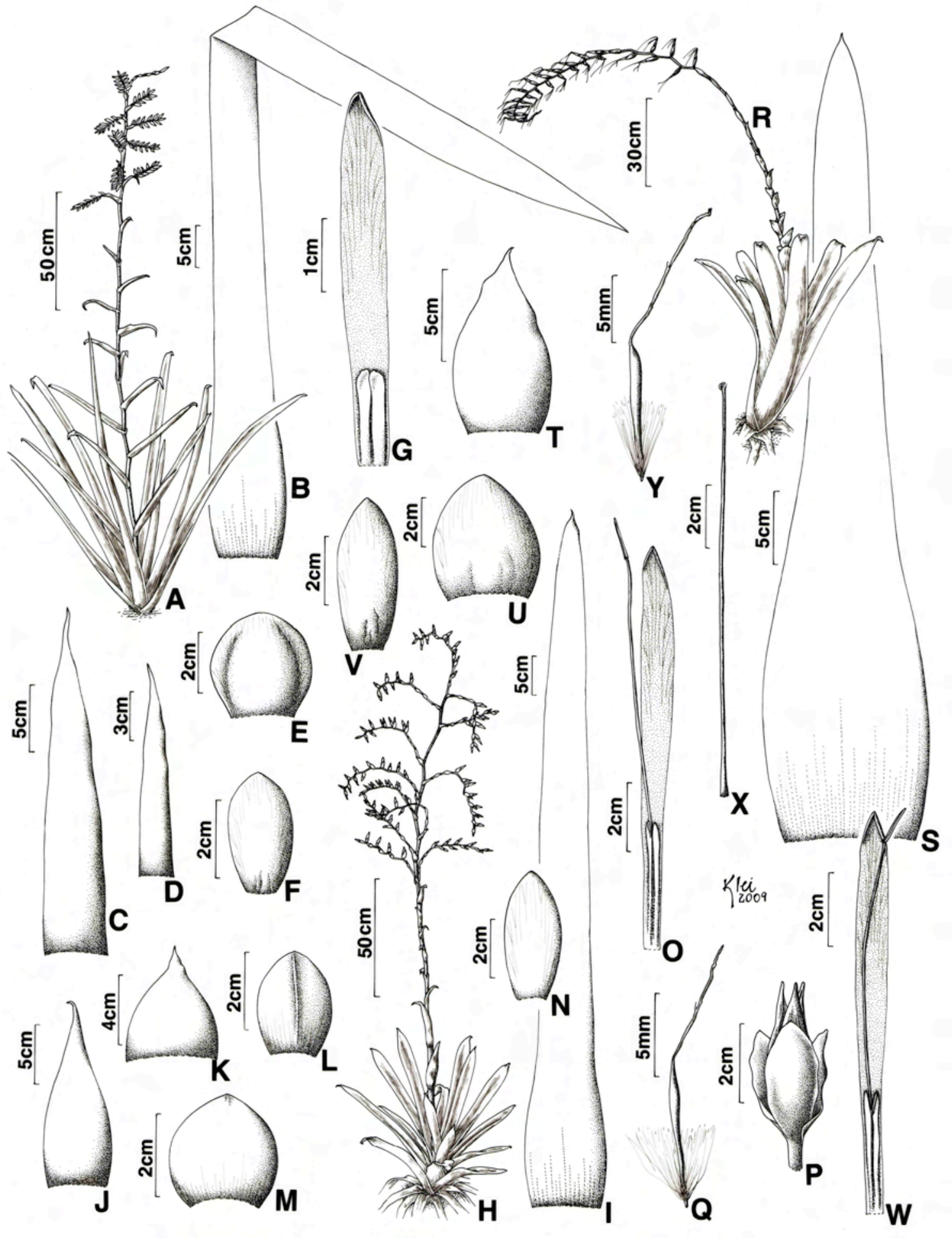

FIG. 26. Alcantarea longibracteata, A. nigripetala e A. simplicisticha.A.-G. A. longibracteata. A. Hábito. B. Folha. C.-D. Brácteas do pedúnculo. E. Bráctea floral. F. Sépala. G. Pétala com apêndices petalíneos. H.-Q. A. nigripetala. H. Hábito I. Folha. J. Bráctea do pedúnculo. K. Bráctea primária. L. Bráctea estéril . M. Bráctea floral. N. Sépala. O. Pétala. P. Cápsula. Q. Semente. R.-Y. A. simplicisticha. R. Hábito. S. Folha. T. Bráctea do pedúnculo. U. Bráctea floral. V. Sépala. W. Pétala, apêndices petalíneos e estame. X. Pistilo. Y. Semente. (Baseado em: A.-G.: Demuner 2267, Leme 7346, H.-Q. Leme 7381, MBML 36853, R.-Y. Leme 7355, Demuner 3551). 


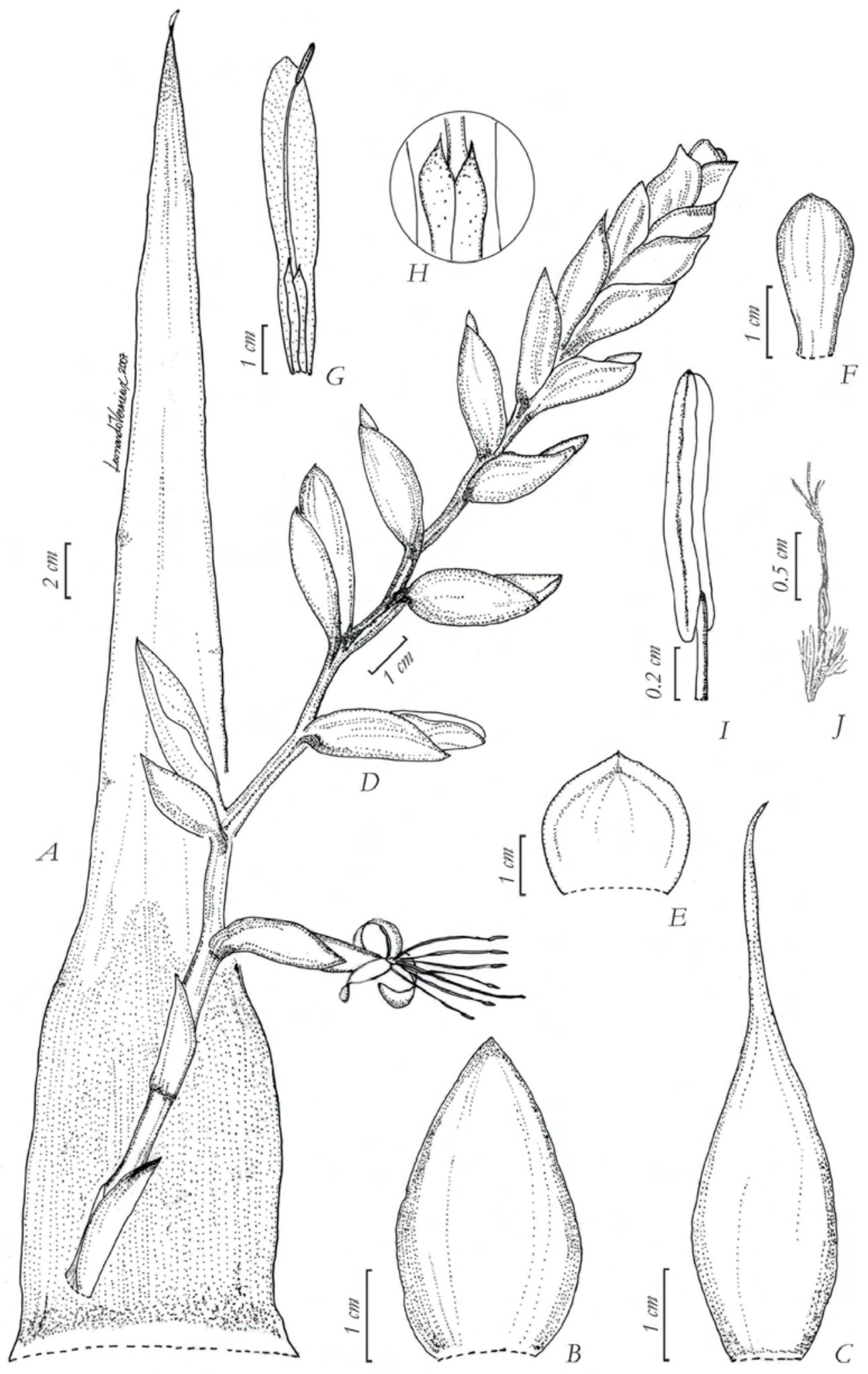

FIG. 27. Alcantarea martinellii. A. Folha. B. Bráctea do pedúnculo (distal). C. Bráctea do pedúnculo (proximal). D. Inflorescência. E. Bráctea floral. F. Sépala. G. Pétala, apêndices petalíneos e estame. H. Apice dos apêndices petalíneos. I. Antera e conetivo, vista dorsal. J. Semente. (Baseado em: P. I. S. Braga 1558 \& R. Braga 47). 

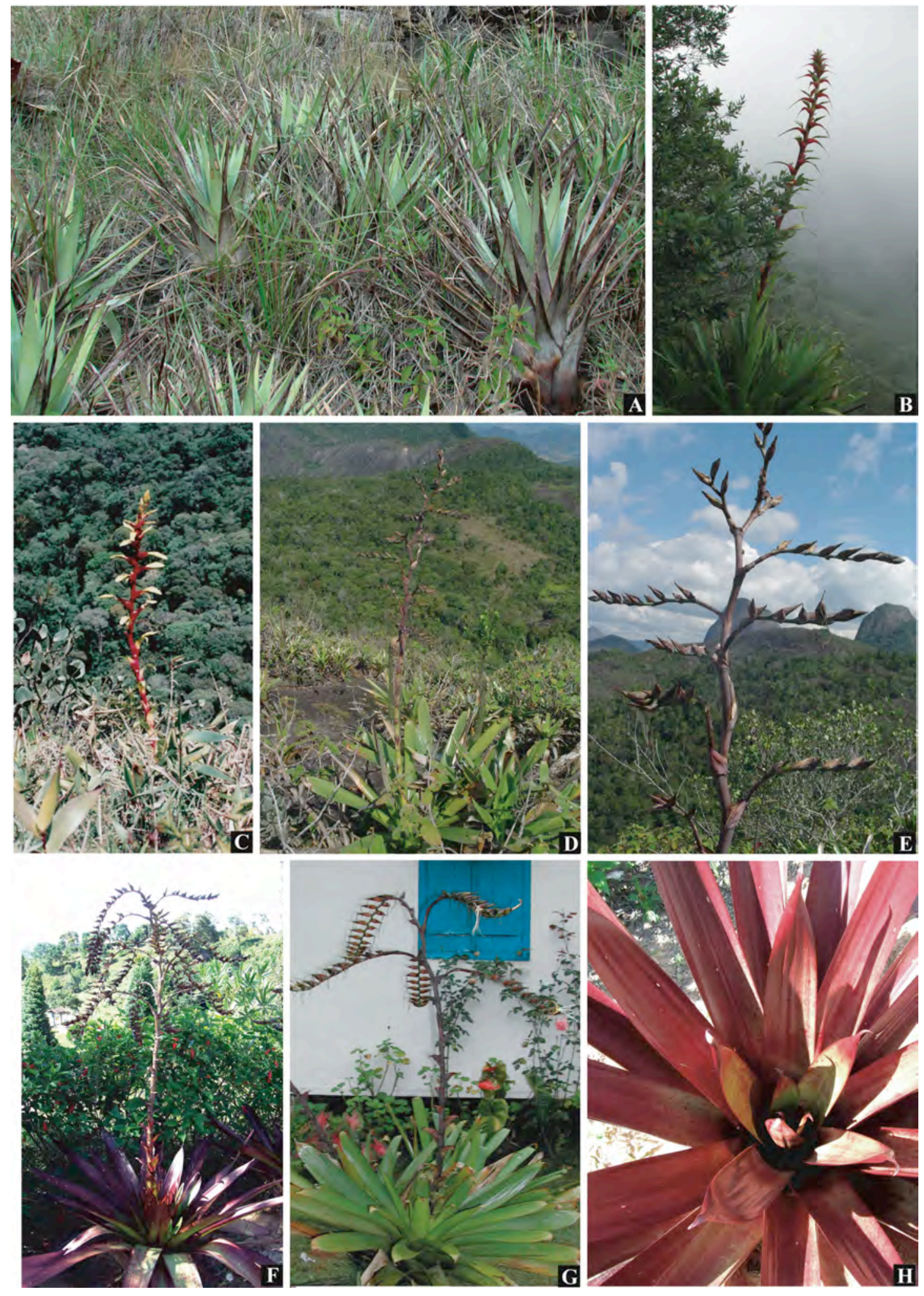

FIG. 28. A. População de Alcantarea martinellii na localidade típica, Pedra do Oratório, Petrópolis, RJ. B.-C. Alcantarea nevaresii em início de floração em Macaé de Cima, Nova Friburgo, RJ. D.-E. Alcantarea nigripetala. D. Hábito. E. Detalhe da inflorescência passada. F.-H. Alcantarea vinicolor. F. Indivíduo em frutificacão. G. Indivíduo em floracão. $\mathrm{H}$. Detalhe de uma roseta totalmente vinosa. Baseado em: A. Moraes 164 (RB), B. Versieux 223 (SP), D.-E. Louzada 22 (SP), F., H. Versieux 376 (SP), G. Versieux 384 (SP). Fotos: L. Versieux, exceto A. (M.A. Moraes) e D.-E. (R. Louzada). 


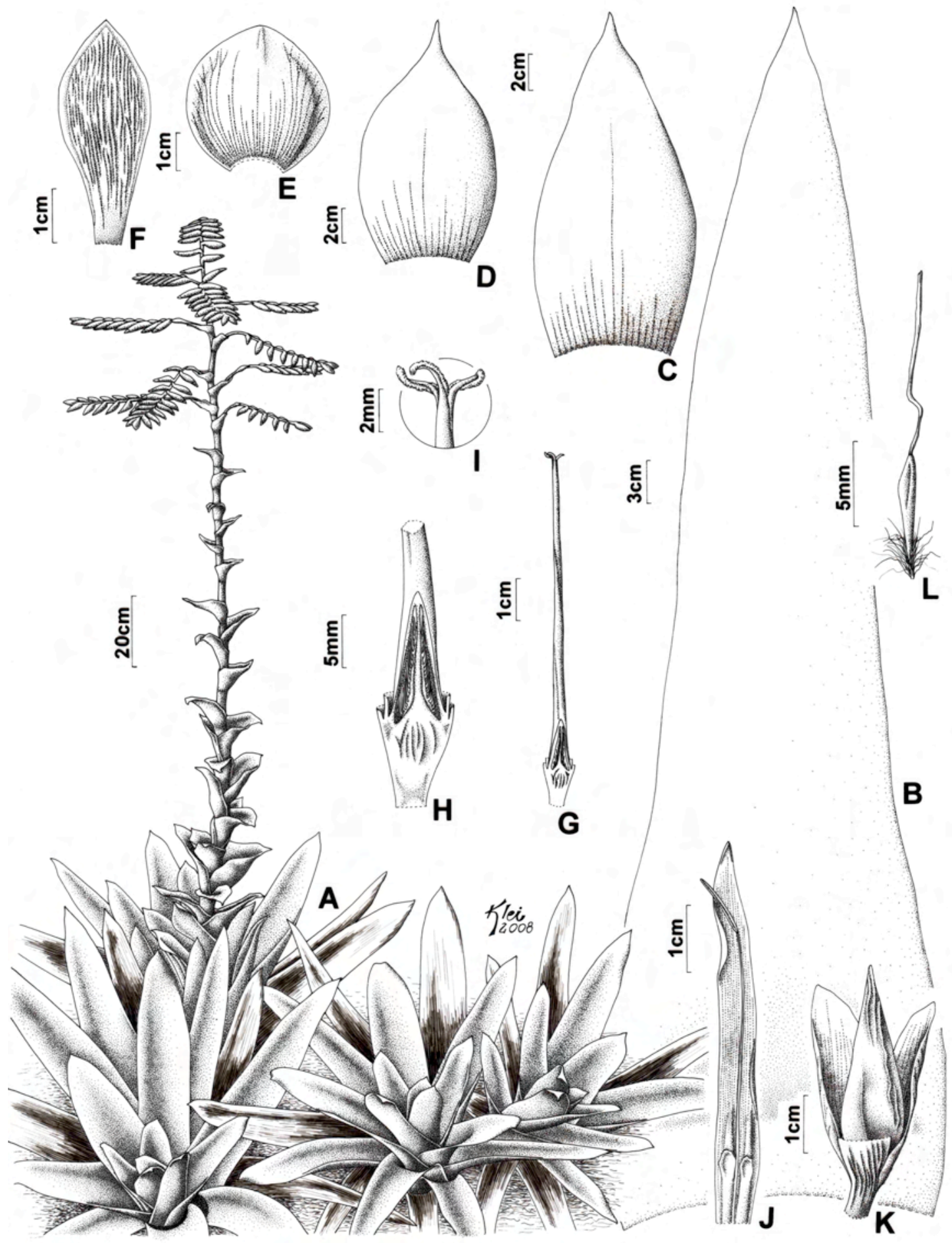

FIG. 29. Alcantarea nahoumii. A. Hábito. B. Folha. C. Bráctea do pedúnculo. D. Bráctea primária. E. Bráctea floral. F. Sépala. G. Pistilo. H. Ovário em corte longitudinal. I. Estigma trífido. J. Pétala com apêndices petalíneos e estame. K. Cápsula. L. Semente. (Baseado em: A-J Versieux 417; K-L Noblick \&Lemos 3547) 

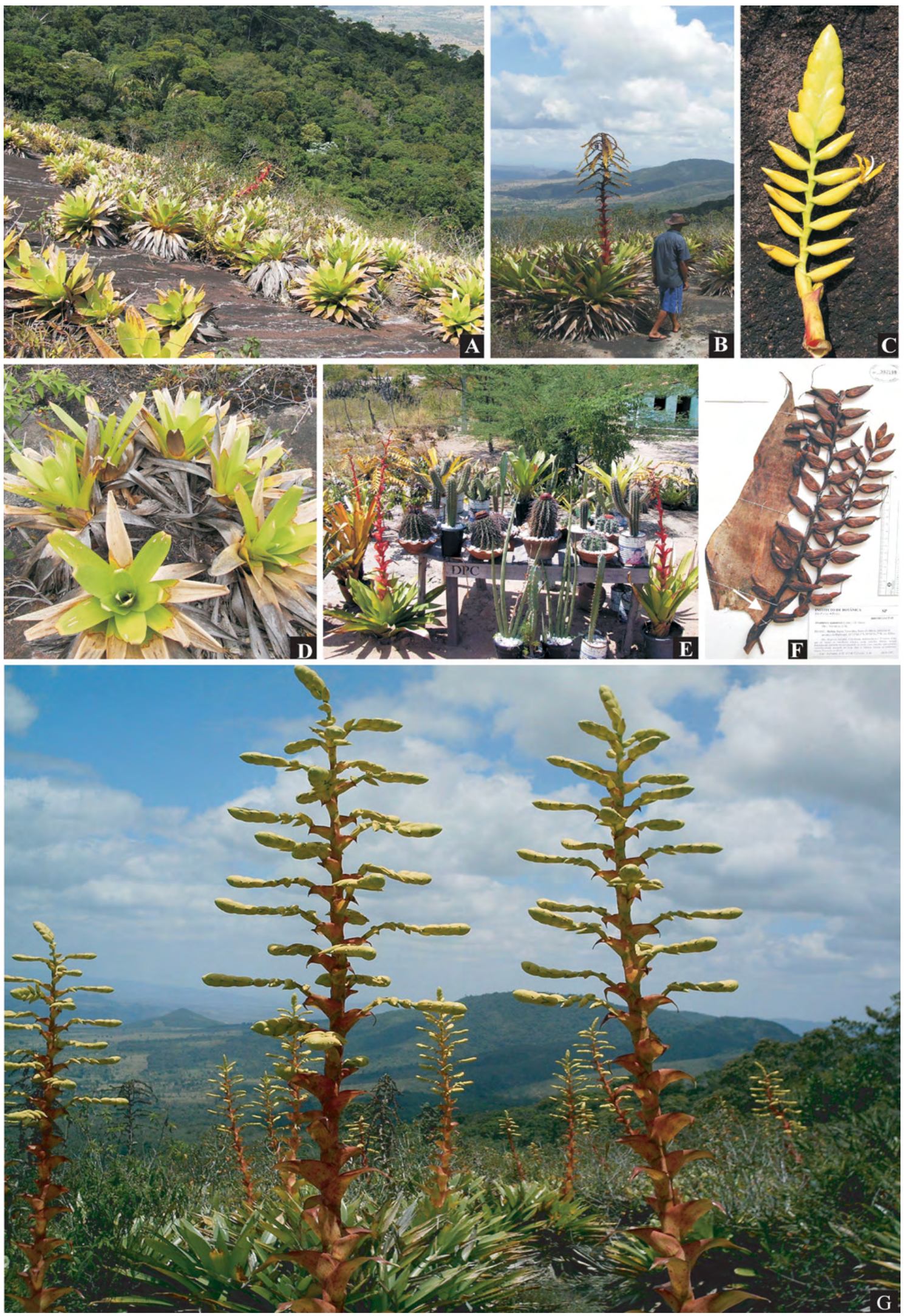

FIG. 30. Alcantarea nahoumii. A. Hábitat. B. Hábito. C. Ramo florido. D. Touceira circular formada por brotos em torno de uma planta-mãe. E. Comercialização de plantas floridas fruto do extrativismo. F. Detalhe de uma ramificação de segunda ordem, em um ramo lateral (seta). G. População florida em sincronismo. (Baseado em: Versieux 417, exceto G; Fotos: L.M. Versieux, exceto G.: HUEFS). 


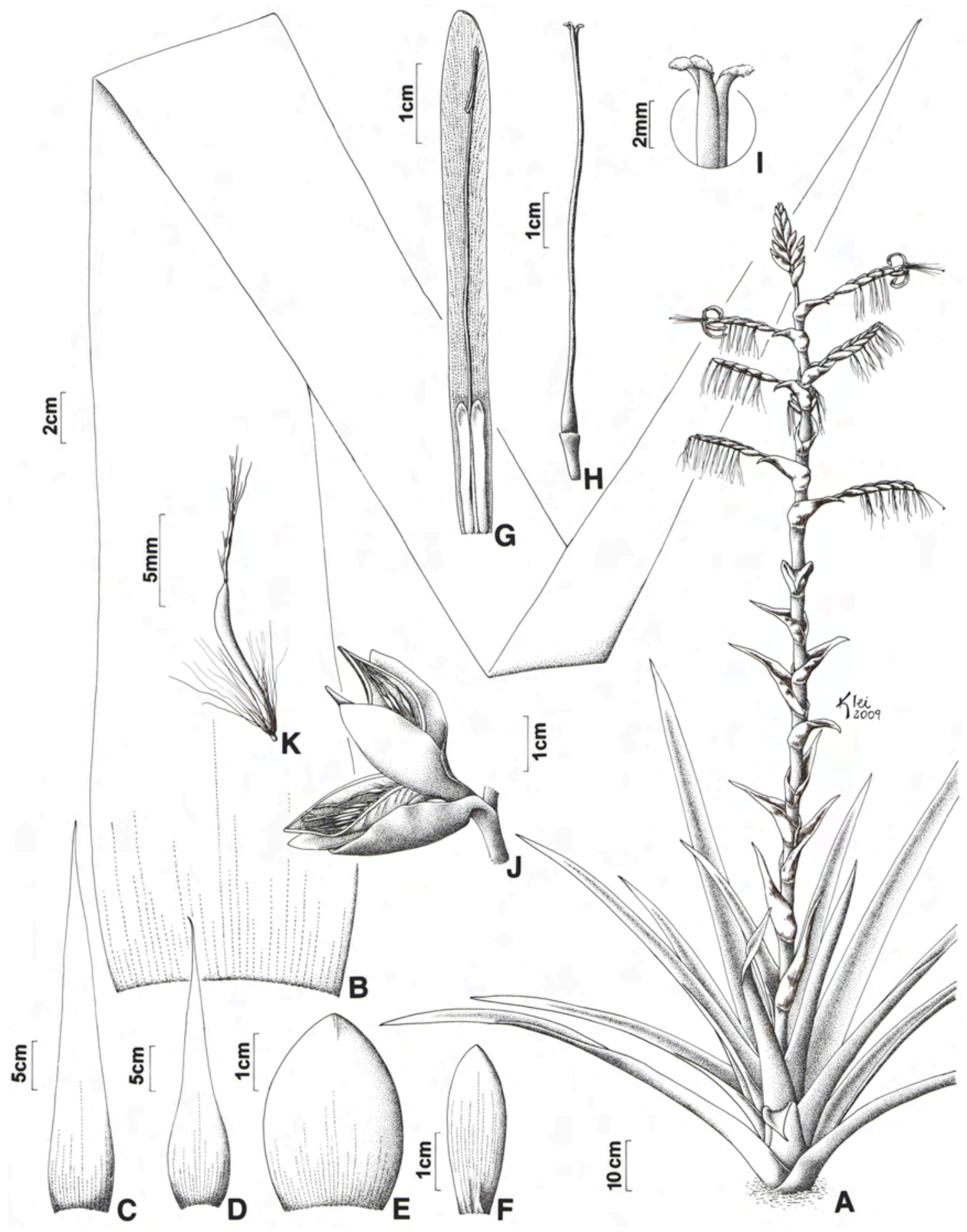

FIG. 31. Alcantarea nevaresii. A. Hábito. B. Folha. C. Bráctea do pedúnculo. D. Bráctea primária. E. Bráctea floral. F. Sépala. G. Pétala com apêndices petalíneos e estame. H. Pistilo. I. Estigma trífido. J. Cápsula madura. K. Semente. (Baseado em: A-I Versieux 223; J-K Leme 2227). 


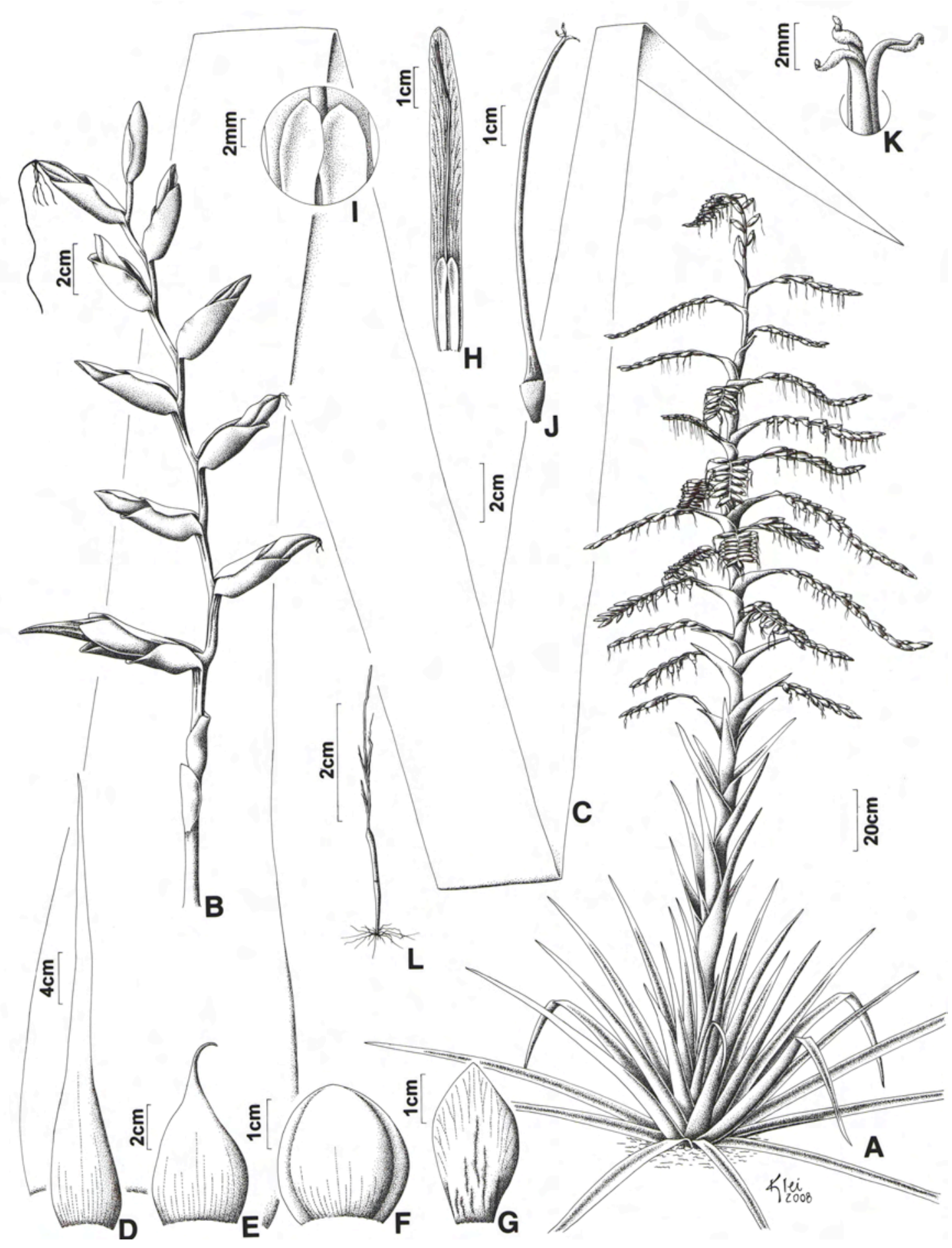

FIG. 32. Alcantarea odorata. A. Hábito. B. Ramo com cápsula imatura e flores passadas. C. Folha. D. Bráctea do pedúnculo. E. Bráctea primária. F. Bráctea floral. G. Sépala. H. Pétala com apêndices petalíneos e estame. I. Apêndices petalíneos, detalhe dos ápices. J. Pistilo. K. Estigma trífido. L. Semente. (Baseado em: A Versieux 432; B-L Versieux 433). 


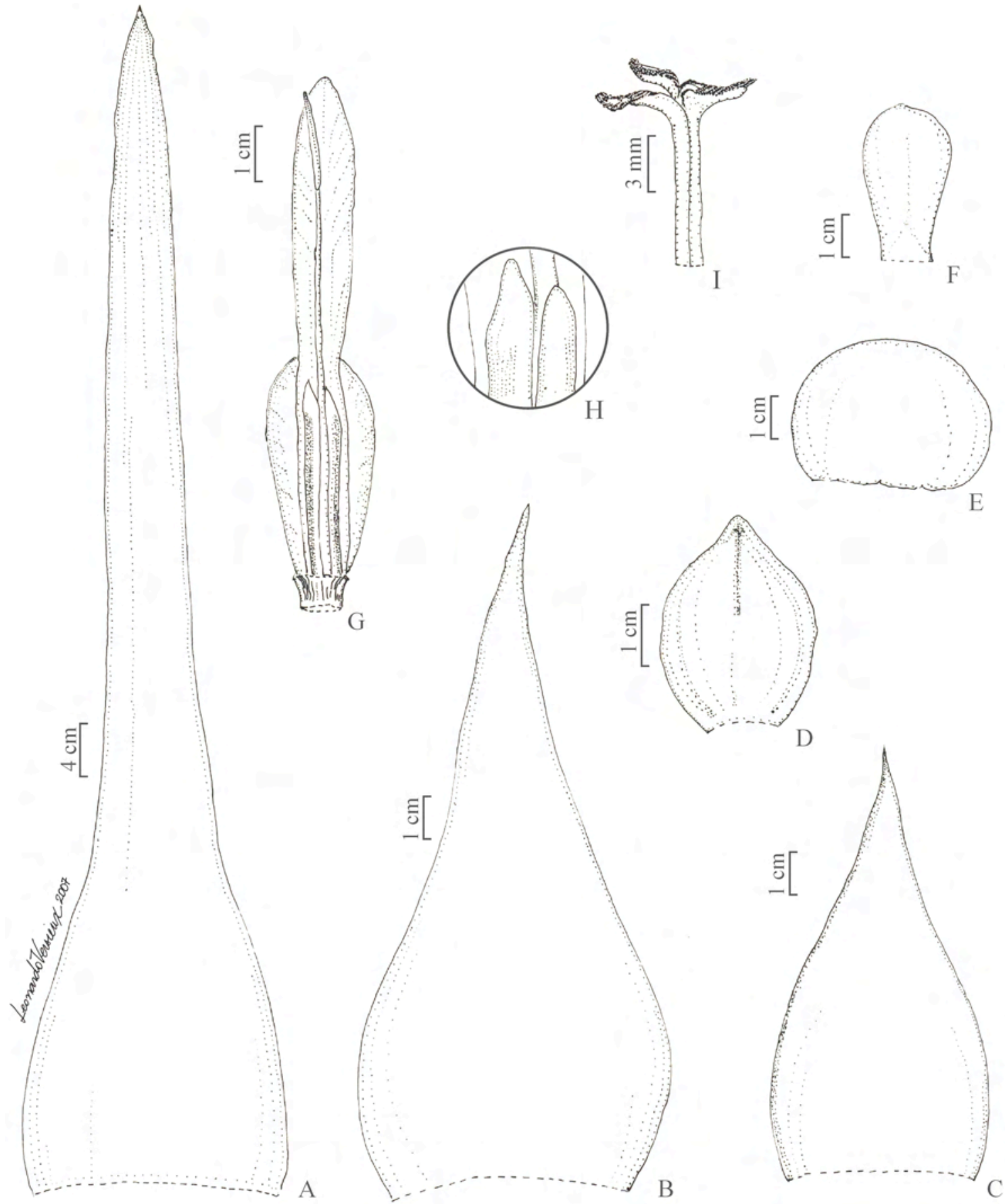

FIG. 33. Alcantarea patriae. A. Folha. B. Bráctea do pedúnculo. C. Bráctea primária. D. Bráctea estéril. E. Bráctea floral. F. Sépala. G. Pétala, apêndices petalíneos e estame antipétalo. H. Detalhe dos apêndices petalíneos. I. Estigma trífido. (Baseado em: Versieux 365). 

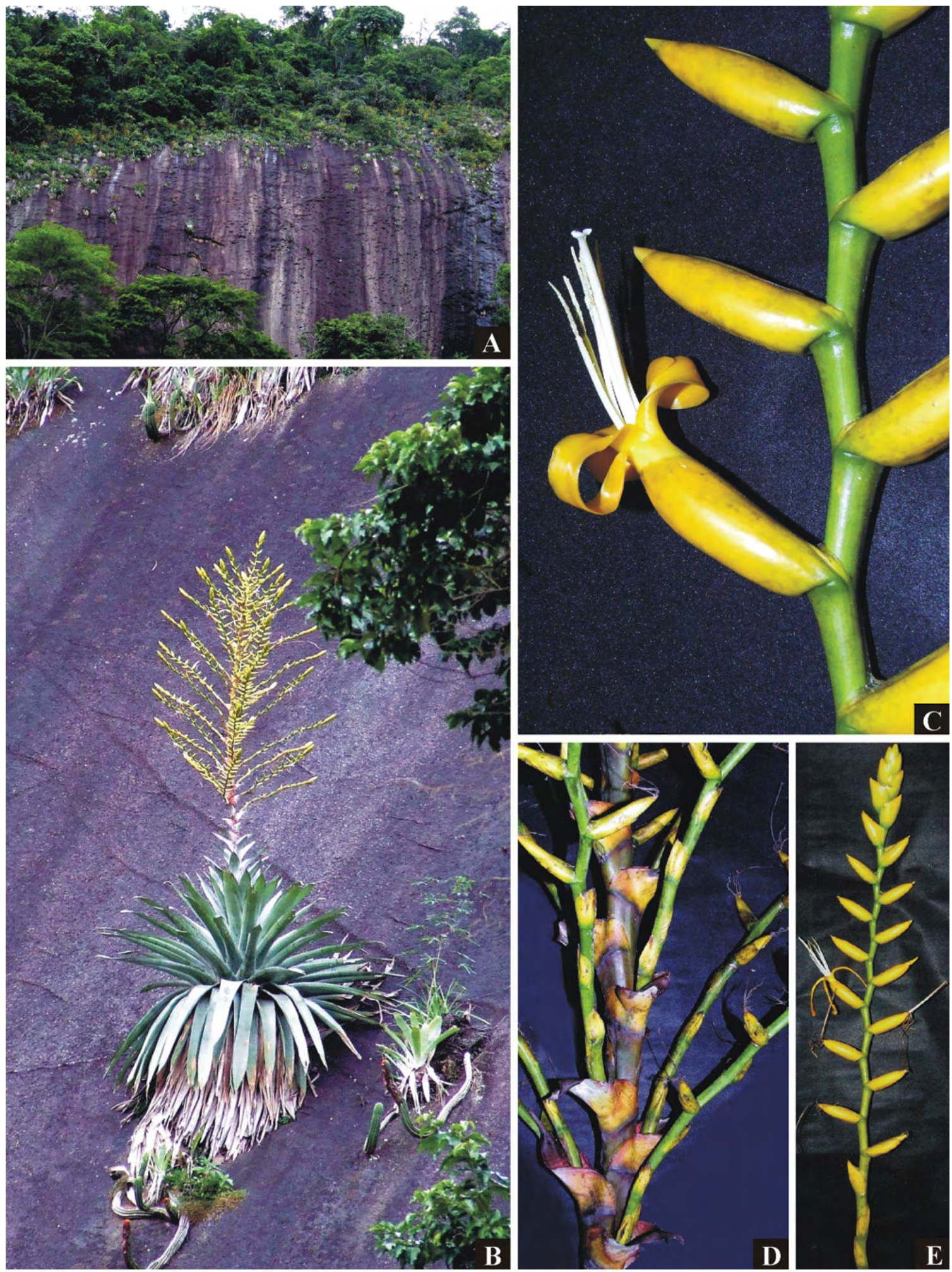

FIG. 34. Alcantarea patriae. A. Habitat. B. Indivíduo florido. C. Ramo com flor aberta. D. Eixo principal da inflorescência e pedúnculos laterais. E. Ramo da inflorescência. (Baseado em: Versieux 365). 


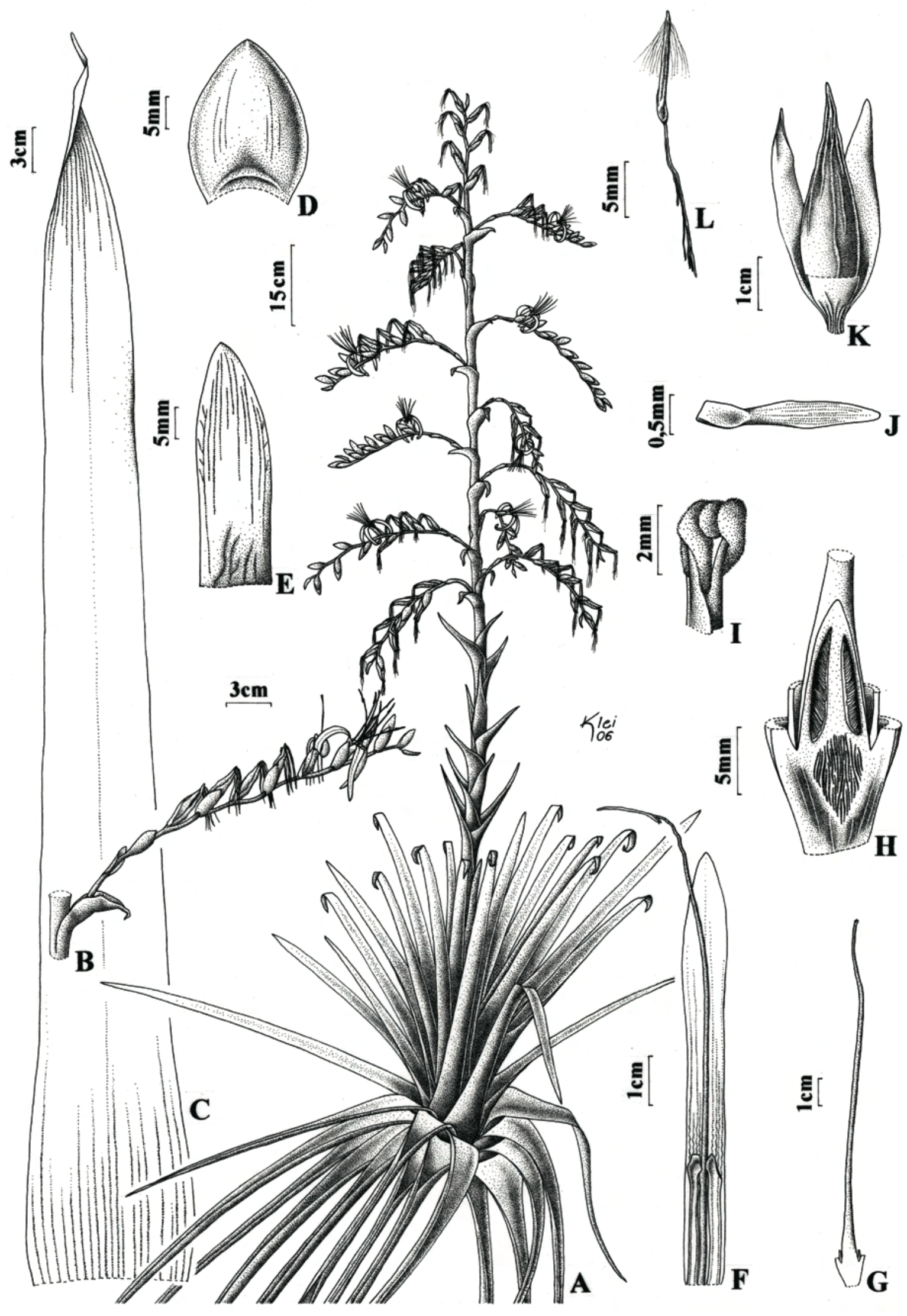

FIG. 35. Alcantarea regina. A. Hábito. B. Ramo da inflorescência. C. Folha. D. Bráctea floral. E. Sépala. F. Pétala, apêndices petalíneos e estame. G. Pistilo. H. Ovário, corte longitudinal. I. Estigma trífido. J. Óvulo. K. Cápsula. L. Semente. (Baseado em: A-J Versieux 265; K-L Campacci s.n. SP396342). 


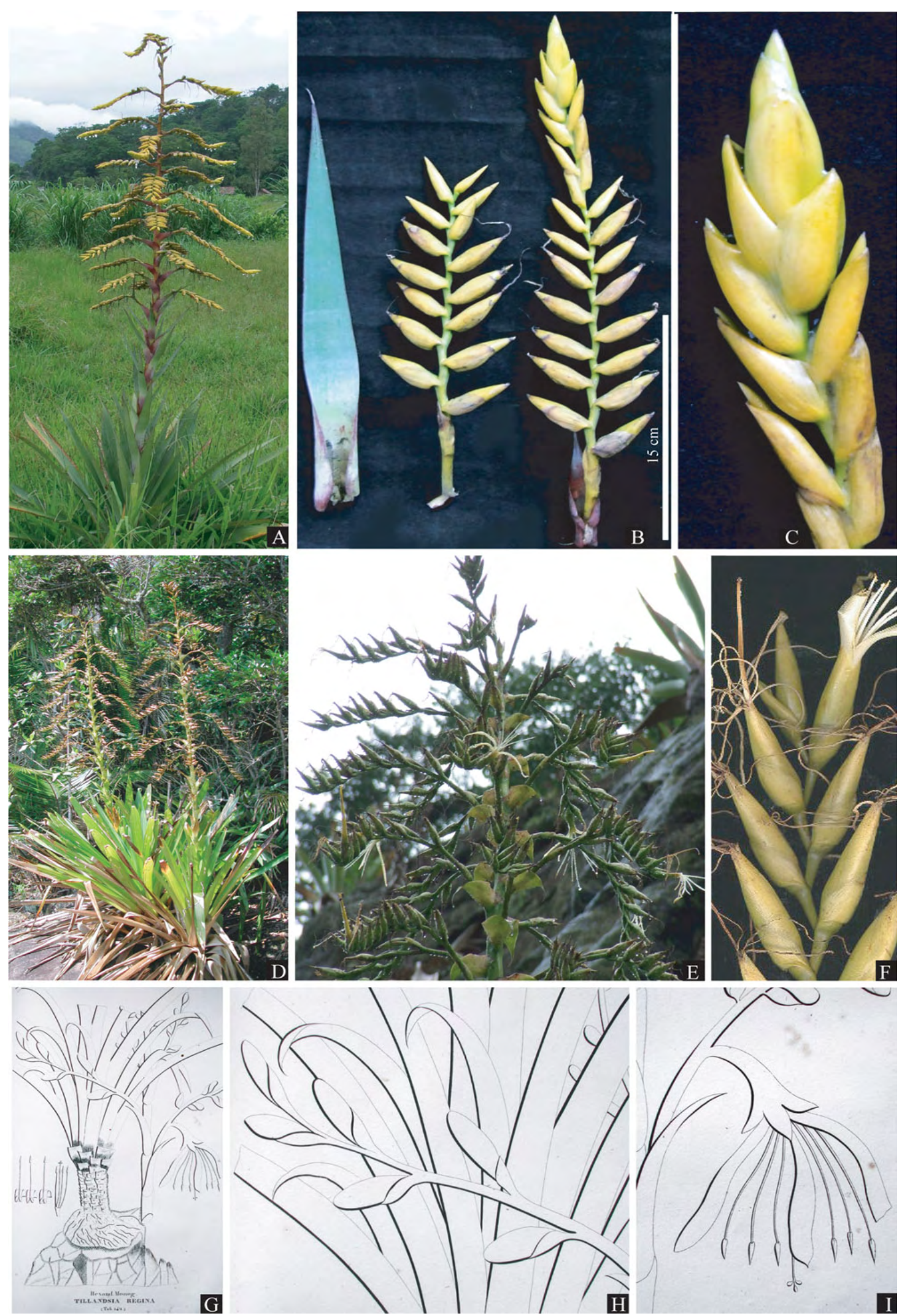

FIG. 36. Alcantarea odorata e A. regina. A.-C. A. odorata. A. Hábito. B. Bráctea do pedúnculo e ramos da inflorescência. C. Ramo da inflorescência com brácteas florais levemente infladas. D.-I. A. regina. D. Hábito. E. Inflorescência. E. Ramo da inflorescência. G.-I. Ilustração da obra princeps. (Baseado em: A Versieux 432; B-C Versieux 433; D Versieux 265; E Versieux 352. Fotos: L.M. Versieux, exceto F., M. Campacci; E., A.M.C. Versieux). 


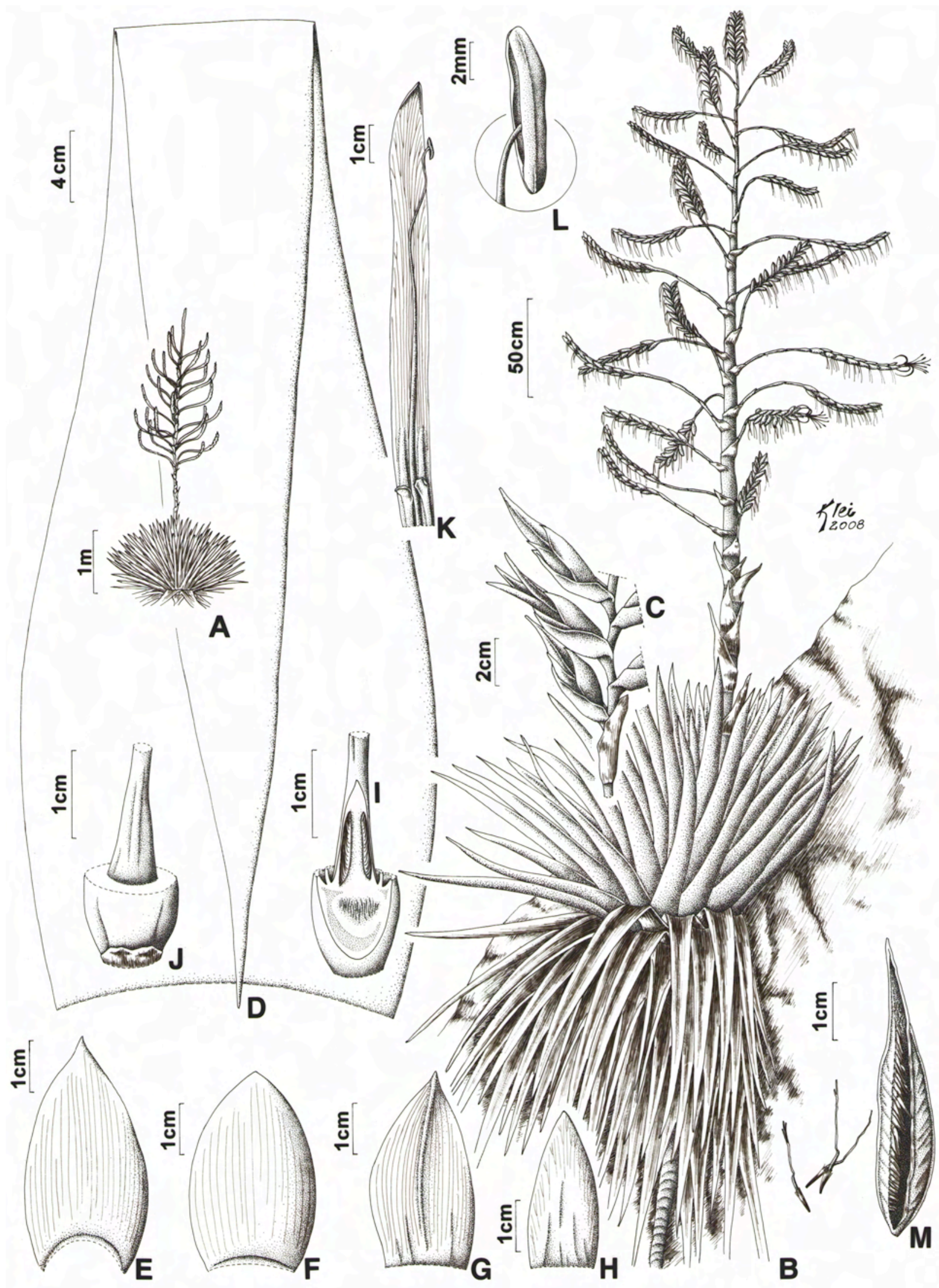

FIG. 37. Alcantarea roberto-kautskyi. A. Hábito no início da floração. B. Hábito no final da floração. C. Cápsulas maduras. D. Folha. E. Bráctea primária. F. Bráctea floral. G. Bráctea estéril. H. Sépala. I.-J. Ovário. K. Pétala, apêndices petalíneos e estame. L. Antera versátil. M. Carpídeo e sementes. (Baseado em: Versieux 430). 

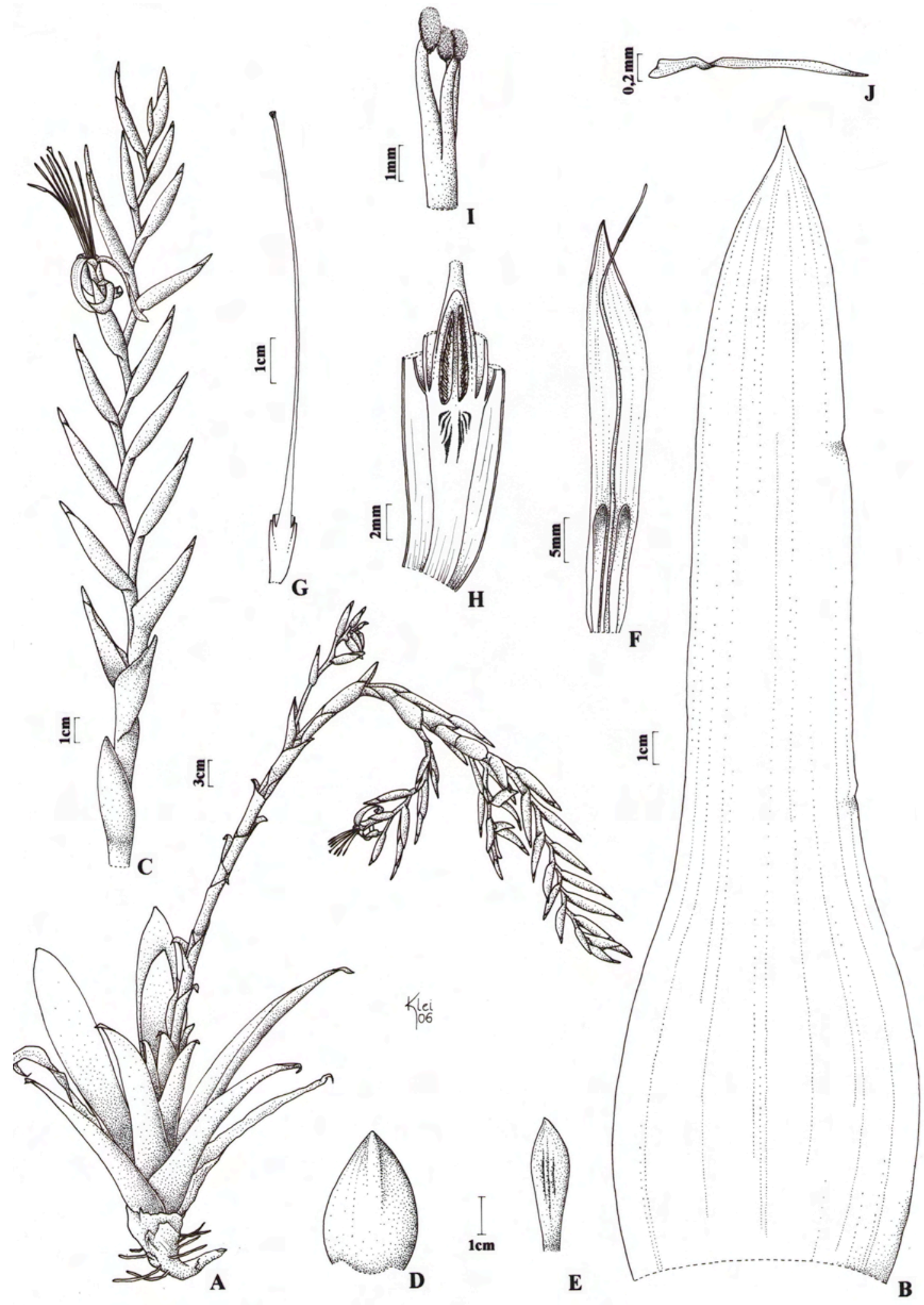

FIG. 38. Alcantarea tortuosa. A. Hábito. B. Folha. C. Ramo terminal da inflorescência. D. Bráctea floral. E. Sépala. F. Pétala, apêndices petalíneos e estame. G. Pistilo. H. Ovário, corte longitudinal. I. Estigma trífido. J. Óvulo. (Baseado em: Versieux 240). 


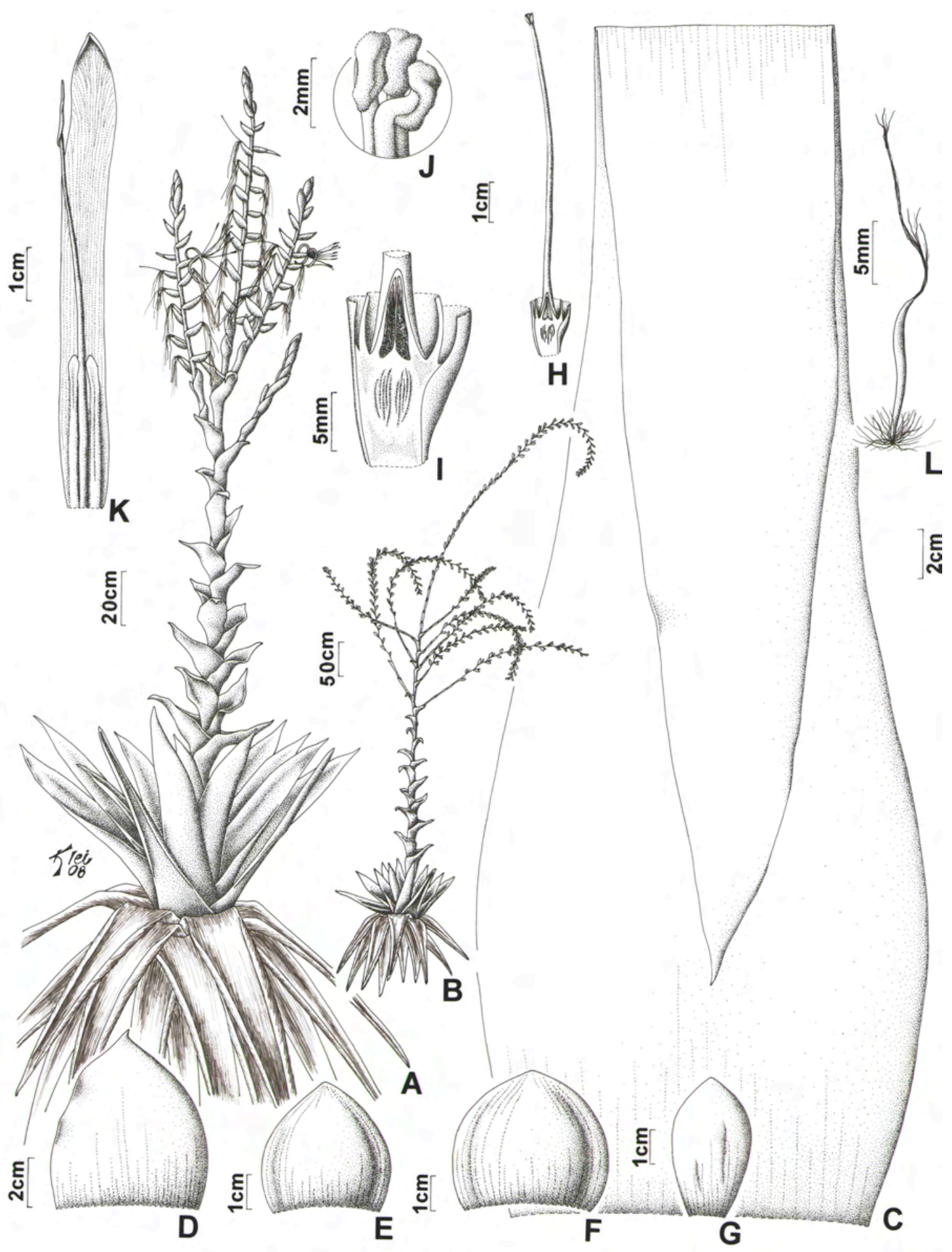

FIG. 39. Alcantarea trepida. A. Hábito na antese. B. Hábito na frutificação. C. Folha. D. Bráctea do pedúnculo. E. Bráctea primária. F. Bráctea floral. G. Sépala. H. Pistilo. I. Ovário, corte longitudinal. J. Estigma trífido. K. Pétala, apêndices petalíneos e estame. L. Semente. (Baseado em: A, C-J Versieux 396; B, L. Versieux 394). 

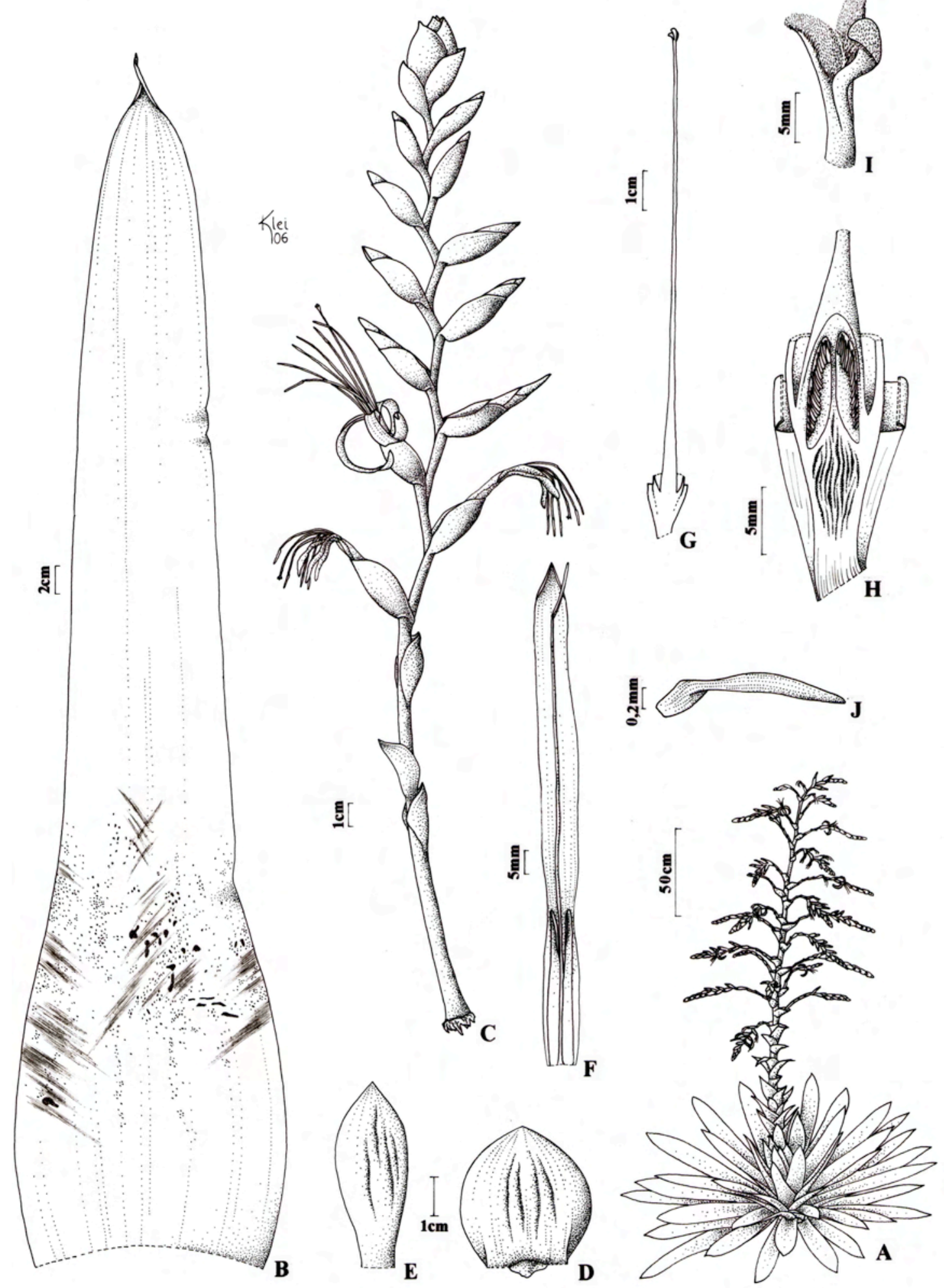

FIG. 40. Alcantarea turgida. A. Hábito. B. Folha. C. Ramo lateral da inflorescência. D. Bráctea floral. E. Sépala. F. Pétala, apêndices petalíneos e estame. G. Pistilo. H. Ovário, corte longitudinal. I. Estigma trífido. J. Óvulo. (Baseado em: Versieux 260). 

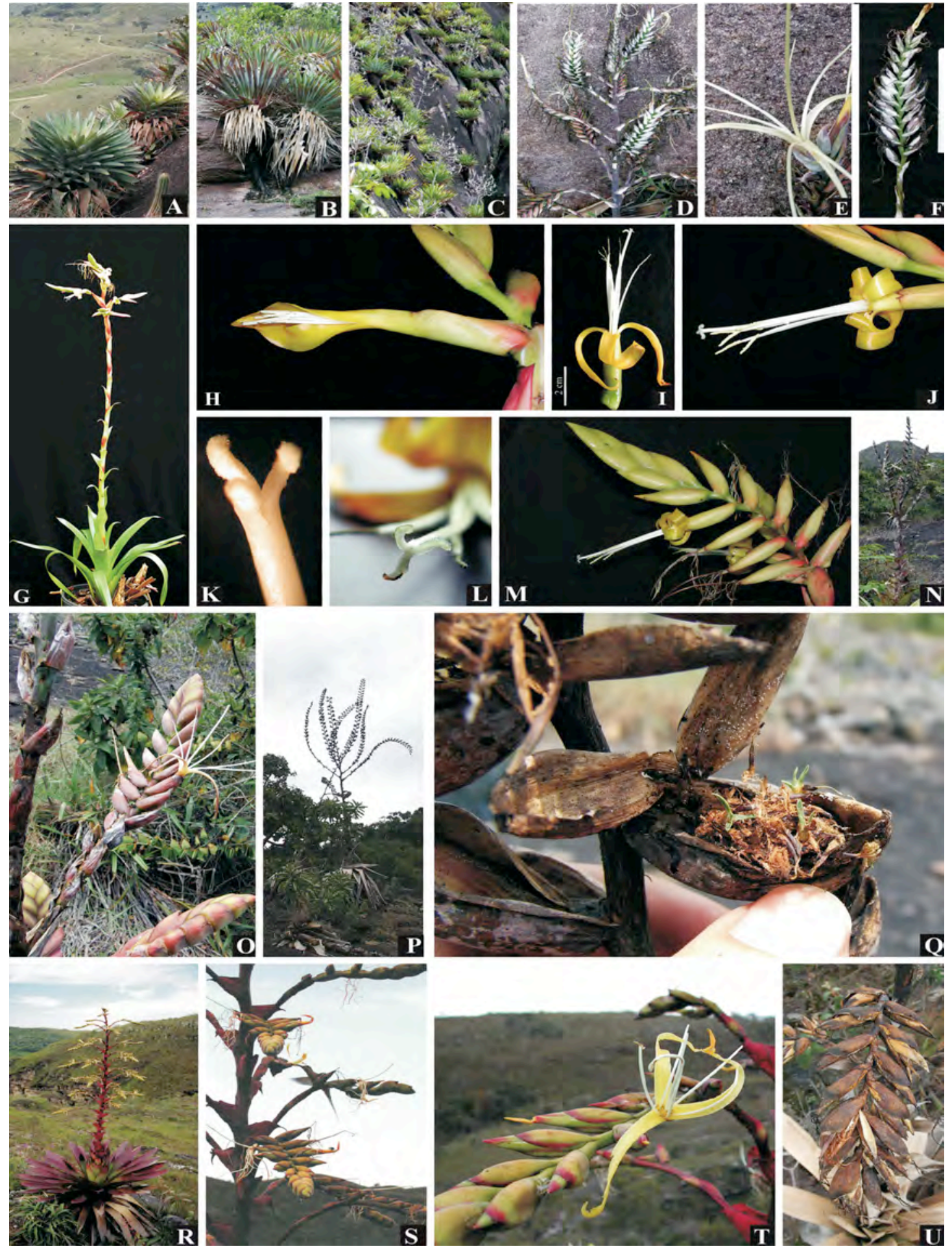

FIG. 41. Alcantarea roberto-kautskyi, A. tortuosa, A. trepida e A. turgida. A.-F. A. roberto-kantskyi. A. Indivíduo vegetativo na localidade-típica. B. Caule. C. População com centenas de indivíduos floridos em Pedra Grande, MG. D. Inflorescência. E. Flor. F. Ramo da inflorescência. G.-M. A. tortuosa. G. Hábito. H. Início da antese. I. Flor aberta. J. Flor aberta com pétalas enroladas. K. Estigma no início da antese. L. Estigma com lobos patentes. M. Ramo terminal da inflorescência. N.-Q. A. trepida. N. Hábito. O. Flor. P. Indivíduo após a frutificação. Q. Sementes geminando dentro da cápsula. R.-U. $A$. turgida. R. Hábito. S. Inflorescência sendo visitada por Phaetornis petrei. T. Flor com pétalas comidas por insetos. U. Cápsulas dispersando sementes. (Baseado em: A. Versieux 398; B.-F. Versieux 430; G.M. Versieux 241; N.-O. Versienx 395; P.-Q. Versieux 394. Fotos: L.M. Versieux, exceto Q.: A.M. Calvente) 


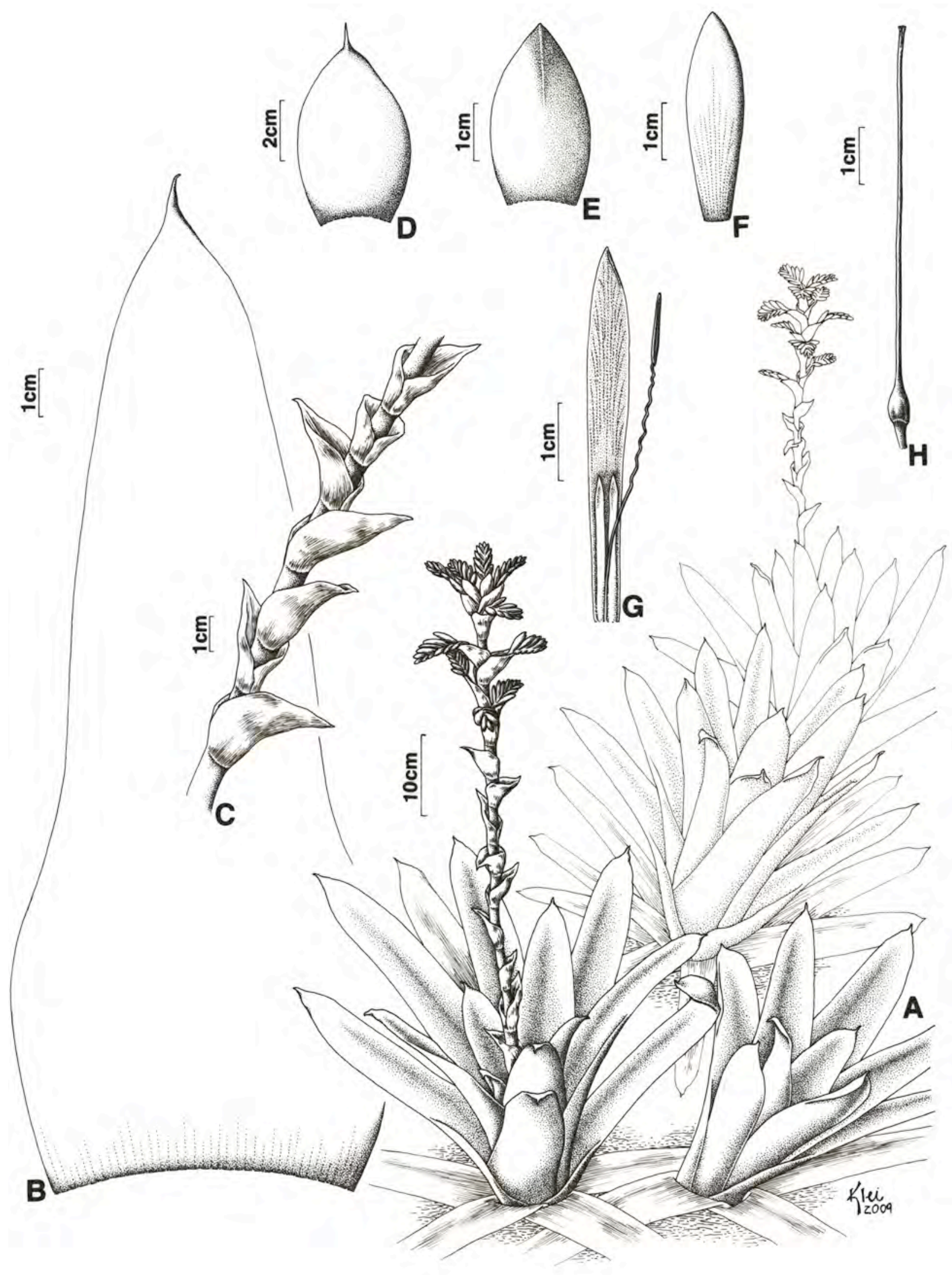

FIG. 42. Alcantarea vasconcelosiana. A. Hábito. B. Folha. C. Pedúnculo. D. Bráctea do pedúnculo. E. Bráctea estéril. F. Sépala. G. Pétala, apêndices petalíneos e estame. H. Pistilo. (Baseado em: Leitão s.n.). 

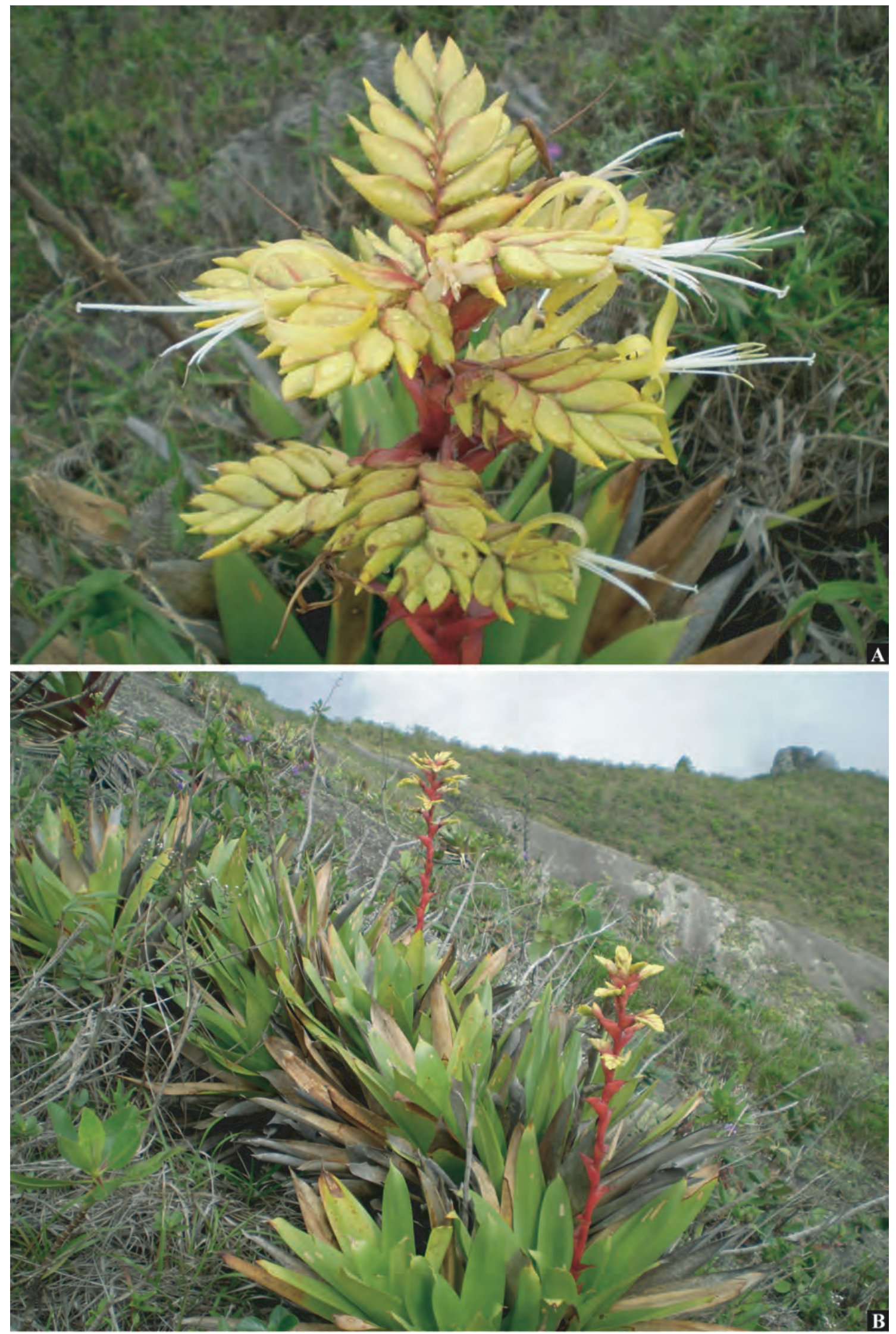

FIG. 43. Alcantarea vasconcelosiana. A. Detalhe da inflorescência densa e das brácteas florais ocultando a ráquila. B. Hábito dos indivíduos no hábitat. (Fotos: Reginaldo Vasconcelos Leitão). 


\section{LITERATURA CITADA}

Antoine, F. 1884. Phyto-Iconographie der Bromeliaceen des Kaiserlichen Koniglichen Hofburg-Gartens in Wien. Wien, In Comission bei Gerold \& Comp., 54p., 35 il.

Baker, J. G. 1889. Handbook of the Bromeliaceae. George Bell \& Sons, London.

Barbará, T., G. Martinelli, M. F. Fay, S. J. Mayo, and C. Lexer. 2007. Population differentiation and species cohesion in two closely related plants adapted to neotropical high-altitude 'inselbergs', Alcantarea imperialis and Alcantarea geniculata (Bromeliaceae). Molecular Ecology 16: 1981-1992.

—., C. Lexer, G. Martinelli, S. Mayo, M. F. Fay, M. Heuertz. 2008. Within-population spatial genetic structure in four naturally fragmented species of a neotropical inselberg radiation, Alcantarea imperialis, A. geniculata, A. glazionana and A. regina (Bromeliaceae). Heredity 101: 285-296.

Barber, H. N. 1955. Adaptive gene substitutions in Tasmanian Eucalypts: I. genes controlling the development of glaucousness. Evolution 9: 1-14.

Barfuss, M. H. J., R. Samuel, W. Till, and T. F. Stuessy. 2005. Phylogenetic relationships in subfamily Tillandsioideae (Bromeliaceae) based on DNA sequence data from seven plastid regions. American Journal of Botany 92: 337-351.

Beaman, R. S. \& W. Judd. 1996. Systematics of Tillandsia subgenus Pseudoalcantarea (Bromeliaceae). Brittonia 48: 1-19.

Beer, J. G. 1857. Die Familie der Bromeliaceen nach ibrem habituellen charakter bearbeitet mit bersonderer berücksichtigung der Ananassa. Wien, Tendler \& Comp. 271p.

Brown, G. K. and A. J. Gilmartin. 1984. Stigma structure and variation in Bromeliaceae - neglected taxonomic characters. Brittonia 36: 364-374.

—. and 1989. Chromosome numbers in Bromeliaceae. American Journal of Botany 76: 657-665.

Carauta, J.P.P. 1973. The text of Vellozo's Flora Fluminensis and its effectives date of publication. Taxon 22: 281-284.

Carrière, E. A. 1881. Vriesea glazioveana. Revue Horticole 53: 50-51.

—. 1888. Vriesea imperialis. Revue Horticole 60: 58.

Ceita, G. O., J. G. A. Assis, M. L. S. Guedes, and A. L. P. C. Oliveira. 2008. Cytogenetics of Brazilian species of Bromeliaceae. Botanical Journal of the Linnean Society 158: 189-193.

Costa, A. F. 2002. Revisão taxonômica do complexo Vriesea paraibica Wawra (Bromeliaceae). Ph.D. thesis. São Paulo: Universidade de São Paulo.

Fleming, L. 1996. Roberto Burle Marx: um retrato. Rio de Janeiro: Index Editora.

Forzza, R. C., A. V. Christianini, M. G. L. Wanderley, and S. Buzato. 2003. Encholirium (Pitcairnioideae - Bromeliaceae): conhecimento atual e sugestões para conservação. Vidalia 1: 7-20.

Gilmartin, A. J. 1983. Evolution of Mesic and Xeric Habits in Tillandsia and Vriesea (Bromeliaceae). Systematic Botany 8: 233-242. 
—. and G. K. Brown. 1987. Bromeliales, related monocots, and resolution of relationships among Bromeliaceae subfamilies. Systematic Botany 12: 493-500.

Graeff, O. R., and Y. V. Pagani. 1996. A associação fogo - capim gordura e o desaparecimento de Alcantarea imperialis. Bromélia 3: 13-15. Grant, J. R. 1994. Xerxes, a new name to replace Alcantara (Asteraceae: Vernoniae). Nordic Journal of Botany14: 287-288.

Grant, J. R. 1995a. The resurrection of Alcantarea and Weruabia, a new genus. Tropische und Subtropische Pflanzenwelt 91: 1-57.

---. 1995b. Addendum to "The ressurection of Alcantarea and Weraubia, a new genus" (Bromeliaceae: Tillandsioideae). Phytologia 78: 119-123.

—. 1995c. Sinopse do gênero Alcantarea. Bromélia 2: 24-26.

—. 2003. Alcantarea heloisae (Bromeliaceae), a new species from Rio de Janeiro State. Vidalia 1: 31-33.

—. and G. Zijlstra. 1998. An annotated catalogue of the generic names of the Bromeliaceae. Selbyana 19: 91-121.

Guedes-Bruni, R. and H. C. Lima. 1997. Mountain ranges of Rio de Janeiro, south-eastern Brazil. Pp. 376-380 in Centres of plant diversity, a guide and strategy for their conservation, vol. 3, eds. S. D. Davis, V. H. Heywood, O. Herrera-MacBryde, J. Villa-Lobos, and A. C. Hamilton. Cambridge, U.K.: WWF and IUCN, IUCN Publications Unit.

Halbritter, H. 1992. Morphologie und sistematische bedeutung des pollens der Bromeliaceae. Grana 31: 197-212.

Harms, H. 1929. Bromeliaceae novae III. Notizblatt des Botanischen Gartens und Museums zи Berlin-Dablem 10: $784-805$.

- 1930. Bromeliaceae. Pp. 65-159 in Die natürlichen Pflanzenfamilien nebst ibren Gattungen und wichtigsten Arten, insbesondere den Nutzpflanzen. Ed. 2, 15a, eds. A. Engler \& K. Prantl. Leipzig: Wilhelm Engelmann.

IUCN. 2001. IUCN Red list categories and criteria: version 3.1. Gland, Switzerland and Cambridge, United Kingdom: IUCN Species Survival Commission.

Leme, E. M. C. 1989. Novas Bromeliáceas nativas do Brasil - VI. Bradea 5: 166-187.

—. 1993. Novas Bromeliáceas nativas do Brasil: parte IX. Pabstia 4: 1-8.

—. 1995. Contribuição ao estudo do gênero Alcantarea I. Bromélia 2: 15-23.

—. 1997a. Contribuição ao estudo do gênero Alcantarea II. Bromélia 4: 29-40.

—. 1997b. Contribuição ao estudo do gênero Alcantarea III. Bromélia 4: 28-32.

- 1999. New species of Brazilian Bromeliaceae: a tribute to Lyman B. Smith. Harvard Papers in Botany 4: 135-168.

- 2007. Improving taxa and character sampling to support generic and infrageneric status of Alcantarea. Journal of the Bromeliad Society 57: 208-215.

-. 2009. Alcantarea mucilaginosa a new species from Espírito Santo, Brazil. Journal of the Bromeliad 
Society 59: 12-15.

- 2009. Notes on Alcantarea: a new medium-sized species and additions to A. roberto-kautskyi. Journal of the Bromeliad Society 59: 19-27.

—. and C. C. Paula. 2008. Two new Alcantarea species from Minas Gerais. Journal of the Bromeliad Society 58: 5-11.

—., C. N. Fraga, L. J. C. Kollmann, and A. P. Fontana. 2008. Three new Alcantarea species from Espírito Santo and Minas Gerais, Brazil. Journal of the Bromeliad Society 58: 205-216.

Lorenzi, H and H. M. Souza. 2001. Plantas ornamentais do Brasil, arbustivas, herbáceas e trepadeiras. 3 ed. Nova Odessa: Instituto Plantarum.

Lüttge, U. 1997. Physiological ecology of tropical plants. Berlin: Springer.

Marchant, C. J. 1967. Chromosome evolution in the Bromeliaceae. Kew Bulletin 21: 161-168.

Martinelli, G. 1994. Reproductive biology of Bromeliaceae in the Atlantic Rainforest of southeastern Brazil. Ph.D. thesis. Scotland: University of St. Andrews.

—. 1997. Biologia reprodutiva de Bromeliaceae na Reserva Ecológica de Macaé de Cima. Pp. 213-250 in Serra de Macaé de Cima: Diversidade Florística e Conservação em Mata Atlântica. eds. H. C. Lima, and R. R. Guedes-Bruni. Rio de Janeiro: Instituto de Pesquisa Jardim Botânico do Rio de Janeiro.

—., C. M. Vieira, M. Gonzalez, P. Leitman, A. Piratininga, A. F. da Costa, and R. C. Forzza. 2008. Bromeliaceae da mata atlântica brasileira: lista de espécies, distribuição e conservação. Rodriguésia 59: 209-258.

- and A. Costa. 1990. Vriesea farneyi (subgenus Alcantarea), a new species from Brazil. Journal of the Bromeliad Society 40: 151-153.

Meirelles, S. T., V. R. Pivello, and C. A. Joly. 1999. The vegetations of granite rock outcrops in Rio de Janeiro, Brazil, and the need for its protection. Environmental Conservation 26: 10-20.

Mendonça, M. P. and L. V. Lins (Eds.). 2000. Lista vermelha das espécies ameaşadas de extinção da flora de Minas Gerais. Belo Horizonte: Fundação Biodiversitas, Fundação Zôo-Botânica de Belo Horizonte.

Mez, C. 1894. Bromeliaceae. Pp. 173-643 in Flora Brasiliensis vol. 3, pars 3, eds. C. F. P. Von Martius, A. G. Eichler, and I. Urban. Leipzig: F. Fleischer.

—. 1896. Bromeliaceae - Vriesea. Pp. 554-618 in Monographiae Phanerogamarum prodromi nunc continuatio, nunc revisio vol. 9, ed. C. De Candolle. Parisiis: Sumptibus Masson \& C.

—. 1934. Bromeliaceae. Pp. 1-667 in Das Pflanzenreich, regni vegetabilis conspectus. Im Auftrage der Preuss. Akademie der Wissenschaften, ed. A. Engler. Fam. IV. 32. (100. Heft). Berlin: Wilhelm Engelmann. Ministério do Meio Ambiente. 2008. Instrução normativa No. 6,de 23 de setembro de 2008. 
Morren, E. 1874. Floraison du Vriesea regina Beer. Vriesea glaziovana Ch. Lem. au jardin du palais imperial de Vienne. Belgique Horticole 325-328.

—. and H. Fonsny. 1881. Les Broméliacées Brésiliennes découvertes en 1879 pendant le voyage des princes Auguste et Ferdinand de Saxe-Cobourg et décrites par M. Le Dr. Henri Wawra de Fernsee, précédé d'une notice biographique et d'une relation de ses voyages. Liège: Boverie.

Porembski, S., G. Martinelli, R. Ohlemüller, and W. Barthlott. 1998. Diversity and ecology of saxicolous vegetation mats on inselbergs in the brazilian atlantic rainforest. Diversity and Distributions 4: 107-119.

Pereira, E. 1974. Species Novae in Brasilia Bromeliacearum - VI. Bradea 1: 383-387.

Reitz, R. 1983. Bromeliáceas e a malária - bromélia endêmica. Pp 1-559 in Flora Ilustrada Catarinense, Parte 1, fasc. Brom. ed. R. Reitz. Itajaí, Brasil: Herbário Barbosa Rodrigues.

Safford H. D. and G. Martinelli. 2000. Southeast Brazil. Pp. 339-389 in Inselbergs. Biotic diversity of isolated rock outcrops in tropical and temperate regions, eds. S. Porembski and W. Barthlott. Berlin: Springer.

Smith, L. B. 1934. Geographical evidence on the lines of evolution in the Bromeliaceae. Botanische Jahrbücher für Systematik, Pflanzengeschichte und Pflanzengeographie 66: 446-468.

—. 1943. Bromeliáceas novas ou interessantes do Brasil - II. Arquivos de Botânica do Estado de São Paulo 1: 102-122.

—. 1944. Flora of Panama (Bromeliaceae). Annals of the Missouri Botanical Garden 31: 73-137.

—. 1955. The Bromeliaceae of Brazil. Smithsonian Miscellaneous Collections 126: 1-290.

—. 1968. Notes on Bromeliaceae XXVII. Phytologia 16: 62-86.

-1973. Vriesea duarteana. Journal of the Bromeliad Society 23: 16-17.

—., and R. J. Downs. 1974. Pitcairnioideae (Bromeliaceae). Flora Neotropica Monograph 14:1-658.

—., _ _ 1977. Tillandsioideae (Bromeliaceae). Flora Neotropica Monograph 14: 663-1492.

—_., _ 1979. Bromelioideae (Bromeliaceae). Flora Neotropica Monograph 14: 1493-2142

—., and R. W. Read. 1975. Notes on Bromeliaceae XXXVII. Phytologia 30: 289-303.

—., and W. Till 1998. Bromeliaceae. Pp. 74-99 in The families and genera of vascular plants, vol. 4, ed. K. Kubitzki. Berlin: Springer Verlag.

Stearn, W. T. 2004. Botanical Latin. Portland: Timber Press, Inc. 546 p.

Szarzynski J. 2000. Xeric Island: environmental conditions on inselbergs. Pp. 37-48 in Inselbergs. Biotic diversity of isolated rock outcrops in tropical and temperate regions, einselbergsds. S. Porembski and W. Barthlott. Berlin: Springer.

Till, W. 2000. Tillandsioideae. Pp. 555-571 in Bromeliaceae: profile of an adaptive radiation ed. D. H. Benzing. Cambridge, United Kingdom: Cambridge University Press.

Vellozo, J. M. C. 1829(1825). Flora fluminensis...Rio de Janeiro: Typographia Nationali. 
—. 1831(1827). Flora fluminensis... Iconografia. vol. 3. Paris.

Versieux, L. M. and T. Wendt. 2006. Checklist of Bromeliaceae of Minas Gerais, Brazil, with notes on taxonomy and endemism. Selbyana 27: 107-146.

—. and —. 2007. Bromeliaceae diversity and conservation in Minas Gerais, Brazil. Biodiversity and Conservation 16: 2989-3009.

—. and M. G. L. Wanderley. 2007a. Two new species of Alcantarea (Bromeliaceae, Tillandsioideae) from Brazil. Brittonia 59: 57-64. and 2007b. Alcantarea (E. Morren ex Mez) Harms. Pp. 59-62 in Flora Fanerogâmica do Estado de São Paulo, vol. 5, eds. M. G. L. Wanderley, G. J. Shepherd, T. S. Melhem, A. M. Giulietti. São Paulo: Imprensa Oficial.

Vogel, S. 1969. Chripoterophilie in der neotropischen Flora. Neue Mitteilugen III. Flora 148:289-323.

Wanderley, M. G. L., and T. S. Melhem. 1991. Flora Polínica da Reserva do Parque Estadual das Fontes do Ipiranga - Família 178 Bromeliaceae. Hoebnea 18: 5-42.

Wawra. H. R.1883. Itinera principum S. Coburgi. Die botanische ausbeute von den reisen ibrer hoheiten der prinzen von Sachsen-Coburg-Gotha. I. Reise der prinzen Philipp und August um die welt (1872-1873). II. Reise der prinzen August und Ferdinand nach Brasilien (1879). Erster Theil. Wien: Druck und commissionsverlag von Carl Gerold's sohn.

Wittmack, L. 1891. Vriesea regina Beer. Gartenflora 40: 160-163.

Wright, C. H. 1915. Tab. 8596. Tillandsia Regina. Brazil. Curtis's Botanical Magazine 141: tab. 8596. 
ÍNDICE DE COLETORES

\begin{tabular}{|c|c|c|}
\hline Coletor & $\begin{array}{c}\mathrm{n}^{\circ} . \text { ou reg. } \\
\text { herb*. }\end{array}$ & Alcantarea \\
\hline Anderson, $W . \mathrm{R}$. & 35521 & duarteana \\
\hline Andreata, R.H.P. & 671 & glaziouana \\
\hline Angeli, $C$. & 15 & glaziouana \\
\hline Brade, A.C. & 18489 & trepida \\
\hline Braga, P.I.S. & 18 & imperialis \\
\hline Braga, P.I.S. & 1558 & martinellii \\
\hline Burle Marx, R. & *HB777777 & burle-marxii \\
\hline Burle Marx, R. & *RB202513 & beloisae \\
\hline Burle Marx, R. & 9 & roberto-kautskyi \\
\hline Caiafa, A.N. & ${ }^{*}$ CESJ30424 & imperialis \\
\hline Calvente, A.M. & 82 & glaziouana \\
\hline Campacci, M.A. & *SP396342 & regina \\
\hline Carauta, J.P.P. & 132 & glaziouana \\
\hline Carauta, J.P.P. & 2810 & glaziouana \\
\hline Carauta, J.P.P. & 3345 & glaziouana \\
\hline Carauta, J.P.P. & 3550 & glaziouana \\
\hline Carauta, J.P.P. & 3558 & glaziouana \\
\hline Castellanos, $A$. & 23497 & geniculata \\
\hline Costa, A.F. & 88 & regina \\
\hline Costa, A. F. & 258 & farneyi \\
\hline Costa, A. F. & 372 & nevaresii \\
\hline Costa, A.F. & 377 & nevaresii \\
\hline Costa, A.F. & 437 & nevaresii \\
\hline Costa, A.F. & 524 & extensa \\
\hline Costa, A.F. & 748 & imperialis \\
\hline Dionyzio & $*$ RB11527 & glaziouana \\
\hline Duarte, A.P. & *HB48160 & odorata \\
\hline Duarte, A.P. & 7535 & vinicolor \\
\hline Duarte, A.P. & 8893 & extensa \\
\hline Duarte, A.P. & 9017 & duarteana \\
\hline Duarte, A.P. & 14058 & odorata \\
\hline Faria, G.A. & 56 & naboumii \\
\hline Farney, $C$. & 391 & glaziouana \\
\hline Farney, $C$. & 1217 & farneyi \\
\hline Ferreira, F.M. & 996 & imperialis \\
\hline Fontana, A.P. & 1389 & trepida \\
\hline Fontana, A.P. & 1405 & roberto-kautskyi \\
\hline Fontana, A.P. & 5241 & trepida \\
\hline Forzza, R.C. & 546 & duarteana \\
\hline Forzza, R.C. & 612 & duarteana \\
\hline Forzza, R.C. & 2080 & regina \\
\hline Forzza, R.C. & 2843 & beloisae \\
\hline Forzza, R.C. & 3202 & imperialis \\
\hline Forzza, R.C. & 4159 & beloisae \\
\hline Forzza, R.C. & 4305 & regina \\
\hline Forzza, R.C. & 4963 & extensa \\
\hline Forzza, R.C. & 5072 & trepida \\
\hline Forzza, R.C. & 5044 & aff. extensa \\
\hline Forzza, R.C. & 5219 & cf. patriae \\
\hline Fraga, C.N. & 1920 & trepida \\
\hline Fraga, C.N. & 2382 & farneyi \\
\hline França, $F$. & 1994 & naboumii \\
\hline Gentry, $A$. & 49496 & glaziouana \\
\hline Gerôme, J. & $*$ P. s.n. & imperialis \\
\hline Glaziou, $A$. & $*$ K s.n. & glaziouana \\
\hline Glaziou, $A$. & $*_{\mathrm{K}}$ s.n. & imperialis \\
\hline Glaziou, $A$. & 8016 & geniculata \\
\hline Glaziou, $A$. & 11685 & geniculata \\
\hline
\end{tabular}

\begin{tabular}{|c|c|c|}
\hline Coletor & $\begin{array}{c}\mathrm{n}^{\mathrm{o}} \text {. ou reg. } \\
\text { herb*. }\end{array}$ & Alcantarea \\
\hline Glaziou, $A$. & 13262 & imperialis \\
\hline Glaziou, $A$. & 15468 & glaziouana \\
\hline Glariou, $A$. & 15469 & imperialis \\
\hline Glaziou, $A$. & 15470 & geniculata \\
\hline Goldschmidt, $A$ & 19 & extensa \\
\hline Hatschbach, G.G. & 28977 & duarteana \\
\hline Hatschbach, G.G. & 29085 & batschbacbii \\
\hline Hatschbach, G.G. & 40820 & batschbachii \\
\hline Hatschbach, G.G. & 48595 & extensa \\
\hline Hatschbach, G.G. & 50973 & duarteana \\
\hline Hatschbach, G.G. & 61610 & odorata \\
\hline Hatschbach, G.G. & 65296 & extensa \\
\hline Heringer, E.P. & 11910 & imperialis \\
\hline Jardim, J.G. & 2817 & nahoumii \\
\hline Kautsky, R.A. & *HB77794 & benzingii \\
\hline Kautsky, R.A. & 1053 & roberto-kautskyi \\
\hline Kollmann, L. & 3538 & aff. extensa \\
\hline Kollmann, L. & 4099 & vinicolor \\
\hline Krieger, L. & 15531 & imperialis \\
\hline Kulmann, J.G. & 6179 & glaziouana \\
\hline Leme, E.M.C. & *HB74149 & extensa \\
\hline Leme, E.M.C. & *HB84605 & glaziouana \\
\hline Leme, E.M.C. & 262 & odorata \\
\hline Leme, E.M.C. & 1813 & duarteana \\
\hline Leme, E.M.C. & 2227 & nevaresii \\
\hline Leme, E.M.C. & 3086 & extensa \\
\hline Leme, E.M.C. & 4898 & turyida \\
\hline Leme, E.M.C. & 5601 & distractila \\
\hline Leme, E.M.C. & 7355 & simplicisticha \\
\hline Leme, E.M.C. & 7381 & nigripetala \\
\hline Leme, E.M.C. & 7650 & vasconcelosiana \\
\hline Leoni, L.S. & 1051 & extensa \\
\hline Lombardi, J.A. & 4748 & turgida \\
\hline Louzada, R.B. & 22 & nigripetala \\
\hline MacWilliams, E.L. & *HB48522 & glaziouana \\
\hline Markgraf & 37645 & glaziouana \\
\hline Martinelli, $G$. & 1781 & geniculata \\
\hline Martinelli, $G$. & 8753 & martinellii \\
\hline Martinelli, $G$. & 9853 & imperialis \\
\hline Martinelli, $G$. & 13143 & farneyi \\
\hline Martinelli, $G$. & 13259 & tortuosa \\
\hline Martinelli, $G$. & 14799 & imperialis \\
\hline Martinelli, G. & 14857 & extensa \\
\hline Martinelli, $G$. & 15517 & geniculata \\
\hline Martinelli, $G$. & 15727 & vinicolor \\
\hline Martinelli, $G$. & 16213 & imperialis \\
\hline Matos, A.M. & $* \mathrm{R} 46318$ & turgida \\
\hline Mee, $M$. & *SP69016 & glaziouana \\
\hline Mello Filho, L.E. & 1147 & beloisae \\
\hline Merrill & *NY s.n. & regina \\
\hline Moltinbo & 51 & glaziouana \\
\hline Moore, $W$. & *K322037 & imperialis \\
\hline Moore, $W$. & *K382039 & imperialis \\
\hline Moraes, M.A. & 164 & martinellii \\
\hline Moreira, A.S. & 107 & glaziouana \\
\hline Mota, R.C. & 3137 & duarteana \\
\hline Naboum, $P$. & *HB73900 & burle-marxii \\
\hline Naboum, P. & *HB74126 & duarteana \\
\hline
\end{tabular}




\begin{tabular}{|c|c|c|}
\hline Coletor & $\begin{array}{c}\mathrm{n}^{\circ} . \text { ou reg. } \\
\text { herb*. }\end{array}$ & Alcantarea \\
\hline Noblick, L.R. & 3547 & nahoumii \\
\hline Noblick, L.R. & 3752 & naboumii \\
\hline Occhioni, $P$. & *RB78006 & glaziouana \\
\hline Occhioni, $P$. & 3822 & glaziouana \\
\hline Oliveira, $\mathrm{R}$. & *HB84646 & glaziouana \\
\hline Pabst, G.F.J. & 8314 & burle-marxii \\
\hline Paula, C.C. & *VIC25415 & naboumii \\
\hline Paula, C.C. & *VIC26351 & odorata \\
\hline Paula, C.C. & $*$ VIC26367 & imperialis \\
\hline Paula, C.C. & 1008 & extensa \\
\hline Paula, C.C. & 1092 & extensa \\
\hline Paula, C.C. & 1094 & odorata \\
\hline Paula, C.C. & 1133 & extensa \\
\hline Paula, C.C. & 1281 & imperialis \\
\hline Paula, C.C. & 2530 & odorata \\
\hline Penna, I.A. & 21 & regina \\
\hline Pereira, E. & *HB74679 & glaziouana \\
\hline Pereira, E. & 10501 & glaziouana \\
\hline Pereira, E. & 10546 & geniculata \\
\hline Pereira, E. & 10560 & imperialis \\
\hline Pereira, E. & 10565 & imperialis \\
\hline Pereira, E. & 10644 & imperialis \\
\hline Pereira, E. & 10795 & geniculata \\
\hline Pinbeiro, F. & 27 & extensa \\
\hline Pinheiro, F. & 189 & regina \\
\hline Queiroz, L.P. & 1096 & naboumii \\
\hline Queiros, L.P. & 2933 & naboumii \\
\hline Reinert, F. & $*$ RB283950 & glaziouana \\
\hline Reinert, F. & $*$ RB285577 & glaziouana \\
\hline Reitz, R. & 6831 & geniculata \\
\hline Reitz, $\mathrm{R}$. & 6843 & extensa \\
\hline Reitz, $R$. & 7462 & cf. martinellii \\
\hline Reitz, R. & 7578 & geniculata \\
\hline Reitz, $R$. & 7604 & glaziouana \\
\hline Reitz, $R$. & 7709 & extensa \\
\hline Reitz, $R$. & 7725 & imperialis \\
\hline Reitz, R. & 7751 & of. patriae \\
\hline Reitz, R. & 7845 & extensa \\
\hline Ribeiro, $R$. & 102 & glaziouana \\
\hline Salino, $A$. & 9305 & burle-marxii \\
\hline Santos Lima & 1417 & beloisae \\
\hline Santos, $N$. & *R173702 & glazionana \\
\hline Schwacke, $W$. & 11911 & imperialis \\
\hline Sellfeld, $A$. & 13 & duarteana \\
\hline Silva, J.M. & 4531 & imperialis \\
\hline Smith, L.B. & 6829 & glaziouana \\
\hline Strang, $H$. & 721 & geniculata \\
\hline Sucre, D. & 1307 & glaziouana \\
\hline Ule, E. & *R46307 & glaziouana \\
\hline van den Berg, $C$. & 895 & naboumii \\
\hline Versieux, L.M. & 157 & turgida \\
\hline Versieux, L.M. & 214 & imperialis \\
\hline Versieux, L.M. & 215 & imperialis \\
\hline Versieux, L.M. & 221 & imperialis \\
\hline Versieux, L.M. & 222 & imperialis \\
\hline Versieux, L.M. & 223 & nevaresii \\
\hline Versieux, L.M. & 238 & beloisae \\
\hline Versieux, L.M. & 239 & beloisae \\
\hline Versieux, L.M. & 240 & tortuosa \\
\hline Versieux, L.M. & 241 & tortuosa \\
\hline
\end{tabular}

\begin{tabular}{|c|c|c|}
\hline Coletor & $\begin{array}{c}\mathrm{n}^{\circ} \text {. ou reg. } \\
\text { herb*. }\end{array}$ & Alcantarea \\
\hline Versieux, L.M. & 245 & farneyi \\
\hline Versieux, L.M. & 246 & farneyi \\
\hline Versieux, L.M. & 247 & farneyi \\
\hline Versieux, L.M. & 254 & duarteana \\
\hline Versieux, L.M. & 255 & duarteana \\
\hline Versieux, L.M. & 260 & turgida \\
\hline Versieux, L.M. & 265 & regina \\
\hline Versieux, L.M. & 266 & imperialis \\
\hline Versieux, L.M. & 267 & regina \\
\hline Versieux, L.M. & 270 & regina \\
\hline Versieux, L.M. & 271 & regina \\
\hline Versieux, L.M. & 285 & geniculata \\
\hline Versieux, L.M. & 300 & turgida \\
\hline Versieux, L.M. & 342 & glaziouana \\
\hline Versieux, L.M. & 343 & glaziouana \\
\hline Versieux, L.M. & 344 & extensa \\
\hline Versieux, L.M. & 352 & regina \\
\hline Versieux, L.M. & 357 & extensa \\
\hline Versieux, L.M. & 359 & extensa \\
\hline Versieux, L.M. & 360 & extensa \\
\hline Versieux, L.M. & 361 & extensa \\
\hline Versieux, L.M. & 362 & extensa \\
\hline Versieux, L.M. & 363 & vasconcelosiana \\
\hline Versieux, L.M. & 368 & extensa \\
\hline Versieux, L.M. & 369 & extensa \\
\hline Versieux, L.M. & 372 & extensa \\
\hline Versieux, L.M. & 373 & extensa \\
\hline Versieux, L.M. & 375 & vinicolor \\
\hline Versieux, L.M. & 376 & vinicolor \\
\hline Versieux, L.M. & 377 & vinicolor \\
\hline Versieux, L.M. & 378 & extensa \\
\hline Versieux, L.M. & 379 & extensa \\
\hline Versieux, L.M. & 380 & extensa \\
\hline Versieux, L.M. & 384 & extensa \\
\hline Versieux, L.M. & 394 & trepida \\
\hline Versieux, L.M. & 395 & trepida \\
\hline Versieux, L.M. & 396 & trepida \\
\hline Versieux, L.M. & 415 & naboumii \\
\hline Versieux, L.M. & 416 & naboumii \\
\hline Versieux, L.M. & 417 & naboumii \\
\hline Versieux, L.M. & 418 & naboumii \\
\hline Versieux, L.M. & 419 & roberto-kautskyi \\
\hline Versieux, L.M. & 421 & burle-marxii \\
\hline Versieux, L.M. & 430 & roberto-kautskyi \\
\hline Versieux, L.M. & 433 & odorata \\
\hline Versieux, L.M. & 450 & imperialis \\
\hline Versieux, L.M. & 451 & imperialis \\
\hline Versieux, L.M. & 452 & imperialis \\
\hline Versieux, L.M. & 453 & imperialis \\
\hline Versieux, L.M. & 456 & geniculata \\
\hline Versieux, L.M. & 469 & extensa \\
\hline Versieux, L.M. & 470 & duarteana \\
\hline Vervloet, R.R. & 372 & extensa \\
\hline Vidal, J. & *R173703 & geniculata \\
\hline Vidal, $U$. & 13 & regina \\
\hline Wanderley, M.G.L. & 2066 & glaziouana \\
\hline Wanderley, M.G.L. & 2488 & turgida \\
\hline Wanderley, M.G.L. & 2621 & duarteana \\
\hline Zappi, D.C. & CFCR10398 & duarteana \\
\hline
\end{tabular}


CAPÍTULO 2: MOLECULAR PHYLOGENY OF ALCANTAREA

(BROMELIACEAE) BASED ON DNA SEQUENCES AND MICROSSATELITE LOCI INDICATES THE MONOPHYLY OF THE GENUS AND SUGGESTS INTERSPECIFIC HYBRIDIZATION

\footnotetext{
"New sources of data (DNA and fossils), better methods (computer algorithms to analyze large data sets and generate evolutionary trees), and advance in theory (only derived characteristics should be used to determine lineages) have combined to yield spectacular progress in inferring evolutionary relationships. These relationships, expressed as evolutionary trees, serve as a framework. for asking questions about biogeography, change in morphology and other characteristics, and the evolutionary process itself. Given all these advances and their implications for classifications, there has never been a more exciting time to be a systematist."
}

Robbin C. MORAn, 2004. A NATURAl History of FERnS

* Manuscrito a ser submetido à revista Annals of Botany. 


\section{Molecular Phylogeny of Alcantarea (Bromeliaceae) based on DNA Sequences and Microsatellite Data Indicates the Monophyly of the Genus and Suggests Interspecific}

\section{Hybridization}

- Background and Aims The genus Alcantarea comprises 26 species endemic to rock outcrops from eastern Brazil Atlantic Rainforest. Most species are ornamental and several are threatened due to habitat loss and by over collection. In this paper we aim to reconstruct the phylogeny of Alcantarea, observing its relationship with the genus Vriesea, to which it used to be a subgenus. We discuss on the disjunct occurrence of Alcantarea in campo rupestre vegetation and also about hybridization within the genus.

- Methods DNA sequence data from two chloroplast markers (trnK-rps16, $\operatorname{trn} \mathrm{C}-p e t \mathrm{~N})$ and from one low copy nuclear gene (Floricaula/Leafy), together with 20 nuclear microsatellite loci were employed to reconstruct a phylogeny of the genus.

-Key results A well-supported monophyly of Alcantarea, in both Bayesian and Parsimony analyses is indicated. Floricaula/Leafy second intron provides near five times more variable characters than cpDNA and can be considered one potential marker for other studies with Bromeliaceae. Sections of the large genus Vriesea are considered paraphyletic. Microsatellites delimit species groups with strong biogeographic correlation and also suggest that hybridization is more frequently then previously known, since individuals of the same species may appear closely related to different species groups. Alcantarea brasiliana is indicated as putative hybrid between $A$. imperialis and $A$. geniculata.

Key words: Atlantic Rainforest, inselbergs, $L E A F Y$ intron, microssatellite, Tillandsioideae, Vriesea. 


\section{INTRODUCTION}

Bromeliaceae (56 genera, 3172 species) is almost exclusive of the Neotropical region (Smith and Downs, 1974; Luther, 2008) and the family is divided into eight subfamilies (Givnish et al., 2007). The subfamily Tillandsioideae have been characterized by the ubiquitous presence of seed appendages finely divided and forming a coma, entire leaves, dehiscent capsular fruit, foliar trichomes generally radially symmetric and by being mostly epiphytic plants (Smith and Downs, 1974). As traditionally defined this subfamily appears monophyletic in several recent molecular phylogenetic works (e.g. Terry et al., 1997a, 1997b; Horres et al., 2000; Barfuss et al., 2005; Schulte et al., 2005; Givnish et al., 2007). Though dominated by epiphytic species within its largest genera (e.g. Tillandsia, Vriesea), the subfamily also encompasses Alcantarea (E. Morren ex Mez) Harms, the rupicolousspecialist and Brazilian endemic genus.

Alcantarea includes ornamental bromeliads, characteristic for their large habit, sometimes reaching up to $5 \mathrm{~m}$ high when flowering, and for the well developed tanks (phytotelma). Key morphological characters that distinguish Alcantarea from Vriesea are the ephemeral, long ligulate and usually spiralescent petals and seeds with both basal and apical appendages (Grant, 1995; Versieux and Wanderley, 2007a). Alcantarea comprises 26 species, strictly rupicolous that occur on inselbergs, from eastern Brazil or, for few disjunct species, on rock outcrops in campo rupestre vegetation of the Espinhaço mountain range.

Inselbergs (from German Insel $=$ island, berg $=$ mountain $)$ are very old dome shaped gneissgranitic mountains mostly inserted within the Atlantic rainforest domain and occuring scattered from each other (Safford and Martinelli, 2000). These habitats are known as 'xeric islands' due to severe growing conditions for plant communities (Szarzynski, 2000).

The importance of inselbergs as venues for rupicolous Bromeliaceae differentiation, particularly Alcantarea, has been demonstrated on a recent series of papers (Barbará et al. 2007, 2008, 2009). As inland islands, these rock outcrops may contribute for a high genetic distance within naturally fragmented populations of the same species (i.e. population partitioning) due to low level of 
genetic exchange (Barbará et al., 2007).

Alcantarea has been traditionally treated as a subgenus of Vriesea Lindl. (Mez, 1894; Smith and Downs, 1977) or as an independent genus (Harms, 1929, 1930; Grant, 1995). According to Harms (1930) the seeds with apical and basal appendages, the long petals, the large habit and bulky inflorescences were characters sufficiently different to elevate Alcantarea to the generic rank. However, subsequent authors treated Alcantarea as a subgenus. Recently, Grant (1995) re-established the genus Alcantarea, after excluding two taxa from Central America and West Indies.

Alcantarea treated either as a genus or as subgenus has been investigated in some phylogenetics analyses, but only represented by few species. Horres et al. (2000) included Alcantarea regina (Vell.) Harms in a broad Bromeliaceae phylogenetic analysis based on $\operatorname{trn} \mathrm{L}$ (UAA) intron sequences and reported a well supported sister relationship between $A$. regina (Vell.) Harms and Vriesea racinae L.B. Sm., both of them showing a 15 base pairs deletion. Costa (2002) included Alcantarea farneyi (A. F. Costa \& Martinelli) J.R. Grant and A. glaziouana (Lem.) Leme and other 66 species of Vriesea in a morphological phylogenetic analysis. Both Alcantarea species analyzed by this author appear in a clade supported by the presence of strongly recurved petals and seed bearing straight and long apical appendages. This Alcantarea clade appeared sister to $V$. neoglutinosa (Vriesea sect. Vriesea), and was embedded in a major clade that included mostly Vriesea sect. Xiphion species, turning Vriesea into a paraphyletic group. Barfuss et al. (2005) presented a molecular phylogeny that employed seven plastid markers and sampled two Alcantarea species - A. duarteana and A. imperialis -, which formed a clade sister to the Brazilian species of Vriesea, but not to the remainder Vriesea species that shared a more recent common ancestor with other species of Weraubia. Therefore, according to Barfuss et al. (2005) the separation of Alcantarea and Weraubia as independent genera would turn Vriesea s.l. paraphyletic. Horres et al. (2007) used Alcantarea regina in a molecular phylogeny and it appeared as sister to a clade that included Gurmania and Tillandsia, but in this analysis Vriesea representatives species were not sampled.

The molecular studies with Bromeliaceae demonstrated an astonishing low variability of chloroplast DNA (cpDNA) sequences (Terry et al., 1997a, 1997b; Horres et al., 2000; Schulte et al., 
2005). Molecular phylogenetics studies focusing on Bromeliaceae started on the 1990's and the first papers dealt with the relationships of the subfamilies (e.g. Ranker et al., 1990). Later, relationships within subfamilies started to receive more attention and were progressively increased in sampling of genera and species (e.g. Givnish et al., 2004, 2007; Barfuss et al., 2005; Schulte et al. 2005). Intrageneric phylogenetics investigations are recent and employ low copy nuclear genes or other molecular techniques rather than sequencing to raise more variable data or combine molecular and morphological data sets (e.g. Sousa et al., 2007; Rex et al., 2007; Schulte et al., 2009).

Microsatellites are repetitive nucleotide sequences arranged in tandem of a motif-sequence of no more than six bases (Goldstein and Schlotterer, 1999). Originally, the term microsatellite was applied mainly to regions that showed only the CA (GT) repetition and other names as STR (short tandem repeats) and SSR (simple sequence repeat) were also used as synonyms to refer to these tandem arranged sequences. Currently, the term microsatellite is the most employed and it can be observed in all genomes of all organisms (Goldstein and Schlotterer, 1999). Microsatellites became important tools for measuring genetic distance in the population genetics works because they are codominant markers, extremely polymorphic that can be employed in the intraspecific level allowing the study of closely related species (Chen et al., 2002), for which other molecular markers would provide few or lack of variation. For distantly related taxa, however, alleles that are identical in length can show hidden motifs demanding additional checking by sequencing (Chen et al., 2002). Other advantages are that microsatellites neutrally evolve and they can represent different genomic regions in a single data set (Ochieng et al., 2007).

The use of microsatellite markers to reconstruct phylogenies is a matter of current debate, taking into account what would be the best methodology to analyze such kind of data and still resolve some uncertainties regarding mutation mechanisms that these loci may be exposed to and homoplasy levels (Petren et al., 1999; Ochieng et al., 2007). Basically three biological processes other than true genetic proximity explain allele sharing patterns: (1) shared ancestral polymorphism $=$ lineage sorting, (2) homoplasy, (3) hybridization. All together these process must be taken in consideration while analyzing suggested relationships. 
For Bromeliaceae, several works dealing with the population genetics have taken broadly use of microsatellite markers turning available specific primers sets for this family (Boneh et al., 2003; Sarthou et al., 2003; Palma-Silva et al., 2007; Paggi et al., 2008). Since the cpDNA for Bromeliaceae have been considered very uniform, in the present work we employed different genetic data sets (i.e. cpDNA, low copy nuclear gene and microsatellite) in order to obtain enough variation or to analyze relationships among taxa in the intergeneric of infrageneric levels. Both chloroplast regions selected to be used $(\operatorname{trn} \mathrm{K}-r p s 16, \operatorname{trn} \mathrm{C}-p e t \mathrm{~N})$ are considered to be variable for this level for other plant groups (Lee and Wen, 2004; Kress et al., 2005; Ran et al., 2006; Whipple et al., 2007). The second intron of Floricaula/Leafy was also employed in our analyses as a nuclear marker. The homeotic gene Floricaula (FLO) was discovered in Antirrbinum majus L. (Coen et al., 1990) and later was also found in Arabidopsis thaliana (L.) Heynh. when it was named Leafy (LFY, Weigel et al., 1992). It codifies for a transcription factor that regulates the identity of apical meristem, fostering the development of leaves or inflorescences (Weigel et al., 1992). The FLO/LFY is considered to be a single copy gene in most angiosperms, except in recent polyploids (Baum et al., 2005).

In the present work we reconstruct the phylogeny of Alcantarea using molecular data and compare the results obtained with the different data sets (i.e. cpDNA vs. low copy nuclear gene vs. microsatellite) to test the hypothesis that Alcantarea is a monophyletic group. We further analyze some morphological features as diagnostic characters and discuss on the biogeographical and biological implications of the results obtained. Particularly, we discuss the colonization of inselberg vs. campo rupestre by Alcantarea species, the evolution of different pollination syndromes and the role of hybridization in Alcantarea evolution.

\section{MATERIALS AND METHODS}

Taxon sampling - Two different samplings were employed, one for sequencing and another for the microsatellite analyses. For sequencing plastid and nuclear loci, a broad sample of Vriesea and Alcantarea species was used (Appendix). Other taxa representing the main lineages within the other 
Tillandsioideae genera (i.e. Tillandsia, Gurmania, Racinaea) and other subfamilies (i.e. Bromelioideae: Nidularium, Pitcairnioideae: Pitcairnia, Deuterocohnia) were also sampled, totaling 70 to 79 taxa in the final cpDNA matrixes. We used Deuterocohnia, Pitcairnia and Nidularium as outgroups for chloroplast analyses while in FLO/LFY analysis we used Tillandsia secunda and Weraubia ororiensis. The choice of the latter two species was based on a recent molecular phylogeny of Tillandsiodeae (Barfuss et al., 2005). For microsatellite the focus was on Alcantarea species. A total of 47 individuals of different populations for 22 species ( $84 \%$ of the total) were sampled (Appendix). It is worthy mentioning that for few species DNA samples could not be obtained because access to populations is difficult due to their restricted occurrence on steep rock walls or difficulties for extracting DNA from herbarium specimens. It was not possible to collect Alcantarea hatschbachii because it is considered to be presumably extinct in wild.

DNA extraction - Genomic DNA was extracted from silica-dried leaves using the CTAB protocol (Doyle and Doyle, 1990) with adaptations for mini-extractions.

Amplification and microsatellite analyses - The following twenty loci of nuclear microsatellite were amplified using primers and PCR conditions described by the authors cited below: Ai4.03, Ai4.10, Ai5.18, VgA04, VgB10, VgC01, VgF01, VgF02, VgG02, VgG03, VgG05 (Palma-Silva et al., 2007), CT5, E6, E6b, E19, P2P19 (Boneh et al., 2003), PaA010, PaD07, PaZ01 (Paggi et al., 2008), Pit8 (Sarthou et al., 2003). Genotypes were analyzed in an ABI PRISM 3100 Genetic Analyser (Applied Biosystems), making use of either FAM or JOE fluorescent dyes. Molecular sizes in base pairs were determined using the GENESCAN-500 ROX size standard (Applied Biosystems). Genotyper 3.7 software (Applied Biosystems) was used to score alleles sizes. A matrix containing all alleles was analyzed in MSA software using the Pairwise Distance Between Individuals. A NJ tree was generated in PAUP 4.0 (Swofford, 2002).

Amplification for Sequencing - A preliminary screening was done based on recent published primers or other phylogenetic works with Poales families (Whipple et al., 2007; Ford et al., 2009). Based on this preliminary screening we selected two plastid markers, the $\operatorname{trn} \mathrm{K}-r p s 16$ and $\operatorname{trn} \mathrm{C}-p e t \mathrm{~N}$. 
Amplifications were performed using primers trnK5'r (5'TACTCTACCRTTGAGTTAGCAAC3'), $r p s 16-4547 \bmod$ (5'A A A G G K G C T C A A C C T A C A R G A C 3'), $t r n$ C (5'CCAGT'TCAAATCTGGGTGTC3') e petN1r (5'CCCAAGCAAGACT'TACTATATCC3') (primers references in Whipple et al., 2007) and a new reverse primer was designed for $\operatorname{pet} \mathrm{N}$ : pet $\mathrm{N}$ BR (5'CCAATCTAAT'TCCAGACAGAGTCA3'). Reactions containing a final volume of $20 \mu$ were performed using: $2 \mu \mathrm{l}$ of $5 \mathrm{x}$ Go taq Promega Buffer, $2 \mu \mathrm{l}$ of BSA, $1 \mu \mathrm{l}$ of $25 \mu \mathrm{M} \mathrm{MgCl}, 1 \mu \mathrm{l}$ of each $10 \mu \mathrm{M}$ primer, $0.4 \mu \mathrm{l}$ of Promega Go Taq, $0.4 \mu \mathrm{l}$ of $10 \mathrm{mM}$ dNTP's and $0.8 \mu \mathrm{l}$ of genomic DNA completed with water. We used the PCR conditions described by Whipple et al. (2007). For the amplification of FLO/LFY second intron $0.8 \mu \mathrm{l}$ of DMSO was added in the reaction and the conditions set were the same as the employed by Frohlich and Meyerowitz (1995) using primers LF s 1x-3: 5' G C C G G C I M G I G G I A A R A A Y G G I Y T I G A 3', LFtxr: 5'CCTGCCIACRTARTGICKCATYTTIGGYTT3'. After initial amplifications, less degenerated primers were designed for Alcantarea and Vriesea: LFY Br f, LFY Br r.

Sequence analyses - Sequencing were obtained in the Jodrell Laboratory, Kew using a ABI 3730 DNA Analyzer or from Macrogen Inc. (South Korea). Sequences were edited in Sequencher v. 4.8 (Gene Codes Corporation) and aligned manually in MacClade v. 4.06 (Maddison and Maddison, 2003). Gaps were codified and then excluded from the analysis together with regions of uncertain homology. Maximum parsimony (MP) analyses were performed in PAUP 4.0 (Swofford, 2002) using heuristic searches set to build random stepwise-addition replicates and to use TBR as branch swapping algorithm saving a maximum of 20 trees per replicate. The analyses of MP and MP bootstrap were executed with 1000 replicates each. The Partition Homogeneity Test (PHT) implemented in PAUP was performed for the search of incongruence between data sets from different markers. Prior to conduct the Bayesian analyses (BA) evolutionary models were estimated for each data set in ModelTest 3.04 (Posada and Crandall, 1998) and the following models of evolution were selected according to the hierarchical likelihood ratio tests (hLRTs): HKY for trnCpetN, F81 for trnk-rps16 and K80 for LFY/FLO. For the Bayesian analyses 10 million generations 
sampled every 100 generation were calculated using MrBayes ver. 3.1.1 using two runs simultaneously (Ronquist and Huelsenbeck, 2003) implemented in BioHPC online platform (Computational Biology Application Suite for High Performance Computing, Cornell University). The standard deviation of split frequencies (i.e., the convergence diagnostic) was analyzed to access both runs convergence and the appropriate burn-in was determined ploting $-\ln \mathrm{L}$ versus generations to verify the stationary.

\section{RESULTS}

\section{Molecular analysis using individual cpDNA data}

$\operatorname{trn} \mathbf{C}-p e t \mathbf{N}$ Data-The aligned molecular matrix for this marker had 28 terminals and a total of 399 characters with 385 being constant, 10 parsimony uninformative, and four being parsimony informative. The cladistic analysis of molecular data yielded one most parsimonious trees of 14 steps (CI 1.0000, RI 1.0000; Table 1). A broader sampling was available for this same marker and the constrict consensus tree is shown in Figure 1. The aligned molecular matrix for this extended sampling had 79 terminals and a total of 399 characters with 337 being constant, 43 parsimony uninformative, and 19 being parsimony informative. The cladistic analysis of molecular data yielded 1681 most parsimonious trees of 72 steps (CI 0.9306, RI 0.9612; Table 1).

$\operatorname{trnK} \mathbf{K}-r p s 16$ Data - The aligned molecular matrix for this marker had 28 terminals and 666 aligned nucleotide sites with 643 being constant, 17 parsimony uninformative, and seven being parsimony informative. The cladistic analysis of molecular data yielded 26 most parsimonious trees of 24 steps (CI 1.0000, RI 1.0000; Table 1). A broader sampling was available for this same marker and the constrict consensus tree is shown in Figure 2. The aligned molecular matrix in this second case had 70 terminals and a total of 658 characters with 574 being constant, 39 parsimony uninformative, and 45 being parsimony informative. The cladistic analysis of molecular data yielded 3817 most parsimonious trees of 107 steps (CI 0.8505, RI 0.9231; Table 1). 


\section{Molecular analysis using low copy nuclear gene}

FLO/LFY second intron Data - Successful PCR amplifications resulted in a single band in all taxa and no multiple sequence variants were found. The aligned molecular matrix for this marker had a total of 624 characters with 527 being constant, 64 parsimony uninformative, and 33 being parsimony informative. The cladistic analysis of molecular data yielded 11606 most parsimonious trees of 109 steps (CI 0.9174, RI 0.9480; Table 1). The semistrict consensus (Fig. 3) as well as the strict (not shown) are resolved, at least for genera relationships.

\section{Molecular analysis using combined datasets}

Partition homogeneity tests indicated that the different data partitions of cpDNA and low copy nuclear gene were not significantly incongruent $(\mathrm{P}=0.079)$ and thus were combined in a single matrix. This combined matrix had a total of 1689 characters with 1556 being constant, 90 parsimony uninformative, and 45 being parsimony informative. The cladistic analysis of molecular data yielded 72405 most parsimonious trees of 153 steps (CI 0.9085, RI 0.9355; Table 1). The Bayesian analyses yielded 99538 Bayesian trees and the 50\% majority-rule consensus is presented together with the posterior probabilities in Fig. 5.

\section{Microsatellite analyses}

A neighbor joining tree (NJ) of individuals based on microsatellite genetic distance (Fig. 6) revealed relationships among 22 species of Alcantarea. Most species were grouped together although Alcantarea burle marxii, $A$. odorata, $A$. nevaresii, $A$. roberto-kautskyi and $A$. aff. extensa did not cluster. Individuals treated here as affinis A. extensa appear in different positions in the $\mathrm{NJ}$ dendrogram. Alcantarea odorata appears sharing alleles with both $A$. beloisae and also with $A$. duarteana. Alcantarea roberto-kautskyi also shares alleles with $A$. regina and to a larger group that includes taxa from Serra dos Órgãos. Results obtained with the microsatellite indicate groups of species that share biogeographic areas or morphological characters (Fig. 6). Biogegraphical or morphologycal characters that could be associated to most species within each group are indicated in color bars, however this are only general 
trends and not exclusive characters. The 'Serra dos Órgãos’ biogeographic group (Fig. 6, yellow bar) unites $A$. brasiliana, A. geniculata, A. imperialis, A. nevaresii and in a sub partition within this group there are $A$. farneyi and $A$. tortuosa, witch occur at Santa Maria Madalena Range (Fig. 6, orange bar), in the extreme northern limit of Serra dos Órgãos. The A. extensa complex appear divided into two subgroups, one would be centered on the core area of $A$. extensa occurrence along southern and southeastern Espírito Santo State, mainly inside the Itapemirim river basin (Fig. 6, green bar). The second would be the eastern Minas Gerais State area (Fig. 6, blue bar), that concentrates individuals collected mainly along the rio Doce river basin (A. aff. extensa, A. turgida), however, $A$. patriae from southern Espírito Santo also appears in this group. Other groups are recognized based on suggestive morphological traits (petal color and shape, leaf indumentum) or by clonal growth habit or geographic proximity of populations but not exactly matching the areas delimited above (Fig. 6).

Table 1. Summary statistics of $\operatorname{trn} \mathrm{C}-\operatorname{pet} \mathrm{N}, \operatorname{trn} \mathrm{K}-r p s 16, F L O / L F Y$ data matrices and parsimony analyses of the three data sets. For both plastid markers (trn $\mathrm{C}-p e t \mathrm{~N}$ and $\operatorname{trn} \mathrm{K}-r p s 16)$ values in parenthesis represent those obtained with the larger sampling only available for them.

\begin{tabular}{|c|c|c|c|}
\hline & $\operatorname{trn} \mathrm{C}-p e t \mathrm{~N}$ & $\operatorname{trn} \mathrm{K}-r p s 16$ & FLO/LFY \\
\hline Aligned length & $399(399)$ & $666(658)$ & 624 \\
\hline Variable characters / $\%$ & $14(62) / 3.5 \%(15.5 \%)$ & $23(84) / 3.4 \%(12.7 \%)$ & $97 / 15.5 \%$ \\
\hline $\begin{array}{l}\text { No. of parsimony- } \\
\text { informative characters / } \%\end{array}$ & $4(19) / 1 \%(4.8 \%)$ & $7(45) / 1 \%(6.8 \%)$ & $33 / 5.3 \%$ \\
\hline No. of MP trees & $1(1681)$ & $26(3817)$ & 11606 \\
\hline Length of MP trees & $14(72)$ & $24(107)$ & 109 \\
\hline Consistency index (CI) & $1.0000(0.9306)$ & $1.0000(0.8505)$ & 0.9174 \\
\hline $\begin{array}{l}\text { CI excluding uninformative } \\
\text { characters }\end{array}$ & $1.0000(0.8077)$ & $1.0000(0.7647)$ & 0.8000 \\
\hline Retention index (RI) & $1.0000(0.9612)$ & $1.0000(0.9231)$ & 0.9480 \\
\hline
\end{tabular}




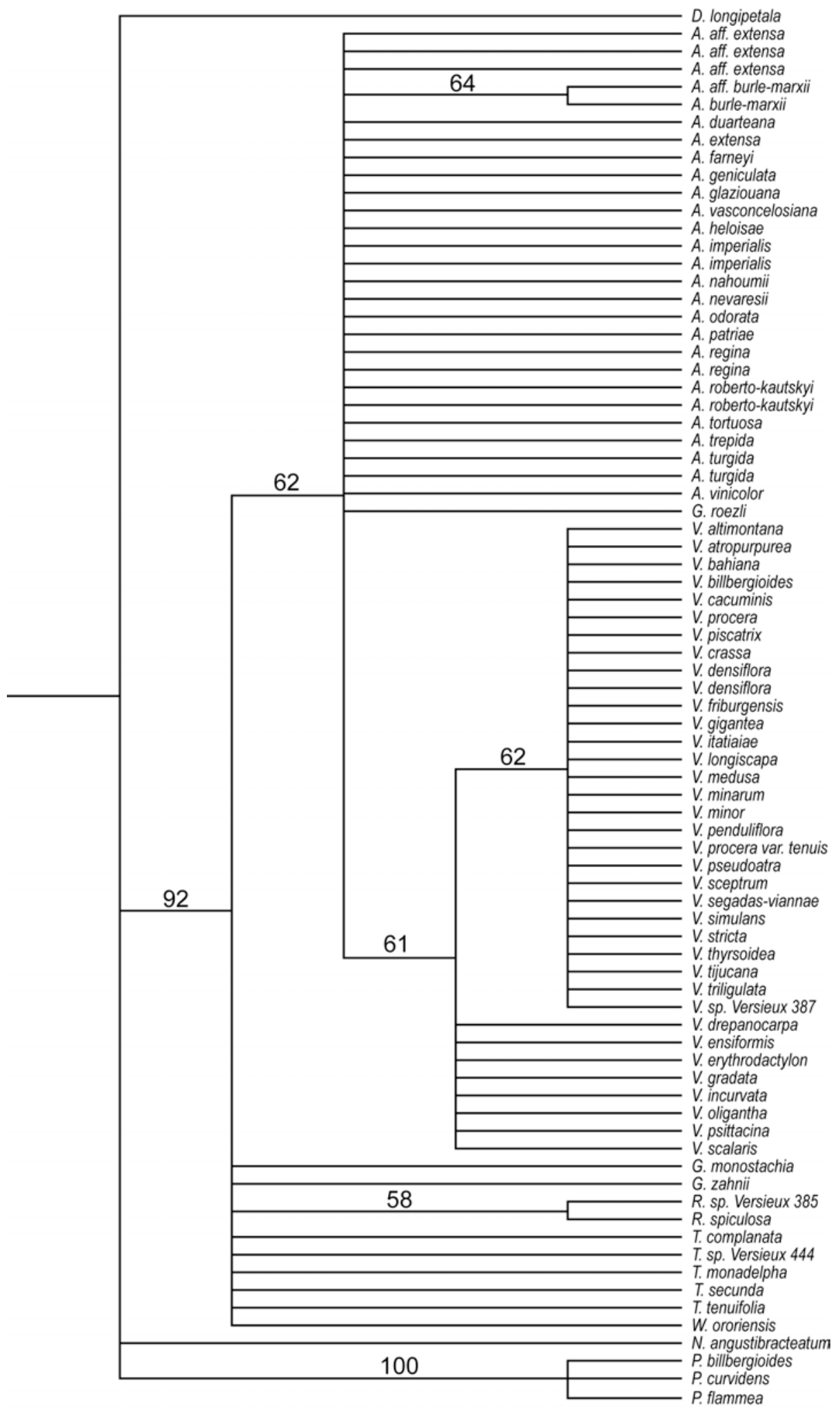

FIG. 1. Strict consensus tree of the most parsimonious trees of $\operatorname{trn} \mathrm{C}-\operatorname{pet} \mathrm{N}$. Numbers above branches are bootstrap percentages $>50 \%$. 


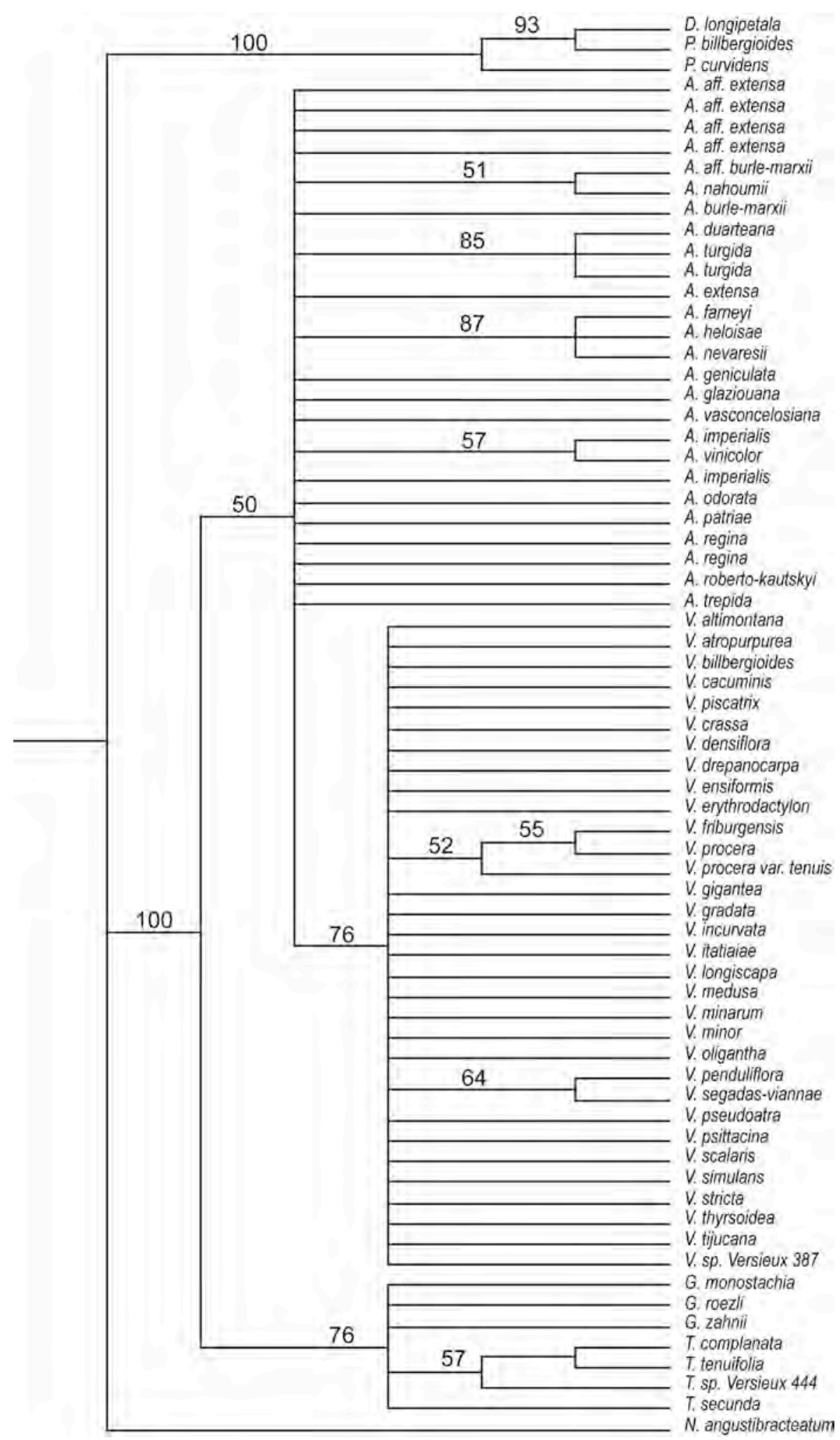

FIG. 2. Strict consensus tree of the most parsimonious trees of $\operatorname{trn} \mathrm{K}-r p s 16$. Numbers above branches are bootstrap percentages $>50 \%$. 


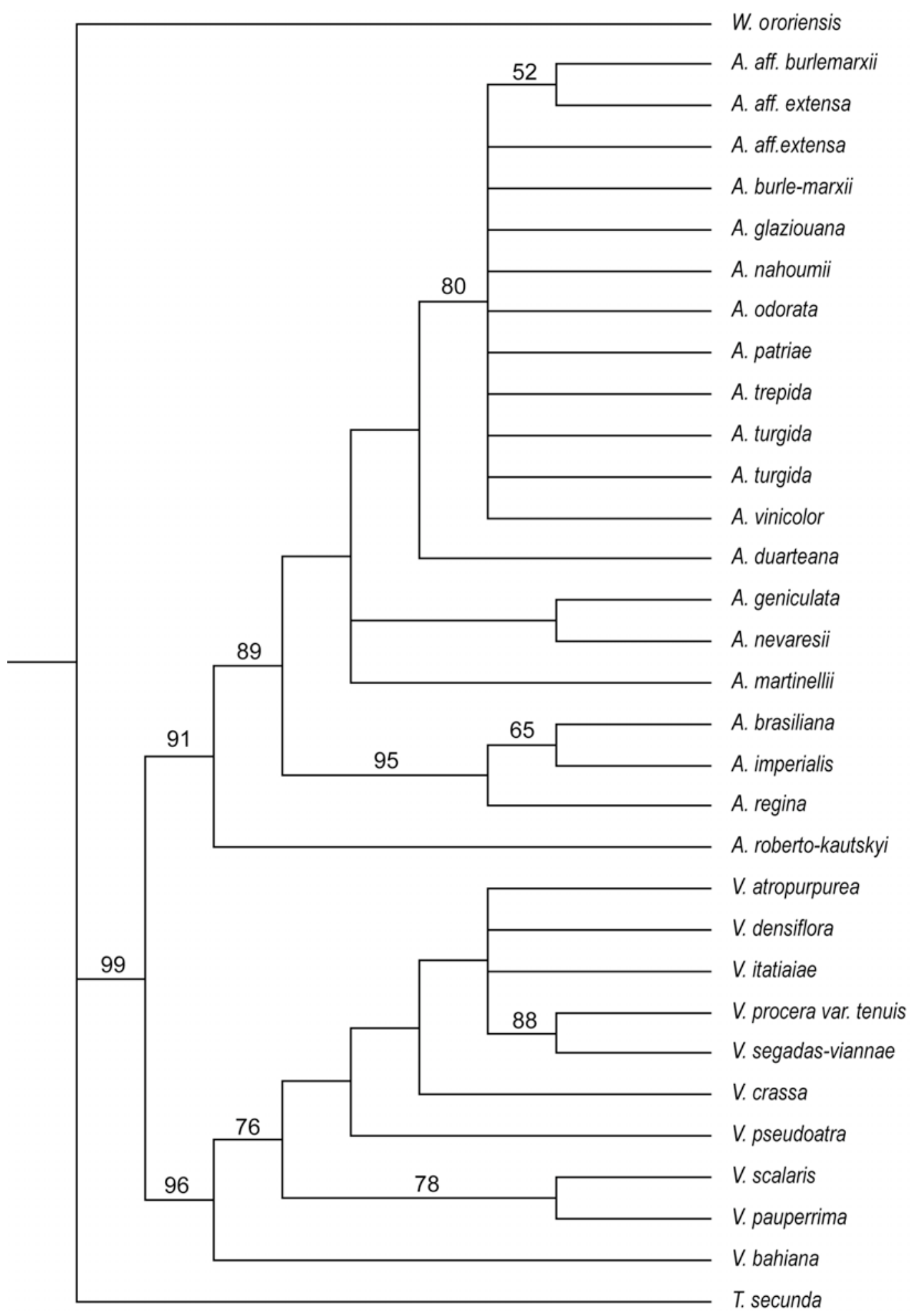

FIG. 3. Semistrict consensus tree of most parsimonious trees resulting from FLO/LFY second intron sequences. Numbers above branches are bootstrap percentages $>50 \%$. 


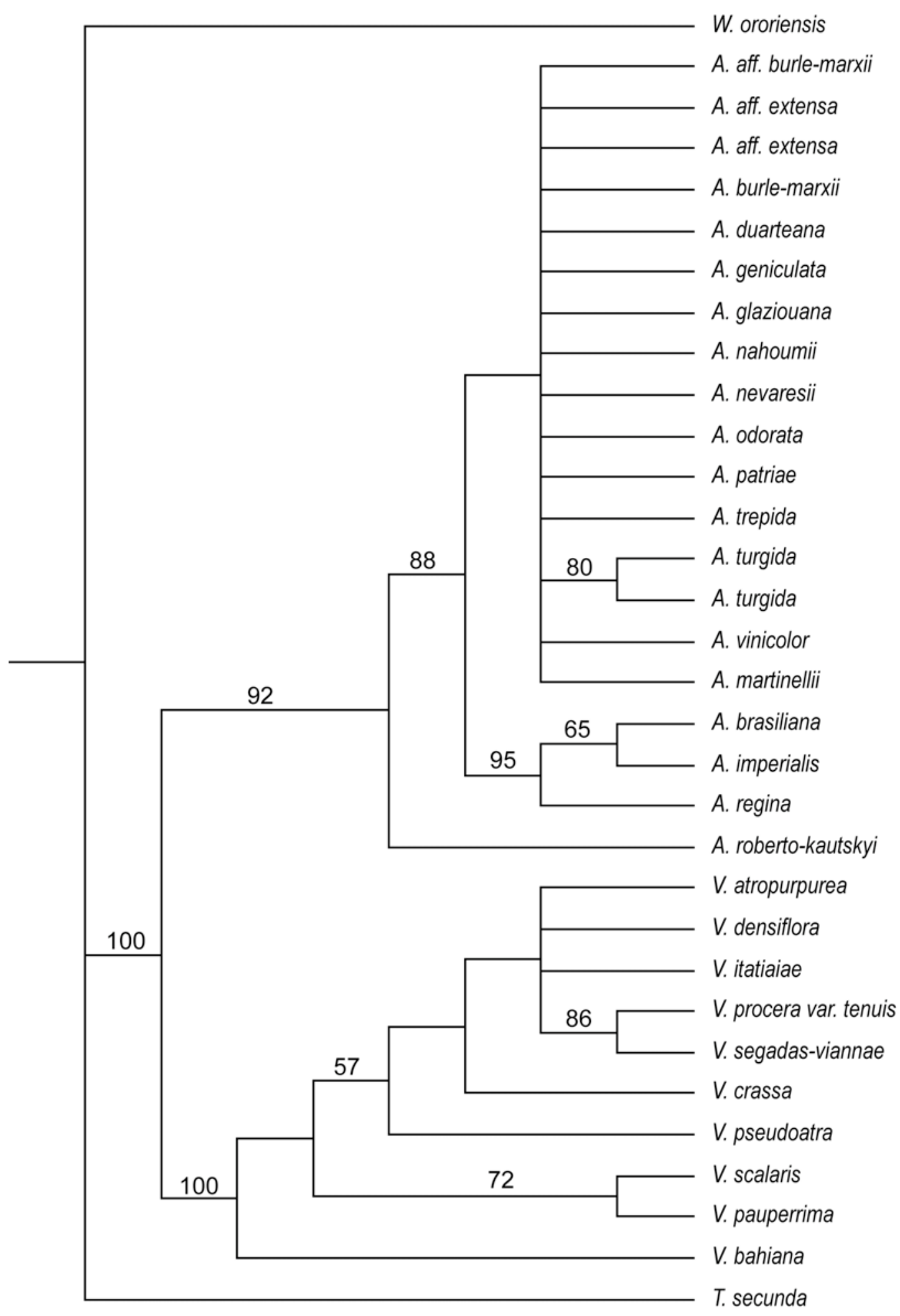

FIG. 4. Semistrict consensus tree of most parsimonious trees resulting from phylogenetic analyses of the combined plastid markers $(\operatorname{trnK}-r p s 16, \operatorname{trn} \mathrm{C}-p e t \mathrm{~N})$ and low copy nuclear gene (FLO/LFY). Numbers above branches are bootstrap percentages $>50 \%$. 


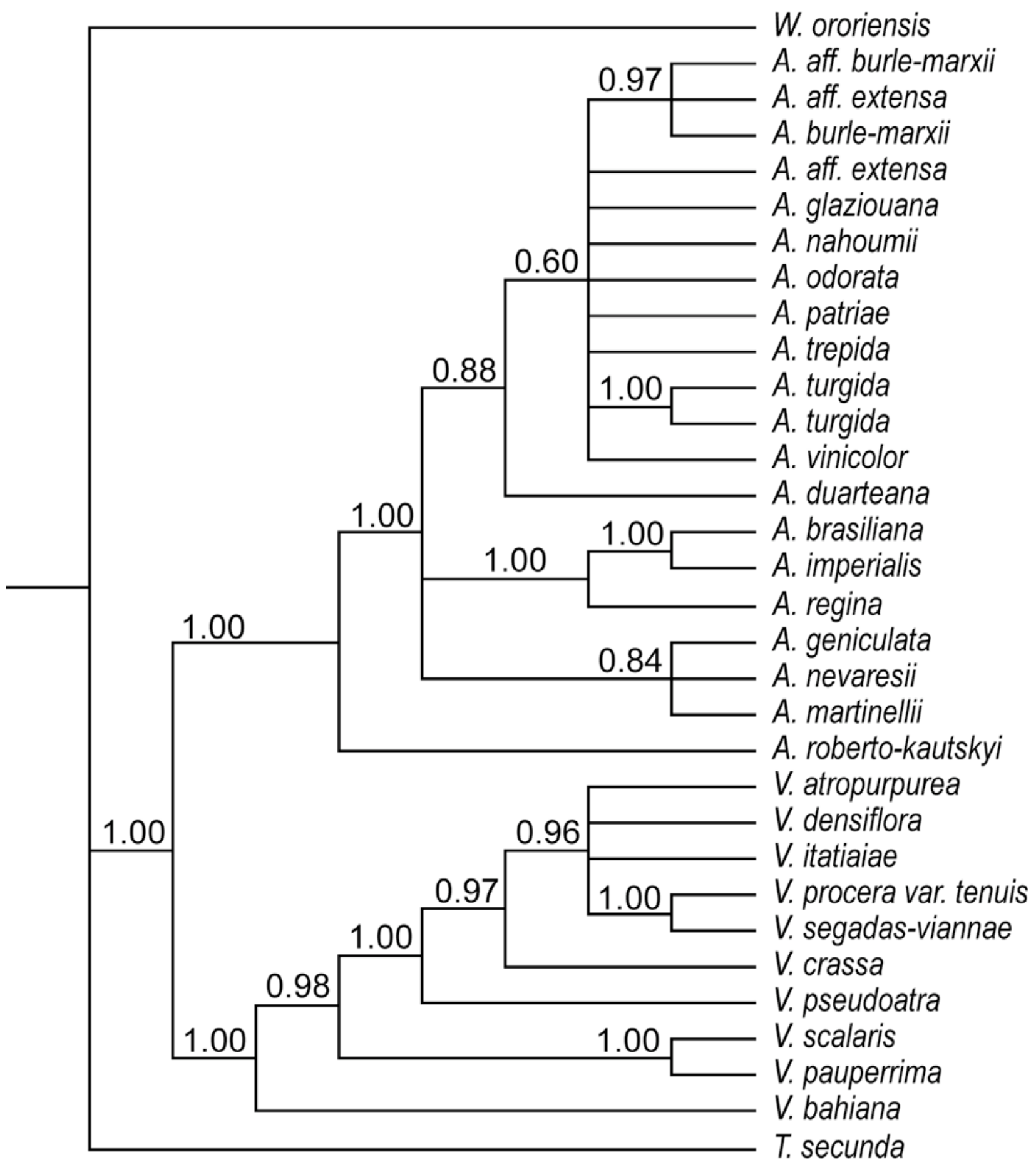

FIG. 5. 50\% Majority-rule consensus of 99538 Bayesian trees from three concatenated regions from

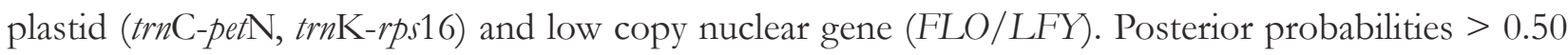
are indicated above branches. 


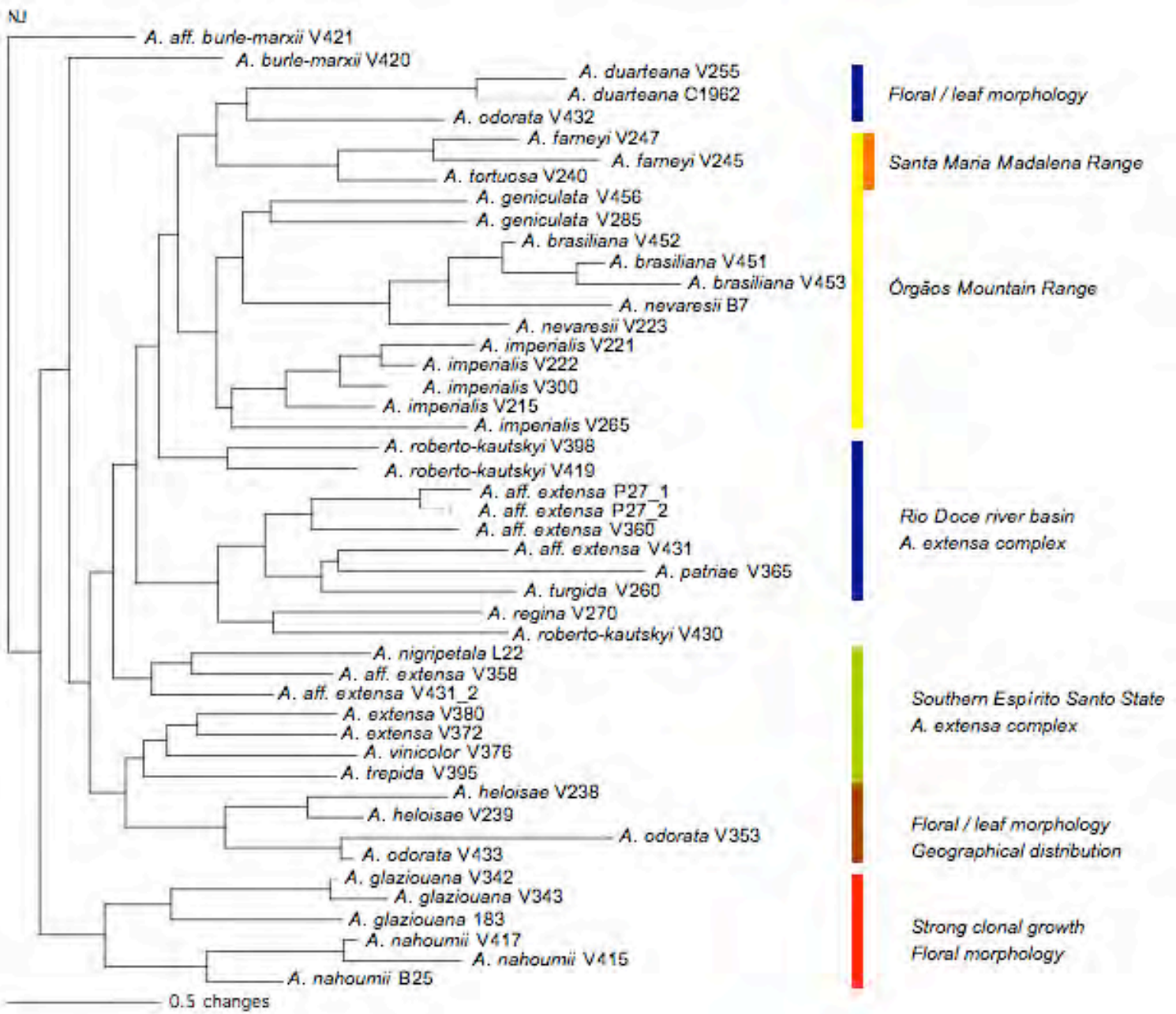

FIG. 6. Neighbor joining tree based on the Pairwise Distance Between Individuals for 20 microsatellite loci from 47 Alcantarea individuals. Colored bars indicate groups that presumably have morphological or biogeographical affinities. Letters and numbers after taxon name indicate collector initials and number (Table 1). 


\section{DISCUSSION}

\section{Phylogenetic relationships of Alcantarea based on cpDNA markers}

Both chloroplast markers employed in this work provided low resolution to reconstruct the phylogeny of Alcantarea. The trnC-pet $\mathrm{N}$ indicates only six clades weakly supported. Within the ingroup, the strict consensus (not shown) is unresolved, with a large polytomy where all species of Alcantarea are found together with one weakly supported clade of Vriesea. The relationship of these two genera could not be elucidated with this marker. The CI and RI values reflect that there is no homoplasy due to reduced variation. A high bootstrap (BS) value (BS=92) supports the monophyly of the subfamily. The $\operatorname{trn} \mathrm{K}-r p s 16$ provided equal or few more informative sites than $\operatorname{trn} \mathrm{C}-p e t \mathrm{~N}$, depending on the sampling employed (Table 1). It was also a larger fragment. The monophyly of Tillandsioideae is also corroborated $(\mathrm{BS}=100)$ and Alcantarea and Vriesea formed a weakly supported clade $(\mathrm{BS}=50)$ with very low resolution. Vriesea emerges monophyletic and Alcantarea is unresolved. Both cpDNA markers employed indicate the monophyly of Vriesea with weak to moderate support. The $\operatorname{trnK}-r p s 16$ also indicate with moderate support the monophyly of Gurmania + Tillandsia.

The low DNA sequence variation observed among the species of Alcantarea for cpDNA regions was not useful to resolve relationships in the generic level. As observed by Terry et al. (1997a) the DNA-variability for Bromeliaceae in general is very low indicating a slow evolution rate for the chloroplast genome that is in sharp contrast with the degree of morphological diversifications within the family. Other authors (e.g. Schulte et al., 2005; Sousa et al., 2007) have attributed this low level of variability within the cpDNA to a rapid radiation and speciation within the Bromeliaceae. Whether the biological reasons for the homogeneity of cpDNA are still under debate, the low resolution tendency is confirmed here for both chloroplast markers.

Most molecular phylogenies so far presented for the Tillandsioideae indicates that this subfamily is monophyletic but large genera such as Gurmania, Vriesea and Tillandsia often appear as polyphyletic (Terry et al. 1997; Barfuss et al., 2005). Our results partially corroborate this former 
conclusion since using either cpDNA or FLO/LFY alone or when combining both data sets high bootstrap values supporting the monophyly of the subfamily were obtained.

Phylogenetic relationships of Alcantarea based on low copy nuclear gene

The data obtained with FLO/LFY second intron strongly indicates the monophyly of Alcantarea $(\mathrm{BS}=91)$ and Vriesea $(\mathrm{BS}=96)$ and that these two genera are sister lineages (BS=99). Within Alcantarea resolution is improved at least for the basalmost lineages. Alcantarea roberto-kaustkyi is the first divergent lineage, followed by a strongly supported clade (A. regina (A. brasiliana, A. imperialis)). The remaining species form a polytomy moderately supported $(B S=80)$ involving nine species. The differences between semistric and strict consensus trees (not shown) for this marker are that in the strict consensus there is lower resolution within Alcantarea. The clade (A. regina (A. brasiliana, $A$. imperialis)) appears in a polytomy together with $A$. duarteana, A. geniculata, A. martinellii, $A$. nevaresii and a moderately supported clade with the remaining species.

This marker also provided better resolution for investigating relationships within Vriesea. Moderate bootstrap values support two clades: one formed by $V$. scalaris and $V$. pauperrima, both belonging to section Vriesea and a second clade containing $V$. procera var. tenuis (Section Vriesea) and $V$. segadas-viannae (Section Xiphion), indicating the paraphyly of these sections, as was already observed by Costa et al. (2002) and by Barfuss et al. (2005).

The higher DNA sequence variation observed among the species of Alcantarea and Vriesea for this marker was useful in resolving relationships better than cpDNA. Data presented in Table 1 indicated that FLO/LFY presented more than five times parsimony-informative characters than the cpDNA markers. The utility of FLO/LFY second intron has been demonstrated in several recent publications, where it was used to resolve intrageneric relationships (e.g. Oh and Potter, 2003; Grob et al., 2003) and here we suggest that it may be useful for broader analyses within Bromeliaceae also. 
Maximum Parsymony (MP) as well as Bayesian analyses (BA) of the combined data sets, corroborate the monophyly of Alcantarea and Vriesea generating higher values than obtained for the markers individually. The topology obtained in the 50\% majority rule consensus of the BA trees is very similar to the semistrict consensus tree obtained using MP. The strict consensus of MP (not shown) is very similar to the semistrict consensus (Figure 4) though there is not resolution for the positioning of the clade (A. regina (A. brasiliana, A. imperialis)) that appears in a polytomy together with the remainder of Alcantarea species excluding A. roberto-kautskyi.

In both MP and BA the topology obtained for the clade Vriesea is identical but the statistic support varies. This topology is also the same as the one that was obtained from LFY/FLO alone.

In the Bayesian analyses $A$. roberto-kautskyi is the earliest diverging lineage and is followed by a polytomy where high posterior probabilities $(\mathrm{PP})$ support the clade (A. regina (A. brasiliana, A. imperialis)), one unresolved and moderately supported ( $\mathrm{PP}=0.84)$ trichotomy of $A$. geniculata, $A$. nevaresii and $A$. martinellii and all the other species are within clade namely core Alcantarea. The core Alcantarea clade is moderately supported $(\mathrm{PP}=0.88)$ and contains $A$. duarteana, which emerges as sister to the rest of the species forming a large and weakly supported ( $\mathrm{PP}=0.60)$ polytomy (Fig. 5).

Both BA and MP analyses present this large and weakly supported polytomy inside core Alcantarea, where most species of Alcantarea are nested in. In this clade are positioned most taxa of the Alcantarea extensa complex (A. aff. burle-marxii, A. aff. extensa, A. trepida, A. turgida, A. vinicolor), characterized by their polystichous stamens and reddish-yellow petals together with species of bright yellow petals and stamens presented in bundles (A. naboumii, A. odorata, A. patriae) and A. glazionana, with milk-white petals.

These analyses based in combined data sets also strongly support $(\mathrm{PP}=1)$ that Alcantarea is sister to the eastern Brazilian Vriesea species. Despite Alcantarea being treated before as an 'ancestral group' in relation to Vriesea, due to its almost ubiquitous compound inflorescences, which were assumed by Grant (1995) to be a pleisiomorphyc character, this hypothesis is not corroborated here. Also, Weraubia ororiensis, which was treated previously within Vriesea, does not appear nested inside the 
clade of Vriesea taxa from eastern Brazil. Nevertheless, to attest the monophyly of Weraubia a much broader sampling of this genus would be desirable.

Alcantarea roberto-kautskyi, the earliest divergent lineage within the genus is unique in regard to several of its morphological features, such as the inflorescence shape (in candelabrum format), versatile anthers and pollen grain shape. In the well supported clade formed by (A. regina ( $A$. imperialis, A. brasiliana)), all species are restricted to the Serra do Mar and Serra da Mantiqueira. A possible morphological sinapomorphy of this clade would be the presence of secund flowers. This distinct position of flowers during anthesis was already employed by Harms (1930) to subdivide Alcantarea into two groups. Also, these species have bat pollinated flowers that produce abundant nectar and have petals that fade from yellow while in bud to whitish at anthesis (Martinelli, 1994, 1997).

The apparently isolated position of $A$. duarteana is somehow corroborated by some of its unique traits, it is a medium sized plant, with bright yellow petals, leaves densely covered by trichomes on both faces (what is a very rare feature within the genus). In addition it occurs restricted in the far inland campo rupestre vegetation in the Diamantina Plateau, Minas Gerais State.

The position of $A$. aff. burle-marxii (Versieux 421) is uncertain since each marker indicated distinct placement (though weakly supported) for it, which could either be related to A. burle-marxii, A. nahoumii or A. aff. extensa. The true identity of this taxon will be focus of additional investigations, but it possibly is an undescribed species.

The phylogeny presented here also made it possible to discuss some relationships within Vriesea. Traditionally, Vriesea subg. Vriesea have been divided into two sections: Xiphion and Vriesea. According to Smith and Downs' (1977) classification these sections are respectively defined on the base of the included vs. exserted stamens and by the dull-green or brownish bracts vs. bracts mostly bright colored with red, orange or yellow. This morphological segregation would somehow reflect the evolution of Chiropterophily in Xiphion and hummingbirds pollination in section Vriesea. Data obtained here with combined data sets in the BA suggests that both sections in their traditional circumscriptions are not monophyletic. These observations are concordant with results reported by 
Costa (2002) that also indicated the paraphyletic nature of these groups based on a morphological cladistic analysis and also by Barfuss et al. (2005) that used molecular data.

The paraphyly of these sections is drawn by the occurrence of $V$. procera var. tenuis (sect. Vriesea) nested inside the clade o sect. Xiphion. Also, V. babiana, which presents most typical characteristics of sect. Xipbion as the included stamens and dull colored bracts appears as the first lineage to diverge within Vriesea, outside the Xiphion clade. This particular species grows sympatrically with Alcantarea nahoumii and their leaves are so similar that many herbarium specimens contain mixed parts of both species. A hybrid origin and a test for lack of reproductive isolation between $V$. babiana and $A$. nahoumii are hypotheses to be further investigated.

In conclusion, the delimitation of Vriesea sect. Vriesea and Xiphion is considered inconsistent and should be carefully examined using a broader sampling of Vriesea species in the future. Furthermore, morphologically based taxonomy of Bromeliaceae has suffered from high levels of homoplasy (Costa 2002, Schulte et al., 2005). In spite of morphological distinctiveness observed within Alcantarea taxa, a low molecular divergence was noticed for both chloroplast markers as well as for $L F Y / F L O$ second intron. These facts could indicate relatively recent and rapid speciation, as observed for other Bromeliaceae genera (Sousa et al., 2007; Schulte et al., 2005) after the evolution of adaptations to survive in the harsh environments of eastern Brazil inselbergs.

The use of microsatellite in phylogenetic studies of Alcantarea

The NJ analysis based on microsatellite loci indicates distinct grouping patterns for the different species of Alcantarea. Alcantarea duarteana, A. farney, A. geniculata, A. brasiliana, $A$ imperialis, $A$ heloisae, A. glazionana and $A$. nahoumii appear forming well defined groups based on microsatellite data. Other species as $A$. odorata, $A$. roberto-kantskyi and $A$. extensa s. l. (including several individuals treated as affinis) appear to be involved in hybridization processes because the different individuals do not cluster together.

Alcantarea odorata is related to $A$. heloisae, as well as to $A$. duateana. Alcantarea roberto-kantskyi 
emerges close to the 'Serra dos Órgãos' mountain range species as well as to $A$. regina and to other individuals of $A$. extensa complex.

Three groups of species belonging to the Alcantarea extensa complex can be noticed. The $A$. extensa, from the type locality (Versieux 380) appears related to the individual from Forno Grande population (Versieux 372) to $A$. vinicolor, and to $A$. trepida. A second group involves $A$. nigripetala and A. aff. extensa. These two groups are mainly composed by individuals collected in the southern and southwestern Espírito Santo State. The third group of $A$. extensa complex taxa includes species that occurs mainly at the eastern Minas Gerais State, such as $A$. aff extensa (Versieux 431, Pinheiro 27), $A$. turgida but also $A$. patriae from Espírito Santo. The position of $A$. patriae in this group is interesting because its flower morphology, i.e. bright yellow petals and stamens presented in bundle, are not typical characteristics of the Alcantarea extensa complex.

A well biogeographic defined group includes most taxa from Serra dos Órgãos mountain range. All A. imperialis individuals sampled throughout this mountain range appear together, independently of the distance among populations or differences in color pattern of leaves and bracts. Alcantarea brasiliana, which has been considered a doubtful taxon, appears related to both $A$. nevaresii and $A$. geniculata. Inside the 'Serra dos Órgãos' group.

A subgroup composed by $A$. farneyi and $A$. tortuosa is observed. These two species occur in sympatry in Santa Maria Madalena, along the Desengano mountain range and show several similarities as the presence of very narrow dark red margins along the leaf blades, coloration and imbrications of bracts, and in some floral characters such as the size of the sepals, the petals, and the petal appendages (Versieux and Wanderley, 2007). These taxa are shown to be close to $A$. duarteana, which is a species that occur isolated in campo rupestre vegetation, ca. $450 \mathrm{~km}$ further northwestern.

Another group formed by the microsatellite data are $A$. beloisae and $A$. odorata, that share close areas of occurrence (northern Rio de Janeiro), leaves and bracts covered by epicuticular wax and similar flower morphology.

An intriguing group that was formed involves $A$. glaziouana, a narrowly endemic species that occurs only close to the sea in Rio de Janeiro and Niterói, together with $A$. nahoumii, which is the 
species with the most northern distribution within the genus, occurring ca. $1250 \mathrm{~km}$ away from Rio de Janeiro in Bahia State. Nevertheless, both species do show morphological similarities regarding inflorescence shape. Sometimes both species can have flowers with small deformations in the pistil and on the stamens. Additionally a strong clonal growth can be noticed in both taxa.

Microsatellite pattern support the view that Alcantarea extensa should be treated as complex of species, as already mentioned by Versieux and Wendt (2006) and Versieux and Wanderley (in review). The lack of clustering between the position of several individuals treated here as affinis (aff.) A. extensa indicates either extensive hybridization or incipient speciation. If we consider this group as a recent divergent taxa that haven't had the necessary time to accumulate differences, reproductive isolation, and fixed apomorphies it would be easier to understand why species boundaries are so hard to define.

As general features of taxa involved in this complex we can mention the radially disposed stamens at anthesis, petal colors that fade from a darker while in bud to a pale color when petals are fully expanded, petals often yellow and wine-red spotted, resembling almost orange or sometimes wine-orange. Also there can be differences between the abaxial (darker) and adaxial (paler) petal faces. The floral bracts tend to be more coriaceous and dilated along the central portion and thinner and yellowish along the margins in sicco, petals are more loosely arranged during anthesis and not so spiralescent recoiled as in other species of the genus. The compound inflorescences frequently are asymmetric, with different sizes of branches, the primary bracts are always shorter then the lateral peduncles and branches are more laxly distributed (Versieux and Wanderley, in review).

The position of $A$. regina and $A$. roberto-kautskyi close to a group of $A$. aff. extensa (Fig. 6 ) is intriguing, because morphological characters do not corroborate such relationship. At this point we should mention that three biological processes may explain allele sharing patterns other than by true phylogenetic proximity: (1) shared ancestral polymorphism = lineage sorting, (2) homoplasy, (3) hybridization. Any of these processes could be evoked to explain this grouping, but in the current work we have not evidences to corroborate any of them in detriment of the other.

Microsatellite may be exposed to size homoplasy due to rapid evolution. Population sampling, as well as the number of loci employed should be maximized in order to alleviate homoplasy 
problems in such analyses. However, according to Kalinowski (2005) small sample size (one or two individuals) would lead to similar results as larger samples for estimating genetic distances using microsatellites when there is a large differentiation among the sampled taxonomic units. Though it is expected that the microsatellite $\mathrm{NJ}$ tree shows groups of species or suggest relationships that are also present in the phylogenetic tree based on combined plastid and low copy nuclear gene sequences as was already observed in other works if similar approach (e.g. Ochieng et al. 2007).

\section{Evolution of some particular traits}

If phylogenetic trees are analyzed together with the microsatellite NJ tree it is possible to confirm that the appearance of some selected traits in distantly related taxa may be consequence of homoplasy.

Limited data is available regarding reproductive biology of most species of Alcantarea. Even so, our results suggest that bat pollination may have evolved at least two times, one in the clade of $A$. imperialis, and a second time in the Alcantarea extensa complex where nighth-blooming flowers with spreading stamens and a large amount of nectar are also present. The presence of bright yellow

petals and stamens in bundles in most species of 'Serra dos Órgãos' group suggest pollination by moths.

Occupation of the campo rupestre vegetation also seems to have occurred repetitive times, one for $A$. duarteana, another for $A$. turgida and a third event for $A$. nahoumii, all the three species are distantly related by genetic distance.

Simple inflorescences also exist in distantly related taxa and appear to have multiple origins. This trait is present in $A$. martinellii, A. farneyi, A. trepida, A. extensa and other species as $A$. benzingii and $A$. hatschbachii that were not sampled.

\section{Hybridization}


Interspecific hybridization, with or without subsequent introgression from one species into another, occurs commonly in natural populations of different plant groups (Rieseberg and Carney, 1998). The great overlap of geographic distribution and of flowering period, which is concentrated during summertime suggests that there are opportunities for hybridization or gene introgression, particularly within the 'Serra dos Órgãos' group and also in the Alcantarea extensa complex, for wich populations of different taxa can be found relatively close to each other.

Data available on reproductive biology of Alcantarea indicate that self-compatibility is also present in the genus, though outcrossing yields more ovules penetration by pollen tubes but without significant difference for fruit set (Martinelli, 1997). This information is particularly important to elucidate what is occurring with some populations of $A$. brasiliana and $A$. imperialis in Serra dos Órgãos. Results obtained here with microsatellite indicate that all the individuals of $A$. imperialis sampled cluster together, no matter if they come from different and distant populations. Nevertheless, $A$. brasiliana that is morphologically very similar to $A$. imperialis appear more related to A. nevaresii and A. geniculata.

Examinations of populations in the field, revision of herbarium specimens and detailed examinations of liquid preserved flowers revealed that $A$. brasiliana may be considered a new synonym of $A$. imperialis, due to the lack of morphological data to separate them.

In addition, when Smith (1943) described $A$. brasiliana, he mistakenly included his description a specimen of A. geniculata (Glaziou 11685).

As noted by Barbará et al. (2007, 2009), A. imperialis and A. geniculata may show low levels of interspecific gene flow when in sympatry. Barbará et al. (2007) also reported a high population differentiation for $A$. imperialis, which was not expected due to the outcrossing mating system, and these authors concluded that restricted gene flow along the fragmented inselbergs would be responsible for that scenario.

It is interesting that sequences of the second intron of LFY do not show any difference between $A$. brasiliana and $A$. imperialis that appear sister to each other with maximum PP support.

Based in our NJ tree, we hypothesize here that $A$. brasiliana is a natural hybrid between $A$. 
geniculata and A. imperialis, species that frequently co-occur around Petrópolis in Serra dos Órgãos.

Other suggestive case of possible hybrid origin presented here involves species of campo rupestre along the Espinhaço range. Alcantarea duarteana appears sister to A. turgida with cpDNA trnkrps16 marker, while microsatellite indicates a relationship of $A$. duarteana with $A$. odorata and species of Santa Maria Madalena range. Morphological similarities of $A$. duarteana with $A$. odorata appear to be greater than of $A$. duarteana to $A$. turgida.

Additional studies on the reproductive biology of other Alcantarea species as well as controlled interspecific crosses would be required to a better comprehension of the importance of hybridization within the genus.

\section{Why treat Alcantarea as a genus?}

Currently, discussions of generic limits within Bromeliaceae accompanied by new combinations, taxa merging or splitting are very common in the literature. It has long been accepted that assigning species to a genus may be extremely difficult, particularly in Bromelioideae and Tillandsioideae subfamilies (Smith and Downs 1979), reflecting fragile delimitations.

Alcantarea has a polemic taxonomic history and has not always been accepted as a genus. Depending on the taxa that were included inside Alcantarea, the apical and basal appendages of the seeds, one of the main diagnostic features of the genus, would not hold for all species, justifying its rejection as a genus (Smith 1955). After the exclusion of one Central American and one Caribbean species, the genus became endemic of Brazil, and the seeds with basal and apical comas were considered as one of the key characters to recognize all the species (Grant, 1995).

A summary of the diagnostic features that have been classically adopted to segregate genera in the Tillandsioideae is diagrammatic presented by Terry et al. (1997) based on the classification of Smith and Downs (1977). In essence, four characters are the backbone of the generic classification: the presence and position of seed appendages, position of ovary, presence or absence of petal appendages and degree of conation of petals. Two of this characters are contrastingly different 
between Vriesea and Alcantarea. Firstly Vriesea has seeds with apical appendages minute, while in Alcantarea apical appendages are well developed and divided, apparently playing a distinct role in seed dispersion (Versieux pers. obs.). Secondly the ovary position of Alcantarea is semi-inferior, while in Vriesea it is superior. Vriesea and Alcantarea share both other diagnostic features that are the free petals and presence of petal appendages. However these two characters are equally shared by Alcantarea, Vriesea and Glomeropitcairnia (Smith and Till, 1998), a genus placed between the basalmost lineages of Tillandsioideae (Beaman and Judd, 1996; Terry et al., 1997; Barfuss et al., 2005). Thus the latter two characters configure a sympleisomorphy. Hence, among the classical used features to segregate genera in Tillandsioideae, a morphological character that ties Vriesea and Alcantarea together would be missing.

It could be argued that sister relationships between Alcantarea and Vriesea clades as we found here not necessarily assures generic status to Alcantarea, which could be maintained in the subgeneric hierarchical level following the traditional classification (Mez, 1894; Smith and Downs, 1977). However, a larger Vriesea containing Alcantarea is not supported by morphological data, since this group would be defined by symplesiomorphic characters only (i.e. petals free and bearing a pair of appendages). Recognizing Alcantarea and V riesea separately would be more practical, since both genera can be easily recognized by their evident diagnostic characters. The largely circumscribed V riesea (sensu Smith and Downs, 1977) now corresponds to the new recently created tribe Vrieseeae W. Till \& Barfuss, which includes Alcantarea, Vriesea and Weraubia (Barfuss et al., 2005).

Recent works have provided new insights that also corroborate the segregation of Alcantarea and Vriesea. Ceita et al. (2008) showed differences between the karyotypes of these genera, while Alcantarea exhibits chromosomes that are uniform in size Vriesea species have bimodal chromosomes, i.e. showing two different classes of size. Leaf anatomical features also point to previously unreported differences (e.g. thickness of the leaves, distinct shapes of the air channels filled with spongy parenchyma, different extension of the aquiferous parenchyma) that are probably related to the occupation of the sunny rupicolous habitat by all Alcantarea species versus radiation into mesic 
and shaded habitat found inside forests, where most Vriesea species are concentrated (Versieux et al., in review).

\section{Overall comparison among different data sets}

While cpDNA yielded mostly unresolved trees, low copy nuclear gene allowed a better resolution among genera and species and microsatellite indicated relationships within the ingroup, also suggesting hybridization events. The distinct level of resolution presented by each data set limits the comparisons among them. However, few clades that were well supported in the trnK-rps 16 consensus trees appear to be topologically incongruent with other data sources (FLO/LFY or microsatellite). The first particular clade that should be highlighted and further investigated is the trichotomy involving $A$. duarteana and two distinct individuals of $A$. turgida. These two species occur in campo rupestre vegetation along the Espinhaço range in Minas Gerais State. The other markers (FLO/LFY or microsatellite) do not support this relationship. Another moderately supported clade is a trichotomy clustering $A$. farney, $A$. heloisae and $A$. nevaresii. Both FLO/LFY and microsatellites indicate proximity of $A$. nevaresii to $A$. geniculata. Though these two clades appear to be in disagreement, congruence test allowed cpDNA data to be combined with LFY/FLO.

\section{CONCLUSIONS}

In conclusion, our phylogenetic analyses have shown that Alcantarea is a monophyletic group and sister to a clade that comprises Brazilian species of Vriesea of both sections Vriesea and Xiphion. The infrageneric classification of Vriesea deserves further investigations, since both sections of Vriesea, as traditionally defined are paraphyletic. Different data sets provided distinct levels of resolution, and microsatellites were good tools to infer close relationships in the ingroup. Tough presenting low resolution it seems that characters traditionally employed in taxonomy of the genus, such as simple inflorescence have evolved several independent times. 


\section{LITERATURE CITED}

Barbará T, Martinelli G, Fay MF, Mayo SJ, Lexer C. 2007. Population differentiation and species cohesion in two closely related plants adapted to neotropical high-altitude 'inselbergs', Alcantarea imperialis and Alcantarea geniculata (Bromeliaceae). Molecular Ecology 16: 1981-1992.

Barbará T, Lexer C, Martinelli G, Mayo S, Fay MF, Heuertz M. 2008. Within-population spatial genetic structure in four naturally fragmented species of a neotropical inselberg radiation, Alcantarea imperialis, A. geniculata, A. glazionana and A. regina (Bromeliaceae). Heredity 101: 285296.

Barbará T, Martinelli G, Palma-Silva C, Fay MF, Mayo SJ, Lexer C. 2009. Genetic relationships and variation in reproductive strategies in four closely related bromeliads adapted to neotropical 'inselbergs': Alcantarea glaziouana, A. regina, A. geniculata and A. imperialis (Bromeliaceae). Annals of Botany 103: 65-77.

Barfuss MHJ, Samuel R, Till W, Stuessy TF. 2005. Phylogenetic relationships in subfamily Tillandsioideae (Bromeliaceae) based on DNA sequence data from seven plastid regions. American Journal of Botany 92: 337-351.

Baum DA, Yoon HS, Oldham RL. 2005. Molecular evolution of the transcription factor LEAFY in Brassicaceae. Molecular Phylogenetics and Evolution 37: 1-14.

Beaman RS, Judd W. 1996. Systematics of Tillandsia subgenus Psendoalcantarea (Bromeliaceae). Brittonia 48: 1-19.

Boneh L, Kuperus P, Van Tienderen PH. 2003. Microsatellites in the bromeliads Tillandsia fasciculata and Gurmania monostachya. Molecular Ecology Notes 3: 302-303.

Ceita GO, Assis JGA, Guedes MLS, Oliveira ALPC. 2008. Cytogenetics of Brazilian species of Bromeliaceae. Botanical Journal of the Linnean Society 158: 189-193.

Chen X, Cho YG, McCouch SR. 2002. Sequence divergence of rice microsatellites in Oryza and other plant species. Molecular Genetics and Genomics 268: 331-343.

Coen ES, Romerom JM, Doyle S, Elliott R, Murphy G, Carpenter R. 1990. FLORICAULA—a 
homeotic gene required for flower development in Antirrbinum majus. Cell 63: 1311-1322.

Costa AF. 2002. Revisão taxonômica do complexo Vriesea paraibica Wawra (Bromeliaceae). PhD thesis, Universidade de São Paulo, Brasil.

Doyle JJ, Doyle JL. 1987. A rapid DNA isolation procedure for small quantities of fresh leaf tissue. Phytochemical Bulletin 19: 11-15.

Ford CS, Ayres KL, Toomey N, Haider N, Stahl JVA, Kelly LJ, Wikstrom N, Hollingsworth PM, Duff RJ, Hoot SB, Cowan RS, Chase MW, Wilkinson MJ. 2009. Selection of candidate coding DNA barcoding regions for use on land plants. Botanical Journal of the Linnean Society 159: $1-11$.

Frohlich MW, Meyerowitz EM. 1997. The search for flower homeotic gene homologs in basal angiosperms and gnetales: a potential new source of data on the evolutionary origin of flowers. International Journal of Plant Sciences 158: S131-S142.

Givnish TJ, Milliam TM, Evans TM, Hall JC, Berry PE, Terry RG. 2004. Ancient vicariance or long-distance dispersal? Inferences about phylogeny and South American - African disjunctions in Rapateaceae and Bromeliaceae based on $n d h \mathrm{~F}$ sequence data. International Journal of Plant Sciences 165: 35-54.

Givnish TJ, Milliam KC, Berry PE, Sytsma KJ. 2007. Phylogeny, adaptive radiation, and historical biogeography of Bromeliaceae inferred from $n d h \mathrm{~F}$ sequence data. Aliso 23: 3-26.

Goldstein DB and Schlotterer C (eds.). 1999. Microsatellites, Evolution and Applications. Oxford University Press. Oxford, Great Britain, 352 p.

Grant JR. 1995. The resurrection of Alcantarea and Weraubia, a new genus. Tropische und Subtropische Pflanzenwelt 91: 7-57.

Grob GBJ, Gravendeel B, Eurlings MCM. 2003. Potential phylogenetic utility of the nuclear FLORICAULA/LEAFY second intron: comparison with three chloroplast DNA regions in Amorphophallus (Araceae). Molecular Phylogenetics and Evolution 30: 13-23.

Goldstein DB, Schlotterer C (eds.). 1999. Microsatellites, Evolution and Applications. Oxford University Press. Oxford, Great Britain, 352 p. 
Harms H. 1929. Bromeliaceae novae III. Notizblatt des Botanischen Gartens und Museums zu BerlinDablem 10: 784-805.

Harms H. 1930. Bromeliaceae. In Engler A, Prantl K, eds. Die natürlichen Pflanzenfamilien nebst ibren Gattungen und wichtigsten Arten, insbesondere den Nutzpflanzen. Ed. 2, 15a,. Leipzig: Wilhelm Engelmann, 65-159.

Horres R, Zizka G, Kahl G, Weising K. 2000. Molecular phylogenetics of Bromeliaceae: evidence from trnL (UAA) intron sequences of the chloroplast genome. Plant Biology 2: 306-315.

Horres R, Schulte K, Weising K, Zizka G. 2007. Systematics of Bromelioideae (Bromeliaceae)evidence from molecular and anatomical studies. Aliso 23: 27-43.

Kalinowski ST. 2005. Do polymorphic loci require large sample sizes to estimate genetic distances? Heredity 94: 33-36.

Kress WJ, Wurdack KJ, Zimmer EA, Weigt LA, Janzen DH. 2005. Use of DNA barcodes to identify flowering plants. Proceedings of the National Academy of Science 102: 8369-8374.

Lee C, Wen J. 2004. Phylogeny of Panax using chloroplast $\operatorname{trn} C$-trnD intergenic region and the utility of $\operatorname{trnC-trnD}$ in interspecific studies of plants. Molecular Phylogenetics and Evolution 31: 894-903.

Maddison WP, Maddison DR. 2003. MacClade: Analysis of phylogeny and character evolution. Version 4.06. Sunderland: Sinauer Associates.

Martinelli G. 1994. Reproductive biology of Bromeliaceae in the Atlantic rainforest of southeastern Brazil. $\mathrm{PhD}$ thesis, University of St. Andrews, Scotland.

Martinelli G. 1997. Biologia reprodutiva de Bromeliaceae na Reserva Ecológica de Macaé de Cima. Pp. 213-250 in Serra de Macaé de Cima: Diversidade Florística e Conservação em Mata Atlântica. eds. H. C. Lima, and R. R. Guedes-Bruni. Rio de Janeiro: Instituto de Pesquisa Jardim Botânico do Rio de Janeiro.

Mez, C. 1894. Bromeliaceae. Pp. 173-643 in Flora Brasiliensis vol. 3, pars 3, eds. C. F. P. Von Martius, A. G. Eichler, and I. Urban. Leipzig: F. Fleischer.

Ochieng JW, Steane DA, Ladiges PY, Baverstock PR, Henry RJ, Shepherd M. 2007. Microsatellites retain phylogenetic signals across genera in eucalypts (Myrtaceae). Genetics and 
Molecular Biology 30: 1125-1134.

Oh SH, Potter D. 2003. Phylogenetic utility of the second intron of LEAFY in Neillia and Stephanandra (Rosaceae) and implications for the origin of Stephanandra. Molecular Phylogenetics and Evolution 29: 203-215.

\section{Paggi GM, Palma-Silva C, Bered F, Cidade FW, Sousa ACB, Souza AP, Wendt T, Lexer C.}

2008. Isolation and characterization of microsatellite loci in Pitcairnia albiflos (Bromeliaceae), an endemic bromeliad from the Atlantic rainforest, and cross-amplification in other species. Molecular Ecology Resources 8: 980-982.

Palma-Silva C, Cavallari MM, Barbará T, Lexer C, Gimenes A, Bered F, Bodanese-Zanettini MH. 2007. A set of polymorphic microsatellite loci for Vriesea gigantea and Alcantarea imperialis (Bromeliaceae) and cross-amplification in other bromeliad species. Molecular Ecology Notes 7: 654-657.

Petren K, Grant BR, Grant PR. 1999. A phylogeny of Darwin's finches based on microsatellite DNA length variation. Proceedings of the Royal Society London 266: 321-329.

Posada D, Crandall KA. 1998. Modeltest: testing the model of DNA substitution. Bioinformatics 14: $817-818$

Ran JH, Wei XX, Wang XQ. 2006. Molecular phylogeny and biogeography of Picea (Pinaceae): Implications for phylogeographical studies using cytoplasmic haplotypes. Molecular Phylogenetics and Evolution 41: 405-419.

Ranker TA, Soltis DE, Soltis PS, Gilmartin AJ. Subfamilial phylogenetic relationships of the Bromeliaceae: evidence from chloroplast DNA restriction site variation. Systematic Botany 15: 425-435.

Rieseberg LH, Carney SE. 1998. Plant hybridization. Tansley Review, 102. New Phytologist 140: 599_ 624.

Rex M, Patzolt K, Schulte K, Zizka G, Vásquez R, Ibisch PL, Weising K. 2007. AFLP analysis of genetic relationships in the genus Fosterella L.B. Sm. (Pitcairnioideae, Bromeliaceae). Genome 50: 90-105. 
Ronquist F, Huelsenbeck JP. 2003. MRBAYES 3: Bayesian inference of phylogeny. Bioinformatics 19: $1572-1574$.

Safford HD, Martinelli G, 2000. Southeast Brazil. In: Porembski S, Barthlott W, eds. Inselbergs. Biotic diversity of isolated rock outcrops in tropical and temperate regions. Berlin: Springer, $339-389$.

Sarthou C, Boisselier-Dubayle C, Lambourdière J, Samadi S. 2003. Polymorphic microsatellites for the study of fragmented populations of Pitcairnia geyskesii L.B. Smith (Bromeliaceae), a specific saxicolous species of inselbergs in French Guiana. Molecular Ecology Notes 3: 221-223.

Schulte K, Horres R, Zizka G. 2005. Molecular phylogeny of Bromelioideae and its implications on biogeography and the evolution of CAM in the family. Senckenbergiana biologica 85: 113-125.

Schulte K, Barfuss MHJ, Zizka G. 2009. Phylogeny of Bromelioideae (Bromeliaceae) inferred from nuclear and plastid DNA loci reveals the evolution of the tank habit within the subfamily. Molecular Phylogenetics and Evolution 51: 327-339.

Smith LB, Downs RJ. 1977. Tillandsioideae (Bromeliaceae). Flora Neotropica Monograph 14: 663-1492.

Smith LB, Downs RJ. 1979. Bromelioideae (Bromeliaceae). Flora Neotropica Monograph 14: 1493-2142.

Smith LB, Till W. 1998. Bromeliaceae. Pp. 74-99 in The families and genera of vascular plants, vol. 4, ed. K. Kubitzki. Berlin: Springer Verlag.

Sousa LOF, Wendt T, Brown GK, Tuthill DE, Evans TM. 2007. Monophyly and phylogenetic relationships in Lymania (Bromeliaceae: Bromelioideae) based on morphology and chloroplast DNA sequences. Systematic Botany 32: 264-270.

Swofford DL. 2002. PAUP* Phylogenetic analysis using parsimony (and other methods), v. 4. Sunderland: Sinauer Associates.

Szarzynski J. 2000. Xeric Island: environmental conditions on inselbergs. In: Porembski S, Barthlott W, eds. Inselbergs. Biotic diversity of isolated rock outcrops in tropical and temperate regions. Berlin: Springer, 37-48.

Tautz D, Renz M. 1984. Simple sequences are ubiquitous repetitive components of eukaryotic genomes. Nucleic Acids Research 12(10):4127-4138. 
Terry RG, Brown GK, Olmstead RG. 1997. Examination of subfamilial phylogeny in Bromeliaceae using comparative sequencing of the plastid locus ndhF. American Journal of Botany 84: 664-670.

Versieux LM, Wanderley MGL. 2007a. Alcantarea (E. Morren ex Mez) Harms. In Wanderley MGL, Shepherd GJ, Melhem TS, Giulietti AM, Flora Fanerogâmica do Estado de São Paulo, vol. 5. São Paulo: Instituto de Botânica, 59-62.

Versieux LM, Wanderley MGL. 2007b. Two new species of Alcantarea (Bromeliaceae, Tillandsioideae) from Brazil. Brittonia 59: 57-64.

Versieux LM, Wendt T. 2006. Checklist of Bromeliaceae of Minas Gerais, Brazil, with notes on taxonomy and endemism. Selbyana 27: 107-146.

Weigel D, Alvarez J, Smyth DR, Yanofsky MF, Meyerowitz EM. 1992. LEAFY controls floral meristem identity in Arabidopsis. Cell 69: 843-859.

Wendt T, Canela MBF, Klein DE, Rios RI. 2002. Selfing facilitates reproductive isolation among three sympatric species of Pitcairnia (Bromeliaceae). Plant Systematics and Evolution 232: 201-212.

Whipple IG, Barkworth ME, Bushman BS. 2007. Molecular insights into the taxonomy of Glyceria (Poaceae: Meliceae) in North America. American Journal of Botany 94: 551-557.

Appendix. List of vouchers for taxa used for molecular analyses.

\begin{tabular}{|c|c|c|}
\hline$\overline{\text { Taxa }}$ & Locality & Voucher (herbarium) \\
\hline $\begin{array}{l}\text { Alcantarea aff. burle-marxii (Leme) J.R. } \\
\text { Grant }\end{array}$ & Brazil, MG, Pedra Grande & Versieux 421 (SP) \\
\hline Alcantarea aff. extensa (L.B. Sm.) J.R. Grant & Brazil, MG, Carangola & Pinbeiro 27 (two individuals) (SP) \\
\hline " & Brazil, MG, Alto Caparaó, cultivated. & Versieux 358, $360(S P)$ \\
\hline " & Brazil, ES, Castelo, Forno Grande & Versieux 372 (SP) \\
\hline “ & Brazil, MG, Padre Paraíso & Versieux 431 (two individuals) (SP) \\
\hline Alcantarea brasiliana (L.B. Sm.) J.R. Grant & Brazil, RJ, Petrópolis, Serra da Estrela & Versieux 451, 452, 453 (SP) \\
\hline Alcantarea burle-marxii (Leme) J.R. Grant & Brazil, MG, Pedra Azul & Versieux $420(S P)$ \\
\hline Alcantarea duarteana (L.B. Sm.) J.R. Grant & Brazil, MG, Diamantina & IBt Living collection 1962; Versieux 255 (SP) \\
\hline Alcantarea extensa (L.B. Sm.) J.R. Grant & Brazil, ES, Cachoeiro do Itapemirim & Versieux $380(S P)$ \\
\hline $\begin{array}{l}\text { Alcantarea farneyi (Martinelli \& A. F. } \\
\text { Costa) J.R. Grant }\end{array}$ & Brazil, RJ, Santa Maria Madalena & Versieux 245, 247 (SP) \\
\hline Alcantarea geniculata (Wawra) J.R. Grant & Brazil, RJ, Teresópolis & Versieux 285, 456 (SP) \\
\hline Alcantarea glaziouana (Lem.) Leme & Brazil, RJ, Rio de Janeiro, Prainha & Versieux $183(S P)$ \\
\hline “ & Brazil, RJ, Rio de Janeiro, Urca & Versieux 342, 343 (SP) \\
\hline $\begin{array}{l}\text { Alcantarea hatschbachii (L.B. Sm. \& Read) } \\
\text { Leme }\end{array}$ & Brazil, MG, Gouveia & Hatschbach 29085, 40820 (MBM) \\
\hline Alcantarea beloisae J.R. Grant & Brazil, RJ, Santa Maria Madalena & Versieux 238, 239 (SP) \\
\hline
\end{tabular}


Alcantarea imperialis (Carrière) Harms

Alcantarea martinellii Versieux \& Wand.

Alcantarea nahoumii (Leme) J.R. Grant

Alcantarea nevaresii Leme

Alcantarea nigripetala Leme \& L. Kollmann Alcantarea odorata (Leme) J.R. Grant

Alcantarea patriae Versieux \& Wand.

Alcantarea regina (Vell) Harms

Alcantarea roberto-kautskyi Leme

Alcantarea tortuosa Versieux \& Wand.

Alcantarea trepida Versieux \& Wand.

Alcantarea turgida Versieux \& Wand.

Alcantarea vasconcelosiana Leme

Alcantarea vinicolor (E.Pereira \& Reitz) J.R. Brazil, ES, Domingos Martins

Grant

Catopsis berteroniana (Schult. f) Mez

Catopsis morreniana $\mathrm{Mez}$

Catopsis sessiliflora (Ruiz \& Pavón) Mez

Deuterocohnia longipetala (Baker) Mez

Gurmania monostachia (L.) Rusby ex Mez

Guzmania roezlii (E. Morren) Mez

Guzmania zabnii (Hooker f.) Mez

Nidularium angustibracteatum Leme

Pitcairnia billbergioides L.B. Sm.

Pitcairnia curvidens L.B. Sm. \& Read

Pitcairnia flammea Lindl.

Racinaea spiculosa (Griseb.) M.A. Spencer Brazil, RJ, Nova Friburgo

\& L.B. Sm.

Racinaea sp.

Tillandsia complanata Benth.

Tillandsia monadelpha (E. Morren) Baker

Tillandsia secunda Kunth

Tillandsia sp.

Tillandsia tenuifolia $\mathrm{L}$.

Vriesea altimontana E. Pereira \& Martinelli

Vriesea atropurpurea Silveira

Vriesea babiana Leme

Vriesea billbergioides E. Morren ex Mez

Vriesea bituminosa Wawra
Brazil, RJ, Nova Friburgo, Lumiar

Versieux 215 (SP)

Brazil, RJ, Nova Friburgo, Macaé de

Cima

Brazil, RJ, Petrópolis, Pedra do Oratório

Royal Botanic Gardens, Kew

Brazil, BA, Santa Teresinha

Royal Botanic Gardens, Kew

Brazil, RJ, Nova Friburgo, Macaé de

Cima

Brazil, ES, Pancas

Brazil, MG, Além Paraíba

Brazil, MG, Muriaé

Brazil, MG, Além Paraíba

Brazil, ES, Jerônimo Monteiro

Brazil, RJ, Mangaratiba

Brazil, ES, Baixo Guandú

Brazil, MG, Pedra Azul

Brazil, MG, Santa Maria do Salto

Brazil, RJ, Santa Maria Madalena

Brazil, ES, Baixo Guandú

Brazil, MG, Conceição do Mato Dentro

Brazil, MG, Alto Caparaó, cultivated

Brazil, Cultivated at IBt

Royal Botanic Gardens, Kew

Royal Botanic Gardens, Kew

Peru, Cajamarca, Lambayeque-

Moyobamba,

Costa Rica, La Selva,

Bolívia, Cochabamba, Villa Tunari,

Las Cruces, Costa Rica

Brazil, RJ, Mangaratiba

Peru, Cajamarca, Lambayeque-

Moyobamba,

Brazil, MG, Santo Antônio do Itambé

Brazil, RJ, Mangaratiba

Brazil, ES, Santa Teresa

Peru, Cajamarca, Lambayeque-

Moyobamba

Costa Rica, La Selva,

Ecuador, Loja, Oña

Costa Rica, Saavegre

Brazil, RJ, Mangaratiba

Brazil, RJ, Santa Maria Madalena

Brazil, MG, Santana do Riacho

Brazil, BA, Santa Teresinha

Brazil, RJ, Teresópolis

Brazil, RJ, Nova Friburgo
Versieux 221, 222 (SP)

Moraes 164 (RB)

Barbará 25c (K)

Versieux 415, 417 (SP)

Barbará 7 (K)

Versieux 223 (SP)

Louz̧ada 22 (SP)

Versieux 353 (SP)

Versieux 432 (SP)

Versieux 433 (SP)

Versieux 365 (SP)

Versieux 265, 270 (SP)

Versieux 398 (SP)

Versieux 419 (SP)

Versieux 430 (SP)

Versieux 240, 241 (SP)

Versieux 394, 395 (SP)

Versieux 260 (SP)

Versieux 363 (SP)

Versieux 376 (SP)

Wanderley 716 (SP)

Bárbara 25a, 25b (K)

Living Collection 15862

Versienx 463 (SP)

Versieux 446 (SP)

Versieux 465 (SP)

(SP 399343)

Versieux 269 (SP)

Versieux 462 (SP)

Versieux 333 (SP)

Versieux 242 (SP)

Versieux 224 (SP)

Versieux 385 (SP)

Versieux 460 (SP)

Versieux 445 (SP)

Versieux 459 (SP)

Versieux 444 (SP)

Versieux 273 (SP)

Versieux 248 (SP)

Versieux 296 (SP), Wanderley 2492 (SP)

Versieux 413 (SP)

Versieux 281 (SP)

Versieux 220 (SP) 
Brazil, RJ, Teresópolis

Vriesea cacuminis L.B. Sm.

Vriesea procera (Mart. ex Schult. f.) Witt.

Vriesea of. simulans Leme

Vriesea crassa $\mathrm{Mez}$

Vriesea densiflora $\mathrm{Mez}$

Vriesea drepanocarpa (Baker) Mez

Vriesea ensiformis (Vell.) Beer

Vriesea erythrodactylon

Morren ex Mez

Vriesea friburgensis $\mathrm{Mez}$

Vriesea gigantea Gaudich.

Vriesea heterostachys (Baker) L.B. Sm.

Vriesea gradata (Baker) Mez

Vriesea incurvata Gaudich.

Vriesea itatiaiae Wawra

Vriesea longicaulis (Baker) Mez

Vriesea longiscapa (Baker) Mez “

Vriesea lubbersii (Baker) E. Morren

Vriesea medusa Versieux

Vriesea minarum L.B. Sm.

Vriesea minor (L.B. Sm.) Leme

Vriesea oligantha (Baker) Mez

Vriesea penduliflora L.B. Sm.

Vriesea piscatrix Versieux \& Wand.

Vriesea procera var. tenuis L.B. Sm.

Vriesea pseudoatra Leme

Vriesea psittacina (Hooker) Lindl. “

Vriesea scalaris E. Morren

Vriesea sceptrum $\mathrm{Mez}$

Vriesea segadas-vianna L.B. Sm.

Vriesea simulans Leme

Vriesea sp.

Vriesea stricta L.B. Sm.

Vriesea thyrsoidea $\mathrm{Mez}$

Vriesea tijucana E. Pereira

Vriesea triligulata $\mathrm{Mez}$

Weraubia bicolor (L.B. Sm) J.R. Grant

Weraubia gladioliflora $(\mathrm{H}$. Wendland) Grant

Weraubia ororiensis (Mez) J.R. Grant
Brazil, MG, Lima Duarte

Brazil, ES, Baixo Guandú

Brazil, MG, Diamantina

Brazil, MG, Alto Caparaó

Brazil, MG, Santo Antônio do Itambé

Brazil, ES, Santa Teresa

Brazil, SP, Ubatuba

E. Brazil, ES, Santa Teresa

Brazil, MG, Lima Duarte

Brazil, MG, Rio Preto

Brazil, RJ, Mangaratiba

Brazil, RJ, Teresópolis

Brazil, SP, Ubatuba

Brazil, SP, Cruzeiro

Brazil, MG, Rio Preto

Brazil, RJ, Nova Friburgo

Brazil, RJ, Teresópolis

Brazil, ES, Castelo

Brazil, MG, Santo Antônio do Itambé

Brazil, MG, Sabará

Brazil, MG, Datas

Brazil, MG, Santana do Riacho

Brazil, MG, Lima Duarte

Brazil, MG, Santana do Riacho

Brazil, MG, Santo Antônio do Itambé

Brazil, RJ, Nova Friburgo

Brazil, RJ, Rio de Janeiro

Brazil, ES, Santa Teresa

Brazil, ES, Santa Teresa

Brazil, SP, São José do Barreiro

Brazil, MG, Santana do Riacho

Brazil, MG, Diamantina

Brazil, ES, Santa Teresa

Brazil, MG, Conceição do Mato Dentro

Brazil, RJ, Nova Friburgo

Brazil, RJ, Rio de Janeiro

Brazil, RJ, Nova Friburgo

Costa Rica, Saavegre

J.R. Bolivia, Cochabamba, Chapare, Villa Tunari

Costa Rica, Saavegre
Versieux 283 (SP)

Versieux 345, 346 (SP)

Versieux 397 (SP)

Wanderley 2515 (SP)

Versieux 355 (SP)

Versieux 332 (SP)

Versieux 389 (SP)

Versieux 436 (SP)

Versieux 386 (SP)

Versieux 347 (SP)

Wanderley 2557 (SP)

Versieux 268 (SP)

Versieux 279 (SP)

Versieux 437 (SP)

IBt living collection 2055

Wanderley 2556 (SP)

Versieux 218 (SP)

Versienx 278 (SP)

Versieux 371 (SP)

Versieux 335 (SP)

Versieux 179 (SP)

Wanderley 2519 (SP)

Versieux 441 (SP)

Versieux 349, 350 (SP)

Wanderley 2475 (SP)

Versieux 257 (SP)

Versieux 234 (SP)

Versieux 288 (SP)

Versieux 391 (SP)

Versieux 388 (SP)

Versieux 449 (SP)

Versieux 440 (SP)

Wanderley 2517 (SP)

Versieux 387 (SP)

Versieux 258 (SP)

Versieux 435 (SP)

Versieux 287 (SP)

Versieux 217 (SP)

Versieux 443 (SP)

Versieux 467 (SP)

(SP 399345) 


\section{CAPÍTULO 3: DELIMITATION OF THE ALCANTAREA EXTENSA COMPLEX (BROMELIACEAE) AND ONE NEW SPECIES FROM ESPÍRITO SANTO, BRAZIL*}

"They will one day reach a stage, which makes it natural to regard them as species. To find the right day - the right stage - however, is difficult..."

T. W. BÖCHER, 1961 - THE DEVELOPMENT OF CYTOTAXONOMY SINCE DARWIN'S TIME. A DARWIN CENTENARY, 26-43.

* Manuscrito submetido à revista Rodriguésia em 17/08/2009. 
Abstract. (Delimitation of the Alcantarea extensa complex (Bromeliaceae) and one new species from Espírito Santo, Brazil) The complex of species related to Alcantarea extensa is presented and delimited as: A. extensa (L. B. Sm.) J. R. Grant, A. vinicolor (E. Pereira \& Reitz) J. R. Grant, A. burle-marxii (Leme) J. R. Grant, A. turgida Versieux \& Wand., A. distractila Leme \& Paula, A. lurida Leme, A. simplicisticha Leme \& A. P. Fontana, A. nigripetala Leme \& L. Kollmann, A. mucilaginosa Leme, and A. trepida Versieux \& Wand. Alcantarea trepida known from the State of Espírito Santo, southeastern Brazil is described as new and illustrated. It is compared with $A$. extensa (L. B. Sm.) J. R. Grant, A. simplicisticha Leme \& A. P. Fontana, and A. vinicolor (E. Pereira \& Reitz) J. R. Grant from which it differs by a robust, erect, compound inflorescence with a larger number of flowers and by the straight and thicker rachilla.

Key words: Atlantic forest, endemism, inselberg, Tillandsioideae, species complex.

Resumo. (Delimitação do complexo Alcantarea extensa (Bromeliaceae) e uma nova espécie do Espírito Santo, Brasil) O complexo de espécies relacionadas à Alcantarea extensa é apresentado e delimitado como: A. extensa (L. B. Sm.) J. R. Grant, A. vinicolor (E. Pereira \& Reitz) J. R. Grant, A. burle-marxii (Leme) J. R. Grant, A. turgida Versieux \& Wand., A. distractila Leme \& Paula, A. lurida Leme, A. simplicisticha Leme \& A. P. Fontana, A. nigripetala Leme \& L. Kollmann, A. mucilaginosa Leme e A. trepida Versieux \& Wand. Alcantarea trepida, conhecida do estado do Espírito Santo, é descrita como nova e ilustrada. É comparada com $A$. extensa, $A$. simplicisticha e $A$. vinicolor, das quais difere pela inflorescência ereta e robusta com flores mais numerosas e pelas ráquilas retas e mais grossas.

Palavras-chave: complexo de espécies, endemismo, inselberg, mata atlântica, Tillandsioideae. 


\section{Introduction}

Alcantarea (E. Morren ex Mez) Harms, Bromeliaceae, subfamily Tillandsioideae, with near 26 rupicolous species is a genus endemic to eastern Brazil, occurring on inselbergs within the Atlantic Rainforest at the States of Bahia, Minas Gerais, Espírito Santo, Rio de Janeiro e São Paulo as well as in open grassland outcrops in campo rupestre vegetation at Bahia and Minas Gerais (Versieux \& Wanderley 2007a).

For several decades, species now belonging to the genus Alcantarea, then classified under Vriesea subg. Alcantarea, were weakly understood taxonomically. This situation, for this horticultural and ecologically important genus, could be partially explained by the missing of well-collected herbarium specimens and also by a fragmentary knowledge of the living plants in the field. Possibly the great dimensions of leaves and inflorescences, together with the difficulties to access the habitat, sometimes demanding rock climbing techniques, and the blooming period concentrated during the raining season, explain why it remains so poorly represented in the scientific collections. More recently, several new species have been described coming from areas that were poorly botanized and also due to the better comprehension of the limits of polyphyletic taxa. Observation of living plants during field work followed by cultivation in greenhouse are now considered key points for better delimiting the species and also to understand morphological features that are difficult to examine (e.g. floral characters) on dried specimens.

The importance of inselbergs as venues for rupicolous Bromeliaceae populations differentiation, particularly Alcantarea, have been demonstrated on a recent series of papers (Barbará et al. 2007; 2008; 2009). As inland islands, these rock outcrops isolated from each other may contribute for high genetic distance within populations of the same species. Speciation or population partitioning within the same species are the evolutionary consequences of the fragmented distribution and low level of genetic exchange (Barbará et al. 2007).

Versieux \& Wendt (2006) noted that Alcantarea extensa should be treated as complex of species, due to the high variation observed among the herbaria material, regarding rosette and inflorescence 
size and colors of bracts and floral parts. The present paper aims to discuss the taxonomic problems and to delimit the complex of species related to $A$. extensa, and to describe the following new taxon.

\section{Results and discussion}

Alcantarea trepida Versieux \& Wand. sp. nov.

Figures 1-2A-I

Type: BRASIL. ESPÍRITO SANTO: Baixo Guandú, inselberg em pastagem, 19²9’26.8”S 4050’37.4’W, 592 m.s.m., 27.I.2007, fl., L. M. Versieux \& A. M. Calvente 396 (Holotypus: SP; Isotypus: $\mathrm{RB})$.

Species nova Alcantareae extensae (L. B. Sm.) J. R. Grant, Alcantareae simplicistichae Leme \& A. P. Fontana et Alcantareae vinicolori (E. Pereira \& Reitz) J. R. Grant floribus luteo-vinosis et staminibus polystichis affinis sed ramis inflorescentiarum longioribus (ad usque $110 \mathrm{~cm}$ longis vs. ad usque $70 \mathrm{~cm}$ longis), erectis, rhachillis crassioribus et rectis (vs. rhachillis flexuosis vel geniculatis) differt.

Rupicolous, (1.5-)2-4 m high, propagating by basal shoots, stem developed, sometimes sprawling. Rosette 0.7-0.9 x 0.6-1.4 m, infundibuliform, phytotelm developed. Leaves numerous, suberect to erect, marcescent. Leaf sheath $18-30 \times 12-20 \mathrm{~cm}$, ovate to oblong-elliptic, pale to dark castaneous abaxially, pale brown adaxially in sicco, whitish green in vivo, densely lepidote on both surfaces, coriaceous; margins membranaceous, wine-red to wine-red hyaline. Blades 40-68 x 8-11 cm, ligulate, concolorous green, lustrous, with or without wine-red spots abaxially or only toward the apex adaxially, subdensely lepidote abaxially, glabrous to sparsely lepidote toward the apex adaxially, straight to weakly arcuate, coriaceous, distinctly nerved, margins with a narrow $(<1 \mathrm{~mm})$ wine-red line; blade apex acute, acuminate, wine-red or green, generally straight, rarely curved, twisted or bent 
downwards. Peduncle $90-110 \times 2-3 \mathrm{~cm}$, erect, straight, stout, cylindrical to weakly sulcate, concolorous green to green underneath the bracts and wine-red on the sun exposed areas, glabrous, distinctly nerved; internodes $3.5-7 \mathrm{~cm}$ long; bracts of the peduncle: the proximal ones: subfoliaceous and erect; the middle and distal ones: $4.5-10 \times 3-7 \mathrm{~cm}$, triangular passing to ovate, apex acute, attenuate (on the proximal ones) to acuminate (on the distal ones), green to totally pale or dark winered, covered by white epicuticular wax on both surfaces, sparsely-lepidote at the base to densely lepidote toward the apex abaxially, densely to sparsely lepidote toward the apex adaxially, suberectpatent to curved, inflated and holding water at the base, distinctly nerved, coriaceous; margins winered. Inflorescence $0.6-0.9 \times 0.3-0.5 \mathrm{~m}$, compound, panicle of spikes, rarely simple, in this case up to $1.1 \mathrm{~m}$ long, ca. $11 \mathrm{~cm}$ wide (excl. the petals), ovoid to ellipsoidal, erect, rachis internodes $2-7 \mathrm{~cm}$ long; primary bract (2-)5-8 x 4-6 cm, ovate to broadly ovate, apex acuminate, inconspicuously mucronate for ca. $3 \mathrm{~mm}$, with the same coloration as the peduncle bracts, dark castaneous at the center and bordered by yellowish pale castaneous in sicco, glabrescent abaxially, densely lepidote at the base adaxially, involute, suberect, shorter than the base of the lateral peduncle, distinctly nerved, coriaceous, with membranaceous dark castaneous margins (ca. $1 \mathrm{~mm}$ wide). Inflorescence branches (1-)4-9, (11-)18-56(-70) flowered, erect to suberect at anthesis and remaining so after fructification; lateral peduncles (9-)13-16 x 1-1.2 cm, cylindrical or nearly so, green to reddish green at the exposed portions, glabrous; sterile bracts 3 or 4, orbicular to broadly elliptic, apex obtuse, weakly uncinate, 3.8-4.4(-5) x 3.2-4.1 cm, wine-reddish castaneous, waxy, glabrous abaxially, subdensely lepidote adaxially, suberect, overlapping each other at least close to the apex, distinctly nerved, the central portion thicker and rugose, ecarinate but sometimes with a protuberance near the apex, coriaceous; margins membranaceous, yellowish-hyaline in sicco; rachilla (13-)40-70(-110) cm, straight, rarely weakly geniculate toward the distal portion, green, glabrous; internodes (1.3-)2.5-5(-6) x 1-1.3(-1.6) $\mathrm{cm}$, almost quadrangular in cross section; floral bract $3.8-4.8 \times 3.8-5.5 \mathrm{~cm}$, orbicular to broadly ovate, apex obtuse, weakly uncinate, green bordered by wine-red to completely brownish wine-red or pale brown at the central portion and bordered by a yellowish hyaline stripe (ca. $7 \mathrm{~mm}$ wide) in vivo, glabrous abaxially, subdensely brown lepidote adaxially, completely enfolding the calyx, suberect to 
patent, distinctly rugose on the central portion, finely nerved along the margins, coriaceous, ecarinate; margins membranaceous, with a narrow ( $<1 \mathrm{~mm}$ wide) wine-red line in vivo, yellowish-hyaline in sicco. Flowers inodorous, distichous; sepals ca. 4 × $2.3 \mathrm{~cm}$, broadly elliptic to oboelliptic, apex obtuse, symmetric, equaling or exceeding the floral bracts by ca. $5 \mathrm{~mm}$, green to yellowish green with winered apex, glabrous to sparsely lepidote toward the apex abaxially, densely brown-lepidote adaxially, chartaceous, ecarinate; margins membranaceous, yellowish-hyaline in sicco; petals $8.7-9.7 \times 1 \mathrm{~cm}$, ligulate, apex obtuse, constricted by the sepals, yellow adaxially, yellow dotted with wine-red abaxially, strongly recurved at anthesis and wilting from the margins to the center without spiraling; petal appendages ca. $32 \times 2 \mathrm{~mm}, 2$, ligulate, longitudinally adnate to the petal for ca. $25 \mathrm{~mm}$, apex obtuse; stamens polystichous; filament $70-95 \times 1.5 \mathrm{~mm}$, weakly flattened at the base to cylindrical, white; anther linear, ca. 15 x $1 \mathrm{~mm}$, yellow, dorsifixed near the base; style $80-90 \times 2 \mathrm{~mm}$, cylindrical to weakly angular, white; stigma lobes ca. 3 x $1 \mathrm{~mm}$, suberect to patent, white; ovary ca. 9 (superior portion) x 5 $\mathrm{mm}$, narrowly ovate, whitish green to white, hypanthium ca. $9 \mathrm{~mm}$; ovules numerous, ca. $0.6 \mathrm{~mm}$. Capsule 4-5 x $1 \mathrm{~cm}$, narrowly-elliptic, apex acute, brown; seed ca. 5 × $1 \mathrm{~mm}$, fusiform, brown; basal coma ca. $6 \mathrm{~mm}$, ferruginous; apical coma ca. $14 \mathrm{~mm}$, ferruginous.

The new species described here can be separated from its congeners by a combination of characters such as the distal penducle bracts size and shape, length and position of the inflorescence branches, which have a thick almost quadrangular sided and completely straight rachis. All individuals showing compound inflorescence present their flowering branches upright and close to each other, remaining upright through fructification. Also, A. trepida presents the largest number of flowers per branch ever reported for the genus, with up to 70 , flowering plants tend to be higher. The closer relatives of this new species probably are $A$. extensa, $A$. simplicisticha and $A$. vinicolor all of them related to each other and belonging to a very homogenous group of species designated here as the $A$. extensa complex, for which many morphological features overlap (Table 1), what may indicate a recent radiation for these taxa. However its densely arranged and long flowering branches that remain in upright position even after the anthesis can distinguish the new species from all its congeners. Also, the rachillas are straight and relatively thick. In $A$. extensa and $A$. vinicolor inflorescences present patent 
to arcuate branches (Fig. 2J, $\mathrm{K}$ ) that are more laxly disposed along the rachis, in $A$. simplicisticha the inflorescence is always simple, suberect-arcuate, and all of them have flexuous to geniculate rachillas. The presence of developed stem is another distinct feature of the new taxon. This stem can be erect and hidden by the old marcescent leaves or be sprawling and longer (Fig. 2H). Other differences among these taxa are summarized in the Table 1.

Along the type locality region, $A$. trepida is sympatric with $A$. roberto-kantskyi, a very distinct species but also presenting erect flowering branches, developed stems, floral bracts and buds densely disposed at the apex of the branches and waxy leaves and bracts. A good hypothesis to be tested in a broad population genetic analysis including both species is to check if in the past $A$. trepida received any genetic contribution from $A$. roberto-kautskyi trough hybridization processes. Low levels of interspecific gene flow for sympatric Alcantarea species have been reported for $A$. imperialis and $A$. geniculata based on population genetic analysis using microsatellite markers (Barbará et al. 2007; 2009). It would be desirable that such kind of analysis, with an extended sampling of the $A$. extensa complex, could be carried out, providing interesting new data on the genetic cohesiveness of these taxa and populations. Nevertheless, the two species treated here are very divergent, $A$. roberto-kautskyi has much more leaves densely arranged, white petals, the inflorescence is fastigiated with the lateral peduncles perpendicular to the rachis, and it was not observed any other species of Alcantarea along the type locality that could be the second parental lineage. Populations of $A$. trepida are well established with thousands of individuals not only at Baixo Guandú, but also $120 \mathrm{~km}$ north at Nova Venécia.

Paratypes: BRASIL. ESPÍRITO SANTO: Baixo Guandú, inselberg em pastagem, 19²9’26.8’S 4050’37.4’W, 592 m.s.m., 27.I.2007, fr., fl., L. M. Versieux \& A. M. Calvente 394, 395 (SP). Nova Venécia, APA Pedra do Elefante, 18.II.2008, fl., Forzza et al. 5072 (RB); Ibidem, Reserva Biológica Duas Bocas, Serra de Baixo, Pedra do Elefante, 19.II.2008, fl., Fraga 1920 (RB), Ibidem, beira da rodovia Nova Venécia - São Gabriel da Palha, prop. do Sr. Valdemar, 9.V.2008, fl. and fr., Fontana et al. 5241 (RB).

Distribution, ecology and conservation: Alcantarea trepida is heliophyte, occurs between 
300-900 m.s.m. on steep rocky walls and also on inselberg plateaus at the municípios of Baixo Guandú, in the central western region and also at Nova Venécia, $120 \mathrm{~km}$ further north in Espírito Santo State. The species is not threatened by extinction because it occurs within the Environmental Protection Area of Pedra do Elefante and the Biological Reserve Duas Bocas. Additionally, populations tend to present high densities of individuals (Fig. 2G) growing on hardly accessible places, as is the case in the type locality (Fig. 2A). Bees frequently eat petals and stamens and nests of Hemiptera sometimes can be seen underneath the primary bracts. Scars caused by these insects can also be seen as brownish protuberances along the lateral peduncles. If these injuries are caused by the Hemiptera phytophagy or by galling activity is still to be investigated. At the type specimen population several capsules were bearing germinated seeds inside (Fig. 2) characterizing a case of viviparity that deserves further investigations.

Phenology: Blooming from December to May. Immature fruit collected in May, and old capsules with seeds germinating inside collected in January.

Etymology: From Latin, Trepidus, a, um means in fright, scared. The specific epithet trepida was chosen here as metaphoric insinuation to the erect branches of the inflorescence that remain upright even after fructification, in a "scared" position.

The Alcantarea extensa complex

Vriesea extensa (= Alcantarea extensa) was described by Smith (1943), from a plant collected in fruit at Cachoeiro do Itapemirim, pico de Itabira, Espírito Santo, and was characterized by its long inflorescence branches and floral bracts showing a protuberance near the apex (gibbous). In the original description, Smith (loc. cit) put under synonym Vriesea regina sensu Wittmack (1891) and discuss that Wittmack's description was based on a plant from Serra do Picú (presently known as Serra de Itatiaia), 1600 m.s.m, on the border of Minas Gerais and Rio de Janeiro States. While checking the protologues we noticed that Smith (1943) probably misunderstood Wittmack's description, which says that his plants were grown from seeds collected at Rio Doce, and also 
mentions the presence of mucilage in the flowers and that the petals have raw meat color and presents illustrations and measures that clearly indicate that the plant he had in hands was, in fact, very close to $A$. extensa. This information is important to clarify the actual range of the species, since A. extensa grows on the southern portion of Espírito Santo, eastern Minas Gerais, and there is only one record for Northern Rio de Janeiro, but there is no occurrence for the Itatiaia range (Serra do Picú) region. After that, Pereira \& Reitz (in Pereira 1974) described Vriesea vinicolor $(=$ A. vinicolor) from Vargem Alta, Espírito Santo State as well. According to these authors $V$. vinicolor could be differentiated from $V$. extensa by the not gibbous floral bracts shorter than the sepals and also by the stamens equaling the length of the petals. Pereira \& Reitz (loc. cit.) also emphasize that the wine-red leaves of $V$. vinicolor were another distinct feature. Versieux \& Wendt (2006) were the first to recognize that $A$. extensa should be treated as complex of species, due to the high variation observed among the herbaria material, regarding rosette and inflorescence size, and colors of bracts and floral parts. Versieux \& Wanderley (2007b) described A. turgida, from Serra do Cipó, Minas Gerais, which is closely related to Alcantarea extensa and $A$. vinicolor but differs by the pale yellow petals, inflorescence shape (tending to be more bilaterally symmetric and pyramidal), shorter inflorescence branches, by the lustrous green leaves without any trace of epicuticular wax, and by the distinct habitat (campo rupestre) and far inland distribution. Leme \& Paula (2008) described $A$. distractila from Ouro Verde de Minas, eastern Minas Gerais State, as a very closely related taxon to $A$. extensa, but showing shorter leaves, longer branches with more spaced and larger flowers. Leme in Leme \& Paula (2008) also described A. lurida collected between Coronel Fabriciano and Braúnas, central-eastern Minas Gerais, and it was compared to $A$. extensa, however presenting red peduncle and rachis, shorter branches and longer flowers with pale yellow petals. Leme et al. (2008) described two other species of Alcantarea that can also be included in the complex: A. simplicisticha from Águia Branca, Espírito Santo, with simple inflorescence and $A$. nigripetala Leme \& L. Kollmann, from Nova Belém, Minas Gerais, which supposedly has black petals. Leme (2009) described A. mucilaginosa, from a cultivated plant collected at Conceição do Castelo, which was also considered to be closely related to $A$. extensa, differing basically by a larger amount of wax over the leaves and bracts and shorter flowering branches, besides a 
copious mucilage production. All the above mentioned taxa (A. extensa, A. vinicolor, A. turgida, $A$. distractila, A. lurida, A. simplicisticha, A. nigripetala, A. mucilaginosa, and A. trepida), together with $A$. burlemarxii, which occurs in Northeastern Minas Gerais, ca. $450 \mathrm{~km}$ far away from the core area of Alcantarea extensa occurrence, can be considered part of the Alcantarea extensa complex. As general features, these taxa present spreading, i.e. radially disposed stamens at anthesis, have petal colors that fade from a darker while in bud to a pale color when petals are fully expanded, most species present yellow wine-red spotted petals, resembling almost orange or sometimes wine-orange, and also there can be differences between the abaxial (darker) and adaxial (paler) petal faces. The floral bracts tend to be more coriaceous and dilated along the central portion and thinner and yellowish along the margins in sicco, petals tend to be more loosely arranged during anthesis and not so spirally recoiled as in other species of the genus, the compound inflorescences frequently are asymmetric, with different sizes of branches, the primary bracts are always shorter then the lateral peduncles and branches are more laxly distributed.

It's worthy mentioning that Vriesea alta (Baker) E. Morren ex Mez, an old name typified by one of Edouard Morrens' watercolors housed at Kew (Fig. 3), and that was considered to belong to Vriesea subg. Alcantarea by Smith \& Downs (1977), also shows some of the features attributed above to the A. extensa complex. Nevertheless, it is a doubtful taxon, excluded from Alcantarea by Grant (1995) and presumably collected at Panamá, Chiriquí, which bloomed under cultivation in Europe, without any recent collected specimens deposited in herbaria.

If we consider Alcantarea extensa complex as a recent divergent taxa that haven't had the necessary time to accumulate differences, reproductive isolation, and fixed apomorphies it would be easier to understand why species boundaries are so hard to define. An analysis employing 20 microsatellite loci data (Versieux et al. unpub. data) indicates that at least two major groups of $A$. extensa or $A$. aff. extensa with biogeographic correlation exist: one comprising the populations at eastern side of the Mantiqueira range and southern Espírito Santo State that are closely related to $A$. vinicolor and to A. trepida. And the second clearly distinct group connects populations from Minas Gerais State, distributed mostly on the western side of the Mantiqueira range, along the rio Doce 
river basin. As a matter of fact the populations from Espírito Santo tend to show leaves usually bluish green, covered by a thick layer of epicuticular wax, a character already mentioned on the type material of A. extensa. On the other hand, plants from Minas Gerais are usually smaller in size and have shorter and lustrous leaves, like $A$. distractila. The population from Carangola, shows petals with slightly convolute praefloration, a very distinct feature for the genus.

Nevertheless better delimitations for the taxa that are involved in this complex, whatever taxonomic status is attributed to them, is difficult due to a great homogeneity in floral characters and an overall resemble that makes indistinguishable sterile plants or incompletely prepared herbaria material (i.e. lacking complete inflorescence or data referring to the number, position, size and arrangement of the branches). The traditionally used character of simple versus compound inflorescences is variable even within the same species as is illustrated here by $A$. trepida, and a closer look underneath the distal peduncle bracts of an unbranched inflorescence may show atrophied ramifications. Variations in inflorescence branch number, amount of wax along the leaves and bracts, leaf and bract color variation between green and red-wine, and amount of mucilage are just general trends to segregate populations. These characters are highly influenced by environmental conditions, especially if under cultivation, and their utility to separate or describe new species is questionable. Thus we suggest more profound analyses for the Alcantarea extensa complex, using additional tools as molecular data, leaf anatomy, and pollen morphology and that new species in this taxonomically complicated group should be based on a population approach, and not relying solely on a single extreme variant cultivated individual.

\section{Acknowledgements}

We thank Dr. Rafaela Forzza, curator of RB for donating duplicate collections to SP. Claudio Nicoletti Fraga provided photographs and information about the Nova Venécia population. Natascha Wagner translated German texts and Alice Calvente helped during fieldwork and allowed the use of one picture. Lynn Parker, from Kew, provided the pictures of Morren's Icon. Financial support was 
provided by FAPESP to the first author and by CNPq to the senior author. We are also grateful to Dr. Tarciso Filgueiras for checking the Latin diagnosis, Derek Butcher and Mark Paul for linguistic advice and to two anonymous referees for their constructive comments.

\section{Literature cited}

Barbará, T.; Martinelli, G.; Fay, M. F.; Mayo, S. J. \& Lexer, C. 2007. Population differentiation and species cohesion in two closely related plants adapted to neotropical high-altitude 'inselbergs', Alcantarea imperialis and Alcantarea geniculata (Bromeliaceae). Molecular Ecology 16(10): 1981-1992.

Barbará, T.; Lexer, C.; Martinelli, G.; Mayo, S. J.; Fay, M. F. \& Heuertz, M. 2008. Within-population spatial genetic structure in four naturally fragmented species of a neotropical inselbergs radiation, Alcantarea imperialis, A. geniculata, A. glazionana and A. regina (Bromeliaceae). Heredity 101: 285-296.

Barbará, T.; Martinelli, G.; Palma-Silva, C.; Fay, M. F.; Mayo, S. \& Lexer, C. 2009. Genetic relationships and variation in reproductive strategies in four closely related bromeliads adapted to neotropical 'inselbergs': Alcantarea glazionana, A. regina, A. geniculata and A. imperialis (Bromeliaceae). Annals of Botany 103: 65-77.

Grant, J. R. 1995. The resurrection of Alcantarea. Tropische und subtropische Pflanzenwelt 91: 7-15.

Leme, E. M. C. \& Paula, C. C. 2008. Two new Alcantarea species from Minas Gerais. Journal of the Bromeliad Society 58(1): 5-11.

Leme, E. M. C.; Fraga, C. N.; Kollmann, L. J. C. \& Fontana, A. P. 2008. Three new Alcantarea species from Espírito Santo and Minas Gerais, Brazil. Journal of the Bromeliad Society 58(5): 205-216. 
Leme, E. M. C. 2009. Alcantarea mucilaginosa a new species from Espírito Santo, Brazil. Journal of the Bromeliad Society 59(1): 12-15.

Pereira, E. 1974. Species Novae in Brasilia Bromeliacearum - VI. Bradea 1(39): 383-387.

Smith. L. B. 1943. Bromeliáceas novas ou interessantes do Brasil - II. Arquivos de Botânica do Estado de São Paulo 1(5): 102-122, tab. 101-134.

Smith, L. B. \& Downs, R. J. 1977. Tillandsioideae (Bromeliaceae). Flora Neotropica Monograph 14(2): 663-1492.

Versieux, L. M. \& Wanderley, M. G. L. 2007a. Alcantarea (E. Morren ex Mez) Harms. In: Wanderley, M. G. L.; Shepherd, G. J.; Melhem, T. S. \& Giulietti, A. M. (eds). Flora Fanerogâmica do Estado de São Paulo. Instituto de Botânica, São Paulo, 5: 59-62.

Versieux, L. M. \& Wanderley, M. G. L. 2007b. Two new species of Alcantarea (Bromeliaceae, Tillandsioideae) from Brazil. Brittonia 59(1): 57-64.

Versieux, L. M. \& Wendt, T. 2006. Checklist of Bromeliaceae of Minas Gerais, Brazil, with notes on taxonomy and endemism. Selbyana 27(2): 107-146

Wittmack, L. 1891. Vriesea regina Beer. Gartenflora 40: 160-163. 
Table 1. Morphological comparison of Alcantarea trepida and its closest relatives.

\begin{tabular}{|c|c|c|c|c|}
\hline Feature & Alcantarea extensa & A. simplicisticha & A. trepida & A. vinicolor \\
\hline$\overline{\text { Plant height (m) }}$ & Up to 3 & Up to 2.4 & Up to 4 & $\overline{\mathrm{Up} \text { to } 2.1}$ \\
\hline Stem & Short & Short & $\begin{array}{r}\text { Developed, } \\
\text { sometimes } \\
\text { sprawling }\end{array}$ & Short \\
\hline $\begin{array}{l}\text { Leaf blade (width } \\
\text { in } \mathrm{cm} \text { ) }\end{array}$ & $5-12$ & $6-7$ & $9-11$ & $6-10$ \\
\hline Leaf texture & Coriaceous & Chartaceous & Coriaceous & Coriaceous \\
\hline $\begin{array}{l}\text { Peduncle bracts } \\
\text { (middle and distal } \\
\text { ones) }\end{array}$ & $\begin{array}{r}3.5-5 \times 3-4 \mathrm{~cm} \text {, } \\
\text { suberect to } \\
\text { arcuate, inflated } \\
\text { at the base and } \\
\text { impounding } \\
\text { water. }\end{array}$ & $\begin{array}{r}5 \times 3 \mathrm{~cm} \text {, erect } \\
\text { and remote, not s } \\
\text { impounding } \\
\text { water. }\end{array}$ & $\begin{array}{r}4.5-10 \times 3-6 \mathrm{~cm} \text {, } \\
\text { suberect, inflated } \\
\text { at the base and } \\
\text { impounding } \\
\text { water. }\end{array}$ & $\begin{array}{r}5-7 \times 2.5-4 \mathrm{~cm} \text {, } \\
\text { suberect-patent, } \\
\text { inflated at the } \\
\text { base and } \\
\text { impounding } \\
\text { water. }\end{array}$ \\
\hline $\begin{array}{l}\text { Peduncle } \\
\text { (diameter in } \mathrm{cm} \text { ) }\end{array}$ & $1.8-3$ & $1-1.3$ & $2.5-3$ & $1.5-2.5$ \\
\hline Inflorescence & $\begin{array}{l}\text { Compound, } \\
\text { rarely simple }\end{array}$ & Simple & $\begin{array}{l}\text { Compound, } \\
\text { rarely simple }\end{array}$ & Compound \\
\hline $\begin{array}{l}\text { Inflorescence } \\
\text { branches } \\
\text { arrangement and } \\
\text { position }\end{array}$ & $\begin{array}{r}\text { Laxly arranged, } \\
\text { branches suberect } \\
\text { or patent }\end{array}$ & $\begin{array}{l}\text { Single branch } \\
\text { (spike) suberect } \\
\text { and arcuate }\end{array}$ & $\begin{array}{r}\text { Densely } \\
\text { arranged, } \\
\text { branches erect }\end{array}$ & $\begin{array}{l}\text { Laxly arranged, } \\
\text { branches arcuate }\end{array}$ \\
\hline Rachilla & Geniculate & $\begin{array}{l}\text { Flexous to } \\
\text { geniculate } g\end{array}$ & $\begin{array}{r}\text { Straitght, if } \\
\text { geniculate only at } \\
\text { the terminal } \\
\text { portions of } \\
\text { branches }\end{array}$ & Geniculate \\
\hline $\begin{array}{l}\text { Rachilla } \\
\text { internodes } \\
\text { (diameter in } \mathrm{cm} \text { ) }\end{array}$ & $0.6-0.7$ & $0.4-0.6$ & $1-1.6$ & $0.4-0.6$ \\
\hline $\begin{array}{l}\text { Number of } \\
\text { flowers per } \\
\text { branch }\end{array}$ & $12-26$ & $30-40$ & $8-70$ & $8-16$ \\
\hline $\begin{array}{l}\text { Floral bracts size } \\
(\mathrm{mm})\end{array}$ & $36-42 \times 38-46$ & $40-46$ x 32-40 & $38-48 \times 38-55$ & $20-32 \times 22-35$ \\
\hline
\end{tabular}




\section{Figure legends}

FIG. 1. Alcantarea trepida. A. Habit at anthesis. B. Habit at fructification. C. Leaf. D. Peduncle bract. E. Primary bract. F. Floral bract. G. Sepal. H. Pistil. I. Ovary. J. Stigma. K. Petal. L. Seed. (A, C-J Versieux 396; B, L. Versieux 394).

FIG. 2. Alcantarea trepida. A. Habitat at Baixo Guandú. B.-D. Variation in inflorescence size. E. Dead individual with opened capsules and upright branches. F. Seeds germinating inside the capsule. G. Population at Nova Venécia. H. Flowering individuals with both compound and simple inflorescences. I. Detail of flower at anthesis. J. Alcantarea extensa at Cachoeiro do Itapemirim, pico de Itabira (type locality), showing patent flowering branches. K. Alcantarea vinicolor under cultivation, showing arcuate branches. L. Alcantarea simplicisticha, detail of the base of an old fruiting spike where the flexuous rachilla and the erect and short peduncle bracts can be seen (arrow). (A.-G. Versieux 394, 395, 396; H.-I. Fraga 1920, J. Versieux 380, K. Versieux 384. L. Cultivated at the Jardim Botânico do Rio de Janeiro. Photos: L. Versieux except G.: A. Calvente and H.-J., L.: C. N. Fraga).

FIG. 3. Vriesea alta (Baker) E. Morren ex. Mez. A. Edourard Morren's Icon housed at Kew, lectotype selected by Smith \& Downs (1977). B. Flower detail. (Photos: Lynn Parker). 


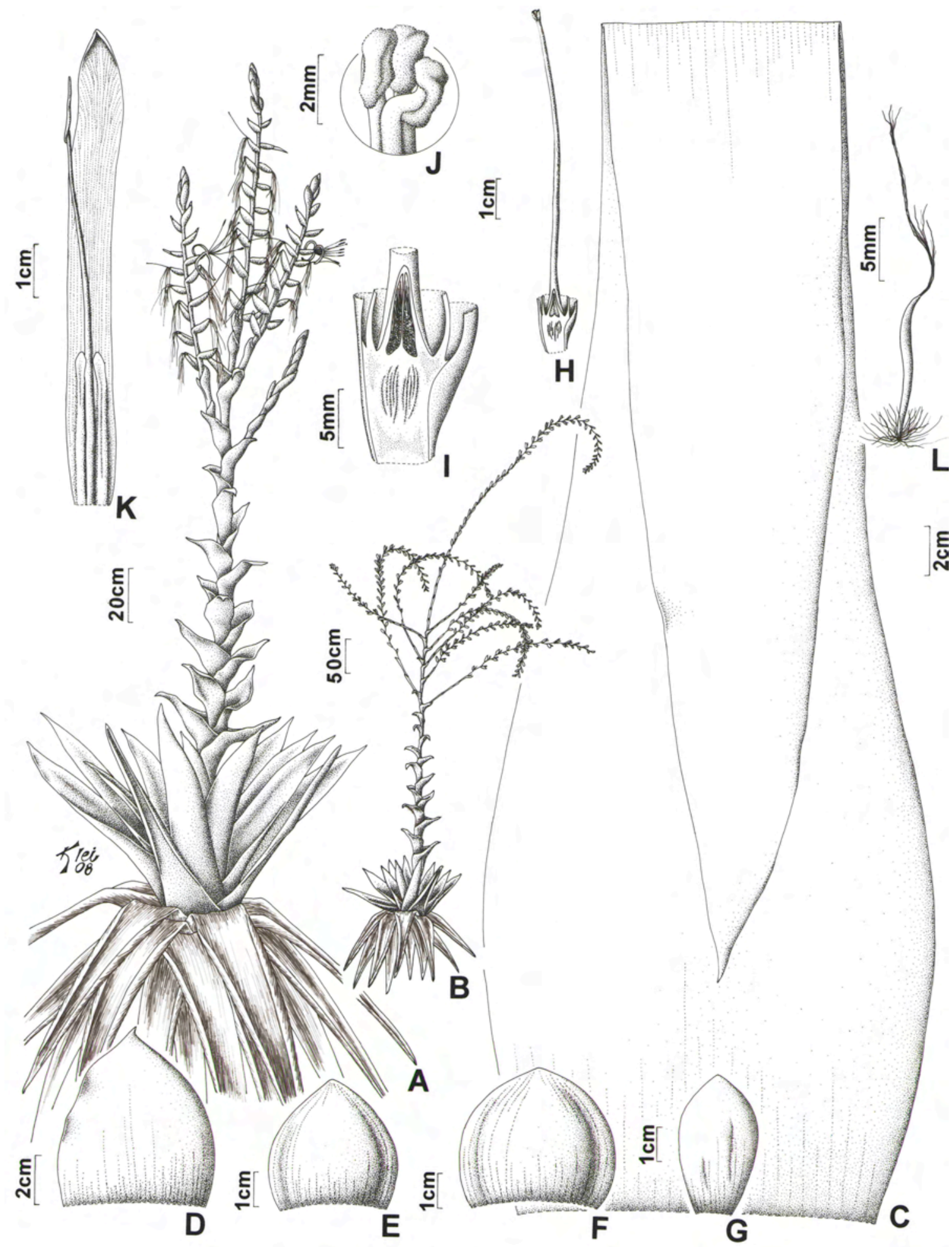

Figure 1 


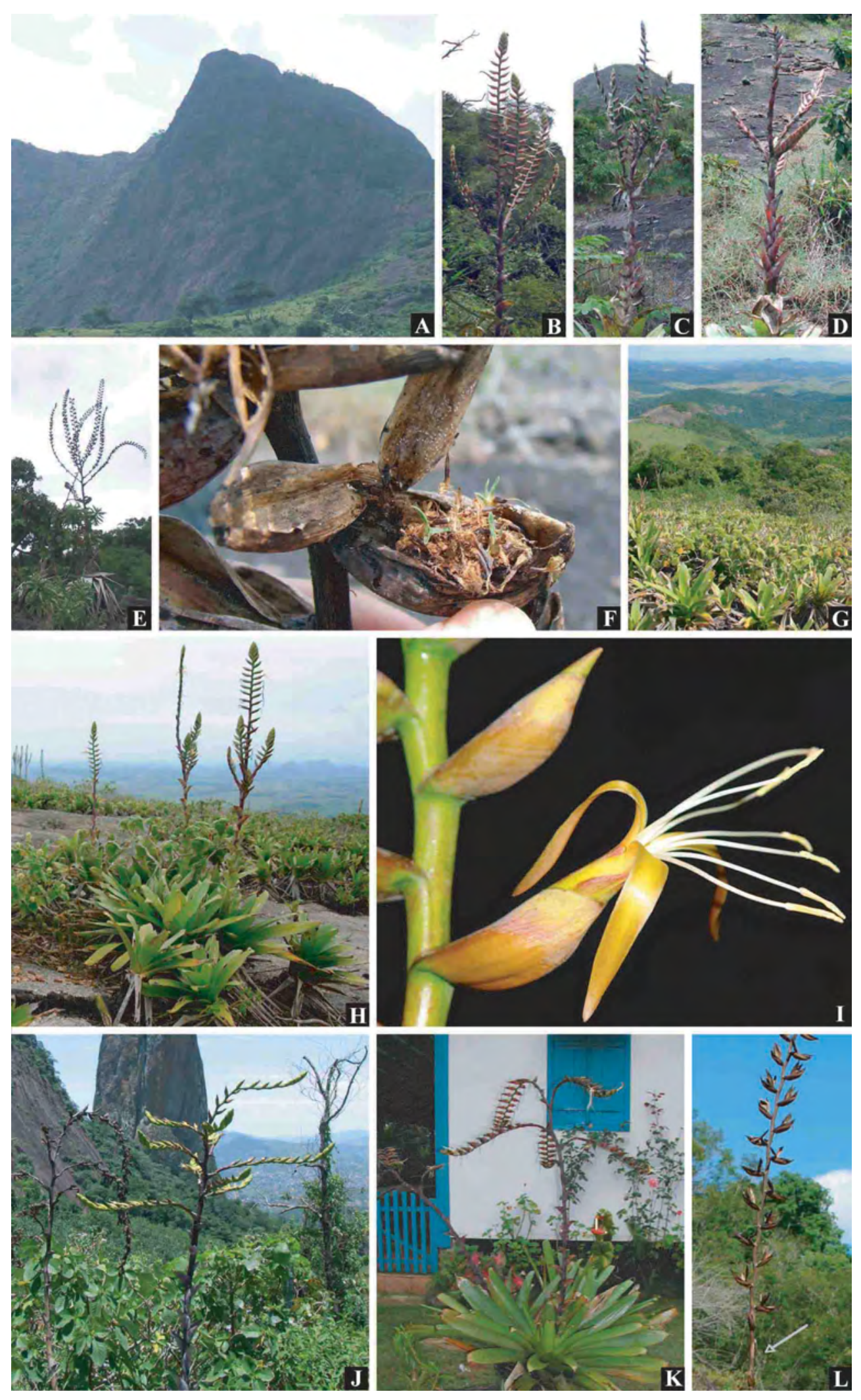

Figure 2 

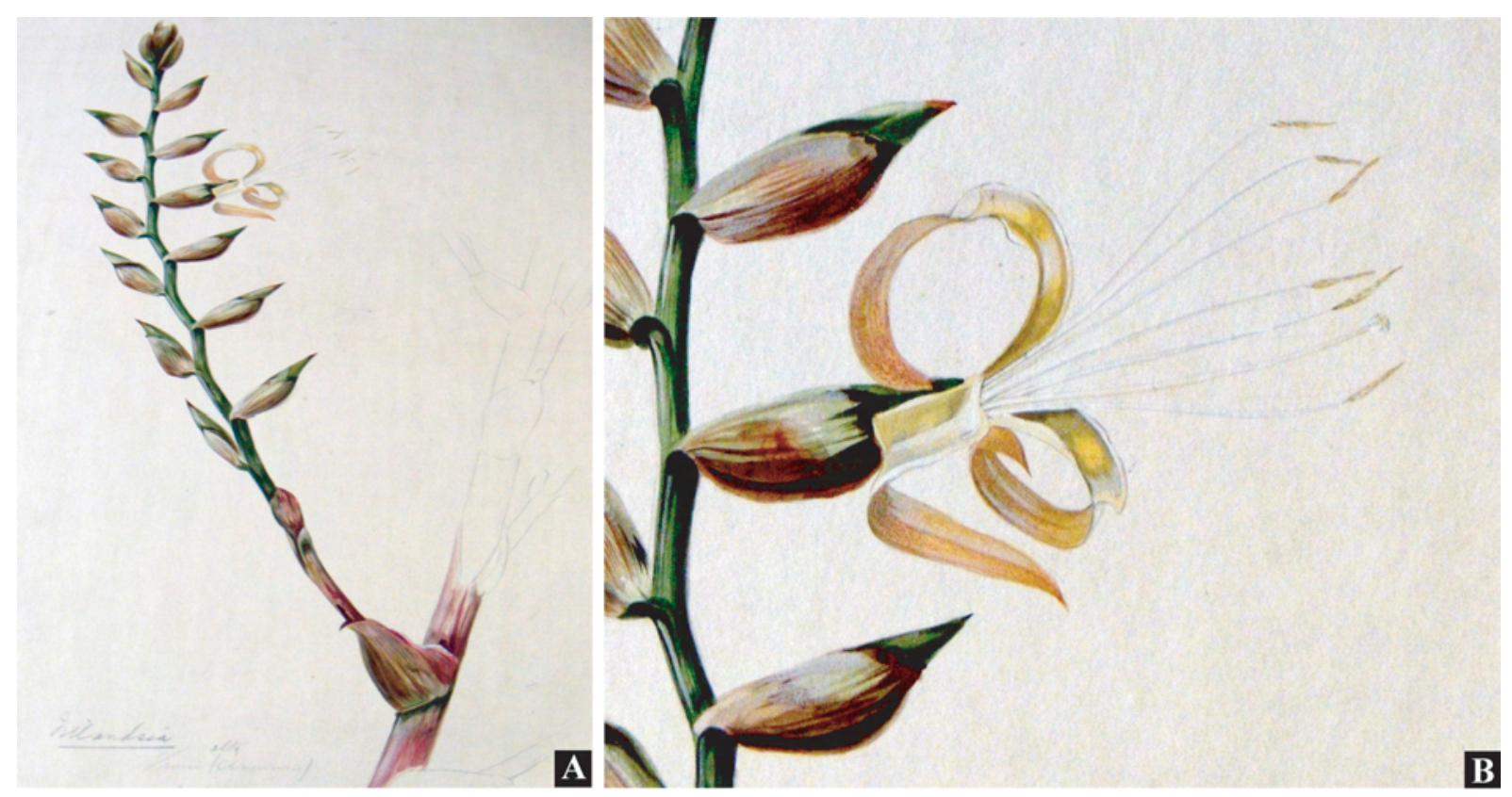

Figure 3 


\section{CAPÍTULO 4: ALCANTAREA (BROMELIACEAE) LEAF ANATOMICAL CHARACTERIZATION AND ITS SYSTEMATICS IMPLICATIONS*}

"To see clearly something that no one has ever examined before, whether one is using a hand lens or an electron microscope, is a creative intellectual act; and to realize how a new observation is related to previous knowledge is an act of insight of the kind on which all advance in scientific knowledge is based."

R. E. Holtrum, 1961

PLANT TAXONOMY AS A SCIENTIFIC DISCIPLINE. ADVANC. SCI. 18(73): 1-9.

* Manuscrito submetido à revista Australian Systematic Botany em 13/10/2009. 


\section{Alcantarea (Bromeliaceae) leaf anatomical characterization and its systematics implications}

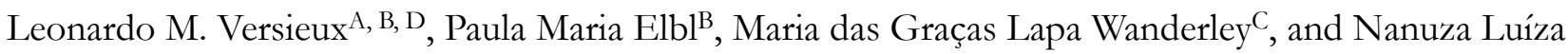
de Menezes ${ }^{\mathrm{B}}$

A. Universidade Federal do Rio Grande do Norte, Departamento de Botânica, Ecologia e Zoologia, Natal, RN, 59072-970, Brazil.

B. Instituto de Biociências, Universidade de São Paulo, Departamento de Botânica, Rua do Matão, trav. 14, n. 321, São Paulo, SP, 05508-090, Brazil.

C. Instituto de Botânica, Caixa Postal 3005, São Paulo, SP, 01061-970, Brazil.

D. Corresponding author. Email: lversieux@yahoo.com.br

Running title: Anatomy of Alcantarea

Author for correspondence: Leonardo M. Versieux, Universidade Federal do Rio Grande do Norte, Departamento de Botânica, Ecologia e Zoologia, 59072-970 Natal, RN, Brasil. Phone/Fax: +00 55 (84) 3215-3441 / Fax (84) 3215-9205. Email: lversieux@yahoo.com.br 


\begin{abstract}
Alcantarea (Bromeliaceae) with 26 species is endemic to eastern Brazil, occurring mainly on gneiss-granitic rock outcrops (inselbergs). Alcantarea has great ornamental potential and several species are cultivated in gardens. Limited data is available in the literature regarding the leaf anatomical features of the genus, though it has been shown that it may provide interesting information for characterizing the Bromeliaceae taxa. In the present work we employed leaf anatomy to better characterize the genus and understand its radiating into harsh environments, such as inselbergs. We also searched for characteristics that can be useful in phylogenetic investigations and in the differentiation of Alcantarea from Vriesea. The anatomical features of the leaves, observed for various Alcantarea species, are in accordance with the general pattern shown by other Bromeliaceae members. However some features are discernable by their importance for sustaining life on rock outcrops, such as: small epidermal thick-walled cells, uneven sinuous epidermal walls, hypodermis often differentiated into lignified layers with thick-walled cells, aquiferous hypodermis bearing collapsible cells, presence of well developed epicuticular stratum. Alcantarea leaves tend to be thicker, have different shapes of the spongy parenchyma, and have chlorenchymatous palisade parenchyma arranged in well-defined arches when compared to the same features in Vriesea species.
\end{abstract}




\section{Introduction}

The monocot family Bromeliaceae is a group of plants almost exclusive of the New World, which exhibits a great morphological and ecophysiological versatility (Smith and Downs 1974; Benzing 2000a). Sheltering 58 genera, 3172 species (Luther 2008), Bromeliaceae can be seen in a wide variety of habitats across tropical and subtropical Americas, ranging from coastal sandy plains - as the Brazilian restingas - and humid tropical forests to deserts and high altitudes vegetation in the Andes (Smith 1934; Pittendrigh 1948; Rundel and Dillon 1998). Currently, Bromeliaceae is considered to be the first lineage to emerge within the Poales order, and is close to Typhaceae and Rapateaceae (Soltis et al. 2005; Chase et al. 2006). Several bromeliads species are key elements in stressful environments (e.g. restingas, swamps, high altitude fields, rock outcrops inside the Atlantic rainforest domain), usually providing more favorable conditions for the establishment (germination and growth) of other species, thus being known as 'nurse plants' (Scarano 2002).

The Atlantic rainforest of eastern Brazil has been considered a center of diversity for Bromeliaceae and a pattern of decreasing numbers of genera and species is observed when approaching the drier inland territory with its associated vegetation (Smith 1934; Reitz 1983; Versieux and Wendt 2007). Most bromeliads, however, present adaptations to save water, such as the rosettes formed by the spirally distributed leaves, where the overlapping bases form a cavity that can be filled up with rainwater (Pittendrigh 1948). This water reservoir is important not only to the plant itself but also to a wide variety of aquatic and soil-type invertebrates and microorganisms, and even vertebrates that can live in or are associated with it (Benzing 2000b). A second key characteristic is the presence of peltate foliar trichomes, also referred as lepidote or stellate or multicellular hairs considered to be the most distinguishing feature of the family (Tomlinson 1969). Their functions range from retarding transpiration and reducing heat load and photoinjury to absorbing water and nutrients (Benzing 1976; 2000b). Concomitant to the evolution of absorptive trichomes, there was a progressive structural and functional reduction of the root system and formation of parenchyma and support structures in Bromeliaceae, which were important to the development of epiphytic and rupiculous life forms 
(Braga 1977). Due to these adaptations, together with others referring to endurance to drought and impoverished substrates, such as xeromorphic leaf structure, Crassulacean Acid Metabolism (CAM) photosynthesis, and heterophylly, Bromeliaceae is able to occupy exceptional habitats, sometimes being almost the exclusive and dominant plant in particular environments (Reinert and Meirelles 1993; Porembski et al. 1998; Benzing 2000a).

Along eastern Brazil, a type of habitat that can be considered stressful for plant communities are the inselbergs (from German Insel = island, berg = mountain), which are very old dome shaped gneiss-granitic mountains, presenting scattered distribution and popularly known in Brazil as "sugar loaf". Most Brazilian inselbergs are inserted within the Atlantic rainforest domain (Safford and Martinelli 2000), where water supply through precipitation could not be considered a limiting factor to plant growth. Nevertheless, over the inselberg bare rock surface, water is quickly lost through runoff, as soil cover is restricted. Also, rock heating by strong solar radiation, that can lead to near $61^{\circ} \mathrm{C}$ over the nude rock surface, contributes to high temperature and accelerated evapotranspiration, characterizing these habitats as 'xeric islands' (Carauta and Oliveira 1984; Szarzynski 2000). In this habitat, plant communities are usually restricted to small mats of vegetation, where Bromeliaceae can be the most important plant family in regard to species number (Porembski et al. 1998; Safford and Martinelli 2000). From the biodiversity conservation point of view, inselbergs are important because in several localities they are the last refuges for vegetation, as they lack any agricultural interest (Porembski et al. 1998) or act as barriers to the urban growth.

Alcantarea (E. Morren ex Mez) Harms, Bromeliaceae, subfamily Tillandsioideae, with 26 rupicolous species is a genus endemic to eastern Brazil, occurring mostly on inselbergs within the Atlantic rainforest of Bahia, Minas Gerais, Espírito Santo, Rio de Janeiro, and São Paulo States. Few species occur on open grassland outcrops in campo rupestre vegetation at Bahia and Minas Gerais as well (Versieux and Wanderley 2007a). Usually Alcantarea species present large habit, sometimes reaching $5 \mathrm{~m}$ high while blooming and forming broad rosettes that can hold up to 40 liters of water (Martinelli 1997, Versieux and Wanderley 2007b, 2007c). 
This work is a contribution to the knowledge of the anatomy of the leaves of Bromeliaceae, particularly of Alcantarea, for which the only reference available is the work of Reinert and Meirelles (1993). We aim to describe the leaf anatomical characteristics that vary among species within Alcantarea, comment on the implications for systematics, and compare our results with other previously published works for Vriesea, a genus to witch Alcantarea has always been considered closely related. Also, we will discuss on the adaptive significance of several features presented by this genus for growing within the harsh environments where they occur on: inselberg and/or campo rupestre.

\section{Materials and methods}

Leaf samples from nine species of Alcantarea were investigated in this work and were obtained during fieldwork in various Brazilian States. Samples taken from the middle of the leaf blade were fixed in the field in a solution of FAA 70\% (formalin-acetic acid-ethanol; Ruzin 1999) and then transferred and preserved in Ethanol 70\%. For Scanning Electron Microscopy (SEM) epidermis from the middle leaf blade was cut and submitted to a progressively dehydrating alcoholic series ranging from $50 \%$ up to $100 \% \mathrm{EtOH}$, critical point dried, mounted on stubs, stained with Platinum and observed under a Digital Scanning Microscope DSM940 (Zeiss, Germany) at the Electronic Microscopy Laboratory, Biosciences Institute, University of São Paulo. For epicuticular wax observation the samples were directly dried in an oven at $40^{\circ} \mathrm{C}$ for three days, mounted and then were spur-coated with Platinum. Chloroform tests were performed to confirm the presence of epicuticular wax. Transverse sections were taken by free hand using a razor blade, bleached by the use of sodium hypochlorite, stained in Safrablau (Bukatsch 1972), dehydrated through an ethanol series and mounted in glycerin. The epidermis was dissociated through immersion in the Franklin's solution (Franklin 1945 modified by Kraus and Arduin 1997), a mixture (1:1) of 30\% of hydrogen peroxide and glacial acetic acid, for $24 \mathrm{~h}$ and then mounted according to the same procedure described for transverse sections. Sections were observed under Light Microscopy (LM) (Leica DMLB) and digital pictures were taken. 
A herbarium specimen for each sample studied in the present work was prepared and is deposited in the herbarium of Instituto de Botânica, São Paulo, Brazil (SP). Voucher material is indicated bellow, followed by its provenance and collector number. Alcantarea burle-marxii (Leme) J.R. Grant, Pedra Azul, Minas Gerais, Versieux 420; Alcantarea duarteana (L.B. Sm.) J.R. Grant, Diamantina, Minas Gerais, Versieux 255; Alcantarea extensa (L.B. Sm.) J.R. Grant, Cachoeiro do Itapemirim, Espírito Santo, Versieux 380; Alcantarea farneyi (Martinelli \& A. F. Costa) J.R. Grant, Santa Maria Madalena, Rio de Janeiro, Versieux 247; Alcantarea geniculata (Wawra) J.R. Grant, Petrópolis, Rio de Janeiro, Versieux 285; Alcantarea glaziouna (Lem.) Leme, Rio de Janeiro, Rio de Janeiro, Versieux 343; Alcantarea nahoumii (Leme) J.R. Grant, Santa Teresinha, Bahia, Versieux 418; Alcantarea nigripetala Leme \& L. Kollmann, Pancas, Espírito Santo, Louzada 22; Alcantarea patriae Versieux \& Wand., Jerônimo Monteiro, Espírito Santo, Versieux 365; Alcantarea roberto-kautskyi Leme, Baixo Guandú, Espírito Santo, Versieux 398, and Santa Maria do Salto, Minas Gerais, Versieux 430; Alcantarea trepida Versieux \& Wand., Baixo Guandú, Espírito Santo, Versieux 394, 395; Alcantarea turgida Versieux \& Wand., Conceição do Mato Dentro, Minas Gerais, Versieux 260.

\section{Results}

Overall leaf morphology

Alcantarea species present simple entire leaves, as do all the other members of Tillandsioideae subfamily. Leaves are rosulate, clearly divided into a leaf sheath plus a leaf blade, present a coriaceous texture and some prominent veins. The leaf sheath is densely lepidote on both faces and is generally thicker than on the leaf blade. The leaf sheath exhibits variable shapes, but is usually ovate. The leaf blade is usually ligulate, sometimes linear-triangular, canaliculate at least close to the base and the apex presents different forms, as acute, obtuse, and most frequently acuminate. Rosette size and form are quite variable in terms of size and shape within the genus. 


\section{Epidermis and mesophyll}

In all examined species epidermal cells on both faces are organized in a single layer (Fig. 1a-k; Fig. $2 a-d, b-o)$. The anticlinal and the internal periclinal cell walls are thick. Cells shapes vary in crosssection: appearing $\mathrm{U}$-shaped in $A$. extensa, A. trepida, A. vinicolor, A. geniculata, A. naboumii, A. patriae and in $A$ burle-marxii, to irregularly polygonal in $A$. farneyi. The epicutilar wax together with the cuticle forms a thick layer over the outer periclinal cell epidermis wall that can be observed in most species (Fig. $2 a, b, i, k, m$ ) and also on the SEM pictures (Fig. 4 and 5). One nearly spherical silica body can be observed inside each cell (Fig. 2b; Fig. 3g, k, l, m; Fig. 4a, n; Fig. 5n). In front view (Fig. 3a, c, e, b, i, j, k, $l, m, n)$ the anticlinal walls of the epidermal cells are sinuous, with different cell shapes varying from more oblong (e.g. Fig. 3a) to more equally sided (e.g. Fig. 3h, k). This variation can be noticed among different species or between the adaxial and abaxial face of the same leaf. The abaxial epidermis is also uniseriate, plane to slightly undulate in $A$. duarteana and $A$. farneyi (Fig. $1 c, k ; 2 e, f)$. The periclinal walls are thick, the outer covered by the epicuticular stratum. The cells present extremely reduced lumen due to the anticlinal wall thickening. In LM and SEM it is possible to see that the abaxial epidermis is also costate with very narrow costal and intercostal zones (Fig. $3 b, f, 4 h, m$ ). Stomata complexes are tetracitic and restricted to the intercostals zones. The subsidiary cells are parallel to the guard cell and may present distinct shapes in cross sections (Fig. 2s-y). Other ordinary epidermal cells that surround the stomata may be arranged in a kind of ring format and showing slightly thicker and straighter walls than their neighbors (Fig. $3 g, h$, $)$.

A multicelular aquiferous hypodermis is present in all studied species and its extension may vary in different taxa. In eight species, however, the hypodermis is a lignified tissue with 2 to 5 layers of thick-walled cells. Fibers cluster not associated to the vascular bundle have a scattered distribution in all species, forming island in the hypodermis or in the mesophyll. Eventually, sheath bundle extensions join up with the mesophyll fibers (island fibers), which can be seen in some species (Fig.1b, $d, f, i, j)$. Under the lignifed layer of hypodermis there are 3-12 layers of aquiferous hypodermis that usually present rounded cells that constitute the water storing tissue or aquiferous parenchyma. The 
cells of these layers are collapsible, and the thin anticlinal walls can be seen as sinuous (Fig. 1i) during the desiccation but shifting to turgid nearly globose cells with stretched walls when well watered (e.g. Fig. 1a). The first hypodermic layers with thick-walled cells seem to be absent in $A$. farneyi and in $A$. duarteana (Fig. 1c, k), where the entire hypodermis is aquiferous. The water storing tissue is variable in width in Alcantarea species and in $A$. duarteana it reaches its largest number of layers (Fig. 1k). Internally within the hypodermis there is a chlorenchymatous palisade parenchyma that can be seen in transversal sections forming arches that can be contiguous (A. patriae, Fig. 1 h) or interrupted by the vascular bundles or by the expansions of the pericyclic fibers (e.g. Fig. 1a, b, e). Bellow the palisade parenchyma there is a spongy parenchyma, with braciform cells positioned in aeration channels (or air-lacunae according to Tomlinson 1969). Analyzing Figures $1 \mathrm{l}$ and $1 \mathrm{~m}$, it is possible to notice the presence of spongy parenchyma in the entire air channel. This spongy parenchyma in air channels is alternated with the vascular bundle and presents different contours among the distinct species (Fig. $1 a-k)$. In cross section the air channels can be seen as elliptic (e.g. Fig. 1a, b) or elliptic but showing a weak constriction close to middle (Fig. $1 e, f, h, \jmath$ ), oblageniform (Fig. 1c) i.e. resembling an up side down bottle, obovate (Fig. 1々), or obtriangular (Fig. 1k). This spongy parenchyma is disposed all along the mesophyll (Fig. $1 \mathrm{~m}$ ) and is flanked by the vascular bundle and is connected to the substomatic chambers in the abaxial face (Fig. 2y). Between the spongy parenchyma and bellow each vascular bundle there is a short area filled with the abaxial hypodermis. Idioblasts were observed in the spongy parenchyma of A. burle-marxii (Fig. 1D).

All the species present colateral vascular bundles in a single series, where the thicker ones alternate with the thinner ones. The larger vascular bundles are completely surrounded by the lignified pericyclic fibers and more externally by the endodermis, the mesophyll inner layer. The pericyclic fibers may present different sizes, sometimes with extended projections toward the adaxial and abaxial aquiferous parenchyma (Fig. 1a, b, e) or they can be reduced and surrounding the vascular tissues (Fig. 1h, k). These fiber extensions usually do not overpass the arched clorenchyma. A layer of thick-walled cells that separates the xylem from the phloem can also be observed in most species. Thin commissural vascular bundle can be seen in longitudinal section (Fig. $1 \mathrm{~m}$ ). 
Epidermis in front view presents rectangular to quadrangular cells with sinuous and thick anticlinal walls and one nearly spherical silica body (Fig. 3). These cells can be laterally compressed along the coastal zones and slightly different from the neighbors cells located in the intercostal zones in the same leaf (Fig. 3b, g, k, D. Trichomes are observed on both faces of the leaf blade of all the analyzed species and their densities vary from sparsely to densely lepidote (Fig. $4 d$, $f$ ). The trichomes emerge from a lower level than the other epidermal cells (Fig. $2 f, j, l, n, p$ ) and the stalk is uniseriate and composed of few cells. The trichome wing cells can be radially symmetric (Fig. 3j, $m$; 4J) or slightly asymmetric (Fig. 3d; 4d).

\section{Discussion}

Overall leaf morphology (size, shape, apex format) and rosette shape can aid in the identification of Alcantarea species. The latter is a variable character that can range from a grass-like or tubular in few species that have limited capacity to hold water (A. benzing, A. duarteana, A. farneyi, A. hatschbachii) to broad, infundibuliform or crateriform rosettes, holding up to 40 liters of water in A. imperialis, A. roberto-kautskyi, A. patriae (Versieux and Wanderley 2007a, 2007b, 2007c; Martinellli 1997).

The leaf anatomical features observed for Alcantarea species are in accordance with the general pattern known for other Bromeliaceae (Robinson 1969; Tomlinson 1969; Braga 1977; Reinert and Meirelles 1993; Arruda and Costa 2003; Palací et al. 2004; Scatena and Segecin 2005).

The presence of trichomes has been reported as one of the most characteristic feature of Bromeliaceae (Tomlinson 1969). Foliar trichomes were observed in both leaf faces in all the studied species. Usually, in adaxial face trichomes may be noticed only by vestiges on the glabrescent leaves or, as in $A$. duarteana and $A$. farneyi, trichomes are densely arranged over both faces and are easily seen even on adult leaves. In these particular species, no crystalloids of epicuticular wax were observed under the trichomes shield and apparently this could be a pattern for densely lepidote Tillandsioideae leaves, as it was also observed by Scatena and Segecin (2005) in the genus Tillandsia. 
Specialized epidermal trichomes have functions that range from retarding transpiration and reducing both heat load and photoinjury, to water and nutritive ions absorption, avoiding herbivory and pathogens, attraction of pollinators and seed dispersers and secretion of possible digestive enzymes used to process prey (in few species of Brocchinia) (Benzing 1976, 2000b). Though all the species analyzed here are from open and well illuminated habitats where trichomes could be playing most of their attributed roles mentioned above, the presence of more densely arranged trichomes over the leaf of $A$. duarteana and $A$. farney may have evolved as a compensatory function, once both of them have very reduced phytotelma when compared to the remainder, namely the large-tank Alcantarea, and both live in high altitude habitat (near $2000 \mathrm{~m}$ ) where mist and dew formation are common, and this source of water could be better absorbed by a denser indumentum.

In all species the trichomes are randomly arranged on the leaf sheath and they are found in rows (i.e. concentrated on the intercostal zone) along the leaf blade as previously observed in Vriesea splitgerberi (Mez) L.B. Sm. \& Pittendrigh (Braga 1977), and in few species of Aechmea (Sousa et al. 2005). Reinert and Meirelles (1993) studied juvenile leaves of Alcantarea glaziouana (Lem.) Leme, then identified as Vriesea geniculata (Wawra) Wawra, and reported that trichomes' density change through the lifetime of the plant, and that they occur in the coastal and intercostal zones of leaves when young and in adult leaves are restricted to the intercostal bands. Our observations confirm the occurrence of glabrescent leaves (i.e. that loose their trichomes during the development) with Alcantarea as usually mentioned in taxonomic descriptions (Versieux and Wanderley 2007a, 2007b), but we also report here that for few species the trichomes extend along the entire leaf. Reinert and Meirelles (1993) observed that juvenile leaves A. glazionana are narrow, strongly canaliculate, succulent, not forming tank while adult plants present nearly flat leaves broad and covered by epicuticular wax, which form a well developed tank. Heterophyllous bromeliads, with juvenile forms densely covered by trichomes were also observed by Adams and Martin (1986) who noticed that juveniles of Tillandsia deppeana were more tolerant of a prolonged period without water than were the adults and that it would show higher levels of photosynthesis following a brief wetting after a period 
of desiccation. These adaptations could favor and protect the young plant until it is completely developed and established.

A central silica body is characteristic of the epidermal cells of most Bromeliaceae as well as of some other monocot families (Robinson 1969; Tomlinson 1969). In Alcantarea the silica body can be noticed on the paradermal sections as well as on SEM images. Silica bodies are broadly seen within the Poales, and sometimes their morphology and presence may define taxonomic groups in other plant families such as Cyperaceae and Poaceae (Mehra and Sharma 1965; Zhang and Clark 2000). This character was already used by Gilmartin and Brown (1987) in a morphological phylogenetic analysis and supported the proximity of Bromeliaceae to other monocot families such as Commelinaceae, Rapateaceae and Strelitziaceae. Recently, the presence of silicon dioxide bodies in leaves and of epicuticular waxes of the Strelitzia type is considered to be a synapomorphy of the larger clade Commelinid (Soltis et al. 2005). An anti-herbivory role and also a growth promotor activity have been attributed to silica in other plant families within the Poales (MacNaughton et al. 1985). Silica bodies' function was once conjectured as being photoprotective because it possibly contributes to the reflection of sunlight preventing overheating and water loss (Baumert 1907 apud Krauss 1949).

The following xeromorphic traits were observed in Alcantarea leaves: small epidermal thickwalled cells, which exhibit considerable resistance to collapse (Oertli et al. 1990 apud Fahn and Cutler 1992); uneven sinuous epidermal walls that strengthen the leaves and help to prevent the separation of the epidermis from the underlying hypodermis, as mentioned by Benzing (2000b); the hypodermis often differentiated into 2 to 5 lignified layers with thick-walled cells what is an adaptation to avoid water loss and to protect the inner water storage tissue layer; aquiferous hypodermis bearing collapsible cells that posses flexible walls that can tolerate cell volume change from a well-watered to a dry situation; presence of well developed epicuticular stratum, with a thick cuticle often covered by Strelitzia type of epicuticular wax and frequently protecting the stomata complexes.

In all species analyzed stomata are restricted to the abaxial face (hypostomatic leaf), and this is a general trend, with few exceptions, for the entire family and confirmed by other authors for 
designated Bromeliaceae genera (Braga 1977; Reinert and Meirelles 1993; Arruda and Costa 2003). In most species stomata are positioned in the same level as common cells of the epidermis. In $A$. farneyi and $A$. duarteana the stomata are in the same level as the adjacent cells, but the epidermis itself is slightly sinuous. Hypostomatic leaves and stomata arranged on the same level as neighboring cells are not considered to be typical xeromorphyc adaptations. Several plant families from arid zones, particularly succulents, present stomata deeply sunken in crypts (e.g. Agavaceae, Fahn and Cutler 1992; Cactaceae, Calvente et al. 2008). In all species stomata are situated above a many-layered hypodermis that delimits a substomatal chamber. According to Fahn and Cutler (1992) substomatal chamber like the one seen in Alcantarea, establishes a long, shallow diffusion gradient between the chlorenchyma and the environment, and a high diffusion resistance. Fahn and Cutler (1992) mention that stomata on both sides of the leaf tend to be more common on leaves of plants of xeric habitats. Nevertheless in all Alcantarea species analyzed here and in most bromeliad species stomata are restricted to the abaxial face. Scatena and Segecin (2005) comments that the presence of hypostomatic leaves, a character assumed to be typical of mesic taxa, may be more related to the phylogenetic ancestry of the bromeliads than be related to an ecological or environmental selection response. In other words, these authors considered that this character would be maintained in Bromeliaceae as a pleisiomorphic condition. Other authors, as Nobel (1999) discuss that hypostomatic leaves may constitute a strategy to minimize water loss by convection currents or breezes that could remove water vapor from the leaf surface, and also that stomata that are surrounded by a thick cuticle have their resistance to water loss slightly enhanced.

Though in cross section the epidermal cells shapes seem to present low variation, the paradermal sections (face view), show that the epidermal cell wall morphology vary. Actually the significance of the epidermal cell morphology for systematics has been assessed for other families with a great number of potentially informative characteristics being possible (e.g. Calvente et al. 2008). In Tillandsia, Scatena and Segecin (2005) report that the epidermal cellular wall shape may vary from near straight to curved or undulate. In the analyzed species of Alcantarea, the epidermal walls are always sinuous. Krauss (1949) noticed that ordinary epidermal cells that surround the stomata 
may be differently distributed, being arranged in a kind of ring format and showing slightly thicker and straighter walls that could help protect the stomata from longitudinal stresses. This pattern of modification was also observed here and we speculate that the remaining sinuous interdigitated thinwalled cells are elastic and can better tolerate turgor shifts.

Epicuticular wax has been reported to be present in several Bromeliaceae species and its importance in prevention of water loss is broadly cited (Palací et al. 2004). Other protective functions of wax may include minimizing mechanical damage to cells and inhibiting fungal and insect attack (Eglinon and Hamilton 1967). The pattern observed for epicuticular wax deposition in Alcantarea is know as Strelitria type and is characterized by the presence of rod-like structures.

The wax composition of one species may differ for distinct parts of the same plant and may vary with season, locale, and the age of the plant (Eglinton and Hamilton 1967). Barber (1955), presented data on the glaucousness of Eucalyptus species (Myrtaceae) and observed changes in wax deposition according to the frost activities, the more glaucous populations occurring in the more frosty localities. As epicuticular wax may vary according to the environment, it is important to carefully consider this variation prior to using such characteristic for taxonomic decisions and species circumscriptions. Palací et al. (2004) suggest that positive effects of wax in Bromeliaceae leaves could be the increase of water impoundment ability and to maintain gas exchange capability through water repellency. Traditionally, waxes have been cited for their importance in reducing sunlight interception by leaves in exposed habitats.

All the species present leaves with colateral vascular bundles in a single series enveloped by the pericycle and the endodermis as already mentioned for Bromeliaceae by Pita (1997), Arruda and Costa (2003), and Scatena and Segecin (2005) following the nomenclature adopted by Van Fleet (1961), Esau (1965), and Menezes et al. (2006). These authors consider the inner mesophyll layer of the leaf as the endodermis (parenchymatous sheath). Comissural vascular bundle can be seen in longitudinal sections and this feature has also been observed in other species by different authors (Braga 1977; Sousa et al 2005). 
Leaf anatomy indicates potential characteristics to be explored in detailed morphological phylogenetic studies in the future. However, for very closely related species or species complexes anatomical features are very homogeneous within the genus Alcantarea. This seems to be particularly true for species of the so-called Alcantarea extensa complex defined by Versieux and Wendt (2006). Alcantarea extensa and a closely related species, A. trepida, can barely be differentiated based on their leaf anatomy.

Alcantarea has always been considered closely related to Vriesea. As matter of fact for most of its taxonomic existence it was treated as a subgenus of Vriesea. Harms (1929) elevated Alcantarea to the generic rank albeit his decision was not followed by subsequent authors (e.g. Smith 1934, 1955; Smith and Downs 1977). It would be desirable for leaf anatomy to provide additional information regarding the relationship of these two genera. Comparing our results to the works of Braga (1977) and Arruda and Costa (2003) that included Vriesea species, it is possible to see that Alcantarea leaves tend to be thicker, which could be interpreted as an adaptation to xeric environment, because generally thinner leaves are related to mesic habitat (Menezes et al. 2006), where most Vriesea species can be found (Smith 1934; Smith and Downs 1977). Other apparent distinction relates to the shapes of the air channels filled with spongy parenchyma, which seems to be narrower and more elongated in Alcantarea while Vriesea shows leaves with broader air channels, almost suborbicular in outline and filled with a more diffuse spongy parenchyma. Also, the presence of a chlorenchymatous palisade parenchyma which is not arranged in well defined arches in Vriesea but in a more planar disposition is another difference. The aquiferous hypodermis in Vriesea seems to be thinner with fewer layers. This could also have evolved as a consequence of growing in a habitat where water supply was not a limiting factor. Externally, the leaves of Alcantarea usually present greater dimensions and more prominent nerves. Measuring, across the genera, such external morphological features along with a quantitative evaluation of the anatomical features (above), would lead to a less qualitatively based and more natural classification.

In conclusion, these results show that despite of the reduction in the number of anatomical variable characters among closely related species, the anatomy of Alcantarea accumulate differences in 
the size and number of layers of the lignified and aquiferous hypodermis. Also, interspecific differences could be seen on epidermis cell shape, on the shape of the air channels, on the density and form of the trichomes on the leaf blade and also on the amount of epicuticular wax produced. Hence, foliar anatomy can be considered a good tool for taxonomic and evolutionary studies for Alcantarea and allied taxa.

\section{Acknowledgments}

This work is part of the Ph.D. thesis of LMV, undertaken at the University of São Paulo. We acknowledge the financial support received from the Brazilian agencies CNPq and FAPESP. We thank Robert Smythe for linguistic advice and two anonymous referees for comments on the manuscript.

\section{References}

Adams WW, Martin CE (1986) Physiological consequences of changes in life form of the Mexican epiphyte Tillandsia deppeana (Bromeliaceae). Oecologia 70, 298-304. doi: 10.1007/BF00379255

Arruda RC, Costa AF (2003) Foliar anatomy of five Vriesea Sect. Xiphion (Bromeliaceae) species. Selbyana 24, 180-189.

Barber HN (1955) Adaptive gene substitutions in Tasmanian Eucalypts: I. genes controlling the development of glaucousness. Evolution 9, 1-14.

Benzing D (1976) Bromeliad trichomes: structure, function, and ecological significance. Selbyana 1, 330-348.

Benzing D (2000a) Introduction. In 'Bromeliaceae: profile of an adaptive radiation'. (Ed D Benzing) pp. 3-15. (Cambridge University Press: Cambridge, UK)

Benzing D (2000b) Vegetative structure. In 'Bromeliaceae: profile of an adaptive radiation'. (Ed D Benzing) pp. 19-77. (Cambridge University Press: Cambridge, UK) 
Braga MMN (1977) Anatomia foliar de Bromeliaceae da Campina. Acta Amazonica 7, 5-73

Bukatsch F (1972) Bemerkungen zur Doppelfarburng Astrablau-Safranin. Mikrokosmos 61, 255.

Calvente AC, Andreata RHP, Vieira RC (2008) Stem anatomy of Rbipsalis (Cactaceae) and its relevance for taxonomy. Plant Systematics and Evolution 276, 1-7. doi: 10.1007/s00606-008-0052-9

Carauta JPP, Oliveira R. (1984) Plantas vasculares dos morros da Urca, Pão de Açúcar e Cara de Cão. Rodriguésia 36, 13-24.

Chase MW, Fay MF, Devey DS, Maurin O, Ronsted N, Davies TJ, Pillon Y, Petersen G, Seberg O, Tamura MN, Asmussen CB, Hilu K, Borsch T, Davis JI, Stevenson DW, Pires JC, Givnish TJ, Sytsma KJ, McPherson MA, Graham SW, Rai HS (2006) Multigene analyses of monocot relationships: a summary. Aliso 22, 63-75.

Eglinon G, Hamilton RJ (1967) Leaf epicuticular waxes. Science 156, 1322-1335.

Fahn A, Cutler DF (1992) 'Xerophytes. Encyclopedia of plant taxonomy'. (Gebruder Borntraeger: Berlin)

Gilmartin AJ, Brown GK (1987) Bromeliales, related monocots, and resolution and relationships among Bromeliaceae subfamilies. Systematic Botany 12, 493-500.

Harms H (1929) Bromeliaceae novae III. Notizblatt des Botanischen Gartens und Museums zu Berlin-Dablem 10, 784-805.

Kraus JE, Arduin M (1997) 'Manual Básico de Métodos em Anatomia Vegetal'. (EDUR Ed. Universidade Rural: Rio de Janeiro)

Krauss BH (1949) Anatomy of the vegetative organs of the pineapple, Ananas comosus (L.) Merr. (Continued) II. The Leaf. Botanical Gazette 110, 333-404

Luther H (2008) 'An Alphabetical list of Bromeliads Binomials, 11 ${ }^{\text {th }}$ ed'. (Bromeliad Society International: Sarasota, USA)

MacNaughton SJ, Tarrants JL, MacNaughton MM, Davis RH (1985) Silica as a defense against herbivory and a growth promotor in African grasses. Ecology 66, 528-535. 
Martinelli G (1997) Biologia reprodutiva de Bromeliaceae na Reserva Ecológica de Macaé de Cima. In 'Serra de Macaé de Cima: Diversidade Florística e Conservação em Mata Atlântica’. (Eds HC Lima, RR Guedes-Bruni) pp. 213-250. (Instituto de Pesquisa Jardim Botânico do Rio de Janeiro: Rio de Janeiro, Brasil)

Mehra PN, Sharma OP (1965) Epidermal silica cell in the Cyperaceae. Botanical Gazette 126, 53-58.

Menezes NL, Silva DC, Pinna GFM (2006) Folha. In 'Anatomia vegetal'. (Eds B Apezzato-da-Glória, SM Carmello-Guerreiro) pp. 303-325. (Editora Universidade Federal de Viçosa: Viçosa, Brasil) Nobel PS (1999) 'Physicochemical and environmental plant physiology, 2nd ed'. (Academic Press: San Diego, California)

Palací CA, Brown GK, Tuthill DE (2004) Vegetative morphology and leaf anatomy of Catopsis (Tillandsioideae: Bromeliaceae). Selbyana 25, 138-150.

Pita PB (1997) Estudos anatômicos dos órgãos vegetativos de Dyckia Schult. f. e Encholirium Mart. ex Schult. f. (Bromeliaceae) da Serra do Cipó - MG. M. Sc. thesis, Departament of Botany, Universidade de São Paulo, São Paulo, Brasil.

Pittendrigh CS (1948) The Bromeliad-Anopheles-Malaria Complex in Trinidad: I - The Bromeliad Flora. Evolution 2, 58-89.

Porembski S, Martinelli G, Ohlemüller R, Barthlott W (1998) Diversity and ecology of saxicolous vegetation mats on inselbergs in the Brazilian Atlantic rainforest. Diversity and Distributions 4, 107-119. doi: 10.1046/j.1365-2699.1998.00013.x

Reinert F, Meirelles ST (1993) Water acquisition strategy shifts in the heterophylous saxicolous bromeliad, Vriesea geniculata (Wawra) Wawra. Selbyana 14, 80-88.

Reitz R (1983) Bromeliáceas e a malária - bromélia endêmica. Flora Ilustrada Catarinense, Parte 1, fasc. Brom.

Robinson H (1969) A monograph on foliar anatomy of the genera Connelia, Cottendorfia, and Navia (Bromeliaceae). Smithsonian Contributions to Botany 2, 1-41.

Rundel PW, Dillon MO (1998) Ecological patterns in the Bromeliaceae of the lomas formations of Coastal Chile and Peru. Plant Systematics and Evolution 212, 261-278. doi: 10.1007 /BF01089742 
Ruzin SE (1999) 'Plant microtechnique and microscopy.' (Oxford University Press: New York)

Safford HD, Martinelli G (2000) Southeast Brazil. In Inselbergs biotic diversity of isolated rock outcrops in tropical and temperate regions'. (Eds S Porembski, W Barthlot) pp. 339-389. (Springer-Verlag Berlin Heidelberg New York: Germany)

Scarano FR (2002) Structure, function and floristic relationships of plant communities in stressful habitats marginal to the Brazilian Atlantic rainforest. Annals of Botany 90, 517-524. doi:10.1093/ aob/mcf189

Scatena VL, Segecin S (2005) Anatomia foliar de Tillandsia L. (Bromeliaceae) dos Campos Gerais, Paraná, Brasil. Revista Brasileira de Botânica 28, 635-649.

Smith LB (1934) Geographical evidence on the lines of evolution in the Bromeliaceae. Botanische Jabrbücher für Systematik, Pflanzengeschichte und Pflanżengeographie 66, 446-468.

Smith LB (1955) The Bromeliaceae of Brazil. Smithsonian Miscellaneous Collections 126,1-290.

Smith LB, Downs RJ (1974) Pitcairnioideae (Bromeliaceae). Flora Neotropica Monograph 14, 1-658.

Smith LB, Downs RJ 1977. Tillandsioideae (Bromeliaceae). Flora Neotropica Monograph 14, 663-1492.

Soltis DE, Soltis PS, Endress PK, Chase MW (2005) 'Phylogeny and evolution of angiosperms.' (Sinauer Associates: Sunderland, Massachusetts)

Sousa GM, Estelita MEM, Wanderley MGL (2005) Anatomia foliar de espécies brasileiras de Aechmea subg. Chevaliera (Gaudich. ex Beer) Baker, Bromelioideae-Bromeliaceae. Revista Brasileira de Botânica 28, 603-613.

Szarzynski J (2000) Xeric Island: environmental conditions on inselbergs. In Inselbergs biotic diversity of isolated rock outcrops in tropical and temperate regions'. (Eds S Porembski, W Barthlot) pp. 37-48. (Springer-Verlag Berlin Heidelberg New York: Germany)

Tomlinson PB (1969) III - Commelinales-Zingiberales. In 'Anatomy of the Monocotyledons' (Ed CR Metcalfe) pp. 193-294. (Clarendon Press: Oxford)

Van Fleet DS (1961) Histochemistry and function of the endodermis. The Botanical Review 27, $165-220$. 
Versieux LM, Wanderley MGL (2007a) Alcantarea (E. Morren ex Mez) Harms. In 'Flora Fanerogâmica do Estado de São Paulo, vol. 5’. (Eds MGL Wanderley, GJ Shepherd, TS Melhem, AM Giulietti) pp. 59-62. (Instituto de Botânica: São Paulo, Brasil)

Versieux LM, Wanderley MGL (2007b) Two new species of Alcantarea (Bromeliaceae, Tillandsioideae) from Brazil. Brittonia 59, 57-64. doi: 10.1663/0007-196X(2007)59[57:TNSOAB]2.0.CO;2

Versieux LM, Wanderley MGL (2007c) A new species of Alcantarea (E. Morren ex Mez) Harms, Bromeliaceae. Hoehnea 34, 409-413.

Versieux LM, Wendt T (2006) Checklist of Bromeliaceae of Minas Gerais, Brazil, with notes on taxonomy and endemism. Selbyana 27, 107-146.

Versieux LM, Wendt T (2007) Bromeliaceae diversity and conservation in Minas Gerais, Brazil. Biodiversity and Conservation 16, 2989-3009. doi: 10.1007/s10531-007-9157-7

Zhang W, Clark LG (2000) Phylogeny and classification of the Bambusoideae (Poaceae). In 'Grasses systematic and evolution' (Eds SWL Jacobs, J Everett) pp. 35-42. (CSIRO: Collingwood)

\section{Figure legends}

Fig. 1. A.-K. Transversal sections of the leaf middle portion $(5 \mathrm{x}$ scale $=250 \mu \mathrm{m}, 10 \mathrm{x}=100 \mu \mathrm{m}$, black and white arrows indicate the endodermis). L.-M. Longitudinal sections of the leaf middle portion. A. Alcantarea burle-marxii (10x), Ap=aquiferous parenchyma, $\mathrm{Pp}=$ palisade parenchyma, $\mathrm{Sp}=$ spongy parenchyma, En=endodermis, $\operatorname{Pr}=$ pericyclic fibers. B. A. extensa (5x). C. A. farneyi (10x). D. A. geniculata (10x). E. A. nahoumii (10x). F. A. nigripetala (5x). G. A. vinicolor (5x). H. A. patriae (10x). I. A. roberto-kautskyi (10x). J. A. trepida (5x). K.-L. A. duarteana. K. Transversal section. (5x). L. Longitudinal section whith a raphide (arrow) $(20 \mathrm{x}$, scale $=50 \mu \mathrm{m})$. M. Longitudinal section of A. burle-marxii (10x) with a comissural vascular bundle (arrow).

Fig. 2. Details of adaxial and abaxial epidermis (scales: $20 \mathrm{x}=50 \mathrm{mmm}, 40 \mathrm{x}=25 \mathrm{mmm}, 100 \mathrm{x}=$ 10mmm). A.-B. A. burle-marxii. A. Adaxial face (20x). B. Abaxial face (100x) with cells containing 
silica bodies (arrow). C.-D. A. extensa. C. Adaxial face (20x). D. Abaxial face (20x). E.-G. A. farneyi. E.F. Abaxial face (40x). G. Vascular bundle (20x) showing pericyclic fibers (Pr) and endodermis (En). H. A. geniculata adaxial face (20x). I.-J. A. nigripetala. I. Adaxial face (40x). J. Abaxial face (20x). K.-L. A. patriae. K. Adaxial face (40x). L. Abaxial face (40x). M.-N. A. roberto-kautskyi. M. Adaxial face (40x). N. Abaxial face (40x). O.-P. A. trepida. O. Adaxial face (20x). P. Abaxial face (40x). Q.-R. A. vinicolor. Q. Adaxial face (20x). R. Abaxial face (40x). S.-Y. Abaxial leaf face showing stomata and subsidiary cells in transversal sections (100x). S. A. farneyi. T. A. geniculata. U. A. heloisae. V. A. nigripetala. W. A. robetokautskyi. X. A. vinicolor. Y. A. patriae, leaf abaxial face $(40 \mathrm{x}$, bar $=25 \mu \mathrm{m})$ showing the substomatic chamber.

Fig. 3. A-N. Adaxial and abaxial epidermis in frontal views $(10 \mathrm{x}$ scale $=100 \mu \mathrm{m}, 20 \mathrm{x}=50 \mu \mathrm{m}, 40 \mathrm{x}=$ $25 \mu \mathrm{m}, 100 \mathrm{x}=10 \mu \mathrm{m})$. A.-B. A. burle-marxii. A. Adaxial face (100x). B. Abaxial face (20x). C.-D. A. duarteana. C. adaxial face (100x). D. Abaxial face with a slightly asymmetric trichome (arrow). E.-F. $A$. extensa. E. Adaxial face (40x). F. Abaxial face showing stomata and vestiges of trichomes arranged in rows (10x). G.-H. A. geniculata. G. Adaxial face (20x). H. Abaxial face showing stomata and trichome (40x). I.-J. Alcantarea patriae. I. Adaxial face showing epidermal anticlinal and periclinal sinuous walls and trichomes (40x). J. Abaxial face depicting radially symmetric trichomes with cell disposed in $4+8$ + 64 concentric rings (arrow). K.-L. Alcantarea vinicolor (40x). K. Adaxial face. L. Abaxial face, showing enlarged detail of the silica body (arrow). M. A. burle-marxii abaxial face with trichomes and silica bodies (arrow) (20x). N. A. roberto-kautskyi adaxial face showing sinuous walls (100x).

Fig. 4. Leaf sheath and leaf blade epidermis Scanning Electron Microscopy images. A.-C. A. burlemarxii leaf sheath. A. Abaxial view showing trichomes and silica bodies. B. Detail of trichome of abaxial face. C. Trichomes on the adaxial face. D.-G. A. duarteana, middle portion of the leaf blade. D.-E. Abaxial face. F.-G. Adaxial. face. D. Trichomes covering the whole surface of the leaf. E. Detail of the epidermis without wax under trichomes. F. Trichomes slightly asymmetric and densely disposed over the abaxial face. G. Detail of trichome showing the $4+8+16+32+64$ concentric cell 
rings. H.-J. A. patriae. H. Abaxial leaf sheath showing epicuticular wax and two stomata. I. Adaxial leaf blade showing epicuticular wax. J. Detail view of individual epicuticular wax crystalloids. K.-M. $A$. trepida abaxial view of the leaf sheath epicuticular wax crystalloids. L. Radially symmetric trichome on the adaxial leaf sheath with the $4+8+32$ concentric ring cells pattern. M. Middle abaxial portion of the leaf blade showing stomata complexes arranged in rows. N.-O. A. vinicolor. N. Adaxial leaf sheath trichomes. O. Middle adaxial leaf face showing epicuticular wax.

Fig. 5. Leaf blade and rachis epidermis Scanning Electron Microscopy for samples treated with dehydrating alcoholic series. A.-C. A. burle-marxii. A. Adaxial view. B. Abaxial view showing stomata and trichomes vestiges arranged in rows. C. Detail of stomata and the different position of the ordinary cells that surround stomata. D.-E. Abaxial view of A. extensa. D. Stomata and vestiges of trichomes. E. Stomata partially covered by epicuticular wax. F. Detail of stomata present on the inflorescence rachis of A. glazionana (arrow). G.-I. A. farneyi. G. Adaxial view showing remnants of trichomes. H. Stomata in rows. I. Detail of the stomata surrounded by thick cuticle. J.-L. A. trepida. J. Glabrescent adaxial face. K. Abaxial view showing stomata in rows. L. Detail of stomata in the abaxial view. M.-O. A. vinicolor. M. Abaxial face showing stomata. N. Detail of silica bodies and sinuous epidermal walls (arrows). O. Detail of stomata. 


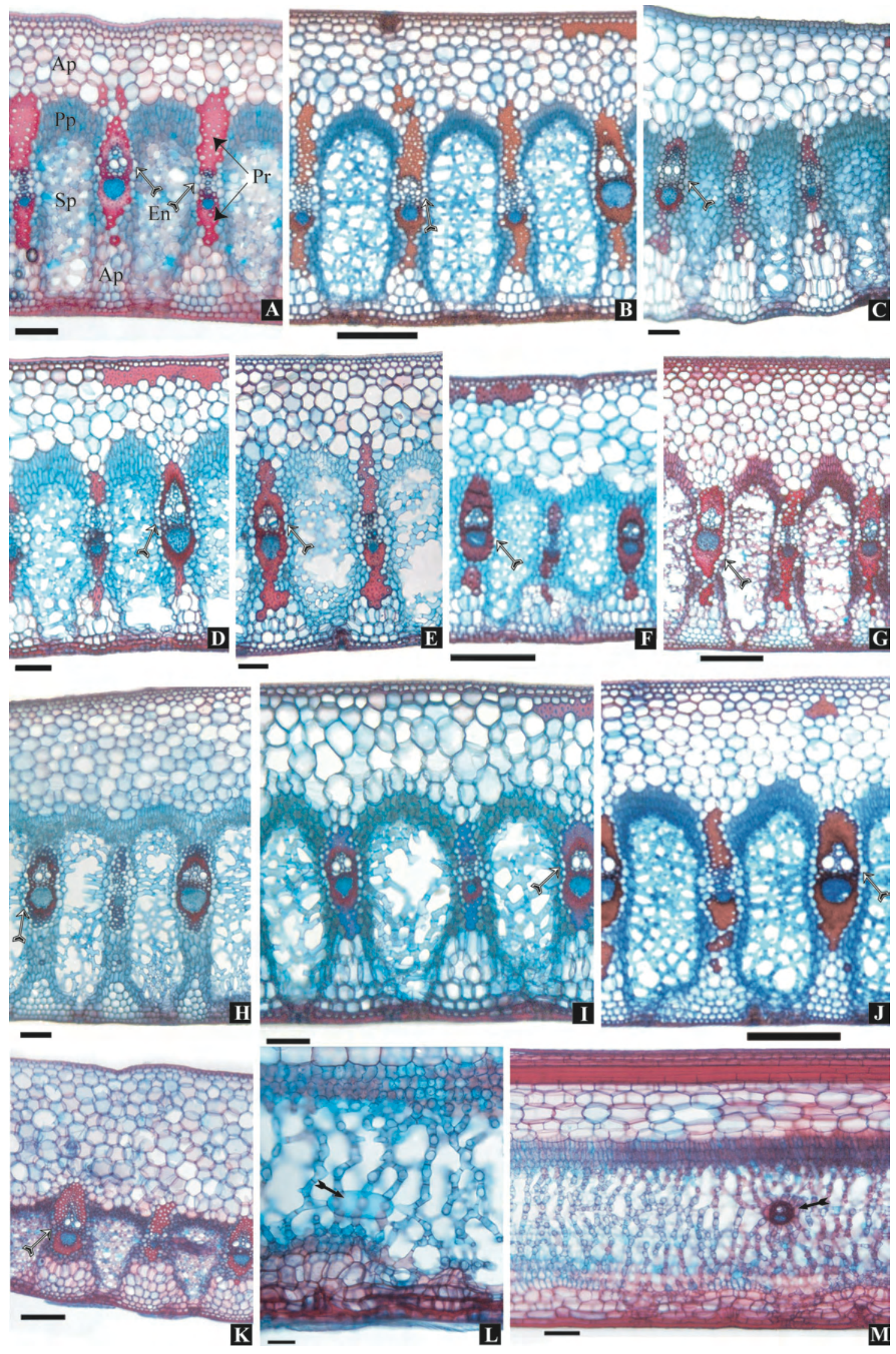

FIG. 1 


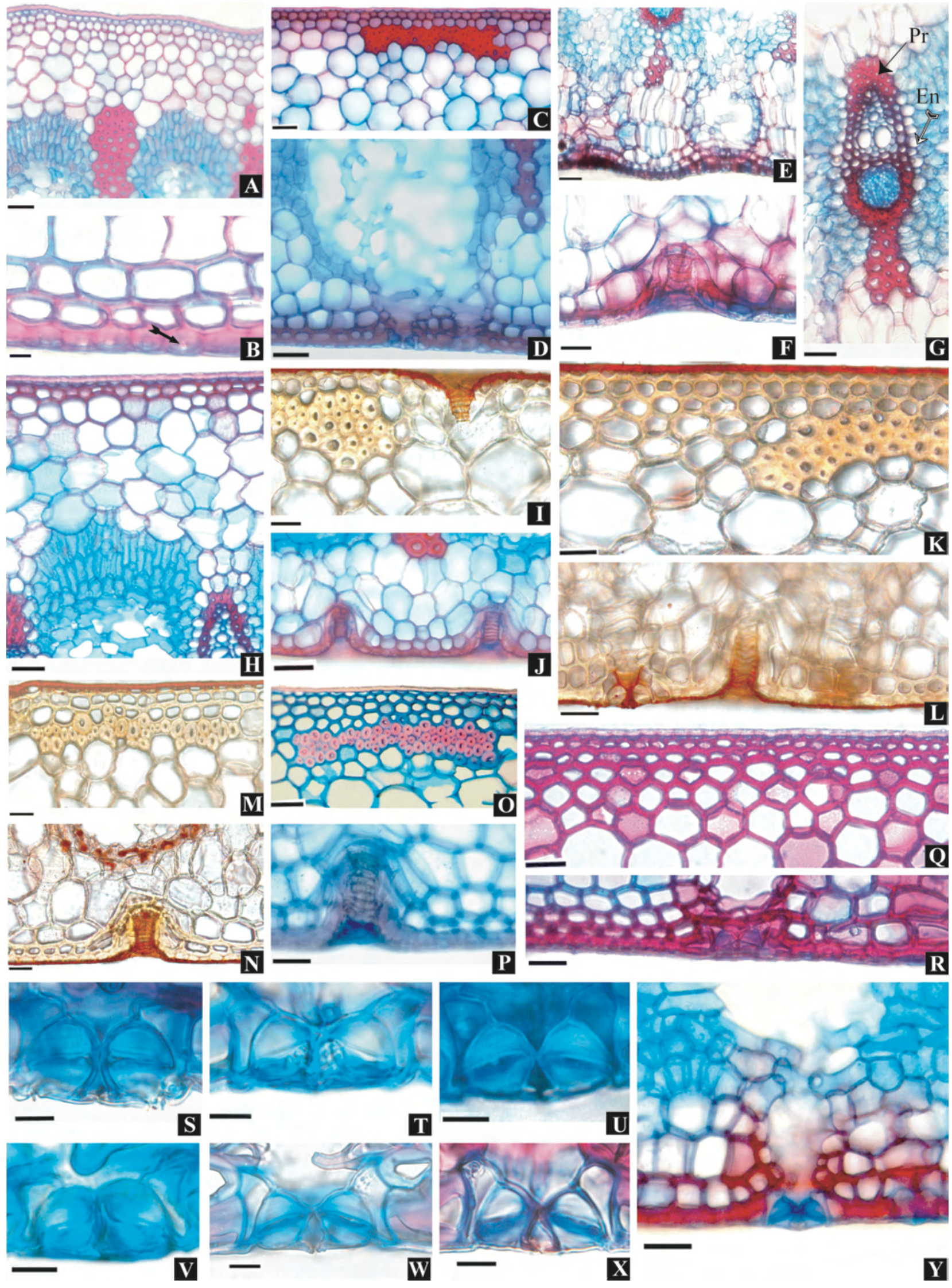

FIG. 2 

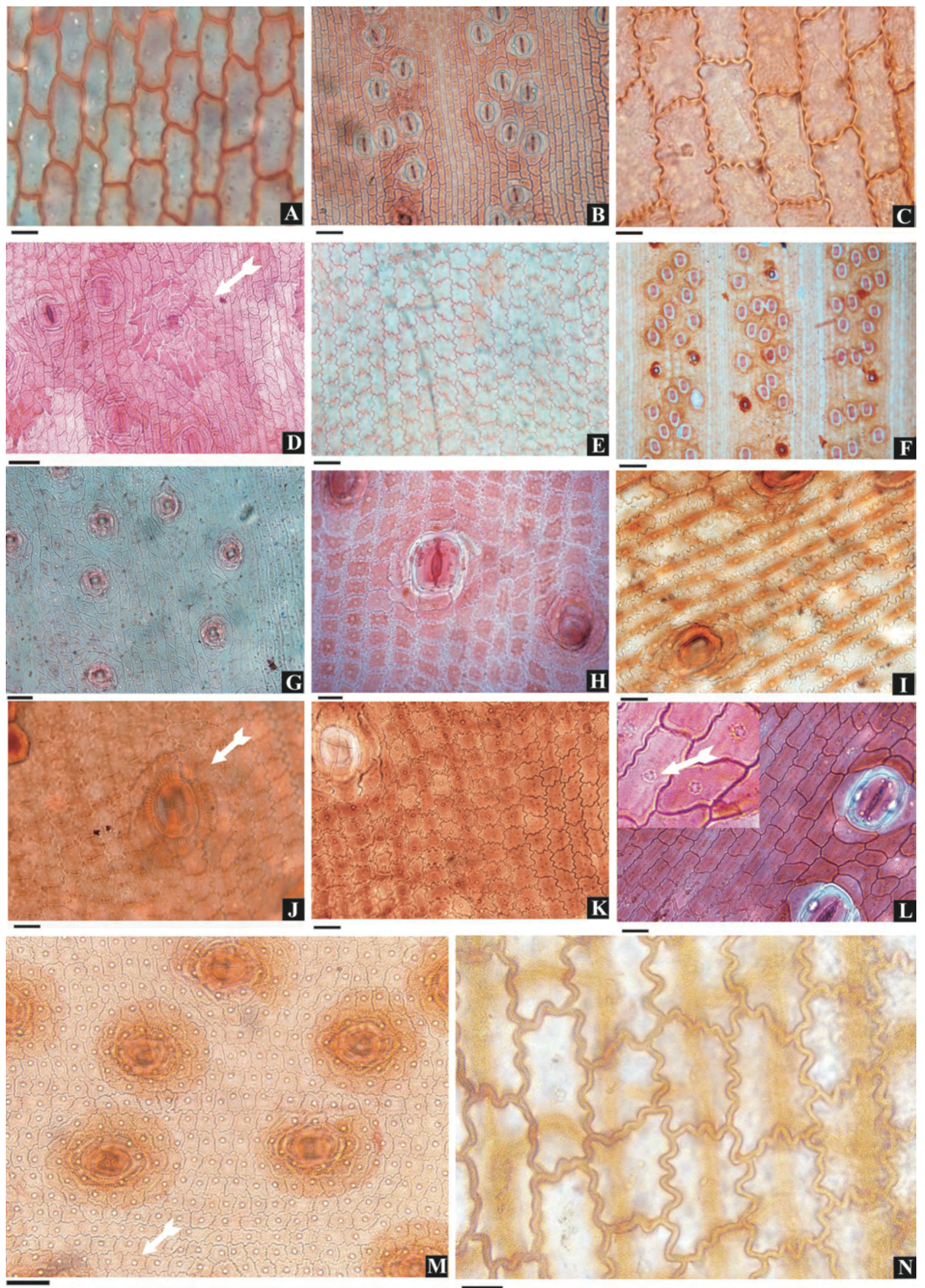

FIG. 3 

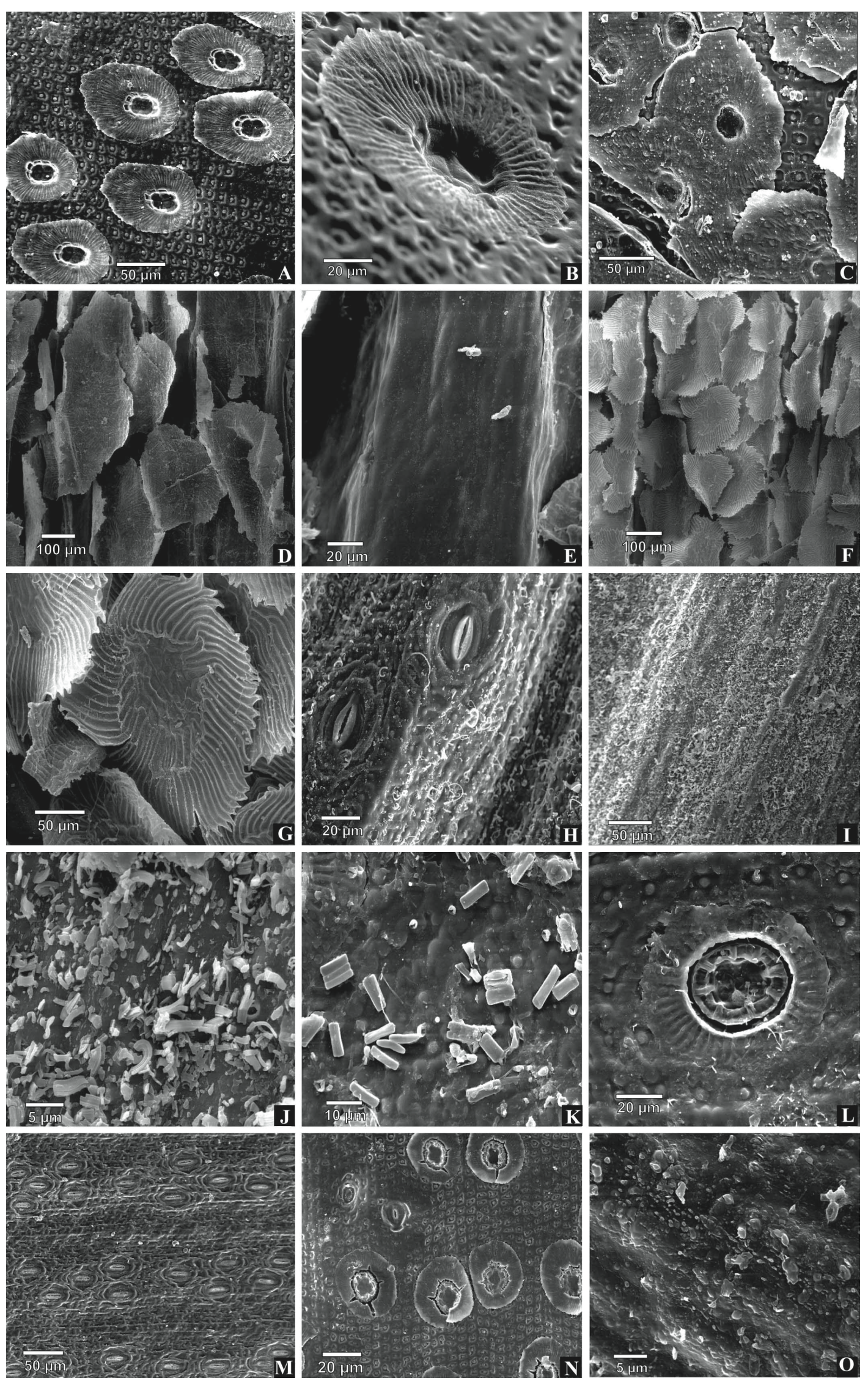

FIG. 4 

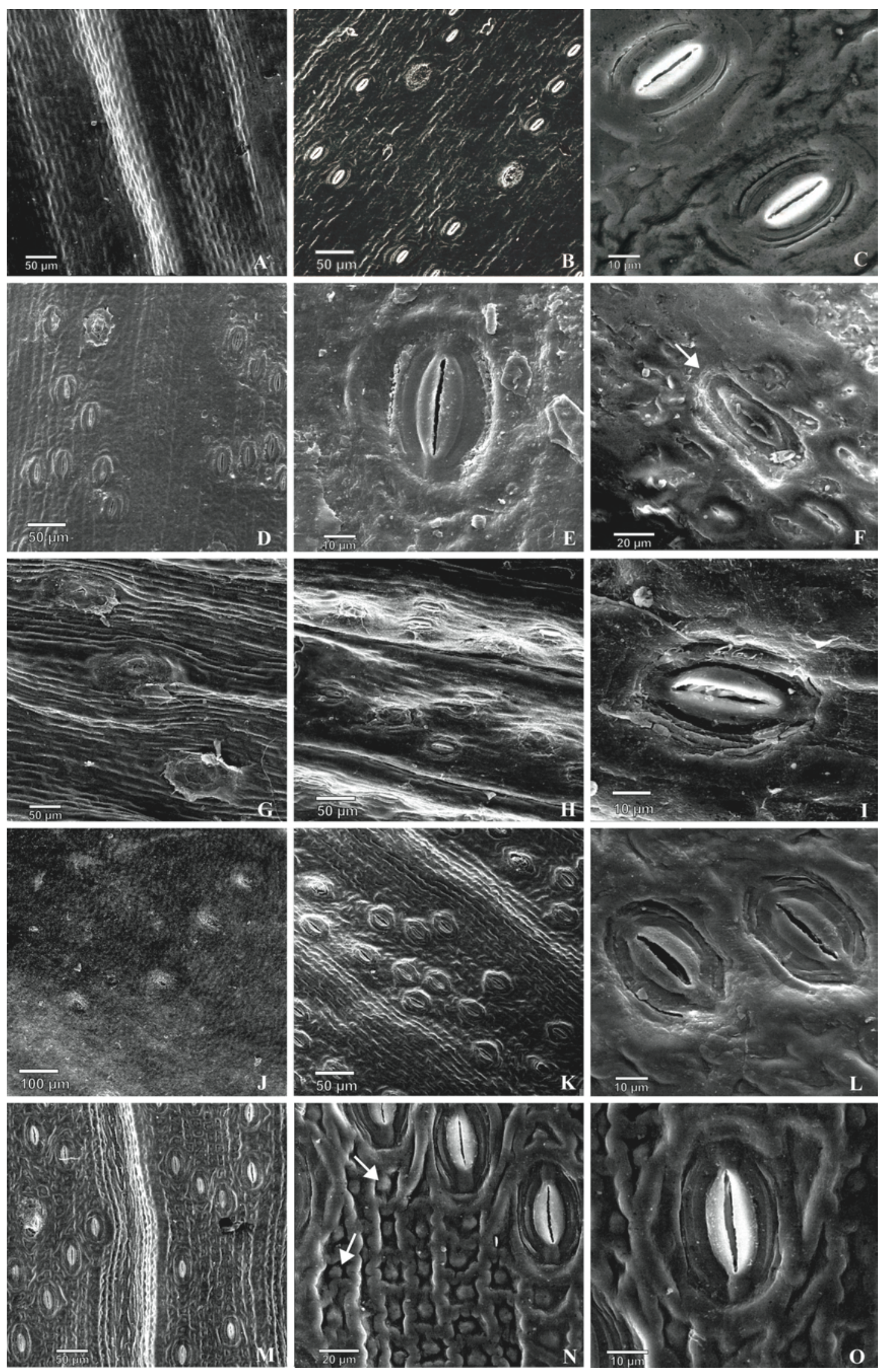

FIG. 5 


\section{APÊNDICE - PUBLICAÇÕES E CURSOS REALIZADOS}

Versieux \& Wanderley 2007: Brittonia 59(1): 57-64

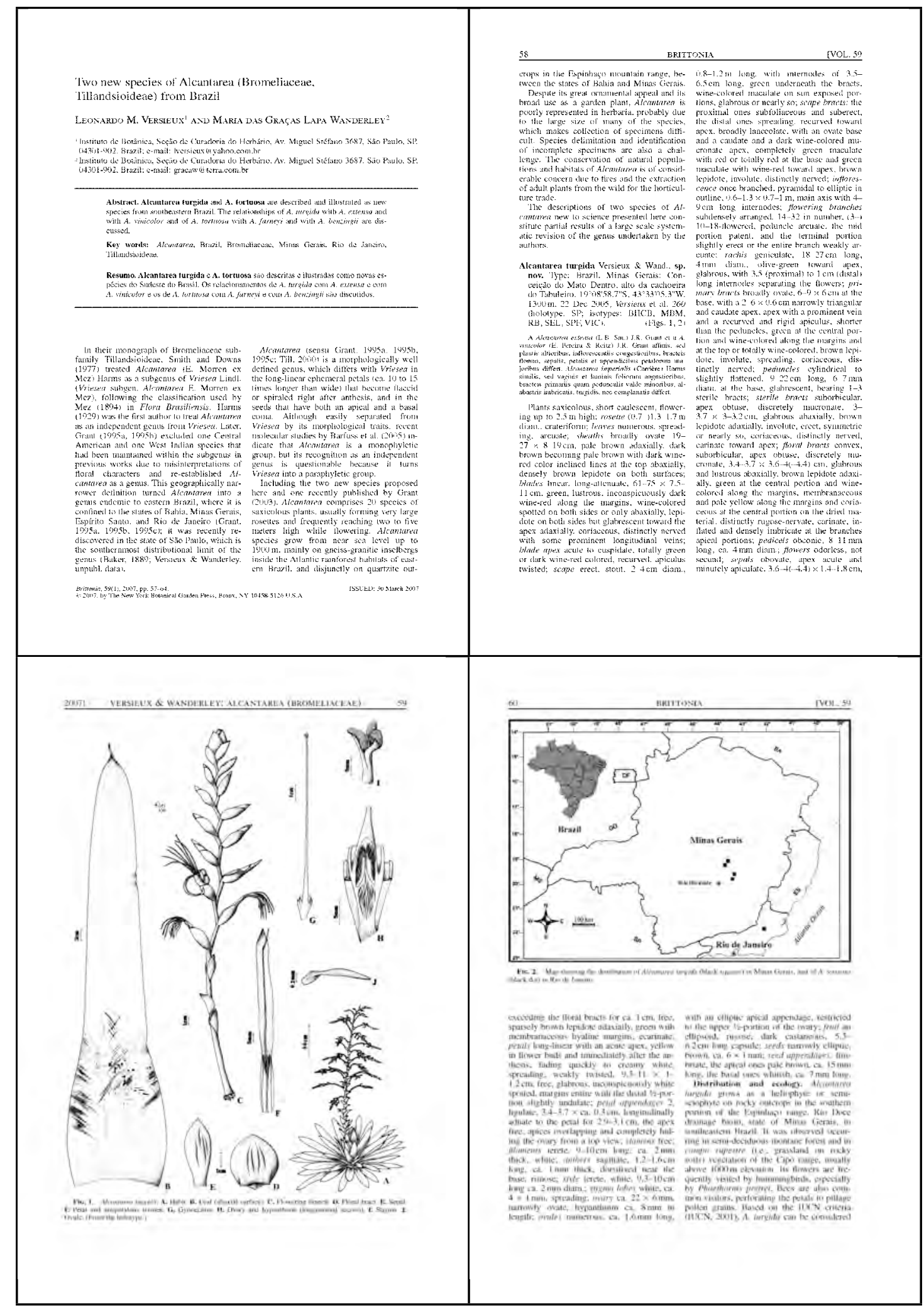




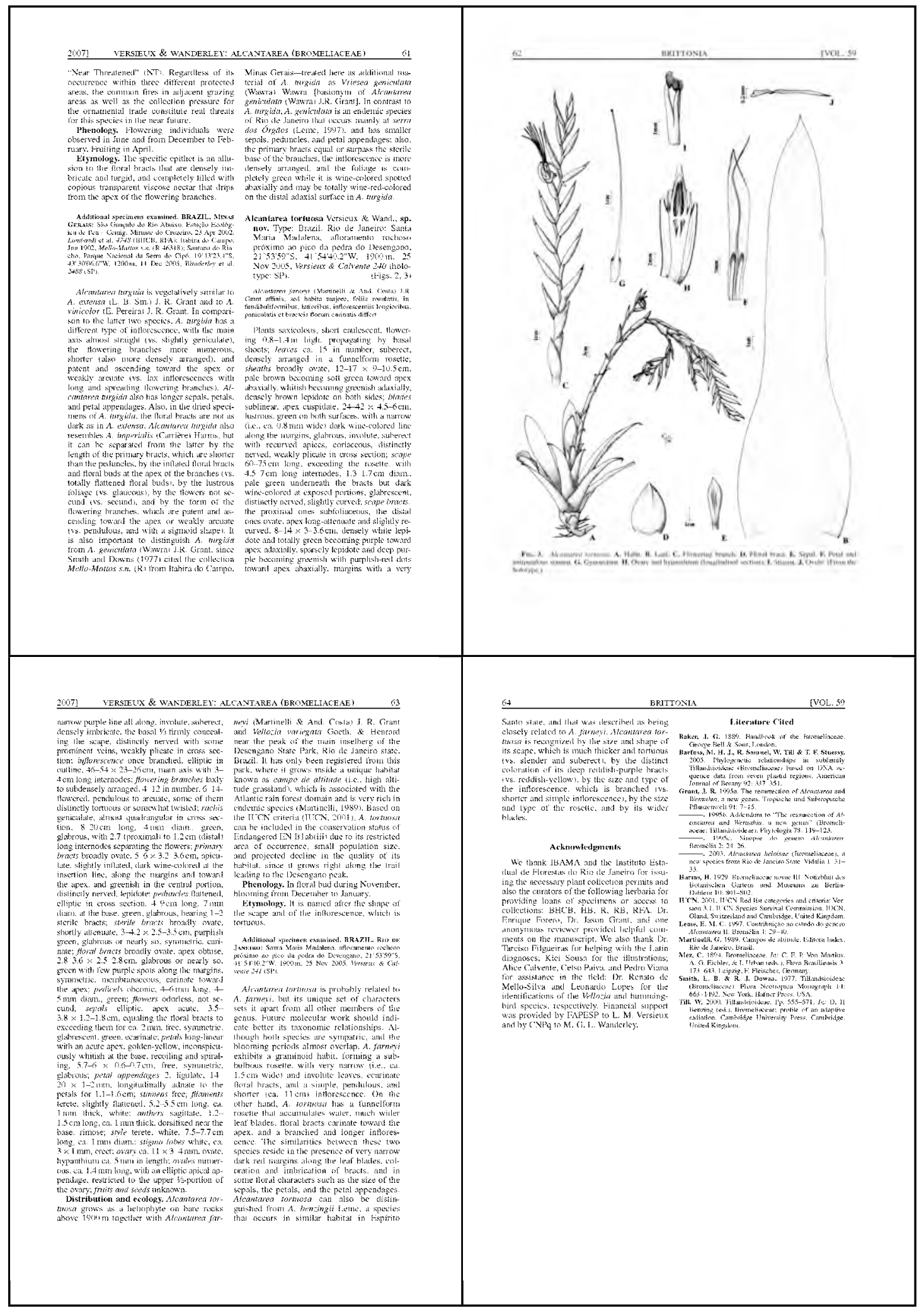


Versieux \& Wanderley 2007: Hoehnea 34(3): 409-413

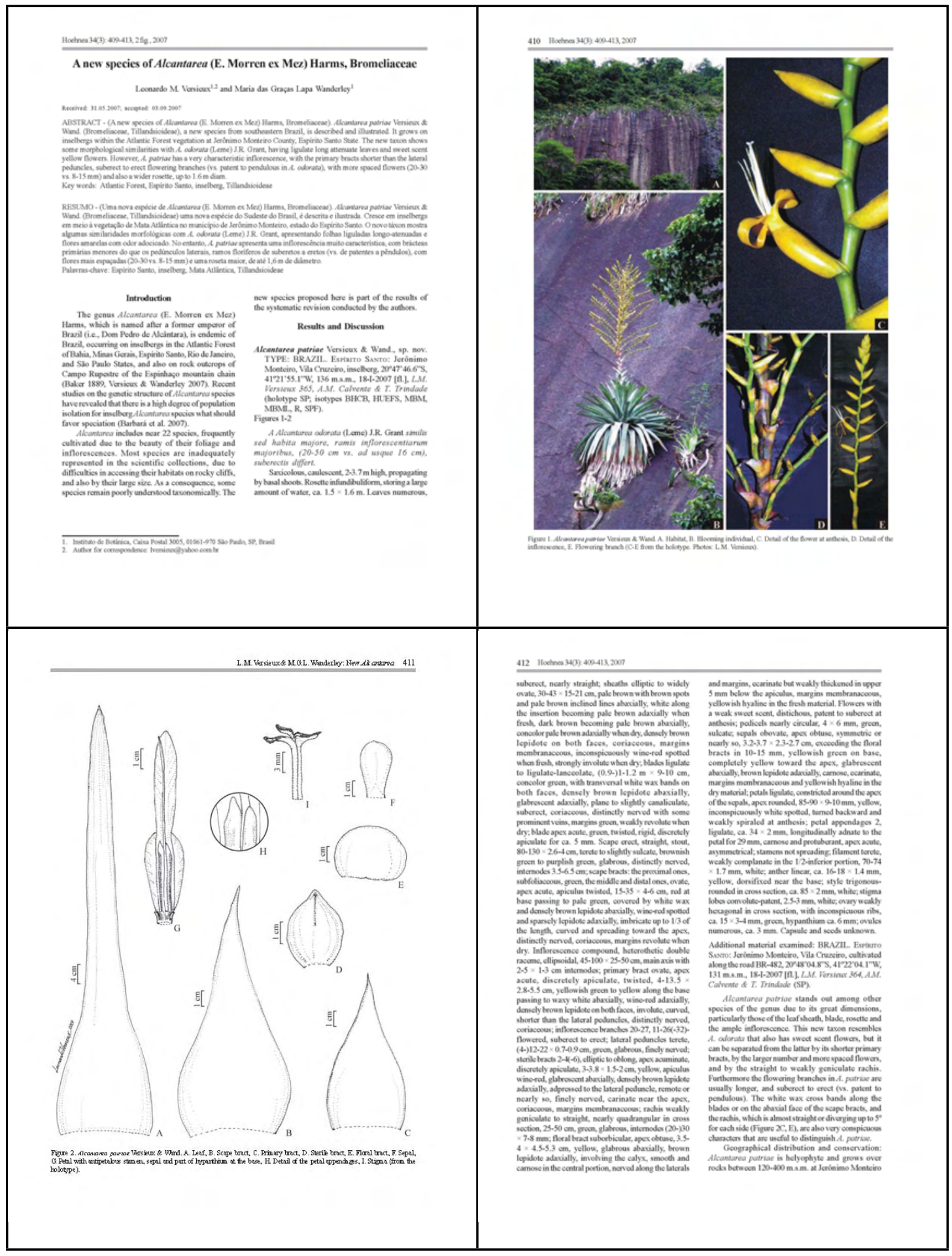


Versieux \& Wanderley 2008: Acta Botanica Brasilica 22(1): 71-74

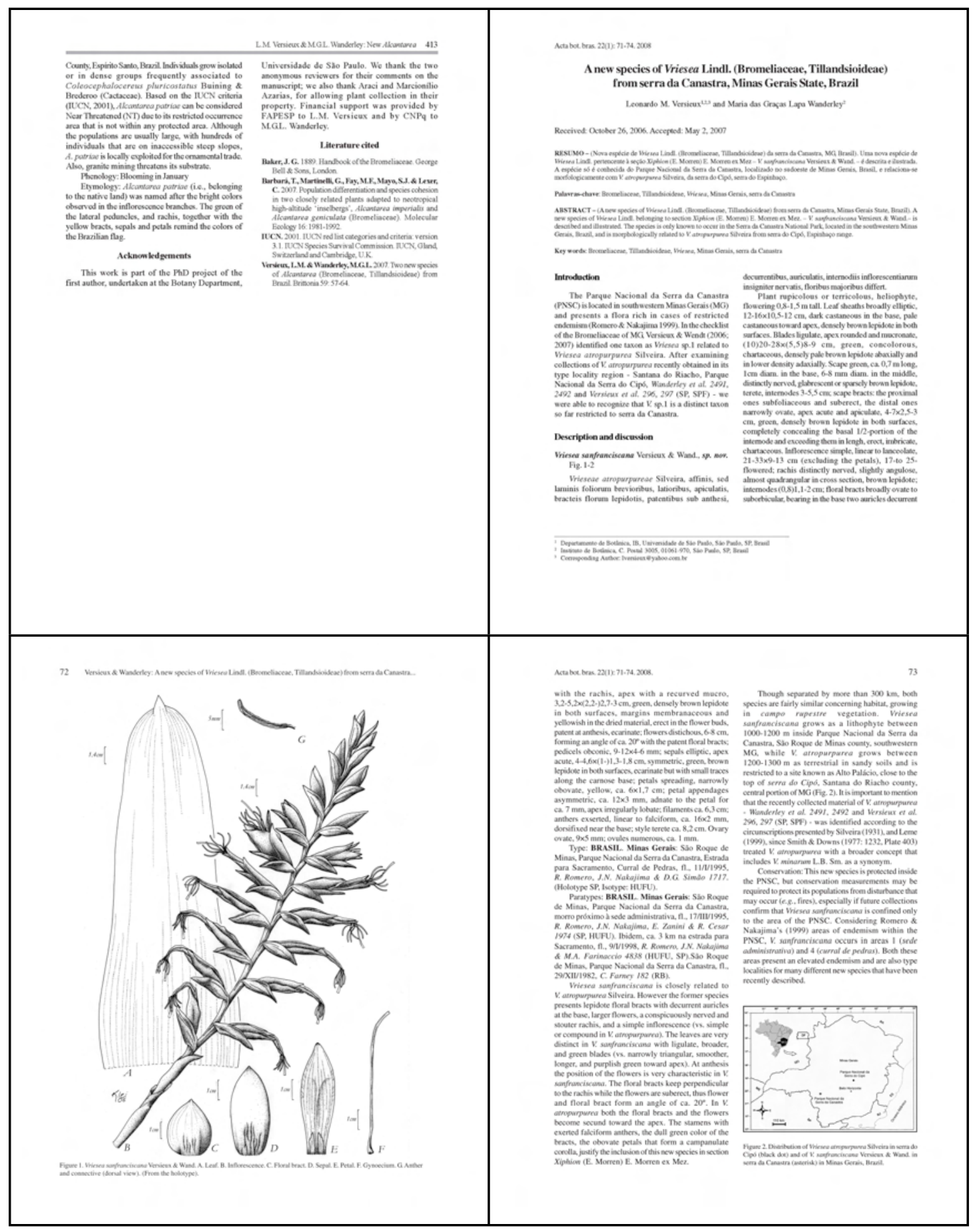


Versieux 2008: Botanical Journal of the Linnean Society 158: 709-715

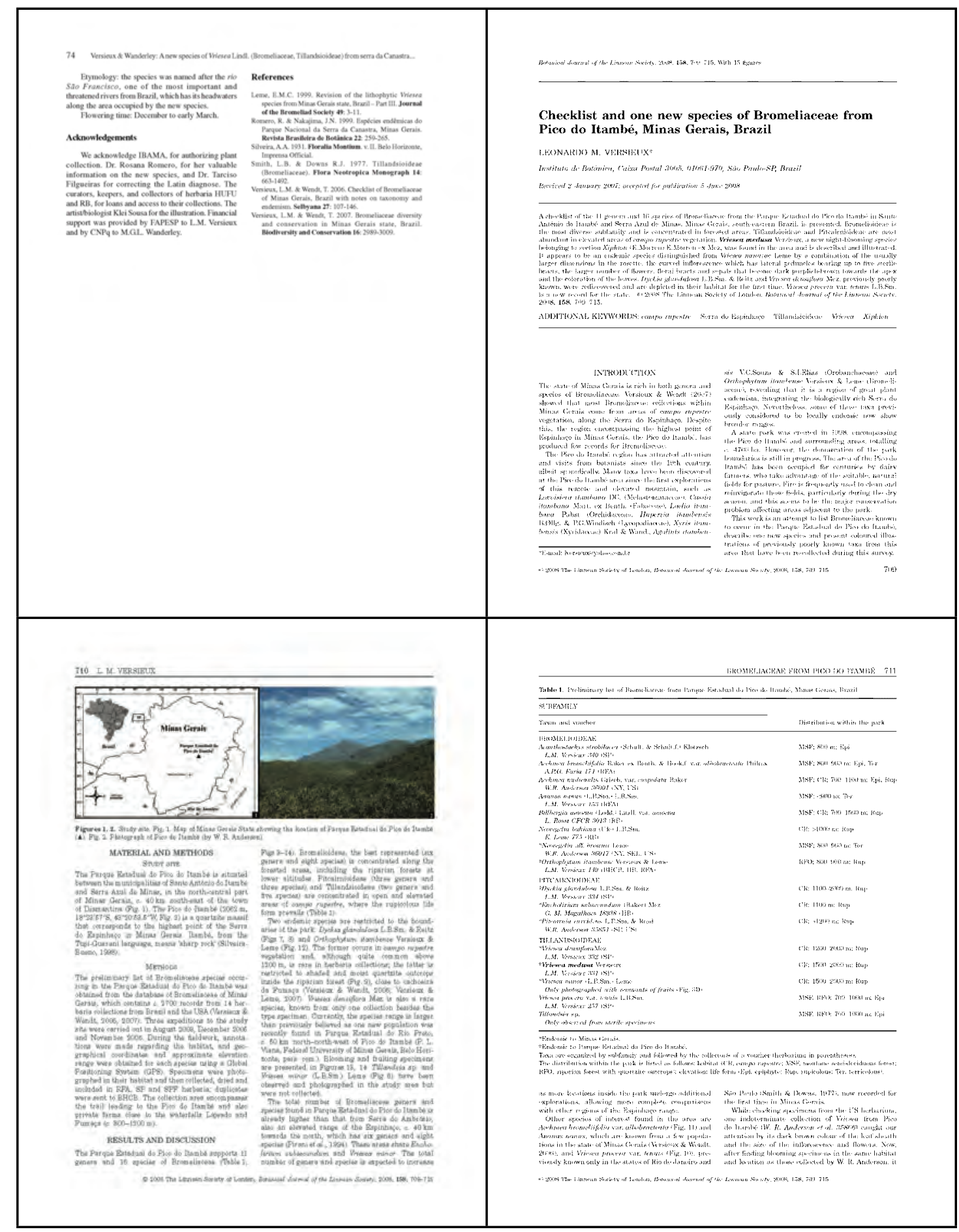




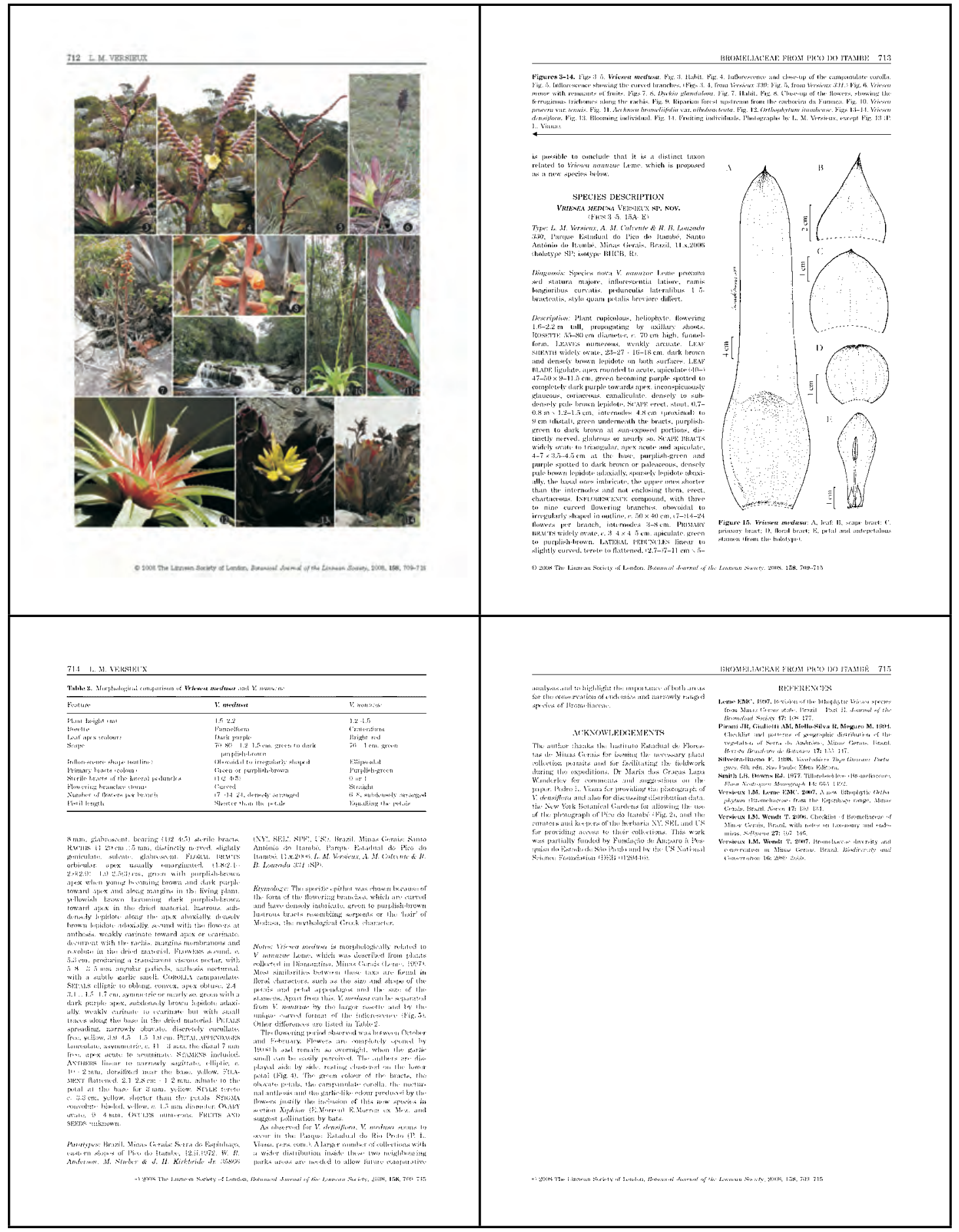


Versieux \& Wanderley 2007: Flora Fanerogâmica do Estado de São Paulo 5: 59-62

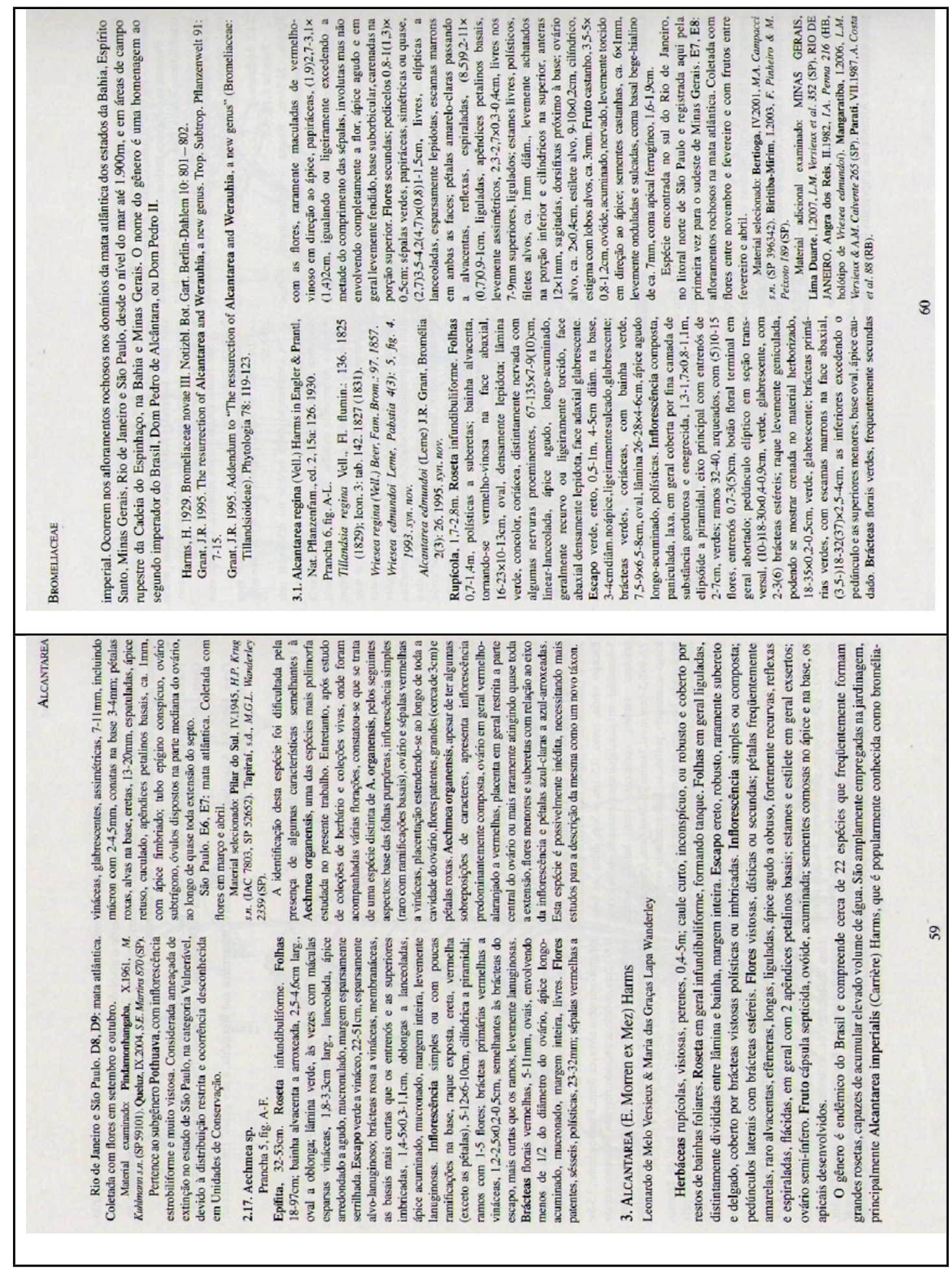




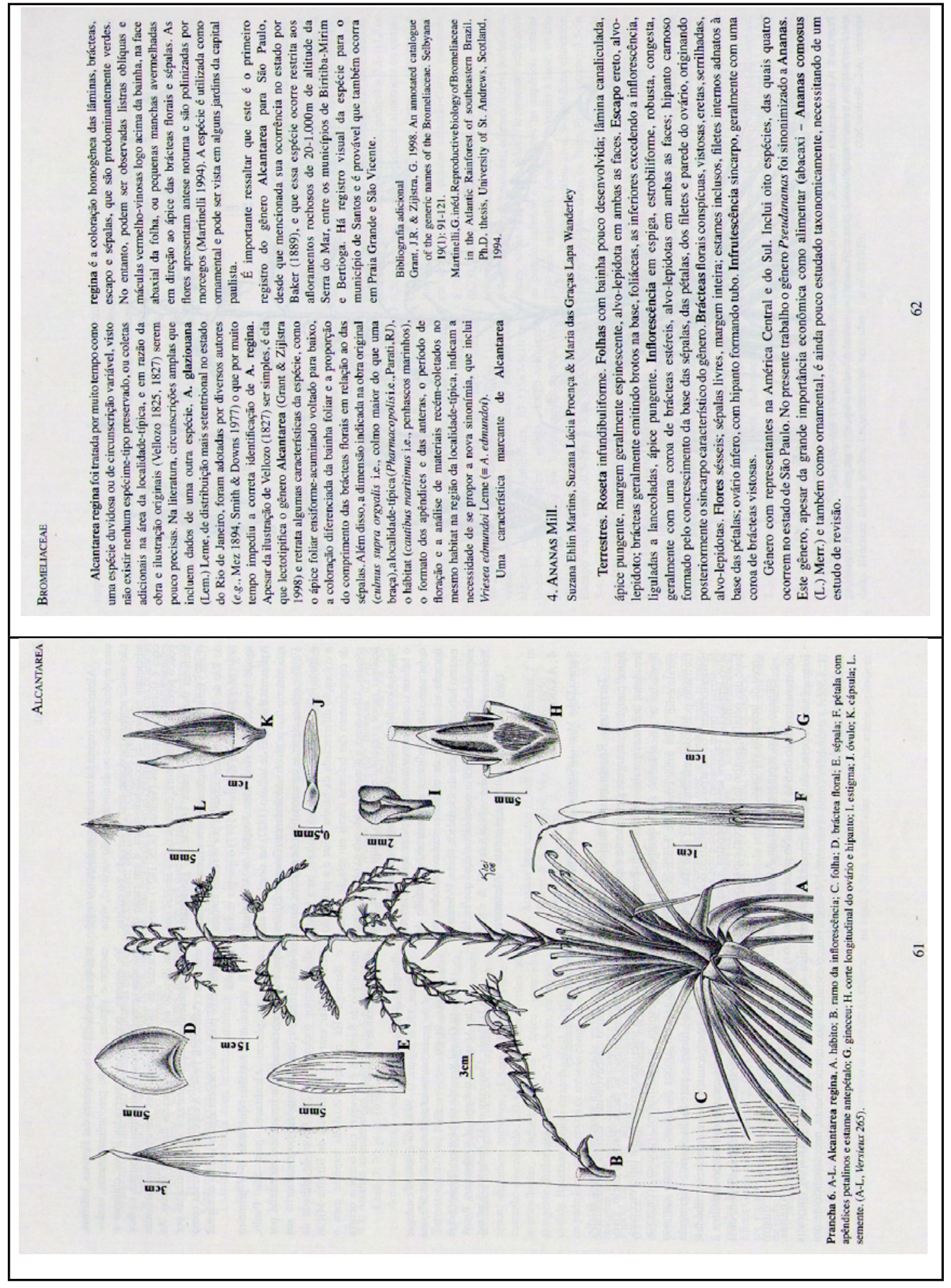


Versieux \& Wanderley. No prelo: Britonia.

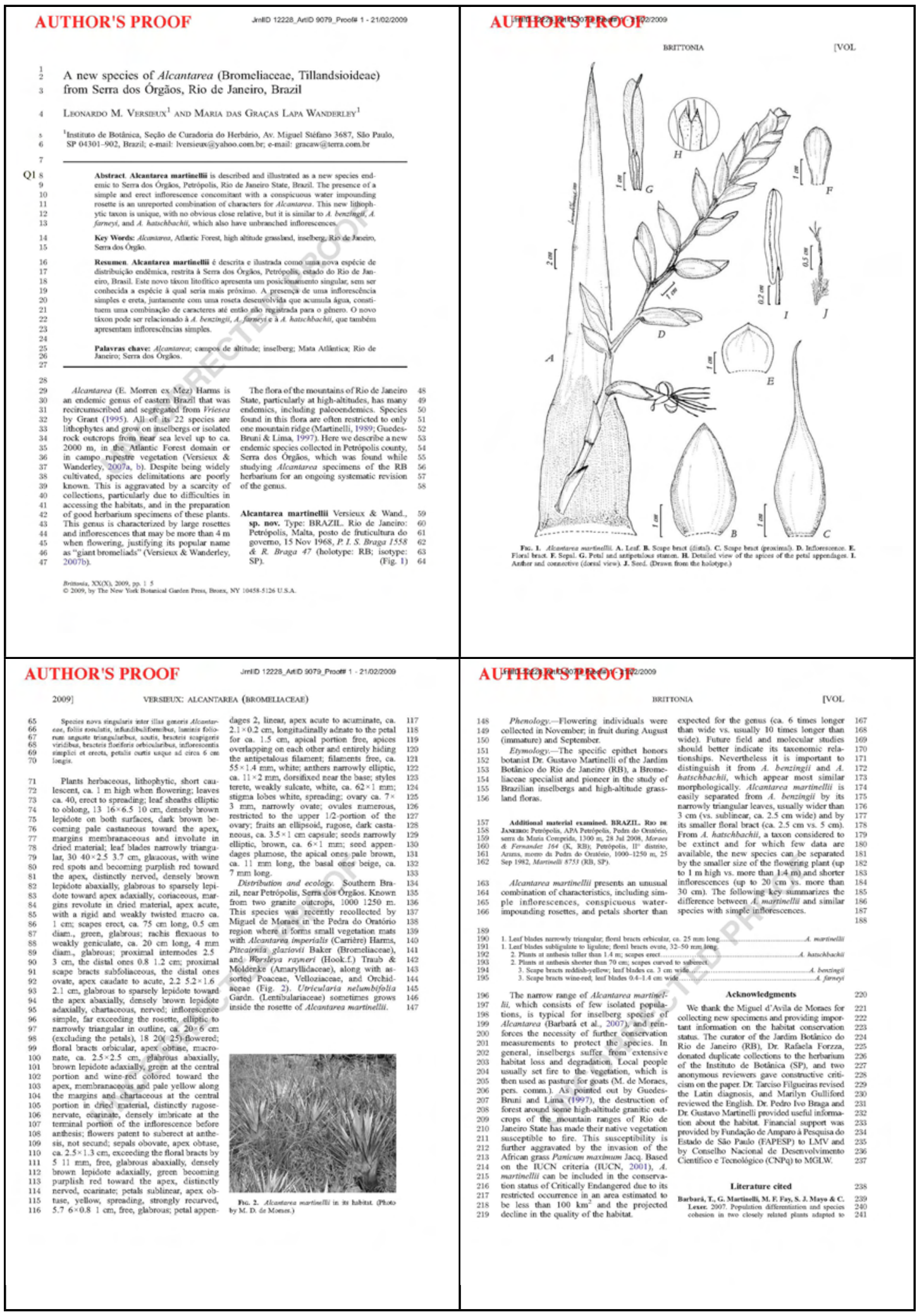


Versieux et al. No prelo. Megadiversidade.

\title{
prova gráfica \\ Bromeliaceae da Cadeia do Espinhaço
}

\author{
LEONARDO M. VERSIEUX ${ }^{1,2}$ \\ TÂNIA WENDT ${ }^{3}$ \\ RAFAEL BATISTA LOUZADA ${ }^{2.4}$ \\ MARIA DAS GRACAS LAPA WANDERLEY ${ }^{2}$ \\ ${ }^{1}$ Doutorando em Botânica, Instituto de Biociências, Universidade de São Paulo \\ 2 Instituto de Botânica, Seção de Curadoria do Herbário, Av. Miguel Stéfano 3687, São Paulo - SP, 04301-902, Brasil \\ 3 Universidade Federal do Rio de Janeiro, CCS, IB, Departamento de Botânica, Ilha do Fundão, Rio de Janeiro - RJ, 21941-590, Brasil \\ ${ }^{4}$ Mestrando em Biodiversidade Vegetal e Meio Ambiente, Instituto de Botânica de São Paulo \\ • email: Iversieux@yahoo.com.br
}

\section{RESUMO}

Bromeliaceae é uma familia de monocotiledôneas de grande importância ecológica na flora da mata atlântica e dos campos rupestres. No presente trabalho apresenta-se um catálogo dos 26 gêneros e 224 espécies de bromélias da Cadeia do Espinhaço, nos estados da Bahia e Minas Gerais. Esta lista foi preparada a partir do levantamento de 17 coleções de herbários, trabalho em campo e consulta à literatura. Para a Bahia, foram listados 19 gêneros e 106 espécies, enquanto que em Minas Gerais ocorrem 23 gêneros e 141 espécies. Das 214 espécies referidas para a Cadeia do Espinhaço, 111 (49,5\%) são endêmicas dessa cadeia de montanhas e apenas $21(9,5 \%)$ ocorrem em ambos os estados, indicando composições florísticas peculiares e ricas em endemismos regionais. A subfamilia Bromelioideae é a mais rica em gêneros e espécies e está melhor representada em Minas Gerais, no sul da Cadeia do Espinhaço. As subfamilias Tillandsioideae e Pitcairnioideae também se destacam pelo grande número de espécies e endemismos nos gêneros Vriesea e Dyckia. O trabalho indica que ainda existem áreas pouco exploradas botanicamente ao longo do Espinhaço, sendo que maior parte das coleções se concentra em menos de dez municípios de cada estado.

\begin{abstract}
Bromeliaceae is a monocot family that has a great ecological importance in the atlantic forest and in campo rupestre vegetation. This paper presents a checklist of the 26 genera and 224 species of Bromeliaceae occurring in the Espinhaço mountain chain that is located in the Brazilian states of Bahia and Minas Gerais. This checklist was based on the survey of 17 herbaria collections, field work and related literature sources. A total of 19 genera and 106 species were inventoried for Bahia, and 23 genera and 141 species are listed for Minas Gerais. Of the total number of species occurring in the Espinhaço, $111(49,5 \%)$ are endemic of this range, and only 21 (9,5\%) occur in both states, reflecting the peculiar vegetations that are rich in narrowly ranged species. Among the three Bromeliaceae subfamilies, Bromelioideae is the richest in number of genera and species and is better represented along the southern portion of the Espinhaço Range, at Minas Gerais. Subfamilies Tillandsioideae and Pitcairnioideae also stand out due to Vriesea and Dyckia,
\end{abstract}


Versieux \& Wanderley. No prelo: Hoehnea.

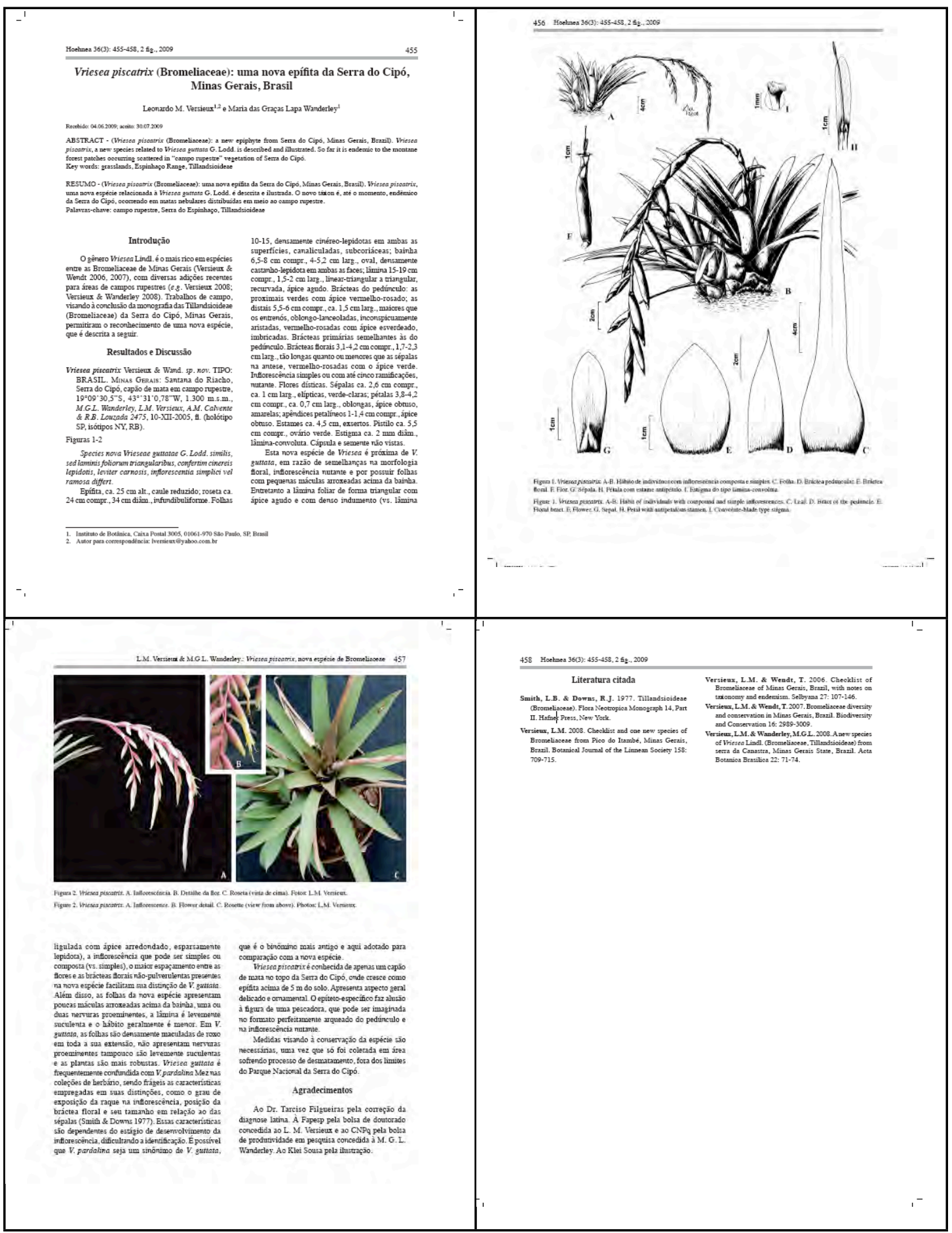




\section{Outros artigos aceitos para publicação, produzidos durante o doutorado:}

Coffani-Nunes, J. V., Versieux, L. M., Wanderley, M. G. L. \& Pirani, J. R. Flora da Serra do Cipó: Bromeliaceae - Tillandsioideae. Boletim de Botânica da Universidade de São Paulo. 2010.

Versieux, L. M. \& Wanderley, M. G. L. Flora da Bahia - Bromeliaceae 1: Alcantarea. Sitientibus, Série Ciências Biológicas. 2010.

Freschi, L., Cambui, C. A., Takahashi, C. A., Semprebom, T. R., Fonseca, A. B. P., Versieux, L. M., Calvente, A. M., Mioto, P. T., Lantansio-Aidar, S.R., Aidar, M. P. M. \& Mercier, H. In Press. Specific leaf areas of the tank bromeliad Gurmania monostachia perform distinct functions in response to water shortage. Journal of Plant Physiology.

\section{Disciplinas cursadas durante o doutorado (2005-2009):}

Genômica - IB USP

Biogeografia de Plantas Vasculares - IB USP

Taxonomia de Leguminosas - Instituto de Botânica

Fisiologia de Plantas Epífitas Superiores - IB USP

Anatomia Comparada dos Órgãos Vegetativos e de Reprodução das Plantas Vasculares em Diferentes Ecossistemas - IB USP

Sistemática de Plantas Tropicales - Universidade de Costa Rica - Organization for Tropical Studies (OTS)

Sistemática Química e Molecular - IB USP

Nomenclatura Taxonômica Vegetal - IB USP 
